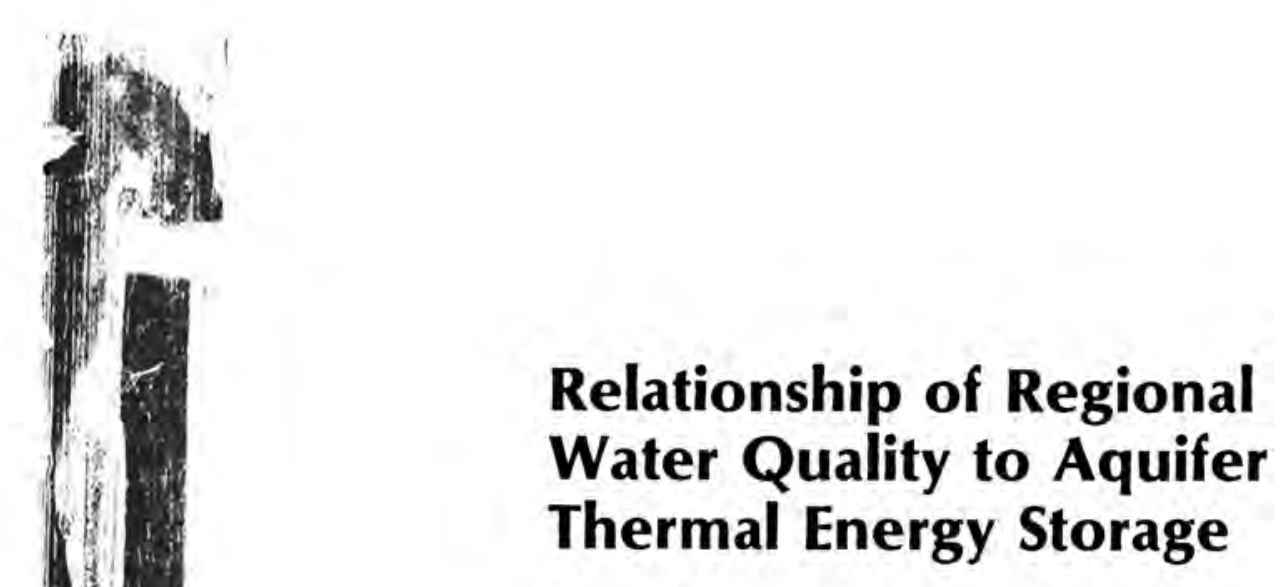

\title{
November 1983
}

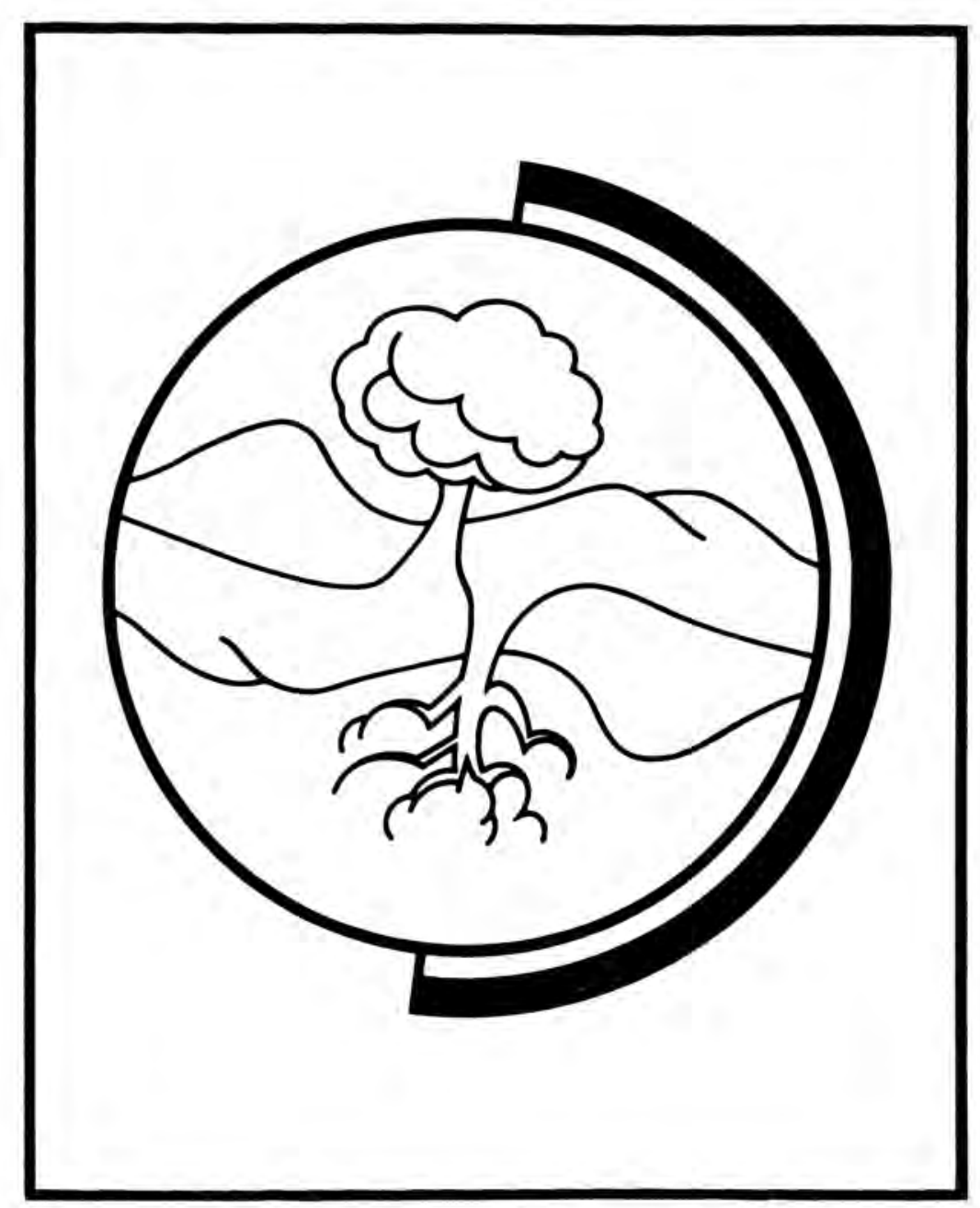

Prepared for the U.S. Department of Energy under Contract DE-AC06-76RLO 1830

Pacific Northwest Laboratory

Operated for the U.S. Department of Energy by Battelle Memorial Institute 


\title{
DISCLAIMER
}

This report was prepared as an account of work sponsored by an agency of the United States Government. Neither the United States Government nor any agency thereof, nor any of their employees, makes any warranty, express or implied, or assumes any legal liability or responsibility for the accuracy, completeness, or usefulness of any information, apparatus, product, or process disclosed, or represents that its use would not infringe privately owned rights. Reference herein to any specific commercial product, process, or service by trade name, trademark, manufacturer, or otherwise, does not necessarily constitute or imply its endorsement, recommendation, or favoring by the United States Government or any agency thereof. The views and opinions of authors expressed herein do not necessarily state or reflect those of the United States Government or any agency thereof.

\author{
PACIFIC NORTHWEST LABORATORY \\ operated by \\ BATTELLE \\ for the \\ UNITED STATES DEPARTMENT OF ENERGY \\ under Contract DE-AC06-76RLO 1830
}

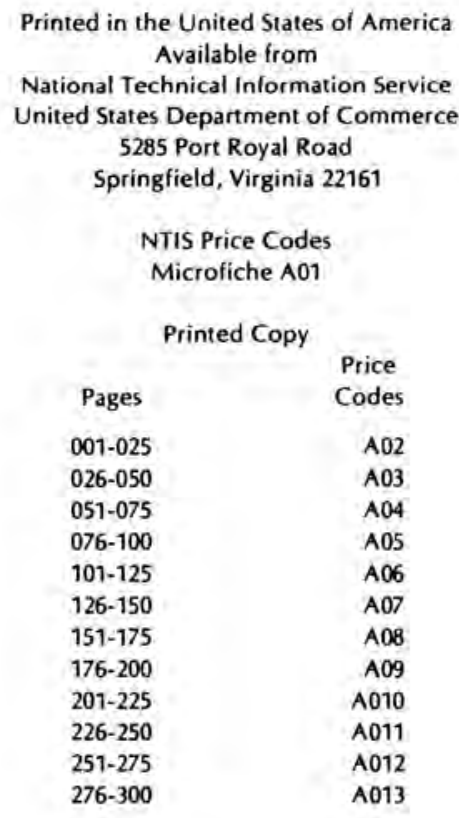


RELATIONSHIP OF REGIONAL WATER QUALITY TO AQUIFER THERMAL ENERGY STORAGE

R. D. Atlen

November 1983

Prepared for the U.S. Department of Energy under Contract DE-AC06-76RLO 1830

Pacific Northwest Laboratory

Richland, Washington 99352 


\section{PREFACE}

Aquifer thermal energy storage (ATES) involves storing temperatureconditioned water within a permeable geologic formation. This method allows storage of solar heat, climatic chill, cogenerated heat, or industrial waste heat for future use in space thermal conditioning or industrial processes. Aquifer thermal energy storage has widespread potential because about half the area of the United States is underlain by aquifers.

This report addresses aspects of regional water quality and associated geology that may affect aquifer thermal energy storage. The study was carried out by Pacific Northwest Laboratory as a task within the Seasonal Thermal Energy Storage (STES) Program. The findings are intended to assist implementation of ATES technology with respect to site screening and selection, as well as evaluation of hydrologic data that relate to energy storage and withdrawal. 

Ground-water quality and associated geologic characteristics may affect the feasibility of aquifer thermal energy storage (ATES) system development in any hydrologic region. This study, conducted by Pacific Northwest Laboratory, sought to determine the relationship between ground-water quality parameters and the regional potential for ATES system development.

Information was collected from available literature to identify chemical and physical mechanisms that could adversely affect an ATES system. Appropriate beneficiation techniques to counter these potential geochemical and lithologic problems were also identified through the literature search. Regional hydrology summaries and other sources were used in reviewing aquifers of 19 drainage regions in the U.S. to determine generic geochemical characteristics for analysis. Numerical modeling techniques were used to perform geochemical analyses of water quality from 67 selected aquifers. Candidate water resources regions were then identified for exploration and development of ATES.

This study identified six principal mechanisms by which ATES reservoir permeability may be impaired: 1) particulate plugging, 2) chemical precipitation, 3) liquid-solid reactions, 4) formation disaggregation, 5) oxidation reactions, and 6) biological activity. Specific proven countermeasures to reduce or eliminate these effects were found.

The chemistry of any ground-water sample was found to result from solution, precipitation, and fluid mixing interactions with minerals and other subsurface waters. Water analyses modeled with the MINTEQ computer code identified three potential problem reactions: 1) precipitation of calcium carbonate at elevated water temperature; 2) solution of silica at elevated temperature, followed by its precipitation at lowered temperature; and 3) oxidation and precipitation of iron compounds. 
Study findings suggest that aquifers composed of quartz sands and sandstones are most promising for low temperature and chill storage. Quartzose rocks are believed to be promising for high temperature storage, provided that silica dissolution and precipitation within the temperature regime of the cycle is not significant.

of the hydrologic regions reviewed, 10 were identified as having the characteristics necessary for ATES development: 1) Mid-Atlantic, 2) SouthAtlantic Gulf, 3) Ohio, 4) Upper Mississippi, 5) Lower Mississippi, 6) Souris-Red-Rainy, 7) Missouri Basin, 8) Arkansas-White-Red, 9) Texas-Gulf, and 10) California. 


\section{ACKNOWLEDGMENTS}

This study was originally conceived by Landis D. Kannberg and John R. Raymond to provide impetus to the aquifer thermal energy storage program on a national scale. William J. Deutsch evaluated ground water chemical analyses using the MINETEQ code; this enabled prediction of solution stabilities for various types of water. Andrea J. Currie provided technical editing and supervised word processing of the Apppendix. Susan $\mathrm{J}$. Arey prepared the several drafts and coordinated production. 



\section{CONTENTS}

PREFACE .....................

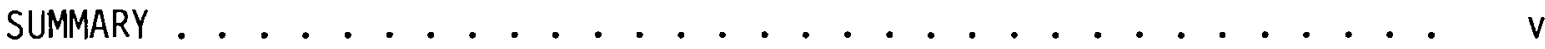

ACKNOWLEDGMENTS ............................. vi

FIGURES ..............................

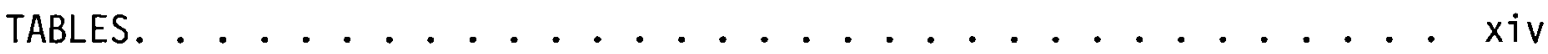

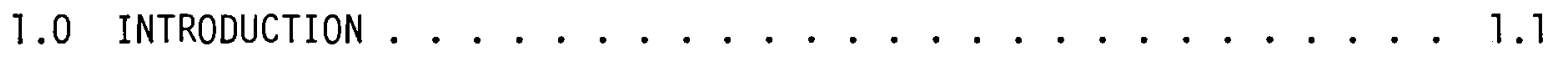

2.0 CONCLUSIONS. . . . . . . . . . . . . . . . 2.1

3.0 MECHANISMS OF SYSTEM IMPAIRMENT. . . . . . . . . . 3.1

3.1 PARTICULATE PlUGGing. . . . . . . . . . . . 3.1

3.2 CHEMiCAl PRECIPITATION. . . . . . . . . . . 3.1

3.2.1 Specific Precipitation Mechanisms. . . . . . . . 3.4

3.2.2 Change in Equilibrium Constants with Temperature . 3.9

3.3 LIQUID-SOLID REACTIONS. . . . . . . . . . . 3.10

3.4 FORMATION DISAGGREGATION. . . . . . . . . . 3.16

3.5 OXIDATION REACTIONS . . . . . . . . . . . 3.17

3.6 BIOLOGICAL ACTIVITY . . . . . . . . . . . 3.17

3.7 SUMMARY . . . . . . . . . . . . . . . . 3.18

4.0 RESERVOIR AND SYSTEM BENEFICIATION . . . . . . . . 4.1

4.1 SCALING REACTIONS AND CONTROL TECHNIQUES. . . . . . . 4.1

4.1.1 Acidification. ............... 4.3

4.1 .2 Slurry Seeding .............. 4.3

4.1 .3 Chelation. ................. 4.4

4.1.4 "Threshold Treatment". . . . . . . . . . 4.4

4.1 .5 Other Treatments . . . . . . . . . 4.5 
4.2 CORROSION PROCESSES AND CONTROL MEASURES. . . . . . . 4.6

4.2.1 Carbonic Acid Corrosion. . . . . . . . . 4.6

4.2.2 Sulfuric Acid Corrosion. . . . . . . . . 4.7

4.2.3 oxygen Corrosion ............ 4.8

4.2.4 Electrochemical Corrosion. ......... 4.9

4.2.5 Inhibition of Corrosion by Inorganic
Precipitation. . . . . . . . . . . 4.13

4.3 BIOFOULING PROCESSES AND CONTROL MEASURES . . . . . 4.13

4.3.1 Sulfate Reducers ............ . 4.14

4.3.2 S7 ime-Forming Bacteria ......... . . 4.15

4.3.3 Iron-0xidizing Bacteria. . . . . . . . . 4.17

4.3.4 Miscellaneous Organisms. ......... . . 4.19

4.4 PARTICULATE PlUGging. . . . . . . . . . 4.21

5.0 OVERVIEW OF REGIONAL HYDROLOGY .................... 5.1

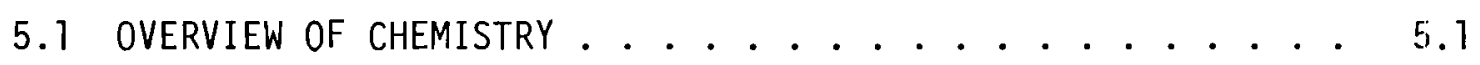

5.2 REGIONAL DESCRIPTIONS .................. 5.5

5.2 .1 Ohio Region. . . . . . . . . 5.7

5.2 .2 Upper Mississippi Region . . . . . . . . . . 5.9

5.2.3 Upper Colorado Region. . . . . . . . 5. 14

5.2.4 Rio Grande Region. . . . . . . . . . 5.16

5.2.5 California Region. . . . . . . . . . 5.17

5.2.6 Texas-Gulf Region. . . . . . . . . 5, 50

5.2.7 Great Basin Region.......... 5. 5 30

5.2.8 Arkansas-White-Red Region. . . . . . . . 5.32

5.2.9 Mid-Atlantic Region. . . . . . . . . . 5.35 
5.2.10 Great Lakes Region. . . . . . . . . 5.47

5.2 .11 Souris-Red-Rainy Region. . . . . . . . 5.50

5.2 .12 Tennessee Region . . . . . . . . . 5.60

5.2 .13 Hawaij Region. . . . . . . . . . 5.70

5.2.14 Lower Mississippi Region . . . . . . . . . 5.71.

5.2 .15 South Atlantic-Gulf Region . . . . . . . 5.77

5.2.16 Alaska Region. . . . . . . . . . 5.83

5.2 .17 Missouri Basin . . . . . . . . . . . 5.91

5.2.18 Lower Colorado Region. . . . . . . . . . 5.103

5.2.19 Pacific Northwest Region . . . . . . . . 5.108

6.0 CHARACTERIZATION OF WATER QUALITY IN REgIONAL AQUIFERS . . . 6.1

7.0 NUMERICAL MODELING . . . . . . . . . . . . 7.1

8.0 FORECASTS OF REGIONAL APPLICABILITY. . . . . . . . . 8.1

REFERENCES. . . . . . . . . . . . . . . R. .

APPENDIX A - SELECTED WATER ANALYSES FOR HYDROLOGIC REGIONS . . . . A. 1

APPENDIX B - NUMERICAL MODELING .............. B. . . . 



\section{FIGURES}

3.1 Solubility of Silica as a Function of Temperature, Plotted as Log ppm $\mathrm{SiO}_{2}$ Against Reciprocal of Absolute Temperature . . . 3.11

5.1 Water Resources Regions of the United States . . . . . . . 5.6

5.2 High-Yield Sources of Ground Water in the Ohio Region . . . . 5.11

5.3 Distribution of Outwash and Alluvial Deposits in the Upper Mississippi Region. . . . . . . . . . . 5.12

5.4 Chemical Characteristics of Stream Base Flows in California. . . 5.23

5.5 Index Map of the Texas-Gulf Region . . . . . . . . . . 5.24

5.6 Prevalent Chemical Types of Water in Rivers at Low Flow in the Arkansas-White-Red Region. . . . . . . . . . . 5.36

5.7 Major Physiographic Divisions of the Mid-Atlantic Region . . . . 5.37

5.8 Diagrammatic Section of North Dakota and Minnesota Showing Location of Aquifers ............... 5.51

5.9 Distribution of Major Aquifer Types in the Tennessee Region. . . 5.61

5.10 Prevalent Chemical Types of Water in Streams at Low Flow in the Lower Mississippi Region . . . . . . . . . . . . 5.72

5.11 Types of Aquifers in the South Atlantic-Gulf Region. . . . . 5.79

5.12 Structural Basins That Contain Freshwater Aquifers in the Missouri Basin Region. . . . . . . . . . . 5.95 


\section{TABLES}

3.1 Solubilities of Gypsum, Bassanite and Anhydrite. . . . . . . 3.5

3.2 Physical, Chemical and Biological Processes That Can Impact Aquifer Thermal Energy Storage Systems . . . . . . . . . . 3.19

5.1 Characteristics of Aquifers in the Ohio Region . . . . . . 5.10

5.2 Principal Water-Bearing Formations of the Upper Colorado Region...................... 5.15

5.3 Undeveloped Ground-Water Reservoirs of the California Region....................... . . . . . . . . .

5.4 Principal Aquifers in the Arkansas-White-Red Region. . . . . . 5.33

5.5 Names and Geographic Distribution of Major Geologic Units Forming Aquifers in the Arkansas-White-Red Region. . . . . . 5.34

5.6 Occurrence of Ground Water in the Great Lakes Region . . . . . 5.49

5.7 Description of Aquifers, Water Quality, and Water-Supply Potential in the Souris-Red-Rainy Region . . . . . . . . . 5.53

5.8 Water Qualities of Physiographic Provinces in the Tennessee Region................... . 5.69

5.9 Generalized Correlation of Coastal Plain Stratigraphic Units and Aquifers . . . . . . . . . . . . . 5.80

5.10 Aquifers of the Lower Colorado Region. . . . . . . . . . 5.104

6.1 Potential Parameters Investigated in Ground Water Analysis . . . 6.2

6.2 Minerals in Aquifers and Associated Rocks. . . . . . . . . 6.3 
RELATIONSHIP OF REGIONAL WATER QUALITY TO AQUIFER THERMAL ENERGY STORAGE

\subsection{INTRODUCTION}

The basic function of an energy storage system is to accept, store and discharge energy in accordance with availability and demand. Thus, a thermal energy storage system provides a buffer between time-dependent energy inputs and thermal and/or electrical power loads. Energy may be supplied to storage as water heated by a working fluid from a solar collection system, by an industrial or utility waste heat source or by a cogeneration power plant. Conversely, chilled water may be stored for future use in air conditioning.

Aquifers are units of permeable rock or unconsolidated sediments that contain water. Most aquifers are of sedimentary origin and are either flat-lying or gently dipping within a particular locale. Aquifers range in depth from as little as $2 \mathrm{~m}$ to several kilometers below ground surface. Confined aquifers are bounded above and below by strata with very low permeabilities that prevent vertical transport of water out of the aquifer; these aquifers are typically saturated with water at pressures determined by the vertical distances to their associated water tables (recharge areas). Because of their large volumes of available containment, aquifers have been used to store natural gas and liquid wastes. Their potential use to store water at high, medium, or low energy levels is a relatively new concept inspired by the need to manage energy efficiently.

Aquifer thermal energy storage (ATES) systems operate in three modes: 1) fluid withdrawal/energy conditioning/injection; 2) fluid storage; and 3) fluid withdrawal/utilization/reinjection. At least two wells are needed to conserve the large volume of water necessary to repeatedly deliver and accept thermal energy.

To determine the effectiveness of an aquifer storage system, its behavior must be evaluated during injection, storage, and withdrawal 
portions of the first and subsequent cycles. Factors important to aquifer utilization include 1) adequate input/output energy rates during successive cycles; 2) negligible degradation of permeability due to physical, chemical or biological processes; 3 ) structural compatibility of the aquifer system with fluctuations in the temperature and pressure of the working fluid; and 4) maintenance of water quality.

Water composition involves factors that could change the permeability of the receiving formation or affect the equipment used to process and inject the water. Well screen obstruction is dominantly affected by chemical precipitation, biological activity, and particulate plugging (Ground Water and Wells 1975). Well casing and surface components are most affected by chemical precipitation and liquid-solid reactions. Any factior that could affect the energy requirements and/or cost of water injection is of concern to ATES system developers. Many of these factors have a synergistic effect upon each other. These factors and their interactions can be identified by onsite testing with the treated water and the receiving formation in question.

In view of the importance of aquifer geochemistry and petrology in relation to aquifer thermal energy storage, a regional water quality survey was conducted to determine the feasibility of this technology in the United States. This survey was performed by the Pacific Northwest Laboratory (PNL) in support of the Seasonal Thermal Energy Storage Program managed =or the U.S. Department of Energy (DOE) by PNL.

The approach involved identification of specific impairment mechanisms originating in potential ground water-ATES system interactions. These mechanisms, which relate to specific states of water chemistry, water temperature, reservoir geology, and system hardware, are discussed in Section 3.0. Section 4.0 discusses techniques for alleviating these ATES system impairment mechanisms. Ground-water resources of the U.S. were reviewed using a series of U.S. Geological Survey Professional Papers (813A through S) to delineate region boundaries and identify major aquifers 
within each region. This review is presented in Section 5.0. References to geochemistry and water quality were obtained mainly by computer searches of the National Ground Water Information Center Data Base, Water Resources Abstracts, and Georef.

In Section 6.0 particular generic ground-water types are identified based upon ratios of dominant solute ions and molecules. These are usually coupled to associated aquifer mineralogy. Each ground-water type is qualitatively considered for ATES applicability. Section 7.0 describes how averaged ground water chemical analyses were evaluated by the MINTEQ code up to $100^{\circ} \mathrm{C}$ to predict relative stabilities of solutions. Impacts of water qualities on associated aquifers are assessed assuming temperatures from $0^{\circ}$ to $200^{\circ} \mathrm{C}$.

The most favorable regions for ATES in the United States are identified in Section 8.0. Their feasibility is based upon projected aquifer performance, energy availability, and assumed demand. 



\subsection{CONCLUSIONS}

Eleven primary conclusions were drawn, based on the findings of this study.

1. Aquifers comprising quartz sands and sandstones are the most promising for low temperature and chill storage. To contain superheated water, a confined aquifer at sufficient discovery pressure would be needed. Appropriate aquifer depths are likely to lie between 50 and $500 \mathrm{~m}$.

2. Freshwater with total dissolved solids of less than $500 \mathrm{mg} / 1$ is desired as the heat transfer fluid to minimize the potential quantity of precipitated minerals.

3. Aquifers of limestones and dolomites may qualify for ATES on the basis of porosity and permeability, but lateral and vertical reservoir extent may be difficult to determine. Carbonate rocks may not contain energy efficiently because of high ratios of reservoir wall area to reservoir volume. The presence of reactive calcite and dolomite would tend to increase the salinity of the working fluid with concomitant probability of carbonate mineral precipitation. Nevertheless, these extensive formations may be feasible in some locales dominated by * carbonate bedrock, e.g., the Florida peninsula.

4. Rock types with storage volume constituted from primary or secondary fractures or sporadic interbeds or lenses include shale, intrusives, volcanics, and metamorphic rocks. Although water quality may be exceptionally high, as in siliceous Precambrian gneisses, the total reservoir volume is likely to be neither sufficient nor calculable for ATES.

5. Generic ground-water types involve the ions $\mathrm{Ca}^{++}, \mathrm{Mg}^{++}, \mathrm{Na}^{+}, \mathrm{K}^{+}$, $\mathrm{HCO}_{3}{ }^{-}, \mathrm{CO}_{3}{ }^{-}, \mathrm{Cl}^{-}, \mathrm{SO}_{4}{ }^{-}$, and $\mathrm{NO}_{3}{ }^{-}$. The nitrate ion originates from man's surface biological activities and has little influence on aquifer geochemistry at moderate depth. Silica is fairly ubiquitous. Iron varies with lithology and location. 
6. Particulate plugging of the near-wellbore aquifer and well screen may be a significant threat to successful ATES system operation. Particles may originate within the geologic formation as native fines: chemically precipitated material, dispersed clay mineral platelets, grains separated by erosion or cement dissolution, or bacterial masses nurtured by the environment. Neutralizing procedures are available to counter both inorganic and organic processes.

7. Precipitates most likely to impact ATES operations by scaling on metal surfaces include $\mathrm{CaCO}_{3},(\mathrm{Ca}, \mathrm{Mg}) \mathrm{CO}_{3}, \mathrm{SiO}_{2}, \mathrm{CaSO}_{4}, 2\left(\mathrm{CaSO}_{4}\right) \cdot \mathrm{H}_{2} \mathrm{O}$, $\mathrm{CaSO}_{4} \cdot 2 \mathrm{H}_{2} \mathrm{O}, \mathrm{Fe}_{2} \mathrm{O}_{3}$, and $\mathrm{FeO}(\mathrm{OH})$. The carbonates are precipitated by increased temperature, whereas the other molecules are precipitated by decreased temperature in most cases. Chemical procedures (i.e., surfactant addition, slurry seeding, chelation, and ion exchange) may be instituted to lessen or eliminate these reactions.

8. Corrosion of well screen, piping, valves, and heat exchanger may be caused by acid attack, oxidation, or electrocinemical reactions. Corrosion inhibitors, resistant alloys, protective coatings, and insulation are used for specific needs.

9. The water resources regions with most promise for near-term development have extensive aquifers, adequate water supplies, available energy sources, and proximate markets for direct use of warm or chilled water. These regions are 1) Mid-Atlantic, 2) South-Atlantic Gulf, 3) Ohio, 4) Upper Mississippi, 5) Lower Mississippi, 6) SourisRed-Rainy, 7) Missouri Basin, 8) Arkansas-White-Red, 9) Texas-Gulf, and 10) California. Aquifer thermal energy storage may also be feasible in other regions. For any locale, site-specific investigations of geology, hydrology, and energy economy will be needed.

10. The physical chemistry of cation and anion associations over germane temperature ranges, as it applies to scale deposition, should be studied by subjecting real ground waters to simulated process conditions. 
11. Sodium chloride type ground water might be considered for ATES because it is unsuitable for most other uses and would, therefore, not be subject to economic competition or usual environmental restrictions. Corrosion-resistant hardware would be required. 



\subsection{MECHANISMS OF SYSTEM IMPAIRMENT}

The permeability of an aquifer used as an ATES system reservoir can be impaired in various ways: particulate plugging, chemical precipitation, liquid-solid reactions, formation disaggregation, oxidation reactions, and biological activity. Some ATES systems would be subjected to the interaction of two or more of these mechanisms. This section describes the six primary mechanisms of ATES system impairment.

\subsection{PARTICULATE PLUGGING}

Particulate plugging can involve material present in the injection water prior to its introduction into the formation, or material formed or produced within the receiving formation (Subcasky 1978). Possible sources of particulate matter in the injection water are silts, formation fines, corrosion products, scale deposits, bacteria, and precipitates from the mixing of chemically incompatible fluids. Through water-rock or waterwater interactions within the formation, particles can be formed or dislodged. These particles can move through the pores and become lodged in pore throats or restrictions.

The possible particulate matter in an injection water could consist of varying numbers of particles of various sizes and shapes. Similarly, the receiving formation could be composed of a series of pores of varying number, size, and length. The rate and degree of permeability damage to the formation would depend upon such factors as particle properties (number and size), pore properties (number and size), and flow rate. The damage could be the result of the formation of a "filter cake" on the face of the injection well, or of plugs or bridges within the pores of the formation.

\subsection{CHEMICAL PRECIPITATION}

Changes in water temperature or pressure can cause the precipitation of certain solid phases (Subcasky 1978). Decreasing the pressure on a particular water may cause the release of dissolved carbon dioxide. Loss 
of carbon dioxide will raise the $\mathrm{pH}$ of the water and decrease the solubility of calcium carbonate, causing precipitation:

$$
\mathrm{Ca}^{++}+2 \mathrm{HCO}_{3}^{-}+\mathrm{CaCO}_{3}+\mathrm{CO}_{2}+\mathrm{H}_{2} \mathrm{O}
$$

The solubility of most materials in water is affected by temperature. For example, the solubility of calcium carbonate decreases with increasing temperature while the solubility of hydrated calcium sulfate (gypsum) increases with increasing temperature. Thus, a solution saturated at one temperature may become supersaturated and form a precipitate at another temperature. The precipitate may form as an adherent deposit on the walls of the system and increase pressure drop or may form as a suspended solid that would plug the receiving formation.

If two or more water sources of differing compositions, concentra-. tions, or pHs are mixed [if the injected water is different from the ir situ (connate) aquifer water], chemical precipitation may occur. For example, an injected water with a high sulfate concentration could form a plugging precipitate when mixed with a formation water with a high barium or calcium concentration, as follows:

$$
\begin{aligned}
& \mathrm{Ba}^{++}+\mathrm{SO}_{4}=+\mathrm{BaSO}_{4} \\
& \mathrm{Ca}^{++}+\mathrm{SO}_{4}=\rightarrow \mathrm{CaSO}_{4}
\end{aligned}
$$

In another example, mixing of one water with a high $\mathrm{pH}$ with another of high calcium or magnesium content could form calcium carbonate or magnesium hydroxide, as shown below:

$$
\begin{aligned}
& \mathrm{Ca}^{++}+\mathrm{HCO}_{3}^{-}+\mathrm{OH}^{-} \rightarrow \mathrm{CaCO}_{3}+\mathrm{H}_{2} \mathrm{O} \\
& \mathrm{Mg}^{++}+2 \mathrm{OH}^{-} \rightarrow \mathrm{Mg}(\mathrm{OH})_{2}
\end{aligned}
$$

Scaling can be described as the formation of an insoluble deposit or precipitate from a physical (e.g., temperature) or chemical (e.g., loss of carbon dioxide) change in a water or from the mixing of two or more waters 
containing incompatible species. Depending upon kinetics and adhesion, the following cases might be distinguished: 1) formation of a deposit on the walls of the processing and injection equipment, 2) sloughing of this deposit to give particles in solution, 3) formation of a suspended solid within the injection water, and 4) precipitation of a deposit on the sand grains of the formation. Chemical reactions between oxygenated water and well casings, piping or heat exchange equipment may produce iron oxide (rust) particles, which subsequently are sloughed into the water. McCune (1977) states that scaling tendencies may be associated with high concentrations of barium, carbonate, and sulfate ions along with solution alkalinity.

The primary problems include silica deposition as the temperature is decreased and/or calcite deposition as the temperature is increased or the partial pressure of carbon dioxide is decreased (Stottlemyre et al. 1979). Precipitation or scaling may occur when the constituent concentration is such that the solubility product is exceeded. In other words, when the fluid becomes supersaturated with respect to a particular mineral, altering the temperature and/or solution pH may cause the mineral, such as calcite $\left(\mathrm{CaCO}_{3}\right)$ or silica $\left(\mathrm{SiO}_{2}\right)$, to precipitate, resulting in scaling. Potential mineral depositions may be calculated if the compositions of the aquifer fluids and host rocks and the thermodynamic equilibrium characteristics are known. Particular reaction rates may not be known; hence, precipitation rates may not be calculable for those systems even though physical conditions and concentrations are known. Other compounds that may precipitate include magnesium carbonate, calcium sulfate, and barium sulfate. Once deposited as scale, barium sulfate cannot be readily removed.

Chemical equilibrium computations for the St. Paul Field Test Facility suggest that calcium and magnesium carbonates and silicates will precipitate at maximum rates between $75^{\circ}$ and $125^{\circ} \mathrm{C}$ (Soderberg and 0 'Gara 1982). Precipitation of amorphous silica and aluminum hydroxide are also predicted after heat recovery and reinjection of ground water at this ATES site. 


\subsubsection{Specific Precipitation Mechanisms}

\subsubsection{Calcium Sulfate}

Pressure drop can be a major cause of gypsum scale in oil wells producing from formations containing anhydrite (Fulford 1968). This effect is attributed to the fact that gypsum and anhydrite solubilities in water are proportional to pressure: the volume of solvent plus solute is less than the volume of water plus either crystalline phase (precipitate).

Other dissolved salts cause variations in the amount of gypsum scale deposition by changing the solubility of calcium sulfate and by affecting the change in volume that results when calcium sulfate dissolves in water. Concentrations of sodium chloride above $240 \mathrm{~g} / 1$ or combinations of sodium chloride and other salts with a total concentration over $240 \mathrm{~g} / 1$ prevent gypsum scale precipitation resulting from pressure decreases (Fulford 1968). However, neither a $\mathrm{MgCl}_{2}$ solution alone nor a $\mathrm{Na}_{2} \mathrm{SO}_{4}$ solution prevents deposition of gypsum scale.

Gypsum scale forms much faster when gypsum crystals are present than when dolomite, anhydrite or no solid phase is present. Clearly, this is a seeding effect.

The solubilities of gypsum $\left(\mathrm{CaSO}_{4} \cdot 2 \mathrm{H}_{2} \mathrm{O}\right)$, bassanite, the hemihydrate $\left(\mathrm{CaSO}_{4} \cdot 1 / 2 \mathrm{H}_{2} \mathrm{O}\right)$ and anhydrite $\left(\mathrm{CaSO}_{4}\right)$ are reported by Betz Laboratories (1976) in Table 3.1 .

Vetter and Phillips (1970) have calculated the solubilities of different $\mathrm{CaSO}_{4}$ compounds in $\mathrm{NaCl}$ brines at various pressures and temperatures. Calculated solubilities are said to be as accurate as experimentally determined concentrations. At $200^{\circ} \mathrm{C}$ the dissolved $\mathrm{wt} \%$ of $\mathrm{CaSO}_{4}$ approaches $20 \%$ in the presence of $26 \% \mathrm{NaCl}$ by weight. At $100^{\circ} \mathrm{C}$ ard lower temperatures the maximum solubility occurs at about $12 \% \mathrm{NaCl}$ by weight.

The area behind the sandface has been identified as a favored location for buildup of calcium sulfate scale (Vetter and Phillips 1970). 
TABLE 3.1. Solubilities of Gypsum, Bassanite, and Anhydrite

\begin{tabular}{|c|c|c|c|}
\hline $\begin{array}{c}\text { Temperature } \\
\left({ }^{\circ} \mathrm{F}\right)\end{array}$ & $\begin{array}{c}\text { Gypsum } \\
\text { (ppm) }\end{array}$ & $\begin{array}{c}\text { Bassanite } \\
\text { (ppm) }\end{array}$ & $\begin{array}{l}\text { Anhydrite } \\
\text { (ppm) }\end{array}$ \\
\hline 32 & 1,850 & $>3,000$ & $>3,000$ \\
\hline 68 & 2,050 & $>3,000$ & 3,000 \\
\hline 104 & 2,100 & $>3,000$ & 2,200 \\
\hline 140 & 2,020 & $>3,000$ & 1,600 \\
\hline 176 & 1,850 & 2,525 & 1,075 \\
\hline 212 & 1,650 & 1,650 & 725 \\
\hline 248 & -- & 1,050 & 450 \\
\hline 284 & -- & 680 & 300 \\
\hline 320 & -- & 410 & 260 \\
\hline 356 & -- & 280 & 140 \\
\hline
\end{tabular}

\subsubsection{Calcium Carbonate}

The solubility of calcium carbonate decreases with increasing temperature from about $80 \mathrm{ppm}$ at $32^{\circ} \mathrm{F}$ to less than $10 \mathrm{ppm}$ at $320^{\circ} \mathrm{F}$ (Betz Laboratories 1976). Its solubility is also dependent upon the partial pressure of carbon dioxide. Loss of carbon dioxide will raise the $\mathrm{pH}$ of the water and decrease the solubility of calcium carbonate, causing precipitation according to the following reaction:

$$
\mathrm{Ca}^{++}+2 \mathrm{HCO}_{3}^{-} \rightarrow \mathrm{CaCO}_{3}+\mathrm{CO}_{2}+\mathrm{H}_{2} \mathrm{O}
$$

Lindemuth et a1. (1976) describe physical chemical calculations to determine the amount of precipitation from a system at equilibrium.

Calcium carbonate cement is also susceptible to solution in ionized solutions. An experiment performed by Reed (1977) demonstrated $80 \%$ removal of calcium carbonate cement by flowthrough of a $3.7 \% \mathrm{KCl}$ solution.

Lane and Kumar (1980) have quantitatively studied scaling behavior in cooling towers. The balance of this section is drawn from their work. 
Calcium carbonate is the predominant dissolved constituent of cooling tower waters. Temperature has a pronounced effect on the formation of scale because the solubility of calcium carbonate decreases as temperature increases.

Langelier (1936) determined the scaling tendencies of water based on the solubility of calcium carbonate. The $\mathrm{pH}$ of saturated calcium carbonate solution can be calculated based on actual solubility of calcium carbonate at definite temperatures and dissolved solids contents. By subtracting this value from the actual $\mathrm{pH}$ of the water to yield the Saturation Index, Langelier developed a way to indicate a water's scaling or corrosive tendency. The Langelier Saturation Index equals actual $\mathrm{pH}$ of the water minus $\mathrm{pH}_{\mathrm{S}}$, where

$$
\mathrm{pH}_{\mathrm{S}}=\mathrm{A}+\mathrm{B}-(\log \mathrm{Ca}+\log \mathrm{M}) .
$$

Ca represents calcium hardness expressed as $\mathrm{CaCO}_{3}$, and $M$ represents methiyl orange alkalinity expressed as $\mathrm{CaCO}_{3}$. "A" represents the second dissociation constant and "B" the solubility product constant for calcium carbonate. These terms are functions of temperature and residues. The Langelier Saturation Index measures only the directional tendency or driving force of a water. It cannot be used as a quantitative measure.

The greatest weakness in the Langelier Saturation Index occurs with waters having relatively low alkalinity and low calcium content. Such waters have a saturation $\mathrm{pH}$ greater than 8.3. For some waters, the Langelier Saturation Index may have to be +1.0 or more to establish the saturation $\mathrm{pH}$ for calcium carbonate. At this level, the buffer capacity is minimal. At the higher levels, the formation of complexes such as $\mathrm{CaOH}^{+}, \mathrm{CaHCO}_{3}^{+}, \mathrm{MgHCO}_{3}^{+}$, and soluble $\mathrm{CaCO}_{3}$ and $\mathrm{MgCO}_{3}$ may be complicating factors, because these complexes remove calcium and lower alkalinity. Langelier Saturation Indices of +0.2 to 1.0 at room temperature may be required.

The Ryznar Stability Index was developed to measure quantitatively the amount of calcium carbonate scale formed by water at a particular 
temperature (Ryznar 1944). The Ryznar Index, R, is determined from the empirical expression

$$
\mathrm{R}=2\left(\mathrm{pH}_{\mathrm{S}}\right)-\mathrm{pH}
$$

A Ryznar Index of 6 or less indicates that the water has a scaling tendency; an index greater than 7 indicates that the water tends to be corrosive, and that scaling may not occur. The Ryznar Index also tells whether a threshold treatment with polyphosphate can be used; if $R$ is greater than 4.5 , polyphosphates will hold the calcium in suspension. The buffering effects of calcium and high alkalinity may provide a nonscaling, noncorrosive water.

The Saturation and Stability Indices are effective aids in producing nonscaling, noncorrosive water.

\subsubsection{Silica}

Solution and reprecipitation of silica is one of the most common geochemical processes. Silica dissolves in water in two possible forms, molecularly dispersed and colloidal states (Krauskopf 1956). Hydration of silica gives the following reaction:

$$
\mathrm{SiO}_{2}(\mathrm{~s})+2 \mathrm{H}_{2} \mathrm{O} \rightarrow \mathrm{H}_{4} \mathrm{SiO}_{4}(\mathrm{aq})
$$

The stoichiometry of this reaction is a function of water activity and temperature. Orthosilicic acid $\left(\mathrm{H}_{4} \mathrm{SiO}_{4}\right)$ (also called monomeric silicic acid or monosilicic acid) is the principal form of silica in solution. With orthosilicic acid, the ionic silica changes into colloidal silica, then to gels, and then becomes insoluble. Finally, the silica changes into the hydrate $\mathrm{SiO}_{2} \cdot \mathrm{nH}_{2} \mathrm{O}$ (Ozawa and Fujii 1970). In natural waters, silica may be either colloidal or in true solution, but the colloidal particles are unstable and disappear in time if the silica concentration in solution is less than $100 \mathrm{ppm}$ (Roy 1945; Weitz and Schuchard 1950). Therefore, most or all of dissolved silica is in the form of orthosilicic acid $\left(\mathrm{H}_{4} \mathrm{SiO}_{4}\right)$.

Lindemuth et al. (1976) described the effects of $\mathrm{pH}$ and moderate temperature on the solubility of silica. The solubility as a function of 
$\mathrm{pH}$ varies as follows: $160 \mathrm{ppm}$ at $\mathrm{pH}=2$; $110 \mathrm{ppm}$ at $\mathrm{pH}=7$; and $5000 \mathrm{ppm}$ at $\mathrm{pH}=11$. The solubility as a function of temperature varies as follows: $150 \mathrm{mg} / 1$ at $10^{\circ} \mathrm{C} ; 500 \mathrm{mg} / 1$ at $125^{\circ} \mathrm{C}$; and $1200 \mathrm{mg} / 1$ at $240^{\circ} \mathrm{C}$.

The solubility of silica at high temperatures and pressures is well known through the work of various investigators (Hitchen 1945; Kennedy 1950; Morey and Hesselgesser 1951; Morey et al. 1962). Solubility of silica in distilled water reaches a maximum at $332^{\circ} \mathrm{C}\left(630^{\circ} \mathrm{F}\right)$ and is $0.075 \%$ by weight. At higher temperatures, solubility decreases until the critical temperature of water, $374^{\circ} \mathrm{C}\left(705^{\circ} \mathrm{F}\right)$, is reached; at this point the solubility is $0.023 \%$ by weight.

The solubility of amorphous silica is little affected by changes in $\mathrm{pH}$ within the range of 0 to 9 , but increases rapidly as the $\mathrm{pH}$ rises above 9 . In other words, silica is more soluble in very dilute alkali than in acid. Krauskopf (1956) concluded that the silicate ion is present in appreciable amounts at a pH above 9. In more acidic solutions, the silicic acid is essentially un-ionized.

Iron silicates and carbonates are soluble in hydrochloric acid, whereas silicic material is soluble in hydrofluoric acid, but not in hydrochloric acid. Ozawa and Fujii (1970) concluded that highly siliceous scale can be removed by using a solution of sodium hydroxide.

Solubility of silica is approximately five times higher in water containing $\mathrm{CO}_{2}$ (Birks and Schulman 1950). Therefore, $\mathrm{CO}_{2}$ could be used to dissolve silica.

When amorphous silica is crystallized in the quartz structure under the influence of temperature, pressure, and chemical impurities, its solubility in water is reduced. Amorphous silica can be converted to quartz in the presence of carbonates of most alkaline earths when it is heated several hundred degrees above its solubility limits (Bricker 1968).

The solubility of silica is related to the concentration of chlorice ions (Harrar et al. 1979). At $90^{\circ} \mathrm{C}$ the solubility of silica declines linearly from $190 \mathrm{mg} / \mathrm{kg}$ at $3.4 \mathrm{~mol} \mathrm{Cl}^{-} / 1$ to $140 \mathrm{mg} / \mathrm{kg}$ at $5.0 \mathrm{~mol} \mathrm{Cl}^{-} / 1$. 
Illustrating this effect, silica scaling increased as the total salt concentration of a Salton Sea brine increased.

Wahl and Yen (1975) found that presence of calcium and magnesium cations in solution enhances precipitation of silica at $90^{\circ} \mathrm{F}$. Iron and aluminum cations also contribute to silica precipitation. These authors believe the physical chemistry of scale deposition should be studied by subjecting real brines to simulated process conditions.

Morey et a1. (1962) determined that stresses and structural irregularities at the surfaces of crushed quartz grains predispose the silica to more rapid solution than occurs with well crystallized quartz.

\subsubsection{Change in Equilibrium Constants with Temperature}

Enthalpy differences can be used to express quantitatively the way an equilibrium constant changes with temperature (Krauskopf 1979). The relationship is given by the van't Hoff equation:

$$
\frac{d \ln K}{d T}=\frac{\Delta H}{R T^{2}}
$$

where $K$ is the equilibrium constant, $T$ is the absolute temperature, and $R$ is the gas constant. This equation can be integrated between limits to yield:

$$
\log \frac{K_{2}}{K_{1}}=\frac{\Delta H}{2.303 R}\left(\frac{T_{2}-T_{1}}{T_{2} T_{1}}\right)
$$

where $K_{2}$ is the constant at temperature $T_{2}$ and $K_{1}$ the constant at $T_{1}$. This form lends itself to calculations of constants over a range of temperatures generally valid up to about $100^{\circ} \mathrm{C}$. For example, the following parameters for calcite apply:

$$
\begin{aligned}
\mathrm{K}_{1} & =10^{-8.35} \\
\mathrm{~T}_{1} & =298 \mathrm{~K} \\
\Delta \mathrm{H} & =-2940 \mathrm{cal} / \mathrm{mole} \\
\mathrm{R} & =1.987 \mathrm{cal} / \mathrm{K}-\mathrm{mole}
\end{aligned}
$$


By substitution and solution the following equilibrium constants are obtained:

$$
\begin{aligned}
& K_{2}=10^{-8.52} \text { at } T_{2}=323 \mathrm{~K} \\
& K_{3}=10^{-8.66} \text { at } T_{3}=348 \mathrm{~K} \\
& K_{4}=10^{-8.78} \text { at } T_{4}=373 \mathrm{~K}
\end{aligned}
$$

The van't Hoff equation can also be used to calculate the enthalpy change for a reaction, given values of the equilibrium constant over $\bar{c}$. range of temperatures (Krauskopf 1979, pp. 168-170). For example, consider the dissolution of quartz in water:

$$
\mathrm{SiO}_{2}(\mathrm{qz})+2 \mathrm{H}_{2} \mathrm{O} \rightleftharpoons \mathrm{H}_{4} \mathrm{SiO}_{4}(\mathrm{aq})
$$

The equilibrium constant is the activity of silicic acid, because the activities of solid quartz and liquid water are unity by convention. In dilute solutions the activity of $\mathrm{H}_{4} \mathrm{SiO}_{4}$ may be taken as equal to its concentration, i.e., the measured solubility of quartz. In Figure 3.1 these solubilities are plotted as logarithms versus reciprocals of the absolute temperature. The enthalpy difference, $\Delta H$, in kilocalories per mole, is found by multiplying the slope by 0.00458 . Because the numerical slope in Figure 3.1 is $1,132, \Delta H=5.18 \mathrm{kcal} / \mathrm{mole}$.

\subsection{LIQUID-SOLID REACTIONS}

Rock formations contain clays and other minerals, usually in equilibrium as flocculates or stable grains within formation waters, both of which may undergo physical and chemical changes when the electrolyte content of the water surrounding them is changed (Hewitt 1963; Subcasky 1978). Thus the spacing between repeating layers of montmorillonite is altered when the degree of hydration is changed by changing the salt content. When mica containing the potassium ion (interplanar spacing $10 \AA$ ) is contacted with a fluid low in potassium content, a cationic exchange cr chemical reaction can occur with larger hydrated ions such as sodium or calcium ions. The spacing can increase to $15 \AA$. Breaking and sloughing of fines can occur. Because the dispersing types of clays are charged species, changing the electric field around the particles by changing the 


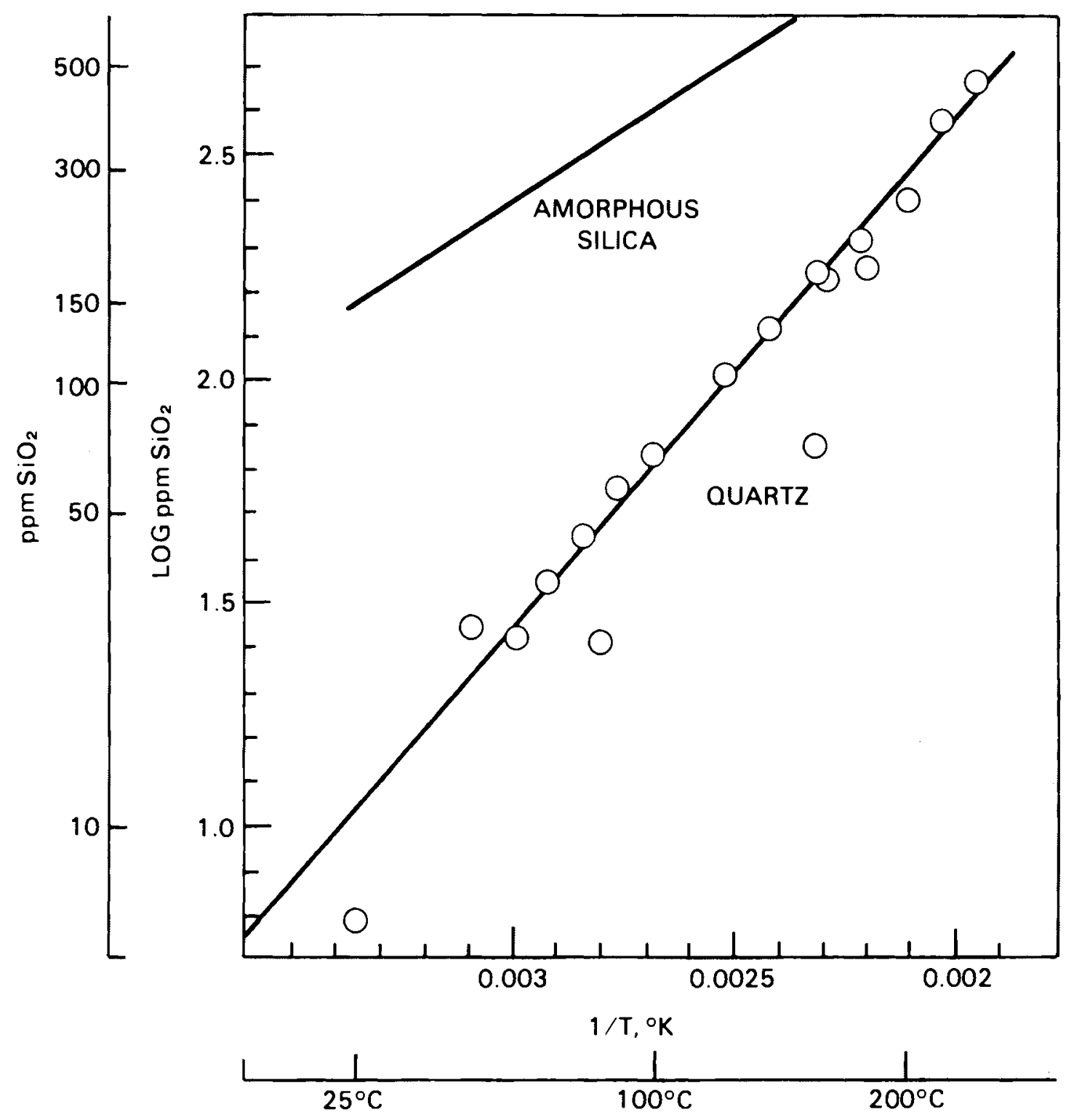

FIGURE 3.1. Solubility of Silica as a Function of Temperature, Plotted as Log ppm $\mathrm{SiO}_{2}$ Against Reciprocal of Absolute Temperature (Krauskopf 1979, p. 170).

electrolyte composition can cause the particles to disperse or coagulate. Dispersed particles can migrate within the formation and plug narrow pores (Hewitt 1963). Pore plugging may also be caused by clay mineral swelling in situ. 
Moore (1960) observed that most reservoir sandstones contain clay minerals. A content of only 1 to $4 \%$ of water-sensitive clays in a finegrained sandstone may completely plug the formation if injection fluid solute cations are not compatible with the clay species. The general order of expansibility of the clay mineral groups is montmorillonite > degraded and mixed-layer clay minerals > illite > kaolinite. Only kaolinite shows essentially no expansion when dispersed in water containing solute cations that cause dispersion of other clay minerals.

The order of replaceability of cations will vary according to concentration, population of exchange positions, nature of anion, nature of cation, and nature of clay mineral. The relative replacing power of one cation by another is shown in the following series:

$$
\mathrm{Li}^{+}<\mathrm{Na}^{+}<\mathrm{K}^{+}<\mathrm{Mg}^{+}<\mathrm{Ca}^{++}<\mathrm{H}^{+}
$$

The exchangeable cations $\mathrm{Ca}^{++}, \mathrm{Mg}^{++}$, and $\mathrm{H}^{+}$increase the attractive force between particles, thus decreasing the thickness of the water film, whereas $\mathrm{Na}^{+}$and $\mathrm{Li}^{+}$decrease the attractive force between the plates, which allows more water to penetrate between the plates. Consequently, clay minerals carrying $\mathrm{Na}^{+}$and $\mathrm{Li}^{+}$cations will display the greatest swelling or expansion ability.

Measurements of the expansion of montmorillonite and other expandable clays have shown that, when $\mathrm{Ca}^{++}$is the exchangeable cation, the clay will adsorb a well-ordered water layer that is only a few molecules thick. However, when $\mathrm{Na}^{+}$is the exchangeable cation, the clay will adsorb a poorly-ordered water layer that is much thicker and causes the clay to expand or swell indefinitely. The cations $\mathrm{Ca}^{++}, \mathrm{Mg}^{++}$, and $\mathrm{H}^{+}$adsprbed on the clay surface tend to cause flocculation, whereas introduction of $\mathrm{Na}^{+}$or dilution of the aqueous medium causes deflocculation. Also, both low $\mathrm{pH}$ and high $\mathrm{pH}$ promote flocculation, but medium high $\mathrm{pH}$ tends to promote deflocculation (Moore 1960). Electrostatic charges are believed to cause flocculation of clay particles (Hewitt 1963). 
Liquid-solid reactions caused by changes in $\mathrm{pH}$ and salinity may impair the transmissivity of an aquifer. Reduction in permeability has been generally attributed to clay mineral particle expansion and dispersion upon contact with water less saline than connate water (Mungan 1965). Laboratory studies show that permeability reduction can also occur in formations containing only relatively nonexpandable clays, such as illite or kaolinite, and can be caused by changes in pH. Further, pH changes can damage even clay-free formations.

Permeability data from samples that are sensitive to particle plugging usually show a less regular reduction in permeability with decreasing salinity than the proportionate decrease that is characteristic of samples containing swelling clays. Although particle dispersion and mobility tend to increase as salinity decreases, a reversal in flow direction causes a marked temporary increase in permeability due to unplugging and reverse transport of particles.

Mungan (1965) attributes permeability reduction to blockage of small aquifer passages with particles of dispersed clay, dislodged cement or other fines. Clays are dispersed by salinity reduction or thermalmechanical disruption. Calcareous cement is dislodged by partial dissolution in acid solution. Siliceous cement is dislodged by partial dissolution in alkaline solution. Specific experimental results illustrate these effects (Mungan 1965).

Flow of either fresh water or $30,000 \mathrm{ppm}$ brine does not cause reduced permeability in Berea sandstone containing chlorite, kaolinite, illite, and interlayered illite (Mungan 1965). However, after injection of brine, the core is immediately damaged by a switch to fresh water injection due to dislodging (dispersion) of clay mineral particles. If the transition from brine to fresh water injection is gradual and continuous, the permeability decline is either less pronounced or absent.

Jones (1964) has speculated that the mechanism responsible for the "salinity contrast" effect is similar to osmosis. Because of the difference in chemical potential between the two solutions, the fresh 
water probably enters the clay aggregates to dilute the brine and, in dcing so, increases pressure within the aggregates to the point that they disrupt, disperse in the fresher water, and plug flow channels. When high salinity contrasts are avoided by diminishing salinity slowly, pressure within aggregates does not increase greatly because time is allowed for it to dissipate.

Sudden high-temperature vaporization of water from a saturated Berea sandstone caused clay dispersal and a large decrease in permeability (Mungan 1965). This effect is attributed to disruption by thermal-mechanical forces.

Three effects have been demonstrated: 1) siliceous cement is dissolved by alkaline solutions (amorphous silica is the most soluble part of the matrix); 2) hydroxyl ions increase the cleavage of clay minerals; and 3) dispersion of $\mathrm{Na}^{+}$or $\mathrm{NH}_{4}^{+}$saturated clays is caused by successive flows of $\mathrm{NaOH}$ or $\mathrm{NH}_{4} \mathrm{OH}$ solutions and distilled water (Mungan 1965). However, $\mathrm{K}^{+}$saturated clays are not readily dispersed by distilled water.

In sum, alkaline solutions can adversely affect permeability by 1) generating silica cement particles, and 2) separating clay mineral layers. Clays saturated with sodium and ammonium ions are more susceptible to freshwater dispersion than those saturated with potassium ions.

Experiments on unconsolidated kaolinite-coated sand grains disclosed separation of the clay during exposure to flows of water, brine, and sodium hydroxide. Even when cores contain as little as $0.4 \%$ kaolinite by weight, permeability can be significantly impaired.

Mungan (1965) drew the following conclusions:

- The primary cause of permeability reduction is blocking of pore passages by dispersed particles.

- Permeability reduction due to salinity changes occurs regardless of the type of clay. 
- Acidic or alkaline solutions can reduce permeability even in clay-free rocks.

In other instances, the rock formation or a portion of the formation may have an appreciable solubility in the injected water if the injected water is not in equilibrium with the formation. Thus, water unsaturated with respect to calcium carbonate can dissolve the cementing carbonate present in some formations. Fines that can plug the formation are liberated. Nonequilibrium water at high $\mathrm{pH}$ and/or high temperature can dissolve considerable amounts of siliceous material. Changes in $\mathrm{pH}$ and/or temperature can redeposit the dissolved materials and plug the formation.

In hydrothermal alterations, silicates, carbonates, and sulfates are the primary solid reagents. If high temperature liquid water is present, hydrolysis and mineral dissolution and precipitation are likely. The end products of hydrolytic reactions can be clay minerals. The potential problems associated with clays have been previously discussed. The problems associated with mineral scaling are evident in geothermal reservoirs.

During hydrolysis, hydrogen ions in solution are exchanged for alkali $(\mathrm{Na}, \mathrm{K})$ and alkaline $(\mathrm{Ca}, \mathrm{Mg})$ cations in the silicate rock minerals. For example, forsterite, a magnesium silicate, can be hydrolyzed to yield free magnesium cations, hydroxide ions, and silicic acid as follows:

$$
\mathrm{Mg}_{2} \mathrm{SiO}_{4}+4 \mathrm{H}_{2} \mathrm{O} \rightarrow 2 \mathrm{Mg}^{2+}+4 \mathrm{OH}^{-}+\mathrm{H}_{4} \mathrm{SiO}_{4}
$$

Kaolinite (clay mineral) can result from the hydrolysis of orthoclase (potassium silicate) by the following simplified reaction:

$$
4 \mathrm{KATSi}_{3} \mathrm{O}_{8}+22 \mathrm{H}_{2} \mathrm{O} \rightarrow 4 \mathrm{~K}^{+}+4 \mathrm{OH}^{-}+\mathrm{Al}_{4} \mathrm{Si}_{4} \mathrm{O}_{10}(\mathrm{OH})_{8}+8 \mathrm{H}_{4} \mathrm{SiO}_{4}
$$

Other layered minerals (e.g., talc, chlorite, illite, and montmorillonite) might be similarly produced from silicates like plagioclase, potassium feldspars, and ferromagnesian minerals. However, these reactions are highly $\mathrm{pH}-$ and temperature-dependent (Stottlemyre et a1. 1979). 
The extent of corrosion with injection water in a metal system depends upon the corrosivity of the water and the activity of the metal. The corrosivity of the water is affected by such factors as temperature, $\mathrm{pH}$, types and amounts of salinity, velocity, and the presence of corrosive gases such as oxygen, carbon dioxide, or hydrogen sulfide. Corrosion leads to destruction and failure of processing and injection equipment. Corrosion products (usually iron oxides and sulfides) can plug the receiving formation (Subcasky 1978). McCune (1977) recommends geochemical analys is of injection water including description of suspended solids. Corrosion problems are indicated by dissolved and suspended iron compounds, hydrogen sulfide content, and acidity.

\subsection{FORMATION DISAGGREGATION}

Disaggregation refers to the dislodging of individual grains within porous media. It can potentially occur when cement is preferentially dissolved or the matrix is mechanically loaded beyond a certain threshold pressure. Potential causes include 1) differential thermal expansion and contraction, 2) static or dynamic fatigue, 3) chemical dissolution, 4) hydrolytic weakening, and 5) mechanical erosion. Adverse consequences likely to be associated with disaggregation include particulate flugging and matrix consolidation. The consequences could also be beneficial it permeability increases near the wells.

Localized differential thermal stresses can result from the inhomogeneity and anisotropy of expansion coefficients for individual minerals and the matrix as a whole. If the differential stresses are high enough, microcracking and fragmentation or dislocation of grains will occur. Microcracking, grain dislocation, or cement dissolution could increase permeability. If, in addition, thermal stresses are cyclical, fatigue may increase these effects (Stottlemyre et al. 1979). 
Cement dissolution in sandstone applies to silica whose water solubility increases with temperature and calcium carbonate whose solubility decreases with temperature.

The presence of water vapor at elevated temperatures might result in the hydrolysis and weakening of chemical bonds, i.e., the Si-0 bond. If this occurs at the tips of preexisting microcracks, the cracks might propagate at stress levels much lower than normally required. Such enhanced crack growth could lead to time-dependent failure (Stottlemyre et a1. 1979).

\subsection{OXIDATION REACTIONS}

Natural subsurface environments tend to be relatively devoid of free oxygen. However, some water-dissolved oxygen will be available in ATES reservoirs. 0xidation reactions may produce relatively insoluble minerals that may, in turn, reduce permeability. Common reactions include the oxidation of ferrous iron oxides to hematite $\left(\mathrm{Fe}_{2} \mathrm{O}_{3}\right)$ and goethite $\left(\mathrm{HFeO}_{2}\right)$ and the oxidation of manganese suboxides to manganite $[\mathrm{MnO}(\mathrm{OH})]$ or pyrolusite $\left(\mathrm{MnO}_{2}\right)$. Insoluble iron and manganese hydroxides may deposit as jelly-1ike amorphous masses that consume large volumes of erstwhile pore space (UOP, Inc. 1975). Also of concern is the oxidation of lead sulfide (galena), zinc sulfide (sphalerite), and iron sulfide (pyrite). Pyrite often occurs in shales. The oxidation reactions produce sulfate ions and lower the $\mathrm{pH}$ of the water (Stottlemyre et al. 1979).

\subsection{BIOLOGICAL ACTIVITY}

Bacteria within injection water are troublesome for several reasons. Bacteria can form slimes that plug a formation or filters. Colonies of bacteria on pipe walls can form oxygen concentration cells that accelerate corrosion and pitting. Certain bacteria (sulfate reducers) under the proper conditions can form hydrogen sulfide. Introducing a sulfate reducer into an injection system or providing the proper nutrients to a system 
already containing the bacteria could result in production of hydrogen sulfide in the water. Hydrogen sulfide is extremely toxic and highly corrosive. It can cause problems in the injection system as well as in the production and heat exchanger system (Subcasky 1978).

Slimes produced by iron bacteria or other organisms are major causes of flow reduction in the well screen and near-wellbore region (UOP, Inc. 1975). Biofouling processes are discussed at length in Section 4.3.

\subsection{SUMMARY}

In sum, Table 3.2 identifies, ranks and exemplifies the mechanisms, both known and inferred, that may act to adversely affect the function(s) of aquifer thermal energy storage systems. Each mechanism listed is a generic chemical, physical or biologic process specifically related to the ATES cycle and range of environments. These processes, in general, may contribute to particulate plugging and loss of permeability. These mechanisms of system impairment are generic expressions of reactions which may occur in regional geohydrologic terranes. Section 5 comprises descriptions of ground-water characteristics within the nineteen water resource:s regions. 
TABLE 3.2. Physical, Chemical and Biological Processes That Can Impact Aquifer Thermal Energy Storage Systems

Estimated Relative

Importance

I (greatest)

II

II

I I

I I

II

II

I I

I I I

I I I

IV

IV (1east)
Mechanism

Particulate Plugging

Precipitation from working fluid (scaling)

Dispersion of clay mineral particles

Bacteria multiplication

Corrosion of metal components

Suspension and transport of existing fines

Mechanical erosion

Differential thermal expansion

Reservoir fatigue ${ }^{(a)}$

Hydrolysis of silicates, carbonates, and sulfates

Reservoir cement dissolution

Oxidation of reservoir or caprock minerals
Example

(See below)

Calcium carbonate, silica, barium sulfate precipitates

Montmorillonite expanded by freshwater

Sulfate-reducing bacteria, iron-oxidizing bacteria

Carbonic acid, sulfuric acid, oxidation, electrochemical

External silt, indigenous uncemented sediment

Sandface and near-wellbore region

Quartz vs. calcium carbonate

Static or cyclical dynamic stress-reduced strength

Orthoclase to kaolinite

Calcite, silica dissolved in water

Pyrite, galena, and sphalerite oxidized with generation of sulfate ions

(a) Coupled with differential thermal expansion 



\subsection{RESERVOIR AND SYSTEM BENEFICIATION}

Reservoir and system beneficiation refers to operating methods that minimize the effects of scaling, corrosion, biofouling, and particulate plugging (McCune 1977). Scaling tendencies are indicated by high $\mathrm{pH}$ and high concentration of ions such as barium, strontium, iron, magnesium, carbonate, and sulfate (McCune 1977; Vetter and Campbell 1979a). Corrosion problems are associated with dissolved and suspended iron compounds, presence of hydrogen sulfide, and low pH.

Scaling and corrosion may be interdependent (Kreitlow 1977). For example, corrosion products of copper, iron, and zinc tend to increase the rate of silica deposition. A layer of scale coating, which is thin, dense, adherent and complete, will greatly reduce the rate of corrosion. On the other hand, a patchy scale coating will tend to concentrate corrosion in the open areas and pitting will result. The corrosion rate of mild steel in water is greatly reduced by the formation of a thin adherent layer of calcium carbonate scale; this explains why hard water is less corrosive than soft water.

Biofouling or particulate plugging may originate from suspended organic materials or from inorganic minerals, especially clay particles.

The Drillers Journal (1965) describes procedures for maintaining the yields of water wells. These include 1) installation of well screens with high intake areas; 2) hydrochloric or sulfamic acid injection to dissolve scale; 3) bactericide injection to eliminate slime; and 4) addition of a sequestering agent to relieve silt or clay plugging.

\subsection{SCALING REACTIONS AND CONTROL TECHNIQUES}

The rate of scale formation is dependent upon ionic concentrations, temperature, solubilities, $\mathrm{pH}$, and the nature of the deposition surface (Kreitlow 1977). Silica is a common deposit from high temperature water, 
whereas calcium carbonate is more prevalent in lower temperature systems. More complex scales may involve other carbonates, sulfates, sulfides, oxides, hydroxides, and fluorides. Cations may include calcium, barium, strontium, iron, magnesium, and others.

Minerals identified in scales include aragonite $\left(\mathrm{CaCO}_{3}\right)$, siderite $\left(\mathrm{FeCO}_{3}\right)$, dolomite $\left((\mathrm{Ca}, \mathrm{Mg}) \mathrm{CO}_{3}\right)$, magnesite $\left(\mathrm{MgCO}_{3}\right)$, huntite $\left(\mathrm{CaMg}_{3}\left(\mathrm{CO}_{3}\right)_{4}\right)$, barite $\left(\mathrm{BaSO}_{4}\right)$, celestite $\left(\mathrm{SrSO}_{4}\right)$, anhydrite $\left(\mathrm{CaSO}_{4}\right)$, gypsum $\left(\mathrm{CaSO}_{4} \cdot 2 \mathrm{H}_{2} \mathrm{O}\right)$, quartz $\left(\mathrm{SiO}_{2}\right)$, hematite $\left(\mathrm{Fe}_{2} \mathrm{O}_{3}\right)$, magnetite $\left(\mathrm{Fe}_{3} \mathrm{O}_{4}\right)$, and fluorite $\left(\mathrm{CaF}_{2}\right)$ (Howard et al. 1978).

To prevent or minimize scale in a technically and economically feasible way requires a thorough knowledge of many of the reactions leading to its formation. Whatever the approach, it will probably be specific to only one of the individual scales formed in a given geothermal operation. For example, a chosen method may prevent the formation of $\mathrm{CaCO}_{3}$ scale, but may have no effect on the silica and heavy metal sulfides scales (Vetter arid Campbel1 1979a).

In addition, the method chosen to fight the individual scale must be compatible with the remaining fluids and operations within the field. This major requirement cannot be overlooked. Chemical brine alterations, e.g., adjusting the $\mathrm{pH}$ to low levels (prevention of carbonate scales) or to high levers (prevention of silica scale), may cause more operating problems than they solve. The same holds true when other methods, including the application of "threshold" inhibitors, are used to prevent sulfate or carbonate scales (Vetter and Campbell 1979a).

Experience in scale control at the East Mesa Geothermal Test Site, near Holtville, California (Lindemuth et al. 1976), may be applicable to similar situations involving ATES. After review of the potential and observed scaling problems with East Mesa brines, several conclusions were drawn:

- Calcium carbonate will precipitate when the brine is flashed, even though little temperature or concentration change results. 
- Barium sulfate will tend to precipitate when the brine is cooled below $212^{\circ} \mathrm{F}$ or concentrated more than approximately $20 \%$.

- Silica can be expected to precipitate, but only after the brine is concentrated above a silica concentration of $500 \mathrm{mg} / 1$ at $160^{\circ} \mathrm{F}$.

Successful concentration of the East Mesa brines required treatment to prevent $\mathrm{CaCO}_{3}$ and $\mathrm{BaSO}_{4}$ precipitation. Silica scaling did not appear to present problems until the brine was concentrated approximately 2.5 times.

In 1976, a concentrated effort was started to develop scale control techniques that would be effective in the brine handling systems and desalting plants. The first step in this program was a study of possible methods to be considered. The following subsections summarize these methods.

\subsubsection{Acidification}

Calcium carbonate deposition has been commonly controlled in cooling water systems and seawater desalting plants by neutralization of bicarbonate alkalinity with sulfuric acid. This method has three distinct disadvantages for the East Mesa geothermal brines. First, the addition of sulfuric acid raises the sulfate concentration in the treated brine, thus compounding problems with barium sulfate. Complete neutralization of the bicarbonate alkalinity may add enough sulfate ion to increase the $\mathrm{BaSO}_{4}$ ion activity product to $1.1 \times 10^{-8}$, which exceeds the solubility 1 imit by approximately 10 times. Howard et al. (1978) prefer hydrochloric acid addition to avoid sulfate precipitation. Second, neutralization of the brine alkalinity increases corrosion problems in the process equipment, both in the brine and in the vapor contact areas. Finally, acidification creates inherent safety problems in the handling of large amounts of corrosive chemicals.

\subsubsection{Slurry Seeding}

A second treatment technique involves the selective precipitation of calcium and silica from the wellhead brine. This method involves adding lime and magnesium oxide to the brine. The resultant precipitate of calcium 
carbonate and magnesium hydroxide is then removed by settling and filtration. Calcium is removed as the insoluble carbonate and silica is reduced, due to absorption on the magnesium hydroxide in the settler: This method suffers from several drawbacks. First, the process would generate largle amounts of sludge, 300 to 600 tons/day for a 1-million gal/day plant. Second, some of the thermal potential of the brine would be lost in the process through the addition of cold reagents and the discharge of sludge. In addition, both the chemistry and fluid dynamics of this process have yet to be demonstrated on geothermal brine.

\subsubsection{Chelation}

Another possible technique is to chemically tie up the calcium and barium with a chelating agent to prevent precipitation. This technique was tried at East Mesa during treatment screening tests in March 1976. The results of this trial indicated the calcium carbonate deposition would be eliminated by use of a chelating agent, but that barium still was precipitated from the brine. This was expected, because the chemical affinity of chelating agents is lowest for barium. In addition, corrosion of the steel evaporator internals increased. The use of chelating agents also involves high operating costs, because the chemical itself must be fed at a stoichiometric ratio to the divalent cations in the brine solution. For these reasons, the use of chelating agents was discarded.

\subsection{4 "Threshold Treatment"}

The scale control method finally selected uses the so-called "thresinold" chemicals that are added to the evaporator feed brine. Threshold chemicals operate by preventing or impairing the crystal growth that would normally occur in a supersaturated solution. This is a surface active phenomenon and, thus, does not require a stoichiometirc relationship to the precipitating species. Crystal nucleation is not prevented but, rather, the growth of those crystals is inhibited; thus, no visible precipitate that might stick to process equipment is formed. This type of scale control treatment has been widely used in steam boilers and circulating water systems for many years. 
Compounds that exhibit this "threshold" effect are sodium and potassium pyrophosphates (polyphosphates), salts of acrylic and methacrylic acids, and various aminoethyl and aminoethylene phosphonates. The selection of the proper compound is usually based on temperature stabililty, compatibility with major brine chemistry, and cost. An additional advantage of this method is that the feeding equipment is compact and simple.

\subsubsection{Other Treatments}

Vetter and Campbell (1979a,b) have controlled $\mathrm{CaCO}_{3}$ wellbore scale deposition by pumping and precipitation of calcium phosphonate by addition of an inhibitor at the wellhead.

The use of conventional water softening through zeolite ion exchange of $\mathrm{Na}^{+}$for $\mathrm{Ca}^{++}$may be considered as a reasonable option to eliminate calcium carbonate.

Cuellar (1975) reported that silica can be precipitated in a retention pond. Concentration was reduced from $225 \mathrm{ppm}$ to $200 \mathrm{ppm}$ over a 3-month interval. This procedure does not appear applicable to ATES with respect to either concentration or time requirement.

Bishop and Bricarello (1976) found that scale deposited during the operation of a geothermal power plant could be removed by using high pressure water in combination with chemical softening.

Major problems exist in downhole geothermal experimentation with scale inhibitors (Vetter and Campbe11 1979a):

- Downhole applications of the chemicals in a flowing well are costly and not without risk to the well itself.

- Compatibility problems between the inhibitors and various components of the brine can lead to serious operating problems and costly subsequent workovers. 
- The hardware required to apply the inhibitors downhole is not yet developed or proven for the special flow conditions in a geothermal we11.

- The necessary information to apply the "squeeze" inhibition technique is not yet available.

- The required hydrothermal stability of the inhibitors has not yet tieen proven or even measured in laboratory experiments.

- The efficiencies of the large number of commercially available inhibitors under the high bottomhole temperatures have never been measured. It is not feasible economically and timewise to measure the efficiency of a large number of inhibitors in actual well tests.

\subsection{CORROSION PROCESSES AND CONTROL MEASURES}

Corrosion processes and control measures were described in "Corrosion of $0 i 1$ and Gas-Well Equipment" (NACE 1958). Four types of corrosion are recognized: 1) carbonic acid corrosion, which is attributed to carbon dioxide and water, possibly exacerbated by low molecular-weight organic acids such as acetic acid; 2) sulfuric acid corrosion, attributed to hydrogen sulfide and water. Presence of carbon dioxide or oxygen accelerates the reaction; 3 ) uxygen corrosion caused by oxidation of metal in the presence of water; and 4) electrochemical corrosion, which involves separation of positive ions from a metal surface exposed to an electrolyte. These processes and control measures are described in more detail in the next four subsections.

\subsubsection{Carbonic Acid Corrosion}

Generation of carbonic acid and subsequent reaction with iron or steel to form iron carbonate is shown below:

$$
\begin{aligned}
& \mathrm{CO}_{2}+\mathrm{H}_{2} \mathrm{O} \rightarrow \mathrm{H}_{2} \mathrm{CO}_{3} \\
& \mathrm{Fe}+\mathrm{H}_{2} \mathrm{CO}_{3}+\mathrm{FeCO}_{3}+\mathrm{H}_{2} \uparrow
\end{aligned}
$$


Although low molecular-weight organic acids accelerate this process, they are not considered the primary cause of carbonic acid corrosion. A partial pressure of carbon dioxide between 7 and 30 psi may indicate corrosion; a partial pressure above 30 psi usually indicates corrosion. Carbonic acid corrosion may take the form of pitting, grooving or "sand-cutting". The latter is a combined corrosion-erosion process. Corrosion may be recognized at the surface by increased content of iron in produced water. Exposure of steel test coupons to the water is another diagnostic method.

Carbonic acid corrosion can be controlled with corrosion inhibitors, alloys resistant to carbonic acid, and protective coatings. Most inhibitors are the polar organic type and are oil-soluble, water-dispersible, or water-soluble. Nine-percent chromium steel is used where inhibition is difficult. Use of all high-strength tubing is not always feasible because of loss of ductility. High chromium stainless steel, copper alloys, and nickel alloys are used in wellhead equipment. Baked phenolic coatings may be applied to well tubing as an alternative to use of inhibitors or alloys.

\subsubsection{Sulfuric Acid Corrosion}

Sulfuric acid corrosion occurs when hydrogen sulfide and water react to produce sulfuric acid, and iron subsequently reacts with the acid to form iron sulfide. The overall simplified reaction is shown below, assuming total consumption of the intermediate phase sulfuric acid.

$$
\mathrm{H}_{2} \mathrm{~S}+\mathrm{Fe}+\mathrm{H}_{2} \mathrm{O} \rightarrow \mathrm{FeS}_{\mathrm{x}}+\mathrm{H}_{2} \uparrow
$$

Metals other than iron also react in essentially the same way to produce like metal sulfides. In the above example, the iron sulfide is a black powder or scale that adheres to the iron or steel surface. The scale tends to cause a local acceleration of corrosion because the iron sulfide is cathodic toward the steel. This reaction causes deep pitting. A further attack is caused by hydrogen embrittlement of the steel; this leads to blistering and cracking. Although neither oxygen nor carbon dioxide is necessary to cause sulfide corrosion, one is always present where the 
process occurs rapidly. Sulfuric acid corrosion may be identified by presence of hydrogen sulfide in extracted water and corrosion of surface equipment. Pitting, scaling and perforation may occur. Sulfide corrosion cracking of casing may occur (NACE 1954).

Sulfuric acid corrosion can be controlled with inhibitors, alloys, and nonmetallic materials. Chemical inhibition is the most widely used methad. Because corrosion is a surface reaction, any modification of the steel-fluid interface will affect corrosion rate. Most inhibitors have an active polar group on one end of the molecule, which adsorbs to the metal, and an oilsoluble tail, which extends into the fluid flow region. The oil-soluble tails coalesce to form a protective oil film that prevents water from contacting the steel. Water-soluble inhibitors are also available. Various alloys of iron, molybdenum, nickel, and aluminum successfully resist sulfide corrosion. However, hard ferritic steels are subject to sulfide cracking and should not be used under severe conditions.

Nonmetallic material and coatings have been proven effective. These include structural plastics for tubing, tanks, and line pipe. Vinyl copolymers, epoxy, acetate butyrate, and other resins, some with glass reinforcement, have been used. Plastic deformation and flammability must be considered. Protective coatings have been used in flood- and injectionwater systems. Coal tar, lead-impregnated vinyl copolymers, furan-based coating, and baked phenolic materials have been used economically. Epoxy and epoxy copolymers are promising.

\subsubsection{Oxygen Corrosion}

The oxygen corrosion reaction occurs when iron combines with oxygen and water to form goethite, $\mathrm{FeO}(\mathrm{OH})$, or hematite, $\mathrm{Fe}_{2} \mathrm{O}_{3}$. The reaction can be explained as follows:

$$
2 \mathrm{Fe}+3 / 2 \mathrm{O}_{2}+\mathrm{H}_{2} \mathrm{O} \rightarrow 2 \mathrm{FeO}(\mathrm{OH}) \rightarrow \mathrm{Fe}_{2} \mathrm{O}_{3}+\mathrm{H}_{2} \mathrm{O}
$$

The rate of this reaction depends upon the degree of protection afforded by the corrosion product. Contact of the metal surface by acid-forming gases, such as hydrogen sulfide and carbon dioxide, usually increases the rate. 
Oxygen and fluctuating stresses (fatigue) are considered the principal causes of failure in drill pipe. Pits caused by oxygen corrosion and "service scars" concentrate local stresses and cause fatigue cracking. oxygen in drilling mud causes corrosion fatigue. Fluid-cutting rapidly enlarges even a tiny perforation until pipe failure occurs. Surface equipment is subject to exterior oxidation.

Control of oxidation is gained by use of corrosion inhibitors, resistant alloys, and protective coatings. Inhibitors include sodium chromate or dichromate, sodium nitrite, polyphosphates, silicates, soluble oils, and organic compounds. Resistant metals used for surface equipment include brass, copper, aluminum alloys, and galvanized steel. Protective coatings may be metalic or nonmetallic. Metallic coatings include chemically deposited metal oxides, hot-dip zinc, or electroplated chromium, cadmium, or zinc. Nonmetallic coatings include paints, varnishes, enamels, lacquers, plastics, bitumens, and inorganic pigments.

\subsubsection{Electrochemical Corrosion}

Electrochemical corrosion can occur when a pipe or casing is exposed to two different environments. For example, iron exposed to an aerated solution may be uncorroded and thus act as a cathode, whereas the same iron exposed to an unaerated solution corrodes and acts as an anode. This effect may occur beneath a single drop of salt solution on an iron surface; the outer ring of the drop does not corrode because oxygen content is highest, but metal under the thick portion of the drop corrodes. This type of pitting action is called "concentration cell" corrosion. When oxygen is the agent causing the damage the cell is called an "oxygen concentration cell". However, if the galvanic effect is caused by variation in metal composition, it is referred to as a "metal concentration cell." When copper corrodes, the metal ion concentration has considerable effect.

\subsubsection{Soil Corrosion of Pipe and Surface Equipment}

The characteristics of soil can affect corrosion. In the cells mentioned previously there was also some sort of a salt present, and these 
salts participated in the current flow. Pure water is a poor conductor of electricity, and corrosion in pure water is considerably different from what would ordinarily be experienced when salts are present. Sandy soils very frequently have no salt present, with the result that very little current flows, and no significant pitting and localizing of attack occurs.

of course, water must be present to allow appreciable currents to flow through the soil. Steel does not corrode in very dry weather. In the same way, corrosion in very dry soils is negligible. Water and the high concentrations of salt account for the severe corrosion found where lines go urider slush pits. Oxygen is still the real corrosive agent; the water and the salt allow it to act and pit the steel.

Limestone has still another effect. It allows a chalky layer (calcareous) to form a somewhat protective coating on the pipe in the cathodic area. This reduces the amount of surface available for reaction and thus decreases corrosion. Organic material, like decaying vegetation, is generally acid. At the same time, there is a deficiency of oxygen, which, when combined with the acidity, results in severe pitting of the oxygen concentration cell type. This effect makes it desirable to insulate from each otier those sections of pipe exposed to markedly different soil conditions-.unless, that is, both sections are under good cathodic protection.

Not only is pipe affected by electrochemical corrosion, but so is all steel equipment in contact with the soil. Large areas of tank-bottom surfaces are exposed to soil that has little access to oxygen. This leads to severe tank-bottom corrosion.

\subsubsection{Casing Corrosion}

Casing is, in one sense, the last line of defense. Hence, casingl corrosion, internal or external is a serious matter.

External corrosion has been ascribed to an electochemical type of attack resulting from a current transfer caused by a potential difference 
between two parts of a well. These potential differences may be between:

- casing in contact with one formation and another

- casing in contact with one formation and a mud cake

- surface flow line and casing

- surface pipe and casing

- areas of dissimilar metallurgy.

Electrochemical action may occur between two formations. In the anode area, oxidation takes place as iron ions go into solution in one formation as a product of corrosion. In the cathode area, reduction takes place and hydrogen atoms are formed at the boundary between the pipe and the other formation. The flow of current is into the formation at the anode or corroding area and into the pipe at the cathode. As this battery action takes place, the layer of hydrogen developed on the cathode offers a resistance to the flow of current in the cell. The cathode thus has been polarized. This polarizing film can be removed by mechanical action or by adding a depolarizing agent that reacts with and removes this hydrogen film. Such an agent must be present for this corrosion reaction to proceed at a rate sufficient to cause a severe corrosion problem. Two common depolarizing agents are oxygen, which reacts with hydrogen, and certain bacteria, which use atomic hydrogen as part of their life process.

When the surface line pipe or a portion of the casing or surface pipe down to a few hundred feet in the well is the cathode, oxygen is an obvious depolarizing agent. When the cathode is at greater depths, it seems likely that the sulfate-reducing bacteria are a major factor in casing corrosion. They may be in the wells originally or be introduced through the mud system. The role of sulfate-reducing bacteria as a factor in causing corrosion is still controversial. 


\subsubsection{Recognizing Electrochemical Corrosion}

Although there are no foolproof ways to determine whether or not electrochemical corrosion caused damage to a piece of equipment, there are common features to this type of attack. On pipe the best indication is isolated areas of severe pitting. On other equipment, such as a valve, severe corrosion at the junction of dissimilar metals may indicate bimetallic attack. Corrosion-erosion can sometimes be confused with bimetallic corrosion, although there are generally indications of velocity effect.

Observations of the ground features can supply valuable information. Areas with heavy vegetation, poorly drained soil, or those contaminated by oil-well brines are possible trouble spots. These should be examined first if damage is suspected.

Control measures are concerned with breaking, reducing, or reversing the direction of current flow. The former can be accomplished in many cases by taking adequate precautions during the design stage of installations. The reversal of current flow is accomplished by cathodic protection (NACE 1958).

\subsubsection{Design}

To minimize well-casing corrosion, it is generally desirable to insulate electrically the surface lines from the well equipment. The surface lines are generally cathodic, while the casing in favorable strata is the anode. It sounds simple to insulate the casing from the surface equipment, but adequate insulating is usually difficult.

Meter bypasses, bolts at flanges, grounded neutrals of the electrical system, remote indicating devices, small inhibitor lines, etc., may also completely nullify efforts to insulate the casing. Electrical grounding necessary as protection against short circuits can be attained by connecting the ground wire to one or several magnesium anodes. If there is a ground wire, such as the grounded center of a 4-wire 3-phase star connection or a 
3-wire 110-220 volt line, there is no adequate way to ground electrically and still keep the casing insulated from surface equipment.

If it is known that a particular shallow zone is always corrosive in a given area, it may be economical to run surface pipe a little deeper to protect against the offending zone.

The corrosion reaction caused by underground water zones can sometimes be stopped or minimized by cementing off the offending zone. If it is suspected that water is moving from one zone to another through a path along the casing, cementing is probably the best solution.

In some areas, where sulfate-reducing bacteria are thought to be a major factor in causing corrosion, a bactericide can be incorporated into the mud system during completion of the well to kill the bacteria.

\subsubsection{Inhibition of Corrosion by Inorganic Precipitation}

At the Reykjavik Municipal Heating Service, with average temperature of $87^{\circ} \mathrm{C}$, a water buildup of protective coatings on pipe surfaces is credited with preventing corrosion (Hermannsson 1970). The coatings always contain $\mathrm{MgO}$ and variously contain $\mathrm{SiO}_{2}, \mathrm{Fe}_{3} \mathrm{O}_{4}$, copper silicate, and so-called "metal oxide." The protective coating may form on a clean metal surface or over a layer of corrosion product. The thermal water contains a very high content of sodium silicate believed to inhibit corrosion. Addition of sodium silicate to water to protect against corrosion has been accepted practice in the U.S. for 60 years; the concentration, 8 to $20 \mathrm{ppm}$ at the start, may be later reduced to $4 \mathrm{ppm}$.

The inhibition of corrosion of carbon steel by deposition of a silica scale was reported by Treseder and Wieland (1976).

\subsection{BIOFOULING PROCESSES AND CONTROL MEASURES}

The role of bacteria in the corrosion of oil field equipment has been extensively studied (NACE 1976). Four generic categories are described: sulfate-reducers, slime-forming bacteria, iron-oxidizing bacteria, and miscellaneous organisms. Each is considered with respect to biologic 
identity and behavior; environmental impact; and treatment. Quantitative analysis of bacteria types and concentrations and specific microbiocidal measures are beyond the scope of this document.

\subsubsection{Sulfate Reducers}

Sulfate-reducing bacteria are extremely small organisms that reduce the inorganic sulfate ion. These bacteria belong to the genera Desulfovibrio and Clostridium. Both organisms are obligate (strict) anaerobes. These bacteria corrode iron in the presence of sulfate ions in aqueous solution as follows:

$$
4 \mathrm{Fe}+\mathrm{SO}_{4}=+4 \mathrm{H}_{2} \mathrm{O} \rightarrow \mathrm{FeS}+3 \mathrm{Fe}(\mathrm{OH})_{2}+2 \mathrm{OH}^{-}
$$

The ferrous hydroxide can be further oxidized to ferric hydroxide by dissolved oxygen in aqueous solution:

$$
4 \mathrm{Fe}(\mathrm{OH})_{2}+\mathrm{O}_{2}+2 \mathrm{H}_{2} \mathrm{O} \rightarrow 4 \mathrm{Fe}(\mathrm{OH})_{3}
$$

Some of the common places in an oil field to look for sulfate-reducing bacteria are:

- stagnant points in flowlines

- under scale deposits or debris in low velocity flowlines, wash tanks, crude $0 i 1$ storage tanks, and water storage tanks

- under the sludge or in the mud at the bottoms of pits

- in sand and gravel filters

- around packers, in the annular space fluid behind the packers, and behind the casing in soil and drilling mud

- at the oil-water interfaces in heat-treaters and oil storage tanks

- within the backfill outside buried pipelines.

Indications of sulfate-reducing bacteria at work are as follows:

- Injection water gradually turns acid, shows increased dissolved sulfide content, or turns black. 
- Abnormal decline in injectivity occurs, along with increased frequency of remedial acid jobs.

- Rapid deterioration of metal in the system takes place, especially in stagnant zones.

- Large amounts of black water and stringy black slime are produced during backflowing of wells.

- Corrosion by sulfate reducers is evidenced by the presence of iron or sulfide, deep pitting, and modules.

Other impacts of sulfate-reducing bacteria include depolarization of cathodes in "corrosion cel1s" by oxidizing and thus removing hydrogen in the presence of organic material; and formation of acetic acid concentration cells.

The following steps are recommended to neutralize sulfate-reducing bacteria:

- clean the system by flushing and addition of surfactants

- backflow injection wells

- acidize injection wells

- backwash filters periodically

- eliminate stagnant zones in the water system

- treat with an effective microbiocide.

\subsubsection{Slime-Forming Bacteria}

Slime-forming bacteria are not restricted to one or several genera, and are difficult to characterize as a separate group of microorganisms. They obtain energy from organic sources such as alcohols, sugars, acids, and hydrocarbons. These bacteria become a problem when they are abundant enough to plug injection wells and filters, and create a corrosive environment by forming concentration cells.

Many oil field waters fulfill the physical and nutritional needs of slime-forming bacteria; therefore, slime formation is fairly common. These 
organisms can exist in fresh water or brine, although they are more common in waters of low salinity. Certain types of slime-forming organisms grow only in aerobic systems, while others grow only in anaerobic systems. On the other hand, many grow well in either environment. Common places where slime-forming bacteria occur in an oil field are listed below:

- open ponds - Mucous-1ike masses are often observed floating on open ponds. These masses usually occur around the edges and may be white, yellow, red, brown, or black. If algae are present, green masses may be observed.

- supply wells - Slime masses, similar to the above, may also be found in water from supply wells, particularly shallow wells carrying dissolved oxygen.

- filters - Large masses of viscous material accumulated on filters can indicate the presence of slime-formers. When this material is black, sulfate-reducers may also be present. Red, orange, or brown masses may be produced by iron-oxidizing bacteria. White or grey slime may also occur.

- lines and equipment - Slime masses may adhere to the sides of pipes.

- injection wells - Slime masses may plug injection wells. It is advisable to catch a backflow sample and analyze it for slime-forming organisms.

- 0il-water interfaces in free-water knockouts, heat treaters, or storage tanks, may support slime-forming bacteria.

Slime-forming bacteria cause plugging of filters and injection wells, and formation of concentration cells.

Plugging of filters and injection wells is often the first indication that slime-formers are present. Plugging is the major problem associated with slime formation in an oil field. Plugging of a formation by bacterial slime does not generally respond well to remedies such as acidizing or surfactant treatments. Backflushing may be more effective. If the problem 
is severe, a fracturing job may be the only way to restore an injection well to its initial state.

Slime masses adhering to the sides of lines and equipment may cause corrosion by the formation of concentration cells. This problem may be particularly severe in aerobic systems where oxygen concentration cells form. Corrosion in this fashion is not related to enzymatic activity as is the case with sulfate reducers, but is caused by shielding of the metal surface. This shielding of the surface in an aerobic system can also help provide a localized anaerobic area suitable for the growth of sulfatereducers.

Control measures for slime-forming bacteria are similar to those used for sulfate-reducers. A combination of physical cleanup, revised mechanical changes, and microbiocide application may be required to produce satisfactory results.

\subsubsection{Iron-0xidizing Bacteria}

Iron-oxidizers are aerobic, but they may grow in systems with less that $0.5 \mathrm{ppm}$ oxygen where they often contribute heavily to slime formations. They occur in open ponds, supply wells, filters, lines and equipment, and injection wells. They are characterized by the ability to oxidize iron from the ferrous to the ferric state and to precipitate it as a coating, according to the following equation:

$$
4 \mathrm{FeCO}_{3}+\mathrm{O}_{2}+6 \mathrm{H}_{2} \mathrm{O} \rightarrow 4 \mathrm{Fe}(\mathrm{OH})_{3}+4 \mathrm{CO}_{2}
$$

This coating and the slime masses associated with it set up oxygen concentration cells that cause corrosion and may establish an anaerobic environment for sulfate-reducers.

These organisms are typically found in fresh water; however, they occasionally occur in brine. Most problems have occurred in fresh water injection systems. These bacteria may cause plugging of source wells on injection wells, requiring expensive remedial treatment. Iron-oxidizing bacteria are aerobic, but may grow in systems having only a few tenths ppm 
of dissolved oxygen. In this type of system, they often contribute heavily to slime formation.

Some common places where iron-oxidizing bacteria occur in an oil field are:

- open ponds - When rusty water is observed, the cause may be ironoxidizing bacteria (or it may be chemical in origin). Iron-oxidizing bacteria often produce masses of yellow-orange slime, which is suggestive of their presence, but the best positive identification is by microscopic examination.

- supply wells - The same symptoms are observed in supply wells containing oxygen.

- filters - A quick buildup of differential pressure may be due to slime or iron oxide formed by iron bacteria. This material is often yelloworange to brown and should be examined microscopically.

- lines and equipment - Iron-oxidizing bacteria may produce slime or iron-oxide scale on lines and equipment.

- injection wells - As in the case of any microorganism found in injection waters, iron bacteria may plug injection wells by accumulation on the formation face. Examination of the backflow material from these wells is the best way to establish the cause of trouble.

Iron-oxidizing bacteria cause problems by plugging of filters and injection wells, and formation of concentration cells.

Plugging of filters and injection wells is often a good indication that iron-oxidizing bacteria are present. Indeed, plugging is the major problem associated with iron-oxidizing bacteria in the oil field. In addition to causing plugging problems, slime masses adhering to the sides of 1 ines and equipment may cause corrosion by the formation of concentration cells. This problem may be particularly severe in aerobic systems where oxygen concentration cells form. Corrosion in this fashion is not related to enzymatic activity as is the case with sulfate-reducers, but is caused by shielding of 
the metal surface. This shielding of the surface in an aerobic system can also help provide a localized anaerobic area suitable for the growth of sulfate reducers. The above discussion indicates that it is important to detect slime formation in its early stages and determine if there is a problem or a potential problem.

Control measures for iron-oxidizing bacteria are similar to those used for sulfate-reducers; a combination of physical clean-up, mechanical changes, and microbiocide application may be required to give satisfactory results.

\subsubsection{Miscellaneous Organisms}

The organisms described in the following paragraphs are often found in oil field water. They may contribute to plugging problems and may cause corrosion by concentration cells; they do not usually cause the severe problems attributed to the previously discussed organisms.

\subsubsection{Algae}

Algae are simple forms of plant life, e.g., green scum in ponds and reservoirs. They are encountered in cooling towers and, in petroleumproduction operations, may contribute to plugging of the formation in water injection systems. Algae manufacture their food by photosynthesis; therefore, their growth is possible only in systems exposed to light. They are found in all types of water, from fresh to brine, and exposed to wide variations of temperature.

\subsubsection{Sulfur Bacteria}

Sufide-oxidizing bacteria occur in several forms; however, they can be considered as two large classes: 1) the aerobic (colorless sulfide oxidizers), and 2) the anaerobic (colored sulfide oxidizers).

Beggiatoa is the best known aerobic colorless sulfide oxidizer. It is found in waters containing hydrogen sulfide, particularly where gathering lines dump into open pits. Beggiatoa is characterized by a grey slime that 
can plug filters. Moreover, this organism is able to produce sulfates in the sulfur cycle; thus, it may provide the nutrient for sulfate-reducing bacteria. Beggiatoa is easily controlled by microbiocides.

The anaerobic, colored sulfide oxidizers, are represented by Chlorobium (green) and Chromatium (purple). Both are anaerobic and require sunlight to carry out photosynthesis. Little is known about these organisms in water injection systems; however, they may contribute to biological fouling. They are easy to control by microbiocidal treatments. Some microorganisms also exist that can oxidize sulfide directly to sulfur.

\subsubsection{Yeast and Molds}

Differentiation between yeasts and molds is sometimes difficult. Here it is sufficient to consider yeasts as unicellular plants with ovoid $\mathrm{cr}$ spherical cells and molds as plants growing in filaments consisting of many cells. Many yeasts and molds grow in both the yeast phase and the filamentous phase--a condition known as dimorphism. Most yeasts and molds found in water injection systems are similar to algae but colorless. They often form a portion of the biological slime found in water injection systems, but they are not generally the major source of the problem. On the other hand, molds are commonly found in cooling systems where they are associated with wood decay, and they often require treatment.

\subsubsection{Protozoa}

Protozoa are the simplest forms of animal life. They are found in both salt and fresh water and can be easily identified microscopically. In water injection systems protozoa are found in open pits and in open tanks. Filters often contain them in large numbers. Generally, the control of other microbial populations suffices to control protozoa.

\subsubsection{Nitrate-Reducing Bacteria}

Nitrate-reducing bacteria (Gass 1977) occur near the surface. These organisms feed on nitrates in the soil and can initiate corrosion of the metal casing. Microbiocidal treatment outside the casing may be indicated. 


\subsection{PARTICULATE PLUGGING}

Particulate plugging may be caused by silt suspended within the ground water (Jorda 1980), fines indigenous to the formation (possibly released by solution of cement), inorganic precipitates deposited by the ground water (scaling due to temperature, pressure or composition change), solids generated by interaction of the ground water with metal components (corrosion due to chemical reactivity), solids generated by dispersion of clay particles, organic matter resulting from bacterial multiplication, and particles formed by addition of chemicals (phosphonates, polyacrylates, calcium flouride, etc.) (Subcasky 1978; Vetter 1979).

Scaling, corrosion, and biofouling have been addressed in the previous sections. Particulate plugging attributable to indigenous or foreign inorganic finely divided crystalline or glassy material can be anticipated by petrologic examination of the aquifer under temperature, pressure, and fluid flow conditions that simulate ATES operation. Foreign fines can be avoided by using the connate water of the aquifer as the working fluid. Indigenous fines are not likely to cause inhibited performance except at and near the wellscreen/sandface region. Four locations of particulate plugging are important: 1) aquifer interstices in the near-wellbore region; 2) aquifer-wellbore intersection; 3) wellscreen perforations; and 4) wellbore cross section in the injection/withdrawal zone. Proper well completion with reaming to sufficient diameter and gravel packing should alleviate particulate plugging. In extreme cases, soil-fixing by inorganic or organic cementation may be required, probably before well completion, to prevent the chance of post-completion plugging.

Particulate plugging associated with adverse clay mineral reactions was summarized in Section 3.3. The principal points are reiterated below. Dispersion of clay mineral aggregates (also called flocculates) can supply particles that migrate and plug intergranular connected microchannels. The means by which this dispersion occurs are related to clay mineral species and exchangeable cation compositions. The general order of dispersibility of clay minerals is as follows: montmorillonite > degraded and mixed-layer 
clay minerals $>$ illite $>$ kaolinite (Moore 1960). The relative replacing power of one cation by another is shown in the following series:

$$
\mathrm{Li}^{+}<\mathrm{Na}^{+}<\mathrm{K}^{+}<\mathrm{Mg}^{++}<\mathrm{Ca}^{++}<\mathrm{H}^{+} \text {. }
$$

The exchangeable cations $\mathrm{Ca}^{++}, \mathrm{Mg}^{++}$, and $\mathrm{H}^{+}$increase the attractive force between clay sheets, thus decreasing the thickness of the separating 'water $f i 1 \mathrm{~m}$, whereas $\mathrm{Na}^{+}$and $\mathrm{Li}^{+}$decrease the attractive force between the sheets and increase the thickness of the interlayer water. Therefore, montmorillonites carrying $\mathrm{Na}^{+}$and $\mathrm{Li}^{+}$cations have the greatest tendency to expand and disperse, and kaolinites carrying $\mathrm{Ca}^{++}, \mathrm{Mg}^{++}$, and $\mathrm{H}^{+}$have the greatest stability. Potassium-carrying clays tend to show good stability.

A change in the chemistry of the immersing water can bring about clay mineral dispersion (Mungan 1965). A sudden transition from a brine, sodium hydroxide, or ammonium hydroxide solution to fresh water can cause clay particle dispersion. In contrast, parameters that promote flocculation are both high and low pH, and presence of electrostatic charges (Moore 1960; Hewitt 1963).

The swelling characteristics of clay minerals may also occur in other layered minerals such as mica, chlorite and talc (Reed 1977). Mica particles are made up of layers that are spaced about $10 \AA$ between repeating layers. Normally, potassium ions are adsorbed at the interface between the layers. When these ions are exchanged with larger hydrated ions such as sodium or calcium ions, the spacing between repeating layers expands to about $15 \AA$. The only way for potassium to exit the particle is between the layers in the expanded region that has been potassium-depleted. Thus, the alteration process is one of potassium diffusing from a central unaltered core through the expanded rim to the leaching solution at the particle's edge. Because the expanded rim of a partially altered mica particle is about $50 \%$ thicker than the unaltered core, severe bending stresses tend to fray the edges of the particle, causing small expanded particles to break off and disperse in the ambient fluid. Dispersed particles flow downstream with the fluid, lodge in pore throats, and restrict fluid flow. This bending and expanding process also stresses and breaks down natural cement, 
which, in turn, causes other small mineral particles to migrate and plug pore channels (Reed 1977).

From the standpoint of reservoir performance, the complete absence of all clay minerals is preferable. According to Moore (1960), even 1 to $4 \%$ of water-sensitive clays in a fine-grained sandstone may completely plug the formation if injection fluid solute cations are not compatible with the clay species. Mungan (1965) found that even $0.4 \%$ of kaolinite can cause significant permeability impairment when it is exposed to adverse salinity change. Because some clay minerals are likely to reside among the quartz grains, it is desirable to reinject only connate water. Softening of calcium-rich water by replacement of $\mathrm{Ca}^{++}$with $\mathrm{Na}^{+}$ions could cause severe clay swelling. Likewise, extraction of $\mathrm{Ca}^{++}$ions by surface seeding and precipitation could cause clay swelling because of effective water dilution.

It is important to study the mineralogy of the reservoir in detail before establishing the chemistry and temperature of water reinjection. In the event that silicates, such as feldspar, hornblende and pyroxene, are present in the reservoir, the possibility of hydrothermal alterations to clay minerals and other similar layered minerals should be examined (Stottlemyre et al. 1979). 



\subsection{OVERVIEW OF REGIONAL HYDROLOGY}

Hydrologic provinces of the U.S. were examined for solute chemistry and total salinity of ground waters in near-surface and deep aquifers. In this section, a general overview of aquifer water chemistry is followed by detailed province descriptions containing specific information applicable to aquifer thermal energy storage.

\subsection{OVERVIEW OF CHEMISTRY}

Usually salinity is less in unconfined surface aquifers than in confined deeper aquifers. Recharge from rainfall and meltwater tends to limit near-surface salinity by dilution. The most important factors affecting solute concentration and species are reservoir mineral composition, chemistry of mixing waters, and temperature. Solute precipitation and natural ion exchange can modify ground-water chemistry. Ground-water contamination due to man's surface activities is not likely to impact intermediate depth and deep aquifers.

Ground-water quality is determined by the content of dissolved solids. Water containing less than $1,000 \mathrm{mg} / 1$ of dissolved solids is considered to be fresh, whereas water containing more than $1,000 \mathrm{mg} / 1$ is judged to be saline. The following classification is used by the U.S. Geological Survey:

$\frac{c}{\text { Class }}$
Fresh
Slightly saline
Moderately saline
Very saline
Briny

Dissolved solids $(\mathrm{mg} / \mathrm{l})$

$0-1,000$
$1,000-3,000$
$3,000-10,000$
$10,000-35,000$
$>35,000$

Ground-water chemistry relates to the composition of dissolved solids. The most common ions and radicals in ground water are $\mathrm{Ca}^{++}, \mathrm{Mg}^{++}, \mathrm{Na}^{+}, \mathrm{K}^{+}$, 
$\mathrm{Cl}^{-}, \mathrm{CO}_{3}{ }^{-}, \mathrm{HCO}_{3}{ }^{-}, \mathrm{SO}_{4}{ }^{-}$, and $\mathrm{NO}_{3}{ }^{-}$. In specific terranes silica, iron, manganese, oxygen, hydrogen sulfide and carbon dioxide may be important. constituents. Minor and trace elements may include $\mathrm{Al}, \mathrm{Ag}, \mathrm{As}, \mathrm{Au}, \mathrm{B}, \mathrm{Ba}$, $\mathrm{Br}, \mathrm{Cd}, \mathrm{Co}, \mathrm{Cr}, \mathrm{Cu}, \mathrm{F}, \mathrm{Hg}, \mathrm{I}, \mathrm{Li}, \mathrm{Mo}, \mathrm{Nb}, \mathrm{Ni}, \mathrm{P}, \mathrm{Pb}, \mathrm{Pt}, \mathrm{Sc}, \mathrm{Se}, \mathrm{Sr}$, Th, $\mathrm{Ti}, \mathrm{U}, \mathrm{V}, \mathrm{W}, \mathrm{Y}, \mathrm{Zn}, \mathrm{Zr}$. (a)

Water may be classified as atmospheric, meteoric, surficial, vadose, phreatic, connate, or juvenile. Ground water is, by definition, phreatic or connate. Presumably, the great majority of the ground-water volume has passed through the evaporation-condensation cycle at the earth's surface. The original character of the water is modified by its traverse through the vadose and phreatic zones. Its chemical condition in any subsurface reservoir has been created by interactions with solid and fluid crustal substances. These interactions involved solution, precipitation, and fluid mixing.

Contact between water and rock is a dominant condition affecting water chemistry (Bedinger and Sniegocki 1976). Rock mineralogy, time, temperature, specific surface, and water volume determine the final composition. Hydraulic conductivity and transmissivity influence the rate of water flow and the time of contact between a volume of ground water and an aquifer (Bloyd 1974). The rate of water transmission is likely to be more rapid through secondary than primary channels. (Primary channels are caused by original permeability such as bedding plane joints, shrinkage cracks, or cooling cracks. Secondary channels were developed by subsequent influences such as faulting, transverse jointing, or solutioning.) Simultaneously, the specific surface is likely to be less. The gradient of the water table also affects rate of ground-water flow (Price and Arnow 1974).

Rocks least likely to react with ground water are quartzose regoliths (Zurawski 1978), quartzose sandstones, and siliceous metamorphic rocks. Limestone, dolomite, shale, basalt, and other volcanic rocks contain reactive minerals. Evaporites such as halite and gypsum are readily

(a) National Ground Water Information Center Data Base, National Water Well Association, February 1982. 
soluble. Ground water in contact with pyrite may become more acidic, dissolve iron and release hydrogen sulfide (Zurawski 1978). Pyrite is common in shale. When acidic rainwater or ground water dissolves limestone and dolomite, it adds $\mathrm{HCO}_{3}{ }^{-}, \mathrm{Ca}^{++}$and $\mathrm{Mg}^{++}$and becomes slightly alkaline. Contact between ground water and residual marine calcareous deposits is qualitatively like the reaction with limestone; $\mathrm{Ca}^{++}$and $\mathrm{HCO}_{3}{ }^{-}$are dissolved. High fluoride ion concentration has been traced to association with tuff (Eakin et a1. 1976). Intrusive rocks such as granite and gabbro may yield alkalis, alkaline earths, and iron by water reactions with feldspathic and ferromagnesian minerals, i.e., orthoclase, albite, mica, amphibole, pyroxene, and olivine.

Iron in ground water has been associated with marine deposits, shallow terrace deposits, glacial deposits, and coal mining terranes (Sinnott and Cushing 1978). Iron is also found in ground waters within basalt (Newcomb 1972). Water associated with Paleozoic outcrops in the Mississippi Valley may be high in iron (Terry et a1. 1979). Iron content tends to decrease downdip, possibly because of ion exchange. Iron occurs in a large proportion of shallow wells over most of Alaska (Zenone and Anderson 1978). Reduction in the rate of ground-water movement by permafrost provides longer residence times for reactions between water and rock, i.e., nearsurface ground water is isolated from rainwater and meltwater.

High concentrations of sodium chloride in deep ground water are often traceable to solution of halite earlier precipitated within marine sediments (Foxworthy 1979). This effect is common in the lower Mississippi region (Terry et a1. 1979). Intensive pumping may cause local migration of saline water.

Water-water mixing (or its absence) has a dominant effect upon ground water composition. Near-surface waters in high precipitation regions tend to be low in salinity, especially if evaporation is minimal (Baker and Wall 1976). Ground-water recharge from relatively fresh surface sources, such as streams and lakes, decreases salinity by dilution (Price and Arnow 1974). Rapid recharge in highly permeable limestone aquifers can maintain 
low concentrations of dissolved solids despite the reactivity of calcium carbonate (Baker and Wa11 1976). Likewise, deep circulation with in valley fill can restrict the concentration of dissolved solids (Eakin et al. 1976). Fresh water within a regolith may circulate through bedrock, lowering its salinity (Zurawski 1978). In the lower Mississippi region, younger Tertiary aquifers may contain freshwater beneath the near-shore region of the Gulf of Mexico because of confinement beneath Miocene clays and dense marls.

Water-water mixing can also increase the salinity of ground water. Saline water may enter freshwater aquifers from adjacent saline-water aquifers and streams (Bedinger and Sniegocki 1976). Saline water from tidal rivers, bays, and ocean may infiltrate fresh water, either naturally or due to freshwater well pumping (Sinnott and Cushing 1978). However, freshwater recharge from rivers, lakes, or fresh reaches of estuaries may offset infiltration. Also, saline water from older marine sedimentary rocks may migrate into shallow aquifers, especially under the influence of pumping (Foxworthy 1979). In the Great Basin, hot springs introduce saline water (Eakin et a1. 1976). These may or may not reach the ground surface. Several hot springs in the Lower Colorado region contain more than 9,000 $\mathrm{mg} / \mathrm{l}$ of $\mathrm{NaCl}$ (Davidson 1979).

Ground-water salinity or chemistry can also be changed by solute precipitation or ion exchange. For example, calcium and carbonate ions may precipitate as calcite when temperature is increased. Conversely, calcium and sulfate ions may precipitate when temperature is decreased. Pressure increase will favor the more dense of either a liquid or liquid-solid system. Potentiometric head determines the pressure on the system. Precipitation may also be caused by evaporation or transpiration (Bedinger and Sniegocki 1976). Commingling of diverse waters may cause precipitation. Ion exchange may replace calcium with sodium at moderate depths (Terry et al. 1979).

In a typical vertical profile, freshwater is found in near-surface and mountain terranes where aquifers are generally unconsolidated and uncon- 
fined and subject to periodic infusions of rainwater or meltwater. The dissolved solids are usually less than $500 \mathrm{mg} / 1$. At greater depths ground water tends to be older, at least partially confined beneath overlying beds, and more saline. Recharge is less frequent and salinity is slight to moderate, i.e., 1,000 to $10,000 \mathrm{mg} / 1$. At great depths ground water is contained within confined aquifers and is in chemical equilibrium with its surrounding lithology. Recharge and dilution do not occur. The ground water is likely below sea level and excluded from the gravity cycle. Salinity is 10,000 to $>35,000 \mathrm{mg} / 1$.

\subsection{REGIONAL DESCRIPTIONS}

Aquifer thermal energy storage depends upon the availability of ground water capable of accepting, storing, and returning heat or chill without undergoing significant precipitation of solutes and without corroding the tubing string and heat exchanger. Although ground waters with solute concentrations too low to precipitate or react are most desirable for ATES, saline waters may be used with proper design for solute extraction, controlled precipitation, or prevention of corrosion. Populous areas in the midwest, east, south Mississippi Valley, and Gulf Coastal Plain are near extensive regional aquifers that probably have potential for ATES.

This section summarizes chemical information about United States aquifer hydrology drawn mainly from U.S. Geological Survey Professional Papers $813 \mathrm{~A}$ through $\mathrm{S}$. The nation is divided into the following water resources regions as shown in Figure 5.1.
A - Ohio
B - Upper Mississippi
C - Upper Colorado
D - Rio Grande
E - California
F - Texas-Gulf
G - Great Basin
H - Arkansas-White-Red
I - Mid-Atlantic 


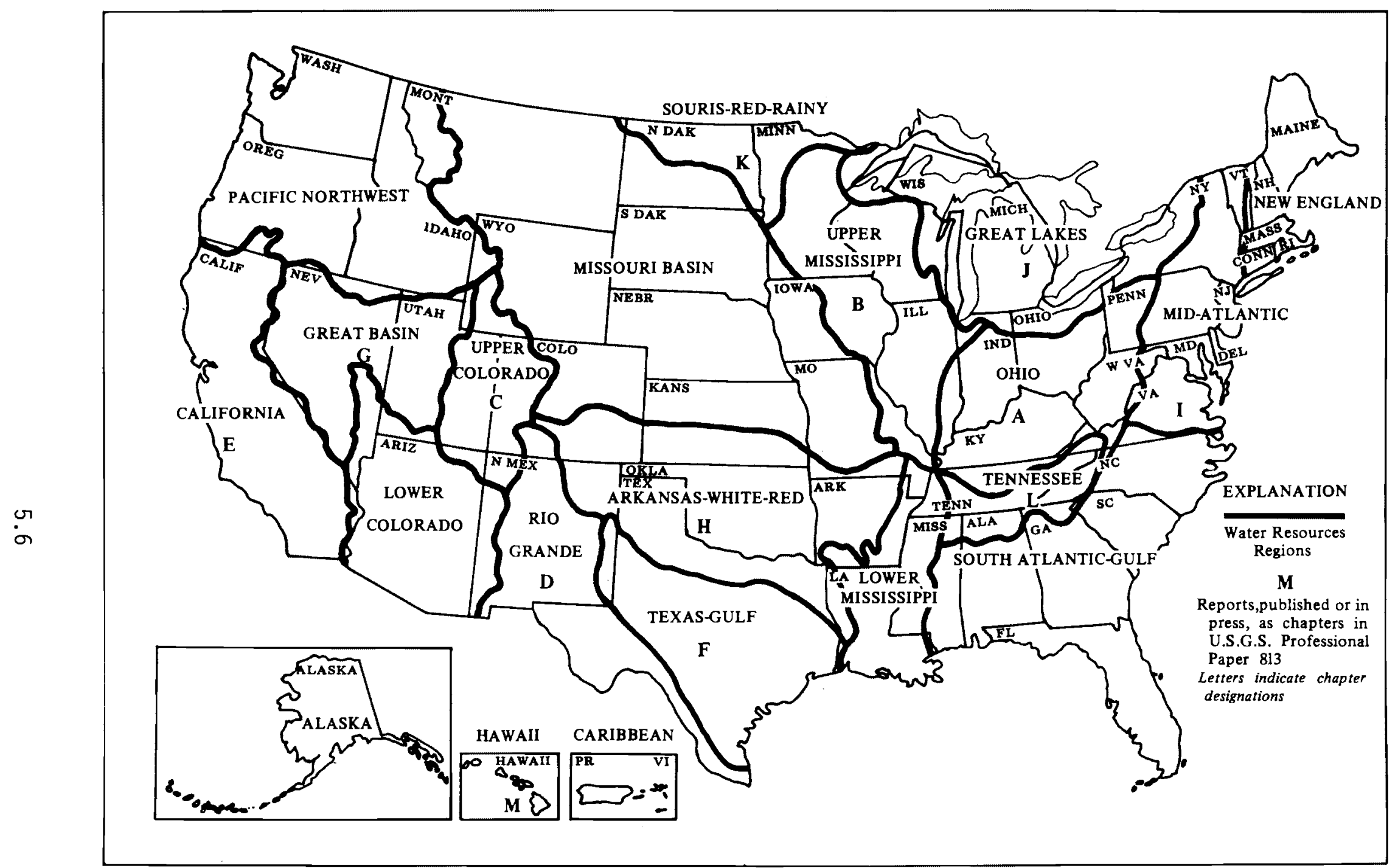

Geographic Index to the Series, U.S. Geological Survey Professional Paper 813, Summary Appraisals of the Nations Ground-Water Resources. Boundaries shown are those established by the United States Water-Resources Council for Water-Resources Regions in the United States.

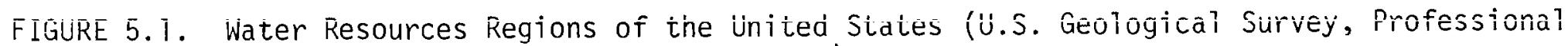
Paper 813, various chapters and years) 
J - Great Lakes

$K$ - Souris-Red-Rainy

L - Tennessee

M - Hawaij

N - Lower Mississippi

0 - South Atlantic Gulf

P - Alaska

Q - Missouri Basin

R - Lower Colorado

S - Pacific Northwest.

The overview attempts to synthesize information from Professional Paper 813 as a whole. The regional treatments of the subject matter are not uniform, probably because they are necessarily compilations of available information. Some of the "chapters", e.g., Hawaij-813M, are quite deficient in chemical information. Because New England is not included in the professional paper, other sources are used. The regional descriptions are weighted to give longer summaries to the more germane chapters. Those treating the Alaska, Lower Mississippian, Mid-Atlantic, Missouri Basin, Souris-Red-Rainy, Tennessee, and Texas-Gulf regions are excellent for the purposes of this document.

The principal generic mechanisms by which solutes are added to ground water are treated. The important cations and anions are identified. Regional and depth characteristics of ground water are described. A subsection on the Columbia Plateau was included to describe unique water chemistry associated with basalt.

\subsubsection{Ohio Region}

Alluvium, outwash, and glaciofluvial deposits constitute the most productive part of the ground-water system in the Ohio Region. Streams draining the glaciated part of the region have redeposited size-sorted glacial sediments well beyond the southern-most encroachment of the glacial ice during the Ice Age and, thus, have helped to create highly permeable aquifers in widespread parts of the region (Bloyd 1974). 
Holocene alluvium, consisting of silt, sand, and gravel, is present in the lower reaches of the major tributary valleys south of the Ohio River. In general, these sediments are finer grained and less permeable than the glaciofluvial deposits.

Outwash, composed predominantly of sand and gravel deposited by melt-water streams, is generally highly permeable and is an excellent source of water. Outwash deposits are most extensive in valleys of major tributaries within the limits of glaciation. Where these deposits are present beyond the limitations of glaciation, they occur as valley-train deposits.

Glaciofluvial deposits, which are a mixture of Pleistocene outwash deposits and Holocene alluvium, occur along many of the major tributary streams and in the Ohio River valley. These deposits are generally excellent sources of water.

Till is the principal type of glacial deposit present in the region. It is a heterogeneous mixture of clay, silt, sand, and gravel, has very low watertransmitting ability, and therefore is a relatively poor source of water. Moraines of unsorted till deposits form low ridges along former fronts of glacial ice sheets.

The Ohio Region is underlain by a series of bedrock units that vary greatiy in thickness and in hydrologic characteristics and that range in age from Precambrian to Tertiary. The most conspicuous large features of the bedrock are the Appalachian and Illinois basins. These two basins are separated from each other and from the Michigan basin to the north by the Cincinnati, Findlay, and Kankakee arches and the Nashville dome. By envisioning a two-bowled candy dish with the bowls separated but molded together by rims, one can envision the general configuration of the surface of the basement rock in the Ohio Region.

The slope on the surface of the basement complex, from the arch areas toward the Appalachian and IIlinois basins, is the central feature controlling the slope or dip of the younger bedrock unit overlying the basement. This general slope or dip is modified locally in areas of folding and faulting. The general dip on the bedrock aquifers east of the Nashville dome and Findlay arch is toward the low point of the Appalachian 
basement-rock depression; the dip on the bedrock aquifers west of the Findlay arch and south of the Kankakee arch is toward the low point of the Illinois basement-rock depression.

Total water available from storage in the outwash and alluvial aquifers in the Ohio River valley and the subbasins is about 23,000 billion gallons. Estimated aquifer characteristics for aquifers in the Ohio Region are listed in Table 5.1. The estimates are derived from previous studies and are considered to be sufficiently accurate for areal application.

The overall distribution of high-yield aquifers is shown in

Figure 5.2. Saline ground water is present throughout. Dissolved solids exceed 1,000 mg/1 at depths greater than $500 \mathrm{ft}$. Salt concentrations in the saline zone range from $1,000 \mathrm{mg} / 1$ to considerably more than the 32,000 to $35,000 \mathrm{mg} / 1$ concentration in sea water (Bloyd 1974).

The largest quantities of saline water are in the Illinois and Appalachian basins. In these basins the depth to bedrock is greatest in Ohio. Assuming that basement rock is the bottom of the saline zone, this lower boundary is about $9,000 \mathrm{ft}$ below sea level in Illinois and about 15,000 to $21,000 \mathrm{ft}$ below sea level in the Appalachian basin (Bloyd 1974).

\subsubsection{Upper Mississippi Region}

Alluvium and outwash deposits constitute the most productive part of the ground-water system in the Upper Mississippi Region. Their distributions are shown in Figure 5.3. Streams draining the glaciated part of the region have redeposited size-sorted glacial sediments beyond the southernmost encroachment of the glacial ice during the Ice Age and thus have helped to create permeable aquifers throughout the region. Subsequent references to the valley of the Mississippi River refer to the area adjacent to the main stem of the river that is underlain by outwash and alluvial deposits (Bloyd 1975).

Holocene-age alluvium consisting of silt, sand, and gravel is present in the valley of the Mississippi River and adjacent to many of the larger streams. These deposits generally are finer grained and are less permeable than the outwash deposits. However, locally, they are excellent sources of water. 
TABLE 5.1. Characteristics of Aquifers in the Ohio Region (Bloyd 1974, p. A-7)

Aquifer

Mad River alluvial aquifer

Ohio River valley outwash and alluvial aquifer

Miami River, Scioto River, Upper Muskingum River, and Whitewater River alluvial aquifers

Allegheny, Lower Wabash, and White River alluvial aquifers

Hocking River, Lower Muskingum River and Upper Wabash River alluvial aquifers

Beaver River alluvial aquifer and alluvial aquifers in the minor tributaries north of the Ohio River

Alluvial aquifers in the major tributaries south of the Ohio River

Mississippian bedrock aquifer (Green River Basin)

Mississippian bedrock aquifer with glacial cover

Pennsylvanian bedrock (Allegheny and Pottsville Formations)

Pennsylvanian bedrock with glacial cover

Silurian bedrock with glacial cover

Pennsylvanian bedrock (Conemaugh Formation)

Pennsylvanian and Permian bedrock (Dunkard Group)

Ordovician bedrock with glacial cover

Silurian bedrock

Mississippian bedrock

Pennsylvanian bedrock (Monongahela Formation)

Devonian bedrock with glacial cover

Ordovician and undifferentiated Paleozoic rocks

Devonian bedrock

\begin{tabular}{cc}
$\begin{array}{c}\text { Hydraulic Condyc- } \\
\left.\text { tivity (gpd/ft } \mathrm{t}^{2}\right)\end{array}$ & $\begin{array}{c}\text { Storage Coefficient } \\
\text { or Specific Yield }\end{array}$ \\
\cline { 1 - 2 } $4,000-4,500$ & 0.25 \\
$400-8,400$ & $0.05-0.20$ \\
$2,500-3,000$ & $0.15-0.20$ \\
2,000 & $0.15-0.20$ \\
$1,500-2,000$ & $0.15-0.20$ \\
$500-1,000$ & 0.15 \\
& \\
500 & 0.10 \\
$>20$ & $0.01-0.05$ \\
$>20$ & $0.01-0.05$ \\
$>20$ & \\
$>20$ & $0.01-0.05$ \\
$>20$ & $0.01-0.05$ \\
$>20$ & $0.01-0.05$ \\
$>20$ & $0.01-0.05$ \\
$>20$ & $0.01-0.05$ \\
$>20$ & $0.01-0.05$ \\
$>20$ & $0.01-0.05$ \\
$>20$ & $0.01-0.05$ \\
$>20$ & $0.01-0.05$ \\
$>20$ & $0.01-0.05$ \\
$>20$ & $0.01-0.05$ \\
& $0.01-0.05$ \\
&
\end{tabular}




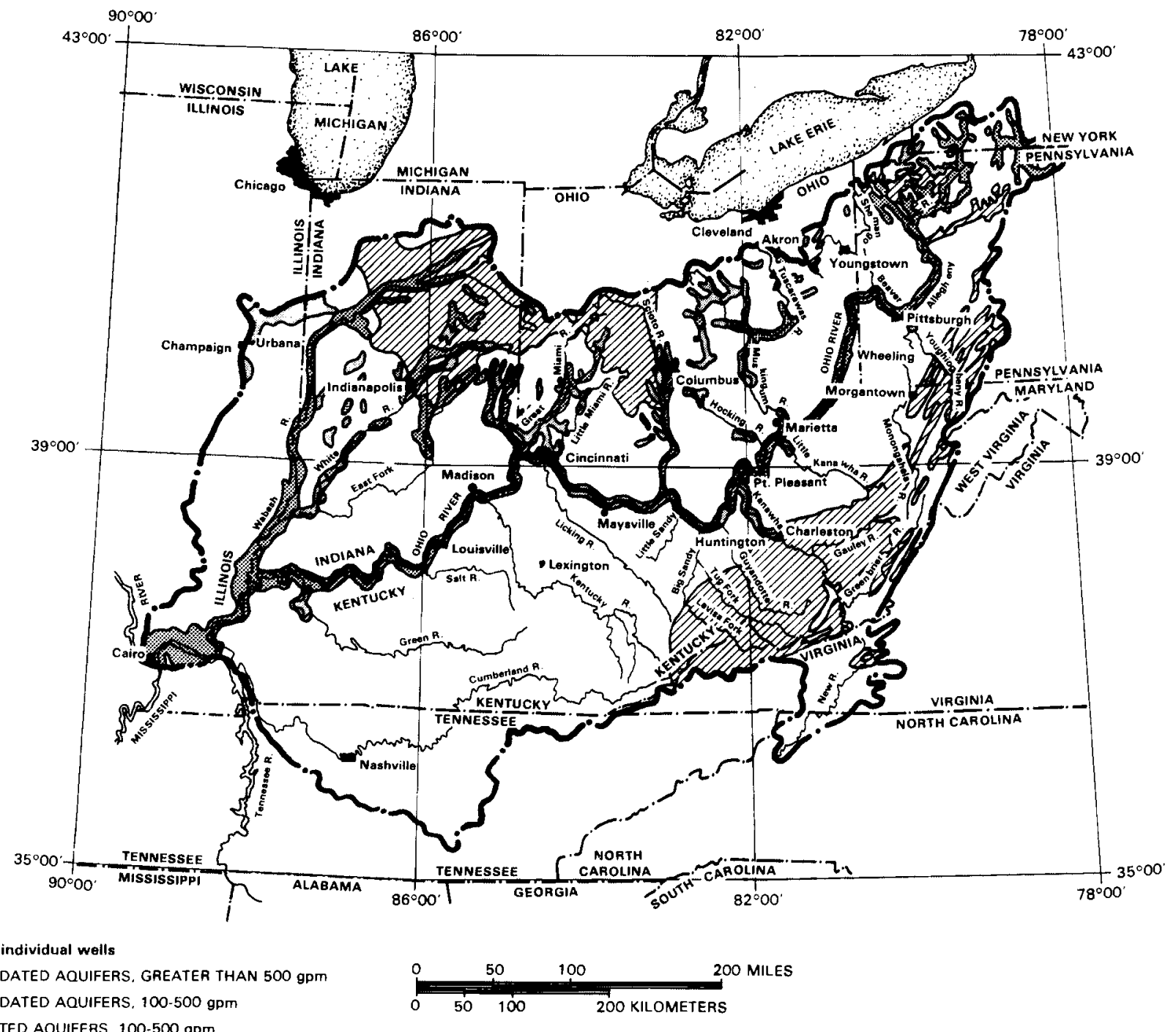

FIGURE 5.2. High-Yield Sources of Ground Water in the Ohio Region (Bloyd 1974, p. A16) 


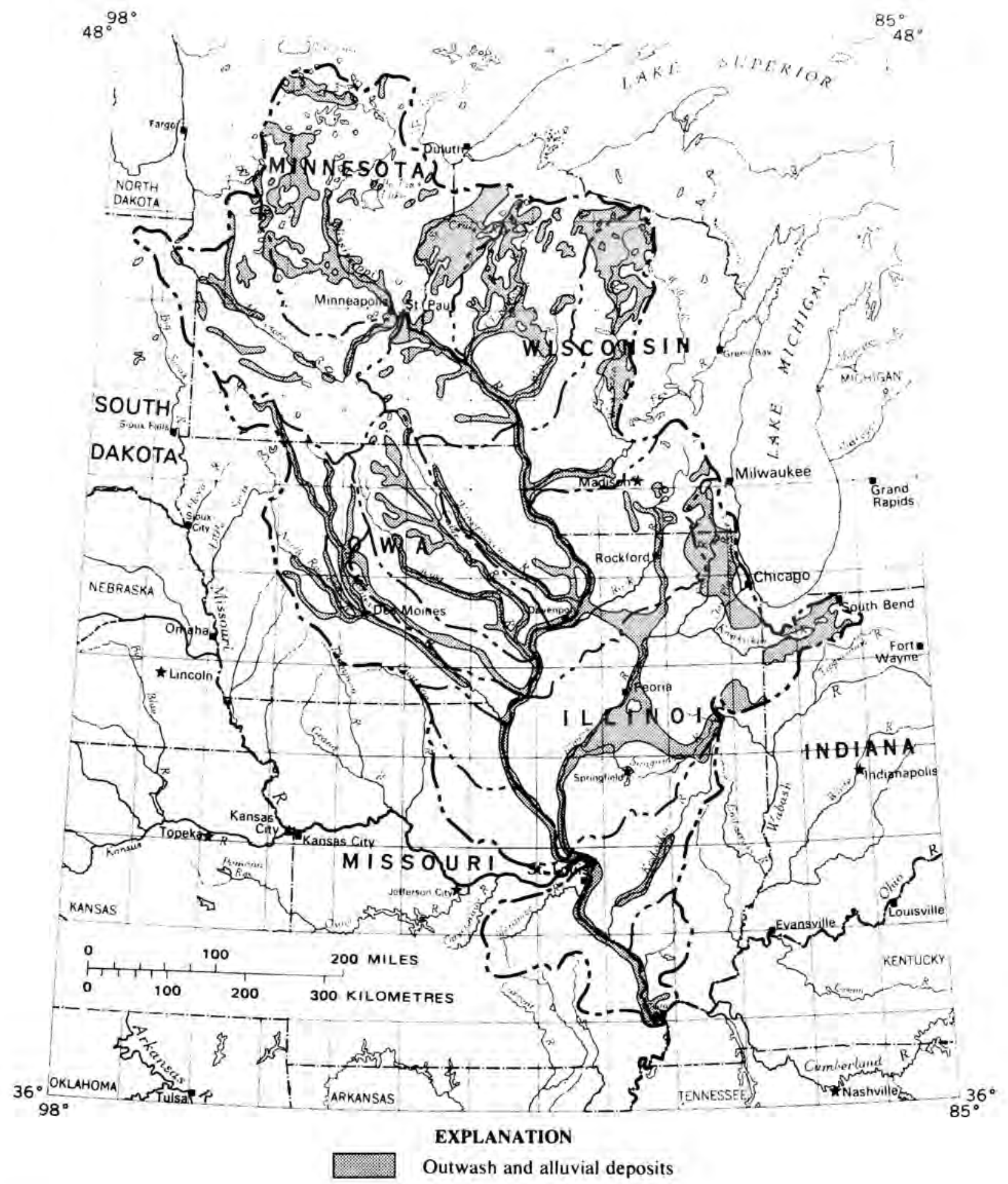

FIGURE 5.3. Distribution of Outwash and Alluvial Deposits in the Upper Mississippi Region (Bloyd 1975, p. B-6) 
Outwash, which is composed predominantly of sand and gravel deposited by melt-water streams, is generally highly permeable and is an excellent source of water. Outwash deposits are most prevalent in Minnesota and Wisconsin, where they are generally in hydrologic connection with and not differentiated from the alluvial deposits.

Another highly productive part of the ground-water system is the buried sand and gravel deposits in the Mahomet bedrock valley of east-central Illinois. The buried valley and its major tributaries underlie about 3,700 square miles in Illinois. Other buried valleys are present in various parts of the region.

Till is the principal glacial deposit in the region. It is a heterogeneous mixture of clay, silt, sand, and gravel; generally it has low transmissivity and, therefore, is generally a poor source of water. Moraines of unsorted till form low ridges along former fronts of glacial ice sheets. Glacial deposits are present in most of the region except for a part of Wisconsin and most of Missouri.

The Upper Mississippi Region is underlain by a series of bedrock units that vary greatly in thickness and in hydrologic characteristics. Depth to the bottom of the bedrock system, or basement, is greatest near the center of the Illinois basin. The basement crops out in the region in two centers of uplift--the Superior Upland and the 0zark Dome. Around these centers of uplift, rocks of younger age crop out in successive belts.

The slope of the basement complex is the central feature controlling the slope or dip of the younger bedrock units overlying the basement. The basement gently slopes toward the regional geosyncline of the Great Plains, west of the region, and slopes less gently toward the Michigan basin, the center of which is in the State of Michigan, and slopes toward the Illinois basin.

Three major bedrock aquifers are present in the Upper Mississippi Region. They are the Mount Simon-Hinckley of Precambrian and Cambrian age, the Cambrian-Ordovician, and the Silurian-Devonian aquifers. Locally, other names may be applied to these aquifers. 
The Mount Simon-Hinckley aquifer is mostly sandstone. It is a source of water in southeastern Minnesota, western and southern Wisconsin, northern Illinois, and easternmost Iowa.

The Cambrian-Ordovician aquifer consists of several sandstone and dolomite formations which act as a hydraulic unit. The aquifer is a source of water in southeastern Minnesota, southern Wisconsin, northern Illinois, Iowa, northwestern Indiana, and much of eastern Missouri.

The Silurian-Devonian aquifer, which consists of several limestone and dolomite formations, supplies water to northeastern Iowa, northern Illinois, southeastern Wisconsin, and northwestern Indiana.

Saline ground water is most prevalent in the deep bedrock aquifers of central and southern Illinois and western Iowa. The largest quantity of saline water occurs in the Illinois basin. Here the basement rock is deepest in the Upper Mississippi region, i.e., about 9,000 ft below sea level (Bloyd 1975).

\subsubsection{Upper Colorado Region}

Because of the varying hydrologic properties of rocks, the geology of the Upper Colorado Region is the principal factor controlling the quantity and availability of ground water for development. The rocks that underlie the region consist mostly of consolidated and semiconsolidated sedimentary strata. Igneous and metamorphic rocks underlie parts of the mountains, and unconsolidated alluvial deposits underlie reaches of major stream valleys (Price and Arnow 1974). The better known water-bearing formations in the units are listed in Table 5.2.

Freshwater is generally available from shallow aquifers in most rock units in areas above an altitude of about 7,000 ft. At lower altitudes, freshwater most commonly occurs in relatively permeable sandstone, such as the Navajo and Dakota sandstones. Freshwater is also found in carbonate rocks, such as the Madison limestone and Morgan formation, which have good hydrologic connection with the principal recharge areas in the mountains (Price and Arnow 1974). 
WYOMING BASIN PROVINCE

A. WEST.CENTRAL PART OF GREEN RIVER BASIN

QUATERNARY

UNCONSOLIDATED SEDIMENTAAY DEPOSITS (MOSTLY ALLUVIAL AND LACUSTRINE IN ORIGIN)

TERTIARY

BRIDGER FORMATION

GREEN RIVER FORMATION

WASATCH FORMATION

JURASSIC

NUGGET SANDSTONE

ORDOVICIAN

BIGHORN DOLOMITE

\section{B - GREAT DIVIDE AND WASHAKIE BASINS}

QUATERNARY

UNCONSOLIDATED SEDIMENTARY DEPOSITS (MOSTLY ALLUVIAL AND LACUSTRINE IN ORIGINI

TERTIARY

BROWNS PARK FORMATION

GREEN RIVER FORMATION

WASATCH FORMAIION-BATTLE SPRING FORMATION

CRETACEOUS

ERICSON FORMATION

ROCK SPRINGS FORMATION

MESAVERDE FORMATION (EAST PART OF AREA)

MISSISSIPPIAN

MADISON LIMESTONE

MIDDLE ROCKY MOUNTAINS PROVINCE

C - SOUTH FLANK OF UINTA MOUNTAINS

OUATERNARY

UNCONSOLIDATED SEDIMENTARY DEPOSITS (MOSTLY ALLUVIUM) CRETACEOUS

DAKOTA SANDSTONE

JURASSIC

NUGGET SANDSTONE

PERMIAN

PARK CITY FORMAIION

PENNSYLVANIAN

WEBER QUARTZITE

MORGAN FORMATION

UINTA BASIN SECTION

D - EASTERN AND CENTRAL PARTS

QUATERNARY

UNCONSOLIDATED SEDIMENTARY DEPOSITS (MOSTLY ALLUVIUM)

TERTIARY

DUCHESNE RIVER FORMAIION

UINTA FORMATION

GREEN RIVER FORMATION

WASATCH FORMATION

CAETACEOUS

FAONTIEA SANDSTONE MEMBER OF MANCOS SHALE

MOWAY SHALE

DAKOTA SANDSTONE

TRIASSIC ??) AND JURASSIC

GLEN CANYON SANDSTONE

PARK CITY FORMATION

PHOSPHORIA FORMATION

PENNSYLVANIAN

WEBER SANDSIONE (QUARTZTE)

MORGAN FORMATION

ROUND VALLEY LIMESTONE

HIGH PLATEAUS OF UTAH

E. NORTHERN PART

QUATERNARY

UNCONSOLIDATED SEDIMENTARY DEPOSITS (MOSTLY ALLUVIUM)

TERTIARY

CRAZY HOLLOW FORMATION

FLAGSTAFF FQRMATION

CRETACEOUS AND TERTIARY

NORTH HORN FORMATION

CAETACEOUS

EMERY SANDSTONE MEMBER OF MANCOS SHALE

FERRON SANDSTONE MEMBER OF MANCOS SHALE

FERRON
JURASSIC

CARMEL FORMATION

TRIASSIC(?) AND JURASSIC

NAVAJO SANDSTONE IGLEN CANYON GROUP

TRIASSIC

WINGATE SANDSTONE (GLEN CANYON GROUP)

F - SOUTHERN PART

QUATERNARY

UNCONSOLIDATED ALLUVIAL AND LACUSTRINE DEPOSITS (PROBABLY

SOME EXTRUSIVE IGNEOUS ROCKS)

TERTIARY

IGNEOUS ROCKS

BRIAN HEAD FORMATION

WASATCH FORMATION

CRETACEOUS

KAIPAROWITS FORMATION

WAHWEAP SANDSTONE

STRAIGHT CLIFFS SANDSTONE
F. SOUTHERN PART icont'd

JURASSIC

CARMEL FORMATION

IRIASSICI? AND JURASSIC

NAVA JO SANDSTONE IGLEN CANYON GROUP

IRIASSIC

WINGATE SANDSIONE IGLEN CANYON GROUP

CANYON LANDS

G HENRY MOUNTAINS VICINITY

QUATERNARY

UNCONSOLIDATED SEDIMENTARY DEPOSITS IMOSILY ALLUVIUM AND DUNE SAND

CRETACEOUS

DAKOTA SANDSIONE

TRIASSICPIAND JURASSIC

NAVAJO SANDSTONE IGLEN CANYON GROUP;

TRIASSIC

WINGATE SANDSTONE IGLEN CANYON GROUP

H. LA SAL MOUTAINS VICINITY

OUATERNARY

UNCONSOLIDATED SEDIMENTARY DEPOSIIS IMOSTLY ALLUVIUM

AND DUNE SAND

CRETACEOUS

DAKOTA SANDSTONE

BURRO CANYON FORMATION

JURASSIC

ENTRADA SANDSTONE

TRIASSIC(?) AND JURASSIC

NAVAJO SANDSTONE (GLEN CANYON GROUP)

TRIASSIC

WINGATE SANDSTONE /GLEN CANYON GROUP

PERMIAN

CUTLER FORMATION

NAVAJO SECTION

I. NORTH-CENTRAL PART

QUATERNAAY

UNCONSOLIDATED ALLUVIUM AND DUNE SAND ISOME IGNEOUS ROCKS)

IERTIARY

CHUSKA SANDSTONE

CRETACEOUS

DAKOTA SANDSTONE

JURASSIC

RECAPIURE SHALE MEMBER OF MORRISON FORMATION

SALT WASH SANDSTONE MEMBER OF MORRISON FORMAIION

SUMMERVILLE FORMATION

COW SPAINGS SANDSTONE

BLUFF SANDSTONE

TRIASSIC(?) AND JURASSIC

NAVAJO SANDSIONE (GLEN CANYON GROUP)

IRIASSICI?

MOENAVE FORMATION

TRIASSIC

OWL ROCK MEMBER OF CHINLE FORMATION

SHINARUMP MEMBER OF CHINLE FORMATION

PERMIAN

CEDAR MESA SANDSTONE MEMBER OF CUTLER FORMATION

$J$ NORTHEAST PART

OUATERNARY

UNCONSOLIDATED SEDIMENTARY DEPOSITS IMOSTLY ALLUVIUM!

UNCONSOL
TERTIARY

SAN JOSE FORMATION

CRETACEOUS

DAKOTA SANDSTONE

JURASSIC

ENTRADA SANDSTONE

SOUTHERN ROCKY MOUNTAIN PROVINCE

K - NORTH PARK AND MIDDLE PARK VICINITY

OUATERNARY

UNCONSOLIDATED SEDIMENTARY DEPOSITS (MOSTLY ALLUVIUM AND GLACIAL DEPOSITS:

$L$. GLENWOOD SPRINGS-MCCOY VICINITY

OUATERNARY

UNCONSOLIDATED ALLUVIUM

MISSISSIPPIAN

LEADVILLE LIMESIONE 
Saline water commonly occurs in shale and siltstone strata that underlie most of the Green River, Great Divide, Washakie, Uinta, Piceance Creek, and San Juan Basins, but even in those areas some of the aquifers locally contain freshwater.

\subsubsection{Rio Grande Region}

The ground-water reservoirs of the region can be classified on the basis of rock characteristics, physiography, and geographic distribution. For convenience of description, the rocks have been divided into four basic types: 1) valley fill--unconsolidated to poorly consolidated sand and gravel interbedded or intermixed with clay and silt; 2) volcanic rocks-primarily basalt but including other flow rocks, tuff, and small intrusive bodies; 3) consolidated sedimentary rocks--primarily shale and sandstone but including limestone, gypsum, and salt; and 4) crystalline rocksintrusive igneous rocks and metamorphic rocks (West and Broadhurst 1975).

The intermontane valleys of the region have been partly filled with unconsolidated sand, gravel and clay--termed "valley fill"--derived by weathering and erosion from the rocks in the adjacent mountains and from similar rocks in the mountains upstream. Alluvial deposits in the Pecos Valley are included in the valley-fill category, but the valley fill shown east of the Pecos River is thin and is not a significant ground-water reservoir.

Locally, the valley fill is interbedded with basalt and other flow rocks derived from volcanic centers in and bordering the valleys. Large masses of basalt and andesite are common, especially in the northern part of the basin. The valley fill, including the interbedded volcanic rocks, is as much as 9,000 ft $(2,700 \mathrm{~m})$ thick in New Mexico and is reported to be more than $30,000 \mathrm{ft}(9,100 \mathrm{~m})$ thick in the north-central part of the San Luis Valley, Colorado. The valley fill comprises the principal ground-water reservoir in the region. In most areas it is capable of yielding a few hundred to a few thousand gallons of water per minute to individual wells.

The mountains consist of volcanic rocks, consolidated sedimentary rocks, and crystalline rocks. The volcanic rocks commonly cap plateaus and low mountain 
ranges and lie above the regional water table. These rocks generally are not significant aquifers except where they are interbedded with or overlie valley fill. The consolidated sedimentary rocks form most of the hills and low mountains. Generally, these rocks are poor aquifers, but locally, beds of limestone containing extensive fractures and solution channels lie below the water table and yield large supplies of water to wells. In many areas the consolidated sedimentary rocks contain soluble minerals, such as halite and gypsum--the principal sources of dissolved solids in ground water. The crystalline rocks generally are dense and yield insignificant quantities of water to wells.

The Rio Grande region is divided into six subregions (West and Broadhurst 1975). These subregions, aquifer types, and water qualitites are shown below.

Subregion
San Luis Valley,
Colorado

Albuquerque, New Mexico

El Paso, Texas

Pecos Valley, New Mexico, Texas

Closed Basins, New Mexico, Texas

Lower Rio Grande, Texas

\subsubsection{California Region}

Most ground-water reservoirs of the California region are in valleys and plains that receive runoff and debris from the mountains. The longest and highest mountain range is the Sierra Nevada, a broad tilted
Dissolved Solids $(\mathrm{mg} / \mathrm{l})$

Valley fill

Volcanic rocks

$<1,000$ to 3,000

Consolidated sediments

Crystalline rocks

Valley fill

125 to 2,620

Valley fill

200 to $>6,000$

Valley fill

$<1,000$ to 35,000

Limes tone

Sands tone

Gypsum

Valley fill

200 to 100,000

Limestone, evaporites

Sandstone

$\sim 500$ to 5,000 
block of relatively impermeable igneous and metamorphic rocks extending from the south end of the Cascade Range at Mt. Lassen southward 400 miles $(640 \mathrm{~km})$. To the west, the great Central Valley of similar length and breadth is composed partly of stream-borne sediments that now contain freshwater to depths of 400 to more than 4,000 ft $(120$ to $1,200 \mathrm{~m}$ ) below sea level (Thomas and Phoenix 1976).

The Central Valley ground-water reservoir includes numerous gravel- and sand-aquifers, formed by streamcarried sediments from the mountains, separated by interstream sediments of chiefly silt and clay; it also includes deep confined aquifers which are separated from shallow aquifers by extensive beds of clay. Also, the pattern of precipitation and surface inflow-generally greater in the north, less to the south--is responsible for other variations in ground-water occurrence. This ground-water reservoir is thus a complex and heterogeneous mass, too large to consider conveniently as a unit and yet with sufficient unity that division on the basis of ground-water characteristics is difficult. For overall water-resource studies and planning in the California Region, the Central Valley drainage basin is divisable into at least two subregions--the Sacramento basin to the north and the San Joaquin Basin southeast of the valley's outlet to San Francisco Bay; it has been divided additionally to form the Delta, where the valley floor is approximately at sea level, and the Tulare Basin of the interior drainage at the south end of the Central Valley.

The Coast Ranges comprise folded and faulted sedimentary and metamorphic rocks generally parallel to the Pacific coastline. Most of the ground-water reservoirs are in the intervening structural valleys and coastal plains; some are along the streams that drain, traverse, or bypass various ranges as they flow toward the ocean. The coastal valleys and mountains are included in four subregions--North Coastal, San Francisco Bay, Central Coastal, and South Coastal--of the California Region, each comprising drainage basins of several streams debouching into the Pacific 0cean. The North Coastal subregion has the greatest precipitation and runoff; its ground-water reservoirs are recharged each rainy season and maintain perennial flow of streams in the rainless season. Water deficiency is prevalent in the South Coastal subregion, where groundwater reservoirs are recharged in wet seasons but where 
the water may remain underground as it moves toward the ocean, appearing at the surface only where it encounters faults or other barriers.

East of the Sierra Nevada and the Transverse Ranges farther south, the California Region includes the Mojave Desert, the Colorado Desert, and the valleys and ranges of the Great Basin in California, designated the North and South Lahontan subregions. Separated from the Pacific Ocean by formidable mountain barriers, these areas are the most arid lands of the region, all in basins of interior drainage except for a narrow zone along the through-flowing Colorado River. The Mojave, Owens, and Susan Rivers are the largest of the few streams with headwaters in high mountains that yield perennial inflow to these arid basins. Other stream channels are dry except when rare torrential storms cause floods of short duration or during brief snowmelt seasons. Ground-water reservoirs are found under the valleys and plains and may be recharged chiefly by intense storms or flood runoff. Discharge from these ground-water reservoir may be by springs, by evapotranspiration where water is at shallow depth, or by subsurface movement toward a lower valley. For example, some water in the Mojave River may recharge ground water and continue downgradient as subsurface flow through half a dozen valleys, perhaps eventually contributing to the "badwater" of Death Valley.

In the northeastern part of the California Region, the Modoc Plateau consists of a thick accumulation of lava flows and tuffs and small volcanic cones. Many of these volcanic rocks are excellent aquifers, readily recharged by precipitation and permeable enough to store and subsequently discharge water at numerous large springs, although most of the plateau is in the rain shadow of the Sierra-Cascades and is semiarid. The total area of these volcanic rocks exceeds 10,000 square miles $\left(26,000 \mathrm{~km}^{2}\right)$, which is chiefly highlands and slopes undesirable for drilling wells or using the water from them. The ground-water reservoirs outiined in this volcanic area include only the plains or valleys where ground-water development is active or likely. Some of these valleys are in the Klamath River basin (North Coastal subregion), and others are in the Sacramento River basin and subregion or in the North Lahontan subregion, part of the Great Basin. 
Undeveloped ground-water reservoirs are described in Table 5.3.

Developed ground-water reservoirs in unconsolidated sediments of the San Joaquin River basin are also candidate unconfined aquifers for ATES. These cover an area of $13,000 \mathrm{~km}^{2}$, are up to $60 \mathrm{~m}$ thick, and have a usable capacity of $69 \mathrm{~km}^{3}$. Dissolved solids range from 90 to $5,000 \mathrm{mg} / 1$ (Thomals and Phoenix 1976). Chemical characteristics of streams at base flow are shown in Figure 5.4. Numerous unconsolidated aquifers are discussed in this reference, but references to specific ground-water chemistry are lacking.

\subsubsection{Texas-Gulf Region}

The Texas-Gulf Region comprises an area of 173,000 square miles $\left(448,000 \mathrm{~km}^{2}\right)$ in Texas, New Mexico and Louisiana. About $95 \%$ of the area is in Texas. The region includes 10 major river basins and 8 intervening coastal basins within the physiographic provinces of the Great Plains, the Central Lowland, and the Coastal Plain.

The climate of the Texas-Gulf Region is marked by extremes in precipitation and evaporation--climatic elements that to a large degree determine the availability of both ground water and surface water. Average annual precipitation ranges from slightly more than 56 in. $(1420 \mathrm{~mm})$ in extreme southeastern Texas and southwestern Louisiana to slightly less than $16 \mathrm{in.}(410 \mathrm{~mm})$ on the High Plains of New Mexico.

An index map of the Texas-Gulf Region is shown in Figure 5.5 .

The Hickory ${ }_{2}$ aquifer underlies about 5,000 square miles $\left(12,950 \mathrm{~km}^{2}\right)$ of the Edwards Plateau and Llano Uplift of central Texas, where the strata are highly faulted and steeply dipping. The aquifer, which consists principally of sand and sandstone, is more than $400 \mathrm{ft}(122 \mathrm{~m})$ thick and extends to maximum depths of almost $5,000 \mathrm{ft}(1,520 \mathrm{~m})$. The yields of the larger-capacity wells generally range between 200 and $500 \mathrm{gal} / \mathrm{min}(13$ to $32 \mathrm{l} / \mathrm{s})$, but the yields of a few wells exceed 1,000 gal/min $(631 / \mathrm{s})$. The aquifer is only slightly developed and is capable of supporting a sizable increase in draft if declines in water levels are acceptable to water planners and users (Baker and Wal1 1976). 
TABLE 5.3. Undeveloped Ground-Water Reservoirs of the California Region (Thomas and Phoenix 1976, pp. E13-E14)

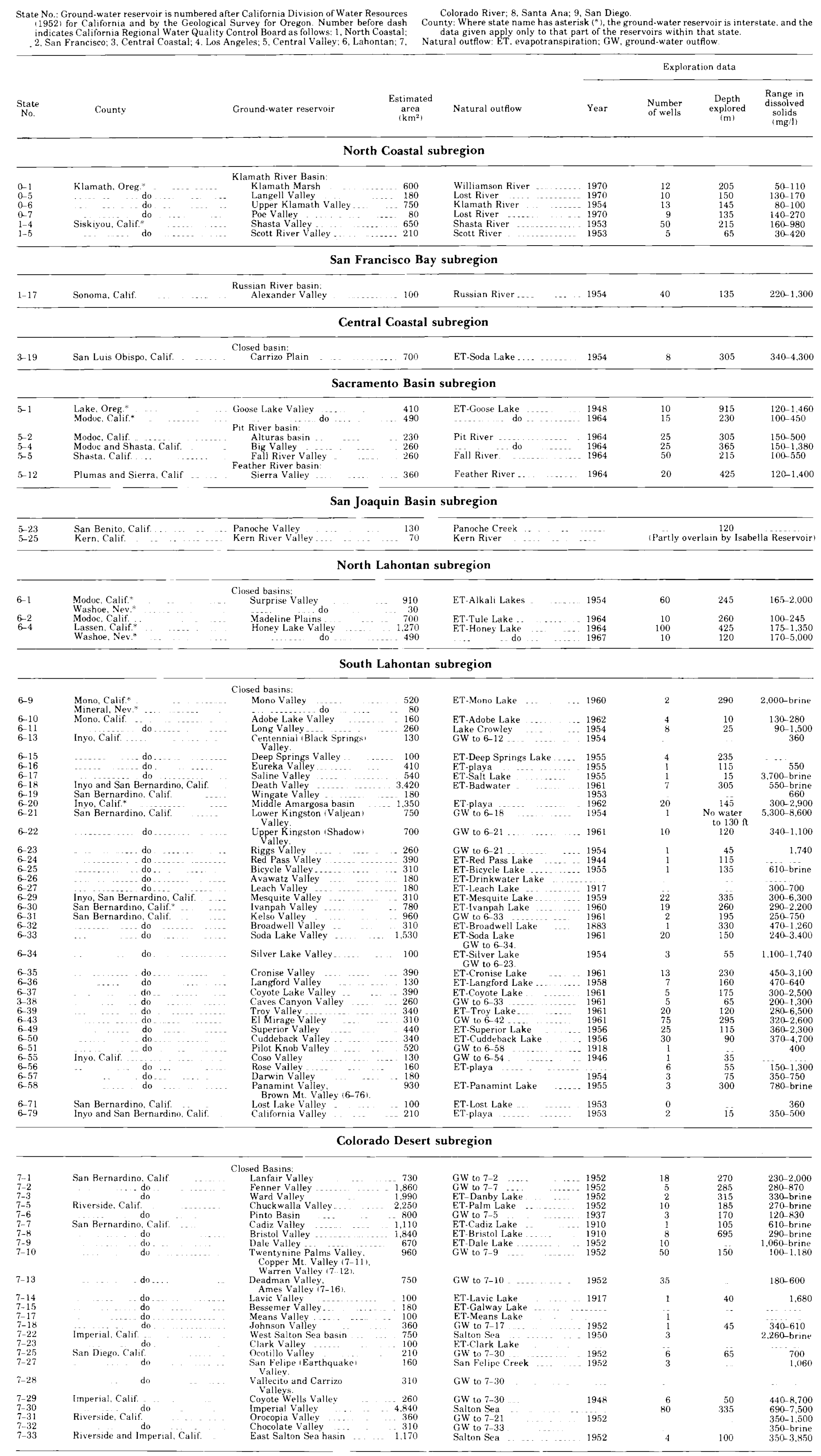





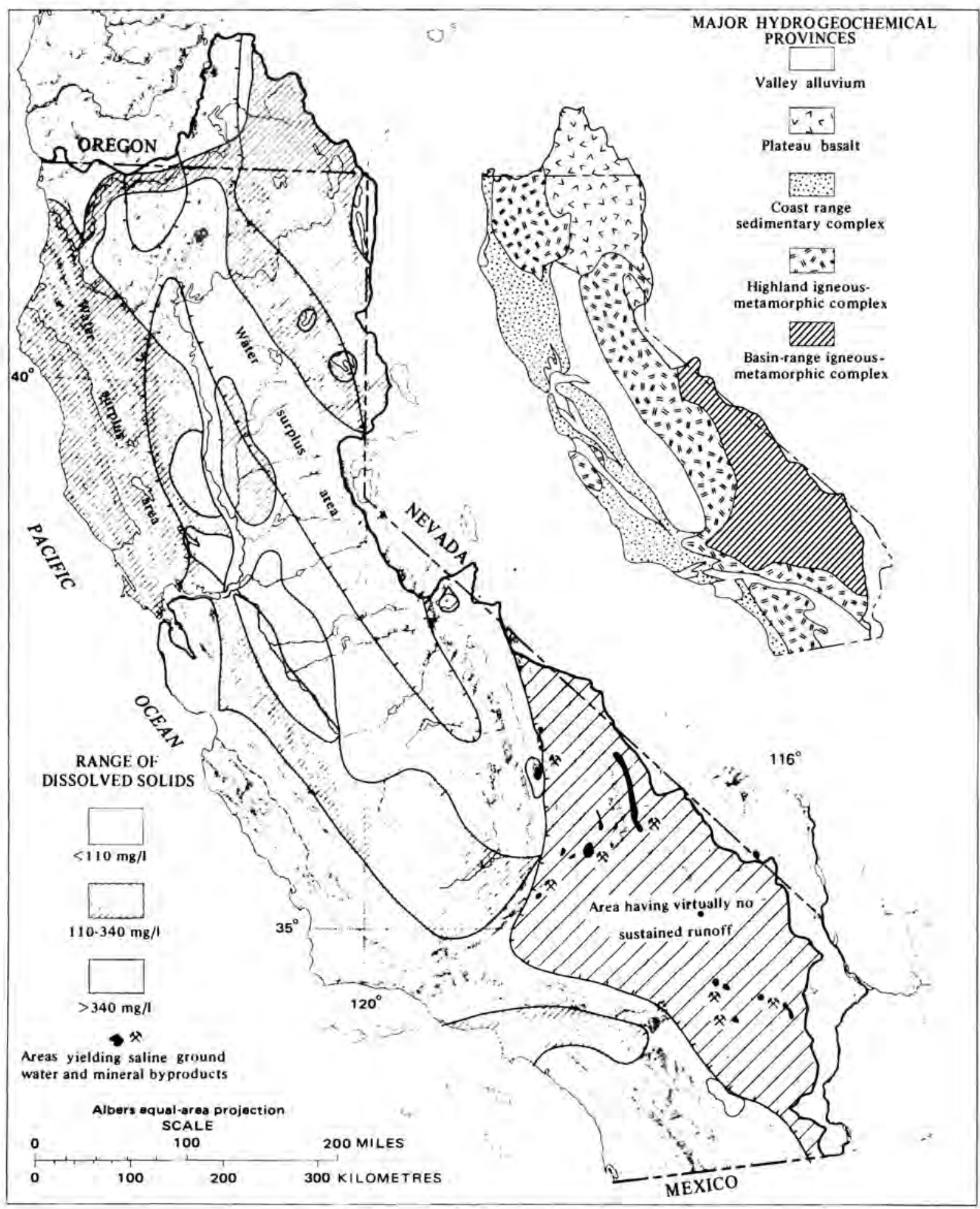

FIGURE 5.4. Chemical Characteristics of Stream Base Flows in California (Thomas and Phoenix 1976, p. E31) 


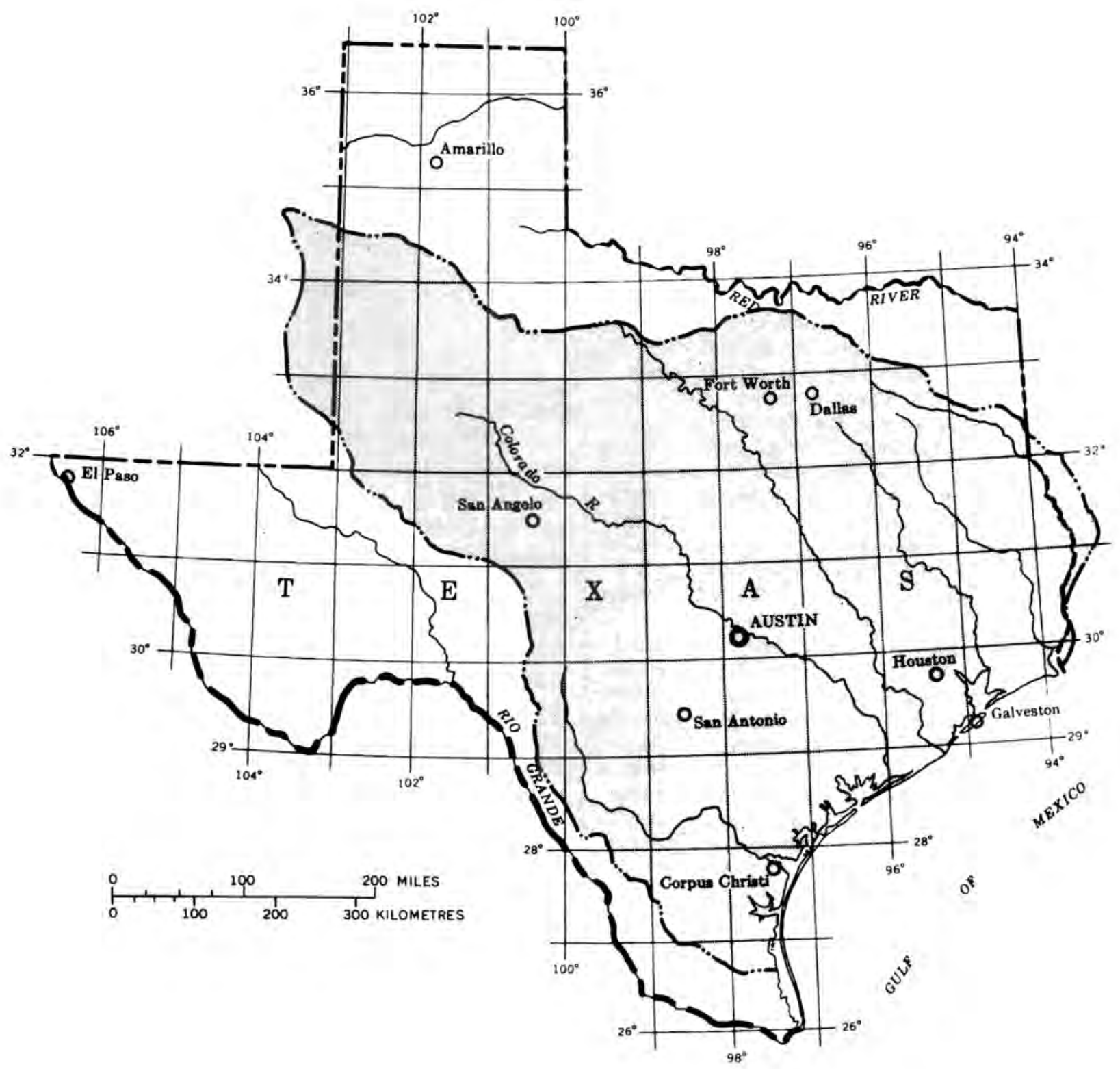

FIGURE 5.5. Index Map of the Texas-Gulf Region (Baker and Wall 1976, p. F2) 
The Ellenburger-San Saba aquifer underlies an area of about 4,000 square miles $\left(10,360 \mathrm{~km}^{2}\right)$ and almost completely surrounds the Precambrian core of the Llano Uplift. The aquifer, which consists of more than $1,000 \mathrm{ft}(305 \mathrm{~m})$ of limestone and dolomite beds that are characterized by substantial secondary permeability, extends to depths of about $3,000 \mathrm{ft}(914 \mathrm{~m})$. A few large springs issue from the aquifer and help sustain the base flow of several streams in the Colorado River basin. Although the yields of largecapacity wells reach $1,000 \mathrm{gal} / \mathrm{min}(63 \mathrm{l} / \mathrm{s})$, the aquifer is not extensively developed. Additional development will reduce the base flow of some streams in the Colorado River basin.

The Santa Rosa aquifer underlies an area of about 1,000 square miles $\left(2,590 \mathrm{~km}^{2}\right)$ east of the High Plains, but its usefulness as a source of potable water is restricted to parts of a few counties. The aquifer, which is composed of gravel, sand, and finer materials, yields water to wells as deep as $450 \mathrm{ft}(137 \mathrm{~m})$. Yields of the larger capacity wells average about $250 \mathrm{gal} / \mathrm{min}(16 \mathrm{l} / \mathrm{s})$, but some wells yield as much as $1,000 \mathrm{gal} / \mathrm{min}(63 \mathrm{l} / \mathrm{s})$. The aquifer is capable of sustaining slight to moderate increases in the volume of water pumped.

The Trinity aquifer which underlies about 20,000 square miles $\left(51,800 \mathrm{~km}^{2}\right)$, constitutes an important ground-water reservoir because of its areal extent and its ability to yield more than $1,000 \mathrm{gal} / \mathrm{min}(63 \mathrm{l} / \mathrm{s})$ of water to large-capacity wells in some places. The aquifer is composed of interbedded sand, shale, and 1 imestone and reaches a maximum thickness of about $1,200 \mathrm{ft}(366 \mathrm{~m})$ at its eastern 1 imit (of water of less than $3,000 \mathrm{mg} / 1$ dissolved solids) where it extends to depths of about $3,500 \mathrm{ft}(1,060 \mathrm{~m})$. The Trinity aquifer is intensively developed in the Dallas-Fort Worth area where the water is pumped for municipal supply and industrial use.

The Edwards-Trinity (Plateau) aquifer underlies about 15,000 square miles $\left(38,200 \mathrm{~km}^{2}\right)$ of the Edwards Plateau. Freshwater (containing less than $1,000 \mathrm{mg} / 1$ dissolved solids) is contained in the sand and sandstone layers of the lower part of the aquifer and in the honeycombed 1 imestone of the upper part. The maximum thickness of the aquifer exceeds $1,000 \mathrm{ft}$ $(305 \mathrm{~m})$. Although the yields of wells in most places are relatively small, they may exceed 3,000 gal/min 
$(190 \mathrm{l} / \mathrm{s})$ in places where secondary permeability of the limestone is well developed. Varying degrees of secondary permeability, however, tend to govern the rate of production of individual wells. The base flow of several streams in the Colorado and Nueces River basins is substantially augmented by natural discharge from numerous springs issuing from solution channels in the limestone. The aquifer is not extensively developed and is capable of supporting a sizable increase in pumpage, but additional development will reduce base flows.

The Edwards (Balcones Fault Zone) aquifer occupies a relatively small area of about 2,500 square miles $\left(6,470 \mathrm{~km}^{2}\right)$ along the Balcones Escarpment, which separates the Edwards Plateau from the Gulf Coastal Plain. The aquifer consists of about $500 \mathrm{ft}(152 \mathrm{~m})$ of extensively faulted limestone and dolomite. The faulting has greatly facilitated the development of secondary permeability, which in turn has created storage space for large quantities of ground water.

The aquifer is extensively developed in much of its extent for municipal supply, industrial use, and irrigation. Ground-water drafts are particularly heavy at San Antonio, where the aquifer provides the entire water supply for the metropolitan area. The capacities of the wells operated by the city of San Antonio are among the world's largest; some exceptional wells yield more than 16,000 gal/min $(1,000 \mathrm{l} / \mathrm{s})$. Springs issuing under artesian pressure from the aquifer largely sustain the low flow of several streams in the Nueces, San Antonio, Guadalupe, and Colorado River basins. Prolonged droughts together with heavy ground-water withdrawals may seriously reduce or even stop some of the springflow.

The Woodbine aquifer underlies about 6,000 square miles $\left(15,500 \mathrm{~km}^{2}\right)$ near the inland extent of the Coastal plain. It consists of as much as $600 \mathrm{ft}$ $(183 \mathrm{~m})$ of sand, sandstone, and shale and extends to maximum depths of about 2,000 ft $(610 \mathrm{~m})$. Yields of wells completed in the aquifer approach $700 \mathrm{gal} / \mathrm{min}$ $(44 \mathrm{l} / \mathrm{s})$ in areas of thick sand accumulations. Although the aquifer is tapped by numerous municipal and industrial wells, it is capable of supporting additional development if water-level declines are acceptable. 
The Carrizo-Wilcox aquifer underlies about 30,000 square miles $\left(77,700 \mathrm{~km}^{2}\right)$ near the inland margin of the Coastal Plain and extends across the region in a band from 30 to 80 miles $(48$ to $129 \mathrm{~km}$ ) wide. The CarrizoWilcox aquifer, which consists of interbedded sand and clay, is one of the most productive aquifers in the region. The maximum thickness of the aquifer is about $3,000 \mathrm{ft}(914 \mathrm{~m})$ at its southern (downdip) 1 imits. Yields of wells vary widely, but some large-capacity wells discharge as much as $3,000 \mathrm{gal} / \mathrm{min}(190 \mathrm{l} / \mathrm{s})$.

In the Carrizo-Wilcox aquifer, water having less than $3,000 \mathrm{mg} / 1$ dissolved solids occurs at depths of more than $5,000 \mathrm{ft}(1,520 \mathrm{~m})$, which is deeper than in any other aquifer in the region. Artesian pressure is sufficient to cause many of the deep wells to flow. The aquifer is intensively developed by irrigation wells in the Winter Garden area southwest of San Antonio, where the annual ground-water draft exceeds the annual recharge.

The Queen City aquifer, which underlies about 14,000 square miles $\left(36,300 \mathrm{~km}^{2}\right)$ of the Coastal Plain, consists of interbedded sand and clay as much as $500 \mathrm{ft}$ $(152 \mathrm{~m})$ thick. The maximum depth of water having less than $3,000 \mathrm{mg} / 1$ dissolved solids is about $2,000 \mathrm{ft}$ $(610 \mathrm{~m})$. Yields of wells are relatively low, but a few large-capacity wells exceed $400 \mathrm{gal} / \mathrm{min}(25 \mathrm{l} / \mathrm{s})$. The aquifer is only slightly developed throughout its extent.

The Sparta aquifer underlies about 9,000 square miles $\left(23,300 \mathrm{~km}^{2}\right)$ of the Coastal Plain and mostly overlies the Queen City and Carrizo-Wilcox aquifers. The Sparta consists of as much as $350 \mathrm{ft}(107 \mathrm{~m})$ of interbedded sand and clay, and water containing less than $3,000 \mathrm{mg} / 1$ dissolved solids extends to depths of more than 2,000 ft $(610 \mathrm{~m})$ in places along the southeastern boundary of the aquifer. Large-capacity wells generally yield about $500 \mathrm{gal} / \mathrm{min}(32 \mathrm{l} / \mathrm{s})$ al though the yields of some we11s exceed $1,000 \mathrm{gal} / \mathrm{min}(63 \mathrm{l} / \mathrm{s})$. Except for relatively heavy localized development, the aquifer is only slightly developed throughout most of its extent.

The Gulf Coast aquifer, which includes the Catahoula, Jasper, Evangeline, and Chicot aquifers, underlies about 35,000 square miles $\left(90,600 \mathrm{~km}^{2}\right)$ of the Coastal Plain and extends from the coastline inland for about 90 to $120 \mathrm{mi}(145$ to $193 \mathrm{~km})$. This aquifer, 
which is the most extensive of the region's groundwater reservoirs, consists of more than $3,500 \mathrm{ft}$ $(1,060 \mathrm{~m})$ of interbedded sand, clay, and grave 1 . Huge quantities of water are pumped from the aquifer for municipal supply, industrial use, and irrigation. The most intensive and concentrated development is in the Houston area, where large-capacity wells yield from 1,000 to more than $3,000 \mathrm{gal} / \mathrm{min}(63$ to $189 \mathrm{l} / \mathrm{s})$, and average about $2,000 \mathrm{gal} / \mathrm{min}(126 \mathrm{l} / \mathrm{s})$. Even though very large quantities of water are being pumped, the Gulf coast aquifer could support substantial additional development, especially in the area northeast of Houston.

The Ogallala aquifer underlies about 19,000 square miles $\left(49,200 \mathrm{~km}^{2}\right)$ of the High Plains of Texas and New Mexico. It is one of the most intensively developed aquifers in the Nation. Within the Texas-Gulf Region, the Ogallala supplies water to an estimated 50,000 irrigation wells.

The Ogallala consists of as much as $500 \mathrm{ft}(152 \mathrm{~m})$ of lenticular beds of gravel, sand, and finer material, and the zone of saturation ranges in thickness from a few feet to more than $250 \mathrm{ft}(76 \mathrm{~m})$. The depths to water range from less than $50 \mathrm{ft}(15 \mathrm{~m})$ to more than $300 \mathrm{ft}(97 \mathrm{~m})$. The yields of irrigation wells range from less than $100 \mathrm{gal} / \mathrm{min}(6.3 \mathrm{l} / \mathrm{s})$ to more than $1,000 \mathrm{gal} / \mathrm{min}(63 \mathrm{l} / \mathrm{s})$, depending largely upon the saturated thickness of the aquifer. Large-scale pumping, which greatly exceeds recharge, is drastically depleting the ground-water reserve.

The various alluvial aquifers in the region occupy an aggregate area of about 1,800 square miles $(4,660$ $\mathrm{km}^{2}$ ). Although alluvium occurs as flood-plain deposits along the Colorado and Trinity Rivers and other streams, the principal deposits are in the Central Lowland east of the High Plains and along the Brazos River. The Central Lowland aquifers are scattered and isolated terrace and flood-plain deposits that consist of as much as $150 \mathrm{ft}(46 \mathrm{~m})$ of gravel, sand, and finer sediments. The yields of large-capacity wells in these deposits range from less than $100 \mathrm{gal} / \mathrm{min}(6.3 \mathrm{l} / \mathrm{s})$ to more than 1,000 gal/min $(63 \mathrm{l} / \mathrm{s})$. The Central Lowland aquifers are not capable of furnishing additional large quantities of water for future development. 
The Brazos River alluvial aquifer underlies a flood plain from 1 to 7 miles $(1.6$ to $11.3 \mathrm{~km})$ wide and follows the long sinuous course of the Brazos River for 350 miles $(563 \mathrm{~km})$. The aquifer consists of as much as $100 \mathrm{ft}(30.5 \mathrm{~m})$ of gravel, sand, and finer sediments. More than 1000 irrigation wells tap the aquifer, which yields from 250 to $500 \mathrm{gal} / \mathrm{min}(16$ to $32 \mathrm{l} / \mathrm{s}$ ) to $50 \%$ of the wells. The maximum yields exceed $1,000 \mathrm{gal} / \mathrm{min}$ $(63 \mathrm{l} / \mathrm{s})$. The Brazos River alluvial aquifer is capable of sustaining additional ground-water withdrawals, but the discharge of the Brazos River will be reduced.

The geographic distribution of the aquifers, taking into consideration the overlap that occurs in places, provides coverage of about four-fifths of the Texas-Gulf Region. Only about one-fifth of the region is not underlain by one or more significant groundwater reservoirs, and even these areas are not totally devoid of ground water, but most rely on smaller or less dependable supplies from relatively minor waterbearing formations.

Analyses of water from wells and springs in the Texas-Gulf Region show great differences in the chemical quality of the ground water, both geographically and with depth of occurrence. Such differences are too numerous to depict on a map, but the lowest concentrations of dissolved solids usually occur in the areas of greatest rainfall and least evaporation--in the aquifers of the eastern part of the region where recharge is abundant. The exceptions to this general rule are the occurrences of water with low concentrations of dissolved solids in the limestone aquifers of the central and western parts of the region where recharge is rapid.

Widely ranging levels of salinity are characteristic of the water in storage in the ground-water reservoirs of the region (Baker and Wa11 1976). Ground water having concentrations of dissolved solids in excess of 3,000 $\mathrm{mg} / 1$ commonly occurs in the deep subsurface below the slightly saline water and downdip in most of the aquifers of the region. Only the EdwardsTrinity (Plateau), Ogallala, and alluvial aquifers, most of which do not have deep subsurface extensions, contain water that is almost entirely 
fresh to slightly saline. Largely because of the natural increase in the salinity of ground water with depth, saline water occurs throughout most of the region. The typical range in dissolved solids in water that is being used from the various aquifers is given below.

Aquifer

Alluvium
Ogallala
Gulf Coast
Sparta
Queen City
Carrizo-Wilcox
Woodbine
Edwards (Balcones Fault Zone)
Edwards-Trinity (Plateau)
Trinity
Santa Rosa
Ellenburger-San Saba
Hickory

Typical range in dissolved solids

\begin{tabular}{l} 
(mg/l) \\
\hline 500 to 2,000 \\
400 to 1,200 \\
300 to 1,000 \\
200 to 800 \\
200 to 800 \\
200 to 1,500 \\
500 to 1,200 \\
300 to 1,200 \\
400 to 1,000 \\
500 to 1,500 \\
400 to 2,500 \\
400 to 2,000 \\
300 to 700
\end{tabular}

\subsubsection{Great Basin Region}

A large amount of ground water is stored in consolidated rocks that occur both in the mountains and beneath the valley alluvium. These ground-water reservoirs generally are not continuous and are extremely difficult to evaluate. Local barriers formed by faults or rock units of low permeability produce a complex pattern of perched ground-water bodies in the mountains. These perched ground-water bodies supply numerous springs and late-season flow of mountain streams.

Carbonate rocks and volcanic rocks compose the consolidated-rock reservoirs. Carbonate rocks in most areas are highly permeable and transmit substantial quantities of water to large springs in eastern Nevada and western Utah. In southern Tonopah subregion, carbonate rocks transmit water in several multi-valley ground-water systems. 
In some areas, volcanic rocks have fracture and interflow openings that store and transmit large quantities of ground water, which sustain the flow of many streams and of numerous springs near bedrockalluvial contacts. Locally, volcanic rocks transmit water readily, such as the Quaternary basalt in Soda Creek and Gem Valleys in the Bear River subregion. Other areas with known volcanic-rock aquifers include Pavant Valley in the Sevier Lake subregion, Curlew Valley in the Great Salt Lake subregion, Winnemucca area in the Humboldt subregion, and Fallon area in the Central Lahontan subregion.

Valley ground-water reservoirs are composed of alluvial deposits which partly fill the structural depressions that form intermontane basins. These deposits generally contain sand and gravel aquifers which, in most places, provide the only supply of ground water available for large-scale development.

Ground water occurs in the porous valley alluvium in a zone of continuous saturation. The water table is near the land surface in topographically low parts of most valleys. Depth to water increases toward the mountains and may be several hundred feet beneath the upper parts of some alluvial fans. The position of the water table is regulated by surface-water altitudes in valleys that contain lakes or large streams. Artesian conditions occur where layers of silt and clay are abundant enough to confine or partly confine water in underlying deposits. This condition is common in the lower parts of most valleys. The most extensive artesian conditions occur in the eastern part of the region. This results in part from the extensive silt and clay deposits that formed during high stages of Lake Bonneville.

Detailed information on thickness of valley ground-water reservoirs generally is not available. Maximum thickness probably varies greatly from area to area. Available information indicates maximum thicknesses of more than 1,000 $\mathrm{ft}(300 \mathrm{~m})$ are common in the larger valleys, but the information available is insufficient to make any generalized statement about the smaller areas. Undoubtedly, the total stored ground water amounts to several billion acre-feet, but data are too few for a firm estimate to be made. 
The chemical quality of ground water in the Great Basin region ranges from fresh (less than $1,000 \mathrm{mg} / 1$ ) to brine (more than $35,000 \mathrm{mg} / 1$ ). Generally in sheds and alluvial aprons at valley margins, the ground water is fresh. Saline water occurs locally near thermal springs and in soluble salt terranes, as in the Middle Sevier River area. In sink areas, such as the Great Salt Lake, Sevier Lake, and Carson Sink, the dissolved solids concentrations may exceed that of ocean water. The ground water beneath playas of small closed valleys is usually brackish but not briny. Water at depth beneath playas may be fresh. For example, water from 1,200 ft deep near Tonopah had a dissolved solids concentration less than $350 \mathrm{mg} / 1$. This indicates deep circulation in the valley fill. In valleys with subsurface discharge into a regional ground-water system, the water throughout the valley-fill reservoir is generally fresh (Eakin et al. 1976).

Individual constituents may cause problems. The fluoride concentration in the Tonapah subregion is high, probably due to leachate from a volcanic tuff.

\subsubsection{Arkansas-White-Red Region}

Six aquifer types are recognized: 1) stream-valley alluvium, 2) terrace alluvium, 3) alluvium of intermontane valleys and buried alluvial valleys, 4) carbonate and gypsum, 5) sand and sandstone, and 6) undifferentiated sandstone, carbonate rock, shale and basalt. Principal aquifers are described in Tables 5.4 and 5.5. The quality of ground water varies considerably, depending upon the original character of water entering the aquifer, the nature of the rocks through which the water has moved, the contaminants introduced, and the concentration of mineralization by evaporation or transpiration. Freshwater is generally present at shallow depths, saline water at greater depths (Bedinger and Sniegocki 1976).

High dissolved solids may occur in waters from shale, salt springs, oil field brine, gypsum beds, limestone and irrigation influx. Saline waters may enter freshwater aquifers from adjacent saline aquifers and streams. Saline water is encountered at depths of less than $500 \mathrm{ft}$ 
TABLE 5.4. Principal Aquifers in the Arkansas-White-Red Region (Bedinger and Sniegocki 1976, p. H18)

\begin{tabular}{|c|c|c|c|c|c|c|c|c|}
\hline Aquifer Type & Nature of Rock & $\begin{array}{c}\text { Thickness } \\
(\mathrm{ft})\end{array}$ & Areal Extent & $\begin{array}{l}\text { Depth } \\
\text { to Water } \\
\text { (ft) }\end{array}$ & $\begin{array}{l}\text { Hydraulic } \\
\text { Conductivity } \\
(\mathrm{ft} / \mathrm{d})\end{array}$ & $\begin{array}{c}\text { Well } \\
\text { yields } \\
\text { gal/min) }\end{array}$ & Development and Use & $\begin{array}{c}\text { Ground water } \\
\text { in Storage } \\
(\text { acre-ft } \\
\left.\times 10^{8}\right)\end{array}$ \\
\hline $\begin{array}{l}\text { Stream } \\
\text { valley } \\
\text { alluvium }\end{array}$ & \multirow{3}{*}{$\begin{array}{c}\text { Sand and } \\
\text { gravel }\end{array}$} & $50-200$ & $\begin{array}{l}\text { Along large } \\
\text { streams in } \\
\text { flood plains. } \\
\text { Extensive in } \\
\text { Arkansas and } \\
\text { Louisiana. }\end{array}$ & $0-30$ & $100-1,500$ & $300-5,000$ & $\begin{array}{l}\text { Extensive; principal } \\
\text { source of ground } \\
\text { water; frequently } \\
\text { overdeveloped. Not } \\
\text { used in some areas. }\end{array}$ & 1 \\
\hline $\begin{array}{l}\text { Terrace } \\
\text { alluvium }\end{array}$ & & $50-600$ & $\begin{array}{l}\text { Plains of } \\
\text { New Mexico } \\
\text { Colorado, } \\
\text { Kansas, and } \\
\text { Oklahoma. }\end{array}$ & $50-300$ & \multirow{2}{*}{$10-700$} & \multirow{2}{*}{$50-1,000$} & \multirow{2}{*}{$\begin{array}{l}\text { Extensive; subject } \\
\text { to overdevelopment } \\
\text { and water mining, } \\
\text { particularly in } \\
\text { High Plains of } \\
\text { Texas. }\end{array}$} & 4.1 \\
\hline $\begin{array}{l}\text { Alluvium of } \\
\text { intermontane } \\
\text { valleys and } \\
\text { buried allu- } \\
\text { vial valleys }\end{array}$ & & $100-5,000$ & $\begin{array}{l}\text { Arkansas } \\
\text { River basin } \\
\text { in Colorado. }\end{array}$ & $0-50$ & & & & 0.2 \\
\hline $\begin{array}{l}\text { Carbonate } \\
\text { and gypsum }\end{array}$ & $\begin{array}{l}\text { Limestone and } \\
\text { dolomite, and } \\
\text { gypsum beds. } \\
\text { Generally a } \\
\text { dense rock, } \\
\text { but subject } \\
\text { to solution } \\
\text { along frac- } \\
\text { ture and } \\
\text { bedding } \\
\text { planes. }\end{array}$ & $50-1,500$ & $\begin{array}{l}\text { Limestone and } \\
\text { dolomite in } \\
\text { southern } \\
\text { Missouri, } \\
\text { northern } \\
\text { Arkansas, } \\
\text { southeastern } \\
\text { Kansas, and } \\
\text { 0klahoma. } \\
\text { Gypsum in } \\
\text { Oklahoma } \\
\text { and Texas. }\end{array}$ & $30-450$ & $50-1,500$ & $50-1,000$ & $\begin{array}{l}\text { Moderately to } \\
\text { heavily developed; } \\
\text { overlooked as a } \\
\text { source of water in } \\
\text { some areas. More } \\
\text { subject to pollution } \\
\text { than other aquifers } \\
\text { because of cavernous } \\
\text { nature. }\end{array}$ & \\
\hline $\begin{array}{l}\text { Sand and } \\
\text { sands tone }\end{array}$ & $\begin{array}{l}\text { Sand grains } \\
\text { ranging from } \\
\text { very fine to } \\
\text { coarse. Gen- } \\
\text { erally cemen- } \\
\text { ted with } \\
\text { siliceous } \\
\text { material or } \\
\text { carbonate. } \\
\text { Unconsoli- } \\
\text { in the } \\
\text { Coastal Plain. }\end{array}$ & $100-500$ & $\begin{array}{l}\text { Sandstone } \\
\text { principally } \\
\text { in Kansas, } \\
\text { New Mexico, } \\
\text { and Oklahoma. } \\
\text { Sand in } \\
\text { Coastal Plain } \\
\text { of Arkansas, } \\
\text { Texas, and } \\
\text { Louisiana. }\end{array}$ & $20-300$ & $\begin{array}{l}\text { Generally } \\
<100\end{array}$ & $10-1,000$ & $\begin{array}{l}\text { Extensive; subject } \\
\text { to overdevelopment } \\
\text { and water mining. } \\
\text { Loss of artesian } \\
\text { head in many areas } \\
\text { ranging from } 2 \text { to } \\
300 \mathrm{ft} \text {. }\end{array}$ & 7.9 \\
\hline $\begin{array}{l}\text { Undiffer- } \\
\text { entiated } \\
\text { sandstone, } \\
\text { carbonate, } \\
\text { shale, or } \\
\text { basalt }\end{array}$ & $\begin{array}{l}\text { Consolidated } \\
\text { rocks, includ- } \\
\text { ing sandstone, } \\
\text { interbedded } \\
\text { shale, carbo- } \\
\text { nate, and } \\
\text { crystalline } \\
\text { igneous rocks. }\end{array}$ & $100-5,000$ & $\begin{array}{l}\text { Sandstone } \\
\text { carbonate, } \\
\text { and shale } \\
\text { locally } \\
\text { throughout } \\
\text { region; } \\
\text { basalt in } \\
\text { parts of } \\
\text { New Mexico, } \\
\text { Colorado, and } \\
\text { northwestern } \\
\text { Oklahoma. }\end{array}$ & 1,200 & $\begin{array}{c}\text { Genera } 11 y \\
<10\end{array}$ & $5-50$ & $\begin{array}{l}\text { Mainly domestic use } \\
\text { not heavily concen- } \\
\text { trated use, because } \\
\text { of low permeability } \\
\text { and low well yields. } \\
\text { oifficult to predict } \\
\text { well yields. }\end{array}$ & i \\
\hline
\end{tabular}


TABLE 5.5. Names and Geographic Distribution of Major Geologic Units Forming Aquifers in the Arkansas-White-Red Region (Bedinger and Sniegocki 1976, p. H19)

\begin{tabular}{|c|c|c|}
\hline Aquifer Types & Major Geologic Unit Names & Distribution \\
\hline Stream valley alluvium & & Valleys of major streams \\
\hline & Seymour Formation & Texas \\
\hline \multirow[t]{2}{*}{ Terrace alluvium } & Equus zone of McPherson Formation & Kansas \\
\hline & Ogallala Formation & $\begin{array}{l}\text { Texas, New Mexico, } \\
\text { Colorado, Kansas, and } \\
\text { Oklahoma }\end{array}$ \\
\hline $\begin{array}{l}\text { Alluvium of intermontane } \\
\text { valleys and buried } \\
\text { alluvial valleys }\end{array}$ & & $\begin{array}{l}\text { Upper Arkansas River } \\
\text { valley and Wet Mountain } \\
\text { valley, Colorado }\end{array}$ \\
\hline \multirow{3}{*}{ Carbonate } & Reeds Spring Limestone & Ok lahoma \\
\hline & Boone Formation & Arkansas \\
\hline & $\begin{array}{l}\text { Roubidoux and Gasconade Formations } \\
\text { and the Eminence and Potosi } \\
\text { Dolomites of the Arbuckle Group }\end{array}$ & $\begin{array}{l}\text { Arkansas, Missouri, } \\
\text { Kansas, and Oklahoma }\end{array}$ \\
\hline Gypsum & Dog Creek Shale and Blaine Gypsum & Oklahoma and Texas \\
\hline \multirow{4}{*}{ Sand and sandstone } & Sparta Sand & Arkansas and Louisiana \\
\hline & $\begin{array}{c}\text { Wilcox Group, Carrizo Sand, and } \\
\text { Trinity Group }\end{array}$ & $\begin{array}{l}\text { Oklahoma, Texas, and } \\
\text { Arkansas }\end{array}$ \\
\hline & $\begin{array}{l}\text { Purgatoire Formation, Cheyenne } \\
\text { Sandstone, and Dakota Sands tone }\end{array}$ & $\begin{array}{l}\text { Colorado, Kansas, New } \\
\text { Mexico and Oklahoma }\end{array}$ \\
\hline & $\begin{array}{l}\text { Vamoosa Formation, Rush Springs } \\
\text { Sandstone, Garber Sandstone, } \\
\text { Wellington Formation, Member of } \\
\text { Gasconade Formation, Simpson } \\
\text { Group, and Gunter Sandstone }\end{array}$ & Oklahoma \\
\hline
\end{tabular}


throughout most of the area. Predominant chemical types of water in rivers at low flow are as follows: 1) $\mathrm{Ca}^{++}, \mathrm{Mg}^{++}, \mathrm{CO}_{3}{ }^{-}, \mathrm{HCO}_{3}{ }^{-}$; 2) $\mathrm{Ca}^{++}, \mathrm{Mg}^{++}$, $\mathrm{SO}_{4}{ }^{=}, \mathrm{Cl}^{-}$; and 3) $\mathrm{Na}^{+}, \mathrm{K}^{+}, \mathrm{SO}_{4}{ }^{+}, \mathrm{Cl}^{-}$. Their distribution is shown in Figure 5.6.

\subsubsection{Mid-Atlantic Region}

The Mid-Atlantic Region is underlain by a wide variety of geologic formations that together control the storage, movement, and chemical quality of the ground water. The rocks range from the unconsolidated clays, sands, and gravels of the Coastal Plain and watercourses to much older rocks west and northwest of the Fall Line. These older rocks include consolidated sedimentary rocks and some ancient intrusive and volcanic rocks in the Piedmont Lowland; limestones, dolomites, sandstones, and shales of the Valley and Ridge province; crystalline igneous and metamorphic rocks of the Piedmont Upland; and those of the Blue Ridge and Adirondack provinces. Most of these older rocks are relatively impermeable, but yield small to moderate supplies of ground water from fractures or joints to depths of about 200 to $300 \mathrm{ft}$ below the surface (Sinnott and Cushing 1978).

The rocks of the region can be grouped into three general classes: 1) unconsolidated deposits that underlie the Coastal Plain, 2) crystalline igneous and metamorphic rocks and consolidated sedimentary rocks found in the remainder of the region, and 3) surficial deposits of glacial origin, occurring widely in the northern part of the region. The glacial deposit of greatest importance with respect to ground water is stratified drift, much of which consists of sand and gravel that commonly occur in stream valleys forming what are called watercourse aquifers.

The general hydrogeologic characteristics of the rocks in each of the principal physiographic provinces of the Mid-Atlantic Region are described in the following subsections.

Locations of the physiographic provinces are shown in Figure 5.7.

\subsubsection{Coastal Plain}

The Coastal Plain lies east of the Fall Line, and forms the southeastern part of the Mid-Atlantic Region. It extends from southern Virginia northeastward through 
us

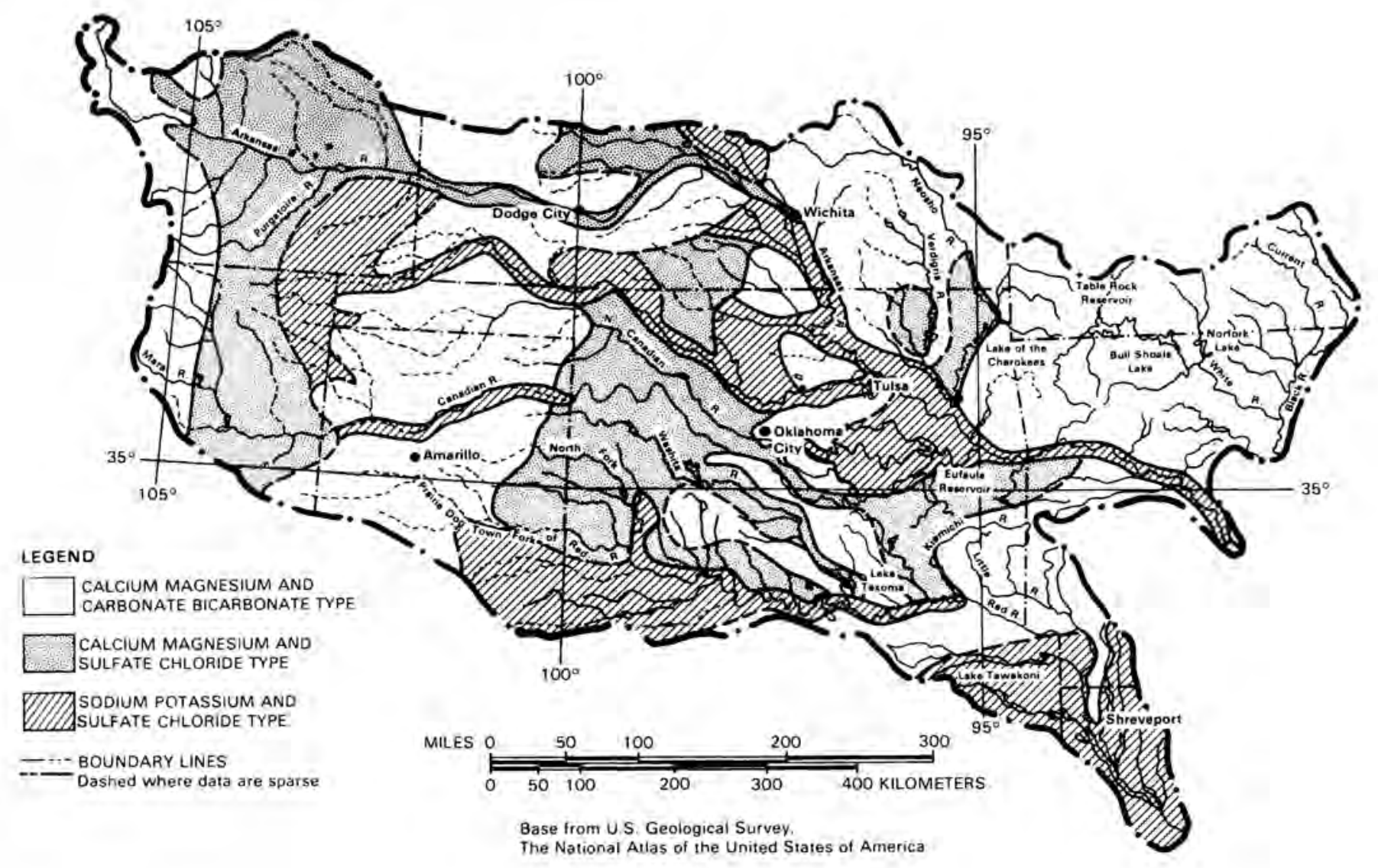

FIGURE 5.6. Prevalent Chemical Types of Water in Rivers at Low Flow in the Arkansas-White-Red Region (Bedinger and Sniegocki 1976, p. H22) 


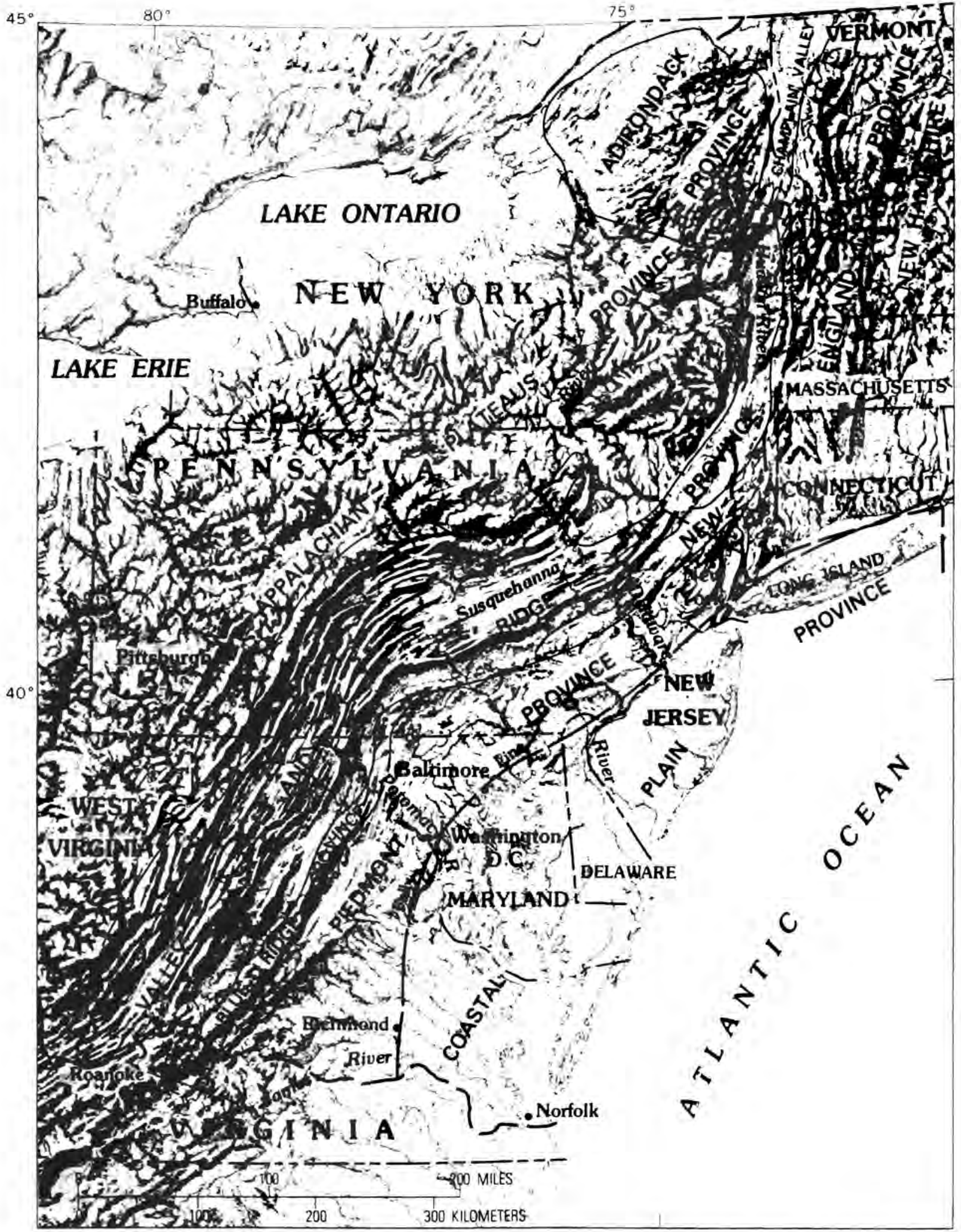

FIGURE 5.7. Major Physiographic Divisions of the Mid-Atlantic Region (Sinnott and Cushing 1978, p. (I8) 
Maryland, Delaware, Pennsylvania, New Jersey, and Long Island. Topographically its surface is nearly flat or gently undulating, and altitudes range from sea level along the Atlantic coast to roughly $250 \mathrm{ft}$ at the $\mathrm{Fall}$ Line.

The Coastal Plain is underlain by unconsolidated deposits. The formations consist mostly of sand and clay with minor amounts of gravel, and locally some beds of "marl" or shell rock. These deposits begin as a feather-edge along the Fall Line and dip gently southeastward in a thickening wedge that rests directly on the underlying crystalline igneous and metamorphic rocks and other hard rocks that make up the basement complex--the seaward extension of the hard rocks of the adjacent Piedmont province. Deposits overlying the basement complex reach a maximum total thickness of more than $8,000 \mathrm{ft}$.

Overall, the general geology of the Coastal Plain deposits appears to be simple. There is, however, considerable complexity in many of its details. The formations are areally extensive. In general, the shallow formations dip more gently than the deeper ones, and the seaward (southeastward) dip is on the order of 10 to $20 \mathrm{ft} / \mathrm{mile}$.

Surficial deposits of the Coastal Plain are largely permeable unconsolidated sand and gravel that is thickest on Long Island and in New Jersey, Delaware, and eastern Maryland. Large quantities of water can be obtained from these deposits by wells generally less than $300 \mathrm{ft}$ deep. Yields of individual wells may be as much as 2,000 gal/min where the greatest thicknesses of coarse material are present. Elsewhere in eastern Maryland and in eastern Virginia, the surficial deposits of the Coastal Plain are thin and yield of individual wells is small.

Deeper artesian aquifers of the Coastal Plain are among the most productive in the Mid-Atlantic Region. The depth of wells may be as much as 1,300 ft and yields of more than 2 million gal/d may be available from some wells.

Beneath the ocean shoreline, and seaward at various distances, the downdip reaches of the artesian aquifers contain brackish water. Large quantities of ground water withdrawn from wells close to an interface 
between freshwater and brackish water may cause encroachment of brackish water into the freshwater part of the aquifer and eventually into wells.

Near the Fall Line, where the Coastal Plain sediments thin out against the basement rocks that are exposed in the Piedmont Province, only small to moderate supplies generally are available. Most wells there will not yield more than a few hundred gallons per minute. Locally, as in the Philadephia-Camden area, somewhat larger yields have been obtained.

A number of distinct stratigraphic units have been delineated in the Coastal Plain, ranging from about 10 in Virginia to more than 20 in New Jersey. Many of these formations are permeable and have been defined as aquifers. Most are of wide areal extent and those that are of particular economic importance as major sources of ground water have been investigated and described. Large rates of withdrawal from one aquifer commonly are reflected in others proximate to it because of vertical leakage through intervening less-permeable beds. Hydraulic continuity through the complex interbedding is characteristic of Coastal Plain sediments. Most of the aquifers are not separate and independent hydrologic units; rather, each is part of a complex hydrologic system, and this system may even include streams and lakes where the aquifers are at or near the land surface.

Because the leaky nature of this complex system allows water to flow from one formation to another, it is generally not relevant to estimate quantities of ground water that are available from the individual aquifers. Rather, it is more meaningful to estimate the quantity available from the entire system. For the Coastal Plain part of the region the minimum quantity of ground water that is being discharged under present hydrologic conditions is estimated to be a little more than 9 billion gal/d.

The surficial deposits of sand and gravel that underlie the southeastern part of the Region probably constitute the most potentially productive aquifer in the Coastal Plain. These surficial deposits, together with the updip parts of deeper aquifers, constitute a water-table aquifer that blankets about 20,000 square miles on Long Island, New York, New Jersey, Delaware, eastern Maryland, and eastern Virginia. Large supplies 
of more than about $5 \mathrm{million}$ gal/d are obtainable from this water-table aquifer. Withdrawals of this magnitude from the deeper artesian aquifers would entail large drawdowns and pumping lifts, and possible dewatering of these aquifers.

Large ground-water withdrawals from the surficial deposits should be located as far as possible from the ocean, consistent with other requirements, in order to minimize the threat of saline encroachment. The watertable aquifer in the surficial deposits also is vulnerable to surface pollutants.

\subsubsection{Piedmont Province}

The basement complex that lies beneath the wedge of Coastal Plain deposits crops out at the surface along the Fall Line, an imaginary line marking the western limit of the Coastal Plain. The Piedmont province is a plateau of gently undulating hills and locally extensive lowlands lying between the Fall Line and the foot of the Blue Ridge in Virginia and Maryland and the Reading Prong of the New England province farther to the northeast. It averages about 50 miles in width, being narrowest in the northeast and widest southward in southern Virginia.

The province is underlain by weathered crystalline methamorphic and igneous rocks, by consolidated sedimentary rocks and some intrusive and volcanic rocks, and by carbonate rocks. The Piedmont contains two subprovinces, the Piedmont Upland and the Triassic Lowland. The upland consists mostly of crystalline rocks, and the lowland consists of relatively soft shale and sandstone and hills or ridges of harder rocks, such as diabase, basalt, and argillite.

Adequate quantities of ground water are available in the Piedmont province for domestic supply, light industry, and small municipalities. In the crystalline rock areas, the most dependable supplies of water are obtained by wells of moderate yield drilled into the lower part of the weathered zone and the upper part of the underlying fractured rock. Wells commonly yield up to about $15 \mathrm{gal} / \mathrm{min}$ per well, and some wells produce as much as $400 \mathrm{gal} / \mathrm{min}$. Yields from wells in the consolidated sedimentary rocks commonly are somewhat greater than those in the crystalline rocks. 
The quality of the ground water in the Piedmont is generally excellent, although in places it is high in iron or is hard where withdrawn from limestone aquifers or other sedimentary rocks containing calcareous materials.

\subsubsection{Blue Ridge Province}

Along the western flank of the Piedmont province in Virginia, Maryland, and southern Pennsylvania lies the narrow northeast-trending Blue Ridge province. Within the Mid-Atlantic Region the average width of this province is less than 10 miles.

The rocks that underlie the Blue Ridge are metamorphosed sedimentary and igneous rocks very much like the crystalline rocks of the Piedmont. The Blue Ridge rocks, however, are more resistant to erosion and stand higher than the carbonate rocks to the northwest and the Piedmont rocks to the southeast. Because of their elevated position, they tend to be stripped of surficial weathered material and fractured rock, and drained of ground water. Expected well yields are less than $50 \mathrm{gal} / \mathrm{min}$. Very little is known about the maximum water-yielding potential of the Blue Ridge rocks. Water from the Blue Ridge rocks generally is of good quality, containing low concentrations of dissolved solids.

\subsubsection{Valley and Ridge Province}

The Valley and Ridge province lies just west of the Blue Ridge and its northeastern counterparts from Virginia to southern New York. In addition, it extends northward, as the Hudson-Champlain section to the Canadian boundary; in this northward extension it lies west of the New England province. The province is bounded on the west by the Appalachian Plateaus and Adirondack provinces. In its southern half it is 50 to 100 miles wide; in eastern Pennsylvania and New York it narrows to about 25 miles.

The province is underlain by folded and faulted sandstones, limestones, dolomites, shales, and quartzites. The structural trend in its southern part is generally northeastward, changing to northward up the Hudson Valley. Differential erosion has resulted in resistant beds standing as ridges, with intervening alluvium-filled valleys. 
The chief sources of ground water in the Valley and Ridge province are permeable fractured sandstones and cavernous limestones. These are readily recharged from precipitation and stream infiltration. Much smaller quantities of ground water are available from the less permeable shales and siltstones. In all these rocks, secondary openings and fractures tighten with depth; hence, the shallow rocks, to depths of several hundred feet, are the most productive to wells.

Dry wells are common in the areas underlain by limestone. Some of these may be attributed to the fact that the water table is extremely deep because of underground drainage through interconnecting solution cavities. Water can usually be obtained by deepening the well to reach the water table. Many dry wells in limestone are caused simply by failure of the wells to penetrate any water-bearing solution cavities or fractures. A copious supply might be found in another well--perhaps only a few feet away--that taps such openings. Thus, exploratory drilling is commonly required.

In the Susquehanna River basin, well yields in the more mountainous part of the bas in area average about $125 \mathrm{gal} / \mathrm{min}$ and may reach 700 to $1,000 \mathrm{gal} / \mathrm{min}$. In the Great Valley section of the same basin, the predominant rocks, limestone and dolomite, are even more productive, and yields of wells may exceed 1,000 gal/min.

In the Hudson-Champlain section, the valley-fill deposit in the Glens Falls, New York, area is a productive aquifer. Well yields average $67 \mathrm{gal} / \mathrm{min}$ but reach $400 \mathrm{gal} / \mathrm{min}$. The bedrock, near Plattsburgh, New York, consists of sandstone and carbonate rocks. It is overlain by relatively impermeable glacial deposits and is in an artesian system. Well yields average about $15 \mathrm{gal} / \mathrm{min}$ from sandstone and $35 \mathrm{gal} / \mathrm{min}$ from carbonate bedrock. Some wells in the carbonate rocks produce as much as $200 \mathrm{gal} / \mathrm{min}$.

The chemical quality of the ground water in the Valley and Ridge province is closely related to the lithology. Water from sandstone is usually soft and generally low in dissolved solids. Water from carbonate rocks generally is hard and is contaminated locally by nitrate. Shales in the eastern panhandle of West Virginia are reported to yield hard water containing excessive iron. In the broad, major downfolded 
(synclinal) basins, high chloride or sulfate content is common. Where coal beds occur, many wells yield acid water that may also contain high iron and sulfate.

Many wells constructed in permeable weathered zones in carbonate-rock aquifers yield turbid water from the residual clay in solution channels and caverns. In the West Virginia panhandle, "lowering the water table removes support of clay plugs in the roofs of water-filled caverns in the bedrock, and the plugs may collapse to cause sink holes at the land surface.

The chemical quality of ground water in the Hudson-Champlain section is generally excellent or good, although hardness and alkalinity are problems locally.

\subsubsection{Appalachian Plateaus Province}

In the western part of the Mid-Atlantic Region, the Appalachian Plateaus province extends from northcentral Pennsylvania into southern New York. A small area in the extreme northwestern part of the Potomac River basin in West Virginia and Maryland also lies in the province.

The underlying bedrock consists of nearly horizontal beds of alternating sandstone, shale, some limestone, and seams of coal.

In Pennsylvania, the average yield per well may be about $200 \mathrm{gal} / \mathrm{min}$. In New York, yields are significantly lower, averaging about $60 \mathrm{gal} / \mathrm{min}$. The quality of water from the bedrock at depths of less than about $250 \mathrm{ft}$ is generally good except near coal mines, where iron is locally troublesome. Saline water commonly occurs at depths of only 300 to $500 \mathrm{ft}$.

The parts of the Appalachian Plateaus province that lie in northern Pennsylvania and New York are glaciated. Outwash deposits from the meltwaters of Pleistocene continental glaciers are found in the lowlands. In addition, postglacial alluvial sands and gravels in the stream valleys form watercourse aquifers. The glacial outwash deposits and the watercourse aquifers are the chief sources of dependable ground-water supplies in the glaciated part of the province. Many wells in sand and gravel deposits yield 
moderate to large supplies of water--some more than $1,000 \mathrm{gal} / \mathrm{min}$. Recharge from the streams can be induced by pumping wells drilled in the watercourse aquifers, but induced infiltration of stream water reduces streamflow.

The quality of the ground water from the glacial deposits is generally good. However, it may be hard where the drift contains limestone pebbles, and iron is troublesome locally, particularly in New York.

\subsubsection{Adirondack Province}

The eastern part of the Adirondack province lies within the Mid-Atlantic Region in northern upstate New York. It is just north of the Appalachian Plateaus province and west of the Hudson-Champlain section of the Valley and Ridge province. The province is a nearly circular uplift of ancient granite, gneiss, and other crystalline rocks surrounded by shale, sandstone, limestone, and dolomite. Valleys contain glacial outwash and alluvium. Many peaks exceed 4,000 ft in altitude; Mount Marcy, the highest mountain in New York, has an altitude of 5,344 ft.

Yields of wells are generally moderate, 15 to $35 \mathrm{gal} / \mathrm{min}$; the water occurs mostly in fractures in both the crystalline rocks and the consolidated sedimentary rocks. Larger yields are obtained locally from solution openings developed along fractures in the carbonate rocks. Locally, substantial yields are available also in glacial outwash deposits in valleys.

The quality of ground water is generally good, and that from the crystalline rocks is excellent--less than $100 \mathrm{mg} / 1$ of dissolved solids.

\subsubsection{New England Province}

In the Mid-Atlantic Region, the New England province is represented by the western part of Vermont, the extreme northwestern part of Massachusetts, and a narrow area extending southwestward across southern New York and northern New Jersey into eastern Pennsylvania as far as Reading.

The bedrock consists of ancient crystalline, igneous, and metamorphic rocks, some of which are 
carbonate rocks. Locally the carbonate rocks are faulted and contain solution openings, forming aquifers that may yield a few hundred gallons per minute. Similar yields may be obtained from deposits of stratified glacial drift in stream valleys (watercourse aquifers).

Ground water of generally good quality can be developed from the various kinds of bedrock and from the stratified drift. The carbonate bedrock, however, yields water that is moderately hard.

\subsubsection{Water Quality}

The chemical quality of ground water in the Mid-Atlantic Region differs from place to place in accordance with the hydrologic history of the water and the nature of rock materials through which it flows. However, in most parts of the Mid-Atlantic Region, freshwater of satisfactory chemical quality for virtually all uses occurs to depths of several hundred feet, and in some areas to a depth of a thousand feet or more. In overview, the Coastal Plain province contains a large, complex blanket of fresh ground water overlying a much greater volume of deep-lying brackish and saline ground water extending downdip (downslope) seaward. The boundary between the updip freshwater and the downdip saline water is mappable. Freshwater, in the great mass of nonmarine formations constituting the oldest sedimentary rocks in the province, extends from several to more than 60 miles downdip from outcrop areas along the western side of the province. The quality of water in these deposits is generally soft and slightly acidic in the outcrop area, with local excessive amounts of iron, and total dissolved solids content on the order of 50 to $150 \mathrm{mg} / 1$. Downdip and at greater depths below the land surface, in parts of the formation confined under younger deposits, the water is more mineralized, is commonly of the calcium bicarbonate type and slightly hard, with dissolved solids on the order of 300 to $500 \mathrm{mg} / 1$. As the boundary between fresh and saline ground water is approached, dissolved solids exceed 1,000 mg/1 (Sinnott and Cushing 1978). 
A large mass of marine deposits rests on and crops out east of the nonmarine strata. These marine deposits contain fresh ground water with dissolved-solids content on the order of 100 to $250 \mathrm{mg} / 1$. Water from these deposits, too, contains excessive concentrations of iron locally, and owing to the abundance of calcium carbonate shells and other calcareous material, moderate to excessive hardness is encountered.

Water in glacial, watercourse, and alluvial deposits is generally soft, containing from less than $50 \mathrm{mg} / 1$ to $150 \mathrm{mg} / 1$ of dissolved solids; locally concentration may be as much as $400 \mathrm{mg} / 1$. Excessive hardness arid high-iron concentrations also occur. Saline water from tidal rivers, bays, and the Atlantic Ocean, where these waters are in contact with low-lying deposits, may infiltrate the fresh ground water, either naturally or by induced landward movement owing to well pumpage. Peripheral to these saltwater bodies, aquifers may contain water with dissolved-solids concentrations of $1,000 \mathrm{mg} / 1$ and much more. The quality of ground water in aquifers subject to freshwater recharge from rivers, lakes, or fresh reaches of estuaries may vary with the quality of the water infiltrating from these surface sources.

Owing to the great variety of rock materials in the provinces west and north of the Coastal Plain, ground-water quality varies widely. Freshwater in the silicate-type rocks (most of the metamorphic crystalline rocks and quartzose sedimentary rocks) that form highland areas, mountains, and ridge areas is different from that in the calcareous carbonate rocks (primarily limestone and dolomite) that commonly underlie major regional lowland valleys. Although there are exceptions, ground water in the silicate-type rocks is generally soft with low dissolved solids, usually less than $200 \mathrm{mg} / 1$. Metamorphic crystalline rocks of the Blue Ridge province, for example, are not readily soluble to ground water, and water derived from wells or springs characteristically is very low in dissolved solids. In contrast, water in the calcareous rocks, such as in the Shenandoah Valley of Virginia, the Valley and Ridge Province, and the Taconic Province of New York and New England, is typically hard, with dissolved-solids content of 200 to $600 \mathrm{mg} / 1$. 
Throughout much of the area of the Appalachian provinces underlain by sedimentary belts of rocks, the fresh ground water is underlain by salty ground water at depths of several hundred to several thousand feet.

\subsubsection{Great Lakes Region}

Ground water is unevenly distributed across the Great Lakes Region. Land-surface features, precipitation, surface and subsurface drainage, and the hydrologic properties of the underlying rocks combine to determine the availability of ground water in any area. Unconsolidated outwash sand and gravel deposits are highly permeable and represent the best aquifers in the region. The most productive aquifers are in the valleys of major streams. These aquifers can be recharged by induced infiltration of streamflow, and the sand and gravel act as natural filters to remove many impurities (Weist 1978).

In areas of the Great Lakes Region where the unconsolidated deposits are poorly permeable, thin, or absent, ground-water sources are limited to the consolidated (bedrock) aquifers. Supplies from these aquifers are generally adequate and dependable, except locally where shale or crystalline rocks crop out. These areas are few and scattered.

Carbonate (limestone and dolomite) aquifers constitute the most common bedrock aquifers in the basin. They occur along the northern and western shore of Lake Michigan, from Illinois to Cleveland, and along the southern shore of Lake Ontario. The carbonates are most productive, with well yields as much as $1,000 \mathrm{gpm}$, where they extrude or are overlain by unconsolidated deposits. Solution processes have developed good permeability in these areas. Sandstone aquifers are the next most common bedrock aquifers. A thick sequence of productive sandstone units (well yields as much as 1,300 gpm) is present along the western and northern part of the Lake Michigan basin. Such productive units with well yields as much as $500 \mathrm{gpm}$ are also present in parts of Michigan and in Ohio, Pennsylvania, and New York. As aquifers, shale beds are the least productive sedimentary unit. Shales are abundant in the southern part of the Great Lakes Bas in from Indiana to the Adirondack Mountains.

Crystalline rocks constitute the bedrock west of Lake Superior and in the Adirondacks regions. Wells in 
these rocks provide adequate yields for domestic and rural supplies and, in exceptional areas, for small commercial and industrial supplies. Water is obtained from fractures and from the upper, weathered part of the rocks.

Yields of as much as $5,000 \mathrm{gal} / \mathrm{min}$ are obtainable from wells in some thick deposits of highly permeable sand and gravel, and yields in excess of $500 \mathrm{gal} / \mathrm{min}$ have been reported from bedrock in some areas. On the other hand, yields of $5 \mathrm{gal} / \mathrm{min}$ may be difficult to obtain in areas underlain by till or crystalline bedrock. Table 5.6 summarizes the occurrence of ground water in the Great Lakes Region.

Well yields and water quality vary across the region, even within the same aquifer system. An important aquifer in one area may yield only small amounts of water elsewhere or water that is too saline for most uses. For example, the Cambrian-Ordovician aquifer system is an important source of water for the Chicago area. However, in northern Indiana the water is so saline that the system is relegated to deep-well waste disposal. In the Lake Superior basin, the Silurian aquifer system yields 50 to $100 \mathrm{gal} / \mathrm{min}$ to wells, whereas in parts of the Lake Michigan basin the system yields as much as 1,000 gal/min. In general, the highest yields are obtained from fractured rock aquifers or those that contain solution channels.

The long-term water-yielding potential of an aquifer is dependent on the availability of recharge. In the Great Lakes Region most recharge from snowmelt and rainfall occurs as water infiltrates the soil and percolates to the water table. However, highest well yields are generally obtained from aquifers that are in direct hydraulic continuity with lakes or streams.

Natural ground-water discharge maintains streamflow during dry periods and helps to maintain lake levels and wetlands. This discharge varies seasonally. At least $30 \%$ of the time, during low flow, nearly all water in streams comes from ground-water discharge. This amounts to nearly 26 billion gallons per day for the region.

At higher streamflows the ground-water discharge may be greater, but data are not readily available to determine amounts. 
TABLE 5.6. Occurrence of Ground Water in the Great Lakes Region

\begin{tabular}{|c|c|c|c|}
\hline Aqui fer System & $\begin{array}{c}\text { Yields of } \\
\text { Highest } \\
\text { Capacity } \\
\text { Wells } \\
\text { (gal/min) }\end{array}$ & Principal Water-Bearing Units & $\begin{array}{l}\text { Areas of } \\
\text { Greatest Potential }\end{array}$ \\
\hline \multicolumn{4}{|c|}{ Unconsolidated Deposits } \\
\hline Glacial lake deposits & $10-20$ & $\begin{array}{l}\text { Sandy zones within the silt } \\
\text { and clay. }\end{array}$ & Indiana-South Bend \\
\hline $\begin{array}{l}\text { Outwash sand and } \\
\text { gravel }\end{array}$ & $50-5000$ & $\begin{array}{l}\text { Highest yields are obtained in } \\
\text { areas with good sources of } \\
\text { recharge. }\end{array}$ & $\begin{array}{l}\text { Jackson, Kalamazoo } \\
\text { area; Au Sable, } \\
\text { Manitee, and }\end{array}$ \\
\hline Ti11 & $10-20$ & Sand and gravel lenses & $\begin{array}{l}\text { Muskegon River } \\
\text { valley; New York- } \\
\text { Genesee River } \\
\text { basin; Ohio- } \\
\text { northeastern } \\
\text { Pennsylvania }\end{array}$ \\
\hline
\end{tabular}

Bedrock

\begin{tabular}{|c|c|c|c|}
\hline Pennsylvanian & $50-700$ & $\begin{array}{l}\text { Sandstone and shale. Brine } \\
\text { and sulfates frequently } \\
\text { encountered in lower part. }\end{array}$ & Southern Michigan \\
\hline Mississippian & $50-1800$ & $\begin{array}{l}\text { Sandstone and shale. May } \\
\text { contain oil, gas, and } \\
\text { brine }\end{array}$ & $\begin{array}{l}\text { Southern Michigan, } \\
\text { northeastern Ohio, } \\
\text { Pennsylvania }\end{array}$ \\
\hline Devonian & $50-700$ & $\begin{array}{l}\text { Mostly carbonate rocks with } \\
\text { some sandstone. May con- } \\
\text { tain oil, gas and brine }\end{array}$ & $\begin{array}{l}\text { Ohio, southern } \\
\text { Michigan, north- } \\
\text { eastern Indiana }\end{array}$ \\
\hline Devonian-Silurian & $50-500$ & Carbonate rocks & Northern Michigan \\
\hline Silurian & $50-1000$ & $\begin{array}{l}\text { Mostly carbonate rocks. } \\
\text { Water is saline in places }\end{array}$ & $\begin{array}{l}\text { Eastern Wisconsin, } \\
\text { Illinois, north- } \\
\text { eastern Indiana, } \\
\text { northwestern Ohio }\end{array}$ \\
\hline Ordovician & $50-500$ & $\begin{array}{l}\text { Carbonate rocks and sandstone. } \\
\text { Saline water at depth }\end{array}$ & Western New York \\
\hline Cambrian-Ordovician & $50-1300$ & $\begin{array}{l}\text { Carbonate rocks and sandstone. } \\
\text { Saline water at depth }\end{array}$ & $\begin{array}{l}\text { Illinois, eastern } \\
\text { Wiscons in }\end{array}$ \\
\hline Cambrian & $50-500$ & $\begin{array}{l}\text { Sandstone. Saline water at } \\
\text { depth }\end{array}$ & Illinois \\
\hline Cambrian-Precambrian & $50-500$ & Sandstone & North Michigan \\
\hline Precambrian & $100-250$ & $\begin{array}{l}\text { Sandstone and crystalline } \\
\text { rocks }\end{array}$ & $\begin{array}{l}\text { Minnesota-- } \\
\text { Mesabi Range }\end{array}$ \\
\hline
\end{tabular}




\subsubsection{Souris-Red-Rainy Region}

Ground water in the Souris-Red-Rainy Region is obtained mainly from aquifers in Pleistocene drift such as drainage-channel deposits, lake deltas, beach deposits, outwash deposits, and small bodies of sand and gravel interbedded with till. In addition, the Souris and Red River basins in North Dakota have aquifers of Precambrian and Paleozoic age; the Dakota, Pierre, and Fox Hills-Hell Creek aquifers of Cretaceous age; and the Fort Union aquifer of Tertiary age. In the Red and Rainy River basins in Minnesota, aquifers are of Precambrian, Paloezoic, and Cretaceous age. The total volume of water having less than $3,000 \mathrm{mg} / 1$ of dissolved solids available from storage in the region is estimated to be $5 \times 10^{8}$ acre-feet. The estimate is based on areas, estimated and known saturated thicknesses, and estimated and known values of specific yields of the various aquifer materials (Reeder 1978).

The region is underlain by a series of bedrock units that differ greatly in thickness and in hydrologic characteristics and that range in age from Precambrian to Quaternary as shown in Figure 5.8. Precambrian crystalline rocks are at or near the land surface (about 1,300 ft above mean sea level) locally in the eastern part of the region and about $15,000 \mathrm{ft}$ below the surface (about $12,000 \mathrm{ft}$ below mean sea level) in the center of the Williston Basin. The central and deepest part of this basin is in the westernmost part of North Dakota, southwest of and beyond the limits of the Souris River basin. Most of North Dakota, including the Souris and the western part of the Red River basins, is in the Williston Basin (see Figure 5.8), which extends northward into Canada, southward into South Dakota, and westward into Montana. Sedimentary rocks of Paleozoic, Cretaceous, and Tertiary age occupy the Williston Basin. These strata gradually thin toward the east and are missing in the southern and eastern parts of the Red River basin and in the Rainy River basin, where Precambrian rocks directly underlie the glacial deposits.

The oldest Paleozoic beds dip westward at an average slope of nearly $50 \mathrm{ft}$ per mile across the eastern three-fourths of North Dakota, but the Tertiary beds dip westward at only a few feet per mile. Sedimentary rocks of Ordovician age overlie the crystalline rocks in most of the Red River and Souris River basins, 


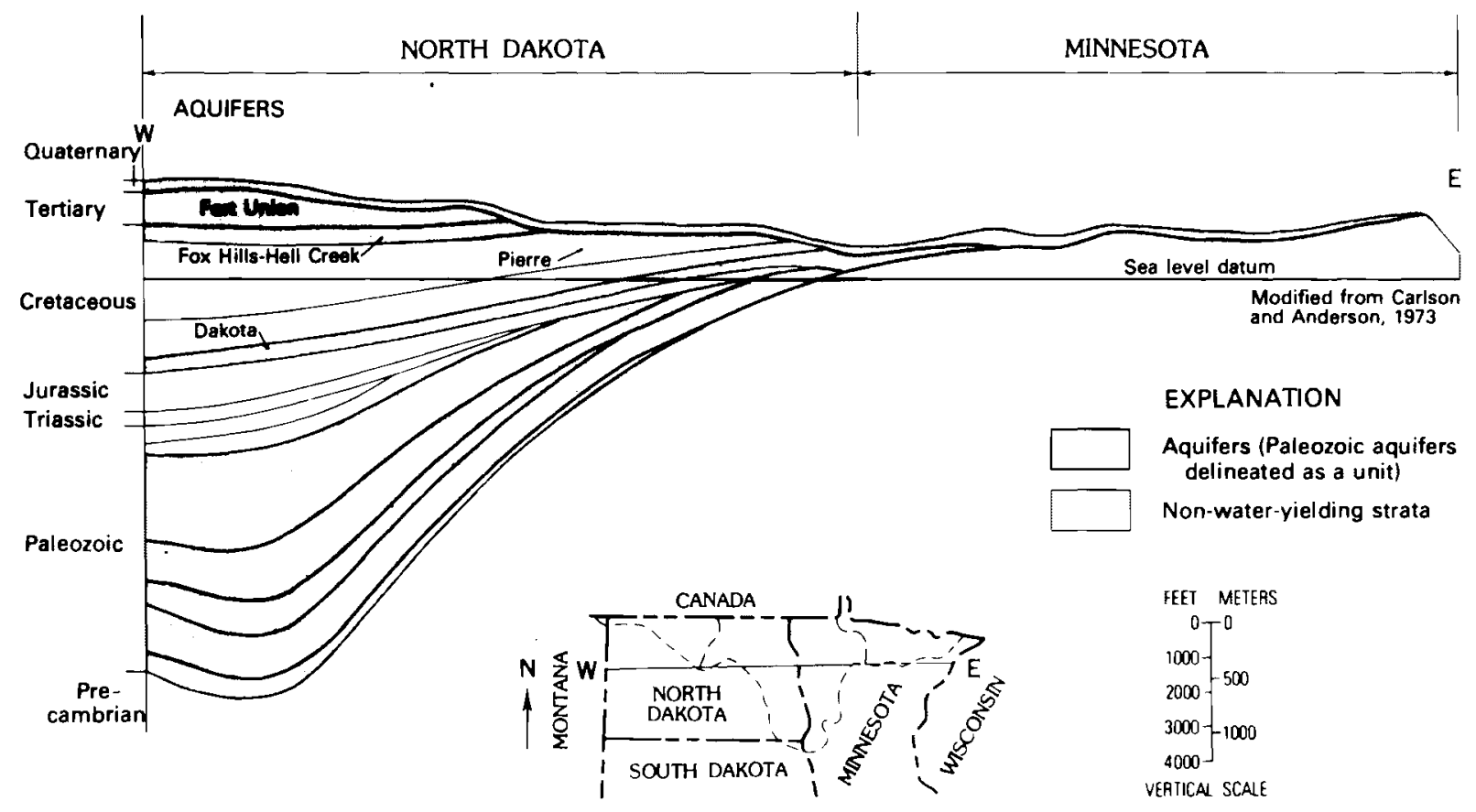

FIGURE 5.8. Diagrammatic Section of North Dakota and Minnesota Showing Location of Aquifers (Reeder 1978, p, K7)

sloping and thickening westward. Rocks of Jurassic and Cretaceous age, which thicken westward from the west border of Minnesota overlie the Paleozoic rocks. Tertiary rocks occur on the west edge of the Red River basin and in much of the Souris River basin.

The entire region has been glaciated, and most of it is covered with drift that ranges in thickness from less than a foot to several hundred feet. The drift is largely till, a heterogeneous mixture of clay, silt, sand, and gravel, but it also contains buried lenses of stratified sand, gravel, silt, and clay, which were deposited along the margin of the glacier or near it. The buried sand units, which range in thickness from a few inches to many feet, cover areas of many square miles.

Lake Agassiz sediments significantly affect the hydrologic system in the Red River basin because they are extremely fine grained, thick, and widespread. The 
thickness of these sediments in the Minnesota part of the lake deposits ranges from less than $1 \mathrm{ft}$ to more than $140 \mathrm{ft}$.

Small well yields are obtained from bedrock aquifers underlying the drift in the Souris and Red River basins. In parts of the Rainy River basin, where productive glacial deposits are thin or absent, small yields of water are obtained locally from fractures in the crystalline bedrock.

Yields of wells in individual bedrock aquifers are generally less than about $100 \mathrm{gal} / \mathrm{min}$ but may be as much as $500 \mathrm{gal} / \mathrm{min} 10 \mathrm{cally}$, and more than $500 \mathrm{gal} / \mathrm{min}$ in a few places. Yields in drift aquifers average less than $100 \mathrm{gal} / \mathrm{min}$ but range from 5 to $1,000 \mathrm{gal} / \mathrm{min}$. A few wells in outwash yield more than $1,000 \mathrm{gal} / \mathrm{min}$. Table 5.7 describes aquifers of the region.

The potentiometric surface in the bedrock formations generally decreases in altitude toward the Red River, indicating that the regional direction of water movement is toward the river. In the Rainy River basin, some ground water probably migrates westward into the Red River basin; but most ground water moves northwestward and is discharged from the area through the Rainy River and Lake of the Woods. These regional patterns of movements of the ground water indicate that recharge from precipitation on upland areas, from surface water, and from ground water entering from adjacent regions moves regionally to discharge areas along the Red River Valley. The general ground-water flow system is much more complex because of the many local flow patterns within the regional system. Much of the ground-water discharge occurs near recharge areas within the region.

Precambrian crystalline rocks, which underlie all of the region, generally are poor aquifers, but locally are sources of small supplies. Along the southeastern edge of North Dakota, and in the eastern part of the Red River basin in Minnesota and in most of the Rainy River basin, small supplies of water can be obtained from the fractures or from weathered zones in the upper part of the crystalline rocks. Generally, wells in the Precambrian aquifer will not yield more than a few gallons per minute. The Precambrian rock surface also generally defines the base of the water-yielding zone of the hydrologic system. The general slope of the crystalline rock surface is from east to west. 
TABLE 5.7. Description of Aquifers, Water Quality, and Water-Supply Potential in the Souris-RedRainy Region (Reeder 1978, p. (K12)

\begin{tabular}{|c|c|}
\hline & Aquifer \\
\hline & Drift and alluvium \\
\hline$\stackrel{5}{\frac{5}{5}}$ & $\begin{array}{l}\text { Upper part of Fort Union } \\
\text { (includes Tongue River } \\
\text { Member). }\end{array}$ \\
\hline ¿̊ & $\begin{array}{l}\text { Cannonball } \\
\text { Member of Fort Union }\end{array}$ \\
\hline
\end{tabular}

Fox Hills-Hell Creek

Pierre

is

Dakota

Paleozoic

Precambrian
Character of Rocks Drift: till, outwash, and lacustrine deposits.

Alluvium: gravel, sand, silt, and clay.

Sandstone, shale and lignite.

Marine sandstone and sandy shale.

Sandstone: sandstone and shale

Shale, brittle, fissile; upper part fractured.

Sandstone and shale

Shale, sandstone, limestone, and dolomite.

Crystalline rocks, upper part fractured and weathered.
Water Quality

Extremely variable from place to place. Dissolved solids generally 250 to $1000 \mathrm{mg} / 1$, but may be as high as 3000 to $10,000 \mathrm{mg} / 1$ in a few places.

Sodium bicarbonate type and locally high sulfate. Dissolved solids 200 to $7000 \mathrm{mg} / \mathrm{l}$.

Sodium chloride type. Dissolved solids less than $3000 \mathrm{mg} / 1$, most water ranges from 1000 to $2500 \mathrm{mg} / 1$.

Sodium bicarbonate type generally, sodium sulfate type locally. Dissolved solids 300 to $3700 \mathrm{mg} / \mathrm{l}$, but most water contains 1000 to $2000 \mathrm{mg} / \mathrm{l}$.

Extremely variable from place to place. Sodium chloride, sodium sulfate type, or combination. Dissolved solids 700 to $12,500 \mathrm{mg} / \mathrm{l}$ but most is less than $3000 \mathrm{mg} / \mathrm{l}$.

Souris basin: sodium chloride type, dissolved solids 4000 to sulfate type, dissolved solids sulfate type, dissolved solids Dakota, less than $2000 \mathrm{mg} / 1$ in

Highly saline. Dissolved solids 14,000 to $54,000 \mathrm{mg} / 1$ in central part of Red basin, and as high as $330,000 \mathrm{mg} / 1$ in western North

Dakota.

Sodium bicarbonate sulfate type, depending largely on type in the adjacent aquifer. Dissolved solids about $1000 \mathrm{mg} / 1$ or more in Red basin, less than $500 \mathrm{mg} / \mathrm{l}$ in Rainy basin.
Water-Supply Potential and Aquifer Occurrence

Extremely variable from place to place. Large potential for large supplies in sand and gravel aquifers. Large potential for small supplies almost everywhere in region.

Small to moderate supplies. Occurs in western two-thirds of Souris basin.

Small to moderate supplies. Occurs in most of Souris basin and extreme western parts of Red basin.

Widely used for domestic and stock supplies. Occurs in eastern part of Souris basin and western two-thirds of Red basin.

Moderate to large supplies. Occurs in western two-thirds of region.

Potential for development of small to large supplies. Occurs in North Dakota and northwestern corner of Minnesotd.

Small supplies, low yields. Occurs in Minnesota and eastern North Dahota. 
Water occurs in the Paleozoic rocks in the Souris River basin and in most of the Red River basin but in places it is highly saline. Although there are several water-bearing units within the Paleozoic rocks, data are insufficient to determine the areal extent, thickness (except locally), and degree of interconnection of the individual units; therefore, all water-bearing Paleozoic rocks are treated here as a single aquifer. The top of the aquifer occurs at depths of about $150 \mathrm{ft}$ in eastern North Dakota and deepens westward to more than $13,500 \mathrm{ft}$ at the bottom of the aquifer in western North Dakota, beyond the limits of the region. It is composed of fine-grained sandstone which yields small dependable supplies of water; and porous, cavernous limestone, which yields large supplies of water. The salinity of the water, however, severely limits its usefulness. Production of water in eastern North Dakota is limited to one industrial well that flows, when not closed, at a rate of about $700 \mathrm{gal} / \mathrm{min}$ and a few domestic wells that are used for sanitation. Water from the Paleozoic aquifer also is produced with oil in the western part of the region. Because of the highly saline water, the Paleozoic aquifers in Minnesota have never been used. Test holes into the Paleozoic rocks have flowed as much as $60 \mathrm{gal} / \mathrm{min}$.

The Dakota aquifer, which is composed of basal Cretaceous sandstone and shale, underlies all of the Souris River basin and the western half of the Red River basin. Aquifers in Cretaceous rocks, which probably are equivalent to the Dakota aquifer, underlie the northwestern Red River basin in Minnesota. The depth to the top of the aquifer gradually increases from $100 \mathrm{ft}$ along the eastern limit of the aquifer in the Red River basin to more than 5,600 ft in the deepest part of the Williston Basin southwest of the Souris River basin. The aquifer materials differ from place to place, but generally consist of interbedded quartzose sand and shale. Sand predominates in the eastern part of North Dakota and shale predominates in the western part.

In the eastern part of North Dakota, the individual sand beds generally are less than $30 \mathrm{ft}$ thick, but locally are as much as $100 \mathrm{ft}$ thick. They generally are composed of fine, medium, or coarse sand that has very little interstitial silt or clay. Interstitial silt and clay decreases permeability of the aquifer and, thus, decreases well yields and the rate of flow 
of water through the aquifer. In the western part, individual beds generally are composed of fine sand and minor amounts of medium sand, and interstitial silt and clay are more common.

Numerous wells tap the Dakota aquifer in the western part of North Dakota. Most of these wells are for domestic and stock use but a few are for municipal and industrial purposes. Flowing wells in the Dakota have discharges that range from less than 1 to 100 $\mathrm{gal} / \mathrm{min}$ and average 2 to $3 \mathrm{gal} / \mathrm{min}$ in most of the Souris-Red-Rainy Region. Pumping rates in excess of $500 \mathrm{gal} / \mathrm{min}$ are obtained from some wells. In the Souris basin part of the region potential well yields range from 50 to $350 \mathrm{gal} / \mathrm{min}$.

The Pierre aquifer is in the upper part of the Pierre Shale of Cretaceous age in the eastern part of the Souris River basin and the western part of the Red River basin. The aquifer may extend westward for a short distance beneath the Fox Hills-Hell Creek aquifer, but no data are available to determine the western limit accurately.

The Pierre is composed of light-gray to black siliceous shale, marlstone, and claystone, and is locally fractured in the upper part. Unfractured shale, marlstone, and claystone are nearly impermeable and will not yield a significant amount of water to wells; therefore, the fractured zones are the only sources of water. The fractures, where present, may extend several hundred feet below the land surface, but they generally are too small to yield significant quantities of water below depths of about $100 \mathrm{ft}$.

Although the Pierre is not a major aquifer, it is the only source of water for many farms and a few municipal supplies. Most farm wells yield less than $6 \mathrm{gal} / \mathrm{min}$. Locally, where the fracture zone is exceptionally thick or the fractures are unusually large, pumping rates range from 50 to $100 \mathrm{gal} / \mathrm{min}$.

The Fox Hills-Hell Creek aquifer of Cretaceous age underlies most of the Souris River basin. The depth to the top of the aquifer gradually increases from a few feet in topographically low areas near the eastern boundary of the aquifer to more than $1,400 \mathrm{ft}$ in topographically high areas near the center of the Williston Basin southwest of the Souris River basin. 
The aquifer is composed of interbedded sand, clay, silt, and lignite, but the lithology differs considerably from place to place. Many of the individual sandy layers in the aquifer are thin and lenticular and do not extend for more than a few miles. However, at least one, and commonly more than one, sandy layer more than $20 \mathrm{ft}$ thick is present. Generally, the individual sandy layers are composed of fine to medium sand with interbedded silt and clay lenses, but locally the sandy layers may be either very fine sand or include considerable amounts of interstitial silt.

Wells in the Fox Hills-Hell Creek aquifer generally yield less than $30 \mathrm{gal} / \mathrm{min}$; but locally, where the sandy layers are unusually thick or contain very little interstitial or interbedded silt or clay, yields may be as much as $150 \mathrm{gal} / \mathrm{min}$.

Sand and lignite beds in the Fort Union Formation of Tertiary age form the Fort Union aquifer in the western two-thirds of the Souris River basin. The Fort Union which may be as thick as 1,100 ft near the center of the Williston Basin, is composed of beds of silty clay, clay, sand, and lignite. Individual beds in the formation generally cannot be traced as much as a mile; however, a few exceptionally thick and extensive beds extend many miles. Most sand beds are less than $10 \mathrm{ft}$ thick, but some are as much as $150 \mathrm{ft}$ thick. Lignite beds generally are 2 to $5 \mathrm{ft}$ thick, but thicknesses of as much as $40 \mathrm{ft}$ have been reported. The sand is generally fine, with medium sand reported locally. The sand also may contain considerable amounts of interstitial clay.

The nonmarine Tongue River Member of the Fort Union Formation, stratigraphically in the upper part of the formation, is the principal bedrock aquifer in the Souris River basin. The underlying marine Cannonball Member yields water that is used for watering livestock but that is generally too salty for human consumption. Although there may be several aquifers in the Fort Union Formation, data generally are insufficient to determine the areal extent, thickness, or degree of interconnection of the units; therefore, all waterbearing units in the Fort Union are considered here as a single aquifer.

The quantity of water the Fort Union aquifer will yield to wells depends on 1) the thickness, sorting, and grain size of the sand beds, and 2) the quantity of 
interstitial or interbedded clay near each well. Properly constructed wells finished in sand beds as thick as $100 \mathrm{ft}$ will yield as much as $50 \mathrm{gal} / \mathrm{min}$ with $20 \mathrm{ft}$ of drawdown. A few wells will yield as much as $100 \mathrm{gal} / \mathrm{min}$, but drawdowns are greater than $20 \mathrm{ft}$.

Drift aquifers of Quaternary age, which are the most important sources of ground water in the region, are distributed throughout most of the Souris and Red River basins and part of the Rainy River basin. Although most of the drift in the region is composed of several tens to several hundred feet of ti11, which yields little or no water to wells, some of the drift consists of stratified sand and gravel which form important sources of water supply. In the Rainy River basin, however, glacial erosion rather than deposition was the primary process shaping the surface of the land, and the deposits are thin or absent, except in the south and west parts of the basin where the glacial deposits thicken to nearly $250 \mathrm{ft}$.

Most of the aquifers are either valley fill or outwash deposits. Melt water flowing from and along the ice front deposited outwash and ice-contact deposits in a network of channels. During subsequent periods of glacial advance and retreat, old channels were blocked and new ones formed. Each successive advance of glacial ice smoothed the terrain by filling the valleys and eroding the hills. Parts of these channels were subsequently filled with sand, gravel, and till, such as in the New Rockford aquifer in east-central North Dakota. Some of these glacial channels are now occupied by modern streams, as illustrated by the Sheyenne River valley in southeastern North Dakota. Deposits in these channels form numerous aquifers scattered throughout the Red and Souris River basins and the western part of the Rainy River basin. Many of the earlier channels were buried by subsequent glacial deposits, and most of the glacial channels exposed at the surface were formed during the most recent advance of glacial ice. Outwash deposits in these youngest channels are generally thin, and only locally form significant aquifers.

The deposits in glacial Lake Agassiz, in the center of the Red River basin, occupy almost one-third of the area of the basin. These deposits are generally too fine grained to be important as a source of ground water. However, some lakeshore deposits, such as deltas and beach ridges, are coarse grained and form 
important aquifers. The Sheyenne delta aquifer in the southeast corner of North Dakota is a notable example. Fine-grained sediments also were deposited in glacial Lakes Cando and Dakota, and glacial Devils Lake in the western part of the Red River basin and in glacial Lake Souris in the Red and Souris River basins.

Alluvium deposited after the glacial periods consists of silt, sand, and gravel in the valleys of some of the larger streams. These deposits generally are finer grained and less permeable than the outwash deposits, but locally they are sources of water.

The ability of the deposits to yield water to wells depends on the grain size and thickness of the materials, but in broad view and ultimately the quantity of water that an aquifer will yield depends on the amount of water in storage and on the amount of recharge. If a sand or gravel deposit is small and enclosed in till or other fine-grained material, it receives little recharge; consequently, such deposits will not yield large quantities of water for sustained periods. Large deposits of saturated sand and gravel, however, contain large quantities of water in storage and may be capable of receiving sustained quantities of recharge over the large area of contact with the clay layers even if they are enclosed within fine-grained deposits; consequently, such deposits form major aquifers that will yield substantial quantities of water for sustained periods.

The quality of ground water in the Souris-RedRainy Region differs from place to place, even within an aquifer (see Table 5.7). Generaliy, water with the best quality is in or near recharge areas or areas with flow sufficient to flush out saline water. Water in surficial outwash in or near recharge areas almost everywhere contains less than $1,000 \mathrm{mg} / 1$ dissolved solids and in many places less than $500 \mathrm{mg} / 1$. Highly mineralized water is found in older, deeper rocks in much of the region and in shallow aquifers where rock has migrated from mineralized aquifers. For example, in the north-central part of the Red River basin, highly mineralized water migrates upward into the drift from the underlying Paleozoic and Dakota aquifers. Water in the drift in these areas generally is a sodium chloride type, with many of the characteristics of the water in the underlying bedrock. 
In the Pierre aquifer, water is a sodium chloride or sodium sulfate type or a combination of the two. The dissolved-solids concentration ranges from 700 to $12,500 \mathrm{mg} / 1$, and the shallow fractured zone generally yields water with 2,000 to $4,000 \mathrm{mg} / 1$ dissolved solids. Most of the water in the Pierre aquifer contains greater quantities of chloride or sulfate, or both, than the limits for drinking water recommended by the U.S. Public Health Service. The Pierre is not a highly productive aquifer.

Water in the Fox Hills-Hell Creek aquifer generally is a sodium bicarbonate type, but locally the water is a sodium sulfate type. Although water from the Fox Hills-Hell Creek aquifer ranges from about 300 to $3,700 \mathrm{mg} / 1$ dissolved solids, water containing less than $1,000 \mathrm{mg} / 1$ dissolved solids occurs near outcrop areas, where little drift overlies the aquifer. Most of the water that contains more than $2,500 \mathrm{mg} / 1$ of dissolved solids occurs where significant thicknesses of drift cover the Fox Hills-Hell Creek aquifer. The drift probably contributes much of the dissolved-solids concentration to recharge water that reaches the Fox Hills-Hell Creek aquifer.

Water in the Fort Union aquifer is a sodium bicarbonate or sodium sulfate type in different places. However, some of the water from the deeper parts of the aquifer in the northern part of North Dakota is a sodium chloride type, with chloride concentration as high as $3,800 \mathrm{mg} / 1$. Elsewhere, the water in the Fort Union aquifer generally contains less than the U.S. Public Health Service recommended limit for chloride of $250 \mathrm{mg} / 1$.

The quality of water differs greatly among shallower (300 ft or less) wells in the Fort Union aquifer. Dissolved-solids concentrations range from about 200 to $6,700 \mathrm{mg} / 1$ in North Dakota. Most water in the Fort Union aquifer that contains more than $3,000 \mathrm{mg} / 1$ dissolved solids is in areas covered with drift. The dissolved-solids concentrations in most of the deeper part of the aquifer is in the 1,000 to $2,500 \mathrm{mg} / 1$ range. The high sodium and dissolved-solids concentrations generally make the water from the Fort Union aquifer unsuitable for irrigation.

In most of the Red River basin in Minnesota the dissolved-solids concentrations in the drift are between 300 and $600 \mathrm{mg} / 1$. In the Rainy River basin and 
in the northeastern part of the Red River basin, the dissolved-solids concentrations in the drift are less than $300 \mathrm{mg} / 1$. The dissolved solids in drift aquifers in the Red and Souris River basins in North Dakota are generally greater than $600 \mathrm{mg} / \mathrm{l}$. Dissolved solids in the drift in North Dakota are as high as $26,000 \mathrm{mg} / 1$, although most water in areas where flow is upward from bedrock aquifers contains less than $10,000 \mathrm{mg} / 1$.

\subsubsection{Tennessee Region}

Three types of aquifers occur in the Tennessee Region: unconsolidated material with intergranular porosity, carbonate rocks with solution openings, and noncarbonate rocks with fractures. One or more of these aquifers is characteristic of each physiographic province as shown in Figure 5.9 (Zurawski 1978).

Unconsolidated materials are significant aquifers in about half of the Tennessee Region. In the Coastal Plain, an area of 4,000 square miles on the western edge of the region, the important aquifers are sand formations which dip to the west. These formations are the most uniformly productive aquifers of the region, commonly yielding 200 to $600 \mathrm{gal} / \mathrm{min}$ to single wells. Parts of another 18,000 square miles are covered by unconsolidated materials, referred to as regolith, which is a mantle of disintegrated rock that has accumulated over the bedrock. Grain size ranges from clay to coarse gravel and is a major factor in determining the regolith's water-bearing properties. The regolith is hydrologically significant in areas where it is thick and permeable, especially in the Highland Rim and parts of the Blue Ridge and Valley and Ridge. In these areas it acts as a sponge in absorbing and storing large amounts of ground water. Where saturated, the regolith yields dependable domestic supplies, but larger supplies can be obtained where fractures or solution openings in the underlying bedrock are hydraulically connected with the regolith (Zurawski 1978).

Carbonate aquifers underlie about half of the Tennessee Region. The rocks in the Valley and Ridge section of the region are steeply tilted but west of the Valley and Ridge are essentially flat lying. Water occurs in openings along fractures, faults, and bedding planes which have become enlarged by circulating ground 


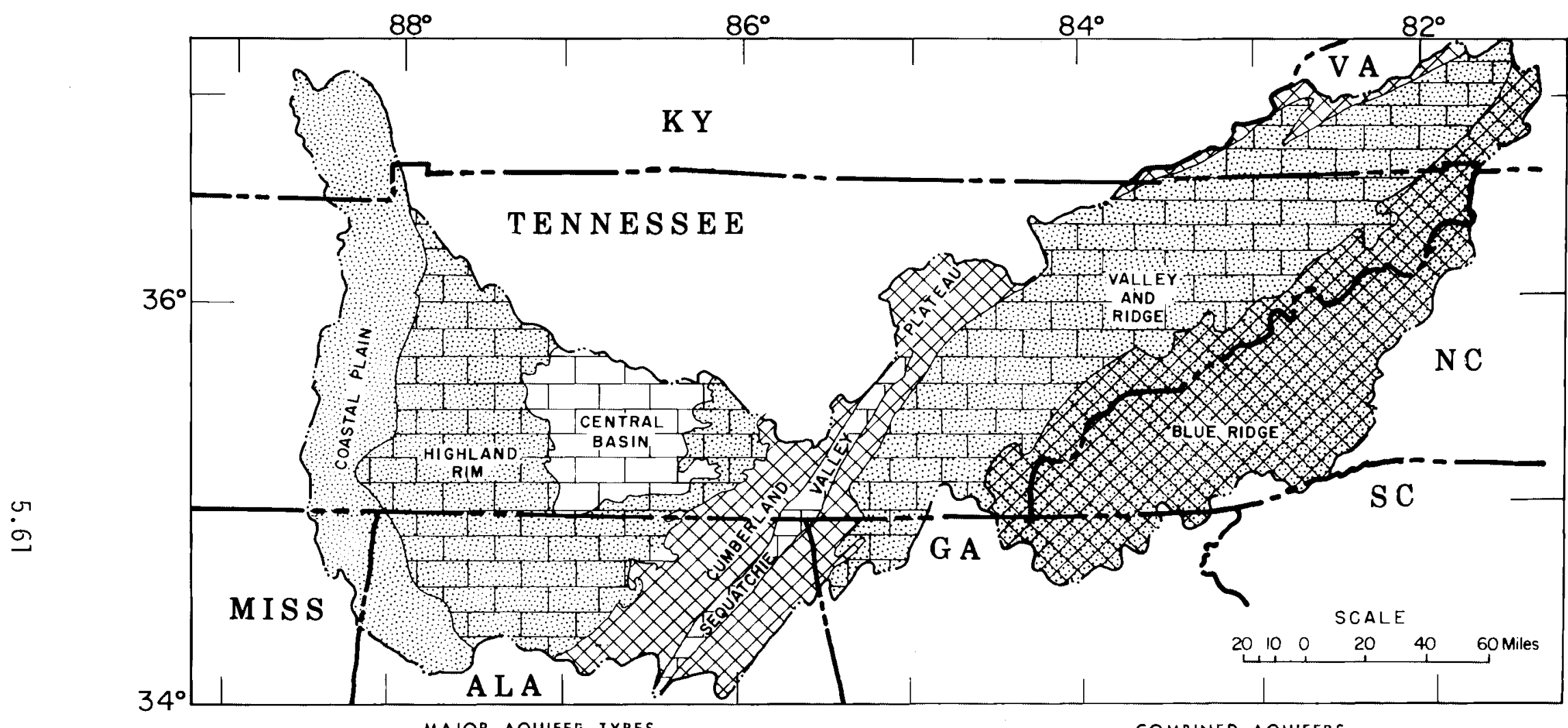

MAJOR AQUIFEE TYPES

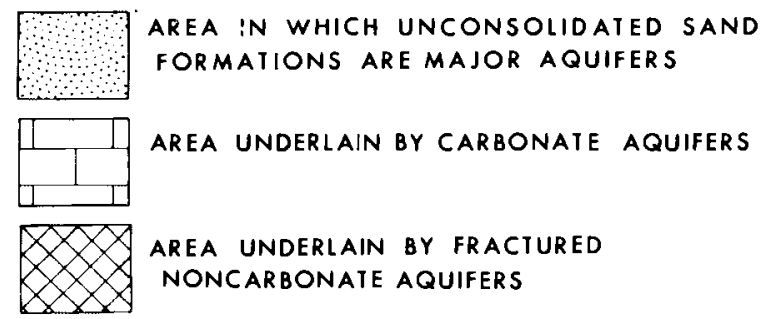

COMBINED AQUIFERS

AREA UNDERLAIN BY CARBDNATE AQUIFERS
WITH HYDROLOGICALIY SIGNIFICANT REGOLITH

X $X$ AREA UNDERLAIN BY FRACTURED NONCARBONATE AQUIFERS WIIH HYDROLOGICALLY SIGNIFICANT KX: REGOLITH

AREAS OF OCCURRENCE ARE GeneraLIZED

FIGURE 5.9. Distribution of Major Aquifer Types in the Tennessee Region (Zurawski 1978, p. L13) 
water. Solution openings occupy a small volume in the rock and generally occur within about $300 \mathrm{ft}$ of 1 and surface. Individual openings range from a fraction of an inch to several feet in height and can be laterally extensive. Wells that penetrate large openings may be able to produce several thousand gallons per minute, but such openings occupy a small portion of the rock. As a result, well yields vary widely in carbonate terrane. Variability of solution openings makes well placement critical in efforts to develop large amounts of ground water from carbonate rocks.

Slightly more than a third of the Tennessee Region is underlain by noncarbonate rocks which, unlike the Coastal Plain deposits, have very little porosity aside from fractures.

These rocks range from sedimentary rocks such as shale and sandstone underlying the Cumberland Plateau to rocks that have been subjected to metamorphism and deformation in the Blue Ridge. Weathering along fractures and faults has created avenues for water movement. These fracture openings probably comprise less than $1 \%$ of the rock volume, and water-bearing fractures are uncommon at depths over $300 \mathrm{ft}$. The fractures at greater depths are likely to be unweathered and closed. Fractures are commonly more abundant near faults. Well production is determined by the depth, size, and degree of interconnection of fractures penetrated and by the thickness of overburden hydraulically connected to the fractures.

Fractured rocks are generally considered to be poor aquifers, but they have generally not been adequately tested to determine their water-yielding potential. Test drilling in the great Smoky Mountains National Park showed that where fractured rock is hydraulically connected to thick regolith, properly located wells can produce $100 \mathrm{gal} / \mathrm{min}$ or more.

The distribution of ground water in the Tennessee Region is influenced by the difference in topography, geology, and hydrology among the six physiographic provinces. Though large amounts of ground water exist in each physiographic area, less preliminary study and exploratory drilling are usually needed to obtain a specified supply in areas where the ground water occurs in the intergranular pore spaces of unconsolidated aquifers, than in areas where water occurs in discrete 
fractures or openings in consolidated rocks. The following sections describe for each physiographic area the topographic, geologic, and hydrologic controls on the distribution of ground water.

\subsubsection{Blue Ridge Province}

The part of the Tennessee Region that lies within the Blue Ridge province is composed of remnants of an ancient mountain chain. The topography is rugged and relief is greater than in other parts of the region. In most places, the dense, massive bedrock contains little water. except where faulted or fractured. Overlying the bedrock is a mantle of regolith that ranges in thickness from a few feet on the steeper slopes to more than $100 \mathrm{ft}$ on the lower slopes of the mountains. The regolith is composed of sand, clay, and rock fragments. It stores large amounts of water, releasing it slowly to the underlying fractures and to springs and streams. The fractures store only limited amounts of water, but they act as collectors which transmit water from the overlying regolith to points of discharge. Most of the bedrock in the Blue Ridge is noncarbonate, but a few areas are underlain by intensely weathered carbonate rocks that contain large amounts of ground water in solution openings and in porous zones.

In the Blue Ridge province the chances of drilling high-producing wells are increased at sites having a thick cover of regolith in relatively low topographic positions within a few hundred feet of a fault zone. The broad valleys underlain by carbonate rocks, such as Cades Cove in the Great Smoky Mountains National Park, may be favorable sites for locating ground-water supplies. However, these occur only in a few small areas of the Blue Ridge.

\subsubsection{Valley and Ridge Province}

The Valley and Ridge province is characterized by northeast-trending ridges underlain by resistant rock separated by valleys underlain by less resistant rock. The rock formations crop out in long, narrow belts parallel to the trend of ridges and valleys; some belts are bounded by faults. The linear ridges and valleys channel surface drainage into a "trellis" pattern of long streams flowing along valley floors fed by short lateral streams. 
All three major aquifer types occur in the Valley and Ridge province. The shale and sandstone formations (fractured noncarbonate rocks) are the poorest aquifers. The largest ground-water supplies are in the soluble carbonate rocks, especially where they are associated with thick regolith. Water moves through enlarged fractures and solution openings emerging as large springs. Some of these flow at an average rate of $4,500 \mathrm{gal} / \mathrm{min}$ or more. The Knox Dolomite, which underlies about $60 \%$ of the province, is the most significant water-bearing formation. The most productive wells are either located in areas of ground-water discharge such as stream valleys or they penetrate fracture zones. These fracture zones are sometimes indicated by straight stream segments and aligned tributaries. Most of the larger water-bearing openings in the knox occur at a depth of less than $300 \mathrm{ft}$. Surface faults indicate areas with deep and numerous fractures which allow deep solution activity.

\subsubsection{Cumberland Plateau}

The Cumberland Plateau section of the Appalachian Plateaus province is about 1,000 to $1,500 \mathrm{ft}$ higher than the adjoining Valley and Ridge province and Highland Rim. It extends about 175 miles northeastsouthwest across the Tennessee Region.

The bedrock is a sequence of mostly horizontal Pennsylvanian sandstone, shale, conglomerate, and coal, underlain by Mississippian and older shale and carbonates. The Mississippian carbonates are exposed where Sequatchie Valley, a 130-mile long, linear valley, cuts deeply into the Plateau. Large springs emerge along the sides of the Plateau and from the Mississippian and older limestones exposed in Sequatchie Valley.

The Pennsylvania rocks have low permeability except where fractured. The regolith is usually thin, providing little ground-water storage. As a result of the uneven distribution of fractures, the average well yield is less than $50 \mathrm{gal} / \mathrm{min}$.

\subsubsection{Highland Rim}

The Highland Rim section of the Interior Low Plateaus province is a gently rolling plateau which occupies a large part of the center of the Tennessee Region. It is extensively dissected where it adjoins 
the Central Basin and Coastal Plain lowlands. The bedrock of the Highland Rim consists of flat-lying Mississippian carbonates. These formations, principally the Fort Payne Chert, a cherty dolomite, and the Tuscumbia Limestone (with its equivalents, the Warsaw Limestone and St. Louis Limestone), constitute the most areally extensive aquifer in the Tennessee Region.

These Mississippian formations weather to form a deep chert regolith typically having a "rubble zone" at the base. The residual chert grades from gravel-sized fragments at the base to a layer of clay-sized chert particles which partially seals the top of the aquifer creating artesian conditions in some areas. The regolith may rest directly on the Chattanooga Shale which retards downward movement of the water, but more commonly it rests on unweathered Fort Payne bedrock. In many places the carbonate bedrock contains solution openings which can transmit water rapidly.

In areas adjacent to the Highland Rim escarpment, water drains out of the bedrock openings as springs and seeps. These springs provide the well-sustained low flow of streams that dissect the edge of the Highland Rim. However, in the broad undissected areas of the Highland Rim, streams barely cut into the regolith and therefore, have little effect on the discharge of water from the regolith and solution openings. The solution openings that supply water to wells in the undissected areas are hydraulically connected to the regolith.

The aquifer formed by the bedrock and regolith of the Fort Payne Chert is named the "Manchester aquifer". This same aquifer is present in the Tuscumbia Limestone and Fort Payne Chert in northern Alabama. Where the regolith is thin and little bedrock overlies the Chattanooga Shale, only small amounts of ground water are available. In areas where sections of Mississippian carbonate rocks remain beneath a thick regolith, however, extensive solution networks may yield large quantities of water to wells and springs. For example, discharge measurements at water Cress Spring in Madison County, Alabama, indicate a sustained flow of about 5,000 gal/min.

\subsubsection{Central Basin}

The Tennessee Region includes the southern part of the Central Basin (Nashville Basin). The Central Basin, a section of the Interior Low Plateaus province, 
is an oval area in middle Tennessee lying about $200 \mathrm{ft}$ lower than the surrounding Highland Rim. The bedrock consists of strata that are generally flat lying but locally folded. Ground water moves through solutionenlarged vertical joints and horizontal bedding-plane openings. Soil cover is usually thin and surface streams are cut into bedrock. The lack of regolith, along with open joints in the rock, allow rapid runoff and infiltration of precipitation. Water is relatively briefly stored above stream level and is rapidly discharged to streams through solution openings. As a result, small streams respond quickly to precipitation and have poorly sustained base flows (Zurawski 1978).

Deeper solution openings are sheetlike and commonly range from 0.005 to $0.2 \mathrm{in}$. in height and about 100 to $2,500 \mathrm{ft}$ in width. Most solution openings are within $300 \mathrm{ft}$ of the surface.

The distribution of ground water in the Central Basin is highly variable. Except for the secondary openings most of the limestone has extremely low porosity. Most wells produce at least some water from bedding-plane cracks as large solution openings are relatively uncommon.

In spite of generally low well production, it is possible in many areas to drill wells capable of producing over $70 \mathrm{gal} / \mathrm{min}$. In some areas it is possible to drill wells capable of producing several hundred gallons per minute. Use of hydrologic and geologic studies in selecting drilling sites in the Central Basin greatly increases the chances of wells penetrating high-yielding solution openings.

The Knox Dolomite, at depths of 350 to $1,500 \mathrm{ft}$ below the surface, comprises an areally extensive artesian aquifer throughout the Central Basin. It is a dependable source of domestic water supplies (usually $10 \mathrm{gal} / \mathrm{min}$ or less) of variable quality. The largest known production from a well finished in the knox in the Central Basin is $50 \mathrm{gal} / \mathrm{min}$. However, in eastern Tennessee, production from single wells in the Knox can exceed $1,000 \mathrm{gal} / \mathrm{min}$.

\subsubsection{Coastal Plain}

A narrow strip of the Coastal Plain province extends along the western edge of the Tennessee Region. 
The major aquifers are two unconsolidated Cretaceous formations, the Coffee Sand and McNairy Formations.

Both the McNairy Formation and the Coffee Sand are capable of yielding municipal and industrial supplies nearly everywhere to the west of the outcrop. The Coffee Sand yields up to about $300 \mathrm{gal} / \mathrm{min}$ to wells. The McNairy Formation, however, is capable of much greater production, and good wells produce 500 to $1,000 \mathrm{gal} / \mathrm{min}$. The amount of water that can be withdrawn from these formations depends, in part, on the thickness of saturated sand layers and the construction of the wells that penetrate them.

In northern Mississippi, test wells in a shattered Paleozoic chert aquifer produced up to $500 \mathrm{gal} / \mathrm{min}$. The Camden Chert and Fort Payne Chert comprise this fractured chert aquifer in Tennessee.

\subsubsection{Water Quality}

The natural quality of ground water in the Tennessee Region depends on many factors, but mainly upon the chemical composition of the rock in which the water occurs. When water from precipitation enters the aquifer as recharge, it is generally low in dissolved solids, soft, and slightly acidic. As the water moves through the aquifer, it acquires a greater concentration of dissolved constituents that change its chemical and physical properties. The least change occurs in the aquifers composed of regolith. The ground water in the regolith remains slightly acidic and low in dissolved solids. This type of ground water is common in the regolith of the Blue Ridge and Highland Rim. Water in the outcrop belt (recharge area) of the unconsolidated aquifers of the Coastal Plain is also fairly close to rainwater in composition, but becomes harder and higher in dissolved solids as it moves deeper below land surface (Z.urawski 1978).

Ground water that comes in contact with sandstone and shale containing pyrite remains soft but may become more acidic and high in concentrations of iron and hydrogen sulfide. This type of water occurs in some noncarbonate formations of the Valley and Ridge, in the Pennsylvanian shale and sandstone of the Cumberland Plateau, and immediately below the Chattanooga Shale of the Highland Rim. 
A third kind of change occurs in water that contacts carbonate rocks. Because rainwater that has passed through the soil is somewhat acidic, it can dissolve limestone and dolomite, becoming enriched in bicarbonate, calcium, and magnesium. As the dissolved solids content increases, the water becomes harder and slightly alkaline. This type of chemical change occurs in carbonate aquifers such as those in the Valley and Ridge, the Highland Rim, the Central Basin, Sequatchie Valley of the Cumberland Plateau, and in limestones underlying coves of the Blue Ridge.

The analyses shown in Table 5.8 are representative of the chemical quality of the ground water from the six physiographic areas of Tennessee. Dissolved constituents, consisting mainly of calcium and bicarbonate ions, are highest in the ground water of the Central Basin, with somewhat lower concentrations in the Highland Rim and Valley and Ridge. Unlike aquifers of the Central Basin, aquifers in the latter two areas do not consist entirely of carbonate rocks, and the influence of the regolith and other noncarbonate rocks is seen in the lower amounts of dissolved constituents, including calcium and bicarbonate.

The analyses for the Blue Ridge, Cumberland Plateau, and Coastal Plain, all areas with mainly noncarbonate aquifers, indicate considerably lower dissolved solids in the ground water of these areas than in carbonate terranes. In the Blue Ridge, where most of the ground water occurs in the highly weathered regolith, dissolved solids are lowest.

Ground-water quality is reflected in the chemical character of stream water during periods of base flow. To some extent, streams can be used to obtain an integrated sample of discharge from the aquifers underlying the watershed.

The rate of water circulation within the aquifer has an important effect on ground-water quality. Where circulation has been rapid, aquifers may have been flushed of readily dissolved substances. Where the regolith is hydraulically connected to well-developed openings in the underlying bedrock, for example, water from the regolith, low in dissolved solids, can circulate rapidly through the openings without great increases in hardness. 
TABLE 5.8. Water Qualities of Physiographic Provinces in the Tennessee Region ${ }^{(a)}$ (Zurawski 1978)

\begin{tabular}{|c|c|c|c|c|c|c|c|c|c|c|c|}
\hline $\begin{array}{c}\text { Phys iographic } \\
\text { Province }\end{array}$ & Silica & Iron & Calcium & Magnesium & Sodium & Potassium & Bicarbonate & Sulfate & Chloride & Fluoride & Nitrate \\
\hline Blue Ridge & 16 & 0.05 & 4.6 & 0.5 & 3.3 & 0.8 & 29 & 1.6 & 0.9 & 0.1 & 0.1 \\
\hline Valley and Ridge & 10 & 0.09 & 38 & 12 & \multicolumn{2}{|c|}{$4.5^{(b)}$} & 178 & 5 & 3.5 & 0.0 & 3.9 \\
\hline Cumberland Plateau & 6.4 & 1.0 & 16 & 3.5 & 3.9 & 1.2 & 60 & 10 & 2.8 & 0.1 & 0.8 \\
\hline Highland Rim & 11.5 & 0 & 39 & 3.8 & \multicolumn{2}{|c|}{$3.4^{(\mathrm{b})}$} & 146 & 4.2 & 4 & 0.1 & 1.9 \\
\hline Central Basin & 7.3 & 0.08 & 79 & 9.7 & 4.4 & 1.5 & 256 & 26 & 5 & 0.3 & 0.5 \\
\hline Coastal Plain & 14 & 0.5 & 16 & 4.6 & 22 & 3.4 & 95 & 12 & 4.7 & 0.2 & 0.7 \\
\hline
\end{tabular}


As a result of situations like these, water from wells that tap very permeable formations or highly developed solution or fracture systems tends to be lower in dissolved solids than is water from poorly interconnected openings.

The quality of ground water from a particular aquifer at any one place tends to be relatively constant with time. This property is most evident where the regolith filters the water that replenishes the aquifer. In aquifers having direct connections with land surface (via sinkholes, for example), marked changes in quality may occur as storm runoff enters the system.

Well-developed openings and highly porous material, when less than about $100 \mathrm{ft}$ below land surface, are very susceptible to pollution. Strong protective measures are needed to ensure that the ground-water quality will remain unimpaired.

\subsubsection{Hawaii Region}

Most fresh ground water is stored near and below sea level to depths ranging to $1,000 \mathrm{ft}$ or more below sea level (Takasaki 1978). The principal fresh groundwater reservoirs consist of thin-bedded basaltic lava flows. These reservoirs contain interconnected water bodies that are impounded by dikes in the interior of the islands or are in dynamic equilibrium with the underlying saline ground water in the outer rims of the islands. Ground water in these settings is referred to, respectively, as dike-impounded water and basal water. Other water bodies, small in comparison, are perched above and isolated from these interconnected water bodies and are called perched water. The term high-level water is often used to describe both dikeimpounded and perched water, or a combination of them when they occur at high altitudes.

Ground-water development is generally most favorable in areas directly downslope from mountain areas of high rainfall and becomes less favorable with increasing distance away from these downslope areas. This downslope direction generally coincides with the downslope flow direction of the lavas and the favorable direction of ground-water flow from the mountains to the sea. Ground water development is seriously limited in leeward areas where rainfall is heavy only on the windward side. 


\subsubsection{Lower Mississippi Region}

Ground water occurs in large quantities in the Lower Mississippi Region and is readily accessible because of the regional geological framework. Almost all the region is within the Gulf Coastal Plain physiographic province; three small areas along the northwest boundary are in the Interior Highlands. The Lower Mississippi Region includes most of the Mississippi embayment, a northeast-trending structural trough underlying part of the Coastal Plain. The Coastal Plain and the embayment received sediment during the Cretaceous, Tertiary, and Quaternary Periods. The older deposits generally consist of alternating layers of sand and clay; the Quaternary beds contain considerable gravel. The more permeable sand and gravel deposits now form the extensive and productive aquifers that underlie the Lower Mississippi Region (Terry et a1. 1979).

Prevalent chemical types of water in streams at low flow are shown in Figure 5.10.

The Cretaceous and older Tertiary units in the northern or embayment part of the area dip toward the axis of the Mississippi embayment, which coincides approximately with the present course of the Mississippi River. In the southern part of the area, the younger Tertiary deposits dip gulfward. Quaternary alluvium blankets most of the area and forms a gulfwardthickening wedge in the southern part.

Except in areas of outcrop and where local dewatering has taken place, water in the Cretaceous and Tertiary aquifers is confined under pressure. Quaternary aquifers are also confined. In some areas, hydrostatic pressures are sufficient to produce natural flows from wells.

Recharge to the aquifers is primarily from rainfall. The movement of water in the confined aquifers generally is downdip unless affected by large withdrawals. In the alluvial aquifers, movement is toward points of discharge. All aquifers locally contain some sal twater: Quaternary aquifers in coastal areas and the older aquifers in their downdip areas.

The vast reserves of saltwater in the Coastal Plain aquifers may prove to be an asset to the area as 


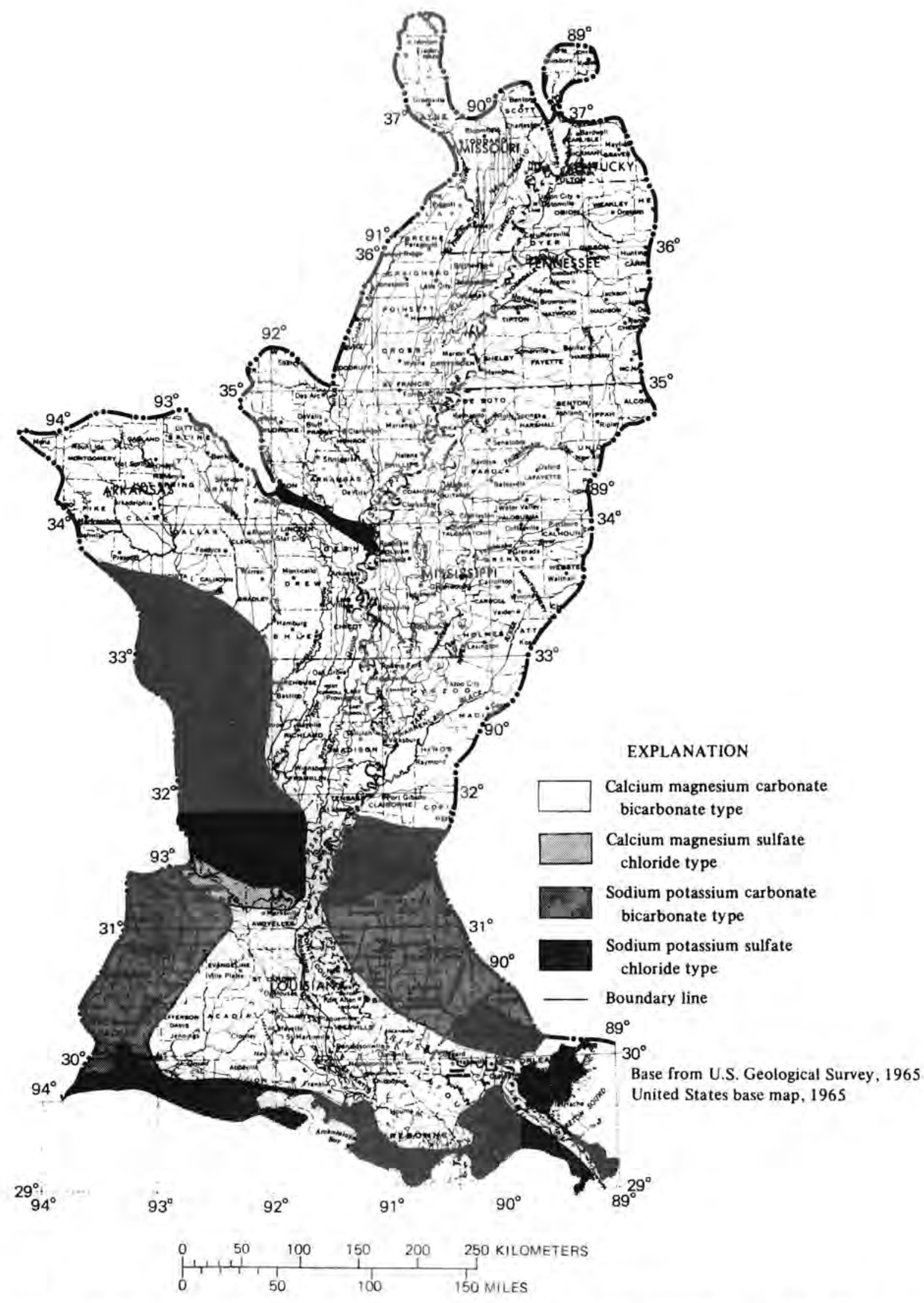

FIGURE 5.10. Prevalent Chemical Types of Water in Streams at Low Flow in the Lower Mississippi Region (Terry et a1. 1979, p. N23) 
desalinization technology advances. The quantity of saltwater available is several times that of freshwater. Some saltwater is now used for purposes such as industrial cooling. Similar uses that can tolerate water of this quality will further enhance the value of the resource.

Aquifers in the parts of the Lower Mississippi Region that lie in the Interior Highlands do not represent a significant resource. Rocks in these areas are of Paleozoic age, mostly hard sandstone and shale, and the ground water they contain occurs in openings along fractures and bedding planes. The interstitial porosity and permeability that make the unconsolidated aquifers of the Coastal Plain so productive do not exist in the Interior Highlands.

An estimated 347,000 billion $\mathrm{ft}^{3}(9,800$ billion $\left.\mathrm{m}^{3}\right)$ or 7,900 million acre-ft (10 million $\left.\mathrm{hm}^{3}\right)$ of freshwater underlies the Lower Mississippi Region.

Ground water is available beneath the entire Lower Mississippi Region. Except for small areas in the Interior Highlands and the coastal area of Louisiana, one or more major aquifers make moderate to large quantities of freshwater available throughout the region.

The three areas in the region that are in the Interior Highlands are the Arkansas Valley and the Ouachita Mountains in west-central Arkansas and the Ozark Plateaus in southeast Missouri. In these areas, small quantities of ground water are available from Paleozoic rocks.

Aquifers of Cretaceous age underlie the northern part of the region. Except for relatively small areas in Arkansas, Tennessee, Mississippi, and Missouri, the Cretaceous material is overlain by Tertiary and (or) Quaternary aquifers that can yield moderate to large quantities of water to individual wells. For this reason, the deeper cretaceous aquifers are not utilized extensively.

The major Cretaceous aquifer is the McNairy Sand Member of the Ripley Formation in Mississippi (equivalent to the McNairy Sand in Tennessee, Missouri, Illinois, and Kentucky, and the Nacatoch Sand in Arkansas). These aquifers are present throughout the 
northern one-fifth of the region within the Coastal Plain and in a small area in southwest Arkansas, a total area of nearly 20,000 square miles $\left(52,000 \mathrm{~km}^{2}\right)$.

Other Cretaceous aquifers are important in some areas where they are the best or only sources of ground water available. In north-central Mississippi and parts of west Tennessee, the Coffee Sand is utilized. It is the best or only source of ground water in many places in this area where the underlying Eutaw Formation is too thin or yields highly mineralized water, or where Paleozoic rocks do not contain aquifers. The Gordo Formation underlies the Eutaw Formation in north-central Mississippi, primarily south of the downdip limit of the Coffee Sand. Water in the Gordo Formation generally is good quality and is the best available in this area.

Tertiary aquifers underlie virtually the entire Lower Mississippi Region, except for three small areas on the western border, two in Arkansas and one in Missouri, and a small strip on the eastern border in Tennessee and Mississippi. The Tertiary aquifers north of a line approximately through Vicksburg, Mississippi to Colfax, Louisiana, are of Eocene age. South of this line, Miocene aquifers overlie the Eocene deposits. These beds dip southward and are, in turn, overlain by Pliocene deposits.

The significant Eocene aquifers, in ascending order of their occurrence, are: the lower wilcox aquifer, the Carrizo Sand (and its stratigraphic equivalent, the Meridian Sand member of the Tallahatta Formation), the Sparta Sand, and the Cockfield Formation.

The lower Wilcox aquifer, the basic unit of the Wilcox Group, occurs throughout the northern one-third of the Lower Mississippi Region and in a strip across central Arkansas. It crops out in a narrow belt in north Mississippi and west Tennessee (Fort Pillow Sand in the subsurface of west Tennessee) and occurs as a subcrop beneath the Quaternary alluvium in Arkansas and Missouri. The lower Wilcox aquifer is a source of water for several cities in northeast Arkansas and northwest Mississippi.

Except for the lower Wilcox aquifer, the Tertiary aquifers mentioned previously are in the Claiborne Group. The basal unit of the Claiborne is the Carrizo 
Sand in Arkansas and Louisiana and its equivalent in Mississippi, the Meridan Sand Member of the Tallahatta Formation. This unit crops out in a narrow band in central Mississippi and southwest Arkansas and is a relatively minor aquifer in central Arkansas and in west Mississippi north of the latitude of Vicksburg. Separating the Carrizo from the overlying Sparta Sand is the Cane River Formation and its equivalents, composed mostly of clay and a few thin beds of fine, almost impermeable sand. The Cane River and its equivalents contain only very minor aquifers in southcentral and southwest Arkansas and in west-central Mississippi. In northwest Mississippi, the Winona Sand (equivalent to the Cane River Formation) becomes more significant and merges into the Memphis aquifer. The Sparta Sand underlies the entire central part of the region. It crops out on the eastern side in a wide belt, from southwest Kentucky through Tennessee and Mississippi, and on the west side in northeast and south-central Arkansas. The Sparta occurs as subcrops beneath the Quaternary alluvium in some areas in Arkansas and Mississippi. The Sparta is a very productive aquifer throughout the northern three-fourths of the region. The Cook Mountain Formation, which is not an aquifer, overlies the Sparta Sand and separates it from the uppermost unit of the Claiborne Group, the Cockfield Formation. The Cockfield Formation directly underlies the Quaternary alluvium in most of the central part of the region. It includes productive aquifers in Arkansas, Louisiana, and Mississippi. The Cockfield crops out in small areas in southeast Arkansas, along the Arkansas-Louisiana State boundary, in northwest Louisiana and in central Mississippi.

North of approximately the 35th parallel, the Memphis aquifer (Memphis Sand in Tennessee) comprises all Claiborne units from the base of the Carrizo Sand to the top of the Sparta Sand. This part of the Claiborne section is a massive sand several hundred feet thick which constitutes a vast ground-water reservoir. As such, the Memphis aquifer is second only to the Mississippi River valley alluvial aquifer as a potential source of large quantities of ground water.

Aquifers of 01 igocene age in the Forest Hill Sand and the overlying Vicksburg Group occur in a small area in the southern half of the Lower Mississippi Region. These aquifers, al though they are not extensive, are the only sources of fresh ground water in the $500 \mathrm{ft}$ 
$(150 \mathrm{~m})$ or more of sediments between the top of the Claiborne Group and the base of the Miocene Series.

Aquifers of Miocene age occur south of a line approximately through Vicksburg, Mississippi, to Colfax, Louisiana. South of approximately the 31st parallel, the Miocene deposits are overlain by the Pliocene Series. These two series are lithologically similar and are referred to in Louisiana, where they occur together, as the Mio-Pliocene aquifer. In Mississippi, the Miocene deposits are divided into the undifferentiated upper Miocene aquifer and the Catahoula Sandstone. Both the Miocene and Pliocene Series are overlain by Quaternary deposits and, except for Miocene outcrops in west-central and southwest Louisiana, are not exposed at the surface. Both of these series are good present and potential sources of moderate to large quantities of fresh ground water. Near the Louisiana coast, water in both series becomes salty gulfward.

Deposits of Quaternary age cover most of the Lower Mississippi Region. Sediments of Pleistocene and Holocene age compose the Mississippi River valley alluvial aquifer, the most extensive source of ground water in the region. The Pleistocene deposits contain gravel at the base, grading upward to finer sand, and are the most productive parts of the aquifer. The overlying Holocene material is composed of very fine sand, silt, and clay. In many areas it forms a confining layer, although it is permeable to varying degrees.

Large quantities of water are available from the Mississippi River valley alluvial aquifer throughout most of the region. The aquifer's value is enhanced in that, generally, only shallow well depths are required, pumping lifts are small, and recharge conditions are favorable. Throughout most of the Lower Mississippi Region, recharge to the alluvial aquifer is by precipitation. In some areas, where overlying fine-grained materials are nearly impermeable, the aquifers are recharged by underflow. Along the coast in Louisiana, especially in the southeastern part of the State, the alluvial aquifer contains saltwater.

Ground water can be obtained with relative ease almost everywhere in the Lower Mississippi Region. For this reason, most public, industrial, and agricultural supplies are from wells. In most areas within the 
region, obtaining adequate quantities of water from surface-water supplies would be economically unfeasible. 20 the total 102,400 square miles $\left(265,200 \mathrm{~km}^{2}\right)$ within the Lower Mississippi Region, about $5 \%$ is covered by surface water. In contrast, $90 \%$ of the region is underlain by two or more aquifers that can yield $100 \mathrm{gal} / \mathrm{min}(6 \mathrm{l} / \mathrm{s})$ or more to individual wells.

: Aquifers in the lower Mississippi are summarized as follows (Terry et a1. 1979):

\begin{tabular}{ll} 
Aquifer Description & \multicolumn{1}{c}{ Age } \\
Sand and gravel & Quaternary \\
Unnamed sedimentary & Miocene-P1 iocene \\
Cockfield formation & Eocene \\
Sparta sand & Eocene \\
Carrizo sand & Eocene \\
Lower Wilcox aquifer & Eocene \\
Ripley formation & Cretaceous \\
(McNairy sand member) &
\end{tabular}

The capacity is $10^{7} \mathrm{hm}^{3}$; areal extent is $52,000 \mathrm{~km}^{2}$; thickness is 600 to $2,000 \mathrm{~m}$; and dissolved solids are less than $3,000 \mathrm{mg} / 1$.

\subsubsection{South Atlantic-Gulf Region}

The South Atlantic-Gulf Region may be divided into two broad components: 1) the Coastal Plain province, about 196,000 square miles, made up of soft unconsolidated sand, gravel, and clay and consolidated or semiconsolidated limestone and 2 ) the remainder (Piedmont province, Blue Ridge province, Valley and Ridge province, and Cumberland Plateau section), about 74,000 square miles, consisting for the most part of hard consolidated rocks--indurated and metamorphosed sedimentary rocks and crystalline igneous rocks (Cederstrom et a). 1979).

The Coastal Plain province is underlain by unconsolidated clay, sand, and gravel and consolidated or semiconsolidated limestone. The deposits, which range in age from Cretaceous to Holocene, form a hugh arc extending from southern Virginia through the Carolinas, Georgia, Alabama, and into eastern Mississippi. From a 
thin edge at the Fall line, most of the deposits thicken seaward; a southward projection forms the peninsula of Florida.

The aquifer types are shown in Figure 5.11.

In most places, the Coastal Plain beds have a gentle dip seaward. Each formation was generally overlapped by the next younger formation and their eroded edges are now exposed in a succession of older (inland) to younger (seaward) arcuate belts. The surface exposures of some formations are irregular. For instance, in northern North Carolina the inner edges of older strata were beveled by the advancing seas, and younger formations extend to the Fall Line.

The Coastal Plain formations are rarely uniform laterally (along the strike) or downdip. Nearshore sandy deltaic continental sediments thicken downdip and grade into deeper water silty or limy marine deposits. Laterally, sediments may also change in proportions of sand and clay, or may become limy.

Sandy terrace deposits were superimposed upon the older formations throughout the Atlantic and Gulf Coastal regions during the Pleistocene Epoch.

Table 5.9 shows the stratigraphic units and aquifers of Cretaceous to Quaternary age that underlie the Coastal Plain province.

The Blue Ridge province is underlain by igneous and metamorphic rocks of older age which have been subjected to repeated stress.

The provinces outside the Coastal Plain are underlain by consolidated sedimentary rocks. In the Valley and Ridge province, these rocks have been greatly folded and faulted. In the adjacent Cumberland Plateau section the rocks have been subjected to less folding and faulting.

Most of the South Atlantic-Gulf Region is underlain by aquifers that are generally capable of yielding to wells $50 \mathrm{gal} / \mathrm{min}$ or more of water containing less than $1,000 \mathrm{mg} / 1$ of dissolved solids. Lower yields are characteristic of aquifers in the consolidated rocks that underlie the Blue Ridge, Valley and Ridge, and Piedmont provinces. In the Piedmont, Blue Ridge, 


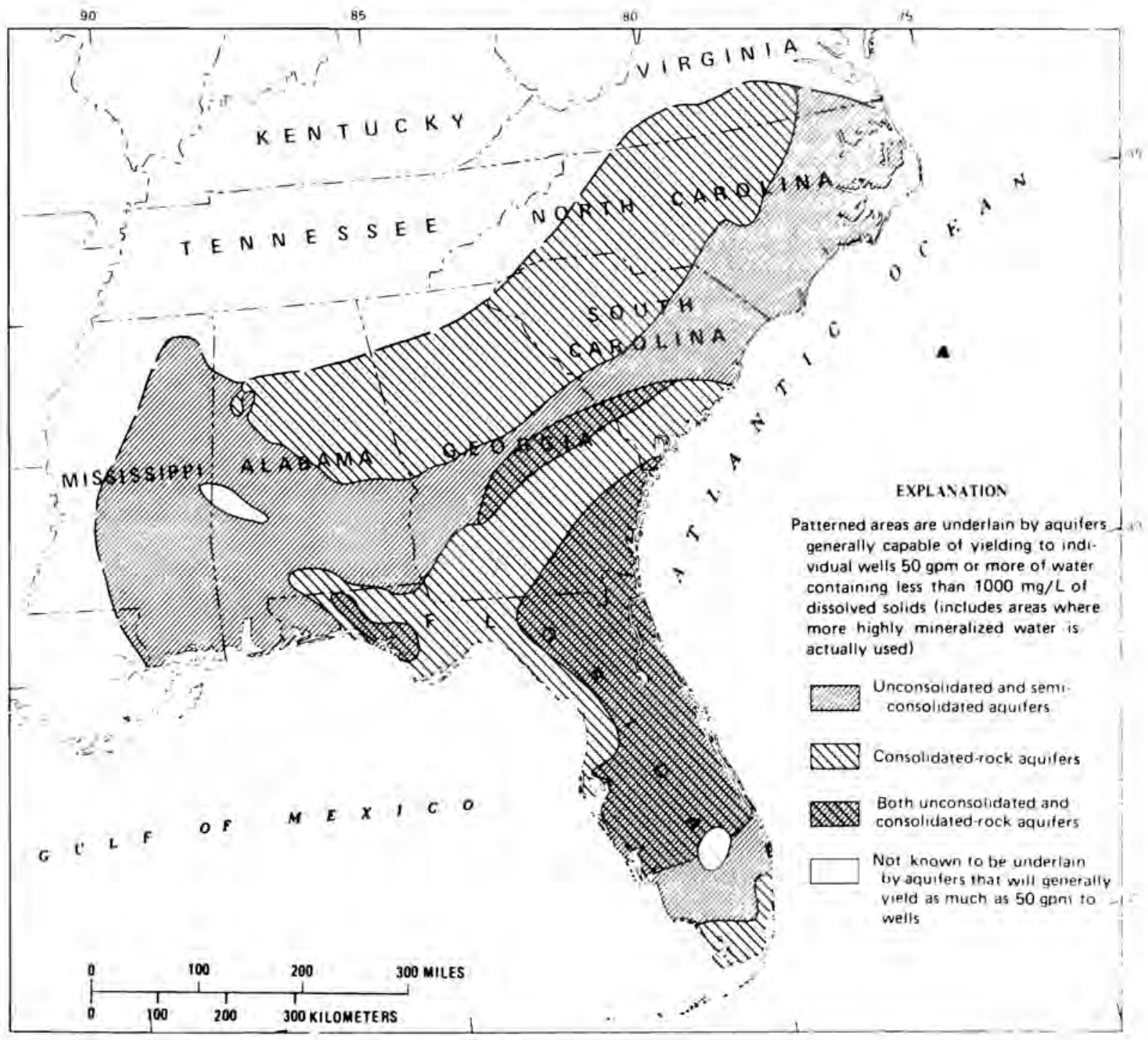

FIGURE 5.11. Types of Aquifers in the South Atlantic-Gulf Region (Cederstrom et a1. 1979, p. 09) 
TABLE 5.9. Generalized Correlation of Coastal Plain Stratigraphic Units and Aquifers

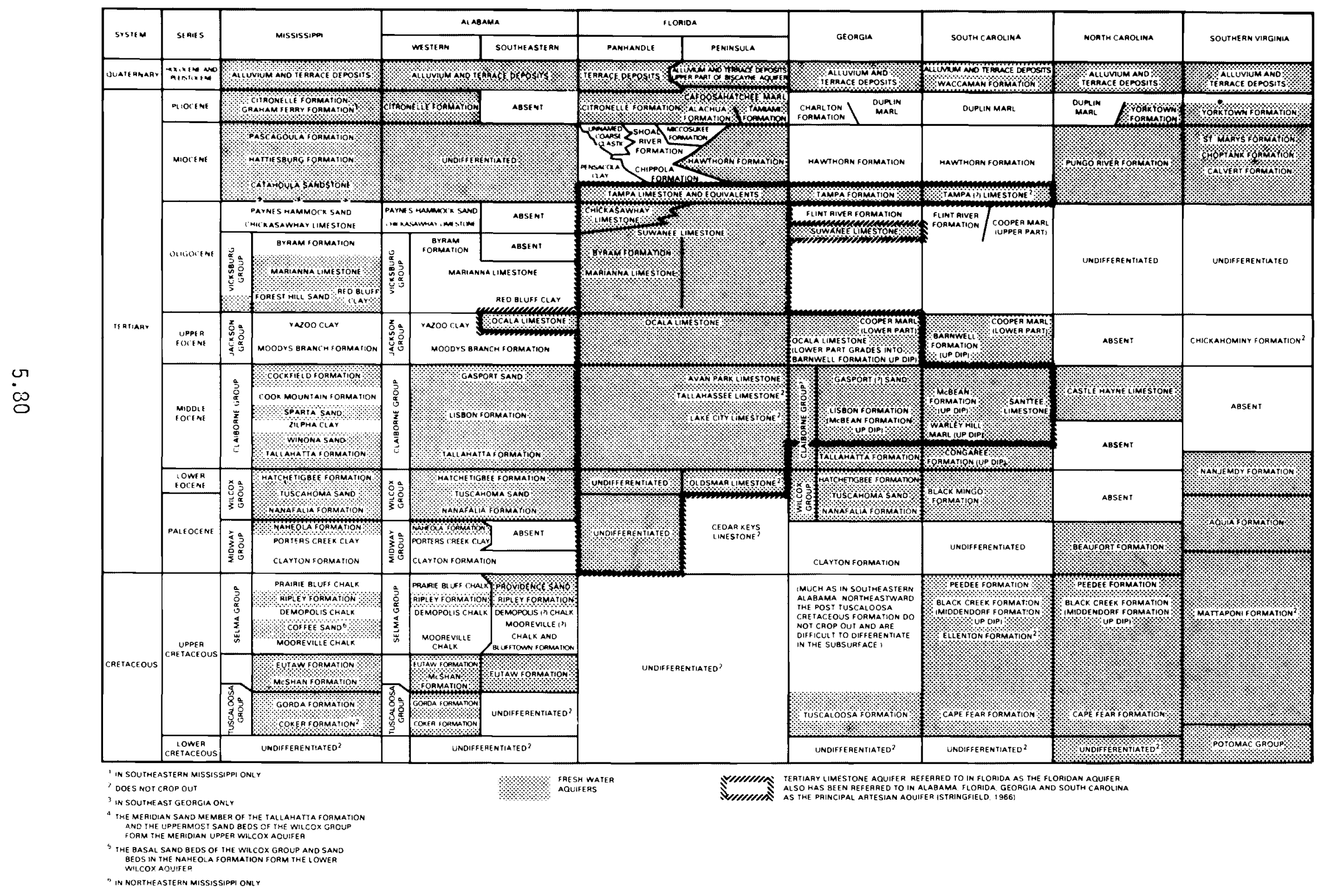


Valley and Ridge provinces, and the Cumberland Plateau section, wells may intersect openings that result from structural deformation and solution, and yields range from substantial to meager.

The most prolific sources of ground water in the South Atlantic-Gulf Region are the highly permeable clastic and limestone aquifers in the Coastal Plain province. In small areas in western Alabama, eastern Mississippi, southeastern North Carolina, and northeastern South Carolina, these aquifers contain only saline water.

The aquifers occurring within each physiographic province in the South Atlantic-Gulf Region generally are not separate units operating independently; rather, each is a part of a complex system. Because of this interrelation, it is generally irrelevant to estimate quantities of water that are available from the individual aquifers. It is more meaningful to estimate the quantity available from the entire system.

Because the base flow of streams is supported almost entirely by ground-water outflow, the quantity of ground water available can be estimated by separating the total amount of stream flow from a region into its component parts--overland flow and base flow. The base-flow component is the approximate yield of the ground-water reservoirs under the existing hydrologic conditions.

Many investigators of the water resources in areas within the Mid-Atlantic Region have estimated the percentage of streamflow that is base flow, or groundwater discharge. In the Coastal Plain, base flow ranges from about 40 to $95 \%$ of the total streamflow; a conservative average would be about $55 \%$. In that part of the region underlain by consolidated rocks, base flow ranges from about 25 to $90 \%$ of the streamflow, a conservative average being about $40 \%$.

The total annual streamflow from the SQuth Atlantic-Gulf Region averages about $303,000 \mathrm{ft}^{3} / \mathrm{s}$ or $196,000 \mathrm{Mgal} / \mathrm{d}, 60 \%$ of which flows into the Gulf of Mexico. However, the proportion of this stream flow that originates in the Coastal Plain as opposed to the remainder of the region was not determined. Using only $40 \%$ (the conservation average percent of streamflow that is baseflow in the consolidated rocks part of the region) and applying this figure to the entire stream- 
flow from the region, the average total yield of ground water from the South Atlantic-Gulf Region under present hydrologic conditions is at least $78,000 \mathrm{Mgal} / \mathrm{d}$ or about $286,000(\mathrm{gal} / \mathrm{d}) / \mathrm{m}^{2}$--the equivalent of about 6 in. of annual recharge. It is impractical and, in fact, environmentally undesirable to intercept all of this water before it is discharged into streams; however, the amount indicates the order of magnitude of ground water available as a potential resource.

The ground-water reservoirs of the region also contain about 600,000 billion cubic feet of water having a dissolved-solids concentration of less than $3,000 \mathrm{mg} / 1$. This volume of water is sufficient to cover the entire region to a depth of about $80 \mathrm{ft}$; however, much of this water cannot be withdrawn economically using present techniques. Moreover, the environmental effects of removing excessive amounts of ground water from storage may not be acceptable.

In most of the region water of good quality is available; however, simple treatment for excessive iron, corrosiveness, and hardness is common (Cederstrom et al. 1979).

In the sandy coastal plain formations there is normally a progressive increase in the mineral content of ground water downdip. Along the outcrop of the aquifers the water is low in mineral content but may be somewhat corrosive, and water from many wells is high in iron.

High chloride concentrations in water in some Upper Cretaceous aquifers appear to be related to the permeability of the sediments. In places, saltwater has been replaced by freshwater that has moved farther downdip in high permeable sediments than in the shallower but less permeable sediments. The movement of water is slower in less permeable sediments.

The younger Tertiary aquifers contain freshwater that extends to or beyond the coast in most areas. In much of the coastal area the Tertiary limestone aquifer is protected from seawater intrusion by a cover of Miocene clays and marls of low permeability. However, deep saline water has migrated into the freshwater zone in a few places in response to sharp lowering of pressure. 
The Pleistocene and Holocene unconsolidated sediments commonly yield slightly acidic water that is low in dissolved solids.

Outside the Coastal Plain, water is generally limited in quantity but of good quality. Except for the carbonate rocks the aquifer materials are relatively insoluble and, therefore, the dissolved-solids concentration in the ground water is low.

In moving downdip, the slightly acidic water becomes neutralized, iron content decreases, and the hardness of water increases. Because of ion exchange at greater depth, the water becomes a soft sodium bicarbonate type. Still farther downdip, the water becomes saline from the presence of seawater with which the formations were once saturated.

A similar progression is seen in water in some limestone aquifers. In those aquifers water may be initially harder than that in sandy formations, but base-exchange action prevents hardness everywhere from becoming excessive downdip.

Low bicarbonate concentrations may be related to rapid recharge through sinkholes and solution openings by water with a low carbon dioxide concentration. On the other hand, high bicarbonate concentrations may be expected where recharge water is high in carbon dioxide as a result of percolation through soil rich in organic matter.

\subsubsection{Alaska Region}

\subsubsection{Regional Occurrence}

The occurrence of ground water in Alaska is allied to the geologic and physiographic framework and is influenced by the distribution of permafrost in all but the south coastal regions. The effects of permafrost on ground-water systems decrease progressively from the continuous permafrost zone of northern Alaska to the southern limit of permafrost. In the continuous permafrost zone, the sediments are entirely frozen to depths as great as 2,000 ft. Ground water is usually present below the base of the permafrost, or locally, above permafrost at places where convective heatflow from surface-water bodies lowers the upper surface of permafrost (the permafrost table) below the depth of 
seasonal freezing. In the discontinuous permafrost zone, the frozen ground is warmer than in the continuous permafrost zone, and larger, interconnected or areally extensive unfrozen areas are present. However, even within this zone of "warm" permafrost, its local distribution is determined largely by subsurface drainage and surface insulation, which are in turn controlled by such factors as slope, geologic materials, and vegetation cover. For example, in the Fairbanks area deposits of silt are extensively frozen and effectively confine ground water in the principal aquifers. However, in the Big Delta area, which has a climate similar to that of Fairbanks, the deposits generally consist of coarse sand and gravel, and permafrost is present as isolated bodies which have little effect on the occurrence of ground water (Zenone and Anderson 1978).

Alaska's geologic framework has been compared to that of western Canada and the western United States. Major landforms include three great mountain ranges: the Brooks, Alaskan, and Coastal; a broad interior lowland drained by large rivers and containing scattered highlands and plateaus; and large coastal plains, valleys, and river deltas. Covering the rocks of the mountain ranges and those of smaller mountains and uplands is the drift of glaciers that occupied these highlands during the Pleistocene Epoch. Outwash deposits derived from and extending beyond the limits of existing and former glaciers and materials originally of alluvial rather than glacial origin occupy the interior valleys and mantle the older rocks in large areas of the interior lowland.

Four generalized geohydrologic environments are recognized in Alaska: 1) alluvium of river valleys, including the flood plains, terraces, and alluvial fans of both major valleys and upland and mountain valleys, 2) glacial and glaciolacustrine deposits of the interior valleys, 3) coastal-lowland deposits, and 4) bedrock of the uplands and mountains.

\subsubsection{Alluvium of River Valleys}

Of the major geohydrologic environments in Alaska, alluvium of river valleys, including the flood plains, terraces, and alluvial fans of both major valleys and smaller mountain and upland valleys, contains the greatest volume of ground water in storage. Alluvial 
deposits also have the greatest recharge potential because they are hydraulically connected to the extensive surface-water drainage system. The Yukon, Tanana, Kuskokwim, Kobuk, and Susitna River basins are the major ground- and surface-water systems. In the lower Tanana basin, for example, the maximum known thickness of alluvium is 2,000 ft (Anderson 1970). In the lower coastal reaches of large river valleys such as the Susitna, the alluvial deposits, perhaps only a few tens of feet thick, are interbedded with thick lacustrine, glacial, and glaciomarine deposits.

In the continuous permafrost region, all the deposits may be frozen except those adjacent to river channels and large lakes. Unfrozen zones may extend completely through the permafrost along the major rivers north of the Brooks Range. Even if such streambed aquifers are present in the continuous permafrost zone, frozen ground severely reduces the storage capacity of the aquifers in the zone as a whole.

In the discontinuous permafrost zone, the volume of frozen ground does not significantly reduce the storage capacity of alluvial aquifers along the major rivers--the Yukon, Tanana, and Kuskokwim--because the thickness of permafrost is generally small relative to the total thickness of unconsolidated deposits. Alluvium along smaller tributary valleys may be mostly frozen, however, and there are areas within the major valleys where frozen ground greatly reduces groundwater storage capacity.

The major ground-water bodies lie beneath the base of permafrost in the discontinuous permafrost zone. At Fairbanks, productive water-bearing deposits are present beneath permafrost that varies widely and irregularly in thickness and has a maximum reported thickness of $265 \mathrm{ft}$. Recharge and discharge of these alluvial aquifers takes place chiefly along stream channels and through lake beds and other thawed zones that perforate the permafrost.

\subsubsection{Glacial and Glaciolacustrine Deposits of Interior Valleys}

Glacial deposits consist largely of till laid down during the Pleistocene epoch as the glaciers advanced from major mountain ranges into the interior plains and lowlands. During the retreat of glaciers, the till was 
covered by permeable water-worked deposits, some of which were buried by till of later glacier advances. Where the glaciers advanced into preglacial lakes, beds and lenses of clay, silt, sand, gravel, and stony clay or silt are interbedded with the till. The sediments are predominantly fine grained and are frozen in northern Alaska and at the higher altitudes of the south-central part of the state. Although these deposits are widely distributed, they have not been extensively explored for ground water and probably do not contain major aquifers except in southern Alaska, where permafrost either is absent or occurs only as small isolated masses.

\subsubsection{Coastal Lowland Deposits}

The coastal lowland deposits of Alaska reflect various combinations of several depositional environments. They can be generalized to include: 1) constructional shoreline features formed on land or in shallow water, including coastal plains, deltas, bars, spits, and beaches, and 2) coastal basins and valleys whose basic configuration was produced chiefly by structural or erosional forces and which subsequently were filled by sediments from both marine and nonmarine (glacial and alluvial) sources.

The Arctic Coastal Plain is the largest coastal lowland deposit in Alaska; it is underlain by as much as $200 \mathrm{ft}$ of unconsolidated silt, sand, and gravel. Permafrost generally extends from the land surface through the entire thickness of the unconsolidated sediments and into the underlying bedrock. Permafrost restricts ground water to local, discontinuous thawed zones under deep lakes and rivers and to places where springs issuing from bedrock maintain a thawed conduit. The water from bedrock beneath permafrost is generally brackish to saline.

Deltas of the Colville, Noatak, Kobuk, and Selawik Rivers and the compound delta of the Yukon and Kuskokwim Rivers form a large part of the coastal lowlands of northern and western Alaska. Smaller deltas are formed by several other rivers in south-central and southeastern Alaska; the largest of these is the Copper River delta. Subsurface data are available only from the Yukon-Kuskokwim and Copper River deltas. Sediments of the deltas consist of sand, silt, and thin beds of gravel. Permafrost is widespread in the upper part of 
the deposits of the Yukon-Kuskokwim delta. It extends from near the surface to a maximum known depth of $600 \mathrm{ft}$ near Bethel. However, a comparison of river stage and ground-water levels at Bethel suggests a hydraulic connection between the river and ground-water system, and thus a lack of permafrost beneath the river. If the sediments of major deltas are in hydraulic connection with their associated rivers, the potential for induced ground-water recharge from streamflow is enormous. Ground-water availability in the deltas is limited, by predominantly fine-grained sediments and to a greater extent by permafrost in northern and northwestern Alaska. Additionally, the thickness of the freshwater aquifer is determined by the position of the freshwater-saltwater interface, which is probably very shallow near the distal edge of the deltas.

Bars, spits, and beaches border the entire coastline of Alaska. The distribution and availability of fresh ground water in these deposits depends on several factors. Along the Arctic Ocean coastline, ground water is perched on permafrost and the thickness of the water body depends on the rate of recharge from rainfall and snowmelt, the depth to the permafrost, and the time since storm waves last inundated the area. In areas without permafrost, the presence of fresh ground water depends on the rate of recharge and discharge and consequently the depth to the freshwater-saltwater interface. Along the Gulf of Alaska coastline, abundant recharge from precipitation, freshwater lagoons, and streamflow create conditions favorable for the occurrence of shallow ground water in permeable coastal sediments.

Deposits of the coastal basins and valleys consist of till interbedded with sand, silt, clay, and gravel of fluvial and marine origin. The largest and bestknown ground-water system of this type is that of the Cook Inlet lowland, particularly in the Kenai and Anchorage areas. Unconsolidated sediments reach a maximum thickness of more than $4,000 \mathrm{ft}$ in the Cook Inlet lowland, but in most wells the thickness is less than 1,000 ft. The sediments are predominantly interbedded glacial till, fine-grained glaciolacustrine deposits and more permeable water-worked deposits of sand and gravel. Throughout the cook Inlet lowland, small quantities of ground water occur under unconfined conditions near the surface or are confined in thin 
water-bearing lenses within the till or glaciolacustrine deposits. Greater volumes of recoverable ground water are found in coarse-grained alluvial deposits, ranging in thickness from 10 to $100 \mathrm{ft}$, such as those forming the confined glacial-outwash aquifers at Anchorage. These deposits may be of limited areal extent, however, and their location is unpredictable without exhaustive subsurface exploration.

\subsubsection{Bedrock}

In approximately $75 \%$ of Alaska, glacial and alluvial deposits are thin, poorly permeable or absent. In such areas, appreciable amounts of ground water occur only in aquifers consisting of consolidated rocks. The occurrence of ground water in bedrock is described here under four general rock types: carbonate rocks, sandstone, volcanic rocks, and metamorphic and intrusive igneous rocks.

Although carbonate rocks are quite extensive in southeastern Alaska, they have not been explored and utilized there as a water source. The Brooks Range area, which lies entirely in the continuous permafrost zone, also contains extensive carbonate-rock deposits. Ground-water movement in these rocks apparently has developed solution cavities and conduits through which the water flows to the surface. Conclusions concerning the occurrence and movement of ground water in carbonate rocks of the Brooks Range are inferred from measurements and observations of spring flows. Some springs in the Brooks Range have discharges as great as $16,000 \mathrm{gal} / \mathrm{min}$.

Sandstone and alternating strata of indurated sand, silt, and clay are widespread throughout the State. Although these deposits have been extensively explored for oil, gas, and coal, few hydrologic data have been reported. Such deposits have been explored for ground water in the western Kenai Peninsula, where they are poor aquifers because of low permeability.

Volcanic rocks are widespread in Alaska, but they are especially prevalent in some areas in the western part of the State, on the Aleutian Chain, Alaska Peninsula, the Seward Peninsula, and in the Wrangell Mountains. The occurrence of ground water in volcanic rocks is highly variable, and only a few wells are 
known to produce water from them. The presence of many springs suggests that basaltic lava flows in the mountains and uplands of the northern Seward Peninsula are promising sources of ground water.

Metamorphic and igneous rocks make up the cores of the principal ranges of Alaska. Ground water occurs chiefly in faults and fractures within these rocks. Probably the most intensive development of bedrock aquifers is in the uplands near Fairbanks (fractured schist), Anchorage (slate and metagreywacke), and a few places on the Kenai Peninsula and southeastern Alaska. Ground water is generally present only in weathered zones at the bedrock surface and in fractures. The probability of penetrating zones of secondary porosity below a depth of 300 to $500 \mathrm{ft}$ diminishes rapidly, and many deep wells are reported to be dry.

\subsubsection{Ground-Water Storage and Availability}

It is estimated that $1.5 \times 10^{14} \mathrm{ft}^{3}$ of ground water, with a dissolved-solids concentration of less than $3,000 \mathrm{mg} / 1$ is stored in aquifers in Alaska. Estimates of the amount of ground water in storage are academic, however, if they cannot be related to the quantity that can be transmitted by the aquifer and economically developed. Aquifer transmissivity, which varies greatly in Alaska and is strongly influenced by permafrost, exerts major control on the availability of ground water. For example, the porosity of predominantly fine-grained glacial and glaciolacustrine sediments is large, and a great volume of water is stored in the sediments. However, the amount of water that can be efficiently recovered is limited by low permeability of the fine-grained sediments themselves and by the limited extent of coarser, more permeable horizons within those sediments. In permafrost zones, even the coarse-grained potential aquifers may be frozen.

There have been attempts at ground-water development in most areas of the State. However, only at Anchorage and perhaps at Fairbanks, Kenai, and Juneau is the basic framework of the ground-water system reasonably well known. Elsewhere, data are too scarce to describe the areal extent, thickness, and hydraulic boundaries of the aquifers.

Individual yields greater than $1,000 \mathrm{gal} / \mathrm{min}$ have been obtained from wells in alluvial deposits in the 
Tanana valley (at Fairbanks, Eielson AFB, Big Delta, and Clear), Cook Inlet lowland (Anchorage and Kenai), and in the glacier-carved coastal valleys at Juneau and Seward. Attempts to develop ground water in the carbonate rocks of the Brooks Range have been largely unsuccessful because of thick (600 to $800 \mathrm{ft}$ ) permafrost, but flows ranging from 500 to as much as $16,000 \mathrm{gal} / \mathrm{min}$ have been measured at springs issuing from those rocks. Yields of 100 to $150 \mathrm{gal} / \mathrm{min}$ have been reported from deltaic sediments of the YukonKuskokwim Rivers.

\subsubsection{Water Quality}

A data base adequate to describe areal variations in the chemical quality of ground water is available for only a few places, such as Juneau, Kenai, Anchorage, and Fairbanks, and data are virtually nonexistent for large areas of the state. Known dissolved-solids concentrations range from less than $25 \mathrm{mg} / 1$ in shallow ground water in stream channel alluvium, to as much as $64,000 \mathrm{mg} / 1$ in saline waters in shallow coastal wells. However, most of the sampled ground water contains less than $400 \mathrm{mg} / 1$ dissolved solids. In inland areas, calcium bicarbonate- or calcium magnesium bicarbonate-type water is most common. Water of sodium bicarbonate or sodium chloride type is present in coastal areas (Zenone and Anderson 1978).

The ground water in coastal areas is sometimes quite saline; springs and deep artesian wells in the Copper River lowland show relatively high mineralization of subpermafrost water. Further, magnesium sulfate bicarbonate-type water occurs in bedrock of the Tanana River valley. Iron is present in objectionable concentrations in a large proportion of shallow wells in most areas of the state. Undesirable concentrations of other constitutents also occur. Chemical analyses show undesirably high concentrations of mercury in the ground water in the Yukon-Kuskokwim delta area, and high concentrations of nitrate are reported locally in the Palmer and Fairbanks areas. Other examples are organic materials in ground water of alluvial stream channels and flood plains, and arsenic in ground water in the bedrock hills north of Fairbanks and in glaciolacustrine clay at Anchorage and Kenai. 
The role of permafrost in directly imparting a particular type of mineralization to ground water is probably minor. Reduction of the rate of ground-water movement by permafrost provides a longer residence time for reactions between the water and the enclosing rocks than in regions without permafrost. Chemical reaction rates and saturation concentrations of some constituents are also affected by low water temperatures in permafrost areas. Ground water beneath permafrost is usually of nearly constant quality at a particular site, although it may differ in composition from one area to another. Ground water above permafrost is subject to variation in quality due to seasonal reduction in recharge and possibly also because of fractionation due to freezing of part of the aquifer.

Streams that receive ground-water inflow show a seasonal variation in concentration of dissolved minerals because of the changing proportions of ground water and surface water that contribute to streamflow. Because ground water is generally more highly mineralized than surface water, the highest concentrations of dissolved solids occur during low-flow periods. Surface-water quality data, particularly during low-flow (or base-flow) periods, can be used as an indication of regional ground-water quality. Dissolved-solids concentration of a stream can be still further increased during low-flow periods in winter as freezing causes rejection of impurities from the ice phase into the remaining water. This phenomenon can cause the winter flow of streams to have an even higher concentration of dissolved minerals than the inflowing ground water.

\subsubsection{Missouri Basin}

The ground-water resources of the Missouri Basin Region are grouped into three general types: unconsolidated and semiconsolidated aquifers, sandstone aquifers, and limestone and dolomite aquifers (Taylor 1978).

5.2.17.1 Unconsolidated and Semiconsolidated Aquifers

Unconsolidated aquifers include valley-fill alluvium, alluvium, dune sand, glacial deposits, and basin-fill alluvium. Semiconsolidated aquifers include deposits of gravel, sand, sandstone, and fractured sandy clay. 
The valley-fill alluvial aquifers consist of unconsolidated gravel, sand, silt, and clay, and are located along, and hydraulically connected to, the principal streams and their tributaries. Therefore the aquifers tend to be elongate. The maximum thickness of valley-fill aquifers is about $240 \mathrm{ft}$ in Colorado along the South Platte River valley but probably averages about $50 \mathrm{ft}$ over the Missouri Basin Region. In general, aquifers in main stream valleys are more extensive and thicker than aquifers in tributary valleys. Valley-fill aquifers are absent in some reaches of the main streams and in the upper reaches of most tributaries. In parts of North Dakota and South Dakota the aquifers are not distinguishable from glacial aquifers and are inundated in some areas by surface-water reservoirs.

Large-capacity wells completed in valley-fill alluvium yield as much as $4,000 \mathrm{gal} / \mathrm{min}$ along the North Platte River in Wyoming. Generally the maximum yields from wells in tributary valleys are smaller because aquifer materials are finer grained and aquifers are less extensive than those in the main stream valleys.

Water quality in the valley-fill aquifers is suitable for most intended purposes. The dissolvedsolids concentration ranges from about $100 \mathrm{mg} / 1$ to about $4,000 \mathrm{mg} / 1$; however, the concentration is normally less than $1,000 \mathrm{mg} / 1$.

Unconsolidated aquifers also occur in glacial deposits that extend in a belt as much as $200 \mathrm{mi}$ wide. The deposits reach a maximum thickness of about $800 \mathrm{ft}$ and contain sand and gravel aquifers in the form of buried channel deposits, extensive outwash deposits, and lenticular outwash deposits. Aquifers in glacial deposits may be formed during various stages of glaciation, complicating the geologic interpretation of their origin and distribution. Glacial aquifers are recharged by precipitation, streams, or leakage from bedrock aquifers below the glacial deposits. Ground water in the glacial aquifers is discharged to streams, springs, underlying bedrock, evapotranspiration, or wells. Well yields are extremely variable and are as much as 2,000 gal/min. Flowing wells derive water from aquifers confined by clay beds.

Water quality in the glacial aquifers is extremely variable, and the dissolved-solids concentration ranges from 300 to $30,000 \mathrm{mg} / 1$. 
Basin-fill aquifers in southwestern Montana consist mostly of poorly consolidated deposits of gravel, sand, silt, and clay of Tertiary age and attain a maximum thickness of about $6,000 \mathrm{ft}$ in intermontane valleys. Basin-fill aquifers are overlain by valleyfill alluvial aquifers in many areas. Basin-fill aquifers are recharged by precipitation, irrigation water, and streams. Ground water moves in the downstream direction. Although basin-fill aquifers are not as transmissive as the overlying valley-fill alluvium, wells yield as much as 1,000 gal/min. Dissolved-solids concentration is normally less than $1,000 \mathrm{mg} / 1$, making the water suitable for most purposes.

The Ogallala aquifer is widespread over parts of Colorado, Nebraska, and Kansas and present in small areas of Wyoming and South Dakota. The Ogallala Formation consists of semiconsolidated gravel, sand, silt, caliche, and clay and attains a maximum thickness of about $400 \mathrm{ft}$. Recharge to the 0gallala occurs directly from precipitation and by leakage through the overlying alluvial and dune-sand aquifers. The water table slopes toward the east, indicating that water in the Ogallala moves slowly from Wyoming and Colorado into Nebraska and Kansas. Discharge from the Ogallala is to streams or to wells. Large-capacity wells yield as much as $3,600 \mathrm{gal} / \mathrm{min}$ for irrigation, municipal, domestic, and livestock purposes. Average well yield is about 1,000 gal/min. Dissolved-solids concentration ranges from about 200 to $600 \mathrm{mg} / 1$.

Continual declines of the water table of the Ogallala aquifer in Colorado, Kansas, Nebraska, and Wyoming indicate the ground water is being depleted as the result of discharge exceeding the long-term recharge. The Colorado Ground Water Commission has established standards that limit well spacing and storage depletion for any new wells completed in the Ogallala in Colorado.

The Arikaree aquifer occurs in parts of Wyoming, South Dakota, Colorado, and Nebraska and underlies the Ogallala aquifer. The Arikaree Formation consists of semiconsolidated sandstone, siltstone, and claystone and attains a maximum thickness of about $600 \mathrm{ft}$. Aquifer recharge is largely from precipitation and irrigation. The Arikaree aquifer may be recharged also by leakage from the overlying Ogallala aquifer in some 
areas. Discharge is to streams and to irrigation, municipal, stock, and domestic wells. Some wells yield as much as 2,000 gal/min. Ground-water mining has occurred in the Arikaree in northwestern Nebraska, as evidenced by a progressive decline in the water table. Continued decline in the water table will gradually increase the cost of lifting water from the aquifer to the land surface and may discourage use of the aquifer. The dissolved-solids concentration in the Arikaree aquifer is only several hundred milligrams per liter.

The Brule Formation of the White River Group underlies the Arikaree Formation and is exposed over parts of Wyoming, South Dakota, Colorado, and Nebraska. The Brule Formation consists of siltstone and fractured sandy clay with a maximum thickness of about $450 \mathrm{ft}$. Precipitation and streamflow recharge the Brule aquifer. Ground-water movement occurs in the siltstone and in the fractures in the sandy clay. Therefore, the Brule aquifer is transmissive even though the aquifer material is fine grained. Extensive vertical and horizontal fractures exist in the Brule. Discharge is to streams and to wells that yield as much as 2,000 gal/min. Withdrawals from wells have caused minor ground-water depletion in Wyoming and Nebraska. The dissolved-solids concentration is normally only several hundred milligrams per liter.

\subsubsection{Sandstone Aquifers}

Sandstone aquifers are widespread in the Missouri Basin Region except in southwestern Montana and most of Nebraska, Kansas, Missouri, and parts of Wyoming and Colorado. Some sandstone aquifers are exposed at the land surface; others are in structural basins of various depths and alternate with relatively impervious beds of shale and limestone.

Structural basins result from folding, faulting, subsidence, or nearby uplifting. Many structural basins in the region contain thick accumulations of sediment. Principal basins are identified in Figure 5.12. Extensive accumulations of fine sediment form confining beds; accumulations of coarser sediment form aquifers. Numerous freshwater aquifers that alternate with confining beds occur in structural basins in Montana, Wyoming, North Dakota, South Dakota, and Colorado. In some cases, a shallow sandstone aquifer may be exposed over the areal extent of the 


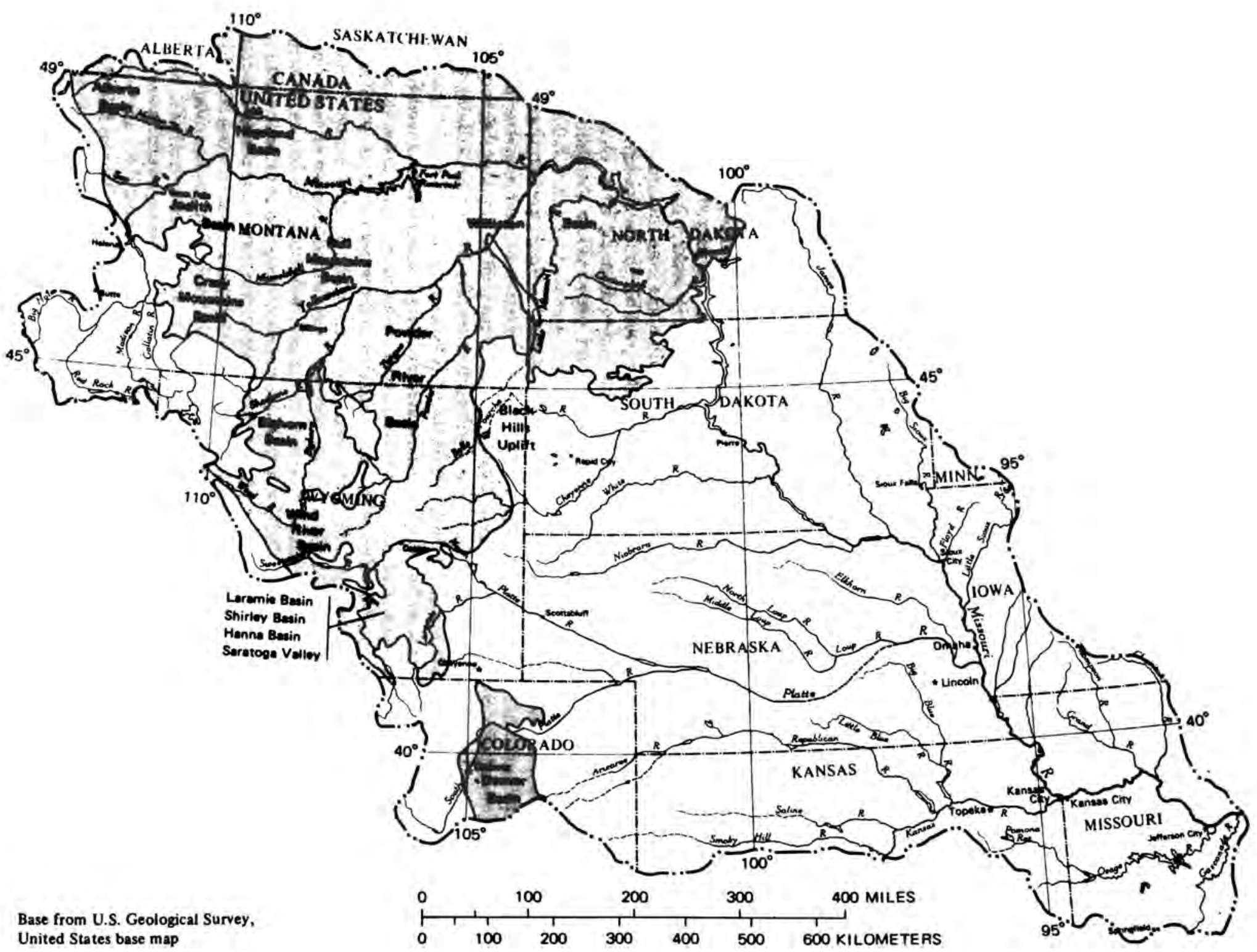

FIGURE 5.12. Structural Basins that Contain Freshwater Aquifers in the Missouri Basin Region (Taylor 1978, p. Q19) 
structural basin. Normally, the sandstone aquifers and confining formations are exposed at the land surface at the margin of the basin. Confined conditions are common, and in many cases flowing wells may be obtained in the sandstone aquifers. Intervening areas between basins are uplifted domes or arches and volcanic rocks.

The Virgelle Sandstone occurs in northwestern Montana in the southern part of the Alberta Basin. In other parts of Montana the Virgelle is the basal member of the Eagle Formation. The Virgelle consists of sandstone and shale and attains a maximum thickness of about $180 \mathrm{ft}$. Precipitation and leakage from overlying glacial deposits recharge the Virgelle aquifer. Discharge is to streams and springs and to wells that yield as much as $250 \mathrm{gal} / \mathrm{min}$ for industrial, municipal, domestic, and livestock uses. Withdrawals from pumped and flowing wells in the aquifer have caused continuing declines in water levels in wells.

The Judith Basin lies in central Montana near the headwaters of the Missouri River and many of its upstream tributaries. Sandstone aquifers include the Judith River Formation, Eagle Sandstone, Dakota Sandstone, Kootenai Formation, Swift Formation, Amsden Group, and Kibbey Formation. The sandstone aquifers are recharged by precipitation, streams, and irrigation water. Discharge is to wells, streams, or by evapotranspiration in areas where the water table is near the land surface. Wells completed in the Judith River, Eagle, and Dakota aquifers yield as much as $70 \mathrm{gal} / \mathrm{min}$; wells completed in the Kootenai and Swift aquifers yield as much as $300 \mathrm{gal} / \mathrm{min}$. Flowing wells are obtained where the aquifers are confined.

The Hogeland Basin lies in southern Saskatchewan and north-central Montana. Sandstone aquifers include the Judith River Formation, Eagle Sandstone, Dakota Sandstone, Kootenai Formation, and Swift Formation. Where exposed, the sandstone aquifers are recharged by precipitation and elsewhere probably by leakage from the overlying glacial aquifers. Discharge from the aquifers is to springs, streams, wells, possibly to the atmosphere by evapotranspiration, and to other aquifers. Flowing wells are obtained in some places where the aquifers are confined. Wells completed in the Judith River aquifer yield as much as $75 \mathrm{gal} / \mathrm{min}$. 
The Bighorn Basin lies mostly in Wyoming but extends slightly into Montana. The sandstone aquifers are recharged by precipitation, streamflow, and leakage from other aquifers. Discharge is to springs, streamflow, to the atmosphere by evapotranspiration, other aquifers, and wells. Flowing wells completed in the Tensleep and Amsden aquifers have yielded 2,000 gal/min. Uses of the ground water include municipal, industrial, irrigation, and fish culture.

In the Wind River Basin aquifers probably are recharged by precipitation or by interaquifer leakage. Some of the sandstone aquifers are fractured, increasing aquifer transmissivity and well yield. Maximum well yield is about $1,100 \mathrm{gal} / \mathrm{min}$. The concentration of dissolved solids or of a particular chemical constituent is very high in several aquifers.

The Laramie, Shirley, and Hanna Basins and Saratoga Valley, near the head-waters of the Platte River in northern Colorado, contain large numbers of formations that consist partiy or completely of sandstone. All of the sandstone aquifers are not present in each basin or valley, but the presence of several aquifers in any basin may represent a large thickness of sandstone and a correspondingly large volume of stored ground water. Most of the sandstone aquifers are recharged by precipitation where exposed. Interaquifer leakage is likely. Wells yield as much as $1,000 \mathrm{gal} / \mathrm{min}$ especially where fracturing has increased the permeability of the aquifers. Water quality is variable, although the water is generally suitable for most purposes.

The Powder River Basin contains sandstone aquifers that extend over a large area in northeastern Wyoming and southeastern Montana. The Wasatch Formation is an aquifer that yields as much as $500 \mathrm{gal} / \mathrm{min}$ to wells in Wyoming, but it is mostly absent in Montana. The dissolved-solids concentration commonly ranges from 500 to $1,500 \mathrm{mg} / 1$. Aquifers in the Fort Unior Formation are sandstone and coal beds. Wells in wyoming in the Fort Union yield as much as $150 \mathrm{gal} / \mathrm{min}$ of water with a normal dissolved-solids concentration of 500 to 1,500 $\mathrm{mg} / 1$. The Fox Hills Sandstone and overlying sandstone beds of the Lance or Hell Creek Formations form an areally extensive and persistent aquifer. The aquifer is probably recharged where exposed at the edge of the basin and by leakage from other aquifers. In northern 
Wyoming, water in the Fox Hills supplies industrial, municipal, and domestic wells with yields as much as $200 \mathrm{gal} / \mathrm{min}$. Dissolved-solids concentration is normally less than $2,000 \mathrm{mg} / 1$.

Additional sandstone aquifers 1 ie below the Fox Hills in the Powder River Basin. The Mesaverde and Frontier aquifers yield as much as $50 \mathrm{gal} / \mathrm{min}$ to wells; the Inyan Kara aquifer may yield $200 \mathrm{gal} / \mathrm{min}$. Dissolvedsolids concentration in the Mesaverde, Frontier, and Inyan Kara aquifers is normally less than $3,000 \mathrm{mg} / 1$. Wells completed in the Sundance aquifer yield a maximum of $50 \mathrm{gal} / \mathrm{min}$. Dissolved-solids concentration ranges from about 500 to $2,000 \mathrm{mg} / 1$ in the Sundance. Wells completed in the Tensleep aquifer yield from 20 to $1,200 \mathrm{gal} / \mathrm{min}$. Higher yields are obtained where the Tensleep is fractured. Dissolved solids in water from the Tensleep aquifer commonly range from 200 to 500 $\mathrm{mg} / 1$ and consist mostly of calcium and bicarbonate.

The Williston Basin extends over western North Dakota, eastern Montana, northwestern South Dakota, and southern Saskatchewan. Sandstone aquifers occur in the Fort Union Formation. Fox Hills Sandstone, Hell Creek Formation, and Dakota Sandstone. The Fort Union Formation consists of shale, sandstone, siltstone, lignite, and clinker beds. Sandstone aquifers in the Fort Union are recharged principally by precipitation. Ground water in southwestern North Dakota generally moves northwest, in the direction of surface drainage. Discharge is to streams and to domestic and stock wells that yield as much as $200 \mathrm{gal} / \mathrm{min}$, but generally much less. Dissolved-solids concentration normally is less than $2,000 \mathrm{mg} / 1$ but may be as high as $7,000 \mathrm{mg} / 1$. Dependable sandstone aquifers in the Fort Union are difficult to locate because of their discontinuous and irregular nature.

The Fox Hills-Basal Hell Creek aquifer is extensive in the Williston Basin. Recharge occurs through outcrops of the aquifer near the Black Hills Uplift and seepage from overlying aquifers. Ground-water movement is to the north, northeast, and east. Natural discharge is by upward leakage through confining beds or by evapotranspiration where the aquifer crops out, as in central North Dakota. In south-central North Dakota east of the Missouri River the potentiometric surface slopes westward, indicating the ground water moves from east to west. Wells in the aquifer yield as much as 
$700 \mathrm{gal} / \mathrm{min}$. Uncontrolled or partly controlled flow from wells in the aquifer has caused water-level declines of about $30 \mathrm{ft}$ in Mercer County, North Dakota. Dissolved-solids concentration generally ranges from 1,000 to $2,000 \mathrm{mg} / 1$.

The Dakota Sandstone is a principal aquifer in the Williston Basin. At the deepest part of the basin near Williston, North Dakota, the top of the Dakota aquifer is more than $5,600 \mathrm{ft}$ below the land surface. In western North Dakota, shale predominates over sandstone in the aquifer; in eastern North Dakota the sandstone predominates over shale. Natural recharge, movement, and natural discharge for the Dakota are not well understood in the Williston Basin. Large artesian pressures in the Dakota led to the drilling of numerous flowing wells, many of which were allowed to flow continuously, wasting ground water from the Dakota aquifer. Water levels declined an estimated $200 \mathrm{ft}$ from 1902 to 1923 in LaMoure and Dickey Counties of North Dakota. The Dakota aquifer may be hydraulically connected to other aquifers whose supply is also being depleted by uncontrolled discharges from wells completed in the Dakota. Dissolved-solids concentration is as much as $11,000 \mathrm{mg} / 1$ in western North Dakota but generally ranges from 2,000 to $3,000 \mathrm{mg} / 1$ in areas of greatest use. Principal ions include sodium, chloride, and sulfate.

The Denver Basin in northeastern Colorado is largely included in the Missouri Basin Region. Groundwater movement is toward the north. Long-term measurements indicate a decline in the water levels in wells completed in the aquifers of the Denver Basin. Wells yield a maximum of about $300 \mathrm{gal} / \mathrm{min}$ for domestic, municipal, and industrial uses. Discharge from naturally flowing wells has been reduced, and in many areas the flow has ceased and wells must be pumped to obtain a water supply. Dissolved-solids concentration ranges from about 170 to $3,700 \mathrm{mg} / 1$.

Important sandstone aquifers in the Missouri Basin Region include the Dakota Sandstone, Inyan Kara Group, Sundance Formation, Minnelusa Formation, and Deadwood Formation. The Dakota Sandstone crops out in eastern Nebraska, western Iowa, central Kansas, possibly southwestern Minnesota, and near uplifted areas. Maximum aquifer thickness, where the aquifer crops out, 
is about $400 \mathrm{ft}$. At depth, west of the outcrop area, the maximum thickness is about $700 \mathrm{ft}$. Recharge is from precipitation and streams on the exposed sandstone and by leakage from shallow aquifers to the underlying Dakota. In southwestern Kansas the water in the Dakota aquifer passes from the Arkansas-White-Red Region into the Missouri Basin Region. Discharge is to streams, springs, or into valley-fill aquifers in local areas. Wells completed in the exposed Dakota Sandstone yield as much as $1,500 \mathrm{gal} / \mathrm{min}$. Dissolved-solids concentration is variable and ranges from about 300 to $30,000 \mathrm{mg} / 1$. The concentration is low at shallow depths where the aquifer is exposed but high at depth and toward the west. Large concentrations of chloride and sulfate are reported in some areas. In parts of Kansas the water quality of some streams has been impaired by base flow from the Dakota.

Principal sandstone units that underlie the Dakota Sandstone primarily in central South Dakota and southcentral North Dakota include the Inyan Kara Group and Sundance, Minnelusa, and Deadwood Formations.

The potentiometric surface of the Dakota slopes from the Black Hills Uplift toward southeastern and northeastern South Dakota. Recharge is from precipitation and streamflow on outcrops near the Black Hills and from leakage from other aquifers. Ground water moves toward the east and partiy into the Souris-RedRainy Region of northern and eastern North Dakota and Upper Mississippi region of Minnesota. Natural discharge from the Dakota is to overlying glacial deposits or possibly other aquifers. Numerous flowing wells have been drilled in the Dakota since the late 1800s. Wells yield as much as $1,500 \mathrm{gal} / \mathrm{min}$ but average about $15 \mathrm{gal} / \mathrm{min}$. Uncontrolled flowing wells have lowered the potentiometric surface, especially along the Missouri River Valley where wells are relatively shallow and artesian pressures are high. Dissolvedsolids concentration ranges from 1,700 to $8,000 \mathrm{mg} / 1$.

The Inyan Kara aquifer and Sundance aquifer lie directly below the Dakota aquifer in South Dakota. Flowing wells are obtained in both aquifers, but few wells have been drilled. Water quality is variable, and dissolved-solids concentrations range from less than $1,000 \mathrm{mg} / 1$ to more than $10,000 \mathrm{mg} / 1$. 
The Minnelusa and Deadwood aquifers are mostly undeveloped. A well completed in the Minnelusa aquifer yielded 4,000 gal/min when drilled. Water in the Deadwood aquifer may be saline.

The Jordan Sandstone is the most productive aquifer in the part of Iowa within the Missouri Basin Region. The Jordan aquifer is hydraulically connected to an overlying dolomite, the Prairie du Chien Formation, and the two units form a single aquifer with a combined thickness that ranges from 300 to $600 \mathrm{ft}$. Municipal wells yield as much as $1,000 \mathrm{gal} / \mathrm{min}$. Dissolved-solids concentration ranges from about 1,500 to $2,000 \mathrm{mg} / 1$.

\subsubsection{Limestone and Dolomite Aquifers}

The few limestone and dolomite aquifers that occur in the Missouri Basin Region are areally extensive and capable of large yields where cavernous. Ground water in limestone or dolomite aquifers occurs in openings that range in size from small pores, joints, and other features to large caverns formed by the solution and removal of rock by ground water. Fractures also may increase the storage and transmissive properties of limestone and dolomite aquifers.

The Madison Group (also Madison Limestone) is an extensive limestone aquifer that occurs in parts of Alberta, Saskatchewan, Montana, Wyoming, North Dakota, South Dakota, Nebraska, and Colorado. Thickness of the Madison Group increases toward the center of the Williston Bas in in northwestern North Dakota, where it is about 2,300 ft thick. The Madison is exposed near major structural uplifts in the Missouri Basin Region, but at the deepest location, about 40 miles northeast of Casper, Wyoming, it is about $16,000 \mathrm{ft}$ below land surface. The areal extent of the Madison aquifer is only approximately known because the geologic structure in Montana and Wyoming is complex and few drillers' logs are available.

Streamflow and precipitation recharge the Madison aquifer where it is exposed; leakage from adjacent aquifers also may recharge the aquifer. Ground-water movement is generally to the north and northeast in northern Wyoming and Montana. Movement is generally toward the east in North Dakota and South Dakota. Discharge is to streams, springs, other aquifers, or 
wells. Numerous springs discharge from the Madison in Montana, and Giant spring near Great Falls, Montana, flows about $300 \mathrm{ft}^{3} / \mathrm{s}$. Wells yield from several hundred to several thousand gallons per minute. Industrial wells that withdraw water for use in oil fields have caused declines of water levels of as much as several hundred feet at places in wyoming. Water temperature in the Madison aquifer increases with depth below 1 and surface and ranges from about $50^{\circ} \mathrm{F}$ to $250^{\circ} \mathrm{F}$. Large concentrations of dissolved solids are often associated with high water temperatures because of increased mineral solubilities. Dissolved-solids concentration in the Madison aquifer ranges from about $300 \mathrm{mg} / 1$ near Lewistown, Montana, to $350,000 \mathrm{mg} / 1$ in the Williston Basin.

Limestone and sandstone aquifers occur in rocks of Permian and Pennsylvania age in Nebraska and Kansas. Similar aquifers occur in rocks of Pennsylvania age in Iowa and Missouri. Total thickness of the limestone and sandstone ranges widely; maximum thickness is several thousand feet. Ground water occurs in pores, caverns, and fractures of the limestone and in interbedded sandstone. Aquifers are recharged by precipitation and are discharged to streams, springs, and wells. Reported well yields range from 3 to 500 gal/min. Water quality is variable. In Iowa and Missouri the dissolved-solids concentration generally increases with depth below land surface. In Kansas the dissolved-solids concentration in the sandstone aquifers increases toward the west. Saline water discharges from mineralized shale, included with aquifers of Permian age, to streams in central Kansas and impairs the quality of surface water. In a few places in Kansas, high concentrations of sulfate, chloride, and nitrate have been detected in water from the aquifers in Permian and Pennsylvania rocks. Zones in the limestone aquifers that transmit and store water readily are difficult to locate because of their random occurrence.

An areally extensive dolomite aquifer lies beneath the Madison aquifer in eastern Montana, northern Wyoming, and the Williston Basin. The aquifer lies at great depths except near uplifts. The dolomite aquifer is known as the Bighorn Dolomite in northern Wyoming and southern Montana, the Red River Formation in the Williston Basin, and the Whitewood Dolomite near the Black Hills. However, the Bighorn, Red River, and 
Whitewood are only approximately equivalent. Maximum thickness of the aquifer is about $550 \mathrm{ft}$. Water temperatures as much as $250^{\circ} \mathrm{F}$ have been measured, and high artesian pressures are reported in the aquifer in South Dakota. Locally, the aquifer may yield several hundred gallons per minute to wells. The aquifer might furnish water to the overlying Madison aquifer through leakage if large amounts of water were withdrawn from the Madison.

The Roubidoux Formation, Gasconade Dolomite, Eminence Dolomite, and Potosi Dolomite in south-central Missouri and southeastern Kansas are utilized for water supplies. The formations are primarily dolomite and represent the principal aquifers of the 0zarks area. The formations constitute a series of adjacent dolomite aquifers that are recharged by precipitation and streamflow. Ground-water movement is toward streams where the aquifers discharge naturally. Ground water is transmitted as rapidly as $1 \mathrm{mi} / \mathrm{d}$ through an extensive system of caverns. Relatively large and rapid ground-water movement is also indicated by the uniform cool temperatures of $56^{\circ}$ to $65^{\circ} \mathrm{F}$ of ground water over a wide range in depth below land surface and the low dissolved-solids concentration. Most of the many large springs in Missouri issue from the Gasconade, Eminence, and Potosi aquifers. Maximum yield of wells completed in the Roubidoux, Gasconade, Eminence, and Potosi aquifers is about $2,000 \mathrm{gal} / \mathrm{min}$. The dissolved-solids concentration in the aquifers is normally less than $350 \mathrm{mg} / 1$.

Limestone and dolomite aquifers are very productive as indicated by large spring flows and well yields. Transmission of ground water in the caverns is more like streamflow than like flow in a fine-grained aquifer.

The principal aquifer types, representative aquifer formations, water qualities, and locations are summarized in Table 5.10 (Taylor 1978).

\subsubsection{Lower Colorado Region}

The lower Colorado region comprises three water provinces that have major differences in geology, physiography, altitude, and climate. These provinces are the Basin and Range lowlands province in the south and west; 
TABLE 5.10. Aquifers of the Lower Colorado Region (Taylor 1978)

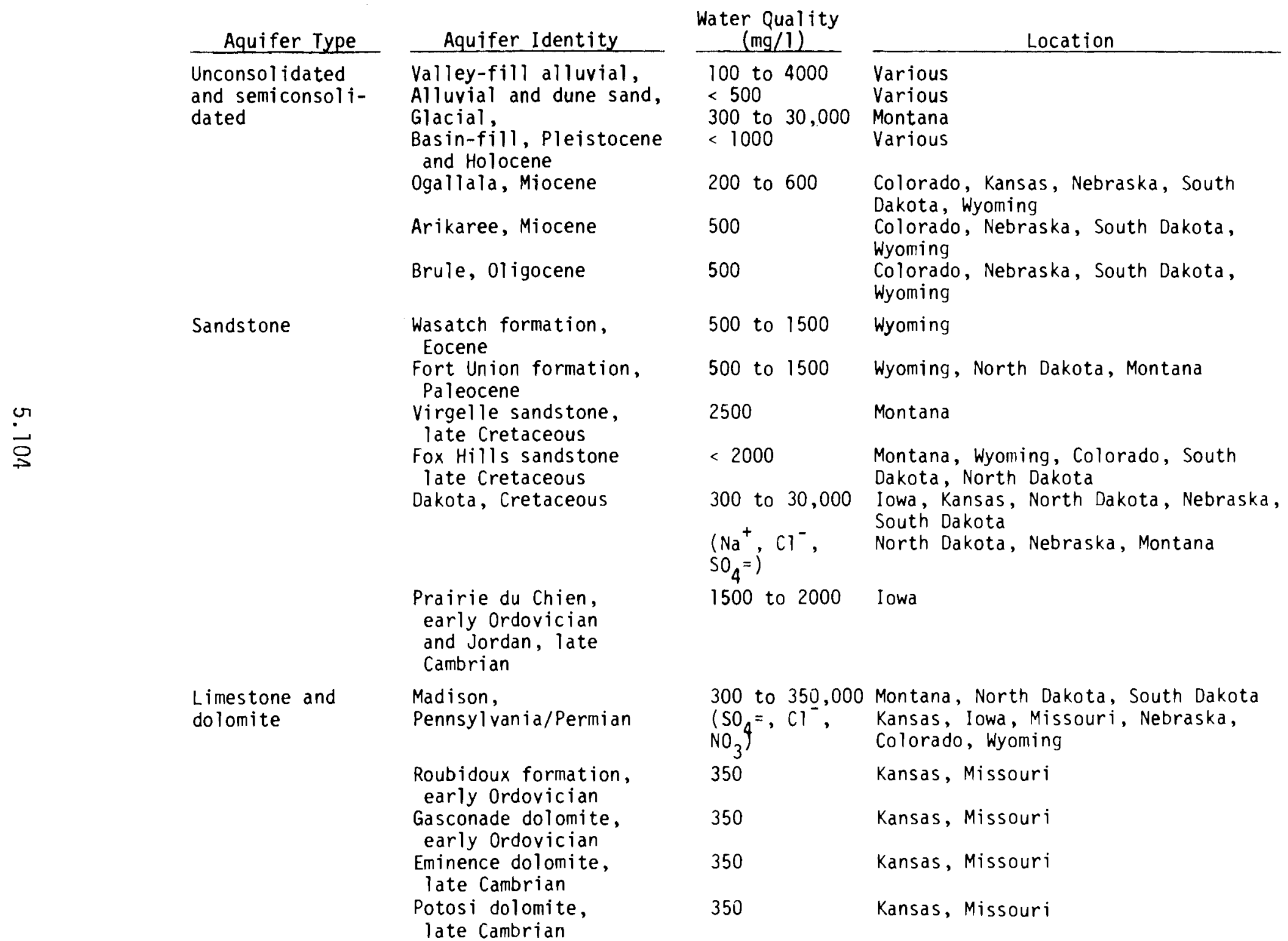


the Plateau uplands province in the northeast; and the Central highlands province, a transitional zone between the other two provinces.

The Basin and Range lowlands province contains extensive highly developed aquifers, which store vast quantities of good-quality water (Davidson 1979). The extensive thick sediments that fill the basins are aquifers into which precipitation and streamflow infiltrate and are stored. The basins are filled to depths of 5,000 to at least $10,000 \mathrm{ft}$ with discrete layers to poorly sorted deposits of clay, silt, sand and gravel. The mountains contain small amounts of ground water; however, precipitation increases in direct proportion to altitude, and a substantial part of the water recharged to the aquifers orginates as runoff from mountainous terrane. The mountains in Arizona and New Mexico are composed of granitic, volcanic, and sedimentary rocks. In Nevada, many of the ranges are limestone and other sedimentary rocks.

Coarser material in the basins is found near the mountains, and fine-grained material is deposited along valley axes and in deeper parts of the basins. Volcanic rocks and evaporite deposits are interbedded with the clastic sediment in many basins. Most of these deposits are poorly to moderately consolidated, and the more deeply buried deposits are the more strongly cemented. Unconsolidated sand and gravel occur along streams and as a blanketing deposit.

The more permeable sand and gravel beds in the uppermost parts of the basins are the most extensively developed sources of ground water; saturated and permeable sand and gravel beds along stream channels or in blanketing deposits yield the greatest amounts but the vast quantity of underlying thick sediment stores the greatest volume of water. In most basins, the water-yielding beds are hydraulically connected and the contained water is unconfined at shallow depths; however, in some places, and generally as depth increases, water-bearing beds are more completely separated by the less permeable beds, and semiconfined artesian conditions prevail.

The dissolved-solids concentrations range from less than 100 to more than $100,000 \mathrm{mg} / 1$ and general1y are less than $1,000 \mathrm{mg} / 1$. Ground water that contains more than $1,000 \mathrm{mg} / 1$ dissolved solids occurs mainly 
along and near the Gila River from Safford to Yuma, Arizona; along the southernmost reach of the Colorado River; in the southeastern part of Nevada; and near Wilcox, Casa Grande, and Tucson. The dissolved-solids concentrations in ground water differ areally and with depth owing to differences in the chemical character of the aquifers. For example, 1,000-ft-deep wells in the Casa Grande area penetrate mainly sand and gravel and minor thicknesses of gypsum and salty clay. Significant amounts of dissolved solids originate near the gypsum and salty beds. Because many wells in the region are open to the entire section of sedimentary deposits penetrated by the well, poor-quality water from such beds is mixed with better-quality water and the final well-discharge product may be so poor as to make the water nearly unusable. Additionally, because of such well construction, ground water having high concentrations of dissolved solids may migrate through the well into other parts of the aquifer, thereby contaminating ground water formerly of good quality.

Generally because of increased residence time or because of greater opportunity for ground water to pass through and dissolve chemicals from the enclosing rocks, ground water at depth contains more dissolved solids than that nearer the surface. In some places, the concentration decreases with depth concurrent with a change in water type. In the Wilcox and Tucson areas, in Pinal County, and in the Beardsley area of northwest Maricopa County, Arizona, the water grades with increasing depth from a calcium bicarbonate to a sodium bicarbonate type. Near Tucson, ground water shows a decrease in calcium relative to sodium with increasing depth, and water at a depth of 2,000 ft contains less dissolved solids than ground water nearer the surface.

The chemical quality of ground water contained in rocks of the mountain blocks generally is similar to that of precipitation and surface flow and contains a lower concentration of dissolved solids than ground water in the sedimentary rocks of the basins. The dissolved-solids concentrations generally are less than $1,000 \mathrm{mg} / 1$. However, well yields are small compared with those in aquifers of the basin.

The Plateau uplands province is underlain chiefly by consolidated sedimentary rocks, which consist mainly of sandstone, siltstone, claystone, and limestone. The 
sandstone and limestone form the chief aquifers in the area; the siltstone and claystone are nearly impermeable and form confining beds throughout most of the area. Where water-bearing beds of sandstone and limestone alternate with the confining beds, the water in the aquifers is under artesian pressure. Sand and gravel deposits along major streams form isolated "shoestring" aquifers of limited areal extent. The water in the "shoestring" aquifers is unconfined. The quantity and chemical quality of water are dependent mainly on precipitation and streamflow, but in some places these aquifers are supplied by ground water discharging from underlying consolidated sedimentary rocks.

The dissolved-solids concentrations in ground water in the rocks of the uplands range from 90 to more than $60,000 \mathrm{mg} / 1$. Although gradation between chemical types of ground water is common, most water with less than $500 \mathrm{mg} / 1$ of dissolved solids is a calcium or sodium bicarbonate type, and most with more than $500 \mathrm{mg} / 1$ is a sodium or calcium sulfate or sodium chloride type. Very highly mineralized water, however, commonly is a bicarbonate sulfate type.

The Central highlands province is similar geologically to the Basin and Range lowlands except that the mountains dominate the adjacent basins. Crystalline igneous and metamorphic rocks form much of the Central highlands; they do not store large amounts of ground water per unit area. Small amounts of ground water can be obtained from fractures in these rocks and from the thin sand and gravel deposits along streams that drain the mountainous terrane. Where geologic conditions are favorable in the highlands province, extensive bedded deposits of volcanic rocks and some of the few sedimentfilled basins store and yield large amounts of water; the greatest water production is obtained from wells tapping these rocks.

Ground water draining from the rocks in and near the Central highlands is the source of perennial flow in the Gila, Salt, and Verde Rivers. The dissolvedsolids concentration of the water generally is less than $1,000 \mathrm{mg} / 1$; however, several springs yield saline water. Clifton Hot Springs yields sodium chloride type water containing more than $9,000 \mathrm{mg} / 1$ dissolved solids to the San Francisco River. Springs along the Salt River yield sodium-chloride type water that contains 
more than $37,000 \mathrm{mg} / 1$ dissolved solids, and springs on the tributary White River yield sodium chloride water that contains more than $8,000 \mathrm{mg} / 1$ dissolved solids.

\subsubsection{Pacific Northwest Region}

More than half of the Pacific Northwest region is underlain by rock materials known, or believed from geologic evidence, to be capable of yielding ground water to wells at moderate to high rates. These are the areas where the ground-water reservoirs are most likely to be economic sources of supplies for irrigation, industrial, and municipal uses (Foxworthy 1979).

The major ground-water reservoirs can be classified mainly in three groups--those made up of 1) predominantly sedimentary rocks (including deposits from streams, glaciers, and the wind), 2) predominantly volcanic rocks, and 3 ) combinations of sedimentary and volcanic rocks.

Differences in the occurrence and movement of ground water in the two main classes of rocks--sedimentary and volcanic--are significant to the functions of these rocks as ground-water reservoirs. The sedimentary rocks yield water to wells mainly from layers of sand and gravel, the kinds of sedimentary rocks in this region most likely to yield water at moderate to high rates. Less permeable sedimentary materials, such as clay and silt, are more common in the region and, although they yield water to wells at lower rates, they serve the extremely valuable function of long-term storage that can drain slowly to adjacent permeable aquifers. These fine-grained deposits have a relatively high porosity, but the pore spaces are so small that considerable force (in the form of hydraulic pressure or weight of overlying rocks) is required to dislodge much of the water they contain. The saturated space within the permeable sedimentary rocks consists mostly of the primary pore space left between the particles of rock materials as they were deposited. Those sedimentary rocks that have been hardened by such natural processes as compaction or cementation may develop secondary joints and fractures which transmit water, but the benefits of such secondary openings commonly do not offset the loss of pore space and permeability that results from the rock-hardening processes. 
The volcanic rocks yield water mainly from permeable zones that occur at or near the contacts between some flow layers; central and lower parts of the flow layers are nearly always denser and much less permeable. The abundance, causes, and nature of the permeable zones differ greatly. The zones tend to occur less commonly in rocks of the Columbia Plateau than in rocks of the Snake River Plain and younger volcanic rocks. They commonly result from the incomplete filling of openings at the top of one flow layer (such as rubble, cinders, or scoria) by the lava of a succeeding flow. Other permeable interflow zones have other origins, including deposition of sedimentary materials during the times between lava outpourings.

The volcanic ground-water reservoirs commonly yield water to wells at high rates but generally can yield less water from storage than the same volume of permeable sedimentary rocks. This is because the total volume of openings in the volcanic rocks is nearly always less than that in productive sedimentary rocks; moreover, many openings in the volcanic rock are likely to be poorly connected.

Both the sedimentary and the volcanic reservoir rocks are layered and, consequently, movement of water through the rocks along the beds (mainly horizontal) is less restricted than movement across the beds (mainly vertical). In the sedimentary reservoirs, vertical movement between the permeable beds (mostly sand and gravel) is commonly impeded by intervening layers of silt, clay, or naturally cemented materials. In the volcanic rocks, vertical movement is impeded by the dense and poorly permeable rock which generally constitutes the bulk of each flow layer. Even the dense parts of the flow layers, however, generally contain enough fracture and joint openings to allow some movement of water, although leakage from one permeable interflow zone to another may be greatly restricted. cross-bed leakage between permeable zones in both the sedimentary and volcanic rocks is "short-circuited" by many wells that are either unlined (uncased) in the interval between permeable zones, or that have casings open to more than one of the zones.

Some large bodies of the saturated permeable rocks are at such great depths, or in such high or rugged terranes, that imminent development is unlikely. However, at many places, as in the Cascade Range in 
Oregon and southern Washington, these remote aquifers are very valuable because of the large quantities of water they supply to streams. Also, some of these remote aquifers are likely to be future sources of water for increased forest irrigation.

The major ground-water reservoirs probably reçeive more than one-half the estimated 4,000 billion $\mathrm{ft}^{3}$ of annual recharge; they contain about two-thirds of the region's ground water in recoverable storage, or 16,000 billion $\mathrm{ft}^{3}$; and the ground-water withdrawal from them in 1970 (about 3,600 $\mathrm{Mgal} / \mathrm{d}$ ) accounted for more than four-fifths of the total for the region that year. Many smaller ground-water reservoirs in the region are capable of yielding water at rates suitable for industrial, irrigation, and public supplies. Some of these include scattered areas along the coastlines of the Pacific Ocean and along major streams. The smaller size of these ground-water reservoirs does not reflect their relative importance in the region; their aggregate volume is several hundred cubic miles, and at many places they are the only usable sources of fresh ground water.

Water quality is currently not a significant limiting factor to the use of water from the major ground-water reservoirs. Although at places some dissolved constituents are found in concentrations greater than desirable for some purposes, most of the ground water is considered good to excellent for common use. Saline ground water is known to underlie several hundred square miles of the major ground-water reservoirs, but it is generally at considerable depth in areas where other sources of fresh ground water are available. Contamination resulting from man's activities is a growing problem, but only in a few areas has it reached proportions that cause serious limitations to continued use of the ground water (Foxworthy 1979).

The data currently available on ground-water quality pertain mostly to inorganic chemical constitutents of the water that occur in varying amounts under natural conditions. Data on occurrences of organic compounds, which include pesticides and industrial products, are becoming available, but are commonly related only to known or suspected cases of ground-water contamination. 
The most widely bothersome natural constitutent in the ground water of the region is dissolved iron, sometimes in combination with manganese. It occurs in undesirable concentrations at places in all the major groundwater reservoirs.

Dissolved iron does not affect the usefulness of ground water for irrigation, but causes problems in some industrial uses of the water and in household use. A treatment to remove or reduce the effects of dissolved iron is a common adjunct to the development of ground-water supplies for public or individual domestic uses.

Ground waters containing enough dissolved minerals to be considered "saline" probably underlie much of the area of the major ground-water reservoirs but are troublesome in only a few places. Well waters with dissolved-solids concentrations of $1,000 \mathrm{mg} / 1$ or more have been found mostly in the Puget Sound, Willamette Valley, High Desert, and Southern Idaho ground-water reservoirs. Ground waters having dissolved-solids concentrations greater than $1,000 \mathrm{mg} / 1$ are mainly in older rocks that are not permeable enough to be important aquifers; almost all these areas also have freshwater aquifers capable of larger yields. The saline ground waters are tapped by wells generally deeper than $100 \mathrm{ft}$, but in a few coastal areas of the Puget Sound ground-water reservoir, salty water is pumped from shallow wells. Also, saline ground water from older rocks locally migrates into shallow aquifers, and even discharges at the land surface as mineral springs in the High Desert and Southern Idaho groundwater reservoirs. In the latter reservoir area most of the springs that yield water with dissolved-solids concentrations greater than $1,000 \mathrm{mg} / 1$ are thermal springs.

Throughout the region, well waters having dissolved solids concentrations of $3,000 \mathrm{mg} / 1$ or more are rare, and generally represent seawater intrusion (Puget Sound ground-water reservoir) or thermal ground water (High Desert and Southern Idaho ground-water reservoirs).

In addition to iron, a few other dissolved constituents occur naturally in waters of the major ground-water reservoirs in undesirably high 
concentrations. These occurrences are generally rather localized, in terms of aquifer zones as well as areal extent, and are mostly in the arid parts of the region. They tend to be near the margins of the major ground-water reservoirs, where the important aquifers are close to older rocks, which generally are the sources of the undesirable constituents. These occurrences include concentrations of sodium and boron that are excessive for irrigation waters, mostly at places in the area of the High Desert groundwater reservoir, and concentrations of fluoride that exceed national drinking water standards, mainly at places in the High Desert and the Columbia Plateau ground-water reservoirs and a few places in thermal waters in the Southern Idaho ground-water reservoir.

The only known naturally occurring dissolved constituent in the region posing a health threat to humans is arsenic in ground water that was used for domestic supplies in the southern part of the willamette valley groundwater reservoir. However, that threat was recognized and alternative supplies developed.

\subsubsection{Columbia Plateau Subregion}

The ground water within the $50,000-\mathrm{mi}^{2}$ area of the layered basalt of the Columbia River Group is a generally uniform bicarbonate water having calcium and sodium in nearly equal amounts as the principal cations. The water contains a relatively large amount of silica (Newcomb 1972).

The 525 chemical analyses indicate that the prevalent ground water is of two related kinds--a calcium and a sodium water. The sodium water is more common beneath the floors of the main synclinal valleys; the calcium water, elsewhere.

In addition to the prevalent type, four special types form a small part of the ground water. These are 1) calcium sodium chloride waters that rise from underlying sedimentary rocks west of the Cascade Range, 2) mineralized water at or near warm or hot springs, 3) water having unusual ion concentrations, especially of chloride, near sedimentary rocks intercalated at the edges of the basalt, and 4) more mineralized water near one locality of excess carbon dioxide. 
TABLE 6.1. Potential Parameters Investigated in Ground Water Analys is

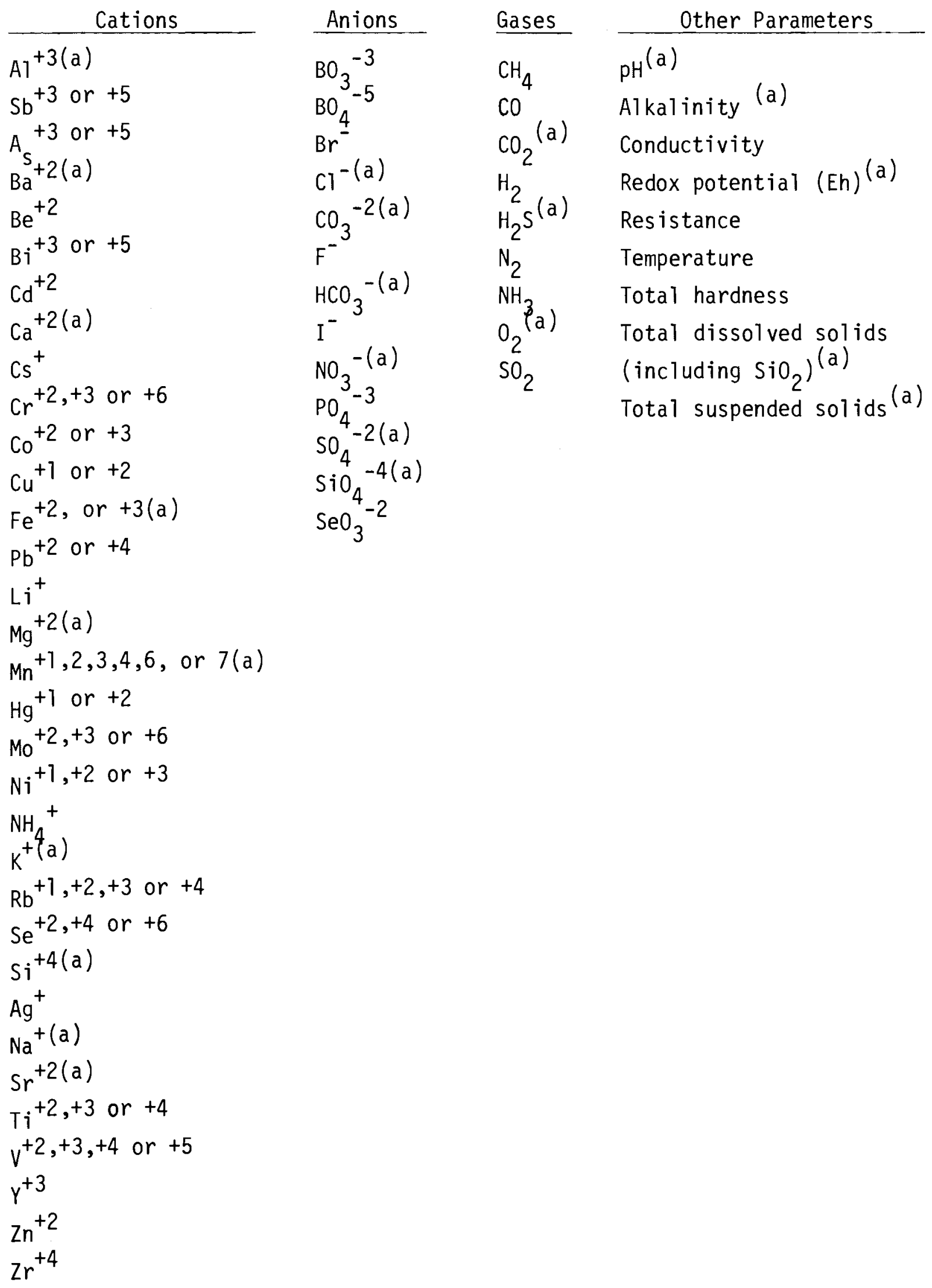

(a)Deemed most important geochemical reactants or influences 


\subsection{CHARACTERIZATION OF WATER QUALITY IN REGIONAL AQUIFERS}

Ground water and aquifer characterization is defined as the chemistry, physical characteristics, and biota of the ground water; the mineralogic, petrologic, structural and physical description of the aquifer over its vertical and horizontal extent; and the geologic environment including stratigraphic succession and geologic province.

Table 6.1 sets forth cations, anions, gases and other parameters that may be included in ground water analysis. Table 6.2 comprises potential rock-forming, accessory, and secondary minerals in aquifers and overlying/ underlying formations. For a given aquifer, the combined solid-fluid system behavior over the temperature-pressure-time constraints of ATES will determine efficiency of operation and feasibility.

Conventional quantitative chemical analyses of water samples from regional aquifers are presented in Appendix A. Most analyses were performed by state or federal agencies. Diverse geologic terranes, drainage conditions, ground-water depths, climates and topographies are included in the regions considered.

For use in aquifer thermal energy storage a ground water should not be subject to precipitation of solute ions over the temperature range of interest; should not react chemically with the piping, heat exchanger or well screen; should not transport and deposit finely divided solid material; and should not support the growth of bacteria. If these conditions are not satisfied, economically and environmentally tolerable water treatments may permit control of potential water quality-related problems. From the standpoint of inorganic chemistry, a low concentration of total dissolved solids is generally desired to minimize the potential quantity of precipitates and reactivity of the water. The precipitates known to cause problems include silica, calcium carbonate, calcium magnesium carbonate, calcium sulfate, and iron oxide. Both calcium sulfate and iron oxide may be hydrated. Less important potential precipitates include manganese oxides, hydrated alkali or alkaline earth borates, calcium fluoride, and ironbearing alkaline earth carbonates. 
The solids dissolved in the ground water have been picked up on the surface, within the overburden, and from minerals and glasses within the basalt. Evidence for the removal of ions from solution is confined to calcium and magnesium, only small amounts of which are present in some of the sodium-rich water.

Minor constituents, such as heavy metals, alkali metals, and alkaline earths, occur in the ground water in trace, or smal1, amounts. The natural radioactivity of the ground waters is very low. Except for a few of the saline calcium sodium chloride waters and a few occurrences of excessive nitrate, the ground water generally meets the common standards of water good for most ordinary uses. The water is clear and colorless and has a temperature slightly higher than would be indicated by the accepted "normal" earth gradient. A small amount of iron is present in some of the water and a slight amount of hydrogen sulfide gas is present in water from most wells.

Carbon-14 determinations indicate that the water has been underground for periods ranging from modern times to several tens of thousands of years. Generally, an increase in the age of the water corresponds to depth and location in the central parts of the main structural basins. The evidence of correlations between chemical characteristics and the age of the water is 1 imited to the excessive nitrate that occurs in young, shallow ground water and to the apparent base-exchange removal of calcium and magnesium that has occurred where the ground water is old. 
TABLE 6.2. Minerals in Aquifers and Associated Rocks

\section{Rock-Forming Minerals}

Quartz(a)

Potassium feldspar (a)

Sodium-calcium feldspar ${ }^{(a)}$

Biotite $^{(a)}$

Muscovite ${ }^{(a)}$

Hornblende

Pyroxene

01 ivine

Calcite ${ }^{(a)}$

Dolomite ${ }^{(a)}$
Accessory Minerals

Magnesite ${ }^{(a)}$

Ankerite (a)

Siderite (a)

Manganese oxides (a)

Magnetite

Hematite

Pyrite (a)

Galena (a)

Barite

Ilmenite

Marcasite ${ }^{(a)}$

Rutile

Spinel

Tourmal ine

Zircon

Sphalerite ${ }^{(a)}$
Secondary Minerals

Kaolinite ${ }^{(a)}$

Montmorillonite ${ }^{(a)}$

Illite ${ }^{(\mathrm{a})}$

Mixed-layer clays (a)

Anhydrite (a)

Gypsum (a)

Talc

Goethite $^{(a)}$

Aragonite

Chlorite (a)

Epidote

Fluorite

(a)Deemed most important geochemical reactants

Thus, for precipitation problems the solute molecule and ions of importance are $\mathrm{SiO}_{2}, \mathrm{Fe}^{\mathrm{x}}, \mathrm{Mn}^{\mathrm{y}}, \mathrm{Ca}{ }^{++}, \mathrm{Mg}^{++}, \mathrm{HCO}_{3}{ }^{-}, \mathrm{CO}_{3}{ }^{=}, \mathrm{SO}_{4}{ }^{=}$and $\mathrm{F}^{-}$, where $x=2$ or 3 , and $y=1,2,3,4,6$ or 7 . Acid-forming anions, i.e., $\mathrm{Cl}^{-}$, $\mathrm{SO}_{4}=\mathrm{HCO}_{3}{ }^{-}$and $\mathrm{CO}_{3}=$, may be involved in metal corrosion. The various cations may act as galvanic agents in electrochemical corrosion. Various chemical environments may stimulate bacterial growth. Clay mineral swelling and dispersion is exacerbated by association of clay laminae with sodium and lithium ions.

The chemical analyses indicate that most ground waters can be described with reference to relative concentrations of calcium, magnesium, sodium, bicarbonate, sulfate and chloride ions. The bicarbonate ion is the most 
ubiquitous, reflecting the widespread occurrence of carbonate minerals, their relatively high solubilities in water, and the prevalence of alkaline ground water. Bicarbonate and carbonate ions do not exist in strongly acid waters. The presence of silica is almost universal but its concentration is typically only 10 to $30 \mathrm{mg} / 1$ because of its limited solubility.

Sodium bicarbonate or sodium calcium bicarbonate waters are frequently found in quartz-rich aquifers such as silt, sand, gravel, siltstone, sandstone, or conglomerate. Calcium bicarbonate waters or sodium calcium bicarbonate waters are often associated with limestone and dolomite. Magnesium may be present as a major ground-water ion in dolomitic terranes. Sodium chloride waters are encountered in coastal regions, especially below sea level, due to sea water commingling with less saline ground water. Sodium chloride waters are also found in inland aquifers as connate marine water or as water in present or past contact with rock salt evaporite deposits or salt domes. Sulfate waters may be derived from solution of gypsum or anhydrite evaporite deposits or from oxidation of sulfide minerals, especially pyrite.

Iron may be derived from numerous primary and secondary minerals including amphiboles, pyroxenes, micas, olivines, sulfides, and oxides. Magnetite, hematite and goethite are extremely common in detrital and sedimentary deposits. Glauconite, commonly found as green pellets in sedimentary rocks, is similar in composition to the iron-bearing mica, biotite.

Potassium is usually associated with sodium but it occurs at much lower concentrations. Potassium may be derived from weathering of orthoclase or microcline feldspar, or from dissolution of a highly soluble evaporate salt such as sylvite or carnallite. In either case the "parent" mineral is likely to be associated with a similar sodium-bearing mineral, i.e., plagioclase or halite.

Manganese, fluorine, boron, and strontium are usually either absent or present in very small amounts. Manganese may originate from silicates, oxides, or carbonates. Fluorine and boron may be derived from hydrothermal 
or volcanic sources. Boron is also found in evaporate deposits as hydrated sodium and calcium borates and borosilicates. When present, strontium is invariably associated with calcium.

Nitrate ions are derived mostly from man's surface biosphere. Nitrogen is derived from sewage, fertilizer, animal excrement, and miscellaneous chemical operations. Nitrate ions are not likely to adversely affect aquifer thermal energy storage because nitrate salts are extremely soluble and concentrations are low, usually decreasing with depth.

The quantitative solute content of water, referred to as total dissolved solids, depends upon the mineralogy of the aquifer, time "in residence", and the frequency and amount of commingling with waters of different chemistry. Temperature and pressure are also important. Very low salinity (less than $500 \mathrm{mg} / \mathrm{l}$ ) is often found in ground waters subjected to continuous or frequent dilution by surface streams, subsurface streams, or heavy vadose water influx, e.g., due to rainfall or snow melting. Siliceous metamorphic rocks, both intrusive and extrusive igneous rocks, and quartz-rich sedimentary rocks tend to be relatively unreactive with water. Slight salinities in the range from 500 to $3,000 \mathrm{mg} / 1$ are associated with less frequent freshwater recharge. Aquifers of 1 imestone, dolomite, argillaceous sediments and glacial drift are often moderately reactive with ground water; therefore, waters contained within these rock types are commonly slightly saline. Salinities above $3,000 \mathrm{mg} / 1$ are usually associated with sodium, calcium, chloride, and sulfate ions. Sodium and chloride ions predominate where present or past seawater solutes control the water chemistry. 


\subsection{NUMERICAL MODELING}

Numerical modeling of geochemical stability was applied to 67 selected U.S. ground waters. The details of this activity are presented in Appendix B. A concise summary of results at this point enables the reader to integrate these late findings with geochemical conclusions from the literature.

Most water samples were near saturation with respect to calcite and, therefore, would not make good candidate working fluids for a "heated-water" thermal energy storage facility unless preventive measures were taken. Solutions sampled from the Pacific Northwest, Souris-Red-Rainy, and Upper Colorado regions were nearly saturated and would not be good candidates based on the "calcite criterion". In contrast, samples from the Lower Mississippi and Mid-Atlantic regions had low values for the calcite saturation index and should not precipitate calcite on heating.

Most waters are well below saturation with respect to gypsum. The likelihood of gypsum precipitation appears small except for waters with high calcium activity.

Most aquifer waters studied were in equilibrium with either quartz or a more soluble polymorph of silica. If amorphous silica controls the equilibrium, silica concentration will rise substantially during temperature increase; on cooling during heat removal, silica will precipitate in an amount equal to that dissolved during temperature rise. All Pacific Northwest region samples showed near-equilibrium conditions with a soluble silica phase.

If iron is present at $10 \mathrm{ppm}$ or higher, it will oxidize, precipitating as ferric hydroxide. Although many analyses show iron concentrations between 1 and $10 \mathrm{ppm}$, portions of these iron concentrations probably occur colloidally and are not subject to precipitation. 
Changes in the chemistry of the ground water induced by heating may result in clay mineral dispersion, e.g., shift from a calcium to a sodium dominated solution.

None of the modeling results conflicts with existing field and laboratory evidence. Every aquifer water must be considered individually for any contemplated ATES application. 


\subsection{FORECASTS OF REGIONAL APPLICABILITY}

Aquifer thermal energy storage requires five conditions: 1) an avai1able source of thermal energy or chill,2) a technically feasible aquifer reservoir, 3) a market for the recovered energy or chi11, 4) compatibility between energy storage and utilization, and 5) economic competitiveness with a)ternative energy supplies. Because these conditions are very locationspecific, they determine regional forecasts of ATES development.

The available source of thermal energy would be surplus heat from combustion, nuclear fission, or solar radiation; or heat cogenerated from combustion. The available source of chill would be atmospheric cold. Therefore, aquifer thermal energy storage of hot water would require ATES system proximity to an electrical generating or industrial plant. Aquifer thermal energy storage of chilled water would require location within a region subject to annual prolonged subfreezing periods. However, the cold storage facility need not be close to an electrical generating plant.

Technically feasible aquifers are characterized by seven design requirements: 1) large volumes, on the order of $10^{7} \mathrm{~m}^{3}$; 2) low thermal conductivities of overlying and underlying strata; 3) sufficiently high transmissivity to accept high input and supply high output rates; 4) fluid migration rates due to convection and advection sufficiently low to maximize thermal containment and recovery efficiency; 5) discovery water pressure sufficient to store thermally conditioned water; 6) geographic proximity to energy supply and consumption points; and 7) environmental acceptability.

A market for the recovered energy or chill consists of residential, commercial, institutional, or industrial utilization. District heating or cooling is the most probable market. Process hot water for industry, e.g., food processing, is also in prospect.

Compatibility between energy storage and utilization simply means that supply and demand are out-of-phase, i.e., cyclical, diurnal, or seasonal. 
Economic competitiveness with alternative energy supplies may be the most difficult criterion based upon recent experiences with gyrating crude petroleum prices and regional forecasts of electrical power demand, especially in the northwestern U.S.

On the basis of known aquifer geology and hydrology, current population distributions and generally escalating energy costs, the following water resources regions are candidates for selected exploration and development of aquifer thermal energy storage:

- Arkansas-White-Red

- California

- Great Lakes

- Lower Mississippi

- Mid-Atlantic

- Missouri Basin

- Ohio

- Souris-Red-Rainy

- South-Atiantic Gulf

- Tennessee

- Texas-Gulf

- Upper Mississippi.

Eight other regions are believed to be less appropriate because of inadequate or unproven geology, restricted use of water resources, or 1 imited demand for energy:

- Alaska

- Great Basin

- Hawai

- Lower Colorado 
- New England

- Pacific Northwest

- Rio Grande

- Upper Colorado.

However, specific sites worthy of preliminary examination are identifiable in both groups. 



\section{REFERENCES}

Anderson, G. S. 1970. "Hydrologic Reconnaissance of the Tanana Basin, Central Alaska." U.S. Geological Survey Hydrol. Inv. Atlas HA-319.

Baker, E. T., Jr., and J. R. Wal1. 1976. "Summary Appraisals of the Nation's Ground-Water Resources - Texas-Gulf Region." U.S. Geological Survey Professional Paper 813-F, U.S. Government Printing Office, Washington, D.C.

Bedinger, M. S., and R. T. Sniegocki. 1976. "Summary Appraisals of the Nation's Ground-Water Resources - Arkansas-White-Red Region." U.S. Geological Survey Professional Paper 813-H, U.S. Government Printing Office, Washington, D.C.

Betz Laboratories, Inc. 1976. "Solubility of Calcium Carbonate Compared to Calcium Sulfate." In Handbook of Industrial Water Conditioning, 7th edition.

Birks, L. S., and J.H. Schulman. 1950. "The Effect of Various Impurities on the Crystallization of Amorphous Silica Acid." Amer. Mineralogist. $35: 1035-1038$.

Bishop, H. K., and J. R. Bricarello. 1976. "Scaling and Corrosion in an Experimental Geothermal Power Plant." Paper No. SPE 6612, pp. 237-239, Socjety of Petroleum Engineers of AIME, Dallas, Texas.

Bloyd, R. M., Jr. 1974. "Summary Appraisals of the Nation's Ground-Water Resources - Ohio Region." U.S. Geological Survey Professional Paper 813-A, U.S. Government Printing Office, Washington, D.C.

Bloyd, R. M., Jr. 1975. "Summary Appraisals of the Nation's Ground-Water Resources - Mississippi Region." U.S. Geological Survey Professional Paper 813-B, U.S. Government Printing Office, Washington, D.C.

Bricker, 0. P. 1968. "Cations and Silica in Natural Waters Controlled by Silicate Minerals." In Symposium on Geochemical Precipitation, Vapors, Soil Moisture, publication no. 78, pp. 110-119, International Association Science Hydrology.

Cederstrom, D. J., E. H. Boswell and G. R. Tarver. 1979. "Summary Appraisals of the Nation's Ground-Water Resources - South Atlantic-Gulf Region." U.S. Geological Survey Professional Paper 813-0, U.S. Government Printing Office, Washington, D.C.

Cuellar, G. 1975. "Behavior of Silica in Geothermal Waste Waters." In Proceedings Second United Nations Symposium on Development and Use of Geothermal Resources, pp. 1343-1347. United Nations, New York, New York. 
Davidson, E. S. 1979. "Summary Appraisals of the Nation's Ground-Water Resources - Lower Colorado Region." U.S. Geological Survey Professional Paper 813-R, U.S. Government Printing Office, Washington, D.C.

Drillers Journal, The Johnson. 1965. "Maintaining the Yield of Water We11s." January-February, pp. 1-4.

Eakin, T. E., D. Price and J. R. Harri11. 1976. "Summary Appraisals of the Nation's Ground-Water Resources - Great Basin Region." U.S. Geological Survey Professional Paper 813-G, U.S. Government Printing Office, Washington, D.C. .

Foxworthy, B. L. 1979. "Summary Appraisals of the Nation's Ground-Water Resources - Pacific Northwest Region." U.S. Geological Survey Professional Paper 813-S, U.S. Government Printing Office, Washington, D.C.

Fulford, R. S. 1968. "Effects of Brine Concentration and Pressure Drop on Gypsum Scaling in 0il Wells." J. Pet. Tech. June, pp. 559-564.

Gass, T. E. 1977. "Ground Water - Don't Let the Bugs Get the Best of You." Water Well J. January, pp. 26-27.

Harrar, J. E., C. H. Otto, Jr., S. B. Deutscher, R. W. Ryon and G. E. Tardiff. 1979. Studies of Brine Chemistry, Precipitation of Solids, and Scale Formation at the Salton Sea Geothermal Field. UCRL-52640, Lawrence Livermore Laboratory, Livermore, California.

Hermannsson, S. 1970. "Corrosion of Metals and the Forming of a Protective Coating on the Inside of Pipes Carrying Thermal Waters Used by the Reykjavik Municipal District Heating Service." Geothermics, Special Issue 2, U.N. Symposium on the Development and Utilization of Geothermal Resources, Pisa, Vo1. 2, Part 2, pp. 1602-1612.

Hewitt, C. H. 1963. "Analytical Techniques for Recognizing WaterSensitive Reservoir Rocks." J. Pet. Tech. August, pp. 813-818.

Hitchen, C. S. 1945. "The Solubility of Silica." Econ. Geol. 40:361-365.

Howard, J., et al. 1978. Geothermal Resource and Reservoir Investigations of U.S. Bureau of Reclamation Leaseholds at East Mesa, Imperial Valley, California. LBL-7094, Lawrence Berkeley Laboratory, Berkeley, California.

Jones, F. 0., Jr. 1964. "Influence of Chemical Composition of Water on Clay Blocking of Permeability." J. Pet. Tech. Apri1, pp. 441-446. 
Jorda, R. M. 1980. A Performance Evaluation of Magma Power Company's Reinjection Well \#46-7 at the East Mesa KGRA, California. SAND 79-7127, Sandia National Laboratory, (Albuquerque, New Mexico and Livermore, California).

Kennedy, G. C. 1950. "A Portion of the System Silica-Water." Econ. Geol. $45: 629-653$.

Krauskopf, K. B. 1956. "Dissolution and Precipitation of Silica at Low Temperatures." Geochim. et Cosmoschim. Acta. 10:27-29.

Krauskopf, K. B. 1979. Introduction to Geochemistry. 2nd ed. McGraw-Hill, New York, New York.

Kreitlow, D. B. 1977. Geothermal Well Downhole Heat Exchanger Design Analysis. M.S. Thesis, Oregon State University, Corvallis, Oregon.

Lane, R., and A. Kumar. 1980. Selection of Cool ing Water Treatment at Military Installations to Prevent Scaling and Corrosion. Technical Report M-280, Construction Engineering Research Laboratory, U.S. Army Corps of Engineers, distributed by Defense Technical Information Center, Alexandria, Virginia.

Langelier, W. F. 1936. "The Analytical Control of Anti-Corrosion Water Treatment." J. Amer. Water Well Assoc. 28(1500).

Lindemuth, T. E., E. H. Houle, S. H. Suemoto and V. C. Van Der Mast. 1976. "Experience in Scale Control with East Mesa Geothermal Brine." Paper no. SPE 6605, pp. 173-179, Soc. of Petroleum Engineers of AIME, Dallas, Texas.

McCune, C. C. 1977. "On-Site Testing to Define Injection-Water Quality Requirements." J. Pet. Tech. January, pp. 17-24.

Moore, J. E. 1960. "Clay Mineralogy Problems in 0il Recovery." The Petroleum Engineer. February, pp. B-40 - B-47.

Morey, G. W., and J. M. Hesselgesser. 1951. "The Solubility of Quartz and Other Substances in Superheated Steam at High Pressures." Trans. ASME. $73: 865-875$

Morey, G. W., R. 0. Fournier and J. J. Rowe. 1962. "The Solubility of Quartz in Water in the Temperature Interval from $25^{\circ}$ to $300^{\circ} \mathrm{C} . "$ Geochimica et Cosmochimica Acta. 26:1029-1043.

Mungan, N. 1965. "Permeability Reduction through Changes in $\mathrm{pH}$ and Salinity." J.Pet. Tech. December, pp. 1449-1453. 
NACE. 1954. "Sulfide Corrosion Cracking of $0 i 1$ Production Equipment." NACE Publication 1G154, pp. 413-419 National Association of Corrosion Engineers, Houston, Texas.

NACE. 1958. "Corrosion of 0il- and Gas-Well Equipment." National Association of Corrosion Engineers and American Petroleum Institute, Dallas, Texas.

NACE. 1976. "The Role of Bacteria in the Corrosion of 0il Field Equipment." Technical Practices Committee Publication No. 3, pp. 1-23 National Association of Corrosion Engineers, Houston, Texas.

Newcomb, R. C. 1972. "Quality of the Ground Water in Basalt of the Columbia River Group, Washington, Oregon and Idaho." U.S. Geological Survey, Water Supply Paper 1999-N.

Ozawa, T., and Y. Fujii. 1970. "A Phenomenon of Scaling in Production Wel ls and the Geothermal Power Plant in the Matsukawa Area." Geothermics, Special Issue 2, United Nations Symposium on the Development and Utilization of Geothermal Resources, Pisa, Vol. 2, Pt. 2, pp. 1613-1618.

Price, D., and T. Arnow. 1974. "Summary Appraisals of the Nation's GroundWater Resources - Upper Colorado Region." U.S. Geological Survey Professional Paper 813-C, U.S. Grovernment Printing Office, Washington, D.C.

Reed, M. G. 1977. "Formation Permeability Damage by Mica Alteration and Carbonate Dissolution." J.Pet. Tech. September, pp. 1056-1060.

Reeder, H. 0. 1978. "Summary Appraisals of the Nation's Ground-Water Resources - Souris-Red-Rainy Region." U.S. Geological Survey Professional Paper 813-K, U.S. Government Printing Office, Washington, D.C.

Roy, C. J. 1945. "Silica in Natural Waters." Amer. J. Sci. $263: 393-403$.

Ryznar, J. W. 1944. "A New Index for Determining Amount of Calcium Carbonate Scale Formed by a Water." J. Amer. Water Well Assoc. $36(472)$.

Sinnott, A., and E. M. Cushing. 1978. "Summary Appraisals of the Nation's Ground-Water Resources - Mid-Atlantic Region." U.S. Geological Survey Professional Paper 813-I, U.S. Government Printing Office, Washington, D.C.

Soderberg, W. E., and J. C. O'Gara. 1982. "St. Paul Field Test Facility." In Underground Energy Storage Program 1981 Annual Report, Vol. II, pp. 31-48. PNL-4281, Pacific Northwest Laboratory, Richland, Washington. 
Stottlemyre, J. A., R. L. Erikson and R. P. Smith. 1979. Potential Petro physical and Chemical Property Alterations in a Compressed Air Energy Storage Porous Rock Reservoir. PNL-2974, Pacific Northwest Laboratory, Richland, Washington.

Subcasky, W. J. 1978. "Petroleum Industry Experience in Water Injection." In Thermal Energy Storage in Aquifers Workshop Proceedings. CONF-7805140, National Technical Information Service, Springfield, Virginia.

Takasaki, K. J. 1978. "Summary Appraisals of the Nation's Ground-Water Resources - Hawaii Region." U.S. Geological Survey Professional Paper 813-M, U.S. Government Printing Office, Washington, D.C.

Taylor, J. 0. 1978. "Summary Appraisals of the Nation's Ground-Water Resources - Missouri Basin Region." U.S. Geological Survey Professional Paper 813-Q, U.S. Government Printing Office, Washington, D.C.

Terry, J. E., R. L. Hosman and C. T. Bryant. 1979. "Summary Appraisals of the Nation's Ground-Water Resources - Lower Mississippi Region." U.S. Geological Survey Professional Paper 813-N, U.S. Government Printing Office, Washington, D.C.

Thomas, H. E., and D. A. Phoenix. 1976. "Summary Appraisals of the Nation's Ground-Water Resources - California Region." U.S. Geological Survey Professional Paper 813-E, U.S. Government Printing Office, Washington, D.C.

Treseder, R. W., and R. Wieland. 1976. "Down-Hole Corrosion in a Salton Sea Geotherma1 We11." Paper No. SPE 6613, pp. 241-245, Society of Petroleum Engineers of AIME, Dallas, Texas.

UOP, Inc. 1975. Ground Water and Wells. Johnson Division, UOP Inc., St. Paul, Minnesota.

Vetter, 0. 1979. "Injection, Injectivity and Injectability in Geothermal Operations." Geothermal Resources Council Transactions, Vol. 3, September, pp. 749-752, Geothermal Resources Counci1, Davis, California.

Vetter, 0. J., and D. A. Campbe11. 1979a. Scale Inhibition in Geothermal Operations - Experiments with Dequest 2060 Phosphonate in Republic's East Mesa Field. LBL-9089 GREMP-5, Lawrence Berkeley Laboratory, Berkeley, California.

Vetter, 0. J., and D. A. Campbe11. 1979b. "Carbonate Scale Inhibition in Republic's East Mesa Geothermal 0perations. "Geothermal Resources Council Transactions, vol. 3, September, pp. 757-760, Geotherma1 Resources Council, Davis, California. 
Vetter, 0. J., and R. C. Phillips. 1970. "Prediction of Deposition of Calcium Sulfate Scale Under Down-Hole Conditions." J. Pet. Tech. October, pp. 1299-1308.

Wahl, E., and I. Yen. 1975. "Scale Deposition and Control Research for Geothermal Utilization." In Proceedings Second United Nations Symposium on the Development and Use of Geothermal Resources, pp. 1855-1864. United Nations, New York, New York.

Weist, W. G., Jr. 1978. "Summary Appraisals of the Nation's Ground-Water Resources - Great Lakes Region." U.S. Geological Survey Professional Paper 813-J, U.S. Government Printing Office, Washington, D.C.

Weitz, E., H. Frank and M. Schuchard. 1950. "Silicic Acid and Silicates." Chem. Zeitung. 74:256-257.

West, S. W., and W. L. Broadhurst. 1975. "Summary Appraisals of the Nation's Ground-Water Resources - Rio Grande Region." U.S. Geological Survey Professional Paper 813-D, U.S. Government Printing Office, Washington, D.C.

Zenone, C., and G. S. Anderson. 1978. "Summary Appraisals of the Nation's Ground-Water Resources - Alaska Region." U.S. Geological Survey Professional Paper 813-P, U.S. Government Printing Office, Washington, D.C.

Zurawski, A. 1978. "Summary Appraisals of the Nation's Ground-Water Resources - Tennessee Region." U.S. Geological Survey Professional Paper 813-L, U.S. Government Printing Office, Washington, D.C. 
APPENDIX A

SELECTED WATER ANALYSES FOR HYDROLOGIC REGIONS 

APPENDIX A

SELECTED WATER ANALYSES FOR HYDROLOGIC REGIONS

Standard water analyses are presented for the following hydrologic regions in the 48 conterminous states:

$\begin{array}{ll}\text { Arkansas - White - Red } & \text { Pacific Northwest } \\ \text { California } & \text { Rio Grande } \\ \text { Great Lakes } & \text { Souris - Red - Rainy } \\ \text { Lower Mississippi } & \text { South Atlantic Gulf } \\ \text { Mid-Atlantic } & \text { Tennessee } \\ \text { Missouri Basin } & \text { Texas Gulf } \\ \text { New England } & \text { Upper Colorado } \\ \text { Ohio } & \text { Upper Mississippi }\end{array}$

Data were obtained by computer search of the National Ground Water Information Center Data Base, Water Resources Abstracts and Georef. Data were not readily retrievable for the following regions: California, Lower Colorado and New England. Great Basin analyses were frequently not attributable to discrete aquifers. Data are also sparse for Alaska and Hawaii. Nevertheless, a wide range in rock types and climatological regions is represented by the analyses reported. Furthermore, the most promising regions for implementing aquifer thermal energy storage are included.

Principal conclusions regarding chemistry and predicted chemical behavior are reported in Sections 4.0 and 5.0. Section 4.0 considers the analyses at large and presents general conclusions regarding influence of rock type, ground-water recharge, connate water, seawater intrusion and other environmental factors. Generic chemical ground-water types are identified. Section 4.0 presents numerical modeling results based upon selected complete chemical analyses. (The reader will note that many analyses omit particular elements, pH or temperature.) Averaged analyses, which are common for many 
Texas counties, were not used in modeling because possible internal inconsistencies could produce unrealistic results.

Most analyses for a particular aquifer and county are presented as a trio based upon high, intermediate and low levels of total dissolved solids. Averaged analyses are presented in four columns--maximum, mean, median, and minimum.

No attempt is made to pinpoint well locations. This study is regionally oriented and does not aim to identify local geohydrology suited to aquifer thermal energy storage.

The analyses are ordered as follows:

1. alphabetically by hydrologic region

2. within each region alphabetically by state

3. within each state in order of increasing geologic type

4. within each geologic period or epoch, alphabetically by formation name, and, if necessary, alphabetically by county.

References cited in the water analysis tables appear at the end of this appendix. 
Hydrologic Region: Arkansas - White - Red Aquifer Name: Alluvium

Aquifer Age: Holocene

Petrology: silt, sand, gravel
State: Oklahoma

Location: Leflore Co.

No. Analyses: 3

Water Type: $\mathrm{Ca}, \mathrm{HCO}_{3}$

Solute Concentration

\begin{tabular}{|c|c|c|}
\hline High & Intermediate & Low \\
\hline- & - & 10 \\
\hline-- & - & -- \\
\hline-- & -- & -- \\
\hline-- & -- & -- \\
\hline 334 & 160 & -- \\
\hline 75 & 28 & -- \\
\hline 121 & 28 & 14 \\
\hline-- & -- & - \\
\hline 868 & 520 & 212 \\
\hline-- & - & -- \\
\hline 244 & 43 & - \\
\hline 310 & 30 & 9.6 \\
\hline-- & - & - \\
\hline- & 70 & -- \\
\hline 1940 & 620 & 217 \\
\hline 1140 & 515 & 172 \\
\hline 428 & 89 & 0 \\
\hline 2860 & 978 & 346 \\
\hline 8.10 & 8.10 & 8.10 \\
\hline-- & -- & -- \\
\hline
\end{tabular}

Well Depth (m)

Constituents (mg/ $\mathrm{l}$ ) and Properties

$\mathrm{SiO}_{2}$

$\mathrm{Fe}$

$\mathrm{Mn}$

$\mathrm{Ca}$

$\mathrm{Mg}$

$\mathrm{Na}$

K

$\mathrm{HCO}_{3}$

$\mathrm{CO}_{3}$

$\mathrm{SO}_{4}$

C1

F

$\mathrm{NO}_{3}$

TDS$$
\text { (n) }
$$ 


\section{TABLE 2. Water Analysis}

Hydrologic Region: Arkansas - White - Red Aquifer Name: Terrace deposits

Aquifer Age: Pleistocene

Petrology: clay, silt, sand, gravel
State: 0klahoma

Location: Kay, McCurtain Co's. No. Analyses: 3

Nater Type: $\mathrm{Ca}, \mathrm{Na}, \mathrm{HCO}_{3}$

Solute Concentration

$\frac{\text { High }}{12} \frac{\text { Intermediate }}{6} \quad \frac{\text { Low }}{10}$

We11 Depth (m)

Constituents $(\mathrm{mg} / \mathrm{l})$

and Properties

$\mathrm{SiO}_{2}$

$\mathrm{Fe}$

$\mathrm{Mn}$

$\mathrm{Ca}$

$\mathrm{Mg}$

$\mathrm{Na}$

$\mathrm{K}$

$\mathrm{HCO}_{3}$

$\mathrm{CO}_{3}$

$\mathrm{SO}_{4}$

$\mathrm{Cl}$

$\mathrm{F}$

$\mathrm{NO}_{3}$

TDS

Hardness as $\mathrm{CaCO}_{3}$

$$
\mathrm{Ca}, \mathrm{Mg}
$$

Noncarbonate

Sp. Cond.

(micromhos $25^{\circ} \mathrm{C}$ )

$\mathrm{pH}$

Temperature $\left({ }^{\circ} \mathrm{C}\right)$

Reference: Havens 1978
790

550

10

$\begin{array}{rcc}-- & -- & -- \\ -- & -- & -- \\ -- & -- & -- \\ 230 & 62 & -- \\ 52 & 32 & -- \\ 140 & 51 & 40 \\ -- & -- & 1.8 \\ 294 & 288 & 132 \\ -- & -- & -- \\ 410 & 32 & 11 \\ 260 & 38 & -- \\ -- & -- & 37 \\ 34 & 90 & 0 \\ 1510 & 481 & 175 \\ & & \\ 790 & 285 & 104 \\ 550 & 49 & 0 \\ 1950 & 736 & 324 \\ 7.40 & & 8.0 \\ 15.0 & 7.90 & 12.0\end{array}$


TABLE 3. Water Analysis

Hydrologic Region: Arkansas - White - Red Aquifer Name: Cane River formation Aquifer Age: Early Middle Eocene Petrology: silt, silty clay, lignite, glauconite
State: Arkansas

Location: Lafayette Co.

No. Analyses: 3

Water Type: $\mathrm{Na}, \mathrm{HCO}_{3}$

Solute Concentration

\begin{tabular}{|c|c|c|}
\hline $\mathrm{High}$ & Intermediate & Low \\
\hline-- & -- & -- \\
\hline 9.2 & 13 & 13 \\
\hline 0 & 0 & 0.39 \\
\hline-- & -- & -- \\
\hline 7.1 & 5.9 & 15 \\
\hline 1.1 & 1.5 & 2.0 \\
\hline 269 & 135 & 28 \\
\hline 2.7 & 3.1 & 3.8 \\
\hline 492 & 275 & 104 \\
\hline 4 & 0 & 0 \\
\hline 0.6 & 0.2 & 7.4 \\
\hline 142 & 63 & - \\
\hline 0 & 0 & 0.3 \\
\hline 0.20 & 1.0 & 0 \\
\hline 679 & 358 & 132 \\
\hline 22 & 20 & 45 \\
\hline 0 & 0 & 0 \\
\hline 1150 & 682 & 218 \\
\hline 8.3 & 7.8 & 7.5 \\
\hline 20.0 & - & -- \\
\hline
\end{tabular}

Well Depth (m)

Constituents $(\mathrm{mg} / \mathrm{l}$ )

and Properties

$\mathrm{SiO}_{2}$

$\mathrm{Fe}$

$\mathrm{Mn}$

$\mathrm{Ca}$

$\mathrm{Mg}$

$\mathrm{Na}$

K

$\mathrm{HCO}_{3}$

$\mathrm{CO}_{3}$

$\mathrm{SO}_{4}$

C1

$\mathrm{F}$

$\mathrm{NO}_{3}$

TDS

e

(a)

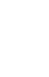

(n)

(1)

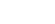

(1)

1

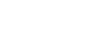

$\mathrm{O}_{3}$

TDS

Hardness as $\mathrm{CaCO}_{3}$

$\mathrm{Ca}, \mathrm{Mg}$

Noncarbonate

Sp. Cond.

(micromhos $25^{\circ} \mathrm{C}$ )

pH

Temperature $\left({ }^{\circ} \mathrm{C}\right)$

Reference: Terry et al. 1979 
TABLE 4. Water Analys is

Hydrologic Region: Arkansas - White - Red

Aquifer Age: Early Middle Eocene

Petrology: very fine to medium sand
Aquifer Name: Carrizo sand

State: Arkansas

Location: Miller Co.

No. Analyses: 3

Hater Type: $\mathrm{Na}, \mathrm{HCO}_{3}$

Solute Concentration

\begin{tabular}{ccc}
\hline High & Intermediate & Low \\
\cline { 3 - 3 }-- & -- & -- \\
& & \\
14 & 8.5 & 10 \\
-- & -- & -- \\
-- & -- & -- \\
2.6 & 1.1 & 0.9 \\
0.8 & 0.3 & 0.4 \\
153 & 65 & 66 \\
2.3 & 1.1 & 1.4 \\
344 & 176 & 169 \\
7 & 0 & 2 \\
0 & 3.4 & 3.0 \\
34 & 4.0 & 2.0 \\
-- & -- & -- \\
0.10 & 0.20 & 0.20 \\
383 & 171 & 169
\end{tabular}

Hardness as $\mathrm{CaCO}_{3}$

$\mathrm{Ca}, \mathrm{Mg}$

10

Noncarbonate

Sp. Cond.

(micromhos $25^{\circ} \mathrm{C}$ )

pH

0

692

8.4

7.6

8.3

Temperature $\left({ }^{\circ} \mathrm{C}\right)$

Reference: Terry et al. 1979 
TABLE 5. Water Analysis

Hydrologic Region: Arkansas - White - Red

Aquifer Name: Antlers sand

Aquifer Age: Cretaceous

Petrology: sand, shale, limestone
State: Oklahoma

Location: Atoka Co.

No. Analyses: 3

Water Type: $\mathrm{Ca}, \mathrm{HCO}_{3}, \mathrm{SO}_{4}$

Solute Concentration

\begin{tabular}{llc}
\hline Maximum & $\frac{\text { Intermediate }}{27}$ & $\frac{\text { Minimum }}{6}$
\end{tabular}

Hel1 Depth (m)

Constituents $(\mathrm{mg} / \mathrm{l})$ and Properties

$\mathrm{SiO}_{2}$

$\mathrm{Fe}$

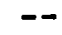

8.0

$\mathrm{Mn}$

$\mathrm{Ca}$

$\mathrm{Mg}$

424

45

342

30

0

365

30

$\mathrm{CO}_{3}$

$\mathrm{SO}_{4}$

3620

575

17

345

30

43

F

0.8

10.0

5970

1240

827

94

$\mathrm{Ca}, \mathrm{Mg}$

528

70

5530

1510

264

(micromhos $25^{\circ} \mathrm{C}$ )

pH

3.2

$--$

6.9

Temperature $\left({ }^{\circ} \mathrm{C}\right)$

--

--

19.0 
Hydrologic Region: Arkansas - White - Red Aquifer Name: Woodbine formation Aquifer Age: Cretaceous

Petrology: sand, sandstone, shale
State: 0k lahoma

Location: Bryan Co.

No. Analyses: 3

Nater Type: $\mathrm{Na}, \mathrm{HCO}_{3}$

Solute Concentration

Maximum $\quad$ Intermediate

We11 Depth (m) 213

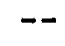

27

Constituents $(\mathrm{mg} / \mathrm{l})$

and Properties

$\mathrm{SiO}_{2}$
$\mathrm{Fe}$
$\mathrm{Mn}$
$\mathrm{Ca}$
$\mathrm{Mg}$
$\mathrm{Na}$
$\mathrm{K}$
$\mathrm{HCO}_{3}$
$\mathrm{CO}_{3}$
$\mathrm{SO}_{4}$
$\mathrm{Cl}$
$\mathrm{F}$
$\mathrm{NO}_{3}$
$\mathrm{TDS}^{2}$

TDS

Hardness as $\mathrm{CaCO}_{3}$

$\mathrm{Ca}, \mathrm{Mg}$

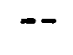

$--$

$--$

3.3

2.9

23

1.7

0.8

11

343

158

18

560

306

120

--

39

88

1.0

3.0

839

Noncarbonate

15

10

103

0

1370

44

13.0

$--$

1.5

410

155

3.3

27

0.4

0

Sp. Cond.

(micromhos $25^{\circ} \mathrm{C}$ )

$\mathrm{pH}$

Temperature $\left({ }^{\circ} \mathrm{C}\right)$

Reference: Havens 1978 
TABLE 7. Water Analysis

Hydrologic Region: Arkansas - White - Red

Aquifer Name: Garber sandstone and Wellington formation

Aquifer Age: Permian

Petrology: sandstone, silty shale
State: 0k lahoma

Location: Cleveland Co.

No. Analyses: $6 \mathrm{C}$

Water Type: $\mathrm{Na}, \mathrm{HCO}_{3}, \mathrm{SO}_{4}$

Solute Concentration

We11 Depth (m)

Constituents $(\mathrm{mg} / \mathrm{l})$

and Properties

$\mathrm{SiO}_{2}$

$\mathrm{Fe}$

$\mathrm{Mn}$

$\mathrm{Ca}$

$\mathrm{Mg}$

$\mathrm{Na}$

$\mathrm{K}$

$\mathrm{HCO}_{3}$

$\mathrm{CO}_{3}$

$\mathrm{SO}_{4}$

$\mathrm{Cl}$

$\mathrm{F}$

$\mathrm{NO}_{3}$

TDS
53

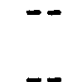

126

58

244

9.1

486

51

1600

400

53

679

Hardness as $\mathrm{CaCO}_{3}$

$\mathrm{Ca}, \mathrm{Mg}$

660

Noncarbonate

Sp. Cond.

(micromhos $25^{\circ} \mathrm{C}$ )

$\mathrm{pH}$

138

3640

8.9

Temperature $\left({ }^{\circ} \mathrm{C}\right)$
Mean

141

18

15.8

9

--

$--$

36.2

20.2

70.2

2.09

315

18.7

189

33.1

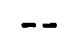

7.0

0

335

109

108

5

12.6

0

978

190

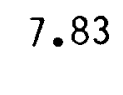

Reference: Wood and Burton 1968 
TABLE 8. Water Analysis

Hydrologic Region: Arkansas - White - Red

Aquifer Name: Garber sandstone and Wellington formation

Aquifer Age: Permian

Petrology: sandstone, silty shale
State: Oklahoma

Location: OKlahoma Co.

No. Analyses: 74

Water Type: $\mathrm{Ca}, \mathrm{HCO}_{3}$

Solute Concentration

\begin{tabular}{lcc} 
Maximum & $\frac{\text { Mean }}{336}$ & $\frac{\text { Minimum }}{203}$ \\
\cline { 2 - 3 }
\end{tabular}

Hell Depth (m)

Constituents $(\mathrm{mg} / \mathrm{l})$

and Properties

$\mathrm{SiO}_{2}$

22

12

8

$\mathrm{Fe}$

$\mathrm{Mn}$

Ca

120

Reference: Wood and Burton 1968

$\mathrm{Mg}$

74

$\mathrm{Na}$

377

K

4.4

$\mathrm{HCO}_{3}$

456

$\mathrm{CO}_{3}$

57

$\mathrm{SO}_{4}$

260

C1

458

$F$

$\mathrm{NO}_{3}$

83

TDS

1070

529

254

2030

Sp. Cond.

(micromhos $25^{\circ} \mathrm{C}$ )

pH

8.9

Temperature $\left({ }^{\circ} \mathrm{C}\right)$
7.6

6.1

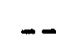

46

21

8.2

1.5

247

0

6.1

9.0

0.2

0.7

0

218

101

201

0

398

138

1.1

4.5

0.8

63

0

4

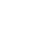

Hardness as $\mathrm{CaCO}_{3}$

$\mathrm{Ca}, \mathrm{Mg}$

$--$

\section{4}

0

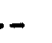


TABLE 9. Water Analysis

Hydrologic Region: Arkansas - White - Red Aquifer Mame: Wellington formation

State: Oklahoma

Aquifer Age: Permian

Location: Kay Co.

Petrology: sand, sandstone

No. Analyses: 3

Water Type: $\mathrm{Na}, \mathrm{SO}_{4}$

Solute Concentration

Maximum $\quad$ Intermediate

Well Depth (m)

8

13

6

Constituents $(\mathrm{mg} / \mathrm{l})$ and Properties

$\mathrm{SiO}_{2}$

$\mathrm{Fe}$

$\mathrm{Mn}$

$\mathrm{Ca}$

$\mathrm{Mg}$

$\mathrm{Na}$

$\mathrm{K}$

$\mathrm{HCO}_{3}$

$\mathrm{CO}_{3}$

$\mathrm{SO}_{4}$

Cl

$\mathrm{F}$

$\mathrm{NO}_{3}$

TDS

Hardness as $\mathrm{CaCO}_{3}$

$\mathrm{Ca}, \mathrm{Mg}$

Noncarbonate

Sp. Cond.

(micromhos $25^{\circ} \mathrm{C}$ )

$\mathrm{pH}$

Temperature $\left({ }^{\circ} \mathrm{C}\right)$

Reference: Havens 1978

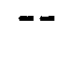

$-$

590

140

240

316

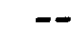

1700

350

38

3640

2000

1800

3820

7.7

18.5
0.088

0.07

$--$

--

--

85

46

--

324

454

--

720

28

250

17

21

3.0

1910

458

1200

330

930

0

2330

761

7.5

7.8

20.0

14.0 
TABLE 10. Water Analysis

Hydrologic Region: Arkansas - White - Red

Aquifer Name: Vamoosa formation

Aquifer Age: Pennsylvanian

Petrology: sand, sandstone
State: Ok lahoma

Location: Creek Co.

No. Analyses: 3

Water Type: $\mathrm{Na}, \mathrm{HCO}_{3}, \mathrm{SO}_{4}$

Solute Concentration

\begin{tabular}{ccc}
\hline Maximum & Minimum \\
\cline { 2 - 3 } 12 & 183 & 70 \\
& & \\
-- & -- & -- \\
-- & 0.02 & -- \\
-- & -- & -- \\
-- & 19 & -- \\
-- & 1.9 & -- \\
58 & 190 & 25 \\
-- & 2.4 & -- \\
92 & 266 & 390 \\
-- & -- & -- \\
65 & 180 & 30 \\
230 & 49 & 13 \\
-- & -- & -- \\
214 & -- & 0.4 \\
859 & 595 & 358
\end{tabular}

515

55

310

440

0

0

1390

1300

648

(micromhos o $25^{\circ} \mathrm{C}$ )

pH

7.3

7.8

8.1

16.0

21.0

24.0 
TABLE 11. Water Analysis

Hydrologic Region: Arkansas - White - Red Aquifer Name: Boone formation

Aquifer Age: Mississippian

Petrology: limestone, dolomite, gypsum
State: 0klahoma

Location: Adair Co.

No. Analyses: 3

Nater Type: $\mathrm{Ca}, \mathrm{HCO}_{3}$

Solute Concentration

Maximum Intermediate Minimum

Nell Depth (m)

23

40

18

Constituents $(\mathrm{mg} / \mathrm{l})$

and Properties

$\mathrm{SiO}_{2}$

$\mathrm{Fe}$

0.025

0

15.0

$\mathrm{Mn}$

$\mathrm{Ca}$

$\mathrm{Mg}$

$\mathrm{Na}$

$\mathrm{HCO}_{3}$

$\mathrm{CO}_{3}$

$\mathrm{SO}_{4}$

Cl

$\mathrm{F}$

$\mathrm{NO}_{3}$

TDS
144

17

12

2.8

400

--

106

4.0

7.0

1.6

334

--

15.0

10.0

0.4

0

320

580

364

108

264

8

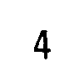

Sp. Cond.

(micromhos $25^{\circ} \mathrm{C}$ )

pH

7.2

7.1

Temperature $\left({ }^{\circ} \mathrm{C}\right)$

Reference: Havens 1978 
Hydrologic Region: Arkansas - White - Red Aquifer Name: Arbuckle group - Upper Aquifer Age: Ordovician

Petrology: limestone, dolomite
State: $0 \mathrm{k}$ 1ahoma

Location: Pontotoc Co. No. Analyses: 3

Hater Type: $\mathrm{Ca}, \mathrm{Mg}, \mathrm{HCO}_{3}$

Solute Concentration

Maximum

49 Intermediate
Mell Depth (m)

Constituents $(\mathrm{mg} / \mathrm{l})$ and Properties

$\mathrm{SiO}_{2}$

$\mathrm{Fe}$

$\mathrm{Mn}$

$\mathrm{Ca}$

$\mathrm{Mg}$

$\mathrm{Na}$

$\mathrm{K}$

$\mathrm{HCO}_{3}$

$\mathrm{CO}_{3}$

$\mathrm{SO}_{4}$

$\mathrm{Cl}$

$\mathrm{F}$

$\mathrm{NO}_{3}$

TDS

Hardness as $\mathrm{CaCO}_{3}$

$\mathrm{Ca}, \mathrm{Mg}$

Noncarbonate

Sp. Cond.

(micromhos $25^{\circ} \mathrm{C}$ )

$\mathrm{pH}$

Temperature $\left({ }^{\circ} \mathrm{C}\right)$

Reference: Havens 1978

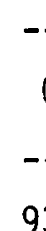

93

53

5.2

1.2

394

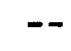

20

30

0.1

97

499

450

127

831

7.5

10.0
8.0

7.9

91

0

42

37

4.1

1.2

324

--

4.9

6.2

3.8

4.4

0

0.8

359

246

380

258

46

0

621

464

13.0 
TABLE 13. Water Analysis

Hydrologic Region: Arkansas - White - Red

Aquifer Name: Roubidoux formation

Aquifer Age: Ordovician

Petrology: limestone, dolomite
State: Oklahoma

Location: Delaware, Ottawa Co's. Mo. Analyses: 3

Water Type: $\mathrm{Ca}, \mathrm{Na}, \mathrm{HCO}_{3}, \mathrm{Cl}$

Solute Concentration

Maximum $\quad$ Intermediate $\quad$ Minimum

Well Depth (m)

355

380

354

Constituents $(\mathrm{mg} / \mathrm{l})$

and Properties

$\mathrm{SiO}_{2}$

$\mathrm{Fe}$

$\mathrm{Mn}$

$\mathrm{Ca}$

$\mathrm{Mg}$

$\mathrm{Na}$

K

$\mathrm{HCO}_{3}$

$\mathrm{CO}_{3}$
175

16.0

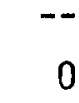

--

32

15

63

3.0

148

194

18

205

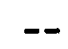

0.2

578

320

142

20

592

106

18

103

0.7

--

2.0

167

156

0

311

7.9

7.9

21.0

0.3

1.6

$--$

.
$\mathrm{SO}_{4}$

$\mathrm{Cl}$

$\mathrm{F}$

$\mathrm{NO}_{3}$

TDS

Hardness as $\mathrm{CaCO}_{3}$

$\mathrm{Ca}, \mathrm{Mg}$

Noncarbonate

Sp. Cond.

(micromhos $25^{\circ} \mathrm{C}$ )

pH

Temperature $\left({ }^{\circ} \mathrm{C}\right)$

Reference: Havens 1978 
TABLE 14. Water Analysis

Hydrologic Region: Arkansas - White - Red Aquifer Name: Simpson group Aquifer Age: Ordovician Petrology: sand, sandstone
State: $0 \mathrm{k}$ lahoma

Location: Pontotoc, Johnston Co's. No. Analyses: 3

Water Type: $\mathrm{Ca}, \mathrm{HCO}_{3}$

Solute Concentration

Maximum

We11 Depth (m)

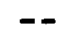

159

34

Constituents $(\mathrm{mg} / \mathrm{l})$

and Properties

$\mathrm{SiO}_{2}$

$\mathrm{Fe}$

$\mathrm{Mn}$

$\mathrm{Ca}$

$\mathrm{Mg}$

$\mathrm{Na}$

$\mathrm{K}$

$\mathrm{HCO}_{3}$

$\mathrm{CO}_{3}$

$\mathrm{SO}_{4}$

C1

$\mathrm{F}$

$\mathrm{NO}_{3}$

TDS

Hardness as $\mathrm{CaCO}_{3}$

$\mathrm{Ca}, \mathrm{Mg}$

335

Noncarbonate

Sp. Cond.

(micromhos $25^{\circ} \mathrm{C}$ )

$\mathrm{pH}$

7.4

7.9

7.9

13.0

Temperature $\left({ }^{\circ} \mathrm{C}\right)$

14

360

258

20

7

$\begin{array}{ll}-- & 608\end{array}$

471

Reference: Havens 1978 


\section{TABLE 15. Water Analysis}

Hydrologic Region: Arkansas - White - Red Aquifer Mame: Arbuckle group - Lower Aquifer Age: Cambrian

Petrology: limestone, dolomite
State: 0k lahoma

Location: Pontotoc Co.

No. Analyses: 3

Water Type: $\mathrm{Ca}, \mathrm{Mg}, \mathrm{HCO}_{3}$

Solute Concentration

\begin{tabular}{lll}
\hline Maximum & $\frac{\text { Intermediate }}{762}$ & Minim \\
762 & 762
\end{tabular}

We11 Depth (m)

Constituents $(\mathrm{mg} / \mathrm{l})$

and Properties

$\mathrm{SiO}_{2}$

$\mathrm{Fe}$

$\mathrm{Mn}$

$\mathrm{Ca}$

$\mathrm{Mg}$

$\mathrm{Na}$

$\mathrm{K}$

$\mathrm{HCO}_{3}$

$\mathrm{CO}_{3}$

$\mathrm{SO}_{4}$

C1

$F$

$\mathrm{NO}_{3}$

TDS

Hardness as $\mathrm{CaCO}_{3}$

$\mathrm{Ca}, \mathrm{Mg}$

270

648

(micromhos $25^{\circ} \mathrm{C}$ )

$\mathrm{pH}$

7.5

Temperature $\left({ }^{\circ} \mathrm{C}\right)$

Reference: Havens 1978
310

0

579

7.5

8.3

64

30

37

39

8.7

14

2.4

378

284

$-$

4.9

7.8

9.0

2.0

1.7

1.6

332

244

236

0

430

17.5 
TABLE 16. Water Analysis

Hydrologic Region: Arkansas - White - Red and Texas Gulf

Aquifer Name: Recent alluvium

Aquifer Age: Holocene

Petrology: clay, silt, sand, gravel
State: Texas

Location: Baylor Co.

No. Analyses: 3

Hater Type: $\mathrm{Na}, \mathrm{HCO}_{3}, \mathrm{SO}_{4}, \mathrm{Cl}$

Solute Concentration

\begin{tabular}{ccc}
\hline Maximum & Intermediate & Minimum \\
\cline { 2 - 3 } 7 & 5 & 7 \\
& & \\
21 & 20 & 10 \\
-- & -- & -- \\
-- & -- & -- \\
389 & 136 & 13 \\
347 & 144 & 12 \\
1049 & 580 & 62 \\
-- & -- & -- \\
560 & 770 & 198 \\
-- & -- & -- \\
1535 & 660 & 13 \\
1811 & 620 & 24 \\
1.9 & 1.4 & 0.9 \\
26.0 & 4.0 & $<0.4$ \\
5460 & 2540 & 240
\end{tabular}

Hardness as $\mathrm{CaCO}_{3}$

$\mathrm{Ca}, \mathrm{Mg}$

2398

930

82

Noncarbonate

Sp. Cond.

(micromhos $25^{\circ} \mathrm{C}$ )

6920

3540

393

pH

7.4

7.6

7.8

Temperature $\left({ }^{\circ} \mathrm{C}\right)$

Reference: Preston 1978 
TABLE 17. Water Analysis

Hydrologic Region: Arkansas - White - Red and Texas GuTf

Aquifer Name: Seymour formation

Aquifer Age: Pleistocene

Petrology: clay, silt, sand, gravel
State: Texas

Location: Baylor Co.

No. Analyses: 3

Water Type: $\mathrm{Na}, \mathrm{HCO}_{3}, \mathrm{SO}_{4}, \mathrm{Cl}$

Solute Concentration

$\begin{array}{lcc}\text { Maximum } & \frac{\text { Mntermediate }}{10} & \frac{\text { Minimum }}{8} \\ \text { spring } & 10 & \end{array}$

Well Depth (m)

Constituents (mg/ $l$ )

and Properties

$\mathrm{SiO}_{2}$

19

$\mathrm{Fe}$

$\mathrm{Mn}$

$\mathrm{Ca}$

$\mathrm{Mg}$

$\mathrm{Na}$

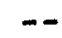

$--$

195

407

2040

$\mathrm{K}$

$\mathrm{HCO}_{3}$

580

$\mathrm{CO}_{3}$

$\mathrm{SO}_{4}$

1660

$\mathrm{Cl}$

3110

$\mathrm{F}$

5.9

$\mathrm{NO}_{3}$

51.0

TDS

7800

2160

Noncarbonate

Sp. Cond.

(micromhos $25^{\circ} \mathrm{C}$ )

$\mathrm{pH}$

9850

7.8

Temperature $\left({ }^{\circ} \mathrm{C}\right)$

Reference: Preston 1978

23

22

1280

267

4860

976

\section{8}

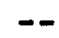

--

43

39

131

462

--

73

51

2.0

29.0

620

3800

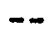

976

7.8 
Hydrologic Region: Arkansas - White - Red Aquifer Name: Antlers formation Aquifer Age: Cretaceous

Petrology: sand, sandstone, limestone interbeds
State: Texas

Location: Cooke Co.

No. Analyses: 21

Water Type: $\mathrm{Na}, \mathrm{HCO}_{3}$

Solute Concentration

Maximum Mean Median Minimum

We11 Depth (m)

Constituents $(\mathrm{mg} / \mathrm{l})$ and Properties

$\mathrm{SiO}_{2}$

$\mathrm{Fe}$

$\mathrm{Mn}$

$\mathrm{Ca}$

$\mathrm{Mg}$

$\mathrm{Na}$

$\mathrm{K}$

$\mathrm{HCO}_{3}$

$\mathrm{CO}_{3}$

$\mathrm{SO}_{4}$

$\mathrm{Cl}$

$\mathrm{F}$

$\mathrm{NO}_{3}$

TDS

Hardness as $\mathrm{CaCO}_{3}$

Sp. Cond.

(micromhos $25^{\circ} \mathrm{C}$ )

$\mathrm{pH}$

Temperature $\left({ }^{\circ} \mathrm{C}\right)$

Reference: Taylor 1976
37.00

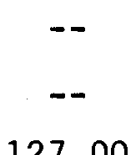

127.00

14.00

312.00

640.00

$--$

85.00

85.00

1.80

6.50

746.00

374.00

1172.00

9.20

8.36

42.85

28.23

0.35

1.24

492.94

30.57

784.57

8.40

38.00

15.00

0.20

1.00

469.37

9.00

845.00

8.00

--

--

1.00

0.00

10.00

315.00

23.00

3.00

0.00

0.00

388.28

1.00

23.00

7.20 
TABLE 19. Water Analysis

Hydrologic Region: Arkansas - White - Red State: Texas

Aquifer Name: Antlers formation

Location: Grayson Co.

Aquifer Age: Cretaceous

No. Analyses: 8

Petrology: interbedded sand, shale and limestone

Nater Type: $\mathrm{Na}, \mathrm{HCO}_{3}$

Solute Concentration

Maximum Mean Median Minimum

We11 Depth (m)

Constituents $(\mathrm{mg} / \ell)$

and Properties

$\mathrm{SiO}_{2}$

$\mathrm{Fe}$

$\mathrm{Mn}$

$\mathrm{Ca}$

$\mathrm{Mg}$

$\mathrm{Na}$

$\mathrm{K}$

$\mathrm{HCO}_{3}$

$\mathrm{CO}_{3}$

$\mathrm{SO}_{4}$

C1

$\mathrm{F}$

$\mathrm{NO}_{3}$

TDS

Hardness as $\mathrm{CaCO}_{3}$

Sp. Cond.

(micromhos $25^{\circ} \mathrm{C}$ )

pH

Temperature $\left({ }^{\circ} \mathrm{C}\right)$

Reference: TayTor 1976
17.00

13.12
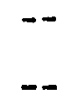

98.00

13.00

530.00

790.00

124.00

495.00

2.70

1.00

1403.00

302.00

2330.00

8.50

8.08

78.00

92.75

1.16

0.47

690.62

54.00

1093.75

$-$
Median

Minimum

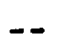

10.00

13.00

$--$

--

2.00

1.00

66.00

248.00

39.00

9.00

0.20

0.40

352.00

9.00

555.00

7.50
876.00

8.10

532.00

13.00

8.10 
TABLE 20. Water Analysis

Hydrologic Region: Arkansas - White - Red Aquifer Name: Antlers formation Aquifer Age: Cretaceous

Petrology: sand, shale, limestone interbeds
State: Texas

Location: Montague Co.

No. Analyses: 15

Nater Type: $\mathrm{Ca}, \mathrm{Na}, \mathrm{HCO}_{3}$
Solute Concentration

Maximum

We11 Depth (m)

Constituents $(\mathrm{mg} / \mathrm{l}$ )

and Properties

$\mathrm{SiO}_{2}$

$\mathrm{Fe}$

$\mathrm{Mn}$

$\mathrm{Ca}$

$\mathrm{Mg}$

$\mathrm{Na}$

$\mathrm{K}$

$\mathrm{HCO}_{3}$

$\mathrm{CO}_{3}$

$\mathrm{SO}_{4}$

$\mathrm{Cl}$

$\mathrm{F}$

$\mathrm{NO}_{3}$

TDS

Hardness as $\mathrm{CaCO}_{3}$

Sp. Cond.

(micromhos $25^{\circ} \mathrm{C}$ )

$\mathrm{pH}$

Temperature $\left({ }^{\circ} \mathrm{C}\right)$

Reference: Taylor 1976
29.00

20.46

Mean
Median

Median

Minimum

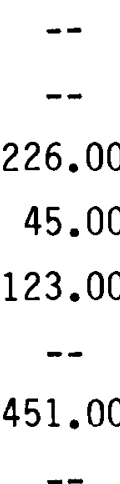

156.00

66.73

74.33

0.25

7.62

564.29

368.86

926.64

1550.00

8.00

7.30
7.30

6.90

10.00

--

--

14.00

5.00

13.00

304.00

24.00

7.00

0.10

0.00

358.00

58.00

578.00

839.00

-- 


\section{TABLE 21. Water Analysis}

Hydrologic Region: Arkansas - White - Red Aquifer Name: Nacatoch sand

Aquifer Age: Cretaceous

Petrology: sand, sandstone, limestone interbeds
State: Texas

Location: Hunt $\mathrm{Co}$.

No. Analyses: 12

Hater Type: $\mathrm{Na}, \mathrm{HCO}_{3}$

Solute Concentration

Maximum $\frac{\text { Mean }}{-.} \quad \frac{\text { Median }}{\ldots} \quad$ Minimum

Well Depth (m)

Constituents $(\mathrm{mg} / \mathrm{l})$

and Properties

$\mathrm{SiO}_{2}$

$\mathrm{Fe}$

$\mathrm{Mn}$

$\mathrm{Ca}$

$\mathrm{Mg}$

$\mathrm{Na}$

$\mathrm{K}$

$\mathrm{HCO}_{3}$

$\mathrm{CO}_{3}$

$\mathrm{SO}_{4}$

$\mathrm{Cl}$

F

$\mathrm{NO}_{3}$

TDS

Hardness as $\mathrm{CaCO}_{3}$

Sp. Cond.

(micromhos $25^{\circ} \mathrm{C}$ )

pH

Temperature $\left({ }^{\circ} \mathrm{C}\right)$

Reference: Taylor 1976
16.00

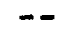

$-$

51.00

14.00

688.00

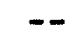

886.00

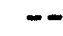

378.00

558.00

4.80

11.00

1699.00

186.00

2160.00

9.10

$-$
12.33

--

$--$

7.00

2.70

320.27

--

507.16

-

102.18

176.50

1.26

3.02

838.75

45.66

1436.60

8.50

--
12.00

10.00

$-$

--

3.00

1.00

271.00

175.00

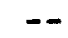

389.00

318.00

-.

1.00

19.00

0.30

0.40

2.50

413.00

8.00

849.00

1530.00

8.60

7.60 


\section{TABLE 22. Water Analysis}

Hydrologic Region: Arkansas - White - Red

Aquifer Name: Woodbine group

Aquifer Age: Cretaceous

Petrology: sand, sandstone, shale

State: Texas

Location: Fannin Co.

No. Analyses: 26

Water Type: $\mathrm{Na}, \mathrm{HCO}_{3}$

Solute Concentration

Maximum

Well Depth (m)

Constituents $(\mathrm{mg} / \mathrm{l})$ and Properties

$\mathrm{SiO}_{2}$

$\mathrm{Fe}$

$\mathrm{Mn}$

$\mathrm{Ca}$

$\mathrm{Mg}$

$\mathrm{Na}$

$\mathrm{K}$

$\mathrm{HCO}_{3}$

$\mathrm{CO}_{3}$

$\mathrm{SO}_{4}$

$\mathrm{Cl}$

$\mathrm{F}$

$\mathrm{NO}_{3}$

TDS

Hardness as $\mathrm{CaCO}_{3}$

Sp. Cond.

(micromhos $25^{\circ} \mathrm{C}$ )

$\mathrm{pH}$

Temperature $\left({ }^{\circ} \mathrm{C}\right)$

Reference: Taylor 1976

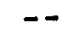

$--$

27.00

9.00

2160.00

$-$

1150.00

277.00

2960.00

4.60

7.00

5586.57

104.00

2700.00

8.60

Mean

Median

13.03

13.00

10.00

8.14

8.20

7.50

Minimum
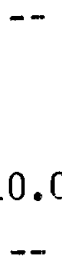

-

2.00

1.00

1.00

0.00

314.00

188.00

63.00

30.00

13.00

0.00

0.20

1126.31

854.00

495.00

2.00

86.00

1300.00

$--$ 


\section{TABLE 23. Water Analysis}

Hydrologic Region: Arkansas - White - Red

Aquifer Age: Cretaceous

Petrology: sand, sandstone, shale Aquifer Name: Woodbine group

State: Texas

Location: Grayson Co.

No. Analyses: 16

Water Type: $\mathrm{Na}, \mathrm{HCO}_{3}, \mathrm{SO}_{4}$

Solute Concentration

Maximum Mean Median Minimum

We11 Depth (m)

Constituents $(\mathrm{mg} / \ell)$

and Properties

$\mathrm{SiO}_{2}$

21.00

11.25

11.00

5.00

$\mathrm{Fe}$

$\mathrm{Mn}$

$\mathrm{Ca}$

134.00

9.00

1050.00

$\mathrm{Na}$

K

$\mathrm{HCO}_{3}$

$\mathrm{CO}_{3}$
7.95

8.00

7.10

18.75

3.68

327.87

395.31

325.37

82.37

1.10

3.62

967.92

61.37

1369.06

618.00

41.00

20.00

14.00

4.00

0.90

0.10

0.40

0.40

394.00

248.00

7.00

415.00
$\mathrm{SO}_{4}$

$\mathrm{Cl}$

$F$

$\mathrm{NO}_{3}$

TDS

Hardness as $\mathrm{CaCO}_{3}$

Sp. Cond.

(micromhos $25^{\circ} \mathrm{C}$ )

$\mathrm{pH}$

8.30

Temperature $\left({ }^{\circ} \mathrm{C}\right)$

1460.00

288.00

2.50

20.00

3076.00

347.00

4020.00

Reference: Taylor 1976 
TABLE 24. Water Analysis

Hydrologic Region: California

Aquifer Mame: Santa Margarita sandstone

Aquifer Age: Miocene

Petrology: sandstone, basal gravel
State: California

Location: Santa Cruz Co.

No. Analyses: 8

Water Type: $\mathrm{Ca}, \mathrm{HCO}_{3}, \mathrm{SO}_{4}$

Solute Concentration

Maximum Minimum

nimum
We11 Depth (m)

Constituents $(\mathrm{mg} / \ell)$

and Properties

$$
\mathrm{SiO}_{2}
$$

$\mathrm{Fe}$

$\mathrm{Mn}$

$\mathrm{Ca}$

$\mathrm{Mg}$

$\mathrm{Na}$

$\mathrm{K}$

$\mathrm{HCO}_{3}$

$\mathrm{CO}_{3}$

$\mathrm{SO}_{4}$

$\mathrm{Cl}$

$F$

$\mathrm{NO}_{3}$

TDS
0.56

$--$

44

12

19

0.9

120

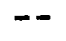

75

19

$--$

$<0.2$

324

160

$\mathrm{Ca}, \mathrm{Mg}$

Noncarbonate

Sp. Cond.

(micromhos $25^{\circ} \mathrm{C}$ )

pH

Temperature $\left({ }^{\circ} \mathrm{C}\right)$

Reference: Muir 1981

7.3

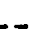

0.1

13

0.8

9.4

0.8

110

$--$

$-$

0.9

8

$-$

1.0

84

37

120

6.9

6.4 
TABLE 25. Water Analysis

Hydrologic Region: Great Lakes

Aquifer Name: Lagro and Trafalgar formations

Aquifer Age: Pleistocene

Petrology: clayey and sandy tills
State: Indiana

Location: Allen Co.

- No. Analyses: 14

Nater Type: $\mathrm{Ca}, \mathrm{HCO}_{3}$

Solute Concentration

\begin{tabular}{ccc}
\hline Maximum & Mean & Minimum \\
\cline { 2 - 3 }-- & -- & - \\
& & \\
-- & -- & -- \\
25 & 5.4 & 1.1 \\
-- & -- & -- \\
207 & 108 & 58 \\
86 & 50 & 27 \\
43 & 25 & 8 \\
11 & 7.1 & 5.2 \\
569 & 467 & 330 \\
-- & -- & -- \\
510 & 151 & 4 \\
23.3 & 4.1 & 0.9 \\
-- & -- & -- \\
-- & -- & -- \\
12.7 & 5.1 & 0.7 \\
1150 & 620 & 274
\end{tabular}

Hardness as $\mathrm{CaCO}_{3}$

$\mathrm{Ca}, \mathrm{Mg}$

874

480

326

Noncarbonate

Sp. Cond.

(micromhos $25^{\circ} \mathrm{C}$ )

pH

Temperature $\left({ }^{\circ} \mathrm{C}\right)$

Reference: Foley et al. 1972 
TABLE 26. Water Analysis

Hydrologic Region: Great Lakes

Aquifer Name: Traverse and Detroit River formations

Aquifer Age: Devonian

Petrology: limestone, dolomite, shale, silt
State: Indiana

Location: Allen Co.

No. Analyses: 31

Water Type: $\mathrm{Ca}, \mathrm{HCO}_{3}, \mathrm{SO}_{4}$

Solute Concentration

Maximum

Well Depth (m)

Constituents $(\mathrm{mg} / \mathrm{l}$ )

and Properties

$\mathrm{SiO}_{2}$

$\mathrm{Fe}$

$\mathrm{Mn}$

$\mathrm{Ca}$

$\mathrm{Mg}$

$\mathrm{Na}$

$\mathrm{K}$

$\mathrm{HCO}_{3}$

$\mathrm{CO}_{3}$

$\mathrm{SO}_{4}$

C1

$\mathrm{F}$

$\mathrm{NO}_{3}$

$\mathrm{Sr}$

TDS

(2)

2.1

132

70

50

10.3

438

630

37.9

15.4

1040
935

$\mathrm{Ca}, \mathrm{Mg}$

Noncarbonate

Sp. Cond.

(micromhos $25^{\circ} \mathrm{C}$ )

$\mathrm{pH}$

Temperature $\left({ }^{\circ} \mathrm{C}\right)$

Reference: Foley et a1. 1972

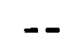

Mean

Minimum
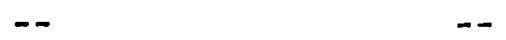

0.06

--

31

26

16

5.4

303

132

214

6.8

5

1.1

$-$

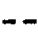

1.2

8.0

238

586

405

237

--
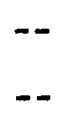


\section{TABLE 27. Water Analysis}

Hydrologic Region: Great Lakes

Aquifer Name: Niagaran series

Aquifer Age: Late Silurian

Petrology: dolomite, dolomitic limestone
State: Wisconsin

Location: Door Co.

No. Analyses: 3

Water Type: $\mathrm{Ca}, \mathrm{HCO}_{3}$

Solute Concentration

Maximum Intermediate Minimum

Well Depth (m)

Constituents $(\mathrm{mg} / \ell)$

and Properties
$\mathrm{SiO}_{2}$

$\mathrm{Fe}$

$\mathrm{Mn}$

$\mathrm{Ca}$

$\mathrm{Mg}$

$\mathrm{Na}$

K

$\mathrm{HCO}_{3}$

$\mathrm{CO}_{3}$

$\mathrm{SO}_{4}$

C1

$\mathrm{F}$

$\mathrm{NO}_{3}$

TDS

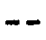

$-$

0.05

$--$

46

42

38.2

375

37

12

$-$

16

500

Hardness as $\mathrm{CaCO}_{3}$

$\mathrm{Ca}, \mathrm{Mg}$

290

Noncarbonate

Sp. Cond.

(micromhos $25^{\circ} \mathrm{C}$ )

pH

Temperature $\left({ }^{\circ} \mathrm{C}\right)$

Reference: Sherri11 1978

790

7.3

11.5
$--$

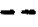

0.08

0.08

--

20

18

15

160

426

--

38

13

2.6

8.0

-

--

38

0.6

370

158

450

124

610

280

7.3

8.2

12.0

11.0 
TABLE 28. Water Analysis

Hydrologic Region: Great Lakes

Aquifer Name: Alexandrian series

Aquifer Age: Early Silurian

Petrology: dolomite; basal gypsum and chert
State: Wisconsin

Location: Door Co.

No. Analyses: 3

Mater Type: $\mathrm{Ca}, \mathrm{HCO}_{3}$

Solute Concentration

Maximum Intermediate

\section{Well Depth (m) \\ Constituents $(\mathrm{mg} / \mathrm{l})$ \\ and Properties}

$\mathrm{SiO}_{2}$

$\mathrm{Fe}$

$\mathrm{Mn}$

$\mathrm{Ca}$

$\mathrm{Mg}$

$\mathrm{Na}$

$\mathrm{K}$

$\mathrm{HCO}_{3}$

$\mathrm{CO}_{3}$

$\mathrm{SO}_{4}$

C1

$F$

$\mathrm{NO}_{3}$

TDS

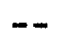

$--$

0.1

$--$

66

35

$--$

$--$

274

--

19

6.0

--

0.7

404

308

$\mathrm{Ca}, \mathrm{Mg}$

Sp. Cond.

(micromhos $25^{\circ} \mathrm{C}$ )

$\mathrm{pH}$

Temperature $\left({ }^{\circ} \mathrm{C}\right)$

Reference: Sherrill 1978
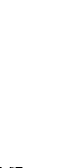

Hardness as $\mathrm{CaCO}_{3}$

$$
\text { Noncarbonate }
$$

--
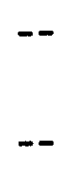

$-$
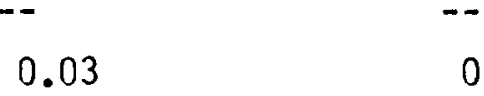

0.21

$--$

62

28

3.0

--

305

307

--

23

22

6.0

1.0

--

14.0

0.2

336

277

270

300

--

470

7.7

11.5 
TABLE 29. Water Analysis

Hydrologic Region: Lower Mississippi

Aquifer Name: Mississippi River Valley

Alluvial Aquifer

Aquifer Age: Quaternary

Petrology: clay, silt, sand, gravel (chert)

States: Arkansas, Louisiana, Mississippi, Missouri and Tennessee

Location: Mississippi Embayment No. Analyses:

Water Type: $\mathrm{Ca}, \mathrm{HCO}_{3}$

Solute Concentration

Maximum

He11 Depth (m)

Constituents $(\mathrm{mg} / \mathrm{l})$ and Properties

$\mathrm{SiO}_{2}$

$\mathrm{Fe}$

$\mathrm{Mn}$

$\mathrm{Ca}$

$\mathrm{Mg}$

$\mathrm{Na}$

$\mathrm{K}$

$\left.\begin{array}{l}\mathrm{HCO}_{3} \\ \mathrm{CO}_{3}\end{array}\right\}$

$\mathrm{SO}_{4}$

$\mathrm{Cl}$

$\mathrm{F}$

$\mathrm{NO}_{3}$

TDS

Hardness as $\mathrm{CaCO}_{3}$

Sp. Cond.

(micromhos $25^{\circ} \mathrm{C}$ )

$\mathrm{pH}$

8.9

70

62

432

174

943

35

716

1000

1870

0.8

132

4190

1790

6430

Temperature $\left({ }^{\circ} \mathrm{C}\right)$

Reference: Boswell et al. 1968

Median

Minimum
26

5.2

66.0

18

21

2.0

291

11

19

0.2

0.7

331

246

552

7.5
4.3

1.6

0

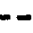

0.1

0.3

2.2

0

0

0

0.3

0

0

18

0

32 
Hydrologic Region: Lower Mississippi

Aquifer Name: Red River Valley Alluvial Aquifer

Aquifer Age: Quaternary

Petrology: clay, silt, sand, gravel (chert)
States: Arkansas and Louisiana Location: Mississippi Embayment No. Analyses:

Water Type: $\mathrm{Ca}, \mathrm{Mg}, \mathrm{Na}, \mathrm{HCO}_{3}$

Solute Concentration

Maximum

Well Depth (m)

Constituents $(\mathrm{mg} / \mathrm{l})$ and Properties

$\mathrm{SiO}_{2}$

$\mathrm{Fe}$

$\mathrm{Mn}$

$\mathrm{Ca}$

$\mathrm{Mg}$

$\mathrm{Na}$

$\mathrm{K}$

$\left.\begin{array}{l}\mathrm{HCO}_{3} \\ \mathrm{CO}_{3}\end{array}\right\}$

$\mathrm{SO}_{4}$

$\mathrm{Cl}$

$\mathrm{F}$

$\mathrm{NO}_{3}$

TDS

Hardness as $\mathrm{CaCO}_{3}$

Sp. Cond.

$\mathrm{pH}$

Temperature $\left({ }^{\circ} \mathrm{C}\right)$ (micromhos $25^{\circ} \mathrm{C}$ )
56

28

$--$

248

147

242

7.7

911

544

610

1.0

560

1850

1180

2680

8.2

7.4

5.1

15

3.3

0.6

5.6

0.6

279

4

10

52

0.2

2.2

490

266

10

905

54

4.5

0

0

51
0.01

Reference: Boswell et al. 1968 
TABLE 31. Water Analysis

Hydrologic Region: Lower Mississippi

Aquifer Name: Alluvium

Aquifer Age: Holocene

Petrology: clay, silt, sand, grave 1
State: Arkansas

Location: Drew Co.

No. Analyses: 3

Nater Type: $\mathrm{Ca}, \mathrm{HCO}_{3}$

Solute Concentration

Maximum Intermediate Minimum

We11 Depth (m)

Constituents (mg/l)

and Properties

$\mathrm{SiO}_{2}$

$\mathrm{Fe}$

$\mathrm{Mn}$

$\mathrm{Ca}$

$\mathrm{Mg}$

$\mathrm{Na}$

K

$\mathrm{HCO}_{3}$

$\mathrm{CO}_{3}$

$\mathrm{SO}_{4}$

C1

$\mathrm{F}$

$\mathrm{NO}_{3}$

TOS

Hardness as $\mathrm{CaCO}_{3}$

$\mathrm{Ca}, \mathrm{Mg}$

707

Noncarbonate

Sp. Cond.

(micromhos $25^{\circ} \mathrm{C}$ )

pH

Temperature $\left({ }^{\circ} \mathrm{C}\right)$
25

10.0

--

74

16

34

$$
2.0
$$

341

0

2.3

26

0.2

1.6

350

250

0

573

4.7

16.0

Reference: Terry et al. 1979 
Hydrologic Region: Lower Mississippi

Aquifer Name: Quaternary

Aquifer Age: Holocene and Pleistocene

Petrology: clay, silt, sand, gravel
State: Arkansas

Location: Drew Co.

No. Analyses: 3

Hater Type: $\mathrm{Ca}, \mathrm{Na}, \mathrm{HCO}_{3}$

Solute Concentration

Maximum

Well Depth (m)

Constituents $(\mathrm{mg} / \mathrm{l})$ and Properties

$\mathrm{SiO}_{2}$

$\mathrm{Fe}$

$\mathrm{Mn}$

$\mathrm{Ca}$

$\mathrm{Mg}$

$\mathrm{Na}$

$\mathrm{K}$

$\mathrm{HCO}_{3}$

$\mathrm{CO}_{3}$

$\mathrm{SO}_{4}$

$\mathrm{Cl}$

$\mathrm{F}$

$\mathrm{NO}_{3}$

TDS

Hardness as $\mathrm{CaCO}_{3}$

$\mathrm{Ca}, \mathrm{Mg}$

Noncarbonate

Sp. Cond.

(micromhos $25^{\circ} \mathrm{C}$ )

pH

Temperature $\left({ }^{\circ} \mathrm{C}\right)$

Reference: Onellion 1956
30

21

27 Intermediate

Minimum

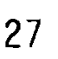

25

10

4.2

0.31

74

32

12

16

11

5.0

34

28

15

2.0

341

0

34

--

70

0

0

2.3

2

2

26

112

17

0.2

1.6

346

--

2.4

1.3

263

142

250

125

50

0

97

0

573

445

172

7.9

7.4

7.9

18.3

18.9 
TABLE 33. Water Analysis

Hydrologic Region: Lower Mississippi

Aquifer Name: Alluvium and terrace deposits

Aquifer Age: Holocene and Pleistocene

Petrology: clay, silt, sand, gravel; iron oxide
State: Arkansas

Location: Bradley, Calhoun, Ouachita Co's.

No. Analyses: 57

Water Type: $\mathrm{Na}(?), \mathrm{HCO}_{3}$

Solute Concentration

Maximum

Well Depth (m)

Constituents $(\mathrm{mg} / \ell$ ) and Properties

$\mathrm{SiO}_{2}$

$\mathrm{Fe}$

$\mathrm{Mn}$

$\mathrm{Ca}$

$\mathrm{Mg}$

$\mathrm{Na}$

K

$\mathrm{HCO}_{3}$

$\mathrm{CO}_{3}$

$\mathrm{SO}_{4}$

C1

$\mathrm{F}$

$\mathrm{NO}_{3}$

TDS

Hardness as $\mathrm{CaCO}_{3}$

$\mathrm{Ca}, \mathrm{Mg}$

399

Noncarbonate

Sp. Cond.

(micromhos $25^{\circ} \mathrm{C}$ )

pH

Temperature $\left({ }^{\circ} \mathrm{C}\right)$

Reference: A1bin 1962

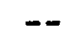

7.5

198

399

4130

7.9

23.3
Mean

Minimum

0.9

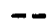

0

$--$

$--$

$--$

$--$

$-$

0

15

--

1.0

3.0

10

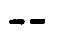

8.8

0.5

--

30

6

5

0

141

46

6.5

4.5

19.4

17.2 
Hydrologic Region: Lower Mississippi

Aquifer Name: Terrace deposits

Aquifer Age: Pleistocene

Petrology: silt, sand, gravel, clay
State: Arkansas

Location: Lafayette Co.

No. Analyses: 3

Hater Type: $\mathrm{Ca}, \mathrm{Na}, \mathrm{HCO}_{3}$

Solute Concentration

Maximum Intermediate Minimum

Hell Depth (m)

Constituents $(\mathrm{mg} / \mathrm{l})$ and Properties

$\mathrm{SiO}_{2}$

19

35

2.3

$\mathrm{Fe}$

Mn

$\mathrm{Ca}$

$\mathrm{Mg}$

$\mathrm{Na}$

K

$\mathrm{HCO}_{3}$

$\mathrm{CO}_{3}$

$\mathrm{SO}_{4}$

C1

$F$

$\mathrm{NO}_{3}$

TDS

0.1

406

Hardness as $\mathrm{CaCO}_{3}$

$\mathrm{Ca}, \mathrm{Mg}$

370

Noncarbonate

38

567

Sp. Cond.

(micromhos $25^{\circ} \mathrm{C}$ )

pH

8.6

Temperature $\left({ }^{\circ} \mathrm{C}\right)$

Reference: Terry et a1. 1979
7.1

8.1

$-$

$-$

17

5.7

7.0

15

15

17

1.2

1.2

88

132

0

0

3.0

0

18

8.0

0

146

117

72

78

0

0

200

286

15.0

18.0 
Hydrologic Region: Lower Mississippi Aquifer Name: Cockfield formation Aquifer Age: Late Eocene

Petrology: silt, sand, lignite, clay
State: Arkansas

Location: Jefferson Co. No. Analyses: 3

Hater Type: $\mathrm{Ca}, \mathrm{Na}, \mathrm{HCO}_{3}, \mathrm{SO}_{4}$

Solute Concentration

Maximum $\quad$ Intermediate $\quad$ Minimum

Hell Depth (m)

Constituents $(\mathrm{mg} / \mathrm{l})$ and Properties

$\mathrm{SiO}_{2}$

$\mathrm{Fe}$

Mn

Ca

$\mathrm{Mg}$

$\mathrm{Na}$

$\mathrm{K}$

$\mathrm{HCO}_{3}$

$\mathrm{CO}_{3}$

$\mathrm{SO}_{4}$

$\mathrm{Cl}$

$\mathrm{F}$

$\mathrm{NO}_{3}$

TDS
2.0

0.05

--

99

24

84

5.4

356

0

220

26

0

2.6

640

346

54

987

Sp. Cond.

(micromhos $25^{\circ} \mathrm{C}$ )

$\mathrm{pH}$

Temperature $\left({ }^{\circ} \mathrm{C}\right)$

Reference: Terry et al. 1979

$\mathrm{Ca}, \mathrm{Mg}$

7.6

20.5
43

43

1.44

0.46

8.8

15.0

2.0

4.0

92

65

2.4

3.8

168

148

0

0

75

75

12

13

0.1

0.1

0.9

0

321

293

30

54

0

0

460

446

8.1

7.7 
TABLE 36. Water Analysis

Hydrologic Region: Lower Mississippi

Aquifer Name: Cockfield formation

Aquifer Age: Late Eocene

Petrology: silt, fine sand, lignite, clay
State: Arkansas

Location: Bradley, Calhoun, Ouachita Co's.

No. Analyses: 27

Water Type: $\mathrm{Na}, \mathrm{HCO}_{3}$

Solute Concentration
Mean

Minimum
Well Depth (m)

Constituents $(\mathrm{mg} / \ell)$ and Properties

$\mathrm{SiO}_{2}$

$\mathrm{Fe}$

$\mathrm{Mn}$

$\mathrm{Ca}$

$\mathrm{Mg}$

$\mathrm{Na}$

K

$\mathrm{HCO}_{3}$

$\mathrm{CO}_{3}$

$\mathrm{SO}_{4}$

C1

$F$

$\mathrm{NO}_{3}$

TDS

Maximum

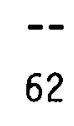

117

138

182

11

428

0

470

58

$--$

$$
9.5
$$

958

Hardness as $\mathrm{CaCO}_{3}$

$\mathrm{Ca}, \mathrm{Mg}$

448

Noncarbonate

Sp. Cond.

(micromhos $25^{\circ} \mathrm{C}$ )

pH

Temperature $\left({ }^{\circ} \mathrm{C}\right)$

Reference: Albin 1962
300

1180

8.2

23.3
0.35

0.04

7.5

1.9

54

3.2

181

0

3.9

8.2

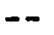

0.6

197

22

0

310

7.6

21.1

1.9

0

1.2

0.7

8

0

0

2.2

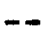

0

27

5

0

25

5.8

18.3 
TABLE 37. Water Analysis

Hydrologic Region: Lower Mississippi

Aquifer Mame: Cockfield formation

Aquifer Age: Late Eocene

Petrology: sand, clay, lignite
State: Arkansas

Location: Drew Co.

No. Analyses: 2

Nater Type: $\mathrm{Na}, \mathrm{HCO}_{3}$

Solute Concentration

Maximum

Well Depth (m)

98 Mean

Minimum

Constituents (mg/ $x$ ) and Properties

$\mathrm{SiO}_{2}$

12

$\mathrm{Fe}$

0.09

$-$

0.42

$\mathrm{Mn}$

$\mathrm{Ca}$

2.4

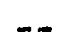

$-$

1.1

0.5

92

$\mathrm{Na}$

1.7

$\mathrm{HCO}_{3}$

$\mathrm{CO}_{3}$

218

2

$\mathrm{SO}_{4}$

Cl

$\mathrm{F}$

$\mathrm{NO}_{3}$

TDS

1.2

20

0

1.4

252

Hardness as $\mathrm{CaCO}_{3}$

$\mathrm{Ca}, \mathrm{Mg}$

8

Noncarbonate

Sp. Cond.

(micromhos $25^{\circ} \mathrm{C}$ )

$\mathrm{pH}$

8.3

Temperature $\left({ }^{\circ} \mathrm{C}\right)$

Reference: Onellion 1956
112 $\begin{array}{ll}-- & 1.0\end{array}$

-- 92

--

$\begin{array}{ll}-- & 217\end{array}$

-- 11

-- 2

-- 12

--

$\begin{array}{ll}-- & 2.0\end{array}$

-- 229

$\begin{array}{ll}-- & 17\end{array}$

$\begin{array}{ll}-- & 0\end{array}$

-- 411

$\begin{array}{ll}-- & 8.7\end{array}$

-- 
TABLE 38. Water Analys is

Hydrologic Region: Lower Mississippi

Aquifer Name: Jackson group

Aquifer Age: Late Eocene

Petrology: silty clay, sand, lignite
State: Arkansas

Location: Bradley, Calhoun, Ouachita Co's.

No. Analyses: 4

Water Type: $\mathrm{Na}, \mathrm{HCO}_{3}$

Solute Concentration

Maximum

We11 Depth (m)

Constituents (mg/ll)

and Properties

$\mathrm{SiO}_{2}$
$\mathrm{Fe}$
$\mathrm{Mn}$
$\mathrm{Ca}$
$\mathrm{Mg}$
$\mathrm{Na}$
$\mathrm{K}$
$\mathrm{HCO}_{3}$
$\mathrm{CO}_{3}$
$\mathrm{SO}_{4}$
$\mathrm{Cl}$
$\mathrm{F}$
$\mathrm{NO}_{3}$
$\mathrm{TOS}$

Hardness as $\mathrm{CaCO}_{3}$

$\mathrm{Ca}, \mathrm{Mg}$

Noncarbonate

Sp. Cond.

(micromhos $25^{\circ} \mathrm{C}$ )

pH

Temperature $\left({ }^{\circ} \mathrm{C}\right)$

Reference: Albin 1962
153

Mean Minimum

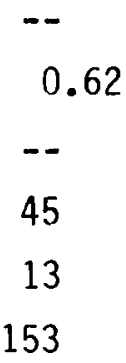

8.2

272

152

15

0.09

0.06

--

25

14

5.0

3.6

75

29

6.0

4.1

237 204

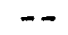

100

4.8

11

7.0

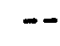

3.8

2.2

--

0.8

482

400

196

100

51

0

734

0

0

535

336

22.8

57.2

20.0 
TABLE 39. Water Analysis

Hydrologic Region: Lower Mississippi

Aquifer Name: Jackson group

Aquifer Age: Late Eocene

Petrology: silty clay, lignite
State: Arkansas

Location: Drew Co.

No. Analyses: 3

Nater Type: $\mathrm{Ca}, \mathrm{Mg}, \mathrm{SO}_{4}$

Solute Concentration
We1l Depth (m)

Constituents $(\mathrm{mg} / \mathrm{l})$ and Properties

$\mathrm{SiO}_{2}$

$\mathrm{Fe}$

$\mathrm{Mn}$

$\mathrm{Ca}$

$\mathrm{Mg}$

$\mathrm{Na}$

$\mathrm{K}$

$\mathrm{HCO}_{3}$

$\mathrm{CO}_{3}$

$\mathrm{SO}_{4}$

$\mathrm{Cl}$

$\mathrm{F}$

$\mathrm{NO}_{3}$

TDS
Maximum

Intermediate

Minimum

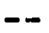

14.0

1.2

0.54

--

6.5

3.8

16

449

3.8

0

341

206

165

12

0

20

0

0

2210

22

46

10

0.4

$--$

1.7

16

5330

2990

104

Hardness as $\mathrm{CaCO}_{3}$

$\mathrm{Ca}, \mathrm{Mg}$

2620

1700

32

26

17

15

5490

3240

157

3.5

3.6

7.3

18.0

20.0

18.0

Reference: Terry et al. 1979 
TABLE 39A. Water Analysis

Hydrologic Region: Lower Mississippi

Aquifer Name: Jackson formation

Aquifer Age: Late Eocene

Petrology: shale, clay, lenses of silt and sand
State: Arkansas

Location: Drew Co.

No. Analyses: 3

Hater Type: $\mathrm{Ca}, \mathrm{Na}, \mathrm{SO}_{4}$

Solute Concentration

$\frac{\text { Maximum }}{4} \frac{\text { Intermediate }}{9} \quad \frac{\text { Minimum }}{5}$

We11 Depth (m)

4

5

Constituents $(\mathrm{mg} / \mathrm{l}$ )

and Properties

$\mathrm{SiO}_{2}$

$\mathrm{Fe}$

$\mathrm{Mn}$

$\mathrm{Ca}$

$\mathrm{Mg}$

$\mathrm{Na}$

K

$\mathrm{HCO}_{3}$

$\mathrm{CO}_{3}$

$\mathrm{SO}_{4}$

Cl

F

$\mathrm{NO}_{3}$

TDS

Hardness as $\mathrm{CaCO}_{3}$

$\mathrm{Ca}, \mathrm{Mg}$

Noncarbonate

Sp. Cond.

(micromhos $25^{\circ} \mathrm{C}$ )

pH

Temperature $\left({ }^{\circ} \mathrm{C}\right)$
36

1.9

257

113

52

14

196

0

952

70

1.0

1.7

1590

1110

945

1960

6.6
20.6
0.81

0.62

$--$

59

30

57

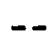

2

0

367

16

--

26

5.9

24

$--$

46

0

66

20

--

0.2

10

658

256

270

89

269

51

803

320

7.6

18.9

Reference: Onellion 1956 
TABLE 40. Water Analysis

Hydrologic Region: Lower Mississippi

Aquifer Age: Late middle Eocene

Petrology: silty clay
Aquifer Name: Cook Mountain formation

State: Arkansas

Location: Grant Co.

No. Analyses: 3

Nater Type: $\mathrm{Ca}, \mathrm{Mg}, \mathrm{Na}, \mathrm{HCO}_{3}$

Solute Concentration

Maximum Intermediate Minimum

We11 Depth (m)

Constituents $(\mathrm{mg} / \mathrm{l})$

and Properties

$\mathrm{SiO}_{2}$

53

32

53

$\mathrm{Fe}$

11.0

0.05

0.12

$\mathrm{Mn}$

Ca

$\mathrm{NO}_{3}$
$\mathrm{Mg}$

$\mathrm{Na}$

K

$\mathrm{HCO}_{3}$

$\mathrm{CO}_{3}$

$\mathrm{SO}_{4}$

C1

$\mathrm{F}$

TDS

Hardness as $\mathrm{CaCO}_{3}$

$\mathrm{Ca}, \mathrm{Mg}$

24

Noncarbonate

Sp. Cond.

(micromhos $25^{\circ} \mathrm{C}$ )

pH

6.3

Temperature $\left({ }^{\circ} \mathrm{C}\right)$

18.5

6.4

2.0

8.2

3.1

44

0

3.2

6.0

0.1

0.2

115

2

96

Reference: Terry et a1. 1979
-.

7.9

2.1

6.0

0.4

5.5

11.0

0.6

0.3

24

0

2.8

5.2

0.1

7.0

74

22

0

78

6.8

21.0
6

0

80

5.6

17.0

4.2

14

0.1

2.9

67

6 
TABLE 41. Water Analysis

Hydrologic Region: Lower Mississippi

Aquifer Name: Cane River formation

Aquifer Age: Middle Eocene

Petrology: silt, silty clay, lignite, glauconite

State: Arkansas

Location: Bradley, Calhoun, Ouachita Co's.

No. Analyses: 9

Water Type: $\mathrm{Na}, \mathrm{Cl}$

Solute Concentration

We11 Depth (m)

Constituents (mg/l) and Properties
$\mathrm{SiO}_{2}$

$\mathrm{Fe}$

$\mathrm{Mn}$

$\mathrm{Ca}$

$\mathrm{Mg}$

$\mathrm{Na}$

K

$\mathrm{HCO}_{3}$

$\mathrm{CO}_{3}$

$\mathrm{SO}_{4}$

C1

$\mathrm{F}$

$\mathrm{NO}_{3}$

TDS

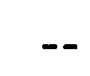

$-$

3.6

$--$

65

18

964

16

400

4

31

1410

$--$

1.9

2720

Hardness as $\mathrm{CaCO}_{3}$

$\mathrm{Ca}, \mathrm{Mg}$

236

Noncarbonate

Sp. Cond.

(microminos $25^{\circ} \mathrm{C}$ )

pH

Temperature $\left({ }^{\circ} \mathrm{C}\right)$

Reference: Albin 1962

26

4610

8.3

21.7

Maximum

Mean

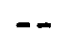

0.4

0.04

$--$

4.9

12

1.7

3.7

3.4

9.3

0.6

268

44

0

0

1.6

0.2

870

4.0

1.2

--

0.2

1450

55

44

22

0

2400

83

8.2

7.4

20.6

18.9 
TABLE 42. Water Analysis

Hydrologic Region: Lower Mississippi

Aquifer Name: Sparta sand

Aquifer Age: Middle Eocene

Petrology: sand and sandy clay
State: Arkansas

Location: Grant Co.

No. Analyses: 3

Hater Type: $\mathrm{Ca}, \mathrm{HCO}_{3}$

Solute Concentration

Maximum $\quad$ Intermediate Minimum

Well Depth (m)

Constituents $(\mathrm{mg} / \mathrm{l})$ and Properties

$\mathrm{SiO}_{2}$

14

16

24

$\mathrm{Fe}$

0.77

0.51

4.2

$\mathrm{Mn}$

$\mathrm{Ca}$

20

$\mathrm{Mg}$

$\mathrm{Na}$

3.5

70
K

$\mathrm{HCO}_{3}$

$\mathrm{CO}_{3}$

$\mathrm{SO}_{4}$

Cl

$\mathrm{F}$

$\mathrm{NO}_{3}$

TDS

5.4

193

4

42

6.5

0.3

2.6

264

64

$\mathrm{Ca}, \mathrm{Mg}$

Noncarbonate

Sp. Cond.

(micromhos $25^{\circ} \mathrm{C}$ )

$\mathrm{pH}$

Temperature $\left({ }^{\circ} \mathrm{C}\right)$

Reference: Terry et a1. 1979

0

433

8.4

--
66

0

266

6.4

20.0
6.7

13

0

53

18.5 
TABLE 43. Water Analysis

Hydrologic Region: Lower Mississippi

Aquifer Name: Sparta sand

Aquifer Age: Middle Eocene

Petrology: sand, clay, lignite
State: Arkansas

Location: Drew Co.

No. Analyses: 2

Hater Type: $\mathrm{Na}, \mathrm{HCO}_{3}$

Solute Concentration

\begin{tabular}{|c|c|c|}
\hline Maximum & Mean & Minimum \\
\hline 195 & -- & 253 \\
\hline 11 & -- & 12 \\
\hline 0.29 & -- & 0.03 \\
\hline-- & -- & -- \\
\hline 1.9 & - & 1.0 \\
\hline 0.4 & -- & 0.1 \\
\hline 184 & -- & 68 \\
\hline 2.0 & -- & 1.2 \\
\hline 425 & -- & 172 \\
\hline 0 & -- & 0 \\
\hline 5.4 & -- & 5.8 \\
\hline 38 & -- & 5.0 \\
\hline 0.6 & -- & 0 \\
\hline 2.5 & - & 1.2 \\
\hline 464 & -- & 188 \\
\hline 6 & -- & 3 \\
\hline 0 & -- & 0 \\
\hline 749 & - & 293 \\
\hline 8.0 & -- & 7.7 \\
\hline-- & -- & 22.8 \\
\hline
\end{tabular}

Reference: Onellion 1956 
TABLE 44. Water Analysis

Hydrologic Region: Lower Mississippi

Aquifer Name: Sparta sand

Aquifer Age: Middle Eocene

Petrology: fine to medium sand and sandy clay
State: Arkansas

Location: Bradley, Calhoun, Ouachita Co's.

No. Analyses: 34

Water Type: $\mathrm{Na}, \mathrm{HCO}_{3}$

Solute Concentration

Mean

Maximum

Wel1 Depth (m)

Constituents $(\mathrm{mg} / \mathrm{l})$ and Properties

$\mathrm{SiO}_{2}$

$\mathrm{Fe}$

$\mathrm{Mn}$

$\mathrm{Ca}$

$\mathrm{Mg}$

$\mathrm{Na}$

K

$\mathrm{HCO}_{3}$

$\mathrm{CO}_{3}$

$\mathrm{SO}_{4}$

C1

$\mathrm{F}$

$\mathrm{NO}_{3}$

TDS

Hardness as $\mathrm{CaCO}_{3}$

$\mathrm{Ca}, \mathrm{Mg}$

Noncarbonate

Sp. Cond.

(micromhos $25^{\circ} \mathrm{C}$ )

pH

Temperature $\left({ }^{\circ} \mathrm{C}\right)$

Reference: Albin 1962
53

23

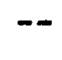

24

6.3

132

5.6

334

2

25

84

1.2

2.1

362

84

20

584

28.3
20

0.3

5.2

2.3

18

3.5

110

0

4.1

5.8

0.1

0.4

147

30

0

210

--

18.9
3.9

0

1.0

0

2.3

0.7

0

0

0.2

3.5

0.1

0

42

4

0

43

--

18.3 


\section{TABLE 45. Water Analysis}

Hydrologic Region: Lower Mississippi

Aquifer Name: Carrizo sand

Aquifer Age: Early Eocene

Petrology: very fine to medium sand
State: Arkansas

Location: Bradley, Calhoun, Ouachita Co's.

No. Analyses: 3

Water Type: $\mathrm{Na}, \mathrm{HCO}_{3}$

Solute Concentration
Constituents $(\mathrm{mg} / \mathrm{l})$
He11 Depth (m) and Properties

$$
\mathrm{SiO}_{2}
$$

$\mathrm{Fe}$

$\mathrm{Mn}$

$\mathrm{Ca}$

$\mathrm{Mg}$

$\mathrm{Na}$

$\mathrm{K}$

$\mathrm{HCO}_{3}$

$\mathrm{CO}_{3}$

$\mathrm{SO}_{4}$

$\mathrm{Cl}$

$\mathrm{F}$

$\mathrm{NO}_{3}$

TDS

Maximum

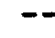

0.77

$--$

20

7.0

1050

11

518

10

6.0

1350

4.7

2820

79

0

Noncarbonate

Sp. Cond.

(micromhos $25^{\circ} \mathrm{C}$ )

$\mathrm{pH}$

Temperature $\left({ }^{\circ} \mathrm{C}\right)$

Reference: Albin 1962

4680

8.4

18.3
Mean

Minimum

m

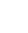
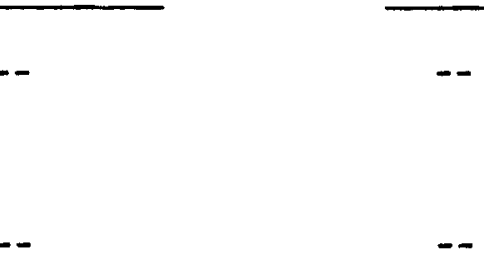

0.04

$-$

4.0

1.2

18

0.6

58

0

0.4

5.8

0.8

90

134

15

0

20

127

7.7

7.2

18.3

18.3 


\section{TABLE 46. Water Analys is}

Hydrologic Region: Lower Mississippi

Aquifer Name: Wilcox group

Aquifer Age: Early Eocene

Petrology: clay, sand, lignite, glauconite

Well Depth (m)

Constituents $(\mathrm{mg} / \mathrm{l})$

and Properties

$\mathrm{SiO}_{2}$

$\mathrm{Fe}$

$\mathrm{Mn}$

Ca

$\mathrm{Mg}$

$\mathrm{Na}$

K

$\mathrm{HCO}_{3}$

$\mathrm{CO}_{3}$

$\mathrm{SO}_{4}$

C1

$\mathrm{F}$

$\mathrm{NO}_{3}$

TDS

Hardness as $\mathrm{CaCO}_{3}$

$\mathrm{Ca}, \mathrm{Mg}$

Noncarbonate

Sp. Cond.

(micromhos $25^{\circ} \mathrm{C}$ )

$\mathrm{pH}$

Temperature $\left({ }^{\circ} \mathrm{C}\right)$

Reference: Albin 1962
State: Arkansas

Location: Bradley, Calhoun, Ouachita Co's.

No. Analyses: 1

Water Type: $\mathrm{Na}, \mathrm{Cl}$

Solute Concentration 
TABLE 47. Water Analysis

Hydrologic Region: Lower Mississippi and Arkansas - White - Red

Aquifer Name: Wilcox group

Aquifer Age: Early Eocene

Petrology: clay, sand, lignite, glauconite
State: Arkansas

Location: Hot Spring Co.

No. Analyses: 3

Hater Type: $\mathrm{Ca}, \mathrm{Na}, \mathrm{HCO}_{3}$

Solute Concentration

Well Depth (m)

Constituents $(\mathrm{mg} / \mathrm{l})$

and Properties

$\mathrm{SiO}_{2}$

$\mathrm{Fe}$

$\mathrm{Mn}$

$\mathrm{Ca}$

$\mathrm{Mg}$

$\mathrm{Na}$

K

$\mathrm{HCO}_{3}$

$\mathrm{CO}_{3}$

$\mathrm{SO}_{4}$

Cl

$\mathrm{F}$

$\mathrm{NO}_{3}$

TDS
12

0.15

$--$

18

5.5

109

3.0

178

0

2.8

114

\section{4}

0.2

352

Hardness as $\mathrm{CaCO}_{3}$

$\mathrm{Ca}, \mathrm{Mg}$

Noncarbonate

Sp. Cond.

(micromhos $25^{\circ} \mathrm{C}$ )

pH

Temperature $\left({ }^{\circ} \mathrm{C}\right)$

Reference: Terry et a1. 1979

68

0

661

Intermediate

Minimum

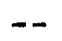

16

4.0

$--$

7.5

2.7

3.2

3.0

41

0

3.6

3.0

0.2

0

64

107

30

0

0

293

82

7.9
19.0

7.8

6.7

18.0

18.0 
Hydrologic Region: Lower Mississippi

Aquifer Name: Midway group

Aquifer Age: Paleocene

Petrology: clay (a poor aquifer)
State: Arkansas

Location: Bradley, Calhoun, Ouachita Co's.

No. Analyses: 1

Water Type: $\mathrm{Na}, \mathrm{Cl}$

Solute Concentration

We11 Depth (m)

Constituents $(\mathrm{mg} / \mathrm{l})$

and Properties

$\mathrm{SiO}_{2}$

$\mathrm{Fe}$

0.7

$\mathrm{Mn}$

$\mathrm{Ca}$

13

$\mathrm{Mg}$

3.1

$\mathrm{Na}$

842

$\mathrm{K}$

8.4

$\mathrm{HCO}_{3}$

320

$\mathrm{CO}_{3}$

0

$\mathrm{SO}_{4}$

6.2

C1

1120

$\mathrm{F}$

$\mathrm{NO}_{3}$

1.5

TDS

2260

Hardness as $\mathrm{CaCO}_{3}$

$\mathrm{Ca}, \mathrm{Mg}$

45

Noncarbonate

Sp. Cond.

(micromhos o $25^{\circ} \mathrm{C}$ )

3970

$\mathrm{pH}$

8.0

Temperature $\left({ }^{\circ} \mathrm{C}\right)$

17.8

Reference: Albin 1962 
TABLE 49. Water Analysis

Hydrologic Region: Lower Mississippi and
Arkansas - White - Red

Aquifer Name: Midway group

Aquifer Age: Paleocene

Petrology: clay
State: Arkansas

Location: Saline Co.

No. Analyses: 3

Water Type: $\mathrm{Ca}, \mathrm{Na}, \mathrm{HCO}_{3}$

Solute Concentration

Maximum Intermediate Minimum

Hell Depth (m)

Constituents $(\mathrm{mg} / \mathrm{l})$

and Properties

$\mathrm{SiO}_{2}$

$\mathrm{Fe}$

$\mathrm{Mn}$

$\mathrm{Ca}$

$\mathrm{Mg}$

$\mathrm{Na}$

$\mathrm{K}$

$\mathrm{HCO}_{3}$

$\mathrm{CO}_{3}$

$\mathrm{SO}_{4}$

$\mathrm{Cl}$

$\mathrm{F}$

$\mathrm{NO}_{3}$

TDS

Hardness as $\mathrm{CaCO}_{3}$

$\mathrm{Ca}, \mathrm{Mg}$

Noncarbonate

Sp. Cond.

(micromhos $25^{\circ} \mathrm{C}$ )

$\mathrm{pH}$

Temperature $\left({ }^{\circ} \mathrm{C}\right)$
7.8

0

--

40

12

34

8.8

254

0

11

7.0

0.5

0

246

150

0

396

7.6

18.0
16

0.3

$--$

19

13

35

9

--

6

7.6

12

0.4

2.6

213

101

0

352

8.5

18.0
12

0.01

$--$

40

13

7.4

3.1

188

0

8.6

7.4

0.2

0.1

184

154

0

318

8.1

19.0

Reference: Terry et a) 1979 


\section{TABLE 50. Water Analysis}

Hydrologic Region: Lower Mississippi

Aquifer Name: Chicot aquifer

Aquifer Age: Pleistocene

Petrology: sand, gravel, silt, clay
State: Southwestern Louisiana

Location: Beauregard and St. Landry Parishes

No. Analyses: 47

Hater Type: $\mathrm{Na}, \mathrm{HCO}_{3}$

Solute Concentration

\begin{tabular}{lll}
\hline High & Intermediate & Low \\
\cline { 2 - 3 } & 150 & 148
\end{tabular}

Well Depth (m)

Constituents $(\mathrm{mg} / \ell$ ) and Properties

$\mathrm{SiO}_{2}$

$\mathrm{Fe}$

$\mathrm{Mn}$

$\mathrm{Ca}$

$\mathrm{Mg}$

$\mathrm{Na}$

K

$\mathrm{HCO}_{3}$

$\mathrm{CO}_{3}$

$\mathrm{SO}_{4}$

C1

$\mathrm{F}$

$\mathrm{NO}_{3}$

TDS

Hardness as $\mathrm{CaCO}_{3}$

$\mathrm{Ca}, \mathrm{Mg}$

Noncarbonate

Sp. Cond.

(micromhos $25^{\circ} \mathrm{C}$ )

pH

Temperature $\left({ }^{\circ} \mathrm{C}\right)$

Reference: Whitfield 1975
42

93

31

46

0.85

$-$

24

8.0

175

2.6

382

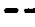

2.2

101

0.3

0

543

0.39

0.09

27

6.9

134

1.8

403

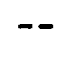

0

44

0.4

0.7

445

96

900

711

7.6

23.5
7.6

7.8

21.5

22.0
60

325

139

2.2

32

0.2

0.1

219

$-$ 
TABLE 51. Water Analysis

Hydrologic Region: Lower Mississippi

Aquifer Name: Gonzales-New Orleans

Aquifer Age: Pleistocene

Petrology: fine to medium sand
State: Louisiana

Location: Gramercy area

No. Analyses: 3

Hater Type: $\mathrm{Na}, \mathrm{HCO}_{3}, \mathrm{Cl}$

Solute Concentration

Maximum

Well Depth (m) 183 Intermediate

175

143

Constituents $(\mathrm{mg} / \mathrm{l})$ and Properties

$\mathrm{SiO}_{2}$

$\mathrm{Fe}$

$\mathrm{Mn}$

Ca

$\mathrm{Mg}$

$\mathrm{Na}$

K

$\mathrm{HCO}_{3}$

$\mathrm{CO}_{3}$

$\mathrm{SO}_{4}$

$\mathrm{Cl}$

$\mathrm{F}$

$\mathrm{NO}_{3}$

TDS

Hardness as $\mathrm{CaCO}_{3}$

$\mathrm{Ca}, \mathrm{Mg}$

Noncarbonate

Sp. Cond.

(micromhos $25^{\circ} \mathrm{C}$ )

pH

Temperature $\left({ }^{\circ} \mathrm{C}\right)$
23

7.7

25

0.03

0.02

3.0

0.6

170

1.8

222

4

0.4

130

0.5

0.04

444

10

18

1200

790

375

23.0

7.8

23.0

8.1 23.0

Reference: Dial and Kilburn 1980 
TABLE 52. Water Analys is

Hydrologic Region: Lower Mississippi

Aquifer Name: Gramercy aquifer

Aquifer Age: Pleistocene

Petrology: fine to coarse sand
State: Louisiana

Location: Gramercy area

No. Analyses: 3

Water Type: $\mathrm{Na}, \mathrm{HCO}_{3}, \mathrm{Cl}$

Solute Concentration

\begin{tabular}{lll}
\hline Maximum & $\frac{\text { Intermediate }}{79}$ & Minimum \\
81 & 79 & 66
\end{tabular}

Hell Depth (m)

26

26

13

$\mathrm{SiO}_{2}$

0.36

0.18

0.91

$\mathrm{Mn}$

$--$

0.04

0.17

$\mathrm{Ca}$

34

18

61

$\mathrm{Mg}$

13

5.6

24

$\mathrm{Na}$

570

K

3.1

$\mathrm{HCO}_{3}$

$\mathrm{CO}_{3}$

272

0

$\mathrm{SO}_{4}$

0.6

C1

820

$F$

0.3

360

100

4.5

2.8

436

344

0

0

1.0

2.8

340

130

$\mathrm{NO}_{3}$

0.7

TDS

1600

0.5

0.2

0.26

0.6

971

503

Hardness as $\mathrm{CaCO}_{3}$

$\mathrm{Ca}, \mathrm{Mg}$

140

68

250

Noncarbonate

Sp. Cond.

(micromhos $25^{\circ} \mathrm{C}$ )

2990

1720

937

pH

7.7

7.8

7.5

Temperature $\left({ }^{\circ} \mathrm{C}\right)$

20.5

21.0 
TABLE 53. Water Analysis

Hydrologic Region: Lower Mississippi

Aquifer Mane: Mississippi River Valley Alluvial Aquifer

Aquifer Age: Pleistocene

Petrology: sand, gravel
State: Louisiana

Location: Caldwell Parish

No. Analyses: 3

Water Type: $\mathrm{Na}, \mathrm{Cl}$

Solute Concentration

Well Depth (m)

Constituents $(\mathrm{mg} / \mathrm{l})$ and Properties

$\mathrm{SiO}_{2}$

$\mathrm{Fe}$

$\mathrm{Mn}$

$\mathrm{Ca}$

$\mathrm{Mg}$

$\mathrm{Na}$

K

$\mathrm{HCO}_{3}$

$\mathrm{CO}_{3}$

$\mathrm{SO}_{4}$

$\mathrm{Cl}$

$\mathrm{F}$

$\mathrm{NO}_{3}$

TDS
20

22

0.62

260

100

2400

20

385

28

4100

0.3

7090

1000

$\mathrm{Ca}, \mathrm{Mg}$

Noncarbonate

Sp. Cond.

(micromhos $25^{\circ} \mathrm{C}$ )

pH

Temperature $\left({ }^{\circ} \mathrm{C}\right)$

12500

6.8

19.5

Intermediate

10

20

25

1.4

250

91

760

12

433

$-$

6.0

1600

0.3

22

3.2

0.6

66

16

29

1.0

302

-.

25

14

0.3

0.1

323

2950

1000

230

5550

530

6.9

6.9

19.0

\section{6}

.

.

.

1$$
\text { ( }
$$

$--$

6.9

\footnotetext{
Reference: Whitfield 1975
} 


\section{TABLE 54. Water Analysis}

Hydrologic Region: Lower Mississippi

Aquifer Name: Mississippi River Valley Alluvial Aquifer

Aquifer Age: Pleistocene

Petrology: sand, gravel
State: Louisiana

Location: Ouachita Parish

No. Analyses: 3

Hater Type: $\mathrm{Ca}, \mathrm{Na}, \mathrm{Cl}$

Solute Concentration

Hell Depth (m)

Constituents $(\mathrm{mg} / \mathrm{l})$

and Properties

$\mathrm{SiO}_{2}$

$\mathrm{Fe}$

$\mathrm{Mn}$

$\mathrm{Ca}$

$\mathrm{Mg}$

$\mathrm{Na}$

$\mathrm{K}$

$\mathrm{HCO}_{3}$

$\mathrm{CO}_{3}$

$\mathrm{SO}_{4}$

C1

$\mathrm{F}$

$\mathrm{NO}_{3}$

TDS

Maximum

7

48

1.1

0.54

340

130

940

5.9

282

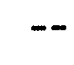

470

1800

0.3

3920

Hardness as $\mathrm{CaCO}_{3}$

$\mathrm{Ca}, \mathrm{Mg}$

Noncarbonate

Sp. Cond.

(micromhos $25^{\circ} \mathrm{C}$ )

pH

Temperature $\left({ }^{\circ} \mathrm{C}\right)$

Reference: Whitfield 1975

1400

6430

6.8

Intermediate

15

Minimum

24

20

3.5

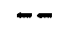

$--$

--

43

30

160

630

6.7

594

459

510

1.0

1400

27

0.2

--

7.7

3420

492

1600

230

5860

$--$ 
Hydrologic Region: Lower Mississippi

Aquifer Name: Norco aquifer

Aquifer Age: Pleistocene

Petrology: fine to coarse sand
State: Louisiana

Location: Gramercy area

No. Analyses: 3

Hater Type: $\mathrm{Na}, \mathrm{Cl}$

Solute Concentration

We11 Depth (m)

Maximum

Constituents ( $\mathrm{mg} / \mathrm{l}$ )

and Properties
$\mathrm{SiO}$
$\mathrm{Mn}$
$\mathrm{Ca}$
$\mathrm{Mg}$
$\mathrm{Na}$
$\mathrm{K}$
$\mathrm{HCO}$
$\mathrm{CO}$
$\mathrm{SO}_{4}$
$\mathrm{Cl}^{2}$
$\mathrm{~F}^{2}$
$\mathrm{NO}_{3}$

TDS
Intermediate

127

21

$--$

$--$

28

18

550

1100

4.3

275

0

12

1700

0.6

0.1

3030

280

$\mathrm{Ca}, \mathrm{Mg}$

Noncarbonate

Sp. Cond.

(micromhos $25^{\circ} \mathrm{C}$ )

$\mathrm{pH}$

Temperature $\left({ }^{\circ} \mathrm{C}\right)$

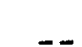

5520

7.6
21.0
3.8

238

0

1.4

800

0.3

0.2

1540

140

2880

7.8
21.5
280

1340

25

1.3

--

55

36

180

2.5

487

0

0.2

210

0.1

0.1

743

7.3

20.0

Reference: Dial and Kilburn 1980 
Hydrologic Region: Lower Mississippi Aquifer Name: Pleistocene Alluvium Aquifer Age: Pleistocene

Petrology: silt, sand and gravel
State: Louisiana

Location: Morehouse Parish

No. Analyses: 3

Water Type: $\mathrm{Ca}, \mathrm{Na}, \mathrm{HCO}_{3}$

Solute Concentration

\begin{tabular}{ccc}
\hline High & Intermediate & Low \\
32 & 20 & 30 \\
& & \\
29 & & 38 \\
6.6 & 28 & 0.05 \\
-- & 0.76 & 0.02 \\
110 & -- & 1.7 \\
43 & 68 & 0.9 \\
71 & 17 & 6.0 \\
2.8 & 27 & 0.6 \\
473 & 1.4 & 18 \\
-- & 348 & -- \\
62 & -- & 0.6 \\
113 & 0.4 & 5.2 \\
0.4 & 11 & 0.1 \\
-- & 0.2 & 2.0 \\
653 & 0.1 & 64 \\
& 327 & \\
452 & & 8 \\
64 & 240 & 0 \\
1140 & 0 & 53 \\
7.0 & 563 & \\
18 & 7.1 &
\end{tabular}

Reference: Sanford 1972 


\section{TABLE 57. Water Analysis}

Hydrologic Region: Lower Mississippi

Aquifer Name: Shallow aquifer

Aquifer Age: Pleistocene

Petrology: sand, gravel
State: Louisiana

Location: Gramercy area

No. Analyses: 3

Nater Type: $\mathrm{Ca}, \mathrm{HCO}_{3}$

Solute Concentration

Maximum

Hell Depth (m)

42

41

41

Constituents $(\mathrm{mg} / \mathrm{l})$ and Properties

$\mathrm{SiO}_{2}$

25

$--$

$\mathrm{Fe}$

$\mathrm{Mn}$

$\mathrm{Ca}$

$\mathrm{Mg}$

$\mathrm{Na}$

$\mathrm{K}$

$\mathrm{HCO}_{3}$

$\mathrm{CO}_{3}$

$\mathrm{SO}_{4}$

$\mathrm{Cl}$

$\mathrm{F}$

$\mathrm{NO}_{3}$

TDS

Hardness as $\mathrm{CaCO}_{3}$

$\mathrm{Ca}, \mathrm{Mg}$

480

Noncarbonate

Sp. Cond. (micromhos $25^{\circ} \mathrm{C}$ )

$\mathrm{pH}$

7.2

Temperature $\left({ }^{\circ} \mathrm{C}\right)$ Intermediate

Minimum

17

28

0.540

100

100

50

53

36

21

16

120

22

2.2

786

281

0

0

1.4

0.2

0.6

580

0.2

240

180

0.2

0.1

0

0

1520

1020

538

400

210

2680

853

959

Reference: Dial and Kilburn 1980
6.7
20.5

7.3 
TABLE 58. Water Analysis

Hydrologic Region: Lower Mississippi

Aquifer Nane: Terrace aquifers

Aquifer Age: Pleistocene

Petrology: poorly sorted siliceous sand and gravel
State: Louisiana

Location: Grant Parish

No. Analyses: 3

Nater Type: $\mathrm{Ca}, \mathrm{HCO}_{3}$

Solute Concentration

Well Depth (m)

Constituents (ng/l)

and Properties

$\mathrm{SiO}_{2}$

$\mathrm{Fe}$

$\mathrm{Mn}$

$\mathrm{Ca}$

$\mathrm{Mg}$

$\mathrm{Na}$

K

$\mathrm{HCO}_{3}$

$\mathrm{CO}_{3}$

$\mathrm{SO}_{4}$

C1

F

$\mathrm{NO}_{3}$

TDS
15

0.15

--

190

110

130

1.8

592

0

420

200

0.5

0.1

1360

940

$\mathrm{Ca}, \mathrm{Mg}$

Noncarbonate

Sp. Cond.

(micromhos $25^{\circ} \mathrm{C}$ )

pH

Temperature $\left({ }^{\circ} \mathrm{C}\right)$

2020

7.3
Intermediate

19

20

15

0.93

0.05

2.0

0.2

4.5

1.6

22

0

0

1.4

0

112

765

610

6

1270

146

6.5

7.3

Reference: Snider and Sanford 1981 
TABLE 59. Water Analysis

Hydrologic Region: Lower Mississippi

Aquifer Name: Terrace aquifers

Aquifer Age: Pleistocene

Petrology: poorly sorted siliceous sand and gravel
State: Louisiana

Location: LaSalle Parish

Mo. Analyses: 3

Mater Type: $\mathrm{Na}, \mathrm{C} 1$

Solute Concentration

Maximum

29

33

0.14

0.03

210

82

1100

19

21

0

19

2200

0.1

3650

TDS

Hardness as $\mathrm{CaCO}_{3}$

$\mathrm{Ca}, \mathrm{Mg}$

860

Noncarbonate

Sp. Cond.

(micromhos $25^{\circ} \mathrm{C}$ )

pH

Temperature $\left({ }^{\circ} \mathrm{C}\right)$

Reference: Snider and Sanford 1981

6770

6.8

Intermediate

13

Minimum

18

15

25.0

0.27

3.7

0.10

38

36

9.7

16

720

74

10

8.8

8

0

0

3.2

220

1200

0.1

0.1

388

2030

140

160

4030

762

5.5

5.5 
TABLE 60. Water Analysis

Hydrologic Region: Lower Mississippi

Aquifer Mame: "700-Foot" Sand

Aquifer Age: Pleistocene

Petrology: fine to coarse-grained sand
State: Louisiana

Location: Washington Parish

No. Analyses: 3

Nater Type: $\mathrm{Ca}, \mathrm{HCO}_{3}$

Solute Concentration

Maximum $\quad$ Intermediate

Well Depth (m)

208

234

234

Constituents $(\mathrm{mg} / \mathrm{l})$

and Properties

$\mathrm{SiO}_{2}$

60

50

27

$\mathrm{Fe}$

$\mathrm{Mn}$

$\mathrm{Ca}$

$\mathrm{Mg}$

$\mathrm{Na}$

$\mathrm{K}$

$\mathrm{HCO}_{3}$

$\mathrm{CO}_{3}$

$\mathrm{SO}_{4}$

$\mathrm{Cl}$

$\mathrm{F}$

$\mathrm{NO}_{3}$

TDS

Hardness as $\mathrm{CaCO}_{3}$

$\mathrm{Ca}, \mathrm{Mg}$

16

Noncarbonate

Sp. Cond.

(microwhos $25^{\circ} \mathrm{C}$ )

pH

Temperature $\left({ }^{\circ} \mathrm{C}\right)$

7.3

6.5

6.8

23.5

24.0

23.5

Reference: Case 1979 


\section{TABLE 61. Water Analysis}

Hydrologic Region: Lower Mississippi

Aquifer Name: "1500-F oot" Sand

Aquifer Age: Pliocene

Petrology: medium-grained sand
State: Louisiana

Location: Washington Parish

No. Analyses: 3

Hater Type: $\mathrm{Na}, \mathrm{HCO}_{3}$

Solute Concentration

Well Depth (m)

Constituents $(\mathrm{mg} / \mathrm{l})$

and Properties

$\mathrm{SiO}_{2}$

$\mathrm{Fe}$

$\mathrm{Mn}$

$\mathrm{Ca}$

$\mathrm{Mg}$

$\mathrm{Na}$

$\mathrm{K}$

$\mathrm{HCO}_{3}$

$\mathrm{CO}_{3}$

$\mathrm{SO}_{4}$

$\mathrm{Cl}$

$\mathrm{F}$

$\mathrm{NO}_{3}$

TDS
45

0.09

--

0

0

52

0.3

119

0

9.6

4.1

0.1

$--$

170

Hardness as $\mathrm{CaCO}_{3}$

$\mathrm{Ca}, \mathrm{Mg}$

0

Noncarbonate

Sp. Cond.

(microwhos $25^{\circ} \mathrm{C}$ )

pH

Temperature $\left({ }^{\circ} \mathrm{C}\right)$

Reference: Case 1979

217

28.0

Maximum

Intermediate

Minimum

44

47

--

0.03

--

0

0.4

0

41

0.4

92

102

0

9.4

0

8.8

3.7

3.3

0.4

0.4

-.

0

156

146

1

--

178

191

$$
7.4
$$

28.0 


\section{TABLE 62. Water Analysis}

Hydrologic Region: Lower Mississippi

Aquifer Name: Evangeline aquifer

Aquifer Age: Miocene and Pliocene

Petrology: sand, silt, clay
State: Southwestern Louisiana

Location: Allen, Beauregard, Evangeline and St. Landry Parishes

No. Analyses: 82

Water Type: $\mathrm{Na}, \mathrm{HCO}_{3}$

Solute Concentration

\begin{tabular}{ccc} 
Maximum & Intermediate & Minimum \\
\cline { 2 - 3 } 99 & 113 & 215 \\
& & \\
28 & 45 & 18 \\
-- & 0.33 & 0.37 \\
-- & -- & 0.03 \\
27 & 3.0 & 13 \\
2.6 & 1.1 & 1.8 \\
465 & 270 & 43 \\
2.6 & 1.2 & 1.9 \\
380 & 647 & 145 \\
-- & -- & -- \\
0 & 0.2 & 5.6 \\
574 & 39 & 5.9 \\
0.8 & 0.8 & 0.1 \\
0 & 0.4 & 0.1 \\
1290 & 680 & 160
\end{tabular}

Hardness as $\mathrm{CaCO}_{3}$

$\mathrm{Ca}, \mathrm{Mg}$

78

12

Noncarbonate

Sp. Cond.

(micromhos $25^{\circ} \mathrm{C}$ )

$\mathrm{pH}$

Temperature $\left({ }^{\circ} \mathrm{C}\right)$
2310

$$
7.7
$$

20.5

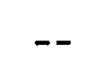

1050

7.2

20.5
40

18

.37

0.03

1.8

1.9

45

5.6

5.9

0.1

0.1

60

254

7.5

22.0

Reference: Whitfield 1975 
Hydrologic Region: Lower Mississippi Aquifer Name: Franklinton aquifer Aquifer Age: Miocene

Petrology: medium to coarse sand
State: Louisiana

Location: Washington Parish No. Analyses: 3

Water Type: $\mathrm{Na}, \mathrm{HCO}_{3}$

Solute Concentration

$\begin{array}{lll}\text { Maximum } & \text { Intermediate } & \text { Minimu } \\ 726 & 837 & 823\end{array}$

Hell Depth (m)

$\mathrm{SiO}_{2}$

$\mathrm{Fe}$

$\mathrm{Mn}$

$\mathrm{Ca}$

$\mathrm{Mg}$

$\mathrm{Na}$

$\mathrm{K}$

$\mathrm{HCO}_{3}$

$\mathrm{CO}_{3}$

$\mathrm{SO}_{4}$

C1

$F$

$\mathrm{NO}_{3}$

TDS

Hardness as $\mathrm{CaCO}_{3}$

$\mathrm{Ca}, \mathrm{Mg}$

Noncarbonate

Sp. Cond.

(micromhos $25^{\circ} \mathrm{C}$ )

$\mathrm{pH}$

Temperature $\left({ }^{\circ} \mathrm{C}\right)$

Reference: Case 1979
53

0.09

0.023

0.4

0

100

18

8.1

$--$

0.06

--

0.005

1.1

0.3

0.4

0.3

108

95

1.3

242

7

7.2

2.0

0.9

0.41

291

1

420

8.7

30.5
4

2

244

6

2.0

18

$--$

--

274

2.0

212

0

5.2

20

0.8

0.6

236

417

375

8.5

8.6

30.5 
TABLE 64. Water Analysis

Hydrologic Region: Lower Mississippi

Aquifer Name: Jasper aquifer

Aquifer Age: Miocene

Petrology: sand, silt, clay
State: Southwestern Louisiana

Location: Allen and Beauregard Parishes

No. Analyses: 8

Water Type: $\mathrm{Na}, \mathrm{HCO}_{3}$

Solute Concentration

Maximum

533

482

353

Well Depth (m)

Intermediate

Minimum

Constituents $(\mathrm{mg} / \mathrm{l})$

and Properties

$\mathrm{SiO}_{2}$

25

15

18

$\mathrm{Fe}$

0.3

0.07

0.03

$\mathrm{Mn}$

$\mathrm{Ca}$

$--$

3.0

1.6

353

$\mathrm{Na}$

K

$\mathrm{HCO}_{3}$

$\mathrm{CO}_{3}$

$\mathrm{SO}_{4}$

$\mathrm{Cl}$

$\mathrm{F}$

$\mathrm{NO}_{3}$

TDS

Hardness as $\mathrm{CaCO}_{3}$

$\mathrm{Ca}, \mathrm{Mg}$

14

10

5

Noncarbonate

Sp. Cond.

(microwhos $25^{\circ} \mathrm{C}$ )

$\mathrm{pH}$

8.3

8.2

8.5

23.5

29.5

28.0

Reference: Whitfield 1975 


\section{TABLE 65. Water Analysis}

Hydrologic Region: Lower Mississippi

Aquifer Name: Ramsey aquifer

Aquifer Age: Miocene

Petrology: medium to coarse-grained

Well Depth (m)

Constituents $(\mathrm{mg} / \mathrm{l})$

and Properties

$\mathrm{SiO}_{2}$

$\mathrm{Fe}$

$\mathrm{Mn}$

$\mathrm{Ca}$

Mg

$\mathrm{Na}$

K

$\mathrm{HCO}_{3}$

$\mathrm{CO}_{3}$

$\mathrm{SO}_{4}$

C1

$\mathrm{F}$

$\mathrm{NO}_{3}$

TDS
State: Louisiana

Location: Washington Parish

No. Analyses: 1

Hater Type: $\mathrm{Na}, \mathrm{HCO}_{3}$

Solute Concentration

Hardness as $\mathrm{CaCO}_{3}$

$\mathrm{Ca}, \mathrm{Mg}$

5

Noncarbonate

104

Sp. Cond.

(micromhos $25^{\circ} \mathrm{C}$ )

pH

6.7

Temperature $\left({ }^{\circ} \mathrm{C}\right)$

31.5

Reference: Case 1979 
TABLE 66. Water Analysis

Hydrologic Region: Lower Mississippi

Aquifer Name: Cockfield formation

Aquifer Age: Eocene

Petrology: sand, silt, interbedded clay
State: Louisiana

Location: Morehouse Parish

No. Analyses: 18

Water Type: $\mathrm{Ca}, \mathrm{HCO}_{3}$

Solute Concentration

Maximum $\quad$ Intermediate

We11 Depth (m)

Constituents $(\mathrm{mg} / \ell)$ and Properties

$\mathrm{SiO}_{2}$

$\mathrm{Fe}$

$\mathrm{Mn}$

$\mathrm{Ca}$

$\mathrm{Mg}$

$\mathrm{Na}$

K

$\mathrm{HCO}_{3}$

$\mathrm{CO}_{3}$

$\mathrm{SO}_{4}$

C1

$\mathrm{F}$

$\mathrm{NO}_{3}$

TDS
27

2.4

--

68

18

30

1.8

336

--

6.8

16

0.2

--

334

242

$\mathrm{Ca}, \mathrm{Mg}$

Noncarbonate

Sp. Cond.

(micromhos a $25^{\circ} \mathrm{C}$ )

$\mathrm{pH}$

Temperature $\left({ }^{\circ} \mathrm{C}\right)$

Reference: Sanford 1972

0

568

6.5

20
23

34

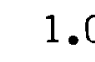

$-$

58

11

15

1.6

260

--

8.2

5.0

3.0

2.0

0.4

0.2

0

0

248

147

190

91

428

221

6.9

6.8 
TABLE 67. Water Analysis

Hydrologic Region: Lower Mississippi

Aquifer Name: Cook Mountain formation

Aquifer Age: Eocene

Petrology: sand beds in clay
State: Louisiana

Location: Morehouse Parish

No. Analyses: 4

Hater Type: $\mathrm{Na}, \mathrm{HCO}_{3}, \mathrm{Cl}$

Solute Concentration

$\begin{array}{lll}\text { Maximum } & \frac{\text { Intermediate }}{133} & \text { Minimum } \\ 100 & 115\end{array}$

We11 Depth (m)

Constituents $(\mathrm{mg} / \ell)$ and Properties

$\begin{array}{lc}\mathrm{SiO}_{2} & 10 \\ \mathrm{Fe} & 0.28 \\ \mathrm{Mn} & -- \\ \mathrm{Ca} & 6.8 \\ \mathrm{Mg} & 0.7 \\ \mathrm{Na} & 451 \\ \mathrm{~K} & 4.7 \\ \mathrm{HCO}_{3} & 520 \\ \mathrm{CO}_{3} & -- \\ \mathrm{SO}_{4} & 1.4 \\ \mathrm{Cl} & 410 \\ \mathrm{~F} & 2.4 \\ \mathrm{NO}_{3} & 0.1 \\ \mathrm{TDS} & 1140\end{array}$

Hardness as $\mathrm{CaCO}_{3}$

$\mathrm{Ca}, \mathrm{Mg}$

Noncarbonate

Sp. Cond.

(microminos $25^{\circ} \mathrm{C}$ )

pH

Temperature $\left({ }^{\circ} \mathrm{C}\right)$

Reference: Sanford 1972
10

0.83

11

1.1

17

7.2

3.1

3.9

170

3.1

138

317

2.7

362

--

0.2

0.2

114

28

0.4

0.7

0.3

0.7

474

370

55

34

0

0

1970

837

639

7.8

7.9

7.4

21

22 
TABLE 68. Water Analysis

Hydrologic Region: Lower Mississippi

Aquifer Name: Sparta sand

Aquifer Age: Eocene

Petrology: sand, silt, clay, lignite
State: Louisiana

Location: Morehouse Parish

No. Analyses: 19

Water Type: $\mathrm{Na}, \mathrm{HCO}_{3}, \mathrm{Cl}$

Solute Concentration

Maximum

229

224

Minimum

151

Constituents $(\mathrm{mg} / \mathrm{l})$

and Properties

$\mathrm{SiO}_{2}$

38

13

11

$\mathrm{Fe}$

1.1

0.18

0.15

$\mathrm{Mn}$

$\mathrm{Ca}$

$\mathrm{Na}$

K

$\mathrm{HCO}_{3}$

$\mathrm{CO}_{3}$

$\mathrm{SO}_{4}$

C1

$F$

$\mathrm{NO}_{3}$

TDS

Hardness as $\mathrm{CaCO}_{3}$

$\mathrm{Ca}, \mathrm{Mg}$

Noncarbonate

Sp. Cond.

(micromhos $25^{\circ} \mathrm{C}$ )

pH

Temperature $\left({ }^{\circ} \mathrm{C}\right)$

Reference: Sanford 1972

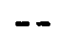

$$
2.3
$$

1.0

465

2.5

440

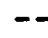

0

460

1.8

0

1200

10

--

1.5

2.2

0.3

1.1

395

0.6

280

0.8

400

413

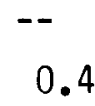

0.2

380

193

0.5

0.1

1.0

988

0

692

10

0

2100

1800

$$
8.4
$$

24
1220

8.2

8.2

23.5

0

(20

24.5 


\section{TABLE 69. Water Analysis}

Hydrologic Region: Lower Mississippi

Aquifer Name: Mississippi River Valley Alluvial Aquifer

Aquifer Age: Pleistocene

Petrology: clay, silt, sand, gravel
State: Mississippi

Location: Sharkey and Yazoo Co's. No. Analyses: 5

Water Type: $\mathrm{Ca}, \mathrm{HCO}_{3}$

Solute Concentration

\begin{tabular}{|c|c|}
\hline$\overline{\text { Maximum }}$ & Intermediate \\
\hline 37 & 33 \\
\hline
\end{tabular}

Well Depth (m)

$\mathrm{SiO}_{2}$

$\mathrm{Fe}$

$\mathrm{Ca}$

112

$\mathrm{Mn}$

$\mathrm{Mg}$

39

$\mathrm{Na}$

$\mathrm{K}$

$\mathrm{HCO}_{3}$

522

$\mathrm{CO}_{3}$

$\mathrm{SO}_{4}$

C1

$\mathrm{F}$

$\mathrm{NO}_{3}$

561

TDS

440

Noncarbonate

Sp. Cond.

(micromhos $25^{\circ} \mathrm{C}$ )

$\mathrm{pH}$

Temperature $\left({ }^{\circ} \mathrm{C}\right)$

Reference: Bettandorff and Leake 1976

31

6.8

30

$--$

100

6.6

14

25

68

32

1.6

21

21

1.4

30

74

7.6

0

0

432

5.4

353

256

7.0

\section{7} 366

--

28

11

0.4

0.2

437

322

6.8

8.0

0.2

3.1

--

--

--

--

8.1

7.7

-- 
TABLE 70. Water Analysis

Hydrologic Region: Lower Mississippi

Aquifer Name: Cockfield formation

Aquifer Age: Late Eocene

Petrology: sand, silt, clay
State: Mississippi

Location: Sharkey and Yazoo Co's. No. Analyses: 7

Hater Type: $\mathrm{Na}, \mathrm{HCO}_{3}$

Solute Concentration

Maximum

111

171

He11 Depth (m)

17

2.9

15

$\mathrm{Fe}$

$\mathrm{Mn}$

$\mathrm{Ca}$

82

36

79

2.7

538

$\mathrm{HCO}_{3}$

$\mathrm{CO}_{3}$

$\mathrm{SO}_{4}$

C1

$F$

$\mathrm{NO}_{3}$

TDS

Hardness as $\mathrm{CaCO}_{3}$

$\mathrm{Ca}, \mathrm{Mg}$

351

Noncarbonate

Sp. Cond.

(micromhos $25^{\circ} \mathrm{C}$ )

pH

7.3

8.3

Temperature $\left({ }^{\circ} \mathrm{C}\right)$

Reference: Bettandorff and Leake 1976
127

7.0

Minimum

2.8

--

28

9.4

17

3.4

138

13

14

0.1

0.1

153

108

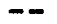

--

-- 
Hydrologic Region: Lower Mississippi

Aquifer Name: Sparta sand

Aquifer Age: Middle Eocene

Petrology: sand, silt, clay
State: Mississippi

Location: Issaquena and Humphreys Co's.

No. Analyses: 15

Water Type: $\mathrm{Na}, \mathrm{HCO}_{3}$

Solute Concentration

$\begin{array}{lll}\text { Maximum } & \frac{\text { Intermediate }}{290} & \text { Minimum } \\ 529 & 248\end{array}$

Wel1 Depth (m)

18

38

Constituents $(\mathrm{mg} / \mathrm{l})$

and Properties

$\mathrm{SiO}_{2}$

14

0.17

0.12

0.63
$\mathrm{Mn}$

$\mathrm{Ca}$

$\mathrm{Mg}$

$\mathrm{Na}$

K

$\mathrm{HCO}_{3}$

$\mathrm{CO}_{3}$

$\mathrm{SO}_{4}$

C1

$\mathrm{F}$

$\mathrm{NO}_{3}$

TDS

--

0.5

0.2

235

6.6

510

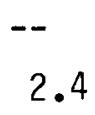

60

0.4

1.9

572

Hardness as $\mathrm{CaCO}_{3}$

$\mathrm{Ca}, \mathrm{Mg}$

Noncarbonate

Sp. Cond.

(micromhos $025^{\circ} \mathrm{C}$ )

$\mathrm{pH}$

Temperature $\left({ }^{\circ} \mathrm{C}\right)$

Reference: Bettandorff and Leake 1976

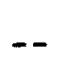

$--$

8.2

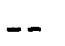

0.7

3.0

0.1

0.6

180

60

1.0

3.0

450

153

--

2.4

9.8

6.0

1.6

0.5

0.1

--

0.5

441

192

10

2

$--$

8.4

7.2 
TABLE 72. Water Analysis

Hydrologic Region: Lower Mississippi and South Atlantic Gulf

Aquifer Name: Meridian sand

Aquifer Age: Early Eocene

Petrology: micaceous quartz sand, clay, silt, lignite
State: Mississippi

Location: Bolivar, Newton and Sharkey Co's.

No. Analyses: 7

Water Type: $\mathrm{Na}, \mathrm{HCO}_{3}, \mathrm{Cl}$

Solute Concentration

Maximum Intermediate Minimum

Hell Depth (m) 579

530

98

Constituents $(\mathrm{mg} / \mathrm{l})$

and Properties

$\mathrm{SiO}_{2}$

$\mathrm{Fe}$

$\mathrm{Mn}$

$\mathrm{Ca}$

$\mathrm{Mg}$

$\mathrm{Na}$

K

$\mathrm{HCO}_{3}$

$\mathrm{CO}_{3}$

$\mathrm{SO}_{4}$

C1

$F$

$\mathrm{NO}_{3}$

TDS

--
0.26
--
5.1
0.6
1060
13
1300
--
3.8
860
4.0
1.5
2680

15

$\mathrm{Ca}, \mathrm{Mg}$

Noncarbonate

Sp. Cond.

(micromhos $25^{\circ} \mathrm{C}$ )

pH

Temperature $\left({ }^{\circ} \mathrm{C}\right)$

Reference: Payne 1975

4490

7.9

34
5.2

0

43

2.9

3.21

12

0.3

4.9

524

4.0

2.6

570

47

0

15

410

3.2

0.6

0.2

0.1

1285

108

10

50

7.9

5.9 
TABLE 73. Water Analys is

Hydrologic Region: Lower Mississippi

Aquifer Name: Tallahatta formation

Aquifer Age: Early Eocene

Petrology: sand, shale
State: Mississippi

Location: Attala and Holmes Co's. No. Analyses: 3

Water Type: $\mathrm{Na}, \mathrm{HCO}_{3}$

Solute Concentration

\begin{tabular}{lcc}
\hline Maximum & $\frac{\text { Intermediate }}{274}$ & Minimum \\
399 & & 62
\end{tabular}

45

0.01

22

$\mathrm{Fe}$

--

6.0

0.2

330

1.7

879

--

2.9

15

187

843

16

2

Noncarbonate

Sp. Cond.

(micromhos $25^{\circ} \mathrm{C}$ )

pH

8.4

Temperature $\left({ }^{\circ} \mathrm{C}\right)$

Reference: Bettandorff and Leake 1976
1.3

0.1

0.1

27

7.7

6.6

0.07

0

6.8

2.4

3.3

2.9

35

6.8

2.5

0

0.5

42

-

$--$

-. 
Hydrologic Region: Lower Mississippi

Aquifer Name: Lower Wilcox

Aquifer Age: Middle Paleocene

Petrology: sand
State: Mississippi

Location: Holmes Co.

No. Analyses: 2

Water Type: $\mathrm{Na}, \mathrm{HCO}_{3}$

Solute Concentration

$\begin{array}{lcc}\text { Maximum } & \text { Intermediate } & \text { Minimum } \\ 408 & -- & 409\end{array}$

Well Depth (m)

14

$-$

12

$\mathrm{Fe}$
$\mathrm{Mn}$

$\mathrm{Ca}$

$\mathrm{Mg}$

$\mathrm{Na}$

K

$\mathrm{HCO}_{3}$

$\mathrm{CO}_{3}$

$\mathrm{SO}_{4}$

$\mathrm{Cl}$

$\mathrm{F}$

$\mathrm{NO}_{3}$

TDS

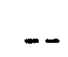

10

0.1

180

1.1

400

--

1.7

48

0.2

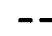

459

25

$--$

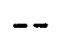

Sp. Cond.

(micromhos $25^{\circ} \mathrm{C}$ )

pH

Temperature $\left({ }^{\circ} \mathrm{C}\right)$

Reference: Bettandorff and Leake 1976

8.4
0.06

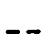

3.4

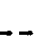

1.3

0.2

162

0.9 384

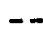

0

32

0.2

0.3

398

4

$--$

$\rightarrow$

8.0 
Hydrologic Region: Mid-Atlantic

Aquifer Name: Potomac-Raritan-Magothy

Aquifer Age: Cretaceous

Petrology: interbedded sand, gravel, silt, clay
State: New Jersey

Location: Trenton to Pennsville No. Analyses: 262

Water Type: $\mathrm{Ca}, \mathrm{Na}, \mathrm{HCO}_{3}$

Solute Concentration

Maximum Median Minimum

We11 Depth (m)

Constituents $(\mathrm{mg} / \mathrm{l})$ and Properties

$\begin{array}{lr}\mathrm{SiO}_{2} & 53 \\ \mathrm{Fe} & 79 \\ \mathrm{Mn} & 15 \\ \mathrm{Ca} & 118 \\ \mathrm{Mg} & 100 \\ \mathrm{Na} & 670 \\ \mathrm{~K} & 100 \\ \mathrm{HCO}_{3} & 1930 \\ \mathrm{CO}_{3} & - \\ \mathrm{SO}_{4} & 770\end{array}$

$\mathrm{SO}_{4}$

C1 810

$\mathrm{F}$

$\mathrm{NO}_{3}$

TDS

53

79

15

118

100

670

100

1930

18

2200
570

230

4200

Sp. Cond.

(micromhos $25^{\circ} \mathrm{C}$ )

pH

Temperature $\left({ }^{\circ} \mathrm{C}\right)$

\section{5}

1.4

0.071

16

4.7

14

4.4

93

--

18

15

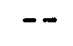

0.03

148

60
0
246

8.3

6.6

14.5
0

0.003

$<0.001$

0.1

0.1

1.8

0.5

0

$-$

0

0.8

--

--

25

Reference: Fusillo and Voronin 1981 
Hydrologic Region: Mid-Atlantic

Aquifer Name: Martinsburg formation

Aquifer Age: Late Ordovician

Petrology: slate and graywacke
State: Pennsylvania

Location: Lehigh Co.

No. Analyses: 25

Water Type: $\mathrm{Ca}, \mathrm{HCO}_{3}$

Solute Concentration (a)

Maximum

He11 Depth (m) 162 Intermediate

Minimum

Constituents $(\mathrm{mg} / \ell$ ) and Properties

\begin{tabular}{|c|c|c|c|}
\hline $\mathrm{SiO}_{2}$ & 16.3 & 12.3 & 7.73 \\
\hline $\mathrm{Fe}$ & 2.24 & 0.63 & 0.013 \\
\hline $\mathrm{Mn}$ & 0.043 & 0.003 & 0 \\
\hline $\mathrm{Ca}$ & 45.3 & 27.3 & 5.83 \\
\hline $\mathrm{Mg}$ & 11.7 & 7.0 & 1.8 \\
\hline $\mathrm{Na}$ & 40.5 & 5.8 & 2.7 \\
\hline K & 1.5 & 0.77 & 0.33 \\
\hline $\mathrm{HCO}_{3}$ & 143 & 67.7 & 29.7 \\
\hline $\mathrm{CO}_{3}$ & -- & -- & -- \\
\hline $\mathrm{SO}_{4}$ & 72.3 & 31.7 & 7.57 \\
\hline $\mathrm{Cl}$ & 34.3 & 5.57 & 1.67 \\
\hline $\mathrm{F}$ & 0.4 & 0.03 & 0 \\
\hline $\mathrm{NO}_{3}$ & 20 & 8.93 & 0.03 \\
\hline TDS & 250 & 145 & 74 \\
\hline \multicolumn{4}{|l|}{ ness as $\mathrm{CaCO}_{3}$} \\
\hline $\mathrm{Ca}, \mathrm{Mg}$ & 157 & 91.3 & 22 \\
\hline Noncarbonate & 86.3 & 39.3 & 0.67 \\
\hline \multirow{2}{*}{$\begin{array}{l}\text { Cond. } \\
\text { romhos } 25^{\circ} \mathrm{C} \text { ) }\end{array}$} & 361 & 233 & 120 \\
\hline & -- & -- & -- \\
\hline erature $\left({ }^{\circ} \mathrm{C}\right)$ & - & -- & -- \\
\hline
\end{tabular}

(a) Averaged from the Pen Argyl, Ramseyburg and Bushkill members. 


\section{TABLE 77. Water Analysis}

Hydrologic Region: Mid-Atlantic

Aquifer Name: Martinsburg formation

Aquifer Age: Late Ordovician

Petrology: slate and graywacke
State: Pennsylvania

Location: Northampton Co.

Mo. Analyses: 11

Water Type: $\mathrm{Ca}, \mathrm{Na}, \mathrm{HCO}_{3}$

\begin{tabular}{cc}
\multicolumn{3}{c}{ Solute Concentration $(\mathrm{a})$} \\
Maximum & Intermediate
\end{tabular}

Well Depth (m)

126

35

12

Constituents $(\mathrm{mg} / \mathrm{l})$

and Properties

$\mathrm{SiO}_{2}$

$\mathrm{Fe}$

$\mathrm{Mn}$

$\mathrm{Ca}$

$\mathrm{Mg}$

$\mathrm{Na}$

K

$\mathrm{HCO}_{3}$

$\mathrm{CO}_{3}$

$\mathrm{SO}_{4}$

Cl

$\mathrm{F}$

$\mathrm{NO}_{3}$

TOS
14.7

0.22

0.28

86.7

17.4

52.3

5.67

203

$--$

74.6

120

0.53

33.7

529

280

187

777

Sp. Cond.

(micromhos $25^{\circ} \mathrm{C}$ )

$\mathrm{pH}$

Temperature $\left({ }^{\circ} \mathrm{C}\right)$
11.3

0.10

0.007

34

6.73

32.9

1.32

107

$--$

38.2

33.4

0.067

5.47

248

116

46.7

382

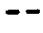

9.07

0.027

0

8.6

2.43

22.1

0.57

50.3

--

9.4

2.0

0

0.13

97

31.3

1.0

151

Reference: Poth 1972

(a) Averaged from the Pen Argyl, Ramseyburg and Bushkill members. 
Hydrologic Region: Mid-Atlantic

Location: Norfolk, Virginia

Aquifers:

Range:

Aquifer Age: Late Cretaceous

Petrology:

$\frac{1}{792-1538 \text { feet }}$

clay, silt, sand

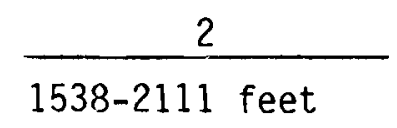

Middle Cretaceous

clay, silt, sand

$\frac{3}{2111-T o t a 1 \text { Depth feet }}$

Early Cretaceous

clay, silt, silty sand

\begin{tabular}{|c|c|c|c|c|c|c|c|}
\hline \multirow{2}{*}{$\begin{array}{l}\text { Depth Interval (m) } \\
\text { Constituents (mg/e) } \\
\text { and Properties }\end{array}$} & $848-868$ & $900-990$ & $1037-1057$ & $1257-1277$ & $1614-1634$ & $2370-2391$ & $2499-2520$ \\
\hline & & & & & & & \\
\hline $\mathrm{SiO}_{2}$ & 12 & 14 & 14 & 24 & 23 & 54 & 12 \\
\hline Al & 0.1 & 0.05 & 0 & 0.3 & 1.1 & 4.1 & 4.5 \\
\hline $\mathrm{Fe}$ & 0.14 & 0.23 & 0.08 & 1.2 & 14 & 16 & 16 \\
\hline Mn & 0.03 & 0.035 & 0.05 & 0.22 & 1.3 & 11 & 13 \\
\hline $\mathrm{Cu}$ & 0.01 & 0.01 & 0.02 & 0.08 & 0.1 & 0.12 & 0.13 \\
\hline $\mathrm{Pb}$ & $<0.1$ & $<0.1$ & $<0.1$ & 0.1 & 0.1 & 0.3 & 0.4 \\
\hline $2 n$ & 0.03 & 0.033 & 0.05 & 0.09 & 0.2 & 0.2 & 0.22 \\
\hline $\mathrm{Ca}$ & 10 & 14 & 20 & 105 & 480 & 2660 & 2940 \\
\hline $\mathrm{Mg}$ & 6.9 & 7.6 & 13 & 58 & 209 & 854 & 846 \\
\hline $\mathrm{Sr}$ & 0.2 & 0.25 & 0.7 & 0.8 & 12 & 66 & 73 \\
\hline $\mathrm{Na}$ & 818 & 1033 & 1290 & 2620 & 5280 & 12600 & 12800 \\
\hline k & 23 & 29 & 27 & 52 & 87 & 124 & 123 \\
\hline $\mathrm{NH}_{3}$ & 2.4 & 2.8 & 3.4 & 5.3 & 5.7 & 4.7 & 5.7 \\
\hline $\mathrm{HCO}_{3}$ & 681 & 639 & 616 & 416 & 217 & 50 & 133 \\
\hline $\mathrm{SO}_{4}$ & 102 & 129 & 140 & 242 & 410 & 1020 & 1050 \\
\hline $\mathrm{Cl}$ & 964 & 1251 & 1680 & 4200 & 9560 & 26000 & 26900 \\
\hline $\mathrm{F}$ & 1.9 & 1.6 & 1.1 & 0.5 & 0.4 & 0.5 & 0.5 \\
\hline$B r$ & 3.7 & 4.4 & 6.5 & 16 & 34 & 98 & 100 \\
\hline I & 0.4 & 0.38 & 0.4 & 0.8 & 2.1 & 3.7 & 3.7 \\
\hline $\mathrm{NO}_{2}$ & 0 & 0.05 & 0 & 0 & 0 & 0.05 & 0.01 \\
\hline $\mathrm{NO}_{3}$ & 0.7 & 0.83 & 1.0 & 1.6 & 2.5 & 1.1 & 1.1 \\
\hline $\mathrm{PO}_{4}$ & 0.15 & 0.18 & 0.02 & 0.01 & 0.04 & 0.06 & 0 \\
\hline 8 & 3.0 & 2.7 & 4.1 & 5.4 & 5.6 & 4.9 & 4.4 \\
\hline TOS & 2300 & 2773 & 3440 & 7630 & 17200 & 45100 & 47700 \\
\hline \multicolumn{8}{|l|}{ Hardness as $\mathrm{CaCO}_{3}$} \\
\hline $\mathrm{Ca}, \mathrm{Mg}$ & 54 & 67 & 101 & 499 & 2070 & 10280 & 10900 \\
\hline Noncarbonate & 0 & 0 & 0 & 154 & 1890 & 10260 & 10900 \\
\hline $\begin{array}{l}\text { Sp. Cond. } \\
\text { (micromhos } 25^{\circ} \mathrm{C} \text { ) }\end{array}$ & 3900 & 4585 & 5940 & 12600 & 26400 & 61300 & 63800 \\
\hline $\mathrm{pH}$ & 7.8 & 8.05 & 7.79 & 7.42 & 6.93 & 7.13 & 6.4 \\
\hline Water Type & $\begin{array}{l}\mathrm{Na}, \mathrm{HCO}_{3}, \\
\mathrm{Cl}\end{array}$ & $\begin{array}{c}\mathrm{Na}, \mathrm{HCO}_{3} \\
\mathrm{Cl}\end{array}$ & $\mathrm{Na}, \mathrm{Cl}$ & $\mathrm{Na}, \mathrm{Cl}$ & $\mathrm{Na}, \mathrm{Cl}$ & $\mathrm{Na}, \mathrm{Cl}$ & $\mathrm{Na}, \mathrm{Cl}$ \\
\hline
\end{tabular}


Hydrologic Region: Missouri Basin

Aquifer Name: Prairie du Chien-Jordan

Aquifer Age: Early Ordovician and Late Cambrian

Petrology: sandstone and dolomite

We11 Depth (m)

Constituents $(\mathrm{mg} / \mathrm{l})$ and Properties

$\mathrm{SiO}_{2}$

$\mathrm{Fe}$

$\mathrm{Mn}$

$\mathrm{Ca}$

$\mathrm{Mg}$

$\mathrm{Na}$

$\mathrm{K}$

$\mathrm{HCO}_{3}$

$\mathrm{CO}_{3}$

$\mathrm{SO}_{4}$

$\mathrm{Cl}$

$\mathrm{F}$

$\mathrm{NO}_{3}$

TDS

Hardness as $\mathrm{CaCO}_{3}$

$\mathrm{Ca}, \mathrm{Mg}$

Noncarbonate

Sp. Cond.

(micromhos $25^{\circ} \mathrm{C}$ )

$\mathrm{pH}$

Temperature $\left({ }^{\circ} \mathrm{C}\right)$

Reference: Horick and Steinhilber 1978
State: Iowa

Location: Buena Vista Co.

No. Analyses: 1

Water Type: $\mathrm{Ca}, \mathrm{Na}, \mathrm{SO}_{4}$

Solute Concentration

515

1.7

0.03

290

74

160

45

323

0

1100

30

1.6

1.3

1970

265

745

2300

7.2 
TABLE 86. Water Analysis

Hydrologic Region: Missouri Basin

Aquifer Name: Prairie du Chien-Jordan

Aquifer Age: Early Ordovician and Late Cambrian

Petrology: sandstone and dolomite
State: Iowa

Location: Pottawattamie Co.

Mo. Analyses: 2

Water Type: $\mathrm{Ca}, \mathrm{Na}, \mathrm{SO}_{4}$

Solute Concentration

\begin{tabular}{lcc}
\hline Maximum & Intermediate & Mini \\
\hline 892 & 830 & 768
\end{tabular}

We11 Depth (m)

Constituents $(\mathrm{mg} / \ell)$

and Properties

$\mathrm{SiO}_{2}$

$\mathrm{Fe}$

$\mathrm{Mn}$

$\mathrm{Ca}$

$\mathrm{Mg}$

$\mathrm{Na}$

K

$\mathrm{HCO}_{3}$

$\mathrm{CO}_{3}$

$\mathrm{SO}_{4}$

$\mathrm{Cl}$

$\mathrm{F}$

$\mathrm{NO}_{3}$

TDS

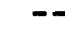

2.0

0.1

216

61

240

40

203

0

740

220

3.0

3.9

1680

Hardness as $\mathrm{CaCO}_{3}$

$\mathrm{Ca}, \mathrm{Mg}$

Noncarbonate

Sp. Cond.

(micromhos $25^{\circ} \mathrm{C}$ )

$\mathrm{pH}$

Temperature $\left({ }^{\circ} \mathrm{C}\right)$
166

596

2300

7.3

24.4
1.42

0.06

206

57.5

230

39

201.5

0

740

215

2.7

3.55

1645

165

586

2250

7.25

22.8
7.2

0.84

0.02

196

54

220

38

200

0

740

210

2.4

3.2

1610

164

576

2200

21.1

Reference: Horick and Steinhilber 1978 
Hydrologic Region: Missouri Basin

Aquifer Name: Alluvial

Aquifer Age: Holocene/Pleistocene

Petrology: sand, gravel, alluvium
Solute Concentration

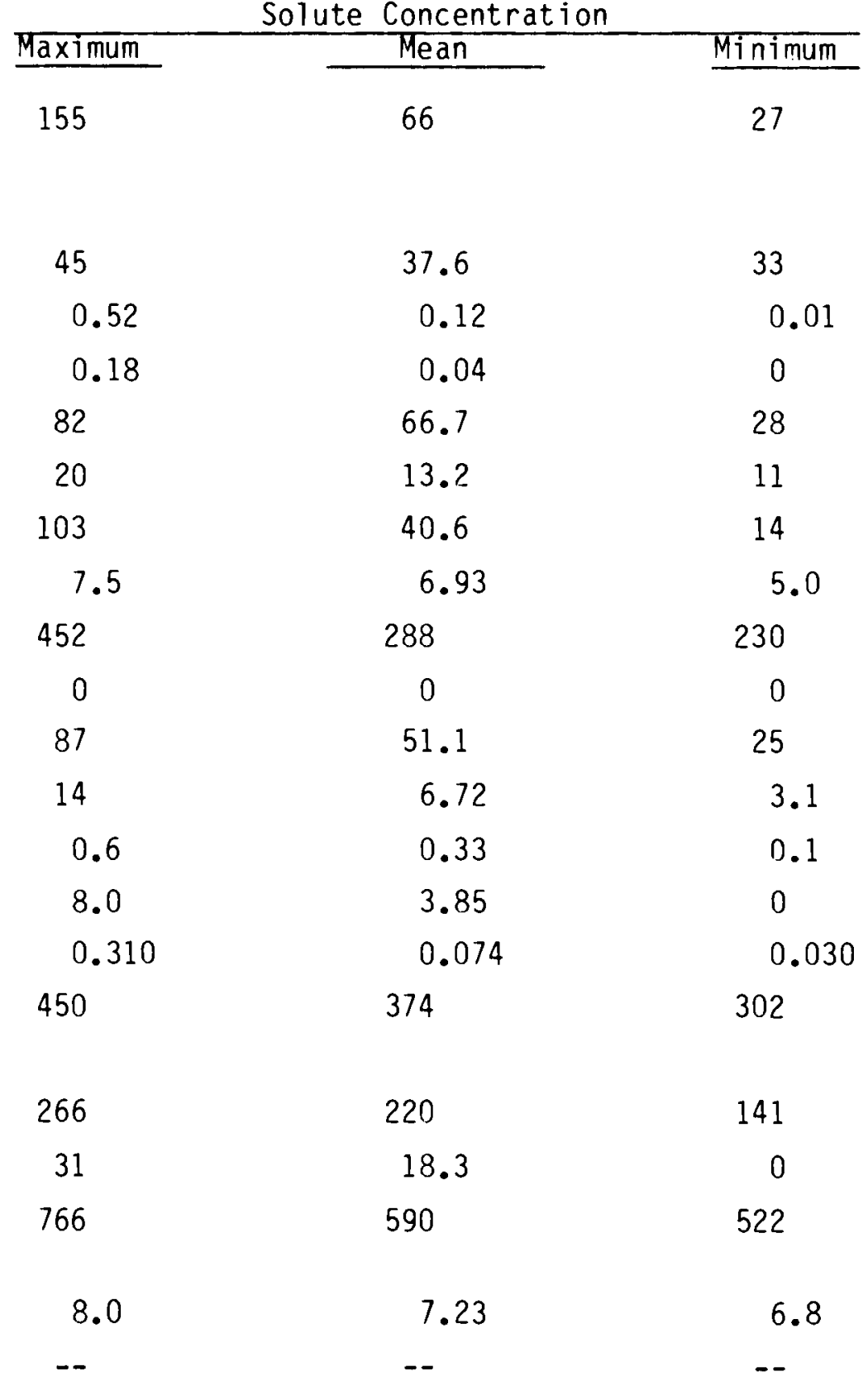

\author{
State: Nebraska \\ Location: Seward Co. \\ No. Analyses: 8 \\ Water Type: $\mathrm{Ca}, \mathrm{Na}, \mathrm{HCO}_{3}$
}

Well Depth (m)

Constituents $(\mathrm{mg} / \mathrm{l})$ and Properties

$\mathrm{SiO}_{2}$

$\mathrm{Fe}$

$\mathrm{Mn}$

$\mathrm{Ca}$

$\mathrm{Mg}$

$\mathrm{Na}$

$\mathrm{K}$

$\mathrm{HCO}_{3}$

$\mathrm{CO}_{3}$

$\mathrm{SO}_{4}$

$\mathrm{Cl}$

$\mathrm{F}$

$\mathrm{NO}_{3}$

B

TDS

Hardness as $\mathrm{CaCO}_{3}$

$\mathrm{Ca}, \mathrm{Mg}$

Noncarbonate

Sp. Cond.

(micromhos $25^{\circ} \mathrm{C}$ )

$\mathrm{pH}$

Temperature $\left({ }^{\circ} \mathrm{C}\right)$

Reference: Keech 1978

Ma


Hydrologic Region: Missouri Basin

Aquifer Name: Principal aquifer

Aquifer Age: Pleistocene

Petrology: sand and gravel
State: Nebraska

Location: Platte Valley

No. Analyses: 6

Water Type: $\mathrm{Ca}, \mathrm{HCO}_{3}, \mathrm{SO}_{4}$

Solute Concentration

Maximum Minimum

Well Depth (m)

Constituents $(\mathrm{mg} / \mathrm{l})$

and Properties

$\mathrm{SiO}_{2}$

51

36

29

$\mathrm{Fe}$

$\mathrm{Mn}$

$\mathrm{Ca}$

151

24

168

23

574

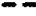

314

31

0.26

33

0.17

1010

TDS

Hardness as $\mathrm{CaCO}_{3}$

$\mathrm{Ca}, \mathrm{Mg}$

Noncarbonate

Sp. Cond.

(micromhos $25^{\circ} \mathrm{C}$ )

$\mathrm{pH}$

7.4

Temperature $\left({ }^{\circ} \mathrm{C}\right)$

12.7
7.03

132.5

21.7

56.5

13.5

252

258

23.8

0.19

16.9

0.11

752

621

12.2
6.6

120

21

10

134

196

15

0.09

4.7

0.08

11.8

Reference: Spalding and Exner 1980 
Hydrologic Region: Missouri Basin

Aquifer Name: Ogallala formation

Aquifer Age: Pliocene

Petrology: silty sandstone, lime cemented
State: Nebraska

Location: Platte Valley

No. Analyses: 5

Water Type: $\mathrm{Ca}, \mathrm{HCO}_{3}$

Solute Concentration

Maximum

We11 Depth (m)

Constituents $(\mathrm{mg} / \mathrm{l}$ )

and Properties

$\mathrm{SiO}_{2}$
Mean

Minimum

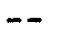

46

44.6

43

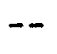

$--$

70

12

33

6.8

295

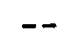

50

10

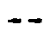

0.1

0.12

338

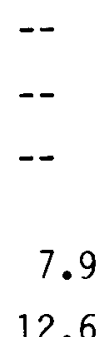

12.6

43

$--$

--

50

7.6

18

5.3

206

$-$

32

5.3

8.38

$--$

0

0.03

296

310

0.02

0.046
$\mathrm{Fe}$

$\mathrm{Mn}$

Ca

$\mathrm{Mg}$

$\mathrm{Na}$

$\mathrm{K}$

$\mathrm{HCO}_{3}$

$\mathrm{CO}_{3}$

$\mathrm{SO}_{4}$

Cl

$\mathrm{F}$

$\mathrm{NO}_{3}$

$\mathrm{PO}_{4}$

TDS

Hardness as $\mathrm{CaCO}_{3}$

$\mathrm{Ca}, \mathrm{Mg}$

Noncarbonate

Sp. Cond.

(micromhos $25^{\circ} \mathrm{C}$ )

pH

Temperature $\left({ }^{\circ} \mathrm{C}\right)$

Reference: Spalding and Exner 1980 
TABLE 90. Water Analysis

Hydrologic Region: Missouri Basin

Aquifer Name: Dakota group

Aquifer Age: Late Cretaceous

Petrology: sandstone

Hell Depth (m)

Constituents $(\mathrm{mg} / \ell)$

and Properties

$\mathrm{SiO}_{2}$

$\mathrm{Fe}$

$\mathrm{Mn}$

$\mathrm{Ca}$

$\mathrm{Mg}$

$\mathrm{Na}$

$\mathrm{K}$

$\mathrm{HCO}_{3}$

$\mathrm{CO}_{3}$

$\mathrm{SO}_{4}$

$\mathrm{Cl}$

$\mathrm{F}$

$\mathrm{NO}_{3}$

B

TDS

Hardness as $\mathrm{CaCO}_{3}$

$\mathrm{Ca}, \mathrm{Mg}$

Noncarbonate

Sp. Cond.

(micromhos $25^{\circ} \mathrm{C}$ )

$\mathrm{pH}$

Temperature $\left({ }^{\circ} \mathrm{C}\right)$

Reference: Keech 1978
State: Nebraska

Location: Seward Co.

No. Analyses: 2

Water Type: $\mathrm{Ca}, \mathrm{Na}, \mathrm{HCO}_{3}$

Solute Concentration

\begin{tabular}{ccc}
\hline Maximum & Mean & Minimum \\
155 & 153 & 150 \\
& & \\
49 & 36.5 & 24 \\
0.19 & 0.115 & 0.04 \\
0.21 & 0.12 & 0.03 \\
133 & 92.5 & 52 \\
44 & 26 & 8 \\
57 & 47.5 & 38 \\
8.8 & 7.1 & 5.4 \\
441 & 367 & 292 \\
0 & 0 & 0 \\
210 & 126 & 42 \\
14 & 12.5 & 11 \\
0.3 & 0.3 & 0.3 \\
0.1 & 0.05 & 0 \\
0.18 & 0.14 & 0.10 \\
731 & 541 & 351 \\
& & \\
511 & 337 & 0 \\
149 & 74.5 & 571 \\
1000 & 786 & -- \\
7.8 & 7.75 &
\end{tabular}


Hydrologic Region: Missouri Basin

Aquifer Name: Glacial drift

Aquifer Age: Pleistocene

Petrology: clay, sand, pebbles, boulders
State: North Dakota

Location: Williams and Mountrail Co's.

No. Analyses: 3

Water Type: $\mathrm{Na}, \mathrm{HCO}_{3}, \mathrm{SO}_{4}$

Solute Concentration

Maximum

9

We11 Depth (m)

Constituents $(\mathrm{mg} / \ell)$

and Properties

$\mathrm{SiO}_{2}$

$\mathrm{Fe}$

0.08

$M n$

Ca

181

$\mathrm{Mg}$

76

$\mathrm{Na}$

70

4.0

$\mathrm{HCO}_{3}$

266

396

$\mathrm{SO}_{4}$

C1

f

32

0

$\mathrm{NO}_{3}$

673

TDS

1590

764

Noncarbonate

$\mathrm{Sp}$. Cond.

(micromhos $25^{\circ} \mathrm{C}$ )

$\mathrm{pH}$

8.1

Temperature $\left({ }^{\circ} \mathrm{C}\right)$

Reference: Paulson and Powell 1962
37

18

0.06

0.48

55

161

50

80

240

344

728

8.5

7.7

Minimum

118

4.5 460

0

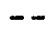

8

0

2

600

1070

-

$-$

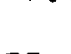




\section{TABLE 92. Water Analysis}

Hydrologic Region: Missouri Basin

Aquifer Name: Fort Union formation

Aqui fer Age: Paleocene

Petrology: clay, sand, siltstone, lignite
State: North Dakota

Location: Williams and Mountrail Co's.

No. Analyses: 3

Water Type: $\mathrm{Na}, \mathrm{HCO}_{3}, \mathrm{SO}_{4}$

Solute Concentration

Maximum $\quad$ Intermediate

21

66

29

Well Depth (m)

Constituents $(\mathrm{mg} / \ell)$ and Properties

$\mathrm{SiO}_{2}$

$\mathrm{Fe}$

$\mathrm{Mn}$

$\mathrm{Ca}$

366

481

80

8.8

240

41

2210

106

Cl

$\mathrm{F}$

$\mathrm{NO}_{3}$

TDS

266

3680

0.4

0.24

0.19

0.48

-.

0

49

4

51

830

10

252

7.0

894

393

158

67

764

428

20

4

1.3

0

41

35

2270

1090

Hardness as $\mathrm{CaCO}_{3}$

$\mathrm{Ca}, \mathrm{Mg}$

2890

16

331

Noncarbonate

Sp. Cond.

(micromhos $25^{\circ} \mathrm{C}$ )

$\mathrm{pH}$

8.2

9.0

8.7

Temperature $\left({ }^{\circ} \mathrm{C}\right)$

Reference: Paulson and Powell 1962 
TABLE 93. Water Analysis

Hydrologic Region: Missouri Basin

Aquifer Name: None specified

Aquifer Age: Pleistocene

Petrology: glacial drift
State: South Dakota

Location: East of the Missouri River

No. Analyses: 3

Water Type: $\mathrm{Ca}, \mathrm{Na}, \mathrm{SO}_{4}$

Solute Concentration

\begin{tabular}{|c|c|c|}
\hline Maximum & Mean & Minimum \\
\hline-- & - & -- \\
\hline 30 & 26 & 20 \\
\hline 4.2 & 1.44 & 0.03 \\
\hline 2.0 & 1.07 & 0.14 \\
\hline 455 & 292 & 337 \\
\hline 175 & 119 & 36 \\
\hline 406 & 193 & 15 \\
\hline 19 & 13.2 & 5.6 \\
\hline 469 & 4.09 & 323 \\
\hline-- & -- & -- \\
\hline 2080 & 1204 & 103 \\
\hline 81 & 38.1 & 3.2 \\
\hline 0.5 & 0.367 & 0.3 \\
\hline 16 & 5.4 & 0.1 \\
\hline 1.2 & 0.637 & 0.06 \\
\hline 3700 & 2245 & 465 \\
\hline 1730 & 1215 & 355 \\
\hline-- & -- & -- \\
\hline-- & -- & -- \\
\hline-- & -- & -- \\
\hline 16.7 & 11.3 & 7.8 \\
\hline
\end{tabular}

Well Depth (m)

Constituents (mg/ $\ell$ )

and Properties

$$
\mathrm{SiO}_{2}
$$

$\mathrm{Fe}$

$\mathrm{Mn}$

$\mathrm{Ca}$

$\mathrm{Mg}$

$\mathrm{Na}$

K

$\mathrm{HCO}_{3}$

$\mathrm{CO}_{3}$

$\mathrm{SO}_{4}$

C1

$\mathrm{F}$

$\mathrm{NO}_{3}$

B

TDS 
Hydrologic Region: Missouri Basin Aquifer Mame: Dakota sandstone

Aquifer Age: Late Cretaceous

Petrology: sandstone and shale
State: South Dakota

Location: $33,000 \mathrm{~m}^{2}$ in eastern South Dakota

No. Analyses: 2

Water Type: $\mathrm{Ca}, \mathrm{Na}, \mathrm{SO}_{4}$

Solute Concentration

\begin{tabular}{ccc}
\hline Maximum & Mean & Minimum \\
\cline { 2 - 3 } 427 & -- & 91 \\
& & \\
13 & 11 & 9 \\
10 & 5.19 & 0.37 \\
0.2 & 0.135 & 0.07 \\
416 & 236 & 55 \\
93 & 53 & 13 \\
543 & 311 & 79 \\
19 & 17 & 15 \\
168 & 143 & 118 \\
-- & -- & -- \\
1270 & 1230 & 1190 \\
105 & 86 & 67 \\
2.9 & 2.05 & 1.2 \\
0.1 & 0.05 & 0 \\
1.5 & 0.86 & 0.22 \\
2270 & 2130 & 1990
\end{tabular}

We11 Depth (m)

Constituents $(\mathrm{mg} / \mathrm{l})$ and Properties

$\mathrm{SiO}_{2}$

$\mathrm{Fe}$

$\mathrm{Mn}$

$\mathrm{Ca}$

$\mathrm{Mg}$

$\mathrm{Na}$

K

$\mathrm{HCO}_{3}$

$\mathrm{CO}_{3}$

$\mathrm{SO}_{4}$

$\mathrm{Cl}$

$\mathrm{F}$

$\mathrm{NO}_{3}$

B

TDS . 
TABLE 95. Water Analysis

Hydrologic Region: Missouri Basin

Aquifer Name: Fox Hills sandstone

Aquifer Age: Late Cretaceous

Petrology: sandstone
State: South Dakota

Location: Northeast of the Black Hills

No. Analyses: 2

Mater Type: $\mathrm{Na}, \mathrm{HCO}_{3}$

Solute Concentration

\begin{tabular}{ccc} 
Maximum & Mean & Minimum \\
\cline { 2 - 3 }-- & -- & \\
& & \\
12 & 11 & 10 \\
0.09 & 0.045 & 0 \\
0.06 & 0.03 & 0 \\
33 & 18.6 & 4.1 \\
6 & 3.1 & 0.2 \\
422 & 326 & 230 \\
7.3 & 4.45 & 1.6 \\
652 & 526 & 400 \\
-- & -- & -- \\
284 & 152 & 19 \\
268 & 135 & 1.1 \\
1.9 & 0.115 & 0.4 \\
2.5 & 0.13 & 0.1 \\
1070 & 927 & 784
\end{tabular}

Hardness as $\mathrm{CaCO}_{3}$

$\mathrm{Ca}, \mathrm{Mg} \quad 107$

59

11

Noncarbonate

Sp. Cond.

(micromhos $25^{\circ} \mathrm{C}$ )

$\mathrm{pH}$

Temperature $\left({ }^{\circ} \mathrm{C}\right)$
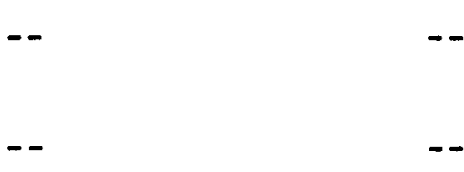

10.56

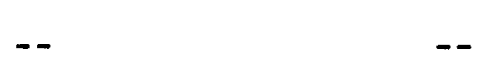

$-$

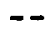

10.0
11
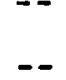

$--$

9.44

Reference: Mineral and Water Resources of South Dakota 1964 
TABLE 96. Water Analysis

Hydrologic Region: Missouri Basin

Aquifer Name: Greenhorn limestone

Aquifer Age: Late Cretaceous

Petrology: limestone, calcareous shale
State: South Dakota

Location: Underlies most of South Dakota

No. Analyses: 2

Water Type: $\mathrm{Na}, \mathrm{SO}_{4}$

Solute Concentration

\begin{tabular}{ccc}
\hline Maximum & Mean & Minimum \\
\cline { 2 - 3 }-- & -- & - \\
& & \\
8.7 & 8.25 & 7.8 \\
3.5 & 2.85 & 2.2 \\
0.15 & 0.08 & 0.01 \\
313 & 164 & 14 \\
82 & 42.8 & 3.6 \\
688 & 424 & 159 \\
20 & 14.3 & 8.6 \\
248 & 198 & 148 \\
-- & -- & -- \\
1220 & 1210 & 1200 \\
83 & 73 & 63 \\
3.0 & 2.7 & 2.4 \\
0.3 & 0.15 & 0 \\
3.6 & 2.20 & 0.79 \\
2190 & 2145 & 2100 \\
& &
\end{tabular}

Hardness as $\mathrm{CaCO}_{3}$

$\mathrm{Ca}, \mathrm{Mg}$

1120

585

50

Noncarbonate

Sp. Cond.

(micromios $025^{\circ} \mathrm{C}$ )

$\mathrm{pH}$

Temperature $\left({ }^{\circ} \mathrm{C}\right)$

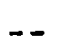

$-$

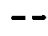

12.8

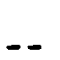

$-$

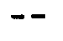

12.5

Reference: Mineral and Water Resources of South Dakota 1964 
TABLE 97. Water Analysis

Hydrologic Region: Missouri Basin

Aquifer Name: Hell Creek formation

Aquifer Age: Late Cretaceous

Petrology: shale, sandstone, sand, gravel, clay

State: South Dakota

Location: Northwestern South Dakota (Corson, Harding, Perkins and Ziebach Co's.

No. Analyses: 2

Water Type: $\mathrm{Na}, \mathrm{HCO}_{3}$

Solute Concentration

\begin{tabular}{ccc}
\hline Maximum & Mean & Minimum \\
\cline { 2 - 3 }-- & -- & - \\
& & \\
15 & 11.9 & 8.8 \\
0.22 & 0.145 & 0.07 \\
0.01 & 0.005 & 0 \\
5.1 & 3.75 & 2.4 \\
1.6 & 0.8 & 0 \\
465 & 379 & 292 \\
2.4 & 1.8 & 1.2 \\
720 & 630 & 540 \\
-- & -- & -- \\
402 & 284 & 165 \\
10 & 9.8 & 9.6 \\
1.4 & 1.0 & 0.6 \\
1.4 & 1.25 & 1.1 \\
1270 & 1014 & 758
\end{tabular}

Wel1 Depth (m)

Constituents $(\mathrm{mg} / \mathrm{l})$

and Properties

$\mathrm{SiO}_{2}$

$\mathrm{Fe}$

$\mathrm{Mn}$

$\mathrm{Ca}$

$\mathrm{Mg}$

$\mathrm{Na}$

K

$\mathrm{HCO}_{3}$

B

$\mathrm{SO}_{4}$

$\mathrm{Cl}$

$\mathrm{F}$

$\mathrm{NO}_{3}$

TDS
19

$\mathrm{Ca}, \mathrm{Mg}$

Noncarbonate

Sp. Cond.

(micromhos $25^{\circ} \mathrm{C}$ )

pH

Temperature $\left({ }^{\circ} \mathrm{C}\right)$
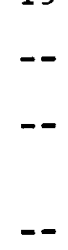

10.0
12.5

$--$

--

9.17
6

0.07

.4

.2 40

65

9.6

758

$-$

$--$

--

8.33

Reference: Mineral and Water Resources of South Dakota 1964 
TABLE 98. Water Analysis

Hydrologic Region: Missouri Basin

Aquifer Name: Niobrara formation and Codell sandstone member of Carlile shale

Aquifer Age: Late Cretaceous

Petrology: chalky marl, shale, sand
State: South Dakota

Location: Underlies most of South Dakota

No. Analyses: 2

Hater Type: $\mathrm{Na}, \mathrm{HCO}_{3}, \mathrm{SO}_{4}$

Solute Concentration

\begin{tabular}{ccc}
\hline Maximum & Mean & Minimum \\
\cline { 2 - 3 }-- & - & -- \\
& & \\
25 & & \\
0.93 & 16.8 & 8.6 \\
0 & 0.47 & 0.01 \\
84 & 0 & 0 \\
22 & 48 & 12 \\
605 & 13.7 & 5.4 \\
16 & 589 & 573 \\
594 & 12.9 & 9.7 \\
-- & 535 & 476 \\
1140 & -- & -- \\
110 & 886 & 632 \\
1.3 & 77.5 & 45 \\
9.0 & 0.85 & 0.4 \\
4.3 & 7.45 & 5.9 \\
2230 & 3.3 & 2.3
\end{tabular}

Hardness as $\mathrm{CaCO}_{3}$

$\mathrm{Ca}, \mathrm{Mg}$

302

177

52

Noncarbonate

Sp. Cond.

(micromhos $25^{\circ} \mathrm{C}$ )

$\mathrm{pH}$

Temperature $\left({ }^{\circ} \mathrm{C}\right)$

10.6

10.6

10.6

Reference: Mineral and Water Resources of South Dakota 1964 
TABLE 99. Water Analysis

Hydrologic Region: Missouri Basin

Aquifer Name: Inyan Kara group

Aquifer Age: Early Cretaceous

Petrology: conglomeratic sandstone, silt, clay, limestone, shale
State: South Dakota

Location: Western South Dakota

No. Analyses: 3

Hater Type: $\mathrm{Ca}, \mathrm{Na}, \mathrm{SO}_{4}$

Solute Concentration

\begin{tabular}{ccc}
\hline Maximum & Mean & Minimum \\
\cline { 2 - 3 }-- & -- & -- \\
& & \\
27 & 16.3 & 10 \\
5.1 & 2.36 & 0.38 \\
0.86 & 0.37 & 0 \\
388 & 209 & 8.7 \\
86 & 52.7 & 1.1 \\
760 & 341 & 131 \\
19 & 11.6 & 5.8 \\
988 & 431 & 132 \\
-- & -- & -- \\
1320 & 992 & 695 \\
90 & 57.3 & 20 \\
7.2 & 3.57 & 0.4 \\
2.6 & 1.5 & 0 \\
1.5 & 0.65 & 0.08 \\
2240 & 1967 & 1550
\end{tabular}

Hardness as $\mathrm{CaCO}_{3}$

$\mathrm{Ca}, \mathrm{Mg}$

1320

737

26

Noncarbonate

Sp. Cond.

(micronhos $25^{\circ} \mathrm{C}$ )

$\mathrm{pH}$

Temperature $\left({ }^{\circ} \mathrm{C}\right)$

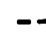

$-$

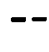

48.3

37.5

26.7 
Hydrologic Region: Missouri Basin

Aquifer Name: Sundance formation

Aquifer Age: Late Jurassic

Petrology: shale, limestone, sandstone
State: South Dakota

Location: Western South Dakota No. Analyses: 2

Nater Type: $\mathrm{Ca}, \mathrm{Na}, \mathrm{SO}_{4}$

Solute Concentration

Maximum

\section{We11 Depth (m) \\ Constituents $(\mathrm{mg} / \mathrm{l})$ \\ and Properties}

$$
\mathrm{SiO}_{2}
$$

$\mathrm{Fe}$

$\mathrm{Mn}$

$\mathrm{Ca}$

$\mathrm{Mg}$

$\mathrm{Na}$

$\mathrm{K}$

$\mathrm{HCO}_{3}$

$\mathrm{CO}_{3}$

$\mathrm{SO}_{4}$

$\mathrm{Cl}$

$\mathrm{F}$

$\mathrm{NO}_{3}$

B

TDS

Hardness as $\mathrm{CaCO}_{3}$

$\mathrm{Ca}, \mathrm{Mg}$

Noncarbonate

Sp. Cond.

(micronhos $25^{\circ} \mathrm{C}$ )

pH

Temperature $\left({ }^{\circ} \mathrm{C}\right)$
16

6.6
0.08
435
140
699

57

326

2360

407

3.5

0.2

1.9

4460

1580

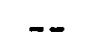

$-$

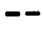

32.78 Mean

-

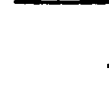

Minimum

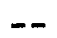

Reference: Mineral and Water Resources of South Dakota 1964 


\section{TABLE 101. Water Analysis}

Hydrologic Region: Missouri Basin Aquifer Name: Minnelusa formation Aquifer Age: Permian/Pennsylvanian Petrology: calcareous sandstone, limestone
State: South Dakota

Location: Black Hills Vicinity

No. Analyses: 2

Hater Type: $\mathrm{Ca}, \mathrm{SO}_{4}$

Solute Concentration

Maximum Mean Minimum

\section{We11 Depth (m) \\ Constituents $(\mathrm{mg} / \mathrm{l})$ and Properties}

$$
\mathrm{SiO}_{2}
$$

$\mathrm{Fe}$

$\mathrm{Mn}$

$\mathrm{Ca}$

$\mathrm{Mg}$

$\mathrm{Na}$

$\mathrm{K}$

$\mathrm{HCO}_{3}$

$\mathrm{CO}_{3}$

$\mathrm{SO}_{4}$

$\mathrm{Cl}$

$\mathrm{F}$

$\mathrm{NO}_{3}$

B

TDS

Hardness as $\mathrm{CaCO}_{3}$

$\mathrm{Ca}, \mathrm{Mg}$

Noncarbonate

Sp. Cond.

(micromhos $25^{\circ} \mathrm{C}$ )

$\mathrm{pH}$

Temperature $\left({ }^{\circ} \mathrm{C}\right)$
12

$$
2.6
$$

0

408

73

5.1

3.2

236

1060

2

0.7

0.2

0.07

1850

1320

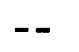

$--$

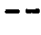

13.33
10.8

1.34

0

228

45

5

2.7

231.5

536

1.3

0.45

0.1

0.035

926

755

Reference: Mineral and Water Resources of South Dakota 1964
190

9.6

0.08

0

48

17

4.9

2.2

227

$--$

11

0.6

0.2

0

0

206

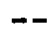

--

--

10.56 


\section{TABLE 102. Water Analysis}

Hydrologic Region: Missouri Basin

Aquifer Name: Pahasapa limestone

Aquifer Age: Mississippian

Petrology: limestone and dolomite
State: South Dakota

Location: Black Hills Vicinity

No. Analyses: 3

Hater Type: $\mathrm{Ca}, \mathrm{SO}_{4}$

Solute Concentration

Maximum Mean Minimum

We11 Depth (m)

Constituents $(\mathrm{mg} / \mathrm{l})$ and Properties

$\mathrm{SiO}_{2}$

38

$\mathrm{Fe}$

$\mathrm{Mn}$

$\mathrm{Ca}$

$\mathrm{Mg}$

$\mathrm{Na}$

$\mathrm{K}$

$\mathrm{HCO}_{3}$

$\mathrm{CO}_{3}$

$\mathrm{SO}_{4}$

Cl

$\mathrm{F}$

$\mathrm{NO}_{3}$

B

TDS

Hardness as $\mathrm{CaCO}_{3}$

$\mathrm{Ca}, \mathrm{Mg}$

1390

Noncarbonate

Sp. Cond.

(micromhos $25^{\circ} \mathrm{C}$ )

$\mathrm{pH}$

Temperature $\left({ }^{\circ} \mathrm{C}\right)$
67.22

29.3

1.3

0.027

218

59

35.2

12.4

174

--

647

47

3.35

0.4

0.14

1206

787

153

--

$-$

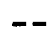

45.37

18.89

Reference: Mineral and Water Resources of South Dakota 1964 


\section{TABLE 103. Water Analysis}

Hydrologic Region: Missouri Basin

Aquifer Name: Deadwood formation

Aquifer Age: Late Cambrian/ Early Ordovician

Petrology: quartz sandstone, shale, limestone, clay
State: South Dakota

Location: Black Hills Vicinity

No. Analyses: 2

Water Type: $\mathrm{Ca}, \mathrm{Mg}, \mathrm{HCO}_{3}$

Solute Concentration

\begin{tabular}{ccc}
\hline Maximum & Mean & Minimum \\
\cline { 2 - 3 }-- & -- & \\
& & \\
11 & 11 & 11 \\
0.98 & 0.53 & 0.08 \\
0.09 & 0.06 & 0.03 \\
54 & 45.5 & 37 \\
31 & 26.5 & 22 \\
7.6 & 5.4 & 3.2 \\
2 & 1.7 & 1.4 \\
312 & 256 & 199 \\
-- & -- & -- \\
31 & 18.1 & 5.2 \\
1.8 & 1.3 & 0.8 \\
0.6 & 0.4 & 0.2 \\
1.5 & 1.3 & 1.1 \\
0.05 & 0.04 & 0.03 \\
260 & 235 & 209 \\
& &
\end{tabular}

Hardness as $\mathrm{CaCO}_{3}$

$\mathrm{Ca}, \mathrm{Mg}$

261

221

181

Noncarbonate

Sp. Cond.

(microminos $25^{\circ} \mathrm{C}$ )

pH

Temperature $\left({ }^{\circ} \mathrm{C}\right)$

16.67

12.78

Reference: Mineral and Water Resources of South Dakota 1964 
TABLE 104. Water Analysis

Hydrologic Region: Missouri Basin

Aquifer Name: Basement complex

Aquifer Age: Precambrian

Petrology: schist, quartzite, slate, marble, pegmatite, granite, amphibolite
State: South Dakota

Location: Black Hills

No. Analyses: 2

Water Type: $\mathrm{Ca}, \mathrm{HCO}_{3}$

Solute Concentration

\begin{tabular}{ccc}
\hline Maximum & Mean & Minimum \\
\cline { 2 - 3 }-- & -- & - \\
& & \\
19 & 19 & 19 \\
0.42 & 0.225 & 0.03 \\
0.05 & 0.035 & 0.02 \\
36 & 29.5 & 23 \\
18 & 12.6 & 7.2 \\
10 & 7.55 & 5.1 \\
4.4 & 3.35 & 2.3 \\
207 & 131 & 54 \\
-- & -- & -- \\
32 & 22 & 12 \\
7.7 & 5.55 & 3.4 \\
0.4 & 0.35 & 0.3 \\
12 & 7.35 & 2.7 \\
0.03 & 0.025 & 0.02 \\
219 & 182 & 145
\end{tabular}

Hardness as $\mathrm{CaCO}_{3}$

$\mathrm{Ca}, \mathrm{Mg}$

165

126

87

Noncarbonate

Sp. Cond.

(micromhos $25^{\circ} \mathrm{C}$ )

pH

Temperature $\left({ }^{\circ} \mathrm{C}\right)$

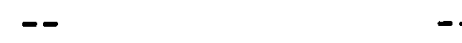

$--$

$--$

$-$

5.3

5.0

Reference: Mineral and Water Resources of South Dakota 1964 


\section{TABLE 105. Water Analysis}

Hydrologic Region: New England

Aquifer Name: Cape Cod

Aquifer Age: Holocene/Pleistocene

Petrology: sand, gravel, silt, clay

State: Massachusetts

Location: Cape Cod

No. Analyses: 202

Water Type: $\mathrm{Na}, \mathrm{HCO}_{3}, \mathrm{Cl}$

Solute Concentration

We11 Depth (m)

Constituents $(\mathrm{mg} / \ell)$

and Properties

$\mathrm{SiO}_{2}$

$\mathrm{Fe}$

$\mathrm{Mn}$

$\mathrm{Ca}$

$\mathrm{Mg}$

$\mathrm{Na}$

$\mathrm{K}$

$\mathrm{HCO}_{3}$

$\mathrm{CO}_{3}$

$\mathrm{SO}_{4}$

$\mathrm{Cl}$

$\mathrm{F}$

$\mathrm{NO}_{3}$

TDS
41

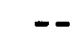

$--$

21

34

264

7.8

100

41

61

480

0.7

6.3

877

Hardness as $\mathrm{CaCO}_{3}$

$\mathrm{Ca}, \mathrm{Mg}$

185

Noncarbonate

Sp. Cond.

(micromhos $25^{\circ} \mathrm{C}$ )

$\mathrm{pH}$

Temperature $\left({ }^{\circ} \mathrm{C}\right)$

Reference: Ryan 1982

1760

7.6

Maximum

Median

Minimum

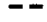

9.1

3.2

--

--

3.6

0.5

2.4

0.3

13.2

3.5

0.9

0.2

11

0

5.7

0.4

6.6

1.1

19

5.8

0

0

0.12

29

70

20

5.0

123

46

6.1

4.2

$-$ 
TABLE 106. Water Analysis

Hydrologic Region: Ohio

Aquifer Name: Glacial outwash

Aquifer Age: Pleistocene

Petrology: clay, till, sand, gravel
State: Ohio

Location: Medina, Ashland, Richland, Morrow, Delaware, Franklin Co's.

No. Analyses: 8

Water Type: $\mathrm{Ca}, \mathrm{HCO}_{3}$

Solute Concentration

Maximum

Well Depth (m)

Constituents $(\mathrm{mg} / \mathrm{l})$ and Properties

$\mathrm{SiO}_{2}$

$\mathrm{Fe}$

$\mathrm{Mn}$

$\mathrm{Ca}$

$\mathrm{Mg}$

$\mathrm{Na}$

$\mathrm{K}$

$\mathrm{HCO}_{3}$

$\mathrm{CO}_{3}$

$\mathrm{SO}_{4}$

Cl

$\mathrm{F}$

$\mathrm{NO}_{3}$

TDS

Hardness as $\mathrm{CaCO}_{3}$

$\mathrm{Ca}, \mathrm{Mg}$

1068

Noncarbonate

Sp. Cond.

(micromhos $25^{\circ} \mathrm{C}$ )

$\mathrm{pH}$

7.2

Minimum
15

7.9

7.49

13.3

1.03

0.046

90.5

18.4

14.7

0.34

145

32.9

12

0.36

0.45

545

364

28.6

716

885

$-$
7.4

0.11

0

0

0

0

1.7

0

$--$

0

2

0.1

0

350

192

0

600

Temperature $\left({ }^{\circ} \mathrm{C}\right)$

Reference: Pree 1962 
TABLE 107. Water Analysis

Hydrologic Region: Ohio

Aquifer Name: Cuyahoga formation

Aquifer Age: Late Mississippian

Petrology: sandstone and shale
State: Ohio

Location: Medina, Ashland, Richland, Morrow, Delaware, Frankl in Co's.

No. Analyses: 9

Water Type: $\mathrm{Ca}, \mathrm{HCO}_{3}$

Solute Concentration

\begin{tabular}{ccc}
\hline Maximum & Mean & Minimum \\
\cline { 2 - 3 }-- & -- & -- \\
& & \\
15 & 12.5 & 10 \\
4.9 & 1.26 & 0.05 \\
0.6 & 0.14 & 0 \\
143 & 57.5 & 0 \\
51 & 13.5 & 0 \\
182 & 26.8 & 0 \\
2.7 & 0.30 & 0 \\
418 & 46.4 & 0 \\
-- & -- & -- \\
86 & 9.56 & 0 \\
34 & 11 & 0 \\
0.7 & 0.23 & 0 \\
1.4 & 0.18 & 0 \\
1066 & 418 & 200 \\
567 & & 122 \\
30 & 244 & 0 \\
774 & 3.33 & 774 \\
8.0 & 774 & 7.1 \\
-- & 7.53 & -- \\
& -- &
\end{tabular}

Reference: Pree 1962 
TABLE 108. Water Analysis

Hydrologic Region: Ohio

Aquifer Name: Columbus Island

Aquifer Age: Lower Devonian

Petrology: limestone
State: Ohio

Location: Medina, Ashland, Richland, Morrow, Delaware, Frankl in Co's.

No. Analyses: 4

Water Type: $\mathrm{Ca}, \mathrm{SO}_{4}$

Solute Concentration

\begin{tabular}{|c|c|c|}
\hline Maximum & $\frac{\text { Solute Concentration }}{\text { Mean }}$ & Minimum \\
\hline-- & -- & -- \\
\hline 11 & 9.27 & 8 \\
\hline 1.6 & 1.40 & 0.23 \\
\hline 0.16 & 0.053 & -- \\
\hline 474 & 366 & 290 \\
\hline 201 & 135 & 101 \\
\hline 48.3 & 32.9 & 18 \\
\hline-- & 3.1 & -- \\
\hline 396 & 392 & 389 \\
\hline-- & -- & -- \\
\hline 1060 & 985 & 878 \\
\hline 45 & 18.9 & 1.5 \\
\hline 2.0 & 1.63 & 1.4 \\
\hline 0.1 & 0.075 & 0 \\
\hline 2840 & 2042 & 1725 \\
\hline 2010 & 1473 & 1210 \\
\hline 1040 & 1021 & 1001 \\
\hline 2730 & 2235 & 1990 \\
\hline 7.7 & 7.35 & 7.0 \\
\hline-- & -- & -- \\
\hline
\end{tabular}

We11 Depth (m)

Constituents $(\mathrm{mg} / \ell)$ and Properties

$\mathrm{SiO}_{2}$

$\mathrm{Fe}$

$\mathrm{Mn}$

$\mathrm{Ca}$

$\mathrm{Mg}$

$\mathrm{Na}$

$\mathrm{K}$

$\mathrm{HCO}_{3}$

$\mathrm{CO}_{3}$

$\mathrm{SO}_{4}$

$\mathrm{Cl}$

$\mathrm{F}$

$\mathrm{NO}_{3}$

TDS

Hardness as $\mathrm{CaCO}_{3}$

$\mathrm{Ca}, \mathrm{Mg}$

Noncarbonate

Sp. Cond.

(micromhos $25^{\circ} \mathrm{C}$ )

pH

Temperature $\left({ }^{\circ} \mathrm{C}\right)$

Reference: Pree 1962 


\section{TABLE 109. Water Analysis}

Hydrologic Region: Ohio

Aquifer Name: Columbus-Bass Island

Aquifer Age: Lower Devonian-Silurian

Petrology: limestones, argillaceous
State: Ohio

Location: Medina, Ashland, Richland, Morrow, Delaware, Frankl in Co's.

No. Analyses: 2

Water Type: $\mathrm{Ca}, \mathrm{SO}_{4}$

Solute Concentration

Maximum

$\mathrm{Fe}$

$\mathrm{HCO}_{3}$

$\mathrm{CO}_{3}$

$\mathrm{SO}_{4}$

C1

$\mathrm{F}$

$\mathrm{NO}_{3}$

TDS

Hardness as $\mathrm{CaCO}_{3}$

$\mathrm{Ca}, \mathrm{Mg}$

Noncarbonate

Sp. Cond.

(micromhos $025^{\circ} \mathrm{C}$ )

$\mathrm{pH}$

Temperature $\left({ }^{\circ} \mathrm{C}\right)$

Reference: Pree 1962
11

10.5

10

0.77

$--$

472

136

56.8

334

1740

1522

Mean

Minimum

0.57

0.36

$--$

448

424

130

124

53

49.2

--

325

316

1451

1335

1219

84

64.5

45

2.3

2.05

1.8

0.4

0.25

0.1

2462

2270

2077

1654

1568

1416

2640

2550

2460

7.3

7.15

7.0
1309 
TABLE 110. Water Analysis

Hydrologic Region: Ohio

Aquifer Name: Glacial outwash

Aquifer Age: Pleistocene

Petrology: clay, till, sand, gravel
State: Pennsylvania

Location: Crawford Co. (western)

No. Analyses: 50

Nater Type: $\mathrm{Ca}, \mathrm{HCO}_{3}$

Solute Concentration

$\begin{array}{ccc}\text { Maximum } & \text { Mean } & \text { Minimum } \\ 23 & 23\end{array}$

We11 Depth (m)

13

5.0

0.03

80

19

27

3.2

315

$\mathrm{HCO}_{3}$
$\mathrm{CO}_{3}$

$\mathrm{SO}_{4}$

C1

$\mathrm{F}$

$\mathrm{NO}_{3}$

TDS

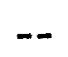

66

130

3.0

2.1

353

250

21

1000

Sp. Cond.

(micromhos $25^{\circ} \mathrm{C}$ )

$\mathrm{pH}$

Temperature $\left({ }^{\circ} \mathrm{C}\right)$
11

0.30

0.02

59

12

14

1.2

195

42

11

0.4

0.20

187

160

140

10

500

109

\section{7}

0

0

41

8.7

3.5

1

85

17

1

0.3

0

60

1

Reference: Schiner and Gallaher 1979 
TABLE 111. Water Analysis

Hydrologic Region: Ohio

Aquifer Name: Berea sandstone

Aquifer Age: Early Mississippian

Petrology: sandstone, siltstone, shale
State: Pennsylvania

Location: Crawford Co. (western)

No. Analyses: 5

Water Type: $\mathrm{Ca}, \mathrm{HCO}_{3}$

Solute Concentration

$\frac{\text { Maximum }}{60} \frac{\text { Mean }}{23} \quad \frac{\text { Minimum }}{6}$

We11 Depth (m)

14

2.8

$\mathrm{SiO}_{2}$

4.5

1.3

$\mathrm{Mn}$

0.03

0.006

$\mathrm{Ca}$

44

32

$\mathrm{Mg}$

$--$

$\mathrm{Na}$

60

11

14

$\mathrm{K}$

$\mathrm{HCO}_{3}$

--

327

4.1

$\mathrm{CO}_{3}$

$\mathrm{SO}_{4}$

$\mathrm{Cl}$

43

4.4

249

80

$-$

2.0

25

10

$\mathrm{F}$

$\mathrm{NO}_{3}$

0.45

TDS

345

4

0

1.8

0.30

0.32

0.09

241

100

Hardness as $\mathrm{CaCO}_{3}$

$\mathrm{Ca}, \mathrm{Mg}$

186

152

64

Noncarbonate

0

0

Sp. Cond.

(micromhos $25^{\circ} \mathrm{C}$ )

$--$

533

$\mathrm{pH}$

Temperature $\left({ }^{\circ} \mathrm{C}\right)$

Reference: Schiner and Gallaher 1979 
TABLE 112. Water Analysis

Hydrologic Region: Ohio

Aquifer Name: Cussewago sandstone

Aquifer Age: Early Mississippian

Petrology: sandstone, some shale

State: Pennsylvania

Location: Crawford Co. (western)

No. Analyses: 23

Nater Type: $\mathrm{Ca}, \mathrm{Na}, \mathrm{HCO}_{3}$

Solute Concentration

\begin{tabular}{lll}
\hline Maximum & $\frac{\text { Mean }}{275}$ & $\frac{\text { Minimum }}{5}$
\end{tabular}

We11 Depth (m)

Constituents $(\mathrm{mg} / \mathrm{l})$

and Properties

$\mathrm{SiO}_{2}$

$\mathrm{Fe}$

$\mathrm{Mn}$

$\mathrm{Ca}$

$\mathrm{Mg}$

$\mathrm{Na}$

$\mathrm{K}$

$\mathrm{HCO}_{3}$

$\mathrm{CO}_{3}$

$\mathrm{SO}_{4}$

Cl

$\mathrm{F}$

$\mathrm{NO}_{3}$

TDS

Hardness as $\mathrm{CaCO}_{3}$

$\mathrm{Ca}, \mathrm{Mg}$

Noncarbonate

Sp. Cond.

(micromhos $25^{\circ} \mathrm{C}$ )

$\mathrm{pH}$

Temperature $\left({ }^{\circ} \mathrm{C}\right)$
15

5.53

0.3

1.3

0.16

84

21

130

4.4

374

--

52

42

0.68

0.95

358

264

66

680

(

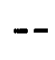

--

0.204

0

0.038

0

19.9

4.53

22.4

0.913

$--$

$-$

--

--

195

90

$--$

17.2

8.92

0.304

0.188

207

163

34

$$
5.35
$$

221

$--$

$--$

Reference: Schiner and Gallaher 1979 
TABLE 113. Water Analys is

Hydrologic Region: Ohio

Aquifer Name: Orangeville shale

Aquifer Age: Early Mississippian

Petrology: shale, some siltstone

Hell Depth (m)

Const ituents (mg/ $\ell$ )

and Properties

$\mathrm{SiO}_{2}$

$\mathrm{Fe}$

$\mathrm{Mn}$

$\mathrm{Ca}$

$\mathrm{Mg}$

$\mathrm{Na}$

K

$\mathrm{HCO}_{3}$

$\mathrm{CO}_{3}$

$\mathrm{SO}_{4}$

Cl

F

$\mathrm{NO}_{3}$

TDS
State: Pennsylvania

Location: Crawford Co. (western)

No. Analyses: 1

Water Type: $\mathrm{Ca}, \mathrm{HCO}_{3}$

Solute Concentration
16

0.42

--

26

8.2

1.5

154

5.1

2.3

$--$

0.08

136

Hardness as $\mathrm{CaCO}_{3}$

$\mathrm{Ca}, \mathrm{Mg}$

99

Noncarbonate

0

Sp. Cond.

(micronhos $25^{\circ} \mathrm{C}$ )

$\mathrm{pH}$

Temperature $\left({ }^{\circ} \mathrm{C}\right)$

Reference: Schiner and Gallaher 1979

$-$

$-$

\section{6}

\section{1}


TABLE 113A. Water Analysis

Hydrologic Region: Ohio

Aquifer Mame: Sharpsville sandstone

Aquifer Age: Early Mississippian

Petrology: sandstone, siltstone, shale, limestone
State: Pennsylvania

Location: Crawford Co. (western)

No. Analyses: 2

Water Type: $\mathrm{Ca}, \mathrm{HCO}_{3}$

Solute Concentration

\begin{tabular}{|c|c|c|}
\hline Maximum & Mean & Minimum \\
\hline 75 & 27 & 8 \\
\hline 19 & 17 & 15 \\
\hline 1.2 & 0.62 & 0.04 \\
\hline 0.04 & 0.035 & 0.03 \\
\hline 84 & 65 & 46 \\
\hline 20 & 17 & 14 \\
\hline 19 & 18.5 & 18 \\
\hline 4.6 & 4.45 & 4.3 \\
\hline 354 & 284.5 & 215 \\
\hline- & -- & -- \\
\hline 22 & 17 & 13 \\
\hline 26 & 13.9 & 1.7 \\
\hline 0.3 & 0.25 & 0.2 \\
\hline 0.95 & 0.475 & - \\
\hline 360 & 296 & 232 \\
\hline 290 & 230 & 172 \\
\hline 2 & 1 & 0 \\
\hline 740 & 555 & 370 \\
\hline-- & - & -- \\
\hline-- & -- & -- \\
\hline
\end{tabular}

Well Depth (m)

Constituents $(\mathrm{mg} / \mathrm{l})$

and Properties

$\mathrm{SiO}_{2}$

$\mathrm{Fe}$

$\mathrm{Mn}$

$\mathrm{Ca}$

$\mathrm{Mg}$

$\mathrm{Na}$

$\mathrm{K}$

$\mathrm{HCO}_{3}$

$\mathrm{CO}_{3}$

$\mathrm{SO}_{4}$

Cl

$\mathrm{F}$

$\mathrm{NO}_{3}$

TDS

Hardness as $\mathrm{CaCO}_{3}$

$\mathrm{Ca}, \mathrm{Mg}$

Noncarbonate

Sp. Cond.

(micromhos a $25^{\circ} \mathrm{C}$ )

$\mathrm{pH}$

Temperature $\left({ }^{\circ} \mathrm{C}\right)$

Reference: Schiner and Gallaher 1979 
TABLE 114. Water Analys is

Hydrologic Region: Ohio

Aquifer Name: Conewango group

Aquifer Age: Late Devonian

Petrology: shale, siltstone, sandstone
State: Pennsylvania

Location: Crawford Co.

No. Analyses: 27

Water Type: $\mathrm{Ca}, \mathrm{Na}, \mathrm{HCO}_{3}$

Solute Concentration

\begin{tabular}{ccc}
\hline Maximum & Mean & Minimum \\
212 & 23 & 7 \\
& & \\
-- & 17 & -- \\
38 & 0.35 & 0 \\
0.70 & 0.02 & 0 \\
100 & 38 & -- \\
23 & 7.5 & -- \\
170 & 40 & 10 \\
12 & 1.6 & -- \\
3340 & 271 & 178 \\
-- & -- & -- \\
47 & 32 & 11 \\
4500 & 25 & 1 \\
1.4 & 0.50 & 0.20 \\
0.19 & 0.14 & 0.9 \\
6360 & 1598 & 162
\end{tabular}

Hardness as $\mathrm{CaCO}_{3}$

160

13000

Sp. Cond.
(micromhos $25^{\circ} \mathrm{C}$ )

$\mathrm{pH}$

Temperature $\left({ }^{\circ} \mathrm{C}\right)$

Reference: Schiner and Gallaher 1979
$\mathrm{Ca}, \mathrm{Mg}$

Sp. Cond.

Hel1 Depth (m)

Constituents (mg/ $\ell$ )

$\mathrm{SiO}_{2}$

$\mathrm{Fe}$

$\mathrm{Mg}$

$\mathrm{Na}$

$\mathrm{HCO}_{3}$

$\mathrm{CO}_{3}$

$\mathrm{SO}_{4}$

Noncarbonate
37

37

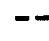

$-$
100

8

650

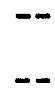

72

1

258 
TABLE 115. Water Analysis

Hydrologic Region: Ohio

Aquifer Name: Conneaut group

Aquifer Age: Late Devonian

Petrology: shale, siltstone
State: Pennsylvania

Location: Crawford Co. (western)

No. Analyses: 4

Hater Type: $\mathrm{Na}, \mathrm{Cl}$

Solute Concentration

$\frac{\text { Maximum }}{105} \frac{\text { Mean }}{23} \quad \frac{\text { Minimum }}{9}$

Well Depth (m)

Constituents $(\mathrm{mg} / \mathrm{l})$

and Properties

$\begin{array}{lc}\mathrm{SiO}_{2} & -- \\ \mathrm{Fe} & 2.17 \\ \mathrm{Mn} & 4.7 \\ \mathrm{Ca} & -- \\ \mathrm{Mg} & -- \\ \mathrm{Na} & 22000 \\ \mathrm{~K} & -- \\ \mathrm{HCO}_{3} & 381 \\ \mathrm{CO}_{3} & -- \\ \mathrm{SO}_{4} & 66 \\ \mathrm{Cl} & 44000 \\ \mathrm{~F} & 0.71 \\ \mathrm{NO}_{3} & -- \\ \mathrm{TDS} & 77500\end{array}$

Hardness as $\mathrm{CaCO}_{3}$

$\mathrm{Ca}, \mathrm{Mg}$

5900

Noncarbonate

Sp. Cond.

(micromhos $25^{\circ} \mathrm{C}$ )

pH

Temperature $\left({ }^{\circ} \mathrm{C}\right)$

Reference: Schiner and Gallaher 1979
1615

76

5.1

0.938

0.24

1.24

0

400

5547

72

220

59

$--$

44.8

$--$

8

1

0.33

0.433

0.16

19499

180

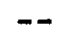

$-$

90600

$-$

$--$
1200 


\section{TABLE 116. Water Analysis}

Hydrologic Region: Pacific Northwest

Aquifer Name: Basalt-undifferentiated

Aquifer Age: Miocene

Petrology: basalt and interbeds

State: Idaho, Oregon, Washington Location: Entire region

No. Analyses: 500

Water Type: $\mathrm{Ca}, \mathrm{Na}, \mathrm{HCO}_{3}$

Solute Concentration

Maximum

We11 Depth (m)

Constituents $(\mathrm{mg} / \mathrm{l})$

and Properties

$\mathrm{SiO}_{2}$

$\mathrm{Fe}$

$\mathrm{Mn}$

$\mathrm{Ca}$

$\mathrm{Mg}$

$\mathrm{Na}$

K

$\mathrm{HCO}_{3}$

$\mathrm{CO}_{3}$

$\mathrm{SO}_{4}$

C1

$\mathrm{F}$

$\mathrm{NO}_{3}$

TDS

Hardness as $\mathrm{CaCO}_{3}$

$\mathrm{Ca}, \mathrm{Mg}$

Noncarbonate

Sp. Cond.

(micrombos $25^{\circ} \mathrm{C}$ )

pH

Temperature $\left({ }^{\circ} \mathrm{C}\right)$

Reference: Newcomb 1972

Minimum

Mean

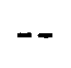

$-$

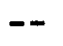

$-$

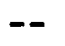

$-$

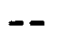

$-$

$--$

$-$

$-$

$-$

$-$

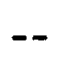

$--$

$--$

$--$

$-$

$-$
55

0.2

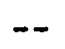

19

8

37

7

150

--

20

10

0.05

$<2.0$

$150-400$

$50-250$

$200-500$

7.8

$--$ 


\section{TABLE 117. Water Analysis}

Hydrologic Region: Pacific Northwest

Aquifer Name: Alluvium

Aquifer Age: Holocene

Petrology: sand, gravel
State: Oregon

Location: East Portland area

No. Analyses: 3

Water Type: $\mathrm{Ca}, \mathrm{Na}, \mathrm{HCO}_{3}$

Solute Concentration

Maximum

We11 Depth (m)

Constituents $(\mathrm{mg} / \ell)$ and Properties

$\mathrm{SiO}_{2}$

$\mathrm{Fe}$

$\mathrm{Mn}$

$\mathrm{Ca}$

$\mathrm{Mg}$

$\mathrm{Na}$

K

$\mathrm{HCO}_{3}$

$\mathrm{CO}_{3}$

$\mathrm{SO}_{4}$

$\mathrm{Cl}$

$\mathrm{F}$

$\mathrm{NO}_{3}$

TDS

Hardness as $\mathrm{CaCO}_{3}$

$\mathrm{Ca}, \mathrm{Mg}$

Noncarbonate

Sp. Cond.

(micromhos $025^{\circ} \mathrm{C}$ )

$\mathrm{pH}$

Temperature $\left({ }^{\circ} \mathrm{C}\right)$

Reference: Hogenson and Foxworthy 1965
57

158

Intermediate

Minimum

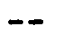

54

40

0.08

0.01

1.8

0

0

0.10

56

39

11

4.4

16

11

79

26

11

7.2

5.2

2.2

132

231

115

0

0

0

7.8

20

3.3

156

0.3

9

2

0.5

0.1

1.2

0

281

155

163

73

50

0

0

726

423

182

7.8

7.4

7.9

17.2

15.6 


\section{TABLE 118. Water Analysis}

Hydrologic Region: Pacific Northwest

Aquifer Name: Basalt-undifferentiated

Aquifer Age: Miocene

Petrology: basalt and interbeds
State: Oregon

Location: East Portland area No. Analyses: 3

Nater Type: $\mathrm{Na}, \mathrm{HCO}_{3}, \mathrm{Cl}$

Solute Concentration

\begin{tabular}{ccc}
\hline Maximum & Intermediate & Minimum \\
\cline { 2 - 3 }-- & -- & -- \\
& & \\
50 & 53 & 60 \\
0.43 & 0.07 & 0.06 \\
0.05 & 0.05 & -- \\
54 & 35 & 5.2 \\
15 & 6.2 & 0.2 \\
96 & 87 & 10 \\
116 & 122 & 9.6 \\
-- & -- & 114 \\
4.6 & 0.3 & 5 \\
225 & 149 & 1.2 \\
0.4 & 0.6 & 92 \\
-- & -- & 3.2 \\
589 & 480 & 326
\end{tabular}

Hardness as $\mathrm{CaCO}_{3}$

$$
\begin{aligned}
& \mathrm{Ca}, \mathrm{Mg} \\
& \text { Noncarbonate }
\end{aligned}
$$

195

114

14

Sp. Cond.

(micromhos $25^{\circ} \mathrm{C}$ )

pH

7.7

7.8

8.6

Temperature $\left({ }^{\circ} \mathrm{C}\right)$

$--$

Reference: Hogenson and Foxworthy 1965 
Hydrologic Region: Pacific Northwest

Aquifer Name: None specified

Aquifer Age: Miocene

Petrology: basalt and interbeds
State: Oregon

Location: Marion Co.

No. Analyses: 3

Water Type: $\mathrm{Ca}, \mathrm{Na}, \mathrm{HCO}_{3}$

Solute Concentration

Maximum Intermediate

Well Depth (m) 37

192

97

Constituents $(\mathrm{mg} / \mathrm{l})$ and Properties

$$
\mathrm{SiO}_{2}
$$

$\mathrm{Fe}$

$\mathrm{Mn}$

$\mathrm{Ca}$

$\mathrm{Mg}$

$\mathrm{Na}$

$\mathrm{K}$

$\mathrm{HCO}_{3}$

$\mathrm{CO}_{3}$

$\mathrm{SO}_{4}$

C1

$\mathrm{F}$

$\mathrm{NO}_{3}$

TDS
54

0.64

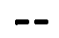

99

11

282

14

110

0

15

585

0.7

1.6

1120

292

202

2030

Sp. Cond.

(micromhos $25^{\circ} \mathrm{C}$ )

$\mathrm{pH}$

Temperature $\left({ }^{\circ} \mathrm{C}\right)$

Reference: Newcomb 1972

7.4

13.3
65

0.03

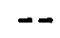

28

1.9

20

3.5

106

0

3.0

24

0.4

0

198

78

0

257

$$
7.4
$$

16.9
43

7.8

41

1.1

10

4.4

14

1.6

80

0

4.2

3.5

0.4

0

120

0

143

13.3 
Hydrologic Region: Pacific Northwest

Aquifer Name: None specified

Aquifer Age: Miocene

Petrology: basalt and interbeds

State: Oregon

Location: Umatilla Ordnance Depot

No. Analyses: 3

Water Type: $\mathrm{Na}, \mathrm{HCO}_{3}$

Solute Concentration

Maximum Intermediate Minimum

We11 Depth (m)

131

Constituents (mg/ $\ell$ )

and Properties

$\mathrm{SiO}_{2}$

$\mathrm{Fe}$

$\mathrm{Mn}$

$\mathrm{Ca}$

$\mathrm{Mg}$

$\mathrm{Na}$

K

$\mathrm{HCO}_{3}$

$\mathrm{CO}_{3}$

$\mathrm{SO}_{4}$

$\mathrm{Cl}$

$\mathrm{F}$

TDS
$\mathrm{NO}_{3}$

62

0.08

0.1

22

13

76

7.2

189

0

103

13

1.1

0.4

391

Hardness as $\mathrm{CaCO}_{3}$

$\mathrm{Ca}, \mathrm{Mg}$

Noncarbonate

Sp. Cond.

(micromhos $25^{\circ} \mathrm{C}$ )

$\mathrm{pH}$

Temperature $\left({ }^{\circ} \mathrm{C}\right)$

Reference: Newcomb 1972

108

0

542

7.8

20.6
233

316
51

0.12

0

10

3.4

88

9.0

0

29

8.8

1.4

0.2

8.2

8.4

73

0.02

0.01

1.8

0.6

70

11

171

4

0.6

18

1.3

0.1

264

$\begin{array}{rc}39 & 7 \\ 0 & -- \\ 458 & 336 \\ 8.2 & 8.4 \\ -- & --\end{array}$


TABLE 121. Water Analysis

Hydrologic Region: Pacific Northwest

Aquifer Name: None specified

Aquifer Age: Miocene

Petrology: basalt and interbeds
State: Washington

Location: Benton, Yakima Co's.

No. Analyses: 3

Water Type: $\mathrm{Ca}, \mathrm{HCO}_{3}$

Solute Concentration

Maximum

130

94

305

Well Depth (m)

Constituents $(\mathrm{mg} / \mathrm{l})$

and Properties

$\mathrm{SiO}_{2}$

43

$\mathrm{Fe}$

$\mathrm{Mn}$

$\mathrm{Ca}$

$\mathrm{Mg}$

$\mathrm{Na}$

K

$\mathrm{HCO}_{3}$

$\mathrm{CO}_{3}$

$\mathrm{SO}_{4}$

$\mathrm{Cl}$

$\mathrm{F}$

$\mathrm{NO}_{3}$

TDS

Hardness as $\mathrm{CaCO}_{3}$

$\mathrm{Ca}, \mathrm{Mg}$

242

52

665

Sp. Cond.

(micromhos $25^{\circ} \mathrm{C}$ )

pH

7.6

16.1
7.9

46

0.06

0

36

9.9

17

10

162

0

40

6.1

0.3

0.1

245

130

0

343

-
7.9

44

0

--

18

6.7

7.5

3.3

96

0

6.2

2.8

0.2

1.8

138

72

0

179

14.5

Reference: Newcomb 1972 
TABLE 122. Water Analys is

Hydrologic Region: Pacific Northwest

Aquifer Name: None specified

Aquifer Age: Miocene

Petrology: basalt and interbeds
State: Washington

Location: Grant Co.

No. Analyses: 3

Nater Type: $\mathrm{Ca}, \mathrm{Mg}, \mathrm{Na}, \mathrm{HCO}_{3}$

Solute Concentration

$\begin{array}{lll}\text { Maximum } & \frac{\text { Intermediate }}{244} & \frac{\text { Minimum }}{28}\end{array}$

We11 Depth (m)

Constituents $(\mathrm{mg} / \ell)$ and Properties

$\mathrm{SiO}_{2}$

$\mathrm{Fe}$

$\mathrm{Mn}$

$\mathrm{Ca}$

$\mathrm{Mg}$

$\mathrm{Na}$

$\mathrm{K}$

$\mathrm{HCO}_{3}$

$\mathrm{CO}_{3}$

$\mathrm{SO}_{4}$

$\mathrm{Cl}$

$\mathrm{F}$

$\mathrm{NO}_{3}$

TDS

Hardness as $\mathrm{CaCO}_{3}$

$\mathrm{Ca}, \mathrm{Mg}$

Noncarbonate

Sp. Cond.

(micromhos $025^{\circ} \mathrm{C}$ )

pH

Temperature $\left({ }^{\circ} \mathrm{C}\right)$

Reference: Newcomb 1972
51

0.26

$--$

40

24

45

10

252

0

69

19

0.6

0.1

383

197

566

7.9

23.3

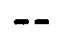

$--$

$--$

27

23

6.4

3.5

164

0

30

16

0.6

0.2

280

162

48

362

8.0

7.9

21.1

75

0.22

12

4.5

47

19

157

0

25

9.7

0.4

1.1

271

330

$-$

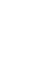




\section{TABLE 123. Water Analysis}

Hydrologic Region: Rio Grande and Texas Gulf

Aquifer Name: Alluvium

Aquifer Age: Holocene

Petrology: sand, clay, silt, caliche, gravel

Well Depth (m)

Constituents $(\mathrm{mg} / \mathrm{l})$ and Properties

$\mathrm{SiO}_{2}$

28

$\mathrm{Fe}$

$\mathrm{Mn}$

$\mathrm{Ca}$

$\mathrm{Mg}$

$\mathrm{Na}$

$\mathrm{K}$

$\mathrm{HCO}_{3}$

$\mathrm{CO}_{3}$.

$\mathrm{SO}_{4}$

C1

$\mathrm{F}$

$\mathrm{NO}_{3}$

TDS

Maximum

7
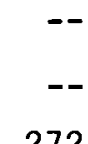

272

153

500

465

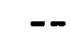

382

1090

1.0

43.5

2700
Hardness as $\mathrm{CaCO}_{3}$

$\mathrm{Ca}, \mathrm{Mg}$

1310

Noncarbonate

Sp. Cond.

(micromhos $25^{\circ} \mathrm{C}$ )

$\mathrm{pH}$

Temperature $\left({ }^{\circ} \mathrm{C}\right)$

Reference: Walker 1979
State: Texas

Location: Menard Co.

No. Analyses: 3

Water Type: $\mathrm{Ca}, \mathrm{HCO}_{3}$

Solute Concentration

Intermediate

Minimum 
Hydrologic Region: Rio Grande and Texas Gulf

Aquifer Name: Ogallala formation

Aquifer Age: Pliocene

Petrology: clay, silt, sand, gravel, caliche
State: Texas

Location: Midland Co.

No. Analyses: 3

Water Type: $\mathrm{Ca}, \mathrm{Na}, \mathrm{SO}_{4}$

Solute Concentration

Maximum Intermediate

Hell Depth (m)

10

11

Minimum

Constituents $(\mathrm{mg} / \mathrm{l})$

and Properties

$\mathrm{SiO}_{2}$

$\mathrm{Fe}$

$\mathrm{Mn}$

$\mathrm{Ca}$

$\mathrm{Mg}$

$\mathrm{Na}$

$\mathrm{K}$

$\mathrm{HCO}_{3}$

$\mathrm{CO}_{3}$

$\mathrm{SO}_{4}$

$\mathrm{Cl}$

$\mathrm{F}$

$\mathrm{NO}_{3}$

TDS

Hardness as $\mathrm{CaCO}_{3}$

$\mathrm{Ca}, \mathrm{Mg}$

2330

Noncarbonate

Sp. Cond.

(micromhos $25^{\circ} \mathrm{C}$ )

pH

Temperature $\left({ }^{\circ} \mathrm{C}\right)$

Reference: Walker 1979

75

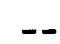

$--$

620

190

590

201

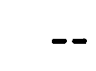

2030

930

24

4560

(3)

5800

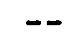

65

5.2

1578

920

$--$

140

2838

555

190

423

126

282

232

222

680

342

4.5

21

1730

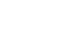

2430

7.4

$--$ 
TABLE 125. Water Analysis

Hydrologic Region: Rio Grande and Texas Gulf

Aquifer Name: Edwards formation

Aquifer Age: Late middle Cretaceous

Petrology: limestone, chert, dolomite
State: Texas

Location: Concho Co.

No. Analyses: 3

Water Type: $\mathrm{Ca}, \mathrm{HCO}_{3}$

Solute Concentration

Maximum

5

Well Depth (m)

Constituents $(\mathrm{mg} / \mathrm{l})$ and Properties

$\mathrm{SiO}_{2}$

$\mathrm{Fe}$

$\mathrm{Mn}$

$\mathrm{Ca}$

$\mathrm{Mg}$

$\mathrm{Na}$

$\mathrm{K}$

$\mathrm{HCO}_{3}$

$\mathrm{CO}_{3}$

$\mathrm{SO}_{4}$

$\mathrm{Cl}$

$\mathrm{F}$

$\mathrm{NO}_{3}$

TDS
21
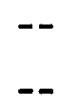

198

22

243

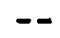

278

257

375

1.1

116

1510
Intermediate

15

24

--

--

135

36

67

--

477

$--$

49

119

0.5

20.5

690

487

$\mathrm{Ca}, \mathrm{Mg}$

590

Noncarbonate

Sp. Cond.

(micromhos $25^{\circ} \mathrm{C}$ )

2150

1137

7.2

7.2

7.4
17

253

24

61

24

52

290

37

58

0.6

8.0

401

681
$\mathrm{pH}$

Temperature $\left({ }^{\circ} \mathrm{C}\right)$

Reference: Walker 1979 


\section{TABLE 126. Water Analysis}

Hydrologic Region: Rio Grande and Texas Gulf

Aquifer Name: Edwards formation

Aquifer Age: Late middle Cretaceous

Petrology: limestone, chert, dolomite
State: Texas

Location: Crockett Co.

No. Analyses: 3

Water Type: $\mathrm{Na}, \mathrm{Cl}$

Solute Concentration

Maximum Intermediate

Minimum

We11 Depth (m)

spring

spring

Constituents $(\mathrm{mg} / \ell)$

and Properties

$\mathrm{SiO}_{2}$

16

18

1

$\mathrm{Fe}$

$\mathrm{Mn}$

$\mathrm{Ca}$

$\mathrm{Mg}$

$\mathrm{Na}$

--

--

294

173

80

2961

1970

59

$\mathrm{K}$

$\mathrm{HCO}_{3}$

--

299

272

104

$\mathrm{CO}_{3}$

$\mathrm{SO}_{4}$

--

884

520

256

$\mathrm{Cl}$

4675

1.5

3320

1680

$\mathrm{F}$

8

$\mathrm{NO}_{3}$

9160

1.5

0.8

4.2

$<0.4$

TDS

6332

3170

Hardness as $\mathrm{CaCO}_{3}$

$\mathrm{Ca}, \mathrm{Mg}$

1447

1040

570

Noncarbonate

Sp. Cond.

(micromhos $25^{\circ} \mathrm{C}$ )

$>12000$

9800

4770

pH

7.1

7.2

7.1

Temperature $\left({ }^{\circ} \mathrm{C}\right)$

Reference: Walker 1979 


\section{TABLE 127. Water Analysis}

Hydrologic Region: Rio Grande and Texas Gulf

Aquifer Name: Trinity group

Aquifer Age: Early and middle Cretaceous

Petrology: diverse sediments
State: Texas

Location: Ector Co.

No. Analyses: 222

Hater Type: $\mathrm{Ca}, \mathrm{Cl}$

Solute Concentration

Well Depth (m)

Constituents $(\mathrm{mg} / \ell)$

and Properties

$\mathrm{SiO}_{2}$

$\mathrm{Fe}$

$\mathrm{Mn}$

$\mathrm{Ca}$

$\mathrm{Mg}$

$\mathrm{Na}$

$\mathrm{K}$

$\mathrm{HCO}_{3}$

$\mathrm{CO}_{3}$

$\mathrm{SO}_{4}$

C1

$\mathrm{F}$

$\mathrm{NO}_{3}$

TDS

Maximum

46

29

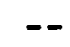

$--$

440

119

1520

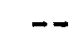

196

494

3060

1.4

9

5800

Hardness as $\mathrm{CaCO}_{3}$

$\mathrm{Ca}, \mathrm{Mg}$

1590

Noncarbonate

Sp. Cond.

(micromhos $25^{\circ} \mathrm{C}$ )

$\mathrm{pH}$

Temperature $\left({ }^{\circ} \mathrm{C}\right)$

Reference: Walker 1979

8290

7.4

Intermediate

55

38

Minimum

28

26

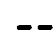

--

335

91

600

2320

--

182

193

--

493

283

4680

1460

1.2

1.4

8

7

8300

2890

2030

1210

11580

4570

7.5

7.5 


\section{TABLE 128. Water Analysis}

Hydrologic Region: Rio Grande and Texas Gulf

Aquifer Name: Trinity group

Aquifer Age: Early and middle Cretaceous

Petrology: diverse sediments
State: Texas

Location: Howard Co.

No. Analyses: 3

Hater Type: $\mathrm{Na}, \mathrm{Cl}$

Solute Concentration

\section{Maximum}

77

We11 Depth (m)

Constituents $(\mathrm{mg} / \mathrm{l})$

and Properties

$\mathrm{SiO}_{2}$

$\mathrm{Fe}$

$\mathrm{Mn}$

$\mathrm{Ca}$

$\mathrm{Mg}$

$\mathrm{Na}$

K

$\mathrm{HCO}_{3}$

$\mathrm{CO}_{3}$

$\mathrm{SO}_{4}$

Cl

$\mathrm{F}$

$\mathrm{NO}_{3}$

TDS

15

$--$

$--$

1020

93

2780

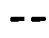

229

$--$

391

5800

1.3

3

10200
Hardness as $\mathrm{CaCO}_{3}$

$\mathrm{Ca}, \mathrm{Mg}$

Noncarbonate

Sp. Cond.

(micromhos a $25^{\circ} \mathrm{C}$ )

pH

Temperature $\left({ }^{\circ} \mathrm{C}\right)$

Reference: Walker 1979

\section{Intermediate}

85

16

16

2930

Minimum

169

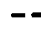

75

2460

540

1.0

1.0

7

9

4390

1110

1370

540

$>12000$

6910

2090

7.3

7.4

7.7 
TABLE 129. Water Analysis

$\begin{aligned} & \text { Hydrologic Region: } \text { Rio Grande and } \\ & \text { Texas Gulf }\end{aligned}$

Aquifer Name: Santa Rosa formation

Aquifer Age: Middle Triassic

Petrology: sandstone, micaceous and shale
State: Texas

Location: Ector Co.

No. Analyses: 2

Water Type: $\mathrm{Na}, \mathrm{HCO}_{3}, \mathrm{SO}_{4}, \mathrm{Cl}$

Solute Concentration

\begin{tabular}{|c|c|c|}
\hline Maximum & Mean & Minimum \\
\hline 396 & - & -- \\
\hline-- & -- & 24 \\
\hline-- & -- & -- \\
\hline-- & -- & -- \\
\hline 28 & -- & 6 \\
\hline 12 & -- & 3 \\
\hline 1146 & -- & 900 \\
\hline-- & -- & -- \\
\hline 671 & - & 700 \\
\hline-- & -- & -- \\
\hline 788 & -- & 730 \\
\hline 880 & -- & 336 \\
\hline-- & - & 11.8 \\
\hline-- & -- & $<0.4$ \\
\hline 3525 & -- & 2430 \\
\hline-- & -- & 28 \\
\hline-- & -- & -- \\
\hline-- & -- & 3540 \\
\hline 8.0 & - & 9.0 \\
\hline-- & -- & -- \\
\hline
\end{tabular}

Reference: Walker 1979 


\section{TABLE 130. Water Analysis}

Hydrologic Region: Rio Grande and Texas Gulf

Aquifer Name: Hickory sandstone

Aquifer Age: Early Cambrian

Petrology: sandstone and clay lenses
State: Texas

Location: Concho Co.

No. Analyses: 2

Water Type: $\mathrm{Na}, \mathrm{HCO}_{3}, \mathrm{Cl}$

Solute Concentration

We11 Depth (m)

Constituents $(\mathrm{mg} / \mathrm{l})$ and Properties

$\mathrm{SiO}_{2}$

$\mathrm{Fe}$

$\mathrm{Mn}$

$\mathrm{Ca}$

$\mathrm{Mg}$

$\mathrm{Na}$

$\mathrm{K}$

$\mathrm{HCO}_{3}$

$\mathrm{CO}_{3}$

$\mathrm{SO}_{4}$

$\mathrm{Cl}$

$\mathrm{F}$

$\mathrm{NO}_{3}$

TDS

Maximum

1272

23

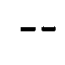

$--$

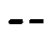

$--$

$--$

$--$

$-$

$-$

$-$

$-$

$-$

$-$

$--$

--

$-$

359

2.6

$<0.4$

1220
Mean

Minimum

1272

24

$\mathrm{Ca}, \mathrm{Mg}$

Noncarbonate

Sp. Cond.

(micromhos $25^{\circ} \mathrm{C}$ )

$\mathrm{pH}$

Temperature $\left({ }^{\circ} \mathrm{C}\right)$

Reference: Walker 1979

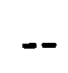

1810

8.1

$-$
24

$--$

$--$

9

3

388

423

30

381

1.0

$<0.4$

1060

34

1830

8.0 
TABLE 131. Water Analysis

Hydrologic Region: Souris - Red - Rainy

Aquifer Name: Buried outwash deposits

Aquifer Age: Hol ocene

Petrology: clay, silt, sand, grave1
State: North Dakota

Location: McHenry Co.

No. Analyses: 15

Water Type: $\mathrm{Na}, \mathrm{HCO}_{3}, \mathrm{SO}_{4}$

Solute Concentration

Maximum

52

27

9

Well Depth (m)

28

4.2

19.7

5.8

$\mathrm{Fe}$

2.8

570

240

520

13

820

54

$\mathrm{CO}_{3}$

$\mathrm{SO}_{4}$

2500

400

C1

$\mathrm{F}$

Mean

9

$0.88 \quad 0$

115

3.5

50

0.1

252

24

6.05

1.6

516

307

4.8

0

440

13

121

2.4

0.74

0.1

6.56

1.0

0.56

0

1159

317
$\mathrm{NO}_{3}$

B

TDS

61

2.2

4580

2400

2000

5400

Sp. Cond.

(micromhos $25^{\circ} \mathrm{C}$ )

pH

Temperature $\left({ }^{\circ} \mathrm{C}\right)$

Reference: Randich 1981

$\mathrm{Ca}, \mathrm{Mg}$

9.1

10.5
Minimum

$0.34 \quad 0.01$

495

9

221

0

1885

500

7.81

7.2

8.55

7.0 
Hydrologic Region: Souris - Red - Rainy Aquifer Name: Glacial drift Aquifer Age: Pleistocene

Petrology: clay, alluvium, till, sand, gravel
State: North Dakota

Location: Westhope Area Bottineau Co.

No. Analyses: 3

Water Type: $\mathrm{Na}, \mathrm{HCO}_{3}, \mathrm{SO}_{4}$

Solute Concentration

Maximum Minimum

We11 Depth (m)

Constituents $(\mathrm{mg} / \mathrm{l})$

and Properties

$\mathrm{SiO}_{2}$

$\mathrm{Fe}$

$\mathrm{Mn}$

$\mathrm{Ca}$

$\mathrm{Mg}$

$\mathrm{Na}$

$\mathrm{K}$

$\mathrm{HCO}_{3}$

$\mathrm{CO}_{3}$

$\mathrm{SO}_{4}$

$\mathrm{Cl}$

$\mathrm{F}$

$\mathrm{NO}_{3}$

TDS

Hardness as $\mathrm{CaCO}_{3}$

$\mathrm{Ca}, \mathrm{Mg}$

Noncarbonate

Sp. Cond.

(micromhos a $25^{\circ} \mathrm{C}$ )

$\mathrm{pH}$

Temperature $\left({ }^{\circ} \mathrm{C}\right)$

Reference: Powell 1962
954

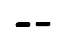

$-$

0.4

215

101

445

10

0

809

242

0

104

2290

413

58

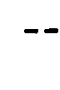

$-$

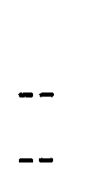

742
0.3

72

57

530

14

463

12

708

291

0

13

1930

1320

179

7

(1)

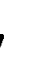

0.6

.2


Hydrologic Region: Souris - Red - Rainy Aquifer Name: Denbigh aquifer Aquifer Age: Pleistocene

Petrology: glacial sediments
State: North Dakota

Location: McHenry Co.

No. Analyses: 17

Water Type: $\mathrm{Ca}, \mathrm{Na}, \mathrm{HCO}_{3}$

Solute Concentration
We11 Depth (m)

Constituents $(\mathrm{mg} / \mathrm{l})$ and Properties

$\mathrm{SiO}_{2}$

$\mathrm{Fe}$

$\mathrm{Mn}$

$\mathrm{Ca}$

$\mathrm{Mg}$

$\mathrm{Na}$

$\mathrm{K}$

$\mathrm{HCO}_{3}$

$\mathrm{CO}_{3}$

$\mathrm{SO}_{4}$

$\mathrm{Cl}$

$\mathrm{F}$

$\mathrm{NO}_{3}$

$\mathrm{B}$

TDS

Hardness as $\mathrm{CaCO}_{3}$

$\mathrm{Ca}, \mathrm{Mg}$

Noncarbonate

Sp. Cond.

(micromhos $25^{\circ} \mathrm{C}$ )

$\mathrm{pH}$

Temperature $\left({ }^{\circ} \mathrm{C}\right)$

Reference: Randich 1981
Mean

21

Minimum

10

18

6.3

0.14

4.1

1.75

0

93

63

12

35

600

21

4.6

99

2.89

7.6

5.6

760

10

60

520

0.7

2.0

1.2

1520

407

0.59

275

21

0

0

73

0.6

0.27

0.1

1.06

1.0

0.20

0

501

263

242

49

1.12

0

2650

821

400

8.4

7.74

7.2

9.5

8.32

7.5 
TABLE 134. Water Analysis

Hydrologic Region: Souris - Red - Rainy

Aquifer Name: New Rockford aquifer

Aquifer Age: Pleistocene

Petrology: glacial sediments

State: North Dakota

Location: McHenry Co.

No. Analyses: 67

Water Type: $\mathrm{Ca}, \mathrm{Na}, \mathrm{HCO}_{3}$

Solute Concentration

Maximum

Well Depth (m)

84 Mean

54

Minimum

Constituents $(\mathrm{mg} / \mathrm{l})$ and Properties

$\mathrm{SiO}_{2}$

$\mathrm{Fe}$

$\mathrm{Mn}$

$\mathrm{Ca}$

$\mathrm{Mg}$

$\mathrm{Na}$

$\mathrm{K}$

$\mathrm{HCO}_{3}$

$\mathrm{CO}_{3}$

$\mathrm{SO}_{4}$

Cl

$\mathrm{F}$

$\mathrm{NO}_{3}$

B

TDS
Hardness as $\mathrm{CaCO}_{3}$

$\mathrm{Ca}, \mathrm{Mg}$

Noncarbonate

Sp. Cond.

(microminos $025^{\circ} \mathrm{C}$ )

$\mathrm{pH}$

Temperature $\left({ }^{\circ} \mathrm{C}\right)$

Reference: Randich 1981
30

4.1

1.3

270

96

470

14

871

15

1100

230

1.3

4.8

2.7

2340

1000

20.9

1.61

0.25

80

25

154

5.18

492

0.70

183

34.3

0.21

1.43

0.29

760

307

42

1243

2800
8.8
11.0

8.8
11.0

510
7.77

8.44
19

9.4

0

0

0

7.2

3.1

1.1

213

0

0.8

0.5

0

0.1

0

235

35

0

380

7.2

7.0 
TABLE 135. Water Analysis

Hydrologic Region: Souris - Red - Rainy

Aquifer Name: Voltaire aquifer

Aquifer Age: Pleistocene

Petrology: glacial sediments
State: North Dakota

Location: McHenry Co.

No. Analyses: 8

Water Type: $\mathrm{Ca}, \mathrm{Na}, \mathrm{HCO}_{3}, \mathrm{SO}_{4}$

Solute Concentration

$\frac{\text { Maximum }}{31} \quad \frac{\text { Mean }}{20} \quad \frac{\text { Minimum }}{13}$

Well Depth (m)

Constituents $(\mathrm{mg} / \ell)$ and Properties

$\mathrm{SiO}_{2}$

35

$\mathrm{Fe}$

$\mathrm{Mn}$

$\mathrm{Ca}$

$\mathrm{Mg}$

$\mathrm{Na}$

$\mathrm{K}$

$\mathrm{HCO}_{3}$

$\mathrm{CO}_{3}$

$\mathrm{SO}_{4}$

$\mathrm{Cl}$

$\mathrm{F}$

$\mathrm{NO}_{3}$

$\mathrm{B}$

TDS

Hardness as $\mathrm{CaCO}_{3}$

$\mathrm{Ca}, \mathrm{Mg}$

600

260

3100

(micromhos $025^{\circ} \mathrm{C}$ )

pH

7.7

9.5
7.5

7.2

8.33

15

1.2

0.2

54

21

13

1.8

216

0

34

0

0

0.4

0.05

335

230

0

610

1320

7.0

Reference: Randich 1981 
Hydrologic Region: Souris - Red - Rainy

Aquifer Name: West Fargo

Aquifer Age: Pleistocene

Petrology: clay, silt, sand, boulder
State: North Dakota

Location: Cass Co. - 1949

No. Analyses: 1

Water Type: $\mathrm{Na}, \mathrm{HCO}_{3}, \mathrm{Cl}$

Solute Concentration

\section{Well Depth (m)}

Constituents $(\mathrm{mg} / \ell)$

and Properties

$\mathrm{SiO}_{2}$

26

$\mathrm{Fe}$

$\mathrm{Mn}$

$\mathrm{Ca}$

$\mathrm{Mg}$

0.39

$\left.\begin{array}{l}\mathrm{Na} \\ \mathrm{K}\end{array}\right\}$

$\mathrm{HCO}_{3}$

$\mathrm{CO}_{3}$

$\mathrm{SO}_{4}$

Cl

--

57

21

325

412

$\mathrm{F}$

$\mathrm{NO}_{3}$

TDS

90

355

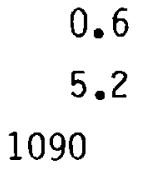

Hardness as $\mathrm{CaCO}_{3}$

$\mathrm{Ca}, \mathrm{Mg}$

228

Noncarbonate

Sp. Cond.

(micromhos $25^{\circ} \mathrm{C}$ )

pH

Temperature $\left({ }^{\circ} \mathrm{C}\right)$

Reference: Klausing 1968 


\section{TABLE 137. Water Analysis}

Hydrologic Region: Souris - Red - Rainy

Aquifer Name: West Fargo

Aquifer Age: Pleistocene

Petrology: clay, silt, sand, boulder
State: North Dakota

Location: Cass Co. - 1965

No. Analyses: 1

Water Type: $\mathrm{Na}, \mathrm{HCO}_{3}, \mathrm{Cl}$

Solute Concentration

We11 Depth (m)

Constituents $(\mathrm{mg} / \ell)$ and Properties

$\mathrm{SiO}_{2}$ 23

$\mathrm{Fe}$

0.66

$\mathrm{Mn}$

$\mathrm{Ca}$

67

$\mathrm{Mg}$

14

$\left.\begin{array}{l}\mathrm{Na} \\ \mathrm{K}\end{array}\right\}$

312

$\mathrm{HCO}_{3}$

377

$\mathrm{CO}_{3}$

$\mathrm{SO}_{4}$

151

$\mathrm{Cl}$

310

$\mathrm{F}$

0.5

$\mathrm{NO}_{3}$

5.3

TDS

1070

Hardness as $\mathrm{CaCO}_{3}$

$\mathrm{Ca}, \mathrm{Mg}$

224

Noncarbonate

Sp. Cond.

(micromhos $25^{\circ} \mathrm{C}$ )

$\mathrm{pH}$

Temperature $\left({ }^{\circ} \mathrm{C}\right)$

Reference: Klausing 1968 
TABLE 138. Water Analys is

Hydrologic Region: Souris - Red - Rainy Aquifer Name: Cannonbal1 member of Fort Union formation

Aquifer Age: Paleocene

Petrology: shale, sand, silt, sandstone, carbonaceous
State: North Dakota

Location: McHenry Co.

No. Analyses: 3

Water Type: $\mathrm{Na}, \mathrm{HCO}_{3}$

Solute Concentration

Well Depth (m) Mean

Minimum

Maximum

46

31

10

Constituents $(\mathrm{mg} / \mathrm{l})$

and Properties

$\mathrm{SiO}_{2}$

$\mathrm{Fe}$

$\mathrm{Mn}$

$\mathrm{Ca}$

$\mathrm{Mg}$

$\mathrm{Na}$

$\mathrm{K}$

$\mathrm{HCO}_{3}$

$\mathrm{CO}_{3}$

$\mathrm{SO}_{4}$

$\mathrm{Cl}$

$\mathrm{F}$

$\mathrm{NO}_{3}$

$\mathrm{B}$

TDS

Hardness as $\mathrm{CaCO}_{3}$

$\mathrm{Ca}, \mathrm{Mg}$

Noncarbonate

Sp. Cond.

(micromhos $25^{\circ} \mathrm{C}$ )

$\mathrm{pH}$

Temperature $\left({ }^{\circ} \mathrm{C}\right)$

Reference: Randich 1981
12

$$
1.8
$$$$
0.04
$$

93

89

350

\section{2}

728

38

530

43

0.9

1.0

2.5

1290

520

0

1400

8.1

9.5
6.9

0.81

0.013

33.9

30

243

3.5

502

12.67

227

19.7

0.43

0.67

1.12

872

182

0

1055

7.95

8.25
7.8

0

0.15

0

4.1

0.4

170

1.5

335

0

51

3.1

0.1

0

0.35

475

12

0

710

7.0 
TABLE 139. Water Analysis

Hydrologic Region: Souris - Red - Rainy

Aquifer Name: Tongue River member of Fort Union formation

Aquifer Age: Paleocene

Petrology: shale, sandstone, silt
State: North Dakota

Location: McHenry Co.

No. Analyses: 3

Water Type: $\mathrm{Na}, \mathrm{HCO}_{3}$

Solute Concentration

\section{Maximum}

We11 Depth (m)

Constituents (mg/ll)

and Properties

$\mathrm{SiO}_{2}$

$\mathrm{Fe}$

$\mathrm{Mn}$

$\mathrm{Ca}$

$\mathrm{Mg}$

$\mathrm{Na}$

$\mathrm{K}$

$\mathrm{HCO}_{3}$

$\mathrm{CO}_{3}$

$\mathrm{SO}_{4}$

$\mathrm{Cl}$

$\mathrm{F}$

$\mathrm{NO}_{3}$

$\mathrm{B}$

TDS

Hardness as $\mathrm{CaCO}_{3}$

$\mathrm{Ca}, \mathrm{Mg}$

Noncarbonate

Sp. Cond.

(micromhos $25^{\circ} \mathrm{C}$ )

pH

Temperature $\left({ }^{\circ} \mathrm{C}\right)$

Reference: Randich 1981

63

19

2.0

0.38

130

670

490

79

0.5

2.5

1.2

1920

620

190

2700

8.2

9.0
Mean

50

38

17.3

15

1.47

1.1

0.16

0.1

59.4

6.2

29.5

5.5

454

31

4.53

3.1

1018

524

0

0

380

270

34.8

6.3

0.33

0.1

1.47

0.9

0.89

0.83

1525

824

269

38

63

0

2033

1200

7.63

7.0

8.17

7.5 
TABLE 140. Water Analysis

Hydrologic Region: Souris - Red - Rainy

Aquifer Name: Fox Hills sandstone

Aquifer Age: Late Cretaceous

Petrology: clay, silt, sand, shale, sandstone
State: North Dakota

Location: McHenry Co.

No. Analyses: 24

Water Type: $\mathrm{Na}, \mathrm{HCO}_{3}, \mathrm{Cl}$

Solute Concentration

Maximum

Wel1 Depth (m)

Constituents (mg/l)

and Properties

$\mathrm{SiO}_{2}$

$\mathrm{Fe}$

$\mathrm{Mn}$

$\mathrm{Ca}$

$\mathrm{Mg}$

$\mathrm{Na}$

K

$\mathrm{HCO}_{3}$

$\mathrm{CO}_{3}$

$\mathrm{SO}_{4}$

Cl

$\mathrm{F}$

$\mathrm{NO}_{3}$

B

TDS

155

1600

1.3

4.5

3.60

3180
Mean

78

16.2

0.29

0.04

9.62

4.72

748

3.96

682

20.04

17.08

737

84

0

5680

(micromhos a $25^{\circ} \mathrm{C}$ )

pH

Temperature $\left({ }^{\circ} \mathrm{C}\right)$
9.3

9.0
0.43

1.65

2.51

1884
Minimum

19

5.7

0

0

2.0

1.1

120

1.1

373

0

0.4

1.4

0.1

0.7

0.20

410

12

0

650

Reference: Randich 1981 
TABLE 141. Water Analysis

Hydrologic Region: Souris - Red - Rainy

Aquifer Name: Hell Creek formation

Aquifer Age: Late Cretaceous

Petrology: clay, shale, siltstone, carbonaceous sand, lignite

State: North Dakota

Location: McHenry Co.

No. Analyses: 24

Water Type: $\mathrm{Na}, \mathrm{HCO}_{3}, \mathrm{Cl}$

Solute Concentration

\begin{tabular}{lll}
\hline Maximum & Mean & Minimum \\
& 57 & 32
\end{tabular}

Well Depth (m)

Constituents $(\mathrm{mg} / \mathrm{l})$

and Properties

$\mathrm{SiO}_{2}$

$\mathrm{Fe}$

$\mathrm{Mn}$

$\mathrm{Ca}$

$\mathrm{Mg}$

$\mathrm{Na}$

$\mathrm{K}$

$\mathrm{HCO}_{3}$

$\mathrm{CO}_{3}$

$\mathrm{SO}_{4}$

$\mathrm{Cl}$

$\mathrm{F}$

$\mathrm{NO}_{3}$

B

TDS
21

$$
2.5
$$

0.74

75

27

890

10

1160

80

690

910

0.6

2.5

4.1

2400

300

$\mathrm{Ca}, \mathrm{Mg}$

Noncarbonate

Sp. Cond.

(micromhos $25^{\circ} \mathrm{C}$ )

$\mathrm{pH}$

Temperature $\left({ }^{\circ} \mathrm{C}\right)$

8.6

12.5
8.71

0.57

0.07

15.22

6.39

640

3.64

895

20.88

84.01

432

0.45

1.18

2.71

1673

64.1

0

2891

8.18

8.23
0

0.02

0

0

0.6

230

2.0

660

0

0

44

0.2

0.7

0.59

987

8

0

1490
7.6

7.0

Reference: Randich 1981 
TABLE 142. Water Analysis

Hydrologic Region: South Atlantic Gulf Aquifer Name: Quaternary terrace Aquifer Age: Holocene Petrology: alluvium

We11 Depth (m) Constituents $(\mathrm{mg} / \mathrm{l})$ and Properties

$\mathrm{SiO}_{2}$

$\mathrm{Fe}$

$\mathrm{Mn}$

$\mathrm{Ca}$

$\mathrm{Mg}$

$\mathrm{Na}$

$\mathrm{K}$

$\mathrm{HCO}_{3}$

$\mathrm{CO}_{3}$

$\mathrm{SO}_{4}$

C1

$\mathrm{F}$

$\mathrm{NO}_{3}$

TDS
State: Al abama Location: Mobile area No. Analyses: 1 Water Type: $\mathrm{Na}, \mathrm{HCO}_{3}$

Solute Concentration
21

15

1.67

--

2.9

1.0

18

0.6

30

$--$

2.2

14

0.1

0.3

86

11

0

112

Sp. Cond.

(micromios $25^{\circ} \mathrm{C}$ )

$\mathrm{pH}$

6.6

Temperature $\left({ }^{\circ} \mathrm{C}\right)$

Reference: Robinson et a1. 1956 


\section{TABLE 143. Water Analysis}

Hydrologic Region: South Atlantic Gulf Aquifer Name: Miocene sands

Aquifer Age: Miocene

Petrology: unconsolidated sediments
State: Alabama

Location: Mobile area

No. Analyses: 3

Water Type: $\mathrm{Na}, \mathrm{Cl}, \mathrm{HCO}_{3}$

Solute Concentration

\begin{tabular}{lll}
\hline Maximum & $\frac{\text { Intermediate }}{228}$ & Minimum \\
64 & 224
\end{tabular}

Well Depth (m)

Constituents $(\mathrm{mg} / \mathrm{l})$

and Properties

$\begin{array}{lc}\mathrm{SiO}_{2} & 16 \\ \mathrm{Fe} & 1.43 \\ \mathrm{Mn} & -- \\ \mathrm{Ca} & 35 \\ \mathrm{Mg} & 19 \\ \mathrm{Na} & 1680 \\ \mathrm{~K} & 11 \\ \mathrm{HCO}_{3} & 408 \\ \mathrm{CO}_{3} & -- \\ \mathrm{SO}_{4} & 6 \\ \mathrm{Cl} & 2630 \\ \mathrm{~F} & 0.8 \\ \mathrm{NO}_{3} & 0.5 \\ \mathrm{TDS} & 4780\end{array}$

Hardness as $\mathrm{CaCO}_{3}$

$\mathrm{Ca}, \mathrm{Mg}$

166

Noncarbonate

Sp. Cond.

(micromhos $25^{\circ} \mathrm{C}$ )

pH

Temperature $\left({ }^{\circ} \mathrm{C}\right)$
7.6
16

.43

5

9

11

6

0.8

.5

9.8
1.33
--
21
23
447

447

$$
6.3
$$

334

$--$

70

620

0.8

5.0

1410

147

0

2490

8.2

25

23.9
8.1

15

1.11

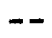

4

0.1

49

1.0

125

$$
3.2
$$

11

0.2

0.4

152

1

0

231

23.9

Reference: Robinson et al. 1956 
TABLE 144. Water Analys is

Hydrologic Region: South Atlantic Gulf Aquifer Name: Tuscaloosa group Aquifer Age: Late Cretaceous Petrology: sandstone

Well Depth (m)

Constituents $(\mathrm{mg} / \mathrm{l})$ and Properties

$$
\mathrm{SiO}_{2}
$$

$\mathrm{Fe}$

$\mathrm{Mn}$

$\mathrm{Ca}$

$\mathrm{Mg}$

$\mathrm{Na}$

$\mathrm{K}$

$\mathrm{HCO}_{3}$

$\mathrm{CO}_{3}$

$\mathrm{SO}_{4}$

C1

$\mathrm{F}$

$\mathrm{NO}_{3}$

TDS
State: Alabama

Location: Russell Co.

No. Analyses: 1

Water Type: $\mathrm{Ca}, \mathrm{HCO}_{3}$

Solute Concentration

198

19

0.36
0.024
65
0.58
28
3.8
174
--
78
13
0.1
$<0.01$
299

Hardness as $\mathrm{CaCO}_{3}$

$$
\left.\begin{array}{l}
\mathrm{Ca}, \mathrm{Mg} \\
\text { Noncarbonate }
\end{array}\right\}
$$

170

(total)

Sp. Cond.

(micromhos $25^{\circ} \mathrm{C}$ )

466

$\mathrm{pH}$

Temperature $\left({ }^{\circ} \mathrm{C}\right)$

$$
7.4
$$

21.4 
TABLE 145. Water Analysis

Hydrologic Region: South Atlantic Gulf Aquifer Name: Upper Cretaceous Series Aquifer Age: Late Cretaceous Petrology: sandstone

Well Depth (m) Constituents $(\mathrm{mg} / \ell)$ and Properties

$\mathrm{SiO}_{2}$

$\mathrm{Fe}$

$\mathrm{Mn}$

$\mathrm{Ca}$

$\mathrm{Mg}$

$\mathrm{Na}$

$\mathrm{K}$

$\mathrm{HCO}_{3}$

$\mathrm{CO}_{3}$

$\mathrm{SO}_{4}$

Cl

$\mathrm{F}$

$\mathrm{NO}_{3}$

TDS
State: Al abama

Location: Crenshaw Co.

No. Analyses: 1

Water Type: $\mathrm{Na}, \mathrm{HCO}_{3}$

Solute Concentration

12
0.011
$<0.001$
5.3
2.2
74
2.2
312
--
32
20
0.1
$<0.01$
357

23
total)
586
8.3
22.8

Sp. Cond. 152

Hardness as $\mathrm{CaCO}_{3}$

$\left.\begin{array}{l}\mathrm{Ca}, \mathrm{Mg} \\ \text { Noncarbonate }\end{array}\right\}$

(micromhos $25^{\circ} \mathrm{C}$ )

$\mathrm{pH}$

Temperature $\left({ }^{\circ} \mathrm{C}\right)$

22.8

Reference: Feder and Lee 1981 
TABLE 146. Water Analysis

Hydrologic Region: South Atlantic Gulf Aquifer Name: Pottsville formation Aquifer Age: Early-Middle Pennsylvanian Petrology: conglomerate, sandstone, shale, coal
State: Alabama

Location: Birmingham area

No. Analyses: 3

Water Type: $\mathrm{Na}, \mathrm{HCO}_{3}, \mathrm{SO}_{4}$

Solute Concentration

\begin{tabular}{ccc} 
Maximum & Intermediate & Minimum \\
\cline { 2 - 3 } & $\begin{array}{cl}\text { mine } \\
\text { shaft }\end{array}$ & mine \\
& shaft
\end{tabular}

Constituents $(\mathrm{mg} / \mathrm{l})$

and Properties

$\mathrm{SiO}_{2}$

18

14
$\mathrm{Fe}$

$\mathrm{Mn}$

$\mathrm{Ca}$

$\mathrm{Mg}$

$\mathrm{Na}$

K

$\mathrm{HCO}_{3}$

$\mathrm{CO}_{3}$

$\mathrm{SO}_{4}$

C1

$\mathrm{F}$

$\mathrm{NO}_{3}$

TDS

Hardness as $\mathrm{CaCO}_{3}$

$\mathrm{Ca}, \mathrm{Mg}$

588

Noncarbonate

336

2910

Sp. Cond.

(micromhos $25^{\circ} \mathrm{C}$ )

pH

6.9

22.2

1.4

112

75

518

5.6

308

1320

14

0.3

3.1

2220

Temperature $\left({ }^{\circ} \mathrm{C}\right)$
12

12

64

38

147

3.8

403

--

277

3.0

0

0.2

756

316

0

1090

7.0

20
2.9

24

11

75

3.1

287

--

28

3.8

0

0.4

305

105

0

491

8.0

18.3

Reference: Robinson et a1. 1953 
TABLE 147. Water Analysis

Hydrologic Region: South Atlantic Gulf Aquifer Name: Bangor limestone

Aquifer Age: Late Mississippian

Petrology: coarsely crystalline, thick bedded
State: Al abama

Location: Birmingham area

No. Analyses: 3

Water Type: $\mathrm{Ca}, \mathrm{HCO}_{3}$

Solute Concentration

Maximum

34

14

0.17

--

66

10

14

1.6

204

$\mathrm{HCO}_{3}$

$\mathrm{CO}_{3}$

$\mathrm{SO}_{4}$

C1

$\mathrm{F}$

$\mathrm{NO}_{3}$

TDS

27

20

0.1

13

281 Intermediate

64

10

$$
0.14
$$$$
\text { -- }
$$

58

$$
3.2
$$

3.4

0.6

164

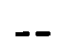

206

39

448

Sp. Cond.

$\mathrm{Ca}, \mathrm{Mg}$

Noncarbonate

(micromhos $25^{\circ} \mathrm{C}$ )

pH

7.3

18.3
7.0

7.5

0.1

8.9

186

158

23

301

$$
\begin{array}{r}
7.5 \\
17.8
\end{array}
$$

Minimum

38

11

0.33

55

2.7

2.4

0.4

164

--

9.5

5.2

0

1.5

169

148

14

278

7.6

16.7

Reference: Robinson et al. 1953 
TABLE 148. Water Analys is

Hydrologic Region: South Atlantic Gulf

Aquifer Name: Hartselle sandstone and Warsaw limestone

Aquifer Age: Late Mississippian

Petrology: sandstone overlying limestone
State: Alabama

Location: Birmingham area

No. Analyses: 1

Water Type: $\mathrm{Ca}, \mathrm{HCO}_{3}$

Solute Concentration
We11 Depth (m)

Constituents (mg/ $l$ )

and Properties

$$
\mathrm{SiO}_{2}
$$

$\mathrm{Fe}$

$\mathrm{Mn}$

$\mathrm{Ca}$

$\mathrm{Mg}$

$\mathrm{Na}$

$\mathrm{K}$

$\mathrm{HCO}_{3}$

$\mathrm{CO}_{3}$

$\mathrm{SO}_{4}$

Cl

$\mathrm{F}$

$\mathrm{NO}_{3}$

TDS
10

0.17

31

1.2

2.4

0.7

95

--

6.5

2.8

0.1

1.0

103

82

4

161

7.4

17.2

Reference: Robinson et al. 1953 


\section{TABLE 149. Water Analysis}

Hydrologic Region: South Atlantic Gulf Aquifer Name: Parkwood formation Aquifer Age: Mississippian

Petrology: sandstone, shale

We11 Depth (m)

Constituents $(\mathrm{mg} / \mathrm{l})$ and Properties

$\mathrm{SiO}_{2}$

$\mathrm{Fe}$

$\mathrm{Mn}$

$\mathrm{Ca}$

$\mathrm{Mg}$

$\mathrm{Na}$

$\mathrm{K}$

$\mathrm{HCO}_{3}$

$\mathrm{CO}_{3}$

$\mathrm{SO}_{4}$

C1

$F$

$\mathrm{NO}_{3}$

TDS
State: Al abama

Location: Birmingham area

No. Analyses: 1

Water Type: $\mathrm{Na}, \mathrm{HCO}_{3}$

Solute Concentration
18

1.1

10

2.5

59

1.0

178

11

6.2

0.1

0

200

Hardness as $\mathrm{CaCO}_{3}$

$\mathrm{Ca}, \mathrm{Mg}$

35

Noncarbonate

Sp. Cond.

(micromhos $25^{\circ} \mathrm{C}$ )

$\mathrm{pH}$

Temperature $\left({ }^{\circ} \mathrm{C}\right)$

Reference: Robinson et al. 1953
309

$$
7.6
$$

17.8 
TABLE 150. Water Analysis

Hydrologic Region: South Atlantic Gulf

Aquifer Name: Fort Payne chert and Warsaw limestone

Aquifer Age: Early Mississippian

Petrology: chert, sandy clay, limestone
State: Al abama

Location: Birmingham area

No. Analyses: 3

Hater Type: $\mathrm{Ca}, \mathrm{HCO}_{3}$

Solute Concentration

Maximum Minimum

Hell Depth (m)

Constituents $(\mathrm{mg} / \mathrm{l})$

and Properties

$\mathrm{SiO}_{2}$

$\mathrm{Fe}$

$\mathrm{Mn}$

$\mathrm{Ca}$

$\mathrm{Mg}$

$\mathrm{Na}$

$\mathrm{K}$

$\mathrm{HCO}_{3}$

$\mathrm{CO}_{3}$

$\mathrm{SO}_{4}$

$\mathrm{Cl}$

$F$

$\mathrm{NO}_{3}$

TDS
90

10

0.75

65

7.2

6.3

1.0

171

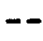

45

$$
8.5
$$

0

0.4

237

Hardness as $\mathrm{CaCO}_{3}$

$\mathrm{Ca}, \mathrm{Mg}$

Noncarbonate

Sp. Cond.

(micromhos $25^{\circ} \mathrm{C}$ )

pH

Temperature $\left({ }^{\circ} \mathrm{C}\right)$

192

52

377

7.5

21.1
57

5.1

11

0.1

0.55

--

43

1.7

2.0

0.4

131

152

$--$

2.2

2.2

3.2

2.2

0.1

0

0.9

0.7

143

128

131

114

6

7

245

218

7.6

7.5

17.2

18.3

Reference: Robinson et al. 1953 
TABLE 151. Water Analysis

Hydrologic Region: South Atlantic Gulf

Aquifer Name: Conasauga limestone

Aquifer Age: Late Cambrian

Petrology: massively bedded to thin bedded and shaly
State: Alabama

Location: Birmingham area

No. Analyses: 3

Nater Type: $\mathrm{Ca}, \mathrm{HCO}_{3}$

Solute Concentration

Maximum $\quad$ Intermediate

Well Depth (m)

94.5

134

Constituents $(\mathrm{mg} / \ell)$

and Properties

$\mathrm{SiO}_{2}$

$\mathrm{Fe}$

$\mathrm{Mn}$

$\mathrm{Ca}$

$\mathrm{Mg}$

$\mathrm{Na}$

$\mathrm{K}$

$\mathrm{HCO}_{3}$

$\mathrm{CO}_{3}$

$\mathrm{SO}_{4}$

$\mathrm{Cl}$

$\mathrm{F}$

$\mathrm{NO}_{3}$

TDS

Hardness as $\mathrm{CaCO}_{3}$

$\mathrm{Ca}, \mathrm{Mg}$

Noncarbonate

Sp. Cond.

(micromhos $25^{\circ} \mathrm{C}$ )

pH

Temperature $\left({ }^{\circ} \mathrm{C}\right)$
11

$$
1.4
$$

96

37

61

1.2

291

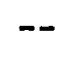

91

112

0.1

20

582

392

153

963

7.3

16.7
11

0.81

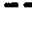

100

19

20

1.9

281

--

69

31

0

17

425

328

96

633

7.2

20.0
270

69

7.3

11

0.11

64

27

26

2.4

246

--

52

36

0

20

372

613

18.3

Reference: Robinson et al. 1953 
TABLE 152. Water Analysis

Hydrologic Region: South At lantic Gulf Aquifer Name: Copper Ridge dolomite Aquifer Age: Late Cambrian

Petrology: fine grained dolomite, chert
State: Alabama

Location: Birmingham area

No. Analyses: 2

Water Type: $\mathrm{Ca}, \mathrm{HCO}_{3}$

Solute Concentration Maximum

spring

48

Well Depth (m)

Constituents $(\mathrm{mg} / \mathrm{l})$ and Properties

$\mathrm{SiO}_{2}$

9.2

8.4

$\mathrm{Fe}$

$\mathrm{Mn}$

$\mathrm{Ca}$

$\mathrm{Mg}$

$\mathrm{Na}$

$\mathrm{K}$

$\mathrm{HCO}_{3}$

$\mathrm{CO}_{3}$

$\mathrm{SO}_{4}$

$\mathrm{Cl}$

$\mathrm{F}$

$\mathrm{NO}_{3}$

TDS

Hardness as $\mathrm{CaCO}_{3}$

$\mathrm{Ca}, \mathrm{Mg}$

142

11

259

Sp. Cond.

(micromhos $25^{\circ} \mathrm{C}$ )

$\mathrm{pH}$

Temperature $\left({ }^{\circ} \mathrm{C}\right)$

Reference: Robinson et al. 1953

Minimum

0.34

0.02

--

34

29

14

14

2.0

0.8

0.6

0.2

160

145

$--$

3.7

1.2

2.5

2.8

0.1

0.1

3.2

3.4

149

131

Noncarbonate

130

11

235

7.5

7.6

16.7

17.8 


\section{TABLE 153. Water Analysis}

Hydrologic Region: South Atlantic Gulf

Aquifer Name: Ketona dolomite

Aquifer Age: Middle Cambrian

Petrology: massively bedded dolomite
State: Alabama

Location: Birmingham area

No. Analyses: 3

Water Type: $\mathrm{Ca}, \mathrm{Mg}, \mathrm{HCO}_{3}$

Solute Concentration

\begin{tabular}{llc} 
Maximum & Intermediate & Minimum \\
\cline { 2 - 3 } & spring & 64
\end{tabular}

Well Depth (m)

Constituents (mg/ $l$ )

and Properties

$\mathrm{SiO}_{2}$
$\mathrm{Fe}$
$\mathrm{Mn}$
$\mathrm{Mg}$
$\mathrm{Na}$
$\mathrm{K}$
$\mathrm{HCO}_{3}$
$\mathrm{CO}_{3}$
$\mathrm{SO}_{4}$
$\mathrm{Cl}$
$\mathrm{F}_{\mathrm{NO}_{3}}$
$\mathrm{TDS}$

Hardness as $\mathrm{CaCO}_{3}$

$$
\begin{aligned}
& \mathrm{Ca}, \mathrm{Mg} \\
& \text { Noncarbonate }
\end{aligned}
$$

Sp. Cond.

(micromhos $25^{\circ} \mathrm{C}$ )

pH

Temperature $\left({ }^{\circ} \mathrm{C}\right)$$$
150
$$

10

0.19

--

32

17

2.1

0.9

161

1.2

5.2

0

10

159

150

18

271

7.7

20

\section{7}

0.47

--

32

18

1.2

0.6

175

--

1.6

2.8

0.1

0.5

153

154

10

278

8.0

16.7
8.9

0.12

--

32

16

1.2

0.4

166

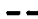

2.0

2.5

0

3.2

148

146

10

268

7.6

18.1

Reference: Robinson et a1. 1953 
TABLE 154. Water Analysis

Hydrologic Region: South Atlantic Gulf

Aquifer Name: Nonartesian aquifer

Aquifer Age: Holocene

Petrology: sand, clayey sand
State: Florida

Location: Polk Co.

No. Analyses: 9

Water Type: $\mathrm{Ca}, \mathrm{HCO}_{3}$

Solute Concentration

Maximum

Intermediate

We11 Depth (m)

Constituents $(\mathrm{mg} / \ell)$

and Properties

$\mathrm{SiO}_{2}$

$\mathrm{Fe}$

$\mathrm{Mn}$

$\mathrm{Ca}$

$\mathrm{Mg}$

$\mathrm{Na}$

$\mathrm{K}$

$\mathrm{HCO}_{3}$

$\mathrm{CO}_{3}$

$\mathrm{SO}_{4}$

C1

$\mathrm{F}$

$\mathrm{NO}_{3}$

$\mathrm{PO}_{4}$

TDS
8

0.51

$--$

57

15

5.4

0.2

205

--

22

20

$-$

0.5

0.89

710

430

$\mathrm{Ca}, \mathrm{Mg}$

Noncarbonate

Sp. Cond.

(micromhos $25^{\circ} \mathrm{C}$ )

pH

Temperature $\left({ }^{\circ} \mathrm{C}\right)$

Reference: Stewart 1966

924

7.6
Minimum

0.4

$-$

--

1

0.6

1.5

0

1

$--$

0

2.5

$-$

0.2

0

20

5

16.2

$-$

4.9

22.2 


\section{TABLE 155. Water Analysis}

Hydrologic Region: South Atlantic Gulf Aquifer Name: Shallow aquifer Aquifer Age: Holocene

Petrology: sand, thin beds of limestone
State: Florida

Location: Martin Co.

No. Analyses: 3

Water Type: $\mathrm{Ca}, \mathrm{Na}, \mathrm{HCO}_{3}, \mathrm{Cl}$

Solute Concentration

Maximum Intermediate

We1l Depth (m)

Constituents $(\mathrm{mg} / \mathrm{l})$

and Properties

$\mathrm{SiO}_{2}$

$\mathrm{Fe}$

$\mathrm{Mn}$

$\mathrm{Ca}$

$\mathrm{Mg}$

$\left.\begin{array}{l}\mathrm{Na} \\ \mathrm{K}\end{array}\right\}$

$\mathrm{HCO}_{3}$

$\mathrm{CO}_{3}$

$\mathrm{SO}_{4}$

$\mathrm{Cl}$

$\mathrm{F}$

$\mathrm{NO}_{3}$

TDS
$--$

0.03

128

26

182

418

139

238

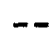

$$
0.6
$$

920

Hardness as $\mathrm{CaCO}_{3}$

$\mathrm{Ca}, \mathrm{Mg}$

Noncarbonate

Sp. Cond.

(micromhos $25^{\circ} \mathrm{C}$ )

$\mathrm{pH}$

Temperature $\left({ }^{\circ} \mathrm{C}\right)$

Reference: Lichtler 1960

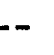

426

1560

7.2

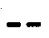

$--$

0.96

0.01

$--$

86

18

126

278

0.4

1.0

605

132

289

106

1150

233

7.3
120

5.1

16

0.1

0.6

7.1

39

2.1

9.7

\section{(20}

32

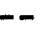

$-$ 
TABLE 156. Water Analysis

Hydrologic Region: South Atlantic Gulf

Aquifer Name: Shallow aquifer

Aquifer Age: Pleistocene-Holocene

Petrology: quartz sand, clay, iron oxide, mollusk shells
State: Florida

Location: Duval Co.

No. Analyses: 3

Nater Type: $\mathrm{Ca}, \mathrm{HCO}_{3}, \mathrm{SO}_{4}$

Solute Concentration

Maximum $\quad$ Intermediate

Well Depth (m)

58

43

12

Constituents $(\mathrm{mg} / \mathrm{l})$ and Properties

$\mathrm{SiO}_{2}$

$\mathrm{Fe}$

$\mathrm{Mn}$

$\mathrm{Ca}$

$\mathrm{Mg}$

$\mathrm{Na}$

$\mathrm{K}$

$\mathrm{HCO}_{3}$

$\mathrm{CO}_{3}$

$\mathrm{SO}_{4}$

$\mathrm{Cl}$

$\mathrm{F}$

$\mathrm{NO}_{3}$

TDS

Hardness as $\mathrm{CaCO}_{3}$

$\mathrm{Ca}, \mathrm{Mg}$

1910

Noncarbonate

Sp. Cond.

(micromhos $025^{\circ} \mathrm{C}$ )

$\mathrm{pH}$

Temperature $\left({ }^{\circ} \mathrm{C}\right)$

Reference: Fairchild 1972

36

596

100

23

232

0

1660

12

2560

1720

2700
8.2

1.0

0.1

7.5
52

--

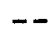

7.9

5.5

2.3

1.6

63

29

19

2.0

2.0

0.3

8

0

0

25

0.1

0.1

48

12

6

105

600

-. 
TABLE 157. Water Analysis

Hydrologic Region: South Atlantic Gulf

Aquifer Name: Biscayne

Aquifer Age: Pleistocene

Petrology: limestone, sand
State: Florida

Location: Hollywood area

No. Analyses: 3

Hater Type: $\mathrm{Ca}, \mathrm{HCO}_{3}$

Solute Concentration

$\frac{\text { Maximum }}{20} \quad \frac{\text { Intermediate }}{39} \quad \frac{\text { Minimum }}{44}$

Well Depth (m)

8.2

8.2

12.0

$\mathrm{Fe}$

$\mathrm{Ca}$

$\mathrm{HCO}_{3}$

$\mathrm{CO}_{3}$

$\mathrm{SO}_{4}$

C1

$\mathrm{F}$

$\mathrm{NO}_{3}$

$\mathrm{Sr}$

TDS

Hardness as $\mathrm{CaCO}_{3}$

$\mathrm{Ca}, \mathrm{Mg}$

Noncarbonate

Sp. Cond.

(micromhos $25^{\circ} \mathrm{C}$ )

$\mathrm{pH}$

Temperature $\left({ }^{\circ} \mathrm{C}\right)$

Reference: Bearden 1974
0.32

0.2

160

15

65

36

596

0.44

2.2

0.01

0.01

88

6.2

82

6.7

15

24

0.7

1.2

304

284

--

8

98

0.2

0

0

685

460

0

1200

7.8

25
8.0

230

100

561

0.2

0

0.93

305

--
8.0

--

0

22

0.2

0

8.2

299

246

0

520

22 
Hydrologic Region: South Atlantic Gulf Aquifer Name: Biscayne

Aquifer Age: Pleistocene

Petrology: limestone, sand
State: Florida

Location: Miami-Fort Lauderdale No. Analyses: 3

Water Type: $\mathrm{Ca}, \mathrm{HCO}_{3}$

Solute Concentration $\underline{\text { Maximum }}$

Well Depth (m)

Constituents $(\mathrm{mg} / \mathrm{l})$ and Properties

$\mathrm{SiO}_{2}$

$\mathrm{Fe}$

$\mathrm{Mn}$

$\mathrm{Ca}$

$\mathrm{Mg}$

$\mathrm{Na}$

$\mathrm{K}$

$\mathrm{HCO}_{3}$

$\mathrm{CO}_{3}$

$\mathrm{SO}_{4}$

$\mathrm{Cl}$

$\mathrm{F}$

$\mathrm{NO}_{3}$

$\mathrm{Sr}$

TDS

Hardness as $\mathrm{CaCO}_{3}$

$\mathrm{Ca}, \mathrm{Mg}$

Noncarbonate

Sp. Cond.

(micromhos $25^{\circ} \mathrm{C}$ )

$\mathrm{pH}$

Temperature $\left({ }^{\circ} \mathrm{C}\right)$

Intermediate

Minimum
250

7.0

0.9

90

5.4

38

3.0

272

$-$

28

57

0.3

0.01

0.87

394

27

663

7.6

28

\section{7}

1.8

4.3

0.03

$-$

92

100

2.8

19

1.5

299

$--$

26

33

0.3

0.01

388

260

15

619

7.4

7.5

28
0.78

Reference: Klein and Hull 1978 
TABLE 159. Water Analys is

Hydrologic Region: South Atlantic Gulf

Aquifer Name: Artesian aquifer

Aquifer Age: Tertiary

Petrology: limestone
State: Florida

Location: Martin Co.

No. Analyses: 3

Hater Type: $\mathrm{Na}, \mathrm{Cl}$

Solute Concentration

\begin{tabular}{rcc}
\hline Maximum & Minimum \\
\cline { 2 - 3 }-- & -- & -- \\
\cline { 2 - 3 } 17 & & \\
0 & 17 & 19 \\
-- & 0.11 & 0.04 \\
148 & -- & -- \\
79 & 131 & 82 \\
541 & 94 & 52 \\
4 & 545 & 250 \\
162 & 14 & 6.4 \\
-- & 164 & 169 \\
148 & -- & -- \\
1140 & 215 & 182 \\
1.0 & 1150 & 450 \\
0.9 & 0.8 & 0.8 \\
2910 & 0 & 0.3 \\
& 2250 & 1126
\end{tabular}

Hardness as $\mathrm{CaCO}_{3}$

$\mathrm{Ca}, \mathrm{Mg}$

696

714

418

Noncarbonate

Sp. Cond.

(micromhos $25^{\circ} \mathrm{C}$ )

3950

4040

2020
7.4

7.3
$\mathrm{pH}$

Temperature $\left({ }^{\circ} \mathrm{C}\right)$

Reference: Lichtler 1960 
TABLE 160. Water Analysis

Hydrologic Region: South Atlantic Gulf Aquifer Name: Shallow aquifer Aquifer Age: Pleistocene to Late Miocene Petrology: sand and limestone
State: Florida

Location: Collier Co.

No. Analyses: 22

Water Type: $\mathrm{Ca}, \mathrm{Na}, \mathrm{HCO}_{3}, \mathrm{Cl}$

Solute Concentration

Maximum Intermediate

12.5

21

Well Depth (m)

73

20

0.76

17

0.9

11.0

$\mathrm{Fe}$

$\mathrm{Mn}$

$\mathrm{Ca}$

$\mathrm{Mg}$

$\mathrm{Na}$

$\mathrm{K}$

$\mathrm{HCO}_{3}$

$\mathrm{CO}_{3}$

$\mathrm{SO}_{4}$

Cl

$\mathrm{F}$

$\mathrm{NO}_{3}$

TDS

Hardness as $\mathrm{CaCO}_{3}$

$\mathrm{Ca}, \mathrm{Mg}$

Noncarbonate

Sp. Cond.

(microminos $25^{\circ} \mathrm{C}$ )

pH

Temperature $\left({ }^{\circ} \mathrm{C}\right)$

Reference: McCoy 1962
1517

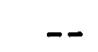

196

89

631

21

236

440

1150

0.1

1.0

2660

4530

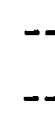

166

32

162

5.6

438

77

325

0.2

1.5

1000

731

184

1720

368

7.8

69

3

8.8

0.6

218

$--$

4.5

15

0.1

0.5

241

--

7.3

-. 
TABLE 161. Water Analysis

Hydrologic Region: South Atlantic Gulf

Aquifer Name: Biscayne aquifer

Aquifer Age: Late Miocene-Pleistocene

Petrology: sand, coquina, calcareous sand, 1 imestone
State: Florida

Location: lower Hillsboro Canal area, southeastern Florida

No. Analyses: 3

Water Type: $\mathrm{Ca}, \mathrm{Na}, \mathrm{HCO}_{3}, \mathrm{Cl}$

Solute Concentration

Maximum Intermediate

Wel1 Depth (m)

20

32

18

Constituents $(\mathrm{mg} / \mathrm{l})$ and Properties

$\mathrm{SiO}_{2}$

9.6

19

10

$\mathrm{Fe}$

$\mathrm{Mn}$

$\mathrm{Ca}$

$\mathrm{Mg}$

$\mathrm{Na}$

K

$\mathrm{HCO}_{3}$

$\mathrm{CO}_{3}$

$\mathrm{SO}_{4}$

C1

$\mathrm{F}$

$\mathrm{NO}_{3}$

TDS
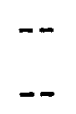

1420

148

4850

30

261

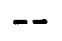

974

9410

0.2

4.0

17000

4150

530

130

3940

102

16

23900

2700

248

(micromhos o $25^{\circ} \mathrm{C}$ )

pH

7.6

7.7

7.6

Temperature $\left({ }^{\circ} \mathrm{C}\right)$

23.9

20.6 


\section{TABLE 162. Water Analysis}

Hydrologic Region: South Atlantic Gulf

Aquifer Name: Secondary artesian aquifer

Aquifer Age: Miocene

Petrology: limestone (Hawthorn formation)
State: Florida

Location: Polk Co.

No. Analyses: 29

Water Type: $\mathrm{Ca}, \mathrm{HCO}_{3}$

Solute Concentration

Maximum Intermediate

Minimum

Well Depth (m)

Constituents $(\mathrm{mg} / \mathrm{l}$ ) and Properties

$\mathrm{SiO}_{2}$

37

$\mathrm{Fe}$

0.25

$\mathrm{Mn}$

$\mathrm{Ca}$

$\mathrm{Mg}$

$\mathrm{Na}$

$\mathrm{K}$

$\mathrm{HCO}_{3}$

$\mathrm{CO}_{3}$

$\mathrm{SO}_{4}$

C1

$\mathrm{F}$

$\mathrm{NO}_{3}$

TDS

Hardness as $\mathrm{CaCO}_{3}$

$\mathrm{Ca}, \mathrm{Mg}$

306

Noncarbonate

Sp. Cond.

(micromhos $25^{\circ} \mathrm{C}$ )

$\mathrm{pH}$

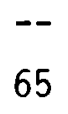

31

11

0.8

337

2.1

31

26

0.8

0.9

343

--

--

13

$-$

65

$-$

$--$

$-$

5.4

5.2

0

9

0

0

6

0.3

0

119

$-$

67

--

724

174

8.4

5.8

27.8

22.2

Reference: Stewart 1966 
TABLE 162A. Water Analysis

Hydrologic Region: South Atlantic Gulf Aquifer Name: Uppermost artesian aquifer Aqui fer Age: Miocene

Petrology: coarse, sandy, phosphatic gravel
State: Florida

Location: Polk Co.

No. Analyses: 1

Water Type: $\mathrm{Ca}, \mathrm{Mg}, \mathrm{HCO}_{3}$

Solute Concentration

We11 Depth (m)

Constituents $(\mathrm{mg} / \ell)$

and Properties

$\mathrm{SiO}_{2}$

$\mathrm{Fe}$

$\mathrm{Mn}$

$\mathrm{Ca}$

$\mathrm{Mg}$

45

$\mathrm{Na}$

$\mathrm{K}$

$\mathrm{HCO}_{3}$

$\mathrm{PO}_{4}$

$\mathrm{SO}_{4}$

$\mathrm{Cl}$

$\mathrm{F}$

$\mathrm{NO}_{3}$

TDS

25

(n)

252

0.14

1.0

8.0

0.3

0

534

Hardness as $\mathrm{CaCO}_{3}$

$\mathrm{Ca}, \mathrm{Mg}$

232

Noncarbonate

737

Sp. Cond.

(micromhos $25^{\circ} \mathrm{C}$ )

$\mathrm{pH}$

7.3

Temperature $\left({ }^{\circ} \mathrm{C}\right)$

23.3

Reference: Stewart 1966 
TABLE 163. Water Analysis

Hydrologic Region: South Atlantic Gulf

Aquifer Name: Floridan aquifer

Aquifer Age: Middle Eocene to Miocene

Petrology: limestone
State: Florida Location: Collier Co. No. Analyses: 7

Hater Type: $\mathrm{Na}, \mathrm{Cl}$

Solute Concentration Maximum

123

136

120

Constituents $(\mathrm{mg} / \mathrm{l})$

and Properties
$\mathrm{SiO}_{2}$

$\mathrm{Mn}$

$\mathrm{Ca}$

$\mathrm{Mg}$

$\mathrm{Na}$

$\mathrm{K}$

$\mathrm{HCO}_{3}$

$\mathrm{CO}_{3}$

$\mathrm{SO}_{4}$

$\mathrm{Cl}$

$F$

$\mathrm{NO}_{3}$

TDS

Hardness as $\mathrm{CaCO}_{3}$

$\mathrm{Ca}, \mathrm{Mg}$

Noncarbonate

Sp. Cond.

(micromhos $25^{\circ} \mathrm{C}$ )

$\mathrm{pH}$

7.9

8.0

8.0
12

0.54

504

288

167

1600

200

196

488

2800

0.5

6010

17

0.02

99

117

960

25

236

455

1490

1.0

3400

728

316

8910

5360

1660

19

54

44

245

316

96

310

947
1.6

1.5

1.1

Temperature $\left({ }^{\circ} \mathrm{C}\right)$

Reference: McCoy 1962 
Hydrologic Region: South Atlantic Gulf Aquifer Name: Floridan aquifer Aquifer Age: Middle Eocene to Miocene Petrology: limestone
State: Florida

Location: Leon Co.

No. Analyses: 3

Water Type: $\mathrm{Ca}, \mathrm{HCO}_{3}$

Solute Concentration

Maximum Intermediate

13

15

13

$\mathrm{Fe}$

$\mathrm{Mn}$

$\mathrm{Ca}$

$\mathrm{Mg}$

$\mathrm{Na}$

$\mathrm{K}\}$

$\mathrm{HCO}_{3}$

$\mathrm{CO}_{3}$

$\mathrm{SO}_{4}$

Cl

$\mathrm{F}$

$\mathrm{NO}_{3}$

TDS

Hardness as $\mathrm{CaCO}_{3}$

$\mathrm{Ca}, \mathrm{Mg}$

Noncarbonate

Sp. Cond.

(micromhos $025^{\circ} \mathrm{C}$ )

$\mathrm{pH}$

Temperature $\left({ }^{\circ} \mathrm{C}\right)$
0.65

274

169

165

459

7.9

1.1

51

10

3.9

193

194

7.6

7

0.3

7.4

275

7.6

5.0

0.3

0

190

178

330

301

7.4

21.7
0.4

4

0.2

0

7.5

1.1

50

9.0

4.8

4

$-$

0

.5

Reference: Hendry and Sproul 1966 
TABLE 165. Water Analysis

Hydrologic Region: South Atlantic Gulf Aquifer Name: Floridan aquifer Aquifer Age: Middle Eocene to Miocene Petrology: limestone
State: Florida Location: Polk Co. No. Analyses: 109 Water Type: $\mathrm{Ca}, \mathrm{HCO}_{3}$

Solute Concentration

\begin{tabular}{ccc}
\hline Maximum & Minimum \\
\cline { 2 - 3 }-- & -- & -- \\
& & \\
31 & -- & 1.1 \\
2.1 & -- & 0.01 \\
-- & -- & -- \\
107 & -- & 15 \\
28 & -- & 0.6 \\
20 & -- & 3.0 \\
4.0 & -- & 0 \\
353 & -- & 32 \\
0.3 & -- & 0 \\
122 & -- & 0 \\
32 & -- & 3 \\
1.0 & -- & 0 \\
4.8 & -- & 0 \\
348 & -- & 62 \\
284 & -- & \\
-- & -- & 40 \\
599 & -- & -- \\
9.1 & -- & 113 \\
27.8 & - & 21.7
\end{tabular}

Reference: Stewart 1966 
TABLE 166. Water Analysis

Hydrologic Region: South Atlantic Gulf

Aquifer Name: Floridan

Aquifer Age: Eocene

Petrology: limestone, dolomite

State: Florida

Location: Baker Co.

No. Analyses: 2

Water Type: $\mathrm{Ca}, \mathrm{Na}, \mathrm{HCO}_{3}$

Solute Concentration

\begin{tabular}{lcc}
\hline Maximum & Mean & Minimum \\
\cline { 2 - 3 } & -- & 186
\end{tabular}

We11 Depth (m)

Constituents $(\mathrm{mg} / \mathrm{l})$ and Properties

$\mathrm{SiO}_{2}$

$\mathrm{Fe}$

$\mathrm{Mn}$

$\mathrm{Ca}$

$\mathrm{Mg}$

$\mathrm{Na}$

K

$\mathrm{HCO}_{3}$

$\mathrm{CO}_{3}$

$\mathrm{SO}_{4}$

C1

$\mathrm{F}$

$\mathrm{NO}_{3}$

TDS

(n) 
TABLE 167. Water Analys is

Hydrologic Region: South Atlantic Gulf Aquifer Name: Floridan

Aquifer Age: Eocene

Petrology: limestone, dol omite
State: Florida

Location: Duval Co.

No. Analyses: 3

Water Type: $\mathrm{Ca}, \mathrm{HCO}_{3}, \mathrm{SO}_{4}$

Solute Concentration

\begin{tabular}{lll}
\hline Maximum & $\frac{\text { Intermediate }}{200}$ & $\frac{\text { Minimum }}{122}$ \\
306
\end{tabular}

Well Depth (m)

21

18
$\mathrm{SiO}_{2}$

$\mathrm{Fe}$

$\mathrm{Mn}$

$\mathrm{Ca}$

$\mathrm{Mg}$

$\mathrm{Na}$

$\mathrm{K}$

$\mathrm{HCO}_{3}$

$\mathrm{CO}_{3}$

$\mathrm{SO}_{4}$

$\mathrm{Cl}$

$\mathrm{F}$

$\mathrm{NO}_{3}$

TDS

--
0.1
--
77
34
--
--
170
--
193
19
0.75
--
572

334

$\mathrm{Ca}, \mathrm{Mg}$

Noncarbonate

Sp. Cond.

(micromhos $25^{\circ} \mathrm{C}$ )

$\mathrm{pH}$

Temperature $\left({ }^{\circ} \mathrm{C}\right)$

Reference: Leve 1966

7.3
1.9

0.01

--

79

52

33

22

8.8

2.4

138

0

101

14

10

0.7

0.5

0

0.1

468

354

332

220

107

461

7.9

--

$-$

$-$ 


\section{TABLE 168. Water Analysis}

Hydrologic Region: South Atlantic Gulf Aquifer Name: Floridan

Aquifer Age: Eocene

Petrology: limestone, dolomite
State: Florida

Location: Nassau Co.

No. Analyses: 3

Nater Type: $\mathrm{Ca}, \mathrm{HCO}_{3}, \mathrm{SO}_{4}$

Solute Concentration

Maximum

173

Intermediate

229

Minimum

174

Constituents $(\mathrm{mg} / \mathrm{l})$

and Properties

$\mathrm{SiO}_{2}$

$\mathrm{Fe}$

$\mathrm{Mn}$

$\mathrm{Ca}$

$\mathrm{Mg}$

$\mathrm{Na}$

K

$\mathrm{HCO}_{3}$

$\mathrm{CO}_{3}$

$\mathrm{SO}_{4}$

C1

$F$

$\mathrm{NO}_{3}$

TDS

Hardness as $\mathrm{CaCO}_{3}$

$$
\begin{aligned}
& \mathrm{Ca}, \mathrm{Mg} \\
& \text { Noncarbonate }
\end{aligned}
$$

Sp. Cond.

(micromhos $25^{\circ} \mathrm{C}$ )

pH

Temperature $\left({ }^{\circ} \mathrm{C}\right)$

Reference: Leve 1966
30

--

$--$

72

33

22

688

10

180

400

1150

0.7

0

3020

940

793

4480

7.6

507
315

158

676

7.5

60

$--$
316

7.3

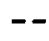

69

34

--

192

134

29

0.65

464

$-$

464

7.5 


\section{TABLE 169. Water Analysis}

Hydrologic Region: South Atlantic Gulf Aquifer Name: Tampa limestone Aquifer Age: Miocene

Petrology: sandy marl, sandy 15 .

He11 Depth (m)

Constituents $(\mathrm{mg} / \mathrm{l})$ and Properties

$\mathrm{SiO}_{2}$

$\mathrm{Fe}$

$\mathrm{Mn}$

$\mathrm{Ca}$

$\mathrm{Mg}$

$\mathrm{Na}$

K

$\mathrm{HCO}_{3}$

$\mathrm{CO}_{3}$

$\mathrm{SO}_{4}$

C1

$\mathrm{F}$

$\mathrm{NO}_{3}$

TDS

Hardness as $\mathrm{CaCO}_{3}$

$\mathrm{Ca}, \mathrm{Mg}$

Noncarbonate

Sp. Cond.

(micromhos $25^{\circ} \mathrm{C}$ )

pH

Temperature $\left({ }^{\circ} \mathrm{C}\right)$

Reference: Owen 1963
State: Georgia

Location: Mitchel1 Co.

No. Analyses: 1

Water Type: $\mathrm{Ca}, \mathrm{Na}, \mathrm{HCO}_{3}$

Solute Concentration
17

0.08

--

26

10

15

2.9

164

--

2.4

3.0

0.5

0

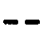

106

263

7.7 
TABLE 170. Water Analysis

Hydrologic Region: South Atlantic Gulf Aquifer Name: Suwannee limestone Aquifer Age: 01 igocene Petrology: oolitic, fragmental
State: Georgia Location: Mitchell Co. No. Analyses: 1

Water Type: $\mathrm{Ca}, \mathrm{HCO}_{3}$

Solute Concentration

We11 Depth (m)

91

Constituents $(\mathrm{mg} / \mathrm{l})$ and Properties

$\mathrm{SiO}_{2}$

27

$\mathrm{Fe}$

0.05

$\mathrm{Mn}$

$\mathrm{Ca}$

36

$\mathrm{Mg}$

10

$\mathrm{Na}$

3.2

1.2

$\mathrm{HCO}_{3}$

167

$\mathrm{CO}_{3}$

$\mathrm{SO}_{4}$

C1

$\mathrm{F}$

$\mathrm{NO}_{3}$

TDS

Hardness as $\mathrm{CaCO}_{3}$

$\mathrm{Ca}, \mathrm{Mg}$

Noncarbonate

Sp. Cond.

(micromhos $25^{\circ} \mathrm{C}$ )

pH
131

264

7.8

2.4

2.5

0.2

0.2

166

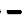

--

Reference: Owen 1963 
TABLE 171. Water Analysis

Hydrologic Region: South Atlantic Gulf Aquifer Name: Ocala limestone

Aquifer Age: Late Eocene

Petrology: limestone

Well Depth (m)

Constituents $(\mathrm{mg} / \ell)$ and Properties

$$
\mathrm{SiO}_{2}
$$

State: Georgia

Location: Albany area

No. Analyses: 4

Water Type: $\mathrm{Ca}, \mathrm{Na}, \mathrm{HCO}_{3}$

Solute Concentration
$\mathrm{Fe}$

$\mathrm{Mn}$

$\mathrm{Ca}$

$\mathrm{Mg}$

$\mathrm{Na}$

$\mathrm{K}$

$\mathrm{HCO}_{3}$

$\mathrm{CO}_{3}$

$\mathrm{SO}_{4}$

$\mathrm{Cl}$

$\mathrm{F}$

$\mathrm{NO}_{3}$

$\mathrm{Sr}$

TDS

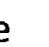

a

g

(

3

1

(1)

3

Hardness as $\mathrm{CaCO}_{3}$

$\mathrm{Ca}, \mathrm{Mg}$

Noncarbonate

Sp. Cond.

(micromhos $25^{\circ} \mathrm{C}$ )

$\mathrm{pH}$

Temperature $\left({ }^{\circ} \mathrm{C}\right)$

Reference: Hicks et al. 1981
9.5

0.01

0.007

43

10

22

0.3

148

--

0.5

2.9

0.3

3.7

0.065

140

124

2

238

7.48

22.1 
TABLE 172. Water Analysis

Hydrologic Region: South Atlantic Gulf

Aquifer Name: Ocala limestone

Aquifer Age: Late Eocene

Petrology: oolitic, fragmental, dolomitic
State: Georgia

Location: Mitchell Co.

No. Analyses: 3

Water Type: $\mathrm{Ca}, \mathrm{HCO}_{3}$

Solute Concentration

\begin{tabular}{ccc} 
Maximum & Mean & Minimum \\
\cline { 2 - 2 }-- & 102 & -- \\
& & \\
11 & 8.37 & 6.7 \\
0.08 & 0.07 & 0.02 \\
-- & -- & -- \\
47 & 46 & 40 \\
2.4 & 1.53 & 0.6 \\
2.2 & 2.0 & 1.8 \\
0.5 & 0.4 & 0.3 \\
145 & 139 & 135 \\
-- & -- & -- \\
1.6 & 0.8 & 0 \\
3.5 & 2.53 & 2.0 \\
0.1 & 0.07 & 0 \\
1.4 & 0.87 & 0 \\
137 & 135 & 130 \\
124 & & 110 \\
-- & 116 & -- \\
225 & -- & 220 \\
7.8 & 223 & 7.5 \\
-- & 7.63 & --
\end{tabular}

Reference: Owen 1963 
TABLE 173. Water Analysis

Hydrologic Region: South Atlantic Gulf

Aquifer Name: Tallahatta formation and Dcala limestone

Aquifer Age: Middle and late Eocene

Petrology: limestone, phosphatic, sandy, cherty 1s. and dolomitic 1s.
State: Georgia

Location: Mitchell Co.

No. Analyses: 2

Water Type: $\mathrm{Ca}, \mathrm{HCO}_{3}$

Solute Concentration

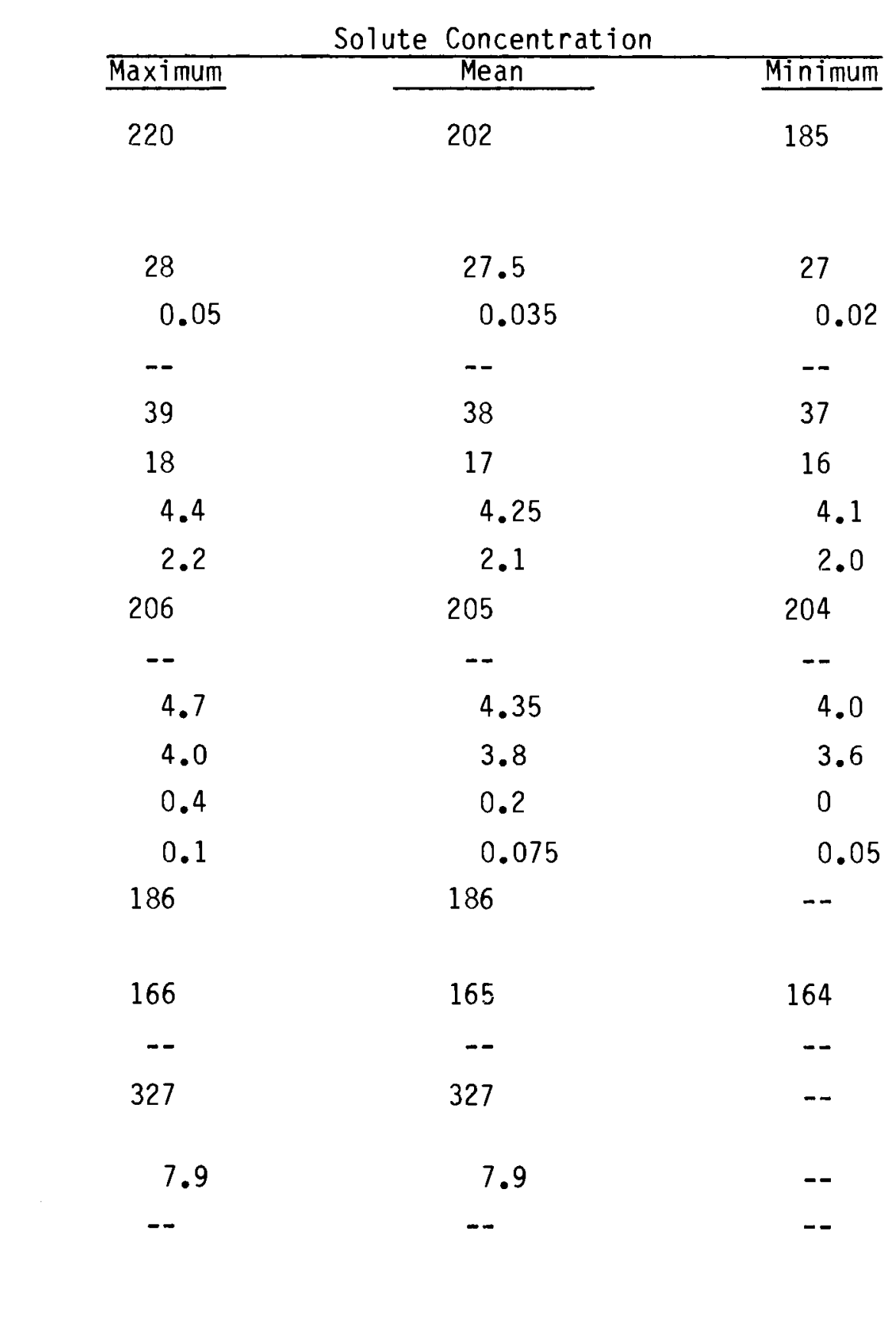

Hell Depth (m)

Constituents $(\mathrm{mg} / \mathrm{l})$

and Properties

$\mathrm{SiO}_{2}$

$\mathrm{Fe}$

$\mathrm{Mn}$

$\mathrm{Ca}$

$\mathrm{Mg}$

$\mathrm{Na}$

$\mathrm{K}$

$\mathrm{HCO}_{3}$

$\mathrm{CO}_{3}$

$\mathrm{SO}_{4}$

Cl

$\mathrm{F}$

$\mathrm{NO}_{3}$

TDS

Hardness as $\mathrm{CaCO}_{3}$

$\mathrm{Ca}, \mathrm{Mg}$

Noncarbonate

Sp. Cond.

(micromhos $25^{\circ} \mathrm{C}$ )

$\mathrm{pH}$

Temperature $\left({ }^{\circ} \mathrm{C}\right)$

Reference: Owen 1963 
TABLE 174. Water Analysis

Hydrologic Region: South Atlantic Gulf

State: Georgia

Aquifer Name: Tallahatta formation Location: Mitchell Co.

Aquifer Age: Middle Eocene No. Analyses: 1

Petrology: limestone, phosphatic, sandy, cherty 1s. and dolomitic 1s.

Water Type: $\mathrm{Ca}, \mathrm{HCO}_{3}$

Solute Concentration

Well Depth (m)

Constituents $(\mathrm{mg} / \mathrm{l})$ and Properties

$\mathrm{SiO}_{2}$

25

$\mathrm{Fe}$

0.04

$\mathrm{Mn}$

Ca

50

$\mathrm{Mg}$

8.1

$\mathrm{Na}$

6.2

$\mathrm{K}$

1.6

$\mathrm{HCO}_{3}$

201

$\mathrm{CO}_{3}$

$\mathrm{SO}_{4}$

6.0

C1

2.5

$\mathrm{F}$

0.2

$\mathrm{NO}_{3}$

0.5

TDS

205

Hardness as $\mathrm{CaCO}_{3}$

$\mathrm{Ca}, \mathrm{Mg}$

158

Noncarbonate

Sp. Cond.

(micromhos $25^{\circ} \mathrm{C}$ )

322

$\mathrm{pH}$

7.9

Temperature $\left({ }^{\circ} \mathrm{C}\right)$

Reference: Owen 1963 
TABLE 175. Water Analysis

Hydrologic Region: South Atlantic Gulf

Aquifer Name: Tallahatta

Aquifer Age: Eocene

Petrology: sand, clayey sand, interbedded limestone
State: Georgia

Location: Albany area

No. Analyses: 7

Nater Type: $\mathrm{Ca}, \mathrm{HCO}_{3}$

Solute Concentration
Well Depth (m)

Constituents (mg/l) and Properties

$\mathrm{SiO}_{2}$

$\mathrm{Fe}$

$\mathrm{Mn}$

$\mathrm{Ca}$

$\mathrm{Mg}$

$\mathrm{Na}$

K

$\mathrm{HCO}_{3}$

$\mathrm{CO}_{3}$

$\mathrm{SO}_{4}$

$\mathrm{Cl}$

$\mathrm{F}$

$\mathrm{NO}_{3}$

TDS

Hardness as $\mathrm{CaCO}_{3}$

$\mathrm{Ca}, \mathrm{Mg}$

Noncarbonate

Sp. Cond.

(microminos $025^{\circ} \mathrm{C}$ )

$\mathrm{pH}$

Temperature $\left({ }^{\circ} \mathrm{C}\right)$

Reference: Hicks et a1. 1981
34

0.137

0.005

40

6.6

9.6

2.8

181

0.368

6.5

3.9

0.1

0.3

196

135

0

300

7.54

22.1 
TABLE 176. Water Analysis

Hydrologic Region: South Atlantic Gulf Aquifer Name: Clayton

Aquifer Age: Early Paleocene

Petrology: calcareous quartz sand and interbedded limestone
State: Georgia

Location: Albany area

No. Analyses: 6

Water Type: $\mathrm{Na}, \mathrm{HCO}_{3}$

Solute Concentration

Well Depth (m)

Constituents ( $\mathrm{mg} / \mathrm{l}$ ) and Properties

$\mathrm{SiO}_{2}$

20

$\mathrm{Fe}$

$\mathrm{Mn}$

$\mathrm{Ca}$

$\mathrm{Mg}$

$\mathrm{Na}$

$\mathrm{K}$

$\mathrm{HCO}_{3}$

$\mathrm{CO}_{3}$

$\mathrm{SO}_{4}$

Cl

F

$\mathrm{NO}_{3}$

TDS

Hardness as $\mathrm{CaCO}_{3}$

$\mathrm{Ca}, \mathrm{Mg}$

Noncarbonate

Sp. Cond.

(micromhos $25^{\circ} \mathrm{C}$ )

$\mathrm{pH}$

Temperature $\left({ }^{\circ} \mathrm{C}\right)$

Reference: Hicks et al. 1981
49

0.152

0.01

12

5

44

3

159

0.34

12

2.5

0.3

0.1

174

0

258

7.3

22.9 
TABLE 177. Water Analysis

Hydrologic Region: South Atlantic Gulf Aquifer Name: Cusseta sand

Aquifer Age: Late Cretaceous

Petrology: silty, micaceous, calcareous, shaley sand
State: Georgia

Location: Albany area

No. Analyses: 3

Nater Type: $\mathrm{Na}, \mathrm{HCO}_{3}$

Solute Concentration

\section{Well Depth (m) \\ Constituents $(\mathrm{mg} / \mathrm{l})$ \\ and Properties}

\begin{tabular}{|c|c|}
\hline $\mathrm{SiO}_{2}$ & 13 \\
\hline $\mathrm{Fe}$ & 15 \\
\hline$M n$ & 0.015 \\
\hline $\mathrm{Ca}$ & 5.2 \\
\hline $\mathrm{Mg}$ & 1.6 \\
\hline $\mathrm{Na}$ & 622 \\
\hline K & 3.8 \\
\hline $\mathrm{HCO}_{3}$ & 903 \\
\hline $\mathrm{CO}_{3}$ & -- \\
\hline $\mathrm{SO}_{4}$ & 4.0 \\
\hline $\mathrm{Cl}$ & 422 \\
\hline $\mathrm{F}$ & 3.3 \\
\hline $\mathrm{NO}_{3}$ & 0.1 \\
\hline $\mathrm{Sr}$ & 0.4 \\
\hline TDS & 1527 \\
\hline \multicolumn{2}{|l|}{ ness as $\mathrm{CaCO}_{3}$} \\
\hline $\mathrm{Ca}, \mathrm{Mg}$ & 21 \\
\hline Noncarbonate & 0 \\
\hline \multirow[t]{2}{*}{$\begin{array}{l}\text { Cond. } \\
\text { rombos }\left(25^{\circ} \mathrm{C}\right)\end{array}$} & 2522 \\
\hline & 8.03 \\
\hline erature $\left({ }^{\circ} \mathrm{C}\right)$ & 22.7 \\
\hline
\end{tabular}

Reference: Hicks et al. 1981 


\section{TABLE 178. Water Analysis}

Hydrologic Region: South Atlantic Gulf Aquifer Name: Providence sand

Aquifer Age: Late Cretaceous

Petrology: dolomitic siltstone, calcareous, clayey, micaceous sandstone
State: Georgia

Location: Albany area

No. Analyses: 1

Water Type: $\mathrm{Na}, \mathrm{HCO}_{3}$

Solute Concentration

\section{We11 Depth (m)}

Constituents $(\mathrm{mg} / \ell)$

and Properties

$\mathrm{SiO}_{2}$

$\mathrm{Fe}$

$\mathrm{Mn}$

$\mathrm{Ca}$

$\mathrm{Mg}$

$\mathrm{Na}$

$\mathrm{K}$

$\mathrm{HCO}_{3}$

$\mathrm{CO}_{3}$

$\mathrm{SO}_{4}$

$\mathrm{Cl}$

$\mathrm{F}$

$\mathrm{NO}_{3}$

$\mathrm{Sr}$

TDS
12

50

0

1.7

0.4

85

1.6

200

7.6

2.4

0.6

0.1

0

223

Hardness as $\mathrm{CaCO}_{3}$

$\mathrm{Ca}, \mathrm{Mg}$

6

Noncarbonate

0

358

(micromhos $25^{\circ} \mathrm{C}$ )

$\mathrm{pH}$

9.2

Temperature $\left({ }^{\circ} \mathrm{C}\right)$

24.0

Reference: Hicks et al. 1981 


\section{TABLE 179. Water Analysis}

Hydrologic Region: South Atlantic Gulf Aquifer Name: Upper Cretaceous Series Aquifer Age: Late Cretaceous Petrology: sandstone

We11 Depth (m)

Constituents (mg/ $\ell$ ) and Properties

$\mathrm{SiO}_{2}$

$\mathrm{Fe}$

$\mathrm{Mn}$

$\mathrm{Ca}$

$\mathrm{Mg}$

$\mathrm{Na}$

$\mathrm{K}$

$\mathrm{HCO}_{3}$

$\mathrm{CO}_{3}$

$\mathrm{SO}_{4}$

$\mathrm{Cl}$

$\mathrm{F}$

$\mathrm{NO}_{3}$

TDS
State: Georgia Location: Dodge Co. No. Analyses: 1

Water Type: $\mathrm{Ca}, \mathrm{HCO}_{3}$

Solute Concentration
29

0.004

0.003

50

1.6

2.0

1.2

160

3.0

2.6

0.1

0.75

168

130

(total)

256

7.4

20.5

Temperature $\left({ }^{\circ} \mathrm{C}\right)$

Reference: Feder and Lee 1981 
Hydrologic Region: South Atlantic Gulf Aquifer Name: Upper Cretaceous Series Aquifer Age: Late Cretaceous Petrology: sandstone

Well Depth (m) Constituents $(\mathrm{mg} / \mathrm{l})$ and Properties

$$
\mathrm{SiO}_{2}
$$

$\mathrm{Fe}$

$\mathrm{Mn}$

$\mathrm{Ca}$

$\mathrm{Mg}$

$\mathrm{Na}$

$\mathrm{K}$

$\mathrm{HCO}_{3}$

$\mathrm{CO}_{3}$

$\mathrm{SO}_{4}$

$\mathrm{Cl}$

$\mathrm{F}$

$\mathrm{NO}_{3}$

TDS
State: Georgia

Location: Richmond Co.

No. Analyses: 1

Water Type: $\mathrm{Ca}, \mathrm{Na}, \mathrm{HCO}_{3}, \mathrm{Cl}$

Solute Concentration
111

19

$$
\begin{aligned}
& 0.006 \\
& 0.002 \\
& 0.5 \\
& 0.35 \\
& 1.0 \\
& 0.2 \\
& 2 \\
& -- \\
& 0.7 \\
& 1.6 \\
& <0.1 \\
& 0.31 \\
& -- \\
& \\
& 3 \\
& \text { (total) } \\
& 9
\end{aligned}
$$

Hardness as $\mathrm{CaCO}_{3}$

$$
\left.\begin{array}{l}
\mathrm{Ca}, \mathrm{Mg} \\
\text { Noncarbonate }
\end{array}\right\}
$$

9

4.8

19.7

Temperature $\left({ }^{\circ} \mathrm{C}\right)$

Reference: Feder and Lee 1981 
TABLE 181. Water Analysis

Hydrologic Region: South Atlantic Gulf Aquifer Name: Black Creek formation Aquifer Age: Late Cretaceous

Petrology: sandstone

Well Depth (m)

Constituents $(\mathrm{mg} / \mathrm{l})$ and Properties

$\mathrm{SiO}_{2}$

$\mathrm{Fe}$

$\mathrm{Mn}$

$\mathrm{Ca}$

$\mathrm{Mg}$

$\mathrm{Na}$

$\mathrm{K}$

$\mathrm{HCO}_{3}$

$\mathrm{CO}_{3}$

$\mathrm{SO}_{4}$

$\mathrm{Cl}$

$\mathrm{F}$

$\mathrm{NO}_{3}$

TDS
State: North Carolina

Location: Wayne Co.

Ho. Analyses: 1

Water Type: $\mathrm{Ca}, \mathrm{Na}, \mathrm{HCO}_{3}$

Solute Concentration

27

23

1.1

0.095

21

3.3

13

3.7

90

18

10

0.1

0.53

136

Hardness as $\mathrm{CaCO}_{3}$

$\left.\begin{array}{l}\mathrm{Ca}, \mathrm{Mg} \\ \text { Noncarbonate }\end{array}\right\}$

66

( $\operatorname{tota} 1)$

202

6.3

18.0

Reference: Feder and Lee 1981 
TABLE 182. Water Analysis

Hydrologic Region: South Atlantic Gulf Aquifer Name: Tuscaloosa equivalents Aquifer Age: Late Cretaceous

Petrology: sandstone

Well Depth (m)

Constituents $(\mathrm{mg} / \mathrm{l})$ and Properties

$\mathrm{SiO}_{2}$

$\mathrm{Fe}$

$\mathrm{Mn}$

$\mathrm{Ca}$

$\mathrm{Mg}$

$\mathrm{Na}$

K

$\mathrm{HCO}_{3}$

$\mathrm{CO}_{3}$

$\mathrm{SO}_{4}$

Cl

$\mathrm{F}$

$\mathrm{NO}_{3}$

TDS
State: North Carolina Location: Cumberland Co. No. Analyses: 1 Water Type: $\mathrm{Ca}, \mathrm{Na}, \mathrm{HCO}_{3}$

Solute Concentration

1.8

0.055

6.5

2.0

10

3.8

54

13

2.5

0.2

0.04

87

Hardness as $\mathrm{CaCO}_{3}$

$\left.\begin{array}{l}\mathrm{Ca}, \mathrm{Mg} \\ \text { Noncarbonate }\end{array}\right\}$

25

(total)

Sp. Cond.

106

(micromhos $25^{\circ} \mathrm{C}$ )

pH

6.5

Temperature $\left({ }^{\circ} \mathrm{C}\right)$

17.9

Reference: Feder and Lee 1981 
TABLE 183. Water Analys is

Hydrologic Region: South Atlantic Gulf Aquifer Name: Black Mingo aquifer Aquifer Age: Early Eocene and Paleocene Petrology: glauconitic sand and coquina
State: South Carolina Location: Georgetown Co. No. Analyses: 1

Water Type: $\mathrm{Ca}, \mathrm{HCO}_{3}$

Solute Concentration

\section{We11 Depth (m) \\ Constituents (mg/ $\mathrm{l}$ ) \\ and Properties}

$\mathrm{SiO}_{2}$

33

$\mathrm{Fe}$

10

$\mathrm{Mn}$

0.1

$\mathrm{Ca}$

51

$\mathrm{Mg}$

3.1

$\mathrm{Na}$

15

K

1.5

$\mathrm{HCO}_{3}$

180

$\mathrm{CO}_{3}$

0

$\mathrm{SO}_{4}$

2.8

Cl

18

$\mathrm{F}$

$\mathrm{NO}_{3}$

TDS

224

Hardness as $\mathrm{CaCO}_{3}$

$\mathrm{Ca}, \mathrm{Mg}$

140

Noncarbonate

324

Sp. Cond.

(micromos $25^{\circ} \mathrm{C}$ )

pH

6.9

Temperature $\left({ }^{\circ} \mathrm{C}\right)$

Reference: Zack 1977 


\section{TABLE 184. Water Analysis}

Hydrologic Region: South Atlantic Gulf Aquifer Name: Black Creek aquifer Aquifer Age: Late Cretaceous

Petrology: montmorillonite, glauconite, sand, limestone, pyrite, lignite
State: South Carolina

Location: Grand Strand area and Horry and Georgetown Co's.

No. Analyses: 1

Water Type: $\mathrm{Na}, \mathrm{HCO}_{3}$

Solute Concentration
We11 Depth (m)

Constituents $(\mathrm{mg} / \mathrm{l})$ and Properties

$\mathrm{SiO}_{2}$

$\mathrm{Fe}$

$\mathrm{Mn}$

$\mathrm{Ca}$

$\mathrm{Mg}$

$\mathrm{Na}$

K

$\mathrm{HCO}_{3}$

$\mathrm{CO}_{3}$

$\mathrm{SO}_{4}$

C1

$\mathrm{F}$

$\mathrm{NO}_{3}$

TDS
19

0.1

0.02

2.4

0.6

320

4.5

642

40

3.7

59

4.0

0.25

772

8

(total)

1260

8.4

Sp. Cond.

(micromhos $25^{\circ} \mathrm{C}$ )

$\mathrm{pH}$

Temperature $\left({ }^{\circ} \mathrm{C}\right)$

Reference: Zack 1977 


\section{TABLE 185. Water Analysis}

Hydrologic Region: South Atlantic Gulf Aquifer Name: Peedee aquifer Aquifer Age: Late Cretaceous

Petrology: clay, silt, sand, glauconite, limestone

We11 Depth (m)

Constituents $(\mathrm{mg} / \mathrm{l})$

and Properties

$\mathrm{SiO}_{2}$

$\mathrm{Fe}$

Mn

$\mathrm{Ca}$

$\mathrm{Mg}$

$\mathrm{Na}$

$\mathrm{K}$

$\mathrm{HCO}_{3}$

$\mathrm{CO}_{3}$

$\mathrm{SO}_{4}$

$\mathrm{Cl}$

$\mathrm{F}$

$\mathrm{NO}_{3}$

TDS
State: South Carolina

Location: Grand Strand area and Horry and Georgetown Co's.

No. Analyses: 1

Water Type: $\mathrm{Ca}, \mathrm{HCO}_{3}$

Solute Concentration

Hardness as $\mathrm{CaCO}_{3}$

$$
\left.\begin{array}{l}
\mathrm{Ca}, \mathrm{Mg} \\
\text { Noncarbonate }
\end{array}\right\}
$$

Sp. Cond.

430

(micromhos $25^{\circ} \mathrm{C}$ )

$\mathrm{pH}$

Temperature $\left({ }^{\circ} \mathrm{C}\right)$

Reference: Zack 1977 
TABLE 186. Water Analysis

Hydrologic Region: South Atlantic Gulf

Aquifer Name: Tuscaloosa equivalents

Aquifer Age: Late Cretaceous

Petrology: sandstone

Well Depth (m)

Constituents $(\mathrm{mg} / \ell)$ and Properties

$\mathrm{SiO}_{2}$

$\mathrm{Fe}$

$\mathrm{Mn}$

$\mathrm{Ca}$

$\mathrm{Mg}$

$\mathrm{Na}$

$\mathrm{K}$

$\mathrm{HCO}_{3}$

$\mathrm{CO}_{3}$

$\mathrm{SO}_{4}$

Cl

$\mathrm{F}$

$\mathrm{NO}_{3}$

TDS

Hardness as $\mathrm{CaCO}_{3}$

$\left.\begin{array}{l}\mathrm{Ca}, \mathrm{Mg} \\ \text { Noncarbonate }\end{array}\right\}$

Sp. Cond.

(micromhos $25^{\circ} \mathrm{C}$ )

$\mathrm{pH}$

Temperature $\left({ }^{\circ} \mathrm{C}\right)$

Reference: Feder and Lee 1981
State: South Carolina

Location: Barnwell Co.

No. Analyses: 1

Water Type: $\mathrm{Ca}, \mathrm{Na}, \mathrm{HCO}_{3}, \mathrm{Cl}$

Solute Concentration

244

8.0

0.004

0.017

3.1

0.84

3.7

0.5

8

$--$

2.4

5.1

0.1

7.1

28

11

(total)

43

5.3

19.0 
Hydrologic Region: South Atlantic Gulf Aquifer Name: Tuscaloosa equivalents

Aquifer Age: Late Cretaceous

Petrology: sandstone

\section{Well Depth (m)}

\section{Constituents $(\mathrm{mg} / \ell)$} and Properties

$\mathrm{SiO}_{2}$

$\mathrm{Fe}$

$\mathrm{Mn}$

$\mathrm{Ca}$

$\mathrm{Mg}$

$\mathrm{Na}$

K

$\mathrm{HCO}_{3}$

$\mathrm{CO}_{3}$

$\mathrm{SO}_{4}$

Cl

$\mathrm{F}$

$\mathrm{NO}_{3}$

TDS

Hardness as $\mathrm{CaCO}_{3}$

$$
\left.\begin{array}{l}
\mathrm{Ca}, \mathrm{Mg} \\
\text { Noncarbonate }
\end{array}\right\}
$$

Sp. Cond.

(micromhos $25^{\circ} \mathrm{C}$ )

pH

Temperature $\left({ }^{\circ} \mathrm{C}\right)$
State: South Carolina

Location: Marlboro Co.

No. Analyses: 1

Water Type: $\mathrm{Na}, \mathrm{Cl}$

Solute Concentration
9.6

0.032

0.1

1.8

1.9

14

1.4

0

0.6

20

$<0.1$

19

75

13 (total)

116

4.4

18.4

Reference: Feder and Lee 1981 
TABLE 188. Water Analysis

Hydrologic Region: Tennessee

Aquifer Name: Fort Payne chert and

St. Louis limestone

Aquifer Age: Early Mississippian

Petrology: thick-bedded cherty limestone
State: Georgia

Location: Dade Co.

No. Analyses: 3

Water Type: $\mathrm{Ca}, \mathrm{HCO}_{3}$

Solute Concentration

\begin{tabular}{ccc}
\hline Maximum & Intermediate & Minimum \\
\cline { 2 - 3 }-- & -- & -- \\
& & \\
7.8 & & 7.6 \\
0.02 & 0.9 & 0.05 \\
-- & -.10 & -- \\
45 & -- & 4 \\
4.7 & 63 & 1.6 \\
0.4 & 1.4 & 1.0 \\
0.5 & 0.3 & 0.1 \\
157 & 150 & 24 \\
-- & -- & -- \\
4.6 & 0.5 & 0.6 \\
1.5 & 3.0 & 6.8 \\
0 & 0.1 & 0 \\
0.5 & 13 & 0.4 \\
143 & 142 & 37
\end{tabular}

Hardness as $\mathrm{CaCO}_{3}$

$\mathrm{Ca}, \mathrm{Mg}$

132

134

17

Noncarbonate

Sp. Cond.

(micromhos $25^{\circ} \mathrm{C}$ )

pH

7.4

7.7

6.8

Temperature $\left({ }^{\circ} \mathrm{C}\right)$

15.6

Reference: Croft 1964 
Hydrologic Region: Tennessee

Aquifer Name: Sequatchie formation

Aquifer Age: Late Ordovician

Petrology: limestone, siltstone, shale, sandstone
State: Georgia

Location: Dade Co.

No. Analyses: 1

Nater Type: $\mathrm{Ca}, \mathrm{HCO}_{3}$

Solute Concentration
We11 Depth (m)

Constituents $(\mathrm{mg} / \mathrm{l})$ and Properties

$\mathrm{SiO}_{2}$

$\mathrm{Fe}$

Mn

Ca

$\mathrm{Mg}$

$\mathrm{Na}$

K

$\mathrm{HCO}_{3}$

$\mathrm{CO}_{3}$

$\mathrm{SO}_{4}$

$\mathrm{Cl}$

$\mathrm{F}$

$\mathrm{NO}_{3}$

TDS
11

0.12

54

3.8

1.7

0.6

181

$--$

4.8

1.5

0.2

0

163

Hardness as $\mathrm{CaCO}_{3}$

$\left.\begin{array}{l}\mathrm{Ca}, \mathrm{Mg} \\ \text { Noncarbonate }\end{array}\right\}$

150

(total)

Sp. Cond.

(micromhos $25^{\circ} \mathrm{C}$ )

$\mathrm{pH}$

7.7

Temperature $\left({ }^{\circ} \mathrm{C}\right)$

Reference: Croft 1964 
TABLE 190. Water Analysis

Hydrologic Region: Tennessee

Aquifer Name: Chickamauga limestone

Aquifer Age: Ordovician

Petrology: cherty limestone
State: Georgia

Location: Dade Co.

No. Analyses: 2

Hater Type: $\mathrm{Ca}, \mathrm{HCO}_{3}$

Solute Concentration

\begin{tabular}{ccc}
\hline Maximum & Minimum \\
\cline { 2 - 3 }-- & Intermediate & -- \\
& & \\
13 & -- & 7.9 \\
0 & -- & 0.08 \\
-- & -- & -- \\
118 & -- & 74 \\
37 & -- & 6.2 \\
7.5 & -- & 6.0 \\
1.6 & -- & 2.7 \\
475 & -- & 224 \\
-- & -- & -- \\
28 & -- & 31 \\
36 & -- & 8.5 \\
0.1 & -- & 0.1 \\
2 & -- & 2.4 \\
510 & -- & 142
\end{tabular}

446

134

$\mathrm{Ca}, \mathrm{Mg}$

$-$

$-$

Noncarbonate

Sp. Cond.

(micromhos $25^{\circ} \mathrm{C}$ )

pH

7.3

7.7

Temperature $\left({ }^{\circ} \mathrm{C}\right)$

Reference: Croft 1964 
TABLE 191. Water Analysis

Hydrologic Region: Tennessee

Aquifer Name: Knox dolomite

Aquifer Age: Early Ordovician

Petrology: cherty dolomite and limestone
State: Georgia

Location: Dade Co.

No. Analyses: 2

Water Type: $\mathrm{Ca}, \mathrm{HCO}_{3}$

Solute Concentration

Maximum Intermediate

Minimum

Well Depth (m)

Constituents (mg/ $\mathrm{l}$ )

and Properties

$\mathrm{SiO}_{2}$

$\mathrm{Fe}$

$\mathrm{Mn}$

Ca

$\mathrm{Mg}$

$\mathrm{Na}$

K

$\mathrm{HCO}_{3}$

$\mathrm{CO}_{3}$

$\mathrm{SO}_{4}$

C1

$\mathrm{F}$

$\mathrm{NO}_{3}$

TDS

223

$\mathrm{Ca}, \mathrm{Mg}$

Noncarbonate

Sp. Cond.

(micromhos $25^{\circ} \mathrm{C}$ )

$\mathrm{pH}$

Temperature $\left({ }^{\circ} \mathrm{C}\right)$

Reference: Croft 1964

8.6
0.03
--
63
16
1.8
0.2
253
--
3.4
5.5
0.1
11
241
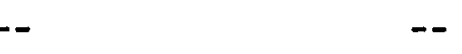

$--$

8.0

0.01

$--$

--

38

17

3.2

0.8

162

$--162$

$--$

$-$

$--$

6.8

7.0

0.1

22

194

--

165

-.

$--$

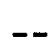

--

7.9

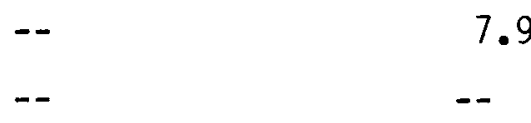


TABLE 192. Water Analysis

Hydrologic Region: Texas Gulf

Aquifer Name: Alluvium

Aquifer Age: Holocene

Petrology: clay, silt, sandstone, gravel
State: Texas

Location: Jones Co.

No. Analyses: 3

Hater Type: $\mathrm{Na}, \mathrm{Cl}$

Solute Concentration

Maximum $\quad$ Intermediate $\quad$ Minimum

Well Depth (m)

Constituents $(\mathrm{mg} / \ell)$

and Properties

$\mathrm{SiO}_{2}$

$\mathrm{Fe}$

$\mathrm{Mn}$

$\mathrm{Ca}$

$\mathrm{Mg}$

$\mathrm{Na}$

K

$\mathrm{HCO}_{3}$

$\mathrm{CO}_{3}$

$\mathrm{SO}_{4}$

Cl

$\mathrm{F}$

$\mathrm{NO}_{3}$

TDS
5

9

15

15

21

31

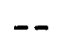

--

Hardness as $\mathrm{CaCO}_{3}$

$\mathrm{Ca}, \mathrm{Mg}$

Noncarbonate

Sp. Cond.

(micromhos $025^{\circ} \mathrm{C}$ )

$\mathrm{pH}$

Temperature $\left({ }^{\circ} \mathrm{C}\right)$

Reference: Price 1978

$$
4.2
$$

215

15200

4350

4.2
215
15200

$>12000$

8.0

7.7

7.5

1.7

1.0

20.0

22

5600

1220

3800

640

8650

1750
461

770

3410

-.

650

254

462

--

8800

427

1180

142

70

158

3230

67

$--$ 
TABLE 193. Water Analysis

Hydrologic Region: Texas Gulf

Aquifer Name: Brazos River alluvium

Aquifer Age: Holocene

Petrology: clay, silt, sand, gravel
State: Texas

Location: Washington Co.

No. Analyses: 5

Water Type: $\mathrm{Ca}, \mathrm{Na}, \mathrm{HCO}_{3}$

Solute Concentration

\begin{tabular}{ccc}
\hline Maximum & Intermediate & Minimum \\
20 & -- & $22(a)$
\end{tabular}

Well Depth (m)

Constituents $(\mathrm{mg} / \mathrm{l})$

and Properties

$\mathrm{SiO}_{2}$

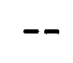

$--$

24

$\mathrm{Fe}$

$\mathrm{Mn}$

$\mathrm{Ca}$

$\mathrm{Mg}$

$\mathrm{Na}$

$\mathrm{K}$

$\mathrm{HCO}_{3}$

$\mathrm{CO}_{3}$

$\mathrm{SO}_{4}$

$\mathrm{Cl}$

$\mathrm{F}$

$\mathrm{NO}_{3}$

$\mathrm{B}$

TDS

Hardness as $\mathrm{CaCO}_{3}$

$\mathrm{Ca}, \mathrm{Mg}$

Noncarbonate

Sp. Cond.

(micromhos $25^{\circ} \mathrm{C}$ )

$\mathrm{pH}$

Temperature $\left({ }^{\circ} \mathrm{C}\right)$

Reference: Sandeen 1983
233

$-$

$--$

86

4.1

27

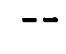

220

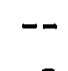

5

35

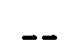

71

--

336
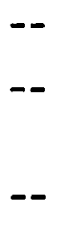

$--$

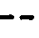

$-$

$-$

$-$

--

$--$

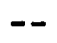

$--$

$-$

$--$

$--$

$--$

--

$-$

367

$--$

--

918

6.8

119

17

62

2.0

463

$-$

54

54

0.2

--

0.06

560

--

$--$

.1

(9)

. 
TABLE 194. Water Analysis

Hydrologic Region: Texas Gulf

Aquifer Name: Quaternary system

Aquifer Age: Holocene

Petrology: clay, silt, sand, gravel, sandstones
State: Texas

Location: Taylor Co.

No. Analyses: 3

Water Type: $\mathrm{Na}, \mathrm{HCO}_{3}, \mathrm{SO}_{4}, \mathrm{Cl}$

Solute Concentration

\begin{tabular}{ccc}
\hline Maximum & Minimum \\
\cline { 2 - 3 } 7 & \multicolumn{1}{c}{ Intermediate } & 8 \\
& & \\
16 & 21 & 10 \\
-- & -- & -- \\
-- & -- & -- \\
100 & 147 & 91 \\
235 & 108 & 34 \\
1010 & 399 & 138 \\
-- & -- & -- \\
960 & 500 & 257 \\
-- & -- & -- \\
1620 & 390 & 125 \\
710 & 600 & 230 \\
2.6 & 1.3 & 0.7 \\
$<0.4$ & 35 & $<0.4$ \\
4170 & 1950 & 760
\end{tabular}

Hardness as $\mathrm{CaCO}_{3}$

$\mathrm{Ca}, \mathrm{Mg}$

1220

810

366

Noncarbonate

Sp. Cond.

5030

2870

1310

(micromhos $25^{\circ} \mathrm{C}$ )

pH

7.6

7.5

7.1

Temperature $\left({ }^{\circ} \mathrm{C}\right)$

Reference: Taylor 1978 
TABLE 195. Water Analysis

Hydrologic Region: Texas Gulf

Aquifer Name: Seymour formation

Aquifer Age: Pleistocene

Petrology: clay, silt, sand, caliche, gravel, conglomerate
State: Texas

Location: Jones Co.

No. Analyses: 3

Water Type: $\mathrm{Na}, \mathrm{Cl}$

Solute Concentration

Well Depth (m)

Constituents $(\mathrm{mg} / \mathrm{l})$ and Properties

$\mathrm{SiO}_{2}$

$\mathrm{Fe}$

$\mathrm{Mn}$

$\mathrm{Ca}$

$\mathrm{Mg}$

$\mathrm{Na}$

K

$\mathrm{HCO}_{3}$

$\mathrm{CO}_{3}$

$\mathrm{SO}_{4}$

C1

$\mathrm{F}$

$\mathrm{NO}_{3}$

TDS

\begin{tabular}{l}
\multicolumn{1}{c}{2} \\
-- \\
-- \\
1720 \\
1220 \\
2440 \\
-- \\
520 \\
-- \\
1160 \\
9100 \\
0.9 \\
500 \\
6400
\end{tabular}

Hardness as $\mathrm{CaCO}_{3}$

$\mathrm{Ca}, \mathrm{Mg}$

9300

Noncarbonate

Sp. Cond.

$>12000$

(micromhos $25^{\circ} \mathrm{C}$ )

pH

7.2

Temperature $\left({ }^{\circ} \mathrm{C}\right)$

Reference: Price 1978

1820

730

6140

3060 Intermediate

9

Minimum

5

21

22

$-$

--

94

227

120

460

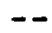

448

$--$

500

500

4.1

105

2020

4050

8.3 
TABLE 196. Water Analysis

Hydrologic Region: Texas Gulf

Aquifer Name: Evangel ine aquifer

Aquifer Age: Pliocene

Petrology: sand, clay
State: Texas

Location: Washington Co.

No. Analyses: 56

Water Type: $\mathrm{Ca}, \mathrm{Na}, \mathrm{HCO}_{3}$

Solute Concentration

Maximum $\quad$ Intermediate

$\mathrm{SiO}_{2}$

$\mathrm{Fe}$

$\mathrm{Mn}$

$\mathrm{Ca}$

$\mathrm{Mg}$

$\mathrm{Na}$

$\mathrm{K}$

$\mathrm{HCO}_{3}$

$\mathrm{CO}_{3}$

$\mathrm{SO}_{4}$

Cl

$\mathrm{F}$

$\mathrm{NO}_{3}$

$\mathrm{B}$

TDS

$\mathrm{Ca}, \mathrm{Mg}$

Noncarbonate

Sp. Cond.

(micromhos $25^{\circ} \mathrm{C}$ )

pH

Temperature $\left({ }^{\circ} \mathrm{C}\right)$

Reference: Sandeen 1983
65

26

379

231

12

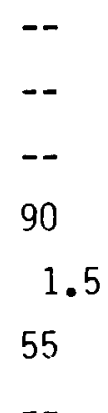

366

344

--

3.2

14

0.2

0

333

260

553

6.4

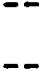

386

261

29

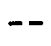

--

--

97

4.5

39

371

3.4

26

0.4

0.5

--
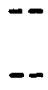

$-$ 


\section{TABLE 197. Water Analysis}

Hydrologic Region: Texas Gulf

Aquifer Name: Catahoula sandstone

Aquifer Age: Miocene

Petrology: sandstone, sand, clay, tuff
State: Texas

Location: Washington Co.

No. Analyses: 27

Water Type: $\mathrm{Ca}, \mathrm{Na}, \mathrm{HCO}_{3}$

Solute Concentration

Maximum Intermediate

55

462

41

Constituents $(\mathrm{mg} / \ell)$ and Properties
4.5

0.4

0

-
-
-
4.5
6
-
4
-
0
7
0.4
0
-

0.3

0

425

266

1.1

13

293

--

8

10

0

$--$

$$
\mathrm{SiO}_{2}
$$

$\mathrm{Fe}$

$\mathrm{Mn}$

$\mathrm{Ca}$

$\mathrm{Mg}$

$\mathrm{Na}$

$\mathrm{K}$

$\mathrm{HCO}_{3}$

$\mathrm{CO}_{3}$

$\mathrm{SO}_{4}$

$\mathrm{Cl}$

$\mathrm{F}$

$\mathrm{NO}_{3}$

$\mathrm{B}$

TDS

162

162

36

--

344

--

10

147

706

423

$\mathrm{Ca}, \mathrm{Mg}$

Noncarbonate

Sp. Cond.

(micromhos $25^{\circ} \mathrm{C}$ )

pH

Temperature $\left({ }^{\circ} \mathrm{C}\right)$

Reference: Sandeen 1983

$-$

87

224

5.8

0.2
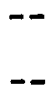

33 
TABLE 198. Water Analysis

Hydrologic Region: Texas Gulf

Aquifer Name: Jasper aquifer

Aquifer Age: Miocene

Petrology: sand, clay, sandstone
State: Texas

Location: Washington Co.

No. Analyses: 117

Water Type: $\mathrm{Ca}, \mathrm{Na}, \mathrm{HCO}_{3}$

Solute Concentration

Maximum

We11 Depth (m)

320

75

Minimum

237

Constituents $(\mathrm{mg} / \mathrm{l})$ and Properties

$\mathrm{SiO}_{2}$

40

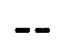

23

$\mathrm{Fe}$

$\mathrm{Mn}$

$\mathrm{Ca}$

$\mathrm{Mg}$

$\mathrm{Na}$

K

$\mathrm{HCO}_{3}$

$\mathrm{CO}_{3}$

$\mathrm{SO}_{4}$

$\mathrm{Cl}$

$\mathrm{F}$

$\mathrm{NO}_{3}$

$\mathrm{B}$

TDS

Hardness as $\mathrm{CaCO}_{3}$

$\mathrm{Ca}, \mathrm{Mg}$

Noncarbonate

Sp. Cond.

(micromitos $25^{\circ} \mathrm{C}$ )

$\mathrm{pH}$

Temperature $\left({ }^{\circ} \mathrm{C}\right)$

Reference: Sandeen 1983

Intermediate
63

$--$

$--$

21

2.6

162

$--$

420

$--$

22

34

0.4

0.2

489

754

8.0

24
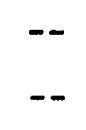

102

1.5

53

--

366

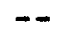

26

34

0

1

--

398

261

182

--

--

593

7.7

26 
TABLE 199. Water Analysis

Hydrologic Region: Texas Gulf

Aquifer Name: Jackson group

Aquifer Age: Eocene

Petrology: lignitic shale, volcanic ash, sandstone
State: Texas

Location: Washington Co.

No. Analyses: 24

Water Type: $\mathrm{Ca}, \mathrm{Na}, \mathrm{HCO}_{3}, \mathrm{SO}_{4}$, $\mathrm{Cl}$

Solute Concentration

Maximum

Well Depth (m)

38 Intermediate

Minimum

Constituents $(\mathrm{mg} / \mathrm{l})$

and Properties

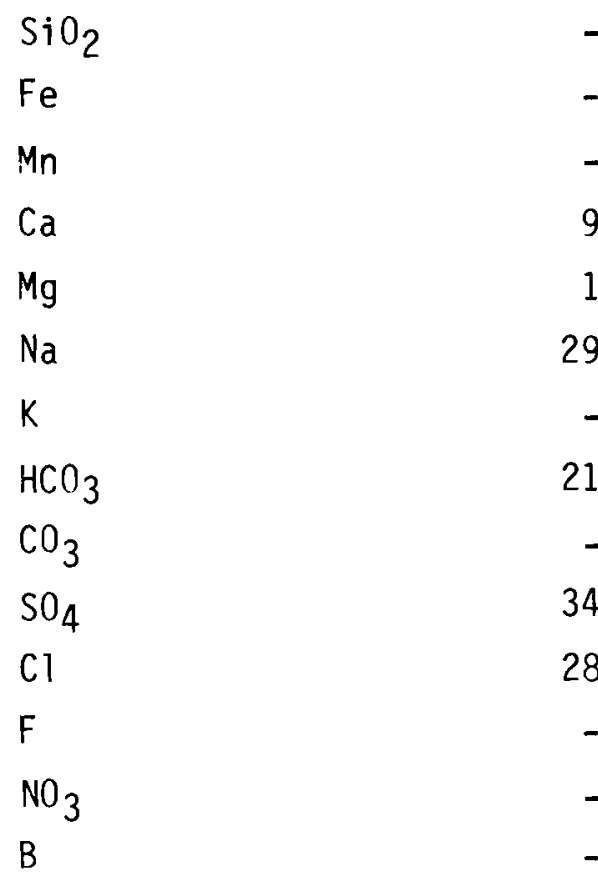

TDS

1135

171

85

--

56

76

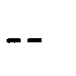

93

22

70

13

1.0

4.3

297

306

63

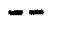

214

694

318

340

0

28

287

109

28

$-$

1.2

0.3

0.1

0

836

426

Hardness as $\mathrm{CaCO}_{3}$

$\mathrm{Ca}, \mathrm{Mg}$

Noncarbonate

Sp. Cond.

(micromhos $25^{\circ} \mathrm{C}$ )

$\mathrm{pH}$

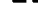

1300

608

Temperature $\left({ }^{\circ} \mathrm{C}\right)$

7.5

7.7

24

Reference: Sandeen 1983 


\section{TABLE 200. Water Analysis}

Hydrologic Region: Texas Gulf

Aquifer Name: Carrizo sand

Aquifer Age: Early Eocene

Petrology: micaceous quartz sand, clay, silt, lignite
State: Texas

Location: McMullen and Wilson Co's.

No. Analyses: 6

Water Type: $\mathrm{Na}, \mathrm{HCO}_{3}$

Solute Concentration

Maximum Intermediate

342

43

Well Depth (m)

1265

16

26

$\mathrm{SiO}_{2}$

36

0.06

$\mathrm{Mn}$

$\mathrm{Ca}$

--

0.6

1.1

$\mathrm{Mg}$

$\left.\begin{array}{l}\mathrm{Na} \\ \mathrm{K}\end{array}\right\}$

$\mathrm{HCO}_{3}$

$\mathrm{CO}_{3}$

$\mathrm{SO}_{4}$

$\mathrm{Cl}$

$\mathrm{F}$

$\mathrm{NO}_{3}$

TDS

591

1790

582

14

$--$

0.6

18

9.5

228

56

17

0.5

0.2

639

1990

8

22

13

Noncarbonate

Sp. Cond.

(micromhos a $25^{\circ} \mathrm{C}$ )

$\mathrm{pH}$

Temperature $\left({ }^{\circ} \mathrm{C}\right)$

Reference: Payne 1975
3130

1060

109

8.5

7.9

6.5

65

36 
TABLE 201. Water Analysis

Hydrologic Region: Texas Gulf

Aquifer Name: Fredericksburg group

Aquifer Age: Late Cretaceous

Petrology: limestone, clay, chert
State: Texas

Location: Taylor Co.

No. Analyses: 3

Hater Type: $\mathrm{Ca}, \mathrm{HCO}_{3}$

Solute Concentration

Maximum

spring

spring
We11 Depth (m)

Constituents $(\mathrm{mg} / \ell)$ and Properties

$\mathrm{SiO}_{2}$
$\mathrm{Fe}$
$\mathrm{Mn}$
$\mathrm{Ca}$
$\mathrm{Mg}$
$\mathrm{Na}$
$\mathrm{K}$
$\mathrm{HCO}_{3}$
$\mathrm{CO}_{3}$
$\mathrm{SO}_{4}$
$\mathrm{Cl}$
$\mathrm{F}$
$\mathrm{NO}_{3}$
$\mathrm{TDS}$

Hardness as $\mathrm{CaCO}_{3}$

$\mathrm{Ca}, \mathrm{Mg}$

Noncarbonate

Sp. Cond.

(micromhos $25^{\circ} \mathrm{C}$ )

pH

Temperature $\left({ }^{\circ} \mathrm{C}\right)$

Reference: Taylor 1978
20

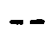

121

27

11

459

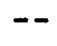

28

16

0.3

$<0.4$

449

413

727

7.6

7.9

7.6

Minimum

18

11

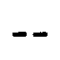

-.

79

20

7

314

--

20

16

10

0.5

0.5

2.0

3.5

384

302

274

367

646

510

-. 


\section{TABLE 201A. Water Analysis}

Hydrologic Region: Texas Gulf

Aquifer Name: Antlers formation

Aquifer Age: Cretaceous

Petrology: sand, sandstone
State: Texas

Location: Denton Co.

No. Analyses: 18

Hell Depth (m)

Constituents $(\mathrm{mg} / \mathrm{l})$ and Properties

$\mathrm{SiO}_{2}$
$\mathrm{Fe}$
$\mathrm{Mn}$
$\mathrm{Ca}$
$\mathrm{Mg}$
$\mathrm{Na}$
$\mathrm{K}$

$\mathrm{HCO}_{3}$

$\mathrm{CO}_{3}$

$\mathrm{SO}_{4}$

C1

$\mathrm{F}$

$\mathrm{NO}_{3}$

TDS

Hardness as $\mathrm{CaCO}_{3}$

Sp. Cond.

(micromhos $25^{\circ} \mathrm{C}$ )

pH

Temperature $\left({ }^{\circ} \mathrm{C}\right)$

Reference: Taylor 1976
Solute Concentration

\begin{tabular}{|c|c|c|c|}
\hline Maximum & Mean & Median & Minimum \\
\hline-- & -- & -- & -- \\
\hline 21.00 & 13.00 & 12.00 & 9.00 \\
\hline-- & -- & -- & -- \\
\hline-- & -- & -- & -- \\
\hline 2.00 & 1.11 & 1.00 & 0.00 \\
\hline 1.00 & 0.16 & 0.00 & 0.00 \\
\hline 289.00 & 221.77 & 223.00 & 179.00 \\
\hline-- & -- & -- & -- \\
\hline 536.00 & 383.27 & 354.00 & 278.00 \\
\hline-- & -- & -- & -- \\
\hline 126.00 & 89.00 & 95.00 & 47.00 \\
\hline 34.00 & 19.55 & 18.00 & 7.00 \\
\hline 1.50 & 0.56 & 0.50 & 0.10 \\
\hline 3.00 & 1.17 & 1.50 & 0.00 \\
\hline 697.00 & 536.22 & 520.00 & 435.00 \\
\hline 10.00 & 6.72 & 7.00 & 2.00 \\
\hline 1140.00 & 773.11 & 837.00 & 84.00 \\
\hline 8.90 & 8.52 & 8.60 & 7.90 \\
\hline-- & -- & -- & -- \\
\hline
\end{tabular}

\author{
Water Type: $\mathrm{Na}, \mathrm{HCO}_{3}$
}


TABLE 202. Water Analysis

Hydrologic Region: Texas Gulf

Aquifer Name: Antlers formation

Aquifer Age: Cretaceous

Petrology: sand, sandstone, limestone and dolomite interbeds
State: Texas

Location: Wise Co.

No. Analyses: 7

Water Type: $\mathrm{Ca}, \mathrm{Na}, \mathrm{HCO}_{3}$

Solute Concentration

\begin{tabular}{cccc}
\hline Maximum & Mean & Median & Minimum \\
\cline { 2 - 2 }-- & -- & -- & -- \\
& & & \\
25.00 & 20.00 & 19.00 & 17.00 \\
-- & -- & -- & -- \\
-- & -- & -- & -- \\
183.00 & 95.71 & 78.00 & 66.00 \\
108.00 & 41.00 & 26.00 & 13.00 \\
128.00 & 75.28 & 77.00 & 23.00 \\
-- & -- & -- & -- \\
530.00 & 391.57 & 355.00 & 178.00 \\
-- & -- & -- & -- \\
288.00 & 82.28 & 56.00 & 20.00 \\
230.00 & 110.00 & 62.00 & 38.00 \\
1.00 & 0.45 & 0.30 & 0.10 \\
33.00 & 9.62 & 2.70 & 0.40 \\
1159.80 & 626.90 & 571.26 & 310.72 \\
900.00 & 405.85 & 375.00 & 216.00 \\
1760.00 & 1010.85 & 888.00 & 514.00
\end{tabular}

Hell Depth (m)

Constituents $(\mathrm{mg} / \mathrm{l})$

and Properties

$\mathrm{SiO}_{2}$

$\mathrm{Fe}$

$\mathrm{Mn}$

$\mathrm{Ca}$

$\mathrm{Mg}$

$\mathrm{Na}$

$\mathrm{K}$

$\mathrm{HCO}_{3}$

$\mathrm{CO}_{3}$

$\mathrm{SO}_{4}$

$\mathrm{Cl}$

$\mathrm{F}$

$\mathrm{NO}_{3}$

TDS

Hardness as $\mathrm{CaCO}_{3}$

Sp. Cond.

(micromhos $25^{\circ} \mathrm{C}$ )

$\mathrm{pH}$

Temperature $\left({ }^{\circ} \mathrm{C}\right)$

Reference: Taylor 1976
7.80

7.42

7.40

7.20 


\section{TABLE 203. Water Analysis}

Hydrologic Region: Texas Gulf

Aquifer Name: Antlers formation

Aquifer Age: Cretaceous

Petrology: sand, sandstone, limestone and dolomite interbeds
State: Texas

Location: Wise Co.

No. Analyses: 10

Mater Type: $\mathrm{Ca}, \mathrm{Na}, \mathrm{HCO}_{3}$

Solute Concentration

Maximum Mean Median Minimum

Well Depth (m)

Constituents $(\mathrm{mg} / \mathrm{l})$ and Properties

$\mathrm{SiO}_{2}$

$\mathrm{Fe}$

$\mathrm{Mn}$

$\mathrm{Ca}$

$\mathrm{Mg}$

$\mathrm{Na}$

$\mathrm{K}$

$\mathrm{HCO}_{3}$

$\mathrm{CO}_{3}$

$\mathrm{SO}_{4}$

$\mathrm{Cl}$

$\mathrm{F}$

$\mathrm{NO}_{3}$

TDS

Hardness as $\mathrm{CaCO}_{3}$

Sp. Cond.

(micromhos $25^{\circ} \mathrm{C}$ )

$\mathrm{pH}$

Temperature $\left({ }^{\circ} \mathrm{C}\right)$

Reference: Taylor 1976
25.00<smiles>[3H]</smiles>

235.00

142.00

129.00

540.00

19.00

394.00

0.70

82.00

1587.61

1160.00

2300.00

8.00

7.26

114.00

128.70

0.27

17.51

697.79

454.70

1292.57

7.20

26.00

48.00

0.20

1.50

432.29

317.00

783.00

55.00

555.00

6.80

21.00

6.00

0.10

0.00

282.30

56.00

-- 
TABLE 204. Water Analysis

Hydrologic Region: Texas Gulf

Aquifer Name: Nacatoch sand

Aquifer Age: Cretaceous

Petrology: sand, sandstone, limestone interbeds
State: Texas

Location: Navarro Co.

No. Analyses: 12

Nater Type: $\mathrm{Na}, \mathrm{HCO}_{3}$

Solute Concentration

Maximum Mean Median Minimum

We11 Depth (m)

Constituents $(\mathrm{mg} / \mathrm{l})$

and Properties

$\mathrm{SiO}_{2}$

$\mathrm{Fe}$

$\mathrm{Mn}$

$\mathrm{Ca}$

$\mathrm{Mg}$

Na

K

$\mathrm{HCO}_{3}$

$\mathrm{CO}_{3}$

$\mathrm{SO}_{4}$

Cl

$\mathrm{F}$

$\mathrm{NO}_{3}$

TDS

Hardness as $\mathrm{CaCO}_{3}$

Sp. Cond.

(micromhos $25^{\circ} \mathrm{C}$ )

pH

Temperature $\left({ }^{\circ} \mathrm{C}\right)$

Reference: Taylor 1976
36.00

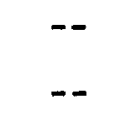

216.00

20.00

611.00

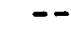

620.00

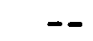

320.00

462.00

1.80

24.00

1588.00

622.00

2680.00

8.50

$-$
19.75

$--$

--

33.91

3.50

388.75

495.75

142.75

272.91

0.89

4.09

1113.29

98.41

1857.00

7.81
15.00

11.00

--

--

7.00

2.00

317.00

510.00

129.00

248.00

0.80

1.00

932.00

24.00

1620.00

7.70
7.10

12.00

19.00

0.40

0.10

454.00

12.00

734.00

$-$ 
TABLE 205. Water Analys is

Hydrologic Region: Texas Gulf

Aquifer Name: Paluxy formation

Aquifer Age: Cretaceous

Petrology: sand, sandstone, limestone interbeds
State: Texas

Location: Dallas Co.

No. Analyses: 13

Water Type: $\mathrm{Na}, \mathrm{HCO}_{3}$

Solute Concentration

Maximum Mean $\quad$ Median Minimum

Well Depth (m)

Constituents $(\mathrm{mg} / \mathrm{l})$ and Properties

$\mathrm{SiO}_{2}$

$\mathrm{Fe}$

$\mathrm{Mn}$

$\mathrm{Ca}$

$\mathrm{Mg}$

$\mathrm{Na}$

$\mathrm{K}$

$\mathrm{HCO}_{3}$

$\mathrm{CO}_{3}$

$\mathrm{SO}_{4}$

$\mathrm{Cl}$

$\mathrm{F}$

$\mathrm{NO}_{3}$

TDS

Hardness as $\mathrm{CaCO}_{3}$

Sp. Cond. (micromhos $025^{\circ} \mathrm{C}$ )

$\mathrm{pH}$

Temperature $\left({ }^{\circ} \mathrm{C}\right)$

Reference: Taylor 1976
19.00

$-$

47.00

55.00

546.00

558.00

700.00

330.00

16.00

0.50

1757.00

230.00

1904.00

9.20

8.35

215.92

104.46

3.07

0.38

860.18

49.16

1384.42

8.30

163.00

12.00

86.00

22.00

0.10

0.20

0.40

257.00

8.00

451.00

1594.00

7.20 
TABLE 206. Water Analysis

Hydrologic Region: Texas Gulf

Aquifer Name: Paluxy formation

Aquifer Age: Cretaceous

Petrology: sand, sandstone, limestone interbeds
State: Texas

Location: Denton Co.

No. Analyses: 7

Water Type: $\mathrm{Na}, \mathrm{HCO}_{3}$

Solute Concentration

Maximum

We11 Depth (m)

Constituents (mg/l)

and Properties

$\mathrm{SiO}_{2}$

$\mathrm{Fe}$

$\mathrm{Mn}$

$\mathrm{Ca}$

$\mathrm{Mg}$

$\mathrm{Na}$

K

$\mathrm{HCO}_{3}$

$\mathrm{CO}_{3}$

$\mathrm{SO}_{4}$

C1

$\mathrm{F}$

$\mathrm{NO}_{3}$

TDS

Hardness as $\mathrm{CaCO}_{3}$

Sp. Cond.

(micromhos $25^{\circ} \mathrm{C}$ )

$\mathrm{pH}$

Temperature $\left({ }^{\circ} \mathrm{C}\right)$

Reference: Taylor 1976

560.00

--

110.00

31.00

1.40

3.50

636.00

94.00

994.00

9.00

--
Mean Median

Minimum

$\begin{array}{cccc}14.00 & 11.00 & 13.00 & 3.00 \\ -- & -- & -- & -- \\ -- & -- & -- & -- \\ 32.00 & 6.00 & 2.00 & 1.00 \\ 4.00 & 1.28 & 1.00 & 0.00 \\ 253.00 & 191.28 & 207.00 & 8.00 \\ -- & -- & -- & --\end{array}$

391.42

420.00

105.00

$-$

60.14

--

12.00

13.71

12.00

7.00

0.65

0.60

0.20

1.21

0.80

0.40

477.71

470.00

122.00

21.00

9.00

2.00

685.00

785.00

84.00

8.44

8.60

7.20

-. 
TABLE 207. Water Analysis

Hydrologic Region: Texas Gulf

Aquifer Name: Paluxy formation

Aquifer Age: Cretaceous

Petrology: sand, sandstone, limestone interbeds
State: Texas

Location: Hood Co.

No. Analyses: 6

Water Type: $\mathrm{Ca}, \mathrm{HCO}_{3}$

Solute Concentration

\begin{tabular}{|c|c|c|c|}
\hline Maximum & Mean & Median & Minimum \\
\hline-- & -- & -- & -- \\
\hline 21.00 & 15.83 & 16.00 & 10.00 \\
\hline-- & -- & -- & -- \\
\hline-- & -- & -- & -- \\
\hline 157.00 & 116.83 & 97.00 & 89.00 \\
\hline 23.00 & 11.33 & 7.00 & 4.00 \\
\hline 35.00 & 16.00 & 8.00 & 7.00 \\
\hline-- & -- & - & $=$ \\
\hline 447.00 & 343.00 & 298.00 & 278.00 \\
\hline-- & -- & -- & -- \\
\hline 74.00 & 33.00 & 18.00 & 13.00 \\
\hline 64.00 & 31.00 & 10.00 & 5.00 \\
\hline 0.50 & 0.28 & 0.20 & 0.20 \\
\hline 32.00 & 11.74 & 5.90 & 0.40 \\
\hline 572.00 & 402.33 & 288.00 & 282.00 \\
\hline 487.00 & 338.50 & 257.00 & 245.00 \\
\hline 894.00 & 655.50 & 493.00 & 470.00 \\
\hline 7.70 & 7.31 & 7.30 & 6.60 \\
\hline-- & -- & -- & -- \\
\hline
\end{tabular}

Well Depth (m)

Constituents $(\mathrm{mg} / \mathrm{l})$ and Properties

$\mathrm{SiO}_{2}$

$\mathrm{Fe}$

Mn

$\mathrm{Ca}$

$\mathrm{Mg}$

$\mathrm{Na}$

K

$\mathrm{HCO}_{3}$

$\mathrm{CO}_{3}$

$\mathrm{SO}_{4}$

C1

F

$\mathrm{NO}_{3}$

TDS

Hardness as $\mathrm{CaCO}_{3}$

Sp. Cond.

(micromhos a $25^{\circ} \mathrm{C}$ )

pH

Temperature $\left({ }^{\circ} \mathrm{C}\right)$

Reference: Taylor 1976 
TABLE 208. Water Analysis

Hydrologic Region: Texas Gulf

Aquifer Name: Paluxy formation

Aquifer Age: Cretaceous

Petrology: sand, sandstone, limestone interbeds
State: Texas

Location: Johnson Co.

No. Analyses: 32

Nater Type: $\mathrm{Na}, \mathrm{HCO}_{3}$

Solute Concentration

Maximum Mean Median Minimum

We11 Depth (m)

Constituents $(\mathrm{mg} / \ell)$ and Properties

\begin{tabular}{|c|c|c|c|c|}
\hline $\mathrm{SiO}_{2}$ & 41.00 & 15.80 & 12.00 & 9.00 \\
\hline $\mathrm{Fe}$ & -- & -- & -- & -- \\
\hline Mn & -- & -- & -- & -- \\
\hline $\mathrm{Ca}$ & 242.00 & 18.56 & 2.00 & 1.00 \\
\hline $\mathrm{Mg}$ & 33.00 & 4.75 & 1.00 & 0.00 \\
\hline $\mathrm{Na}$ & 408.00 & 187.59 & 184.00 & 18.00 \\
\hline K & -- & -- & -- & -- \\
\hline $\mathrm{HCO}_{3}$ & 684.00 & 432.03 & 411.00 & 296.00 \\
\hline $\mathrm{CO}_{3}$ & -- & -- & -- & -- \\
\hline $\mathrm{SO}_{4}$ & 308.00 & 68.18 & 41.00 & 0.00 \\
\hline $\mathrm{Cl}$ & 251.00 & 24.31 & 13.00 & 7.00 \\
\hline$F$ & 7.50 & 1.44 & 0.50 & 0.10 \\
\hline $\mathrm{NO}_{3}$ & 3.20 & 0.81 & 0.40 & 0.00 \\
\hline TDS & 1157.99 & 534.08 & 458.00 & 317.00 \\
\hline Hardness as $\mathrm{CaCO}_{3}$ & 740.00 & 62.90 & 9.00 & 2.00 \\
\hline $\begin{array}{l}\text { Sp. Cond. } \\
\text { (micromhos } 25^{\circ} \mathrm{C} \text { ) }\end{array}$ & 1820.00 & 914.03 & 803.00 & 501.00 \\
\hline pH & 9.00 & 8.26 & 8.30 & 6.90 \\
\hline Temperature $\left({ }^{\circ} \mathrm{C}\right)$ & -- & -- & -- & -- \\
\hline
\end{tabular}


Hydrologic Region: Texas Gulf

Aquifer Name: Paluxy formation

Aquifer Age: Cretaceous

Petrology: sand, sandstone, limestone interbeds
State: Texas

Location: Parker Co.

No. Analyses: 10

Hater Type: $\mathrm{Ca}, \mathrm{HCO}_{3}$

Solute Concentration

Maximum Mean Median Minimum

Well Depth (m)

Constituents $(\mathrm{mg} / \mathrm{l})$

and Properties

$\mathrm{SiO}_{2}$

$\mathrm{Fe}$

$\mathrm{Mn}$

$\mathrm{Ca}$

$\mathrm{Mg}$

$\mathrm{Na}$

K

$\mathrm{HCO}_{3}$

$\mathrm{CO}_{3}$

$\mathrm{SO}_{4}$

Cl

$\mathrm{F}$

$\mathrm{NO}_{3}$

TDS

Hardness as $\mathrm{CaCO}_{3}$

Sp. Cond. (micromos $25^{\circ} \mathrm{C}$ )

pH

Temperature $\left({ }^{\circ} \mathrm{C}\right)$

Reference: Taylor 1976
28.00

--

$-$

127.00

54.00

126.00

620.00

77.00

121.00

0.80

4.20

723.00

540.00

1200.00

7.80

7.44

40.10

26.70

0.28

1.31

436.80

312.00

693.80
606.00

7.40

7.20

13.00

--

10.00

7.00

12.00

312.00

13.00

5.00

0.00

0.40

327.00

55.00

510.00

393.00

306.00

510.00 
Hydrologic Region: Texas Gulf

Aquifer Name: Paluxy formation

Aquifer Age: Cretaceous

Petrology: sand, sandstone, limestone
State: Texas

Location: Tarrant Co.

No. Analyses: 22

Water Type: $\mathrm{Na}, \mathrm{HCO}_{3}$

Solute Concentration

Maximum

We11 Depth (m)

Constituents (mg/l)

and Properties

$\mathrm{SiO}_{2}$
$\mathrm{Fe}$
$\mathrm{Mn}$
$\mathrm{Mg}$
$\mathrm{Na}$
$\mathrm{K}$
$\mathrm{HCO}_{3}$
$\mathrm{CO}_{3}$
$\mathrm{SO}_{4}$
$\mathrm{Cl}$
$\mathrm{F}$
$\mathrm{NO}_{3}$
$\mathrm{TDS}$

Hardness as $\mathrm{CaCO}_{3}$

Sp. Cond.

(micromhos $25^{\circ} \mathrm{C}$ )

20.00

11.80

12.00

0.00

Mean

Median

Minimum

$\mathrm{pH}$

Temperature $\left({ }^{\circ} \mathrm{C}\right)$

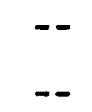

82.00

11.00

335.00

$--$

6.47

2.00

$--$

2.00

1.00

1.00

209.09

207.00

0.00

20.00

498.00

438.81

452.00

321.00

158.00

69.95

58.00

19.00

125.00

18.72

13.00

5.00

2.00

0.74

0.70

0.00

3.50

1.04

0.40

0.00

847.41

534.47

512.44

315.00

249.00

23.22

8.00

2.00

1160.00

836.76

806.00

500.00

9.10

8.60

8.70

7.70

Reference: Taylor 1976 
TABLE 211. Water Analysis

Hydrologic Region: Texas Gulf

Aquifer Name: Twin Mountains formation

Aquifer Age: Cretaceous

Petrology: interbedded sand, shale, and limestone
State: Texas

Location: Dallas Co.

No. Analyses: 25

Water Type: $\mathrm{Na}, \mathrm{HCO}_{3}$

Solute Concentration

Maximum Mean Median Minimum

He11 Depth (m)

Constituents $(\mathrm{mg} / \mathrm{l})$

and Properties

$\mathrm{SiO}_{2}$

$\mathrm{Fe}$

$\mathrm{Mn}$

$\mathrm{Ca}$

$\mathrm{Mg}$

$\mathrm{Na}$

$\mathrm{K}$

$\mathrm{HCO}_{3}$

$\mathrm{CO}_{3}$

$\mathrm{SO}_{4}$

$\mathrm{Cl}$

$\mathrm{F}$

$\mathrm{NO}_{3}$

TDS

Hardness as $\mathrm{CaCO}_{3}$

Sp. Cond. (micromhos a $25^{\circ} \mathrm{C}$ )

$\mathrm{pH}$

Temperature $\left({ }^{\circ} \mathrm{C}\right)$

Reference: Taylor 1976

$$
43.00
$$

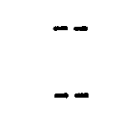

233.00

58.00

1137.00

628.00

2832.00

355.00

10.80

2.00

4497.00

824.00

2385.00

8.70

8.30

326.64

148.16

2.56

0.62

1177.29

53.83

1607.20

8.30

181.00

124.00

2.00

0.40

938.00

18.00

1470.00
8.00

4.00

$--$

--

2.00

0.00

182.00

222.00

19.00

64.00

1.20

0.20

527.00

8.00

880.00 
TABLE 212. Water Analys is

Hydrologic Region: Texas Gulf

Aquifer Name: Twin Mountains formation

Aquifer Age: Cretaceous

Petrology: interbedded sand, shale and limestone
State: Texas

Location: Ellis Co.

No. Analyses: 10

Mater Type: $\mathrm{Na}, \mathrm{HCO}_{3}$

Solute Concentration

Maximum

We11 Depth (m)

Constituents $(\mathrm{mg} / \mathrm{l})$

and Properties

$\mathrm{SiO}_{2}$

$\mathrm{Fe}$

$\mathrm{Mn}$

$\mathrm{Ca}$

$\mathrm{Mg}$

$\mathrm{Na}$

$\mathrm{K}$

$\mathrm{HCO}_{3}$

$\mathrm{CO}_{3}$

$\mathrm{SO}_{4}$

$\mathrm{Cl}$

$\mathrm{F}$

$\mathrm{NO}_{3}$

TDS

Hardness as $\mathrm{CaCO}_{3}$

Sp. Cond.

(micromhos $25^{\circ} \mathrm{C}$ )

$\mathrm{pH}$

Temperature $\left({ }^{\circ} \mathrm{C}\right)$

Reference: Taylor 1976

20.00

--

26.00

11.00

461.00

556.00

$--$

440.00

315.00

2.00

1.60

1225.27

110.00

2100.00

8.40

Mean

Median

18.62

20.00

15.00

8.12

8.10

7.90
Minimum
$-$

2.00

0.00

241.00

467.00

75.00

69.00

1.10

0.20

630.00

10.00

1069.00

1494.87

14.00

-- 
TABLE 213. Water Analysis

Hydrologic Region: Texas Gulf

Aquifer Name: Twin Mountains formation

Aquifer Age: Cretaceous

Petrology: interbedded sand, shale and 7 imestone
State: Texas

Location: Hood Co.

No. Analyses: 19

Water Type: $\mathrm{Ca}, \mathrm{Na}, \mathrm{HCO}_{3}$

Solute Concentration

Maximum Mean Median

Well Depth (m)

Constituents (mg/l)

and Properties

$\mathrm{SiO}_{2}$

$\mathrm{Fe}$

$\mathrm{Mn}$

$\mathrm{Ca}$

$\mathrm{Mg}$

$\mathrm{Na}$

$k$

$\mathrm{HCO}_{3}$

$\mathrm{CO}_{3}$

$\mathrm{SO}_{4}$

C1

F

$\mathrm{NO}_{3}$

TDS

Hardness as $\mathrm{CaCO}_{3}$

Sp. Cond.

(micromhos $25^{\circ} \mathrm{C}$ )

pH

Temperature $\left({ }^{\circ} \mathrm{C}\right)$

Reference: Taylor 1976
21.00

12.61

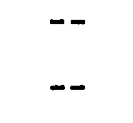

146.00

35.00

276.00

550.00

--

165.00

55.00

3.10

162.00

752.00

460.00

1123.00

8.80

7.75

51.36

23.31

0.60

10.54

447.76

168.00

719.94

13.00

0.00

$-$

55.00

12.00

63.00

350.00

$-$

39.00

20.00

0.40

0.40

403.00

206.00

624.00

7.70

6.90 
TABLE 214. Water Analysis

Hydrologic Region: Texas Gulf

Aquifer Name: Twin Mountains formation

Aquifer Age: Cretaceous

Petrology: interbedded sand and shale
State: Texas

Location: Johnson Co.

No. Analyses: 7

Water Type: $\mathrm{Na}, \mathrm{HCO}_{3}$

Solute Concentration

$\underline{\text { Maximum }}$ Mean $\quad$ Median

Well Depth (m)

Constituents $(\mathrm{mg} / \mathrm{l})$ and Properties

$\mathrm{SiO}_{2}$

$\mathrm{Fe}$

$\mathrm{Mn}$

$\mathrm{Ca}$

$\mathrm{Mg}$

$\mathrm{Na}$

K

$\mathrm{HCO}_{3}$

$\mathrm{CO}_{3}$

$\mathrm{SO}_{4}$

$\mathrm{Cl}$

$\mathrm{F}$

$\mathrm{NO}_{3}$

TDS

Hardness as $\mathrm{CaCO}_{3}$

Sp. Cond. (micromhos $25^{\circ} \mathrm{C}$ )

$\mathrm{pH}$

Temperature $\left({ }^{\circ} \mathrm{C}\right)$

Reference: Taylor 1976
15.00

$--$

$--$

4.00

3.00

259.00

452.00

160.00

42.00

1.60

1.50

688.24

54.00

1120.00

8.70

8.45

107.42

32.85

1.22

0.88

552.20

15.42

987.75

--
Median

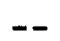

11.00

13.00

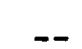

--

2.00

1.00

1.00

167.00

232.00

356.00

378.00

77.00

16.00

0.70

0.20

382.60

7.00

797.00

972.00

7.90 
TABLE 215. Water Analysis

Hydrologic Region: Texas Gulf

Aquifer Name: Twin Mountains formation

Aquifer Age: Cretaceous

Petrology: interbedded sand, shale and limestone
State: Texas

Location: Parker Co.

No. Analyses: 15

Hater Type: $\mathrm{Ca}, \mathrm{Na}, \mathrm{HCO}_{3}$

Well Depth (m)

Constituents $(\mathrm{mg} / \mathrm{l})$

and Properties

$\mathrm{SiO}_{2}$

$\mathrm{Fe}$

$\mathrm{Mn}$

$\mathrm{Ca}$

$\mathrm{Mg}$

$\mathrm{Na}$

$\mathrm{K}$

$\mathrm{HCO}_{3}$

$\mathrm{CO}_{3}$

$\mathrm{SO}_{4}$

C1

$\mathrm{F}$

$\mathrm{NO}_{3}$

TDS

Hardness as $\mathrm{CaCO}_{3}$

Sp. Cond.

(micromhos $25^{\circ} \mathrm{C}$ )

$\mathrm{pH}$

Temperature $\left({ }^{\circ} \mathrm{C}\right)$

Reference: Taylor 1976
Solute Concentration

\begin{tabular}{|c|c|c|c|}
\hline Maximum & Mean & Median & Minimum \\
\hline-- & -- & -- & -- \\
\hline 32.00 & 17.23 & 16.00 & 10.00 \\
\hline-- & -- & -- & -- \\
\hline-- & -- & -- & -- \\
\hline 178.00 & 70.13 & 67.00 & 1.00 \\
\hline 79.00 & 29.93 & 20.00 & 1.00 \\
\hline 317.00 & 111.33 & 95.00 & 16.00 \\
\hline-- & -- & -- & -- \\
\hline 590.00 & 429.38 & 411.00 & 328.00 \\
\hline-- & -- & -- & -- \\
\hline 234.00 & 86.26 & 83.00 & 16.00 \\
\hline 229.00 & 65.26 & 42.00 & 0.00 \\
\hline 0.90 & 0.30 & 0.20 & 0.00 \\
\hline 170.00 & 22.93 & 0.40 & 0.00 \\
\hline 1085.48 & 584.24 & 515.95 & 125.60 \\
\hline 710.00 & 273.86 & 291.00 & 4.00 \\
\hline 1610.00 & 1006.58 & 819.00 & 673.00 \\
\hline 8.70 & 7.58 & 7.40 & 7.10 \\
\hline-- & -- & -- & -- \\
\hline
\end{tabular}

\begin{tabular}{ll} 
& Solute Concentration \\
\hline Maximum & Mean
\end{tabular}

0.00

.00

6.00

$-$

6.00

0.00

0.00

.00

673.00

.10

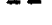


TABLE 216. Water Analysis

Hydrologic Region: Texas Gulf

Aquifer Name: Twin Mountains formation

Aquifer Age: Cretaceous

Petrology: interbedded sand and shale
State: Texas

Location: Tarrant Co.

No. Analyses: 16

Nater Type: $\mathrm{Na}, \mathrm{HCO}_{3}$

Solute Concentration

Maximum Mean Median Minimum

We11 Depth (m)

Constituents $(\mathrm{mg} / \boldsymbol{l})$ and Properties

$\mathrm{SiO}_{2}$

20.00

13.50

13.00

10.00

$\mathrm{Fe}$

$\mathrm{Mn}$

$\mathrm{Ca}$

$\mathrm{Mg}$

$\mathrm{Na}$

$\mathrm{K}$

$\mathrm{HCO}_{3}$

$\mathrm{CO}_{3}$

$\mathrm{SO}_{4}$

$\mathrm{Cl}$

$\mathrm{F}$

$\mathrm{NO}_{3}$

TDS

Hardness as $\mathrm{CaCO}_{3}$

Sp. Cond.

(micromhos $25^{\circ} \mathrm{C}$ )

$\mathrm{pH}$

Temperature $\left({ }^{\circ} \mathrm{C}\right)$

Reference: Taylor 1976
8.80

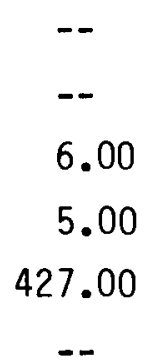

617.00

256.00

227.00

7.00

2.50

1133.48

30.00

1950.00

8.29

156.56

94.37

1.70

0.68

883.69

14.18

1437.76

$--$

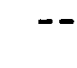

2.00

2.00

323.00

540.00

138.00

85.00

1.80

0.20

830.20

11.00

1380.00

8.30
7.80

2.00

1.00

284.00

510.00

73.00

44.00

0.00

0.00

716.71

7.00

1137.00 
TABLE 217. Water Analysis

Hydrologic Region: Texas Gulf

Aquifer Name: Woodbine group

Aquifer Age: Cretaceous

Petrology: sand, sandstone, shale
State: Texas

Location: Collin Co.

No. Analyses: 11

Water Type: $\mathrm{Na}, \mathrm{HCO}_{3}$

Solute Concentration

Maximum

Mean

Median

Minimum

Well Depth (m)

Constituents $(\mathrm{mg} / \mathrm{l})$

and Properties

$\mathrm{SiO}_{2}$

14.00

12.36

12.00

10.00

$\mathrm{Fe}$

$\mathrm{Mn}$

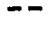

--

$-$

--

$\mathrm{Ca}$

3.00

1.36

1.00

1.00

2.00

1.18

1.00

0.00

$\mathrm{Na}$

441.00

244.27

211.00

151.00

$\mathrm{K}$

$\mathrm{HCO}_{3}$

800.00

--

425.81

376.00

306.00

$\mathrm{CO}_{3}$

$\mathrm{SO}_{4}$

253.00

--

--

$--$

$\mathrm{Cl}$

129.00

106.54

105.00

37.00

50.00

37.00

12.00

2.80

1.42

1.10

0.70

4.50

1.24

0.40

0.40

TDS

1162.00

627.75

563.00

388.66

18.00

8.90

9.00

2.00

1840.00

1020.00

890.00

615.00

(micromhos $25^{\circ} \mathrm{C}$ )

8.50

8.26

8.30

7.80

Temperature $\left({ }^{\circ} \mathrm{C}\right)$

--

Reference: Taylor 1976 
TABLE 218. Water Analys is

Hydrologic Region: Texas Gulf

Aquifer Name: Woodbine group

Aquifer Age: Cretaceous

Petrology: sand, sandstone, shale
State: Texas

Location: Dallas Co.

No. Analyses: 23

Water Type: $\mathrm{Na}, \mathrm{HCO}_{3}, \mathrm{SO}_{4}$

Solute Concentration

Maximum Mean Median Minimum

Well Depth (m)

Constituents (mg/l)

and Properties

$\mathrm{SiO}_{2}$

32.00

12.75

12.00

8.00

$\mathrm{Fe}$

$\mathrm{Mn}$

Ca

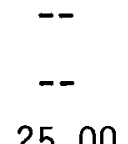

$--$

--

4.43

3.00

1.00

4.00

1.42

1.00

0.00

$\mathrm{Na}$

922.00

467.39

465.00

207.00

K

$\mathrm{HCO}_{3}$

$\mathrm{CO}_{3}$

$\mathrm{SO}_{4}$

C1

$\mathrm{F}$

1013.00

619.56

561.00

276.00

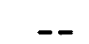

504.00

320.30

572.00

127.52

380.00

44.00

97.00

10.00

4.50

2.40

2.00

1.10

$\mathrm{NO}_{3}$

1.00

0.48

0.40

0.00

TDS

Hardness as $\mathrm{CaCO}_{3}$

Sp. Cond.

(micromhos $25^{\circ} \mathrm{C}$ )

2418.00

1236.70

1257.00

546.00

75.00

17.39

14.00

3.00

3130.00

1855.26

1900.00

880.00

8.60

8.11

8.10

7.50

Temperature $\left({ }^{\circ} \mathrm{C}\right)$

Reference: Taylor 1976 
TABLE 219. Water Analysis

Hydrologic Region: Texas Gulf

Aquifer Name: Woodbine group

Aquifer Age: Cretaceous

Petrology: sand, sandstone, shale
State: Texas

Location: Ellis Co.

No. Analyses: 64

Water Type: $\mathrm{Na}, \mathrm{HCO}_{3}, \mathrm{SO}_{4}$

Solute Concentration

Maximum Mean Median Minimum

Well Depth (m)

Constituents $(\mathrm{mg} / \ell)$

and Properties

$\mathrm{SiO}_{2}$

$\mathrm{Fe}$

$\mathrm{Mn}$

$\mathrm{Ca}$

$\mathrm{Mg}$

$\mathrm{Na}$

$\mathrm{K}$

$\mathrm{HCO}_{3}$

$\mathrm{CO}_{3}$

$\mathrm{SO}_{4}$

$\mathrm{Cl}$

$\mathrm{F}$

$\mathrm{NO}_{3}$

TDS

Hardness as $\mathrm{CaCO}_{3}$

Sp. Cond.

(micromhos $25^{\circ} \mathrm{C}$ )

$\mathrm{pH}$

Temperature $\left({ }^{\circ} \mathrm{C}\right)$

Reference: Taylor 1976
23.00

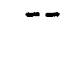

25.00

4.00

1200.00

1060.00

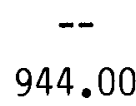

1310.00

6.40

10.00

3032.00

32.00

4990.00

8.70

8.07

366.00

189.67

2.85

1.83

1489.89

15.17

2226.34

8.00

7.30
8.00

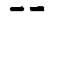

0.00

0.00

222.00

--

382.00

16.00

16.00

0.00

0.00

611.00

4.00

975.00

2190.00 
TABLE 220. Water Analysis

Hydrologic Region: Texas Gulf

Aquifer Name: Woodbine group

Aquifer Age: Cretaceous

Petrology: sand, sandstone, shale
State: Texas

Location: Johnson Co.

No. Analyses: 29

Hater Type: $\mathrm{Na}, \mathrm{HCO}_{3}, \mathrm{SO}_{4}$

Solute Concentration

Maximum Mean Median Minimum

Well Depth (m)

Constituents $(\mathrm{mg} / \mathrm{l})$

and Properties

$\mathrm{SiO}_{2}$
$\mathrm{Fe}$
$\mathrm{Ca}$
$\mathrm{Mg}$
$\mathrm{Na}$
$\mathrm{K}$
$\mathrm{HCO}_{3}$
$\mathrm{CO}_{3}$
$\mathrm{SO}_{4}$
$\mathrm{Cl}$
$\mathrm{F}$
$\mathrm{NO}_{3}$
$\mathrm{TDS}^{2}$

$$
27.00
$$

12.62

11.00

8.00

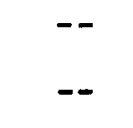

405.00

89.00

510.00

920.00

1100.00

120.00

9.80

56.00

2022.00

1380.00

2340.00

8.30

7.51

231.79

46.55

1.21

3.70

732.77

171.68

1120.93

(micromhos $25^{\circ} \mathrm{C}$ )

pH

Temperature $\left({ }^{\circ} \mathrm{C}\right)$

Reference: Taylor 1976

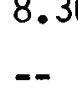

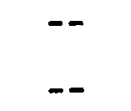

$$
24.00
$$

9.00

162.00

325.00

181.00

31.00

0.70

1.20

589.00

92.00

932.00

7.60
6.00

58.00

20.00

0.20

0.00

367.00

4.00

551.00

-- 


\section{TABLE 221. Water Analysis}

Hydrologic Region: Texas Gulf

Aquifer Name: Woodbine group

Aquifer Age: Cretaceous

Petrology: sand, sandy clay, shale
State: Texas

Location: Tarrant Co.

No. Analyses: 5

Water Type: $\mathrm{Ca}, \mathrm{Na}, \mathrm{HCO}_{3}, \mathrm{SO}_{4}$

Solute Concentration

Maximum Mean Median Minimum

We11 Depth (m)

Constituents $(\mathrm{mg} / \mathrm{l})$

and Properties

$\mathrm{SiO}_{2}$

23.00

15.40

14.00

11.00

$\mathrm{Fe}$

$\mathrm{Mn}$

$\mathrm{Ca}$

$\mathrm{Mg}$

$\mathrm{Na}$

$\mathrm{K}$

$\mathrm{HCO}_{3}$

$\mathrm{CO}_{3}$

$\mathrm{SO}_{4}$

C1

$F$

$\mathrm{NO}_{3}$

TDS

Hardness as $\mathrm{CaCO}_{3}$

Sp. Cond.

(micromhos $25^{\circ} \mathrm{C}$ )

$\mathrm{pH}$

Temperature $\left({ }^{\circ} \mathrm{C}\right)$

Reference: Taylor 1976

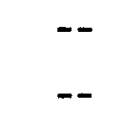

194.00

21.00

205.00

$--$

378.00

154.00

0.90

27.00

927.00

550.00

1360.00

7.70

.
256.00

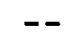

$--$

83.40

13.60

102.80

271.40

133.00

87.60

0.66

6.46

576.05

264.00

895.60

7.40

7.50

179.00

85.00

0.80

0.40

625.00

202.00

937.00
73.00

289.00

16.00

5.00

32.00

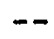

124.00

9.00

13.00

0.30

0.00

173.00

6.70

\section{m}


Hydrologic Region: Texas Gulf

Aquifer Name: Antlers formation

Aquifer Age: Early Cretaceous

Petrology: sand, clay, siltstone, chert
State: Texas

Location: Taylor Co.

No. Analyses: 3

Water Type: $\mathrm{Ca}, \mathrm{HCO}_{3}$

Solute Concentration

Maximum Intermediate

31

Constituents $(\mathrm{mg} / \mathrm{l})$

and Properties

$\mathrm{SiO}_{2}$

14

$\mathrm{Fe}$

$\mathrm{Mn}$

$\mathrm{Ca}$

$\mathrm{Mg}$

$\mathrm{Na}$

$\mathrm{K}$

$\mathrm{HCO}_{3}$

$\mathrm{CO}_{3}$

$\mathrm{SO}_{4}$

$\mathrm{Cl}$

$\mathrm{F}$

$\mathrm{NO}_{3}$

TDS

Hardness as $\mathrm{CaCO}_{3}$

$\mathrm{Ca}, \mathrm{Mg}$

Noncarbonate

Sp. Cond.

(micromhos $25^{\circ} \mathrm{C}$ )

$\mathrm{pH}$

Temperature $\left({ }^{\circ} \mathrm{C}\right)$

Reference: Taylor 1978
430
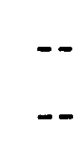

151

13

19

$<1$

327

--

15

61

0.2

112

550

868

7.4

7.4

7.5

24
15

22

12

14

Minimum

119

18

22

10

344

325

40

12

54

0.3

12

446

370

282

734

524

$$
0.2
$$

$<0.4$

320

$--$
$--$ 
TABLE 223. Water Analysis

Hydrologic Region: Texas Gulf

Aquifer Name: Choza formation

Aquifer Age: Late Permian

Petrology: dolomite, limestone, gypsum, shale
State: Texas

Location: Jones Co.

No. Analyses: 3

Water Type: $\mathrm{Na}, \mathrm{SO}_{4}, \mathrm{Cl}$

Solute Concentration

Maximum $\quad$ Intermediate $\quad$ Minimum

We11 Depth (m) seep

12

10

Constituents $(\mathrm{mg} / \mathrm{l})$ and Properties

$\mathrm{SiO}_{2}$

$\mathrm{Fe}$

$\mathrm{Mn}$

$\mathrm{Ca}$

$\mathrm{Mg}$

$\mathrm{Na}$

$\mathrm{K}$

$\mathrm{HCO}_{3}$

$\mathrm{CO}_{3}$

$\mathrm{SO}_{4}$

$\mathrm{Cl}$

$F$

$\mathrm{NO}_{3}$

TDS

Hardness as $\mathrm{CaCO}_{3}$

$\mathrm{Ca}, \mathrm{Mg}$

Noncarbonate

Sp. Cond.

(micromhos $25^{\circ} \mathrm{C}$ )

$\mathrm{pH}$

Temperature $\left({ }^{\circ} \mathrm{C}\right)$

Reference: Price 1978

$>12000$
9600

$\quad 8$
--
--
540
2010
4230
--
920
--
12000
3480
5.9
357
23100

12 22

$-$

$-$

1250

422

690

364

1820

920

326

367

2120

3170

5000

740

2.2

3.8

168

0.4

11200

5800

2550

6000

-.

$>12000$

6640

7.9

7.6 
TABLE 224. Water Analysis

Hydrologic Region: Texas Gulf

Aquifer Name: Choza formation

Aquifer Age: Late Permian

Petrology: dolomite, anhydrite, shale, sandstone
State: Texas

Location: Taylor Co.

No. Analyses: 3

Water Type: $\mathrm{Ca}, \mathrm{SO}_{4}$

Solute Concentration

\begin{tabular}{lll}
\hline Maximum & Intermediate & Minin \\
12 & 34 & 21
\end{tabular}

We11 Depth (m)

21

Constituents $(\mathrm{mg} / \mathrm{l})$ and Properties

$\mathrm{SiO}_{2}$

$\mathrm{Fe}$

$\mathrm{Mn}$

$\mathrm{Ca}$

$\mathrm{Mg}$

$\mathrm{Na}$

$\mathrm{K}$

$\mathrm{HCO}_{3}$

$\mathrm{CO}_{3}$

$\mathrm{SO}_{4}$

$\mathrm{Cl}$

$\mathrm{F}$

$\mathrm{NO}_{3}$

TDS

Hardness as $\mathrm{CaCO}_{3}$

$\mathrm{Ca}, \mathrm{Mg}$

2720

Noncarbonate

Sp. Cond.

(micromhos $25^{\circ} \mathrm{C}$ )

$\mathrm{pH}$

Temperature $\left({ }^{\circ} \mathrm{C}\right)$

Reference: Taylor 1978

17

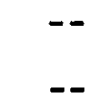

610

290

387

8

265

2600

437

4490

4570
15

21
1.1

14

1790

367

2950

7.5

7.3

7.5

310

36

164

1.0

31

610

2840

1030

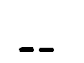




\section{TABLE 225. Water Analysis}

Hydrologic Region: Texas Gulf

Aquifer Name: San Angelo formation

Aquifer Age: Late Permian

Petrology: sandstone, chert, clay, gypsum, shale
State: Texas

Location: Taylor Co.

No. Analyses: 3

Water Type: $\mathrm{Ca}, \mathrm{Mg}, \mathrm{Na}, \mathrm{HCO}_{3}$, $\mathrm{SO}_{4}, \mathrm{Cl}$

Solute Concentration

Maximum

12

7

Constituents $(\mathrm{mg} / \ell)$

and Properties

$\mathrm{SiO}_{2}$

20

31

37

$\mathrm{Fe}$

$\mathrm{Mn}$

$\mathrm{Ca}$

$\mathrm{Mg}$

$\mathrm{Na}$

K

$\mathrm{HCO}_{3}$

$\mathrm{CO}_{3}$

$\mathrm{SO}_{4}$

$\mathrm{Cl}$

$\mathrm{F}$

$\mathrm{NO}_{3}$

TDS

Intermediate

18

Minimum 
Hydrologic Region: Texas Gulf

Aquifer Name: Vale formation

Aquifer Age: Late Permian

Petrology: dolomite, gypsum, clay, shale
State: Texas

Location: Jones Co.

No. Analyses: 3

Hater Type: $\mathrm{Na}, \mathrm{SO}_{4}, \mathrm{Cl}$

Solute Concentration

Maximum Intermediate

8

26

Well Depth (m)

6

Minimum

Constituents $(\mathrm{mg} / \mathrm{l})$

and Properties

$\mathrm{SiO}_{2}$

12

9

13

$\mathrm{Fe}$

$\mathrm{Mn}$

Ca

$\mathrm{Mg}$

$\mathrm{Na}$

K

$\mathrm{HCO}_{3}$

$\mathrm{CO}_{3}$

$\mathrm{SO}_{4}$

C1

$\mathrm{F}$

$\mathrm{NO}_{3}$

TDS

Hardness as $\mathrm{CaCO}_{3}$

$\mathrm{Ca}, \mathrm{Mg}$

Noncarbonate

Sp. Cond.

(micromhos $25^{\circ} \mathrm{C}$ )

pH

Temperature $\left({ }^{\circ} \mathrm{C}\right)$

Reference: Price 1978
4600

7.3

$--$

-

580

770

3470

407

--

4700

5000

2.3

320

15000

$>12000$

7.5

7.7

1060

6900

11760

5.2

1.5

8

5500

10400

2500

160

1540

317

2290

1200 


\section{TABLE 227. Water Analysis}

Hydrologic Region: Texas Gulf

Aquifer Name: Vale formation

Aquifer Age: Middle Permian

Petrology: dolomite, anhydrite, clay, shale, sandstone
State: Texas

Location: Taylor Co.

No. Analyses: 3

Water Type: $\mathrm{Na}, \mathrm{HCO}_{3}, \mathrm{SO}_{4}, \mathrm{Cl}$

Solute Concentration

Maximum $\quad$ Intermediate

Well Depth (m)

Constituents $(\mathrm{mg} / \mathrm{l})$ and Properties

$\mathrm{SiO}_{2}$
$\mathrm{Fe}$
$\mathrm{Mn}$
$\mathrm{Ca}$
$\mathrm{Mg}$
$\mathrm{Na}$
$\mathrm{K}$
$\mathrm{HCO}_{3}$
$\mathrm{CO}_{3}$
$\mathrm{SO}_{4}$
$\mathrm{Cl}$
$\mathrm{F}$
$\mathrm{NO}_{3}$
$\mathrm{TDS}$

TDS

Hardness as $\mathrm{CaCO}_{3}$

$\mathrm{Ca}, \mathrm{Mg}$

1080

Noncarbonate

Sp. Cond.

(micromhos $25^{\circ} \mathrm{C}$ )

$\mathrm{pH}$

Temperature $\left({ }^{\circ} \mathrm{C}\right)$

Reference: Taylor 1978

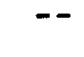

196

143

337 
TABLE 228. Water Analysis

Hydrologic Region: Texas Gulf

Aquifer Name: Arroyo formation

Aquifer Age: Early Permian

Petrology: limestone, dolomite, shale, sandstone, anhydrite
State: Texas

Location: Taylor Co.

No. Analyses: 3

Nater Type: $\mathrm{Ca}, \mathrm{Na}, \mathrm{HCO}_{3}, \mathrm{SO}_{4}$, $\mathrm{Cl}$

Solute Concentration

Well Depth (m) Intermediate Minimum

\begin{tabular}{ccc}
\hline Maximum & Intermediate & Mini \\
18 & -- & 8
\end{tabular}

Constituents $(\mathrm{mg} / \mathrm{l})$ and Properties

$\mathrm{SiO}_{2}$

16

15

12

$\mathrm{Fe}$

$\mathrm{Mn}$

$\mathrm{Ca}$

$\mathrm{Mg}$

157

$\mathrm{Na}$

570

$\mathrm{K}$

$\mathrm{HCO}_{3}$

510

$\mathrm{CO}_{3}$

$\mathrm{SO}_{4}$

720

$\mathrm{Cl}$

650

$\mathrm{F}$

1.2

$\mathrm{NO}_{3}$

3.5

TDS

2460

860

670

378

Noncarbonate

Sp. Cond.

(micromhos $25^{\circ} \mathrm{C}$ )

$\mathrm{pH}$

8.2

7.6

7.7

Temperature $\left({ }^{\circ} \mathrm{C}\right)$

Reference: Taylor 1978 


\section{TABLE 229. Water Analysis}

Hydrologic Region: Texas Gulf

Aquifer Name: Lueders formation

Aquifer Age: Early Permian

Petrology: limestone, shale, dolomite

State: Texas

Location: Taylor Co.

No. Analyses: 3

Water Type: $\mathrm{Ca}, \mathrm{Na}, \mathrm{SO}_{4}, \mathrm{Cl}$

Solute Concentration

Maximum $\quad$ Intermediate

We11 Depth (m)

Constituents $(\mathrm{mg} / \mathrm{l})$

and Properties

$\mathrm{SiO}_{2}$

$\mathrm{Fe}$

$\mathrm{Mn}$

$\mathrm{Ca}$

$\mathrm{Mg}$

$\mathrm{Na}$

$\mathrm{K}$

$\mathrm{HCO}_{3}$

$\mathrm{CO}_{3}$

$\mathrm{SO}_{4}$

$\mathrm{Cl}$

$\mathrm{F}$

$\mathrm{NO}_{3}$

TDS
9

20

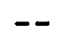

780

293

1750

242

$--$

600

4320

0.9

143

8030

3160

10500

(micromhos $25^{\circ} \mathrm{C}$ )

$\mathrm{pH}$

Temperature $\left({ }^{\circ} \mathrm{C}\right)$

Reference: Taylor 1978

$\mathrm{Ca}, \mathrm{Mg}$

Noncarbonate

7.1

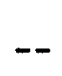

9

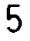

20

21

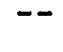

580

174

193

67

540

250

182

426

458

297

1960

415

0.9

2.1

70

29

3910

1460

2230

710

7.2

7.3

5200

2250 
TABLE 230. Water Analys is

Hydrologic Region: Upper Colorado

Aquifer Name: Alluvium

Aquifer Age: Holocene

Petrology: clay, sand, gravel, boulders
State: Colorado

Location: Routt Co.

No. Analyses: 8

Water Type: $\mathrm{Ca}, \mathrm{HCO}_{3}$

Solute Concentration

$\frac{\text { Maximum }}{15} \frac{\text { Mean }}{7} \quad \frac{\text { Mini }}{3}$

We11 Depth (m)

Constituents $(\mathrm{mg} / \mathrm{l})$ and Properties

$\mathrm{SiO}_{2}$

41

$\mathrm{Fe}$

0.35

0.45

$\mathrm{Ca}$

87

27

29

5.1

$\mathrm{HCO}_{3}$

$\mathrm{CO}_{3}$

$\mathrm{SO}_{4}$

$\mathrm{Cl}$

$\mathrm{F}$

$\mathrm{NO}_{3}$

TDS

370

0

97

13

0.2

2.2

386

290

58

Noncarbonate

550

(micromhos $25^{\circ} \mathrm{C}$ )

pH

Temperature $\left({ }^{\circ} \mathrm{C}\right)$
15.6

0.10

0.074

47.2

13.4

11.1

2.21

188

0

29.8

4.31

0.163

1.04

222

173

21

340

7

8.57
7

0.02

0

7.5

1.7

2.2

0.6

23

0

3.8

0.5

0.1

0.01

46

26

0

75

5.9

5

Reference: Covay and Tobin 1981 
TABLE 231. Water Analysis

Hydrologic Region: Upper Colorado

Aquifer Name: Browns Park formation

Aquifer Age: Miocene

Petrology: siltstone, sandstone, conglomerate, some volcanic ash
State: Colorado

Location: Routt Co.

No. Analyses: 11

Water Type: $\mathrm{Ca}, \mathrm{Na}, \mathrm{HCO}_{3}$

Solute Concentration

\begin{tabular}{ccc}
\hline Maximum & Minimum \\
\cline { 2 - 3 } 98 & 37 & 13 \\
& & \\
60 & 25.5 & 10 \\
0.09 & 0.022 & 0 \\
0.11 & 0.011 & 0 \\
250 & 74.3 & 3.7 \\
160 & 22.0 & 0.2 \\
340 & 77.4 & 6.1 \\
9.3 & 3.48 & 0.5 \\
720 & 278 & 56 \\
67 & 6.1 & 0 \\
1100 & 123 & 4.9 \\
91 & 24.4 & 1.9 \\
15 & 1.83 & 0.1 \\
32 & 6.61 & 0.04 \\
2140 & 525 & 89
\end{tabular}

We11 Depth (m)

Constituents $(\mathrm{mg} / \mathrm{l})$

and Properties

$\mathrm{SiO}_{2}$

60

$\mathrm{Fe}$

$\mathrm{Mn}$

$\mathrm{Ca}$

$\mathrm{Mg}$

$\mathrm{Na}$

$k$

$\mathrm{HCO}_{3}$

$\mathrm{CO}_{3}$

$\mathrm{SO}_{4}$

$\mathrm{C} 1$

F

$\mathrm{NO}_{3}$

TDS

2140

1300

279

10

$\mathrm{Ca}, \mathrm{Mg}$

930

118

0

Sp. Cond.

1400

580

135

(micromhos a $25^{\circ} \mathrm{C}$ )

$\mathrm{pH}$

9.2

7.45

6.3

Temperature $\left({ }^{\circ} \mathrm{C}\right)$

15.0

8.23

4.0 


\section{TABLE 232. Water Analysis}

Hydrologic Region: Upper Colorado

Aquifer Name: Mesaverde group

Aquifer Age: Late Cretaceous

Petrology: sandstone, carbonaceous shale, coal

Well Depth (m)

Constituents $(\mathrm{mg} / \mathrm{l})$ and Properties
$\mathrm{SiO}_{2}$

$\mathrm{Fe}$

$\mathrm{Mn}$

$\mathrm{Ca}$

$\mathrm{Mg}$

$\mathrm{Na}$

$\mathrm{K}$

$\mathrm{HCO}_{3}$

$\mathrm{CO}_{3}$

$\mathrm{SO}_{4}$

$\mathrm{Cl}$

$\mathrm{F}$

$\mathrm{NO}_{3}$

TDS

35

0.05

0.03

120

45

56

7.9

390

$--$

140

44

0.2

14

700

Hardness as $\mathrm{CaCO}_{3}$

$\mathrm{Ca}, \mathrm{Mg}$

470

Noncarbonate

Sp. Cond.

(micromhos $25^{\circ} \mathrm{C}$ )

$\mathrm{pH}$

Temperature $\left({ }^{\circ} \mathrm{C}\right)$

150

1030

\section{8}

15
State: Colorado

Location: Routt Co.

No. Analyses: 3

Mater Type: $\mathrm{Ca}, \mathrm{HCO}_{3}$

Solute Concentration Mean

11

4

Minimum

20.7

12

0.027

0

0.013

72.3

26

32.3

10

24.2

3.7

4.2

1.1

283

120

--

83

15

15.9

1.2

0.1

8.81

0.43

419

133

313

110

81

8

608

225

8.13

7.6

10.83

6

Reference: Covay and Tobin 1981 
TABLE 233. Water Analysis

Hydrologic Region: Upper Colorado

Aquifer Name: Mancos shale

Aquifer Age: Late and Early Cretaceous

Petrology: shale, interbedded sandstones and limestones
State: Colorado

Location: Routt Co.

No. Analyses: 10

Water Type: $\mathrm{Ca}, \mathrm{Na}, \mathrm{HCO}_{3}, \mathrm{SO}_{4}$

Solute Concentration

$\begin{array}{ccc}\text { Maximum } & \frac{\text { Mean }}{40} & \frac{\text { Minimum }}{42}\end{array}$

We11 Depth (m)

Constituents $(\mathrm{mg} / \ell)$

and Properties

$\begin{array}{lc}\mathrm{SiO}_{2} & 22 \\ \mathrm{Fe} & 3.10 \\ \mathrm{Mn} & 0.23 \\ \mathrm{Ca} & 360 \\ \mathrm{Mg} & 210 \\ \mathrm{Na} & 740 \\ \mathrm{~K} & 5.6 \\ \mathrm{HCO} & \\ \mathrm{CO}_{3} & 1990 \\ \mathrm{SO}_{4} & -- \\ \mathrm{Cl} & 1700 \\ \mathrm{~F}_{\mathrm{NO}} & 320 \\ \mathrm{NDS}_{3} & 3.8 \\ \mathrm{TDS} & 17\end{array}$

Hardness as $\mathrm{CaCO}_{3}$

$\mathrm{Ca}, \mathrm{Mg}$

1800

Noncarbonate

1300

3970

Sp. Cond.

(micromhos $25^{\circ} \mathrm{C}$ )

pH

7.8

Temperature $\left({ }^{\circ} \mathrm{C}\right)$

13

\section{7}

6.3

0.519

0.010

0.041

0

91.2

2.7

37.8

149

2.84

477

--

238

43.2

0.57

2.35

1.8

5.6

1.1

100

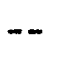

7.7

1.8

0.1

0.01

825

121

387

14

172

0

1146

240

7.0

5

Reference: Covay and Tobin 1981 
TABLE 234. Water Analysis

Hydrologic Region: Upper Colorado

Aquifer Name: Basement Complex

Aquifer Age: Precambrian

Petrology: metamorphic
State: Colorado

Location: Routt Co.

No. Analyses: 3

Water Type: $\mathrm{Ca}, \mathrm{HCO}_{3}$

Solute Concentration

\begin{tabular}{lcc} 
Maximum & $\frac{\text { Mean }}{265}$ & Minimum \\
\cline { 2 - 3 } & &
\end{tabular}

Wel1 Depth (m)

Constituents (mg/l) and Properties

$\mathrm{SiO}_{2}$

18

$\mathrm{Fe}$

$\mathrm{Mn}$

$\mathrm{Ca}$

$\mathrm{Mg}$

$\mathrm{Na}$

K

$\mathrm{HCO}_{3}$

$\mathrm{CO}_{3}$

$\mathrm{SO}_{4}$

C1

$\mathrm{F}$

$\mathrm{NO}_{3}$

TDS

Hardness as $\mathrm{CaCO}_{3}$

$\mathrm{Ca}, \mathrm{Mg}$

Noncarbonate

Sp. Cond.

(micromhos $025^{\circ} \mathrm{C}$ )

pH

Temperature $\left({ }^{\circ} \mathrm{C}\right)$
180

8.0

0.66

0.11

51

13

27

2.5

260

23

13

0.2

1.7

263

14

430

38
14.5

0.327

0.053

26.1

6.77

12.1

1.73

124

--

10.1

6.23

0.13

0.61

143

92.7

4.67

228

7.47

16.3
8.6

0.02

0.02

9.2

3.1

3.2

1.3

53

2.7

1.5

0.1

0

64

40

0

105

7.1

5

Reference: Covay and Tobin 1981 
TABLE 235. Water Analys is

Hydrologic Region: Upper Mississippi

Aquifer Name: Prairie du Chien-Jordan

Aquifer Age: Early Ordovician and Late Cambrian

Petrology: sandstone and dolomite

\section{We11 Depth (m)}

Constituents (mg/l) and Properties

$\mathrm{SiO}_{2}$

$\mathrm{Fe}$

$\mathrm{Mn}$

$\mathrm{Ca}$

$\mathrm{Mg}$

$\mathrm{Na}$

K

$\mathrm{HCO}_{3}$

$\mathrm{CO}_{3}$

$\mathrm{SO}_{4}$

C1

F

$\mathrm{NO}_{3}$

TDS
State: Iowa

Location: Allamakee Co.

No. Analyses: 1

Hater Type: $\mathrm{Ca}, \mathrm{HCO}_{3}$

Solute Concentration

202

$$
\begin{gathered}
0.04 \\
<0.05 \\
87 \\
18 \\
1.8 \\
1.1 \\
334 \\
0 \\
19 \\
2.0 \\
0.5 \\
0.8 \\
304
\end{gathered}
$$

274

18

530

Sp. Cond.

(micromhos $25^{\circ} \mathrm{C}$ )

$\mathrm{pH}$

$$
7.4
$$

11.1

Temperature $\left({ }^{\circ} \mathrm{C}\right)$

Reference: Horick and Steinhilber 1978 
TABLE 236. Water Analysis

Hydrologic Region: Upper Mississippi

Aquifer Name: Prairie du Chien-Jordan

Aquifer Age: Early Ordovician and Late Cambrian

Petrology: sandstone and dolomite

We11 Depth (m)

Constituents $(\mathrm{mg} / \ell)$ and Properties

$\mathrm{SiO}_{2}$

$\mathrm{Fe}$

$\mathrm{Mn}$

$\mathrm{Ca}$

$\mathrm{Mg}$

$\mathrm{Na}$

K

$\mathrm{HCO}_{3}$

$\mathrm{CO}_{3}$

$\mathrm{SO}_{4}$

C1

$\mathrm{F}$

$\mathrm{NO}_{3}$

TDS
State: Iowa

Location: Floyd Co.

No. Analyses: 1

Water Type: $\mathrm{Ca}, \mathrm{HCO}_{3}$

Solute Concentration

413

0.9

0

53

23

5.5

4.0

243

0

17

2.0

1.0

0

244

227

$\mathrm{Ca}, \mathrm{Mg}$

0

429

(micromios $25^{\circ} \mathrm{C}$ )

pH

8.3

Temperature $\left({ }^{\circ} \mathrm{C}\right)$

11.1

Reference: Horick and Steinhilber 1978 
TABLE 237. Water Analysis

Hydrologic Region: Upper Mississippi

Aquifer Name: Alluvium

Aquifer Age: Holocene

Petrology: sand and gravel
State: Wisconsin

Location: St. Croix Co.

No. Analyses: 26

Water Type: $\mathrm{Ca}, \mathrm{HCO}_{3}$

Solute Concentration

Maximum

We11 Depth (m)

Constituents $(\mathrm{mg} / \mathrm{l})$

and Properties

$\mathrm{SiO}_{2}$

25

6.7

0.74

61

29

3.8

1.2

304

$-$

17

6.9

0.3

--

TDS

Hardness as $\mathrm{CaCO}_{3}$

$\mathrm{Ca}, \mathrm{Mg}$

33

Noncarbonate

Sp. Cond.

(micromhos $25^{\circ} \mathrm{C}$ )

pH

8

Temperature $\left({ }^{\circ} \mathrm{C}\right)$

Reference: Borman 1976
Median

Minimum
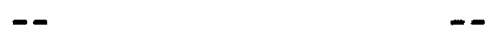

12

0

0

28

12

2.6

1.6

0.9

0.4

212

131

--

9.6

--

2.0

2.3

0

0.1

0

10

$--$

$--$

12

0

--

--

7.1

7.6

-- 
Hydrologic Region: Upper Mississippi Aquifer Mame: Sand and Gravel Aquifer Age: Holocene and Pleistocene Petrology: clay, silt, sand, gravel
State: Wisconsin Location: Walworth Co. No. Analyses: 26 Nater Type: $\mathrm{Ca}, \mathrm{HCO}_{3}$

Solute Concentration
Well Depth (m)

Constituents $(\mathrm{mg} / \mathrm{l})$ and Properties

$\mathrm{SiO}_{2}$

$\mathrm{Fe}$

$\mathrm{Mn}$

$\mathrm{Ca}$

$\mathrm{Mg}$

$\mathrm{Na}$

$\mathrm{K}$

$\mathrm{HCO}_{3}$

$\mathrm{CO}_{3}$

$\mathrm{SO}_{4}$

$\mathrm{Cl}$

$\mathrm{F}$

$\mathrm{NO}_{3}$

TDS

Maximum

26

10

0.2

108

49

88

4.3

466

--

67

19

1.0

$>500$ Mean

Minimum

--

18

1.7

0.03

76

36

5.1

1.2

370

--

7.5

7.0

2.3

0

0

20

1.2

1.9

0.8

37

--

0.6

2.0

0.2

0.2

$<3$

346

$<100$

Hardness as $\mathrm{CaCO}_{3}$

$\mathrm{Ca}, \mathrm{Mg}$

450

330

100

Noncarbonate

127

22

0

Sp. Cond.

(micromhos $25^{\circ} \mathrm{C}$ )

pH

8.1

14

7.6

11
6.9

9

Reference: Borman 1976 


\section{TABLE 239. Water Analys is}

Hydrologic Region: Upper Mississippi

Aquifer Name: Drift

Aquifer Age: Pleistocene

Petrology: glacial deposits
State: Wisconsin

Location: Barron Co.

No. Analyses: 19

Water Type: $\mathrm{Ca}, \mathrm{HCO}_{3}$

Solute Concentration

Maximum

Constituents $(\mathrm{mg} / \ell)$

and Properties

$$
\mathrm{SiO}_{2}
$$

$\mathrm{Fe}$

$\mathrm{Mn}$

$\mathrm{Ca}$

$\mathrm{Mg}$

$\mathrm{Na}$

$\mathrm{K}$

$\mathrm{HCO}_{3}$

$\mathrm{CO}_{3}$

$\mathrm{SO}_{4}$

$\mathrm{Cl}$

$\mathrm{F}$

$\mathrm{NO}_{3}$

B

TDS

Hardness as $\mathrm{CaCO}_{3}$

$\mathrm{Ca}, \mathrm{Mg}$

Noncarbonate

Sp. Cond.

(micromhos $25^{\circ} \mathrm{C}$ )

$\mathrm{pH}$

7.3

Temperature $\left({ }^{\circ} \mathrm{C}\right)$

Reference: Bell and Hindall 1975
23

27

18

160

20

Intermediate

Minimum

$\begin{array}{lr}-- & - \\ 0.06 & 0 \\ -- & - \\ 44 & 24\end{array}$

11

4.2

5.2

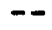

0

0.02

$-$

$--$

9.3

3.6

2.6

1.1

4.5

0.6

164

73

30

0

0

6.2

8.4

10

0

0.1

3.2

0.04

0.18

69

136

82

38

22

14

-.

7.0 
Hydrologic Region: Upper Mississippi Aquifer Name: Niagara Aquifer Age: Silurian Petrology: dolomite
State: Wisconsin

Location: Walworth Co. No. Analyses: Unspecified Water Type: $\mathrm{Ca}, \mathrm{Mg}, \mathrm{HCO}_{3}$ Solute Concentration

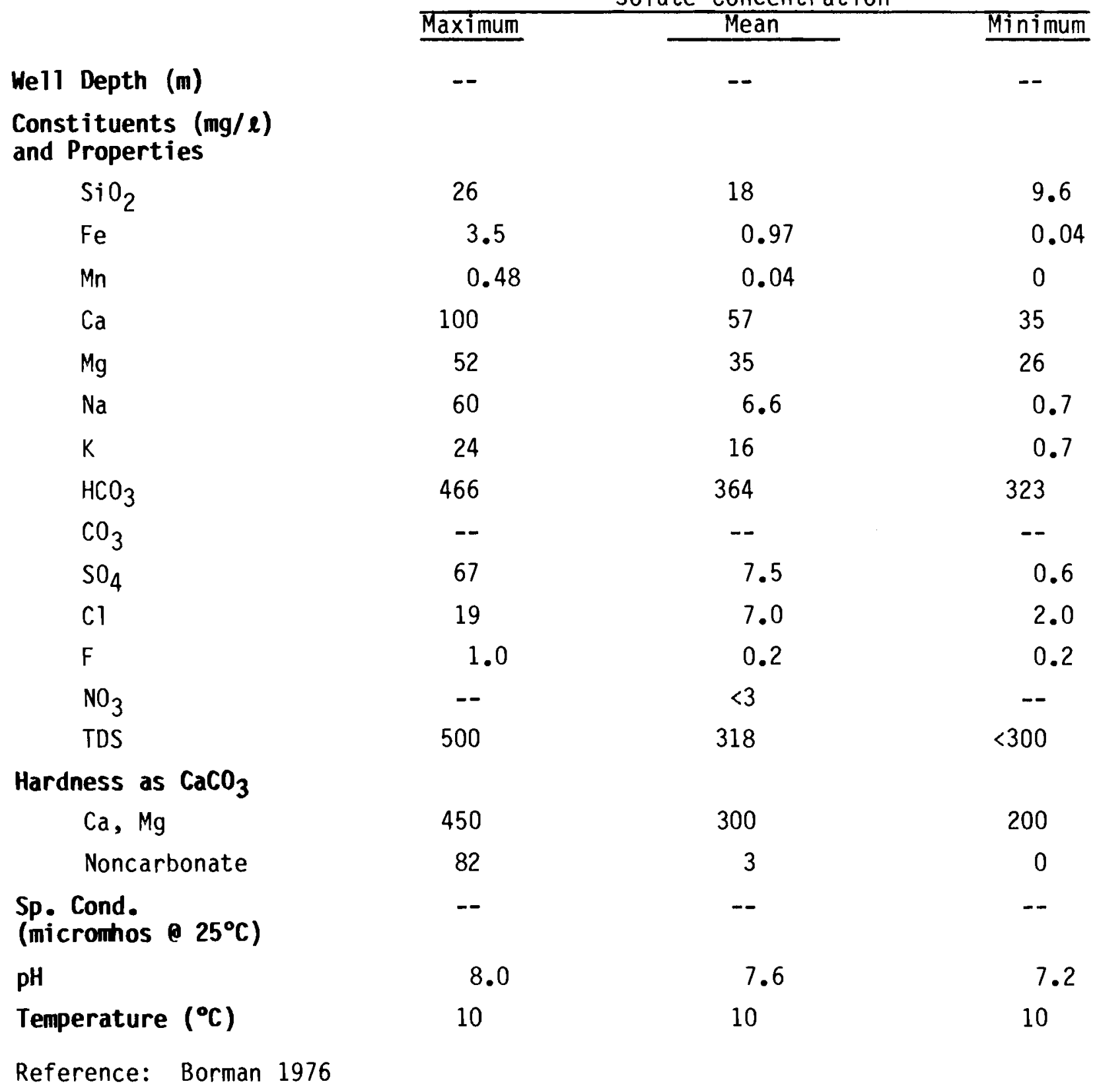


TABLE 241. Water Analysis

Hydrologic Region: Upper Mississippi

Aquifer Name: Galena-Platteville

Aquifer Age: Middle Ordovician

Petrology: dolomite, some shale
State: Wisconsin

Location: Walworth Co.

No. Analyses: Unspecified

Nater Type: $\mathrm{Ca}, \mathrm{HCO}_{3}$

Solute Concentration

\begin{tabular}{ccc}
\multicolumn{3}{c}{ Solute Concentration } \\
\cline { 2 - 3 } Maximum & Median & Minimum \\
\cline { 2 - 3 }-- & -- & -- \\
& & \\
21 & 17 & 14 \\
5.3 & 1.8 & 0.05 \\
0.24 & 0.03 & 0 \\
84 & 68 & 61 \\
39 & 32 & 19 \\
22 & 4.4 & 0 \\
6.7 & 1.4 & 0.7 \\
440 & 362 & 310 \\
-- & -- & -- \\
34 & 9.3 & 0.2 \\
15 & 2.0 & 0 \\
0.4 & 0.2 & 0.2 \\
-- & $<3$ & -- \\
375 & 327 & 300 \\
350 & & \\
84 & 317 & 300 \\
-- & 18 & 0 \\
7.9 & -- & -- \\
14 & 7.5 & 7.2 \\
& 12 &
\end{tabular}

Well Depth (m)

Constituents $(\mathrm{mg} / \mathrm{l})$ and Properties

$\mathrm{SiO}_{2}$

$\mathrm{Fe}$

$\mathrm{Mn}$

$\mathrm{Ca}$

$\mathrm{Mg}$

$\mathrm{Na}$

$\mathrm{K}$

$\mathrm{HCO}_{3}$

$\mathrm{CO}_{3}$

$\mathrm{SO}_{4}$

$\mathrm{Cl}$

$\mathrm{F}$

$\mathrm{NO}_{3}$

TDS

Hardness as $\mathrm{CaCO}_{3}$

$\mathrm{Ca}, \mathrm{Mg}$

Noncarbonate

Sp. Cond.

(micromhos $25^{\circ} \mathrm{C}$ )

pH

Temperature $\left({ }^{\circ} \mathrm{C}\right)$

Reference: Borman 1976 


\section{TABLE 242. Water Analysis}

Hydrologic Region: Upper Mississippi

Aquifer Name: St. Peter and Prairie du Chien

Aquifer Age: Ordovician

Petrology: sandstone
State: Wisconsin

Location: St. Croix Co.

No. Analyses: 75

Water Type: $\mathrm{Ca}, \mathrm{Mg}, \mathrm{HCO}_{3}$

Solute Concentration

Maximum

We11 Depth (m)

Constituents $(\mathrm{mg} / \mathrm{l})$

and Properties

$\mathrm{SiO}_{2}$

35

$\mathrm{Fe}$

46

$\mathrm{Mn}$

Ca

$\mathrm{Mg}$

$\mathrm{Na}$

$\mathrm{K}$

$\mathrm{HCO}_{3}$

$\mathrm{CO}_{3}$

$\mathrm{SO}_{4}$

$\mathrm{Cl}$

$\mathrm{F}$

$\mathrm{NO}_{3}$

$$
1.0
$$

89

47

30

5.7

400

Median

Minimum

$-$

$-$

18

6.4

0.01

0

0

0

49

26

24

11

3.4

1.4

0.9

0.2

230

116

--

35

31

0.4

$-$

12

2.3

5.5

0.9

0.2

0.1

80

14

TDS

Hardness as $\mathrm{CaCO}_{3}$

$\mathrm{Ca}, \mathrm{Mg}$

94

27

0

Noncarbonate

Sp. Cond.

(micromhos $25^{\circ} \mathrm{C}$ )

$\mathrm{pH}$

8.4

7.6

6.9

Temperature $\left({ }^{\circ} \mathrm{C}\right)$

Reference: Borman 1976 
TABLE 243. Water Analysis

Hydrologic Region: Upper Mississippi

Aquifer Name: Sandstone

Aquifer Age: Ordovician and Cambrian

Petrology: sandstone, dolomite, siltstone
State: Wisconsin

Location: Walworth Co.

No. Analyses: Unspecified

Water Type: $\mathrm{Ca}, \mathrm{HCO}_{3}$

Solute Concentration

Maximum Median Minimum

We11 Depth (m)

Constituents $(\mathrm{mg} / \mathrm{l})$ and Properties

$\mathrm{SiO}_{2}$

$\mathrm{Fe}$

$\mathrm{Mn}$

$\mathrm{Ca}$

$\mathrm{Mg}$

$\mathrm{Na}$

K

$\mathrm{HCO}_{3}$

$\mathrm{CO}_{3}$

$\mathrm{SO}_{4}$

Cl

$\mathrm{F}$

$\mathrm{NO}_{3}$

TDS
18

4.8

0.04

83

46

75

5.9

442

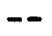

63

14

0.8

--

500

400

68

Nonc arbonate

Sp. Cond.

(micromhos $25^{\circ} \mathrm{C}$ )

$\mathrm{pH}$

Temperature $\left({ }^{\circ} \mathrm{C}\right)$

Reference: Borman 1976

7.8

14
13

1.1

0.02

72

34

10

2.0

393

12

2.2

0.3

$<3$

341

307

2.4

7.5

12
200

0

7.2

10

8.7

0.05

0

37

18

1.8

1.0

293

0

0

0.1

300

-- 
Hydrologic Region: Upper Mississippi

Aquifer Name: Cambrian Sandstone

Aquifer Age: Cambrian

Petrology: sandstone
State: Wisconsin Location: St. Croix Co. No. Analyses: 75

Water Type: $\mathrm{Ca}, \mathrm{HCO}_{3}$

Solute Concentration Median

Well Depth (m)

Constituents $(\mathrm{mg} / \ell)$ and Properties
$\mathrm{SiO}_{2}$

$\mathrm{Fe}$

$\mathrm{Mn}$

$\mathrm{Ca}$

$\mathrm{Mg}$

$\mathrm{Na}$

K

$\mathrm{HCO}_{3}$

$\mathrm{CO}_{3}$

$\mathrm{SO}_{4}$

$\mathrm{Cl}$

$\mathrm{F}$

$\mathrm{NO}_{3}$

TDS

Maximum

340

Hardness as $\mathrm{CaCO}_{3}$

$\mathrm{Ca}, \mathrm{Mg}$

Noncarbonate

Sp. Cond.

(micromhos $25^{\circ} \mathrm{C}$ )

$\mathrm{pH}$

Temperature $\left({ }^{\circ} \mathrm{C}\right)$

Reference: Borman 1976
24

2.6

0.17

66

33

22

1.7

--

27

32

0.3

$--$

17

0.06

0.03

42

16

2.6

0.9

207

$--$

10

1.8

0.1

9.4

0

0

24

9.7

1.3

0.4

107

--

2.0

0

0

--

--

69

12

0

$-$

--

8.0

7.7

7.0 


\section{TABLE 245. Water Analysis}

Hydrologic Region: Upper Mississippi

Aquifer Name: Eau Claire-Mt. Simon

Aquifer Age: Cambrian

Petrology: sandstone

We11 Depth (m)

Constituents $(\mathrm{mg} / \ell)$

and Properties

$$
\left.\begin{array}{l}
\mathrm{SiO}_{2} \\
\mathrm{Fe} \\
\mathrm{Mn}
\end{array}\right\}
$$

$\mathrm{Ca}$

$\mathrm{Mg}$

$\mathrm{Na}$

K

$\mathrm{HCO}_{3}$

$\mathrm{CO}_{3}$

$\mathrm{SO}_{4}$

C1

F

$\mathrm{NO}_{3}$

B

TDS

Maximum

10

0.40

26

7.9

3.1

0.5

23

0

7.4

20

0.1

15

0.13

182
Hardness as $\mathrm{CaCO}_{3}$

$\mathrm{Ca}, \mathrm{Mg}$

Noncarbonate

Sp. Cond.

(micromhos $25^{\circ} \mathrm{C}$ )

$\mathrm{pH}$

98

78

$--$

6.6

Temperature $\left({ }^{\circ} \mathrm{C}\right)$
State: Wisconsin

Location: Barron Co.

No. Analyses: 3

Water Type: $\mathrm{Ca}, \mathrm{HCO}_{3}$

Solute Concentration

Intermediate

24

40

Minimum

0.05

0.35

20

3.1

1.6

2.7

1.7

1.1

12

0

3.4

6.0

0

1.5

0.54

50

118

62

14

28

4

$-$

6.4

6.6

$--$

Reference: Bell and Hindall 1975 
Albin, D. R. 1962. "Resume of the Ground-Water Resources of Bradley, Calhoun, and Ouachita Counties, Arkansas." Water Resources Summary No. 1, U.S. Geological Survey in cooperation with Arkansas Geological and Conservation Commission, Little Rock, Arkansas.

Bearden, H. W. 1974. "Ground-Water Resources of the Hollywood Area, Florida." Report of Investigations No. 17, U.S. Geological Survey in cooperation with Bureau of Geology, Florida Department of Natural Resources and the City of Hollywood, Tallahassee, Florida.

Bell, E. A. and S. M. Hindall. November 1975. "The Availability of Ground Water for Irrigation in the Rice Lake-Eau Claire Area, Wisconsin." Information Circular No. 31, U.S. Geological Survey in cooperation with Wisconsin Geological and Natural History Survey, Madison, Wisconsin.

Bettandorff, J. M. and S. A. Leake. 1976. "Water for Industrial and Agricultural Development in Attala, Holmes, Humphreys, Issaquena, Sharkey, and Yazoo Counties, Mississippi." U.S. Geological Survey in cooperation with the Mississippi Research and Development Center, Jackson, Mississippi.

Borman, R. G. July 1976. "Ground-Water Resources and Geology of St. Croix County, Wisconsin." Information Circular No. 32, U.S. Geological Survey in cooperation with Wisconsin Geological and Natural History Survey, Madison, Wisconsin.

Borman, R. G. November 1976. "Ground-Water Resources and Geology of Walworth County, Wisconsin." Information Circular No. 34, U.S. Geological Survey in cooperation with Wisconsin Geological and Natural History Survey, Madison, Wisconsin.

Boswell, E. H., E. M. Cushing and R. L. Hosman. 1968. "Quaternary Aquifers in the Mississippi Embayment," with a discussion of "Quality of the Water" by H. G. Jeffery. Geological Survey Professional Paper 448-E, Washington, D.C.

Brown, D. L. 1971. "Techniques for Quality-of-Water Interpretations from Calibrated Geophysical Logs, Atlantic Coastal Area." Groundwater, Vol. 9, pp. 25-38.

Case, H. L., III. 1979. "Ground-Water Resources of Washington Parish, Louisiana." Water Resources Technical Report No. 18, Louisiana Department of Transportation and Development Office of Public Works in cooperation with the U.S. Geological Survey, Baton Rouge, Louisiana.

Covay, K. J. and R. L. Tobin. 1981. "Quality of Ground Water in Routt County, Northwestern Colorado." Water-Resources Investigations Open File Report 80-956, U.S. Geological Survey, Lakewood, Colorado. 
Croft, M. G. 1964. "Geology and Ground-Water Resources of Dade County, Georgia." Geological Survey Information Circular 26, Georgia State Division of Conservation, Department of Mines, Mining and Geology in cooperation with the U.S. Geological Survey, Atlanta, Georgia.

Dial, D. C. and C. Kilburn. 1980. "Ground-Water Resources of the Gramercy Area, Louisiana." Water Resources Technical Report No. 24, Louisiana Department of Transportation and Development Office of Public Works in cooperation with the U.S. Geological Survey, Baton Rouge, Louisiana.

Fairchild, R. W. 1972. "The Shallow-Aquifer System in Duval County, Florida." Report of Investigations No. 59, U.S. Geological Survey in cooperation with the City of Jacksonville, Duval County and the Florida Department of Natural Resources, Bureau of Geology, Tallahassee, Florida.

Feder, G. L. and R. W. Lee. 1981. "Water-Quality Reconnaissance of Cretaceous Aquifers in the Southeastern Coastal Plain." Open-File Report 81-696, U.S. Geological Survey, Denver, Colorado.

Foley, C. F., N. K. Bleuer, R. K. Leininger, and W. C. Herring. 1972. "Strontium and Other Notable Chemical Constituents of Well-Water of Allen County, Indiana." Proc. Indiana Acad. Science, Vol. 82, pp. 274-280.

Fusillo, T. V. and L. M. Voronin. May 1981. "Water-Quality Data for the Potomac-Raritan-Magothy Aquifer System, Trenton to Pennsville, New Jersey." Open-File Report 81-814, U.S. Geological Survey in cooperation with the New Jersey Department of Environmental Protection, Division of Water Resources, Trenton, New Jersey.

Havens, J. S. May 1978. "Ground-Water Records for Eastern Ok lahoma, Part 2-Water-Quality Records for Wells, Test-Holes, and Springs." Open-File Report 78-357, U.S. Geological Survey in cooperation with Federal, State, and Local Agencies, Oklahoma City, Oklahoma.

Hendry, C. W., Jr. and C. R. Sproul. 1966. "Geology and Ground-Water Resources of Leon County, Florida." Bulletin No. 47, Florida Geological Survey, Tallahassee, Florida.

Hicks, D. W., R. E. Krause and J. S. Clarke. 1981. "Geohydrology of the Albany Area, Georgia." Information Circular 57, Georgia Geological Survey in cooperation with the U.S. Geological Survey and the Albany Water, Gas, and Light Commission, Atlanta, Georgia.

Hogenson, G. M. and B. L. Foxworthy. 1965. "Ground Water in the East Portland Area, Oregon." Water-Supply Paper 1793, U.S. Geological Survey in cooperation with the Oregon State Engineer, Washington, D.C.

Horick, P. J. and W. L. Steinhilber. 1978. "Jordan Aquifer of Iowa." Miscellaneous Map Series 6, Iowa Geological Survey in cooperation with the U.S. Geological Survey, Iowa City, Iowa. 
Keech, C. F. January 1978. "Water Resources of Seward County, Nebraska." Nebraska Water Survey Paper 46, Conservation and Survey Division, Insitute of Agriculture and Natural Resources, The University of Nebraska in cooperation with the U.S. Geological Survey, Lincoln, Nebraska.

Klausing, R. L. 1968. "Geology and Ground Water Resources of Cass County, North Dakota." Part III, County Ground Water Studies 8, Bulletin 47, U.S. Geological Survey in cooperation with the North Dakota State Water Commission, North Dakota Geological Survey, and Cass County Board of Commissioners, Grand Forks, North Dakota.

Klein, H. and J.E. Hull. September 1978. "Biscayne Aquifer, Southeast Florida." Water-Resources Investigation 78-107, U.S. Geological Survey in cooperation with the U.S. Environmental Protection Agency, Tallahassee, Florida.

Leve, G. W. 1966. "Ground Water in Duval and Nassau Counties, Florida." Report of Investigations No. 43, U.S. Geological Survey in cooperation with the Division of Geology and Duval County and the City of Jacksonville, Tallahassee, Florida.

Leve, G. W. 1968. "Reconnaissance of the Ground-Water Resources of Baker County, Florida." Report of Investigations No. 52, U.S. Geological Survey in cooperation with the Florida Board of Conservation, Division of Geology, Tallahassee, Florida.

Lichtler, W. F. 1960. "Geology and Ground-Water Resources of Martin County, Florida." Report of Investigations No. 23, U.S. Geological Survey in cooperation with the Florida Geological Survey and the Central and Southern Florida Flood Control District, Tallahassee, Florida.

McCoy, H. J. 1962. "Ground-Water Resources of Collier County, Florida." Report of Investigations No. 31, U.S. Geological Survey in cooperation with Collier County, the City of Naples and the Florida Geological Survey, Tallahassee, Florida.

McCoy, H. J. and J. Hardee. 1970. "Ground-Water Resources of the Lower Hillsboro Canal Area, Southeastern Florida." Report of Investigation No. 55, U.S. Geological Survey in cooperation with the Bureau of Geology, Division of Interior Resources, Florida Department of Natural Resources and the cities of Boca Raton and Deerfield Beach, Tallahassee, Florida.

Mineral and Water Resources of South Dakota, Section I. 1964. Report of the U.S. Geological Survey in cooperation with the South Dakota Geological Survey and Water Resource Development in South Dakota. Report of the Bureau of Reclamation.

Muir, K. S. April 1981. "Assessment of the Santa Margarita Sandstone as a Source of Drinking Water for the Scotts Valley Area, Santa Cruz County, California." Water-Resources Investigations 81-6, U.S. Geological Survey, Men lo Park, California. 
Newcomb, R. C. 1972. "Quality of the Ground Water in Basalt of the Columbia River Group, Washington, Oregon, and Idaho." Water-Supply Paper 1999-N, U.S. Geological Survey, Washington, D.C.

Onellion, F. E. 1956. "Geology and Ground-Water Resources of Drew County, Arkansas." Water Resources Circular No. 4, U.S. Geological Survey in cooperation with Arkansas Geological and Conservation Commission, Little Rock, Arkansas.

Owen, Vaux, Jr. 1963. "Geology and Ground-Water Resources of Mitchell County, Georgia." Information Circular 24, U.S. Geological Survey in cooperation with Georgia Department of Mines, Mining and Geology, Atlanta, Georgia.

Paulson, Q. F. and J. E. Powe11. 1962. "Geology and Ground Water Resources of Tioga and Hofflund Flats Areas, Williams and Mountrail Counties, North Dakota." North Dakota Ground Water Studies No. 43, U.S. Geological Survey in cooperation with the North Dakota State Water Conservation Commission, and the North Dakota Geological Survey, Bismarck, North Dakota.

Payne, J. N. 1975. "Geohydrologic Significance of Lithofacies of the Carrizo Sand of Arkansas, Louisiana, and Texas and the Meridian Sand of Mississippi." Prof. Paper 569-D, U.S. Geological Survey, Washington, D.C.

Poth, C. W. 1972. "Hydrology of the Martinsburg Formation in Lehigh and Northampton Counties, Pennsylvania." Water Resource Report 30, U.S. Geological Survey in cooperation with the Pennsylvania Geological Survey, Fourth Series, Harrisburg, Pennsylvania.

Powe11, J. E. 1959. "Progress Report on the Geology and Ground Water Resources of the Westhope Area, Bottineau County, North Dakota." North Dakota Ground Water Studies No. 27, U.S. Geological Survey in cooperation with the North Dakota State Water Conservation Commission and the North Dakota Geological Survey, Bismarck, North Dakota.

Prée, H. L. Jr. 1962. "Ground-Water Resources Along State Route 1, Between Harrisburg and Medina, Ohio." Information Circular No. 7, State of Ohio, Department of Natural Resources, Division of Water, Columbus, Ohio.

Preston, R. D. July 1978. "Occurrence and Quality of Ground Water in Baylor County, Texas." Report 218, Texas Department of Water Resources, Austin, Texas.

Price, R. D. April 1978. "Occurrence, Quality, and Availability of Ground Water in Jones County, Texas." Report 215, Texas Department of Water Resources, Austin, Texas.

Randich, P. G. 1981. "Ground-Water Data for McHenry County, North Dakota." County Ground-Water Studies 33--Part II, Bullet in 74--Part II, North Dakota Geological Survey, U.S. Geological Survey in cooperation with the North Dakota Geological Survey, North Dakota State Water Commission, and McHenry County Water Management District, Bismarck, North Dakota. 
Robinson, W. H., J. B. Ivey, and G. A. Billingsley. 1953. "Water Supply of the Birmingham Area, Alabama." Geological Survey Circular 254, U.S. Geological Survey, Washington, D.C.

Robinson, W. H., W. J. Powe11, and E. Brown. 1956. "Water Resources of the Mobile Area, Alabama." Geological Survey Circular 373, U.S. Geological Survey, Washington, D.C.

Ryan, B. J. 1982. "Cape Cod Aquifer, Cape Cod, Massachusetts." Jour. New Engl and Water Works Ass'n., Vol. 96, pp. 25-54.

Sandeen, W. M. November 1972. "Ground-Water Resources of Washington County, Texas." Report 162, Texas Department of Water Resources, Austin, Texas.

Sanford, T. H., Jr. 1972. "Ground-Water Resources of Morehouse Parish, Louisiana." Water Resources Bulletin No. 19, State of Louisiana Department of Conservation Geological Survey and Department of Public Works in cooperation with the U.S. Geological Survey, Baton Rouge, Louisiana.

Schiner, G. R. and J. T. Gallaher. 1979. "Geology and Groundwater Resources of Western Crawford County, Pennsylvania." Water Resource Report 46, U.S. Geological Survey in cooperation with the Pennsylvania Geological Survey, Fourth Series, Harrisburg, Pennsylvania.

Sherrill, M. G. 1978. "Geology and Ground Water in Door County, Wisconsin, with Emphasis on Contamination Potential in the Silurian Dolomite." WaterSupply Paper 2047, U.S. Geological Survey, Washington, D.C.

Snider, J. L. and T. H. Sanford, Jr. 1981. "Water Resources of the Terrace Aquifers, Central Louisiana." Water Resources Technical Report No. 25, U.S. Geological Survey in cooperation with State of Louisiana Department of Transportation and Development, Office of Public Works, Baton Rouge, Louisiana.

Spalding, R. F. and M. E. Exner. 1980. "Areal, Vertical, and Temporal Differences in Ground Water Chemistry: I. Inorganic Constituents." Jour. Environ. Qual., Vol. 9, pp. 466-479.

Stewart, H. G., Jr. 1966. "Ground-Water Resources of Polk County." Report of Investigations No. 44, U.S. Geological Survey in cooperation with the Division of Geology, the Board of County Commissioners of Polk County and the Southwest Florida Water Management District, Tallahassee, Florida.

Taylor, H. D. February 1976. "Water-Level and Water-Quality Data from Observation Wells in Northeast Texas." Report 198, Texas Water Development Board, Austin, Texas.

Taylor, H. D. October 1978. "Occurrence, Quantity, and Quality of Ground Water in Taylor County, Texas." Report 224, Texas Department of Water Resources, Austin, Texas. 
Terry, J. E., C. T. Bryant, A. H. Ludwig, and J. E. Reed. May 1979. "WaterResources Appraisal of the South-Arkansas Lignite Area." Open-File Report 79-924, U.S. Geological Survey in cooperation with the Arkansas Geological Commission, Little Rock, Arkansas.

Walker, L. E. July 1979. "Occurrence, Availability, and Chemical Quality of Ground Water in the Edwards Plateau Region of Texas." Report 235, Texas Department of Water Resources, Austin, Texas.

Whitfield, M. S. 1975. "Geohydrology of the Evangeline and Jasper Aquifers of Southwestern Louisiana." Water Resources Bulletin No. 20, State of Louisiana Department of Conservation, Geological Survey and Department of Public Works in cooperation with the U.S. Geological Survey, Baton Rouge, Louisiana.

Whitfield, M. S., Jr. 1975. "Geohydrology and Water Quality of the Mississippi River Alluvial Aquifer, Northeastern Louisiana." Water Resources Technical Report No. 10, State of Louisiana Department of Public Works in cooperation with the U.S. Geological Survey, Baton Rouge, Louisiana.

Wood, P. R. and L. C. Burton. 1968. "Ground-Water Resources in Cleveland and Oklahoma Counties, Oklahoma." Circular 71, Oklahoma Geological Survey in cooperation with the U.S. Geological Survey, the University of Oklahoma, Norman, Ok lahoma.

Zack, A. 1977. "The Occurrence, Availability, and Chemical Quality of Ground Water, Grand Strand Area and Surrounding Parts of Horry and Georgetown Counties, South Carolina." Report No. 8, U.S. Geological Survey in cooperation with South Carolina Water Resources Commission, Columbia, South Carolina. 

APPENDIX B

NUMERICAL MODELING 

APPENDIX B

\section{NUMERICAL MODELING}

Selected U.S. ground waters were modeled geochemically to ascertain compatibility with aquifer thermal energy storage systems. This appendix describes the methodology used to perform the analyses and the results obtained.

\section{B.1 MODELING METHODOLOGY}

Sixty-seven chemical analyses of ground water were provided from Appendix A. The data apply to samples of ground water throughout the continental U.S., and represent several of the U.S. Geological Survey's hydrologic regions. The regions represented are South Atlantic Gulf (24 analyses), Lower Mississippi (21), Souris-Red-Rainy (8), Pacific Northwest (5), Upper Colorado (5), Upper Mississippi (3), and Middle Atlantic (1). The selected samples are those for which a relatively complete chemical analys is was available. The analys is included solution $\mathrm{pH}$, temperature, and concentrations of $\mathrm{Ca}, \mathrm{Mg}, \mathrm{Na}, \mathrm{K}, \mathrm{Cl}, \mathrm{SO}_{4}, \mathrm{CO}_{3} / \mathrm{HCO}_{3}, \mathrm{Fe}, \mathrm{F}, \mathrm{Mn}, \mathrm{NO}_{3}$, and $\mathrm{SiO}_{2}$.

The samples were modeled using the MINTEQ ${ }^{(a)}$ computer code to estimate the saturation state (equilibrium, undersaturated, or oversaturated) of the solution with respect to various minerals (e.g., calcite, quartz, and gypsum). The saturation state of the water is useful to know when evaluating the potential use of the aquifers for thermal energy storage. Changes in the temperature of the ground water may induce chemical reactions, especially mineral precipitation, that might inhibit the injection or recovery of the thermally altered water.

\footnotetext{
Ta) Felmy, A. R., D. C. Girvin and E. A. Jenne. MINTEQ-A Computer Program for Calculating Aqueous Geochemical Equilibria. Pacific Northwest Laboratory, Richland, Washington (to be published).
} 
To use the available water chemistry data with MINTEQ, the carbonate and bicarbonate concentrations were combined to give a value for total inorganic carbon in terms of carbonate $\left(\mathrm{CO}_{3}\right)$. Also, the $\mathrm{SiO}_{2}$ value was converted to $\mathrm{H}_{4} \mathrm{SiO}_{4}$. The redox potential (Eh) was not measured for any of the samples; instead, an estimated value of $+100 \mathrm{mv}$ was assigned to all samples. This value is fairly characteristic of mildly oxidizing ground waters. A modeling number (US001 to US067) was assigned to each sample. A listing of the model numbers with descriptive information and chemical values input to MINTEQ is shown in Table B.l.

\section{B.2 RESULTS AND INTERPRETATION}

The modeling results presented in Table B. 2 are only as good as the analytical data provided. One method of evaluating the quality of the data is to determine the electrical balance of each solution. An imbalance means that one or more of the dissolved constitutents was not correctly determined or, perhaps, an important constitutent was neglected. MINTEQ calculates the cation/anion balance of the speciated components, and the results for the 67 samples are shown in Figure B.1. Generally, an imbalance of greater than $5 \%$ renders the analysis suspect of error or omission. Twenty-one of the analyses have an imbalance greater than $5 \%$ and tweive have an imbalance greater than 10\%. Despite these discrepancies, all of the samples have been modeled but those that have high imbalances are noted in the following discussion of mineral saturation. Interpretation of the modeling results is concentrated on calcium minerals (calcite and gypsum) and silica minerals (quartz and its polymorphs) because these solids have the greatest potential for affecting the permeability of aquifers considered for thermal energy storage systems. The possibilities of iron mineral clogging and clay mineral swelling in these systems are also considered.

\section{B.2.1 Calcium}

The saturation indices of calcite and gypsum for the 67 water analyses modeled are 1 isted in Table B.3 and displayed in Figure B.2. A saturation index of zero means the solution is at equilibrium with respect to that 
TABLE B.1. Water Sample Characteristics

\begin{tabular}{|c|c|c|c|c|c|c|c|}
\hline 0 & $\begin{array}{l}\text { 1 MOUELING } \\
\text { NIJMRER }\end{array}$ & $\begin{array}{l}2 \text { HYOROLOGIC } \\
\text { REGION }\end{array}$ & 3 STATE & $\begin{array}{l}\text { (A)l concentratio } \\
4 \text { AQUIFER }\end{array}$ & $\begin{array}{l}n \text { Unltg } \ln m g / 1) \\
5 \text { LITHOLOGY }\end{array}$ & $\begin{array}{l}6 \text { WELL UEPTH } \\
\text { (MEIEKS) }\end{array}$ & ? REFEKENCE \\
\hline 1 & & $\mathrm{LH}_{4}$ & $A R$ & COCKF IELO & SILI SAND, & & IERRY ET AL \\
\hline 2 & usune & $L M \& A N R$ & $A R$ & WILCOX & CLAY, SAND & & TEKHY EI AL. \\
\hline 3 & 115003 & LM & $A R$ & COOK MTN & SILTY CLAY & & TEKRY ET AL. \\
\hline 4 & USก04 & LM & $A R$ & SPARTA SAND & SAND SANOY & & TERAY ET AL. \\
\hline 5 & USi) 05 & LM & $A R$ & SPARTA SAND & SAND, CLAY, & 253 & UNELLIUN, 1956 \\
\hline 6 & 115000 & LM & $A R$ & QUATERNARY & CLAY, SILT, & 30 & ONELLIUN, 1956 \\
\hline 7 & US007 & LM & $A R$ & JACKSON FM & SHALE, CLAY, & 4 & UNELLION, 1956 \\
\hline 8 & USOOB & LM & LA & $1500-F 00 T$ & MED G GRAIN SAND & & CASE, 1919 \\
\hline 9 & 0.5009 & LM & LA & RAMSEY & MED TO COARS & 593 & CASE, 1979 \\
\hline 10 & 45010 & LM & LA & FRANKLINTUN & MED TO COARSE & 726 & CASE, 1979 \\
\hline 11 & USกi: & LM & LA & MISS RIVER & SAND, GRAVEL & 10 & WHITFIELU, 1415 \\
\hline 12 & US 012 & LM & LA & TERRACE & SILICEOUS SAND & 6 & SNIUER \& SAINFURD \\
\hline 13 & 45013 & LM & LA & "SHALLOW" & SAND, GRAVEL & 41 & DIAL \& KILBUHN, 1980 \\
\hline 14 & USO14 & LM & LA & GRAMERCY & FINE TO COARSE & 79 & DIAL O KILBUHN, 1990 \\
\hline 15 & USO15 & LM & LA & GUNZALES & FINE TO MED & $\$ 75$ & DIAL KILBURN, 1980 \\
\hline 16 & USU10 & LM & LA & CHICOT & SAND, GRAVEL, & $186 \quad 10 \quad 289$ & WHITFILLU, 1975 \\
\hline 17 & 15017 & LM & LA & JASPER & SANO, SILT, & 531 TO 534 & WHITFIELU, 1975 \\
\hline 18 & US018 & LH & LA & SPARTA SAND & SANO, SANOY SILTS & 227 T0 230 & \\
\hline 19 & USOIQ & LM & LA & COOK MTN & SAND $\&$ CLAY & 129 T0 138 & SANFUK1D, 1972 \\
\hline 20 & 115020 & LM & LA & COCKFIELD & SANO, SILT, & $62 T 0 \quad 65$ & SANFUKO, 1972 \\
\hline 21 & USO2! & LM & LA & PLEISTOCENE & SILT, SAND, & $27 \quad 10 \quad 37$ & SANFUHD 1972 \\
\hline 22 & 45022 & ma & $\mathrm{N}^{\prime \prime}$ & POTOMAC, RARITAN, \& & SAND, GRAVEL, & & FUSILLU OVOROHIN \\
\hline 23 & USO23 & $P N$ & $O R$ & & SAND, GRAYEL & & HUGEHSUN \& FOXHOMTHY, \\
\hline 24 & US024 & $P N$ & $O R$ & & BASALT & & HUGEIYSUN \& FUXWOKIHY, \\
\hline 25 & U5025 & $P N$ & $O R$ & & BASALT & & NEWCU149, 1972 \\
\hline 26 & USO20 & PN & WA & & BASALT & 130 & NEKCUMH, 1972 \\
\hline 27 & US027 & $P_{N}$ & $m a$ & BASALT & BASALT & 244 & NENCOMAQ, 1972 \\
\hline 28 & USO28 & SRR & ND & FOX HILLS & CLAY, SILT, & 78 & RANDICH, 1981 \\
\hline 29 & USก29 & SRR & nO & HELL CREEK & CLAY, SHALE, SILTSTONE, & 57 & RANOICH, $198 !$ \\
\hline 30 & 45030 & SRR & NO & CANNONEALL & SHALE, SAND, SILT, & 31 & RANOICH, 1981 \\
\hline 31 & 105031 & SRE & NO & TONGUE RIVER OF & SHALE, SANDSTONE, & 50 & KANOICH, 1981 \\
\hline 32 & US032 & SRR & No & NEW ROCKFURD & GLACIAL SEDS & 54 & RANDICH, 1381 \\
\hline 33 & US033 & SRR & NO & VOLTAIRE & & 20 & KANUICH, 1981 \\
\hline 34 & USO34 & $S R R$ & ND & DENGIGH & GLACIAL SEDS & $2 !$ & RANDICH, $198 !$ \\
\hline 35 & USO35 & SRR & ND & BURIED OUTWASH & CLAY, SILT, & 27 & \\
\hline 36 & USO36 & SAG & $A L$. & "MIOCENE sanos" & & 64 & ROBIHSOY ET AL. \\
\hline 37 & 115037 & $S A G$ & $A L$ & HARTSELLE SS & SS OVERLYING & & RUEINSUN EI AL. \\
\hline 38 & US 038 & $S \triangle G$ & $A L$ & PARKHOOD FM & SS, SH & 335 & RUBIHSUN ET AL, 1953 \\
\hline 39 & USO39 & EAG & $A L$ & BANGOR LS & LS & 34 & RUBIINSUN EI AL. \\
\hline 40 & 45040 & SAG & AL. & CONASAUGA LS & LS & 134 & ROBINSUIS ET AL. \\
\hline 41 & U5041 & $S A G$ & $A L$ & KETONA DOLOMITE & MASSIVE DOLOMITE & 0 & ROUINSUN EI AL. \\
\hline 42 & US042 & SAG & $A L$ & POTTSVILLE FM & CONGL,SS,SH,COAL & "MINE SHAFT" & RUBIISSUN EI AL. \\
\hline 43 & USO43 & $S A G$ & $\Delta L$ & FORT PAYNE CHERT \& & CHERT, SANDY CLAY, & 57 & HOBIHSUN ET AL. \\
\hline 44 & US044 & $S A G$ & $A L$ & COPPER RIDGE & DOLO, CHERT & "SPRING" & RUBIISSON ET AL. \\
\hline 45 & USO- 5 & SAT & $\Delta L$ & TUSCALIIOSA GRP & ss & 198 & FEOEK \& LEE, \\
\hline 46 & USO46 & SAG & $A L$ & "UPPER CRETACEOUS & ss & 152 & FEDER \& LEE \\
\hline 47 & US047 & $S A G$ & $\mathrm{FL}$ & BISCAYNE & LS, SAND & & $\bar{K} L E I N \&$ HULL, \\
\hline 48 & USO4B & SAT, & $\mathrm{FL}$ & BISCAYNE & LS, SAND & 20 & BEAHOEN, 1974 \\
\hline 49 & US 049 & $S A G$ & FL & "NONARTESIAN AQUIFER" & SAND, CLAYEY SAND & & SIEWART, 1966 \\
\hline 50 & 125050 & $S A G$ & FL. & "SECONDARY & LS & & STEWAHT, 1906 \\
\hline 51 & US05i & $S A G$ & $\mathrm{FL}$ & FLORIOAN AQUIFEA & LS & & STEWAKT, $196 \mathrm{~b}$ \\
\hline 52 & US052 & SAG & $F L$ & FLORIDAN AIUIIFER & LS & & HENCKY S SPRUUL \\
\hline 53 & USOS 3 & $S A G$ & FL & BISCAYNE & SAND, COQUINA, LS & 32 & MCCOY \& HARUEE, \\
\hline 54 & $1 / 5054$ & $S A G$ & GA & CLAYTON & CALC OTZ SAND \& & & HICXS EI AL. \\
\hline 55 & US055 & SAIG & GA & TALLAHATTA & SAND, CLAYEDY SAND, & & HICKS ET AL. \\
\hline 56 & US056 & $S A G$ & GA & CUSSETA SAND & SILTY, MICACEOUS, CALC & & HICKS EI AL. \\
\hline 57 & US057 & SAG & GA & PROVIDENCE SAND & DOLOMITIC SILTSTONE & & HICKS EI AL. \\
\hline 58 & USOS 8 & SAG & NC & BLACK CREEK & ss & 27 & FEDER \& LEE, \\
\hline 59 & 115059 & $S A G$ & NC & TUSCALOOSA & ss & 26 & FEDEN \& LEE, \\
\hline 60 & 115000 & uc & co & BASEMENT COMPLEX & METAMORPHICS & 265 & COVAY \& IODIN, \\
\hline 61 & US001 & UC & co & MESAVEROE & SS, CARBO SH, & 18 & COVAY \& 108 IN, \\
\hline B. 2 & 115002 & UC & co & MANCOS SHALE & SHALE, INTERBEDDED & 10 & COVAY TUBIN, \\
\hline 63 & $1 / 5003$ & UC & CO & "ALLUVIUM" & CLAY, SANO, GRAYEL & 7 & COVAY TOBIN, \\
\hline 64 & US 1064 & UC & co & BROWINS PARK & SILTSTONE, SS, CONGL, & 98 & COVAY t TUEIN, \\
\hline 65 & USUOS & $U M$ & WI & GALENA-PLATTEVILLE & DOLO, SH & & BURMAN, 1976 \\
\hline 66 & US006 & $U M$ & $m !$ & "SAND \& GRAVEL" & CLAY, SILT, & & BOKMAN, 1976 \\
\hline 67 & USOE7 & UM & WI & NIAGARA & DOLOMITE & & BURHAN, 1976 \\
\hline
\end{tabular}



(bi) concontrotion units in mo/l)

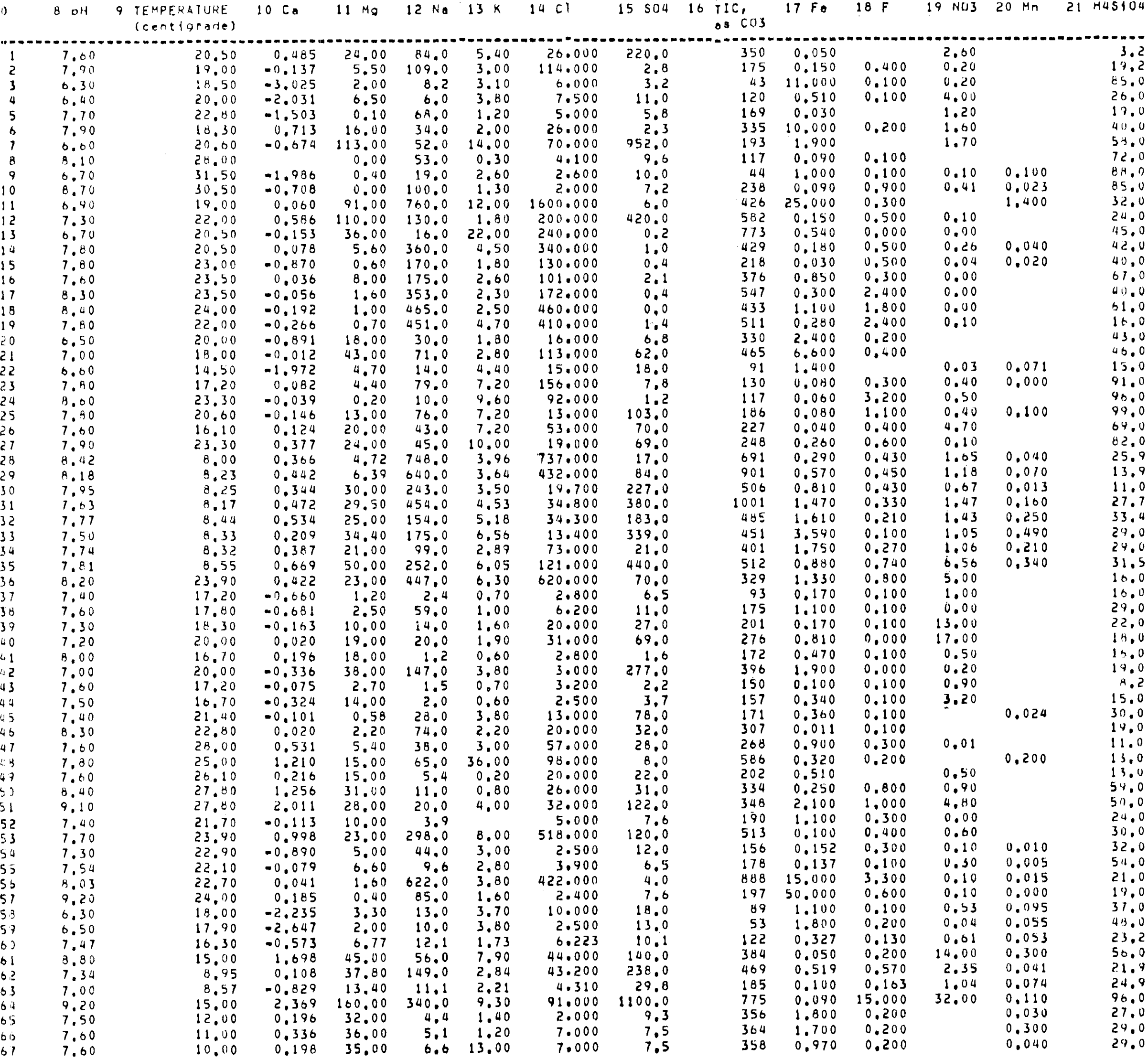





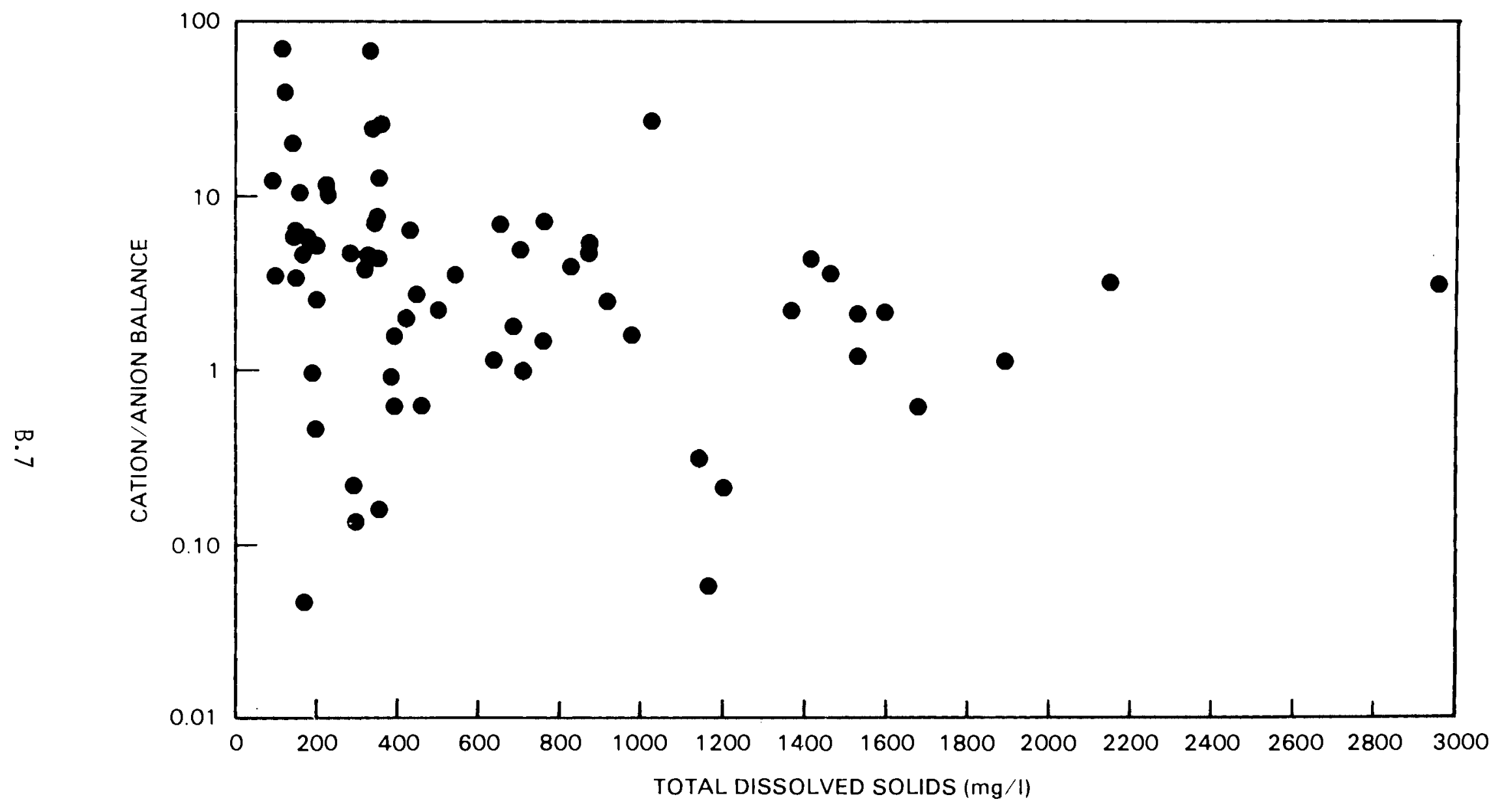

FIGURE B.1. Cation/Anion Balance Versus Total Dissolved Solids for U.S. Ground Waters 

TABLE B.3. Saturation Indices of Selected Materials

\begin{tabular}{|c|c|c|c|c|c|c|c|c|c|}
\hline 0 & $\begin{array}{l}1 \text { mudeting } \\
\text { rusteteg }\end{array}$ & $\begin{array}{l}2 \text { CAIIUN/ANIUN } \\
\text { MALAIVCE }\end{array}$ & $\begin{array}{l}3 \text { Calcito } \\
\text { S.1. }\end{array}$ & $\begin{array}{l}4 \text { Dolomite } \\
\text { S. }\end{array}$ & $\begin{array}{l}5 \text { GYosum } \\
\text { S.I. }\end{array}$ & $\begin{array}{l}6 \text { Quartz } \\
\text { S.I. }\end{array}$ & $\begin{array}{l}7 \text { Chalcedony } \\
\text { S.1. }\end{array}$ & $\begin{array}{l}8 \sin (1,91) \\
\text { s. } 1 .\end{array}$ & Y FERKIARGHIIL \\
\hline 1 & 14001 & $1445 t+00$ & 0.485 & 0,588 & & -0.402 & $=0.403$ & -1.410 & 0.152 \\
\hline 2 & $\begin{array}{l}\text { usion } \\
\text { us } 02\end{array}$ & $\begin{array}{l}1.57 a t-01 \\
1.578 t-1\end{array}$ & $\begin{array}{r}0.403 \\
-0.137\end{array}$ & $\begin{array}{r}0.300 \\
-0.577\end{array}$ & $\begin{array}{r}-3.370 \\
-370\end{array}$ & 0.398 & -0.109 & -0.017 & 1,559 \\
\hline 3 & USUD 3 & $3.903 t+01$ & -3.025 & -6.351 & -3.591 & 1.054 & 0.545 & 0.037 & -1.214 \\
\hline 4 & usuca & $4.50 H t+100$ & -2.031 & -4.232 & -2.715 & 0.516 & 0.013 & -0.444 & $=2.293$ \\
\hline 5 & usun 5 & $9.5<1 E-01$ & -1.503 & -3.758 & -4.201 & 0.334 & -0.158 & -0.664 & 0.419 \\
\hline 6 & USO06 & $4.310 t+00$ & 0.713 & 0.964 & -2.941 & 0.728 & 0.216 & -0.290 & 3.350 \\
\hline 7 & 105067 & $2.1 A 7 t+00$ & -0.674 & -1.457 & $-0,204$ & 0.859 & 0.354 & $=0.148$ & -1.400 \\
\hline 8 & USUOB & $4.7913 t=02$ & & & & 0.828 & 0.356 & -0.147 & 2.1121 \\
\hline 9 & USU0O & $6.1902 E+01$ & -1.986 & -4.177 & -3.882 & 0.871 & 0.413 & -0.049 & -0.0334 \\
\hline 10 & USO10 & $2.180 t=01$ & -0.708 & & -4.604 & 0.836 & 0.374 & -0.128 & 2.044 \\
\hline 11 & USU11 & $3.1195 t+00$ & 0.060 & -0.100 & -2.434 & 0.631 & 0.124 & $=0.384$ & $0.02 h$ \\
\hline 12 & US012 & $2.197 t+00$ & 0.566 & 1.146 & $=0.624$ & 0.453 & -0.042 & $-0,540$ & $=n .300$ \\
\hline 13 & 105013 & $2.700 t+01$ & -0.153 & -0.524 & -3.984 & 0.749 & 0.248 & $=0.259$ & $-1 \cdot d 07$ \\
\hline 14 & USU14 & $1.584 t+00$ & 0.078 & -0.124 & -3.977 & 0.716 & 0.215 & $=0.242$ & 1.327 \\
\hline 15 & USก15 & $2.722 t+00$ & .0 .870 & $-2.1+38$ & $=4.995$ & 0.654 & 0.105 & -0.343 & 1.061 \\
\hline 16 & USU1B & $3.635 E+00$ & 0.036 & -0.149 & -3.428 & 0.872 & 0.383 & -0.123 & 1. לso \\
\hline 17 & US 117 & $5.164 E+00$ & -0.056 & -0.124 & -5.144 & 0.640 & 0.151 & -0.354 & 2.643 \\
\hline 18 & USO & $2.041 t=01$ & $=0.192$ & -0.479 & & 0.813 & 0.326 & $=0.179$ & 3. 240 \\
\hline 19 & 115010 & $3.11 \cup E-01$ & $=0.266$ & -1.277 & -4.279 & 0.274 & -0.221 & $=0.128$ & 1.542 \\
\hline 20 & USO 20 & $2.432 E+01$ & -0.891 & -2.139 & $=2.476$ & 0.735 & 0.232 & -0.275 & -1.317 \\
\hline 21 & USก21 & $6.82 z t+00$ & -0.012 & -0.232 & $-1,466$ & 0.797 & 0.286 & -0.222 & 11.445 \\
\hline 22 & (45) 22 & $0.272 E+00$ & -1.972 & -4.323 & -2.501 & 0.366 & $=0.160$ & -0.670 & -1.402 \\
\hline 23 & $u \leqslant 0 \geq 3$ & b.3ㄴ.7t-01 & 0.082 & -0.751 & -2.482 & 1.104 & 0.589 & 0.081 & 1.147 \\
\hline 24 & USO 24 & $0.722 t+01$ & .0 .039 & -1.239 & -4.178 & 1.013 & 0.523 & $0.0 \$ 7$ & 1.947 \\
\hline$<5$ & USก $\geq 5$ & $0.22 \geq t-01$ & -0.146 & -0.288 & -1.775 & 1.085 & 0.535 & 0.078 & 1.007 \\
\hline 6. & U $5 \cup 2 b$ & $1.926 E+00$ & 0.124 & -0.081 & -1.525 & 1.002 & 0.483 & -0.026 & 0.008 \\
\hline 27 & US.) 27 & $9.350 t=01$ & 0.377 & 0.790 & -1.727 & 0.960 & $0.07 \mathrm{i}$ & -0.035 & 1.055 \\
\hline 28 & USU 8 & $1.100 t+00$ & 0.366 & 0.471 & -3.146 & 0.711 & 0.157 & -0.350 & ?.5०1 \\
\hline 29 & US U29 & $0.127 t=01$ & 0.442 & 0.556 & -2.245 & 0.439 & $=0.114$ & -0.627 & 2.5113 \\
\hline 30 & USOSO & $4.745 E+00$ & 0.344 & 0.688 & $=1.397$ & 0.337 & $=0.217$ & -0.729 & 2.009 \\
\hline 31 & US $13 !$ & $1.213 E+00$ & 0.472 & 0.689 & -1.058 & 0.742 & 0.189 & -0.324 & 1.327 \\
\hline $3 ?$ & US 132 & $1.462 t+00$ & 0.534 & 0.618 & -1.115 & 0.816 & 0.264 & $=0.249$ & $1 . x \in 1$ \\
\hline 33 & 151333 & $2.4 \operatorname{sot}+00$ & 0.209 & 0.073 & $=0.870$ & 0.758 & 0.205 & -0.308 & 1.506 \\
\hline 14 & USUS4 & $2.173 E+00$ & 0.387 & 0.345 & $=2.060$ & 0.756 & 0.204 & -0.309 & 1.060 \\
\hline 35 & US 35 & $5.7 \mathrm{HSE}=02$ & 0.669 & 1.039 & $=0.717$ & 0.740 & 0.230 & $=0.274$ & 1.051 \\
\hline 35 & USU3o & $4.3411 t+00$ & 0.422 & 1.149 & -2.175 & 0.239 & $-0,248$ & -0.754 & 3.191 \\
\hline 37 & 45037 & $3.504 t+00$ & $=0.660$ & -2.544 & -2.666 & 0.349 & $=0.165$ & -0.674 & 0.154 \\
\hline 38 & 45030 & $2.510 t+00$ & -0.681 & -1.767 & -2.950 & 0.598 & 0.085 & -0.423 & 1,351 \\
\hline 39 & U5!) 39 & $4.035 t+00$ & -0.163 & -0.942 & -1.867 & 0.471 & $=0.034$ & -0.347 & -0.111 \\
\hline 40 & U. $S 040$ & $0.334 t+00$ & 0.020 & -0.457 & -1.379 & 0.357 & $=0.146$ & -0.053 & 0.213 \\
\hline 41 & USi) 1 & $1.04 .1 E+01$ & 0.190 & 0.325 & -3.3146 & 0.355 & -0.162 & -0.070 & 2.240 \\
\hline 42 & $1 / 5042$ & $7.012 t+00$ & $=0.336$ & -0.668 & -1.072 & 0.382 & -0.121 & -0.624 & -0.042 \\
\hline 43 & US 1443 & $3.456 t+00$ & -0.075 & -1.212 & -3.003 & 0.059 & $=0.456$ & -0.964 & 0.5112 \\
\hline 44 & 135014 & $5.642 t+00$ & $=0.324$ & -0.852 & -2.937 & 0.329 & -0.187 & -0.046 & 0.719 \\
\hline 45 & 43045 & $1.32+t=01$ & $=0.101$ & -2.011 & -1.422 & 0.556 & 0.050 & -0.438 & 0.515 \\
\hline 60 & 115040 & $2.651 t+01$ & 0.020 & -0.087 & -2.836 & 0.327 & -0.165 & -0.671 & 1.209 \\
\hline 47 & แSง & $1.544 E+00$ & 0.531 & 0.131 & -1.789 & 0.018 & $=0.453$ & -0.457 & 1.000 \\
\hline 48 & 13018 & $1.756 t+00$ & 1.210 & 1.662 & -2.221 & 0.136 & -0.347 & -0.052 & 1.065 \\
\hline 49 & $\operatorname{tis} 049$ & $9.053 \mathrm{E}-01$ & 0.216 & 0.129 & -2.027 & 0.119 & $=0.300$ & -0.064 & 1.393 \\
\hline 50 & 15050 & $7.340 t+00$ & 1.256 & 2.487 & -1.918 & 0.737 & 0.265 & -0.239 & 2.670 \\
\hline $5 !$ & 《Sण $5 !$ & $1.204 t+01$ & 2.011 & $\begin{array}{r}3.760 \\
-0.764\end{array}$ & $=1.236$ & 0.605 & 0.135 & $=0.371$ & 3.105 \\
\hline 52 & & $4.447 t+100$ & -11.113 & -0.694 & $\begin{array}{l}-2.489 \\
-1\end{array}$ & 0.454 & -0.042 & $\begin{array}{l}=0.249 \\
-0.474\end{array}$ & \\
\hline ss & US SS S & $3.544 t+00$ & 0.948 & 1.380 & $=1.119$ & 0.519 & 0.031 & $\begin{array}{l}-0.474 \\
-0.437\end{array}$ & $\begin{array}{r}0.796 \\
-0.0000\end{array}$ \\
\hline 54 & (15) & $5.021 t+00$ & $=0.890$ & -1.911 & $=2.637$ & 0.560 & $\begin{array}{l}0.069 \\
0.303\end{array}$ & -0.201 & $\begin{array}{r}-0.050 \\
0.570\end{array}$ \\
\hline 55 & US:155 & $4.736 t=01$ & -0.079 & -0.698 & $\begin{array}{l}-2.630 \\
.4 .036\end{array}$ & $\begin{array}{l}0.744 \\
0.380\end{array}$ & & $=0,019$ & 3. KHI \\
\hline 56 & US1,56 & $2.09: 0 E+00$ & 0.041 & $=0.179$ & $\begin{array}{l}=0.036 \\
=3.978\end{array}$ & $\begin{array}{l}0.380 \\
0.242\end{array}$ & $\begin{array}{l}-0.113 \\
-0.245\end{array}$ & -0.751 & 4.404 \\
\hline & $\begin{array}{l}\text { USU57 } \\
\text { Us } 058\end{array}$ & & $\begin{array}{r}0.185 \\
-2.235\end{array}$ & $\begin{array}{r}0.025 \\
-5.074\end{array}$ & $\begin{array}{l}-3.978 \\
-2.388\end{array}$ & $\begin{array}{l}0.242 \\
0.70 !\end{array}$ & 0.190 & $-0.31 \mathrm{~A}$ & $=? .314$ \\
\hline $\begin{array}{l}58 \\
59\end{array}$ & USUSa & $\begin{array}{l}2.2020+01 \\
1.202 t+01\end{array}$ & -2.647 & -5.608 & -2.972 & 0.816 & 0.304 & -0.204 & -1.440 \\
\hline 60 & USuei) & $3.317 t+00$ & .0 .573 & -1.555 & -2.577 & 0.525 & 0.007 & -0.302 & 0.011 \\
\hline का & USObl & $4.655 t+00$ & 1.598 & 3.143 & -1.110 & 0.911 & 0.387 & -0.122 & 1.139 \\
\hline 02 & USOnz & $3.844 t+00$ & 0.108 & -0.100 & -0.974 & 0.625 & 0.075 & -0.437 & 0.085 \\
\hline 63 & USO०3 & $1.160 t+01$ & $=0.829$ & -2.148 & -1.919 & 0.686 & 0.134 & -0.578 & -1.5 .44 \\
\hline bu & USOSA & $3.171 E+100$ & 2,369 & 4.735 & -0.290 & 1.116 & 0.592 & 0.062 & 1.614 \\
\hline 6.5 & us1105 & $4.544 t+00$ & 0.196 & 0.176 & -2.362 & 0.663 & 0.126 & -0.365 & 1.276 \\
\hline 66 & USODO & $7.577 t+00$ & 0.336 & 0.444 & -2.426 & 0.711 & 0.170 & $\begin{array}{l}-0.342 \\
-0.330\end{array}$ & $\begin{array}{l}1.517 \\
1.253\end{array}$ \\
\hline & & & 0.198 & & -2.524 & 0.727 & 0.182 & -0.530 & 1.253 \\
\hline
\end{tabular}





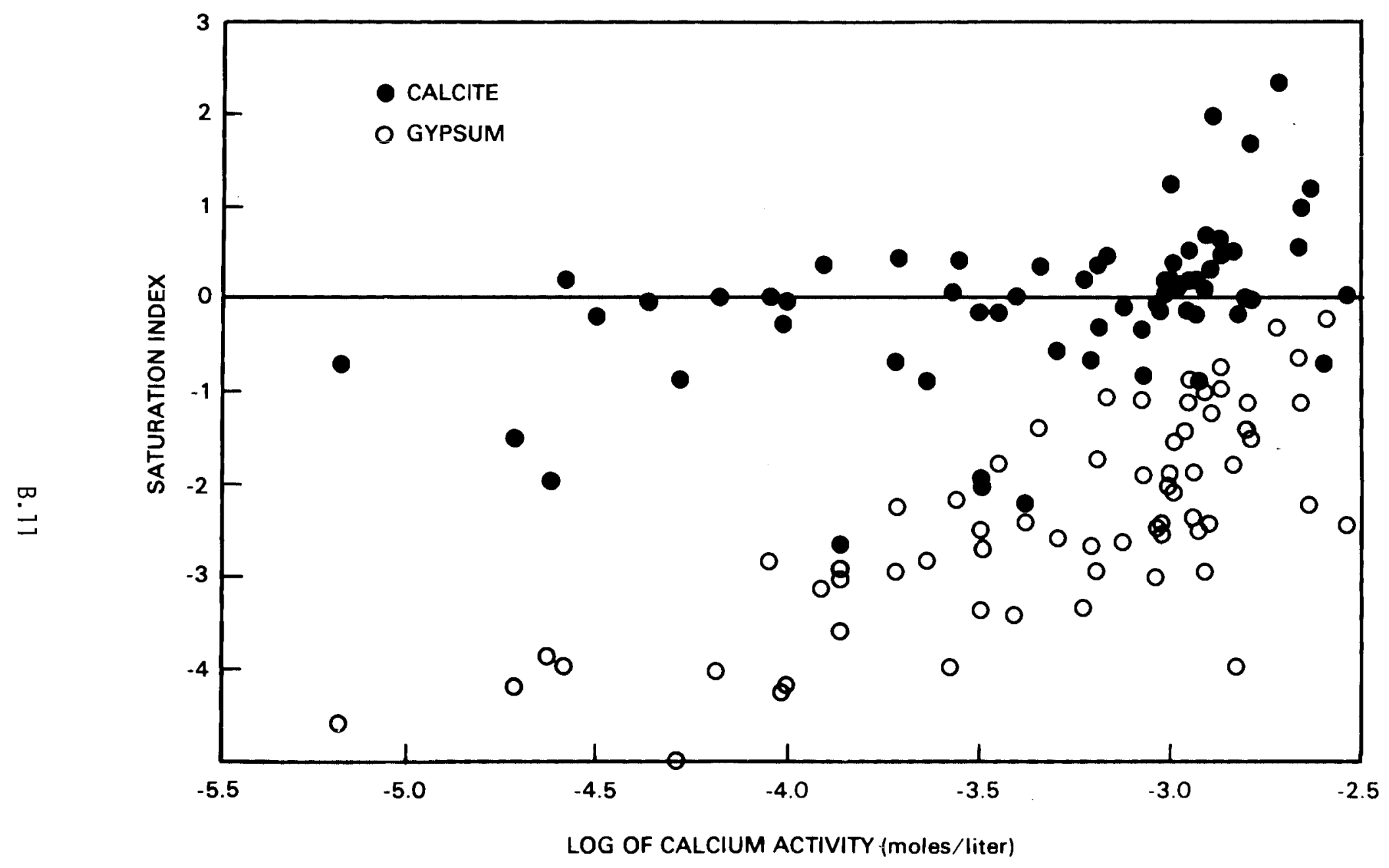

FIGURE B.2. Saturation Indices of Calcite and Gypsum Versus Calcium Activity in U.S. Ground Waters 
mineral. An index greater than zero implies oversaturation and one less than zero means undersaturation. Injection impairment at the DOE-sponsored Minnesota Field Test Facility has been shown to be caused by calcite precipitation resulting from the heating of ground water that was initially at equilibrium with calcite. It is a reasonable assumption that heating other ground waters that are near saturation with calcite would also result in injection problems caused by calcite precipitation if some form of water treatment were not employed. Figure B.2 shows that most of the samples modeled are near saturation with respect to calcite and, therefore, would not make good candidate working fluids for a "heated-water" thermal energy storage facility, unless preventive measures are taken.

In Figures B.3, B.4, and B.5, the calcite saturation indices are displayed by hydrologic region to determine if any of the regions are better than others. In general, the solutions sampled from the Pacific Northwest, Souris-Red-Rainy, and Upper Colorado regions are all close to saturation with calcite and would not be good candidates based on this criterion. of the other regions studied, only seven samples had a calcite saturation index less than -1.0. Ground waters with a saturation index greater than -1.0 are either oversaturated with respect to calcite or would be oversaturated if the solution temperature were to be raised to values normally considered for thermal energy storage, say $150^{\circ} \mathrm{C}$. Four of the seven waters that are we 11 below calcite saturation have cation/anion imbalances greater than 10\%; the remaining three have imbalances less than $7 \%$. The samples with the high imbalance are noted in Figures $B .4$ and $B .5$ by circles around the data points. The poor quality of the data for these samples could be the reason for the calculation of a low value for the calcite saturation index. The two samples for the Lower Mississippi region (USO04 and USO05) and the one from the Mid-Atlantic (USO22) that have low saturation indices for calcite and reasonable cation/anion balances should not precipitate large quantities of this mineral on heating. An additional sample (US008) had a reported calcium concentration of zero, which does not seem reasonable, but if it is true, it would also fall in the acceptable category.

B. 12 


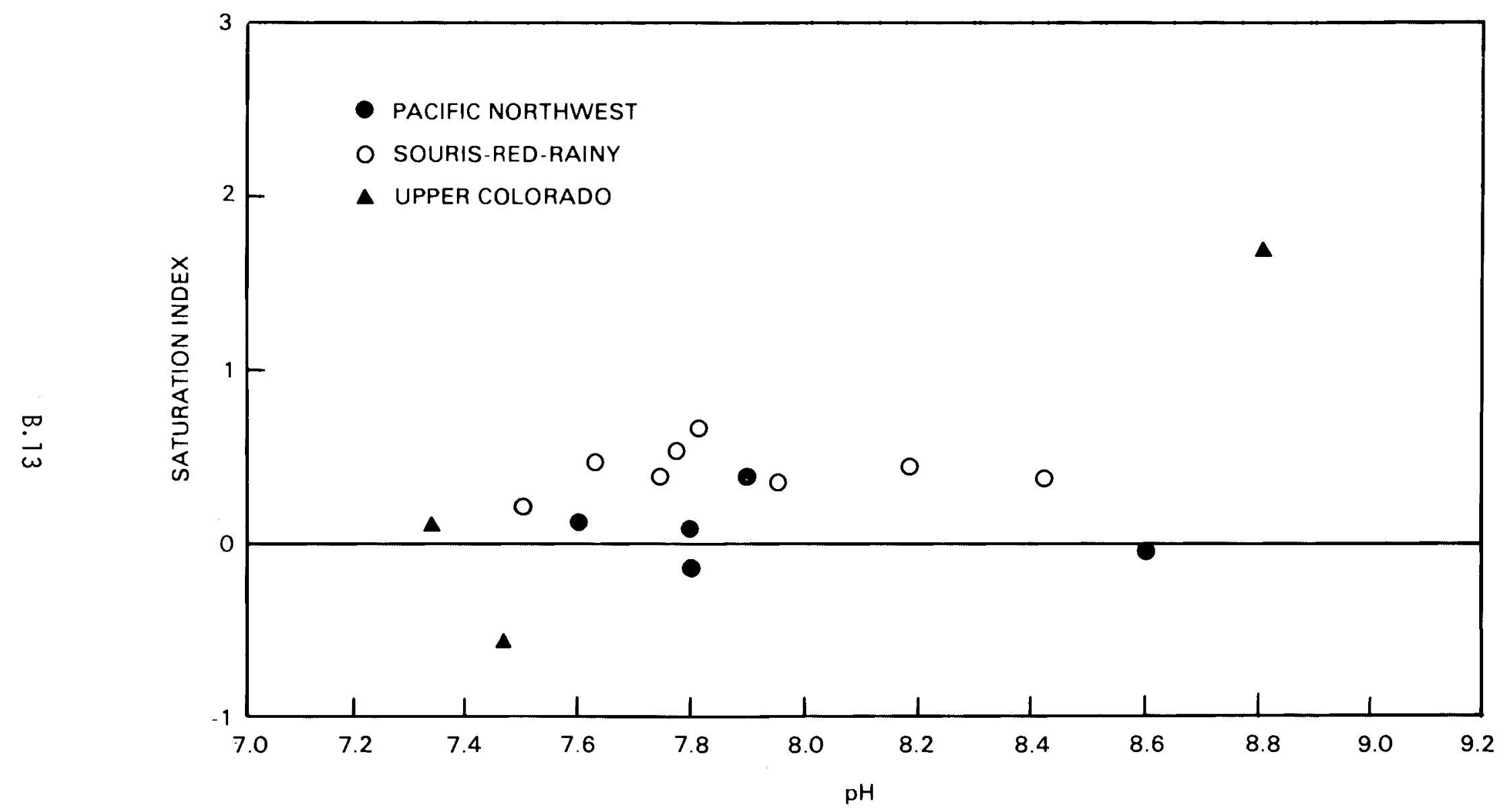

FIGURE B.3. Saturation Indices of Calcite for U.S. Ground Waters in the Pacific Northwest, Souris-Red-Rainy, and Upper Colorado Regions 


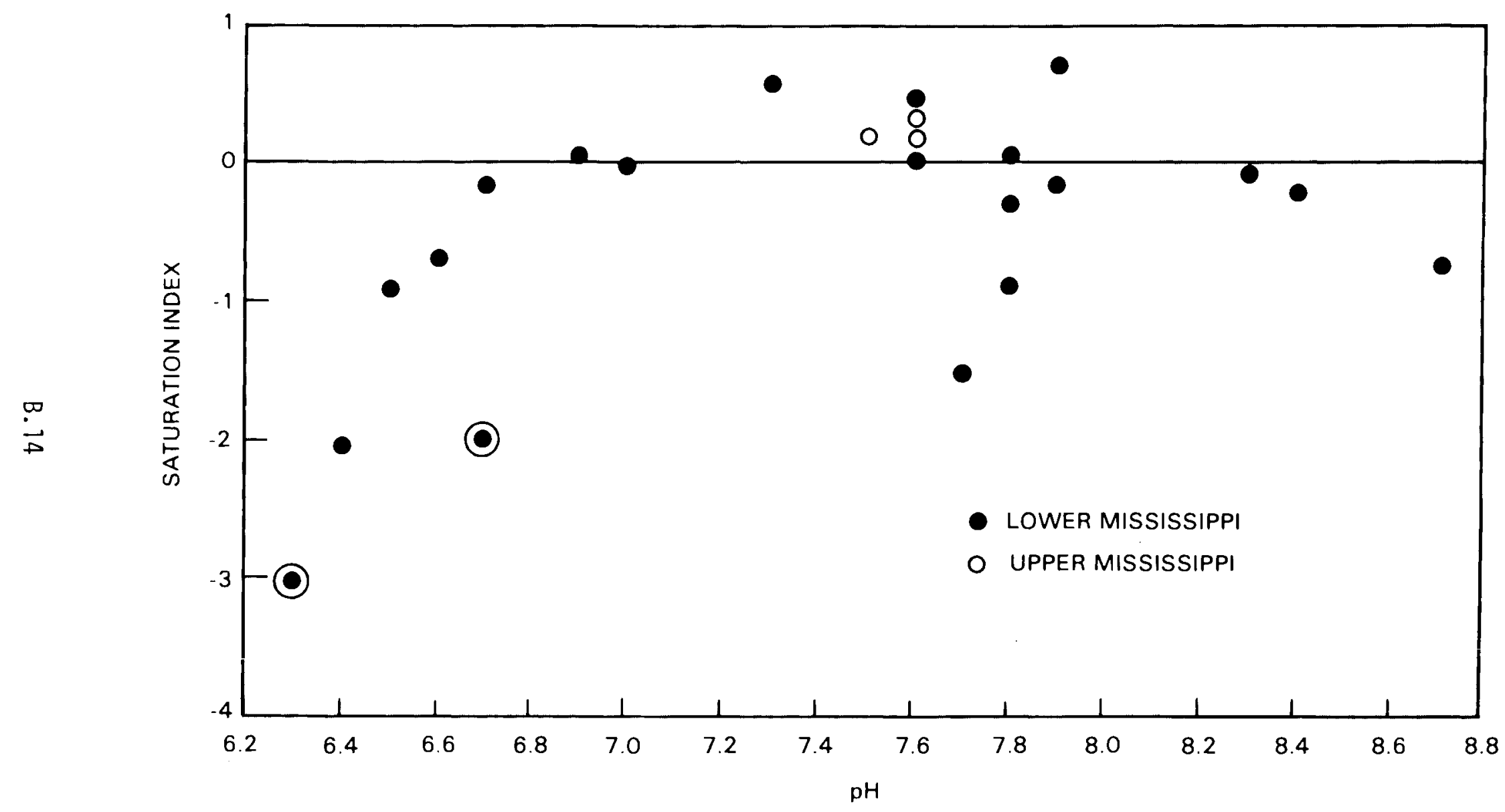

FIGURE B.4. Saturation Indices of CaTcite for U.S. Ground Waters in the Lower Mississippi and Upper Mississippi Regions 


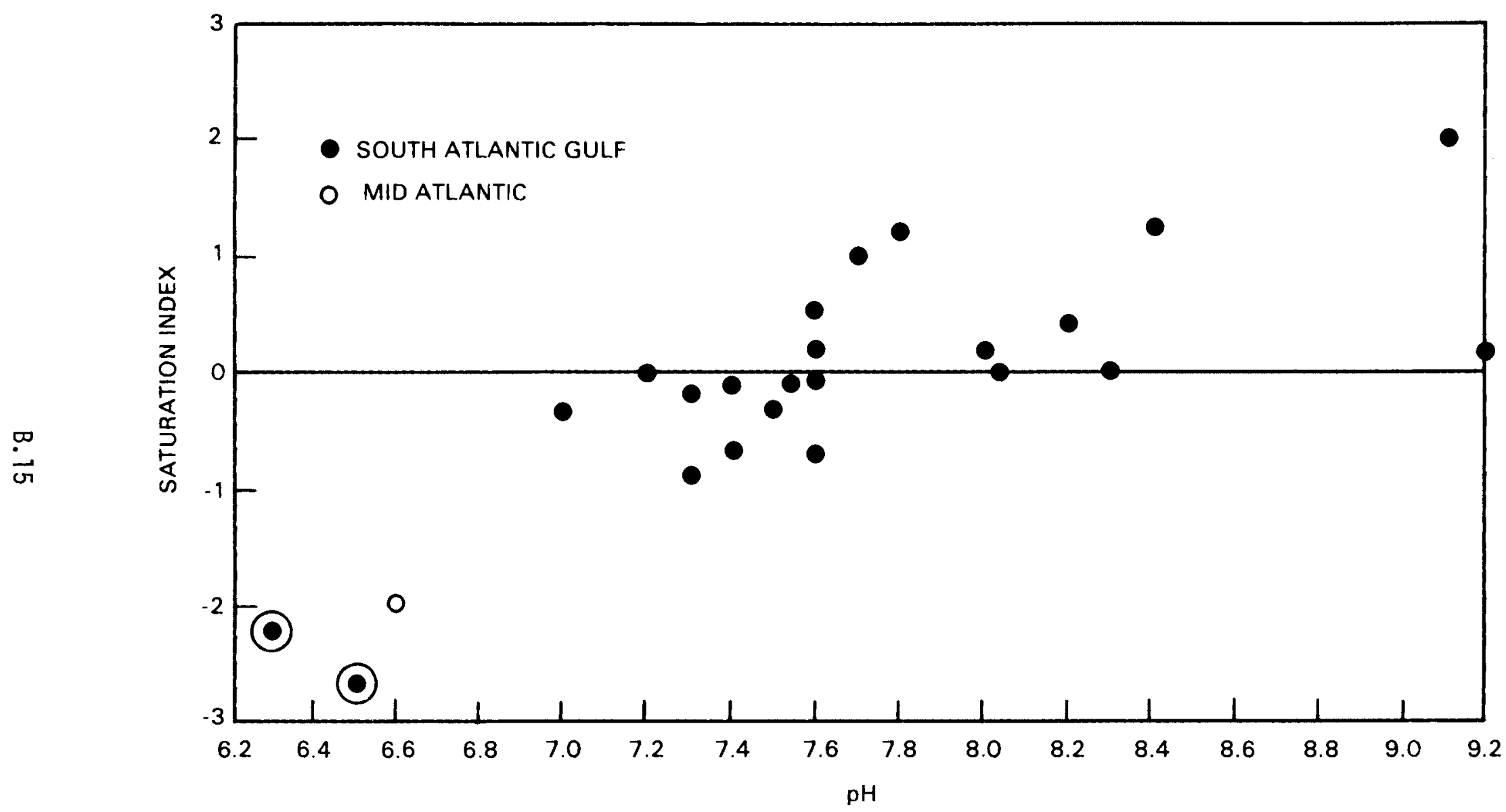

FIGURE B.5. Saturation Indices of Calcite for U.S. Ground waters in the South Atlantic Gulf and Middle AtTantic Regions 
Several of the calcite saturation indices are computed to be greater than 1. This is true for samples US048, US050, US051, US061, and US064. The rate of formation of calcite is fairly rapid compared to most groundwater flow rates. Consequently, it is doubtful that such a supersaturated condition could be maintained in a ground-water system. Thus, the calcium and carbonate data for these samples are suspected of erroneous determination.

The saturation indices for gypsum for these ground waters was shown in Figure B.2. In general, the waters are well undersaturated with respect to this solid; however, at the higher calcium activities, saturation is approached and precipitation of gypsum could be a problem.

\section{B.2.2 Silica}

Silica $\left(\mathrm{SiO}_{2}\right)$ is present in most aquifers either incorporated in aluminosilicate minerals or as quartz or one of its polymorphs. As shown in Figure B.6, most of the aquifer ground waters studied are in equilibrium with either quartz or a more soluble polymorph of $\mathrm{SiO}_{2}$. The determination of which silica phase is controlling silica concentration in the ground water is important because the solid will limit the total amount of dissolved silica at temperature. If quartz is controlling silica concentration in a solution and the solution temperature is raised from $10^{\circ} \mathrm{C}$ to $150^{\circ} \mathrm{C}$, the amount of $\mathrm{SiO}_{2}$ in solution will increase by about $150 \mathrm{ppm}$. However, if amorphous silica glass is the controlling factor, silica concentration would rise by $500 \mathrm{ppm}$ for a similar increase in temperature. When the temperature of the solution decreases as heat is recovered, silica will precipitate and the amount of solid formed will be proportional to the amount dissolved during the heating cycle. The samples that are computed to be close to saturation with respect to noncrystalline silica $\left[\mathrm{SiO}_{2}\right.$ (amorphous or glass)] probably have an amorphous silica phase in the aquifer and this solid would dissolve to give a high concentration of silica in the heated water. When the water is cooled, the precipitation of a silica mineral could cause plugging of the aquifer; this effect would have to be considered in choosing 


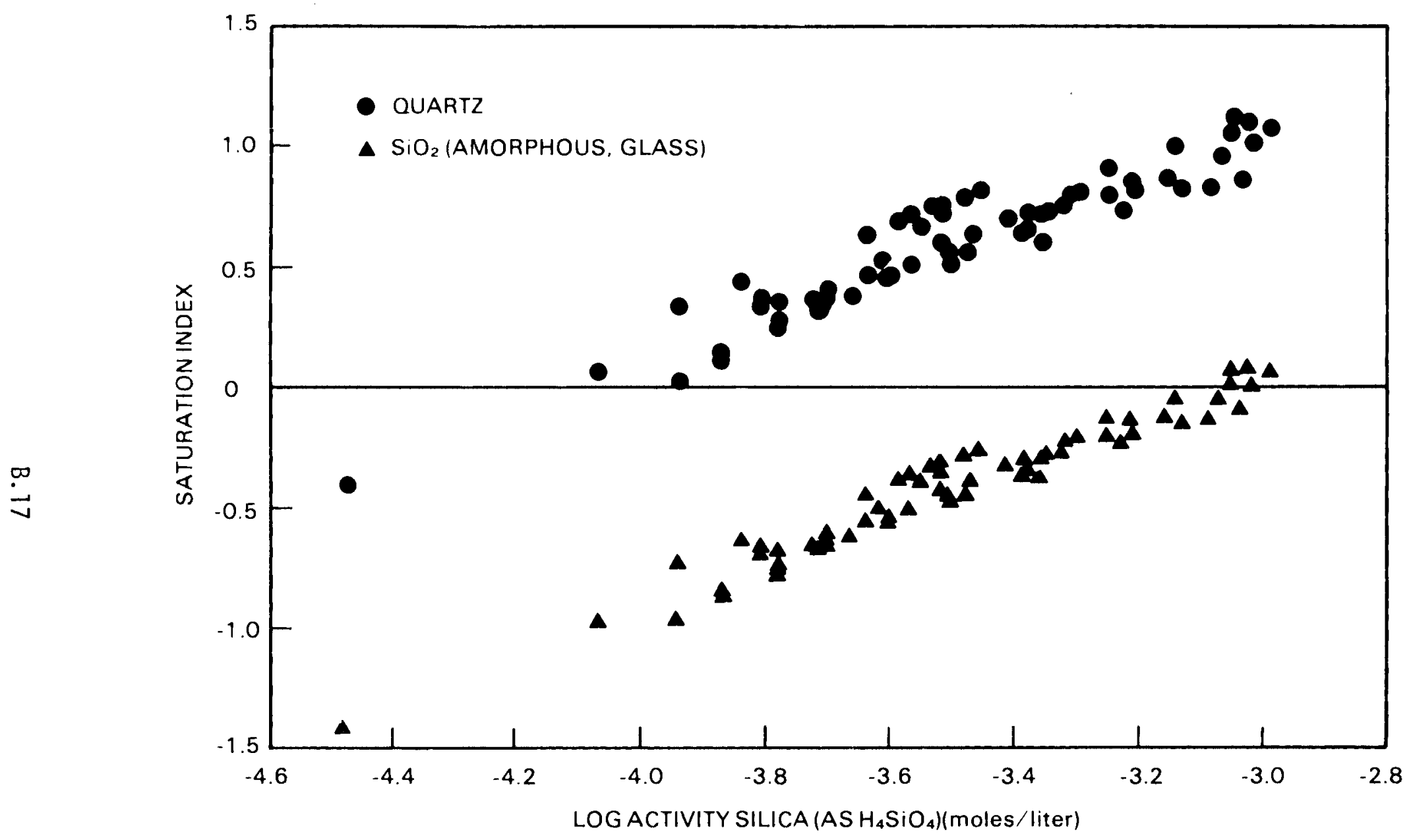

FIGURE B.6. Saturation Indices of Silica Minerals Versus Activity of Silica in U.S. Ground Waters 
one of these sites for a thermal energy storage location. All of the Pacific Northwest samples modeled showed near equilibrium conditions with a soluble silica phase.

\section{B.2.3 Iron}

Iron is often present in ground waters as a trace element with a dissolved concentration of less than $1 \mathrm{ppm}$. However, iron also forms very small colloids that can flow with the ground water and, if the samples of the ground water are not filtered prior to the iron analysis, the resulting concentration value may be erroneously high. Figure B.7 shows the concentrations of iron for the water samples modeled. Many analyses show iron concentrations of greater than $1 \mathrm{ppm}$. At the measured $\mathrm{pH}$ and under assumed mildly oxidizing redox conditions, iron concentrations this high would not be possible because ferric hydroxide would precipitate and lower the iron concentration. Consequently, some of the analyses for iron are suspect. It is possible that, under highly reducing conditions the iron concentration could reach 10 to $20 \mathrm{ppm}$, but it is doubtful that the waters modeled have such a low redox potential. If iron is present in the ground water at the tens of ppm level, then it could cause problems in the surface plant facility of a thermal energy storage system. If ground water with a high iron content is pumped through the system, the iron would oxidize and precipitate as ferric hydroxide. Also, pumping oxygenated water on the return cycle into an aquifer containing reduced sediments may mobilize many trace metal contaminants (e.g., As, Se, and Mo) that were tied up in reduced minerals.

\section{B.2.4 Clay Dispersion}

In addition to mineral precipitation problems that may occur during aquifer injection, changes in the chemistry of the ground water induced by heating the water may result in clay mineral dispersion that could cause a decrease in permeability. The chemical change in the ground water that would accompany calcite precipitation is reduction in the concentrations of calcium and carbonate. If the dominant cation in the grourid water is 


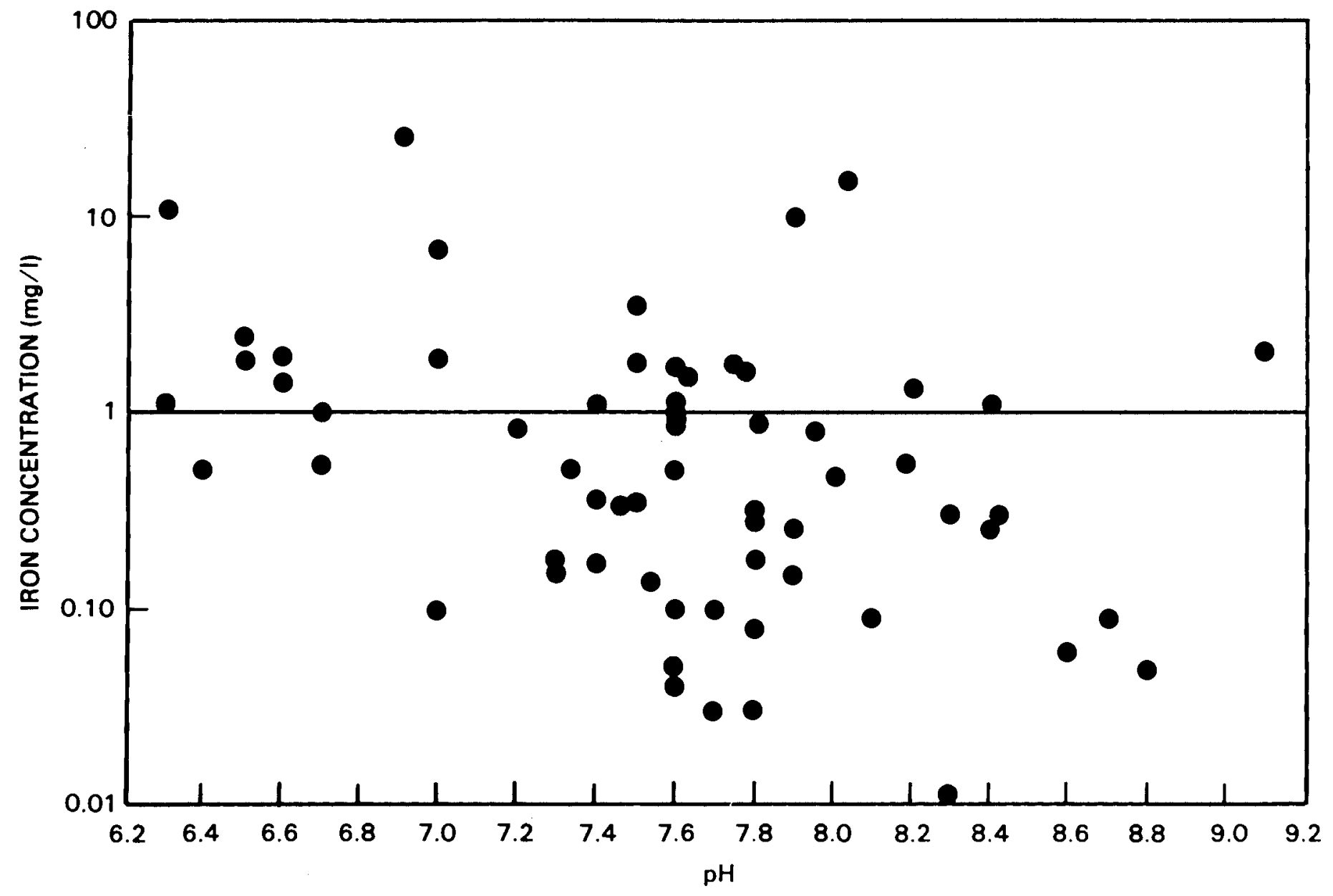

FIGURE B.7. Total Iron Concentration Versus pH for U.S. Ground Waters 
originally calcium, the precipitation of calcite could shift the dominance to another cation, probably sodium. Studies of oil field injection have shown that a shift in chemistry from a $\mathrm{Ca}$ - to Na-dominated solution could cause clay swelling and resulting changes in aquifer permeability. Figure B. 8 plots the activity of calcium versus sodium for the ground waters studied. Most of the ground waters are sodium-dominated but quite a few have calcium as the dominant cation. The mineralogy of the aquifer sediments for the calcium-dominated ground waters should be determined to ascertain if clay swelling is a potential problem for these systems.

\section{B. 3 SUMMARY AND CONCLUSIONS}

Most of the 67 water analyses modeled in this study have some negative feature that might interfere with their use in a heated-water thermal energy storage system. Many of the waters are at equilibrium or oversaturated with respect to calcite. This mineral becomes less soluble at increased solution temperatures. Consequently, it would precipitate and perhaps cause injection/recovery problems at an energy storage plant. Silica minerals are more soluble at increased solution temperatures. This characteristic may cause problems related to aquifer physical stability if the silica matrix is dissolved to any great extent. During the cooling phase the silica may precipitate and partially plug the aquifer and/or piping. Some of the ground waters modeled are at equilibrium with relatively soluble amorphous phases of silica that would compound the potential silica dissolution/ precipitation problem. If the high iron concentrations reported for a few of the analyses are correct, then the precipitation of oxidized iron compounds are possible problems at these sites. Finally, the $\mathrm{Ca} / \mathrm{Na}$ ratio of the solution may be affected by heating the ground water. If the sediments of the aquifer are susceptible to swelling, this change in chemistry of the ground water might impair aquifer injection.

The methodology described in Section B.l could be used in making a preliminary evaluation of the chemical compatibility of a particular ground water for storage of thermal energy. The results show that certain aquifers 


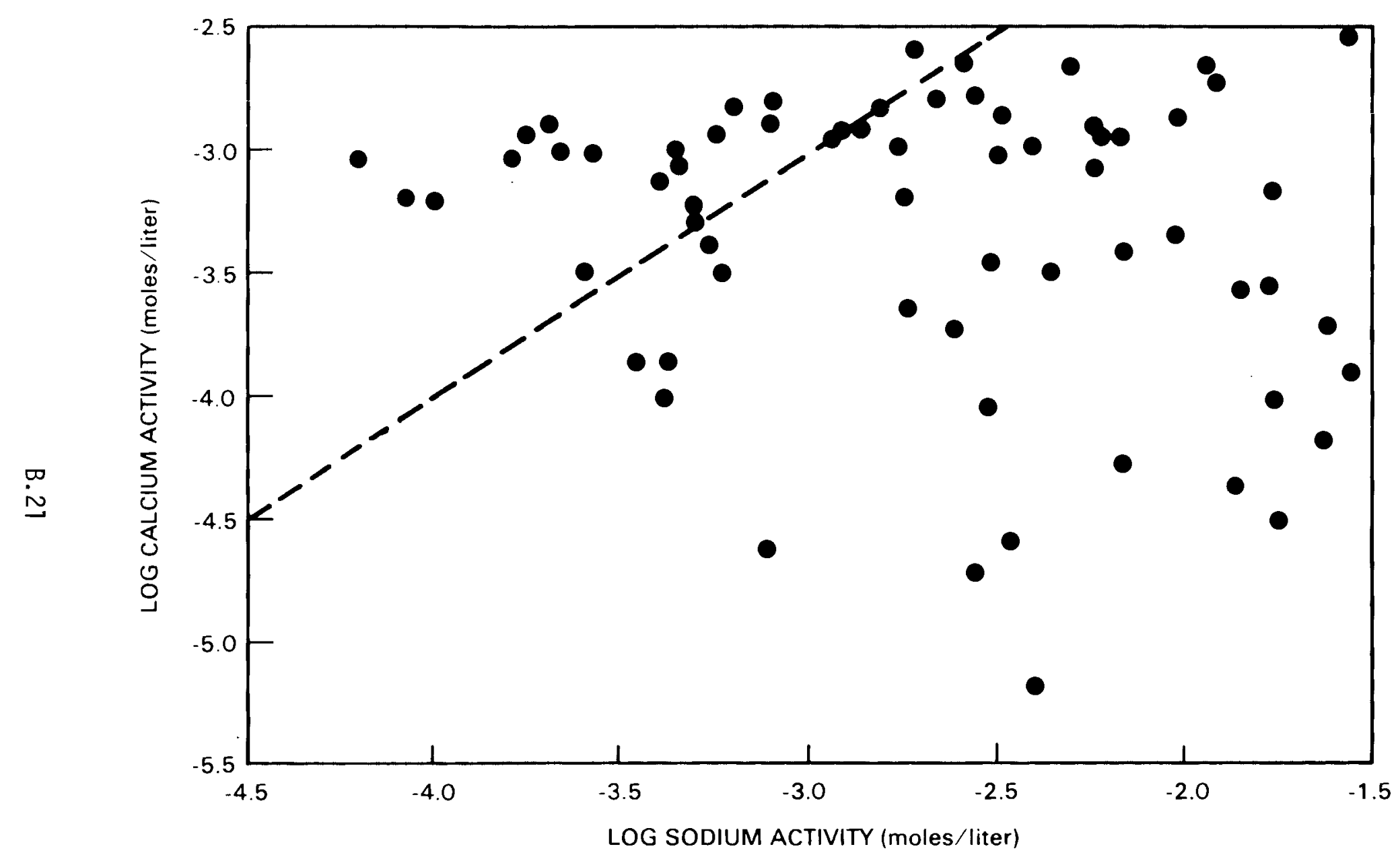

FIGURE B.8. Calcium Activity Versus Sodium Activity in U.S. Ground Waters 
contain ground waters with chemical properties that would influence their potential use as thermal energy storage reservoirs. However, the few analyses modeled are not sufficient to eliminate all sites in an entire hydrologic region as potential storage areas. Although it is true that ground-water chemistry can be uniform over large geographic areas, potential local variations would affect the evaluation of a site. As a consequence, the merits of each potential site should be determined by a thorough individual site characterization that includes geochemical factors.

\section{B.4 FUTURE WORK}

Additional information can be obtained from the chemical data by mass transfer modeling and sensitivity analyses. The work described here showed that most of the waters are near saturation with calcite. However, calcite precipitation will affect injection/recovery only if the volume precipitated is significant. As part of additional modeling work, the temperature of each solution could be raised from ambient to $150^{\circ} \mathrm{C}$ and calcite could be precipitated to maintain equilibrium at increased temperatures. The model would compute the mass of calcite precipitated. It is possible that for some of the waters this would be small. The modeling of the effect of temperature increase on solution composition would also provide data on silica mineral solubility and potential problems from this source.

The Eh had to be estimated for this study because no measured values were available. Additional modeling could be performed with different $E$ h values to determine if the reported iron concentrations are accurate and if colloids are present. 
PNL-4929

UC-94e

\section{DISTRIBUTION}

No of

Copies

OFFSITE

US Department of Energy

Attn: 1. Gyuk

Office of Energy Systems Res.

Forrestal Bldg, CE-141 5E-052

Washington, DC 20585

US Department of Energy

Attn: R. Shivers

Office of Energy Systems Res.

Forrestal B1dg, CE-141 5E-052

Washington, DC 20585

27 DOE Technical Information Center

Auburn University

Attn: F. J. Molz

School of Engineering

Auburn, AL 36830

Colorado School of Mines

Attn: Donald Langmuir

Dept of Chemistry and

Geochemistry

Golden, C0 80401

GeoTrans Inc.

Attn: J. W. Mercer

P0 Box 2550

Reston, VA 22090

Walter Hausz

4520 Via Vistosa

Santa Barbara, CA 93110

Lawrence Berkeley Laboratory

Attn: C. F. Tsang

University of California

Bldg. 90, Room 1012-H

1 Cyclotron Road

Berkeley, CA 94720
No of

Copies

Charles F. Meyer

1141 Cima Linda Lane

Santa Barbara, CA 93108

Minnesota Geological Survey

Attn: M. Walton

319 15th Avenue S.E.

Minneapolis, MN 55455

New York State Energy Research \& Development Agency

Attn: Gunnar Walmet

Rockefeller Plaza

Albany, NY 12223

Oak Ridge National Laboratory

Attn: J. F. Martin

PO Box $Y$

Oak Ridge, TN 37830

Office of Congressman

Sid Morrison

Attn: Kevin Billings, Legislative Asst.

1330 Longworth B1dg.

Washington, DC 20515

Rocket Research

Attn: L. B. Katter

York Center

Redmond, WA 98052

Tennessee Valley Authority

Attn: William Waldrop

Asst. Branch Chief

Water Systems Develop. Branch

Division of Water Management

PO Drawer E

Norris, TN 37828

Terra Tek, Inc.

Attn: C. Cooley

University Research Park

400 Wakara Way

Salt Lake City, UT 84108 
No of

Copies

University of Minnesota

Attn: W. E. Soderberg

Program Director, ATES

Physical Plant Operations

200 Shops Bldg.

319 15th Avenue S.E.

Minneapolis, MN 55455

US Army Corps of Engineers

Attn: Library

PO Box 59

Louisville, KY 40202

US Department of Interior

Attn: Natural Resources

Library, Lucy Howton

Serials Branch (G/E)

Washington, DC 20240

FOREIGN

Public Works of Canada

Attn: E. L. Morofsky

C456 Sir Charles Tupper B1dg.

Riverside Dr. and Heron Rd.

Ottawa, Ontario

K1A 0M2 Canada

\section{ONSITE}

DOE Richland Operations Off.

H. E. Ransom/D. R. Segna

Pacific Northwest Laboratory

R. D. Allen

W. Deutsch

L. D. Kannberg (10)

J. R. Raymond

Technical Information (5)

Publishing Coordination (2) 